A Grammar of Logba (Ikpana) 
Published by

LOT

phone: +31302536006

Janskerkhof 13

fax: +31302536406

3512 BL Utrecht

e-mail: lot@let.uu.nl

The Netherlands

http://www.lotschool.nl

Cover illustration: Akpan Waterfall at Logba Tota—Recorded on video by Kofi Dorvlo.

ISBN 978-90-78328-57-5

NUR 616

Copyright (C) 2008: Kofi Dorvlo. All rights reserved. 


\title{
A Grammar of Logba (Ikpana)
}

\author{
Proefschrift
}

ter verkrijging van

de graad van Doctor aan de Universiteit Leiden, op gezag van de Rector Magnificus prof.mr. P.F. van der Heijden, volgens besluit van het College voor Promoties te verdedigen op dinsdag 27 mei 2008

klokke 15:00 uur

door

Kofi Dorvlo

geboren te Keta, Ghana

in 1953 
Promotor: $\quad$ Prof. dr. M. Mous

Co-promotor: $\quad$ Dr. F.K. Ameka

Referent: $\quad$ Prof. dr. B. Heine (University of Cologne)

Overige leden: $\quad$ Prof. dr. G.L. van Driem

Dr. J.A.B.K. Essegbey (University of Florida, Gainesville)

Prof. dr. Th.C. Schadeberg 


\section{Table of Contents}

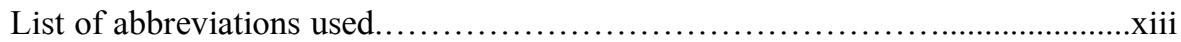

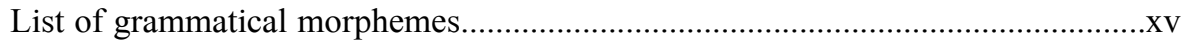

Map of Ghana Togo Mountain languages...........................................................

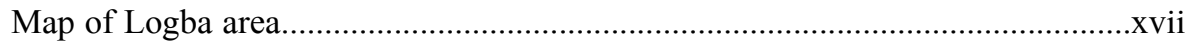

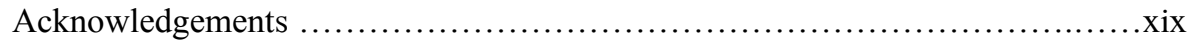

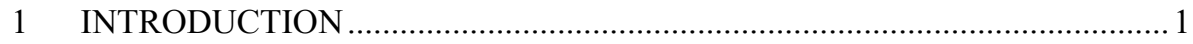

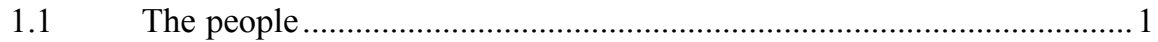

1.1.1 Settlement in the GTM area .......................................................... 2

1.1.2 Geographical location................................................................ 3

1.1.3 Some religious practices......................................................... 4

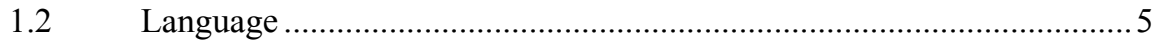

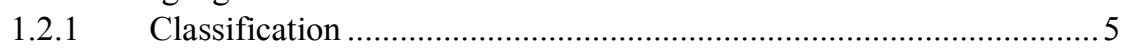

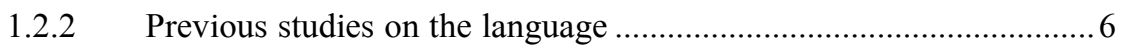

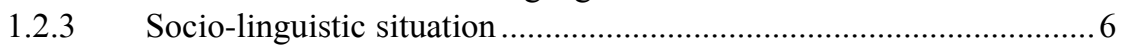

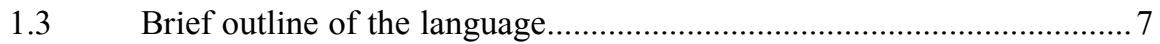

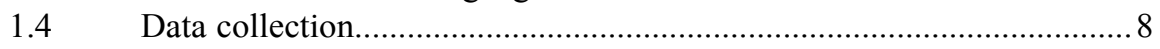

1.5 Methodological and theoretical framework ....................................... 9

1.6 Outline of the grammar and presentation of data ................................ 9

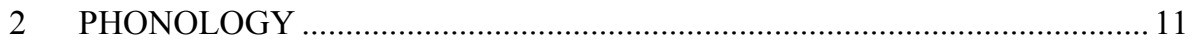

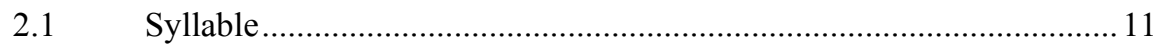

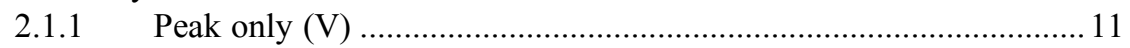

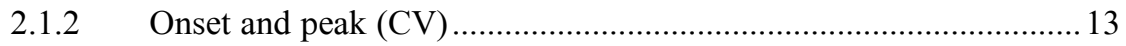

2.1.3 Two consonants onset and a peak (CCV) ...................................... 13

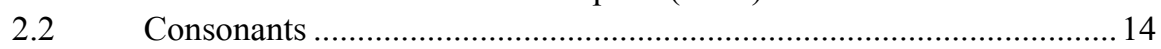

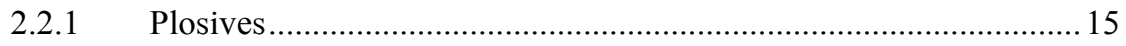

2.2.2 Fricatives .............................................................................. 16

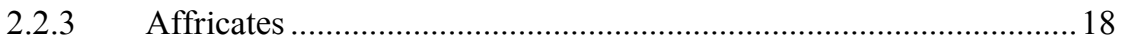

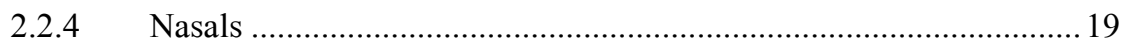

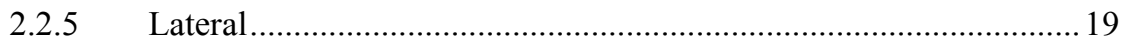

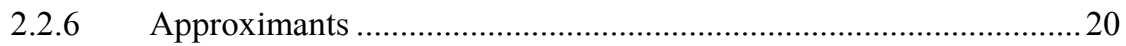

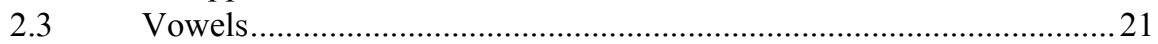

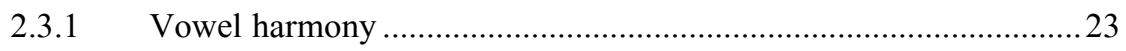

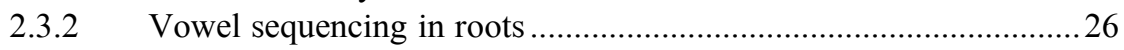

2.3.3 Vowel sequences across morpheme boundaries ........................... 26

2.3.4 Noun + determiner................................................................2 27

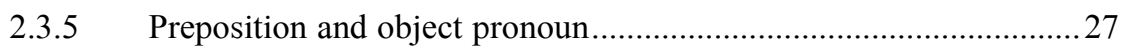

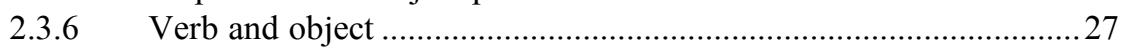

$2.4 \quad$ Tone

2.4.1 Change of tone in low tone monosyllabic verbs................................ 30

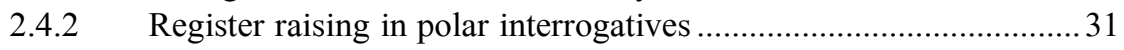

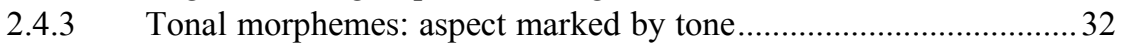

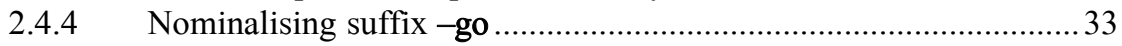




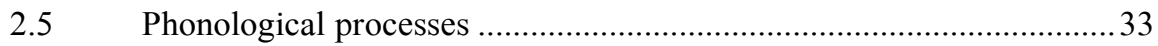

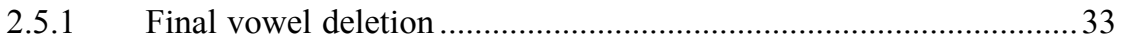

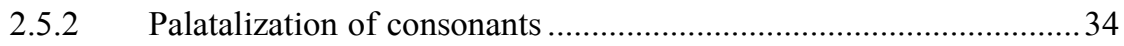

2.5.3 Vowel elision and labialization ............................................................ 34

2.5.4 Pronoun + verb stem + object pronoun .......................................... 35

2.5.5 Assimilation of tense and aspect markers ............................................ 36

2.5.5.1 Present progressive ..................................................................... 36

2.5.5.2 Habitual and past progressive....................................................... 37

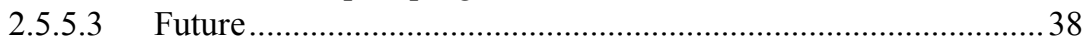

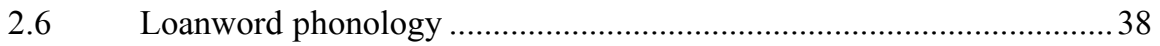

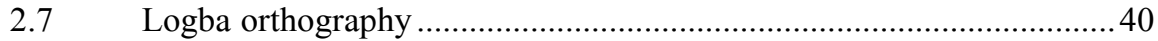

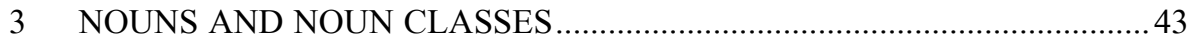

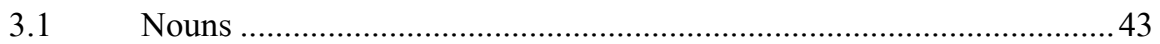

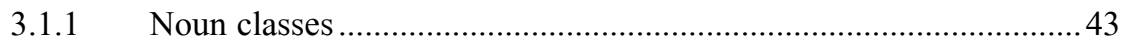

3.1.2 The prefix classes ................................................................... 44

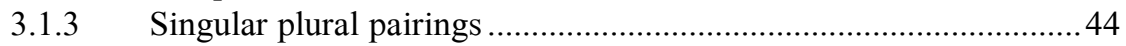

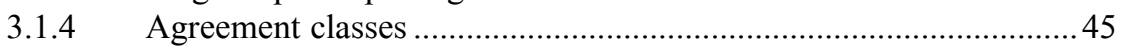

3.2 Subject agreement markers ............................................................... 45

3.2.1 Further statements about the nouns................................................ 47

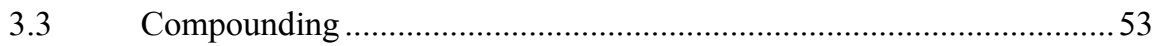

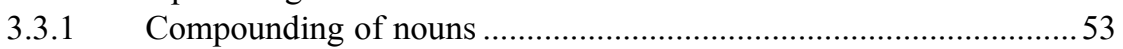

3.3.2 Compounding of postpositional phrase + noun ................................53

3.3.3 Compounding of noun + wasa ........................................................5

3.3.4 Compounding of noun + sex-determining word.................................53

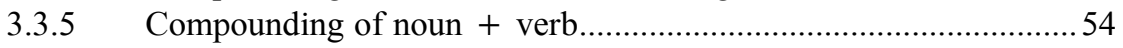

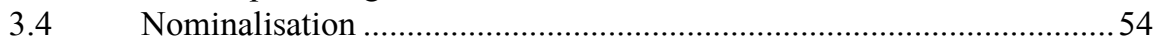

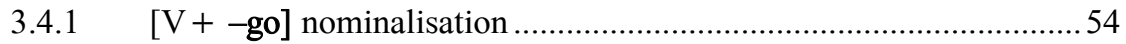

3.4.2 Nominalisation involving nominalised verbs ....................................56

3.4.3 Agentive nominalisation $[\mathrm{V}+$-wo] ................................................56

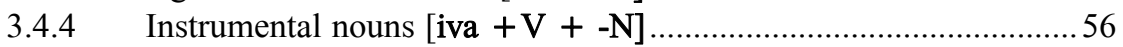

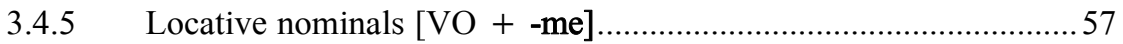

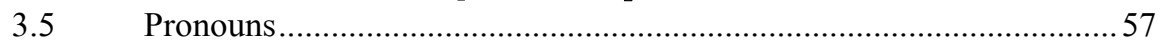

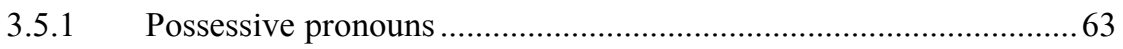

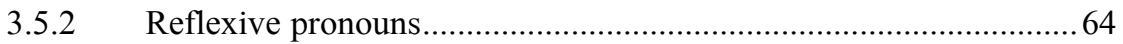

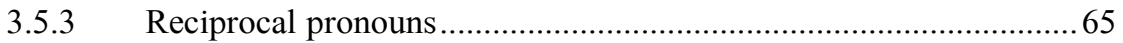

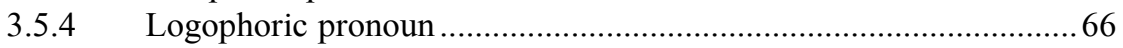

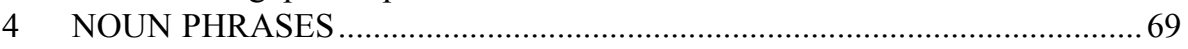

4.1 Noun phrases ........................................................................................ 69

4.1.1 Types of noun phrases................................................................. 70

4.1.1.1 Conjoined noun phrase ................................................................70

4.1.1.2 Alternate noun phrase ............................................................. 71

4.1.1.3 Possessive noun phrase............................................................ 71

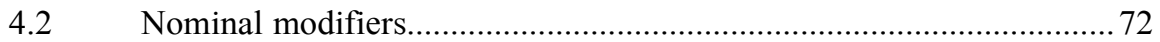

4.2.1 Adjectives ................................................................................ 72

4.2.2 Non-derived adjective and its semantic type ................................. 73 
4.2.3 Derived adjectives and processes of their derivation.......................73

4.2.3.1 Suffixation of - yi to value property verb ................................. 74

4.2.3.2 Compounding of an intransitive verb root and a noun ............... 74

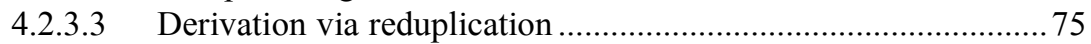

4.2.4 Derived nominals................................................................... 76

4.2.4.1 Adding nominalising suffix [-go] to a verb................................76

4.2.4.2 Compounding the stem wasa to a noun.................................... 77

4.2.5 The use of ideophones................................................................... 78

4.2.6 Verb phrase for expression of quality concepts.............................. 79

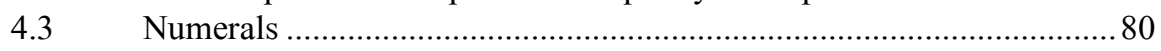

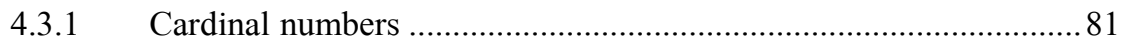

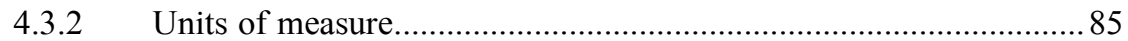

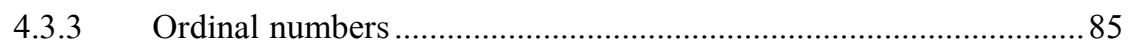

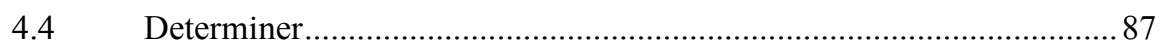

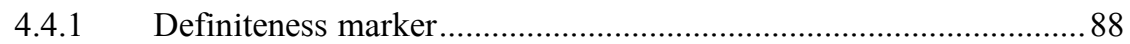

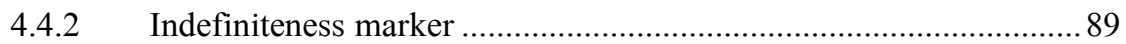

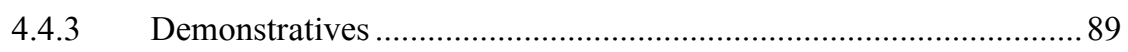

Intensifiers ...................................................................................... 92

5 ADPOSITIONS AND ADPOSITIONAL PHRASES ….............................95

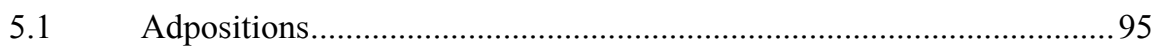

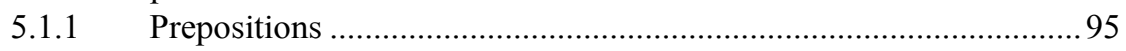

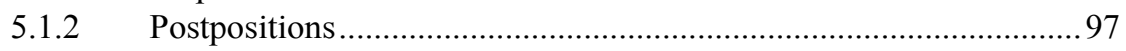

6 BASIC CLAUSE STRUCTURE, NON-VERBAL AND LOCATIVE CONSTRUCTIONS ........................................................................................ 103

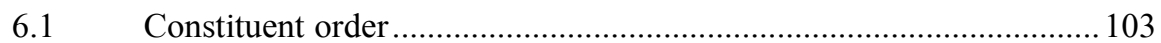

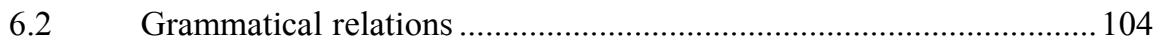

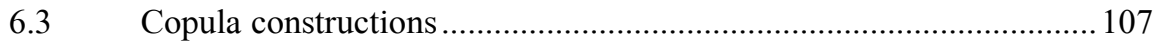

6.3.1 Equative constructions................................................................ 107

6.3.2 Predicative possessive constructions ............................................. 109

6.4 Comparative constructions ............................................................ 110

6.4.1 Structures expressing superlative ............................................. 112

6.4.2 Structures expressing equality .................................................... 113

6.4.3 Comparisons expressing semblative............................................ 113

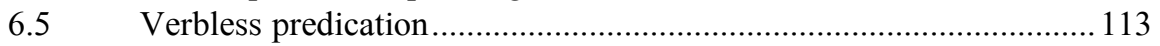

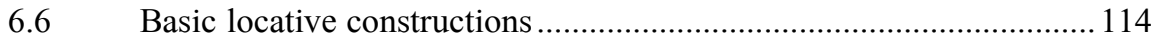

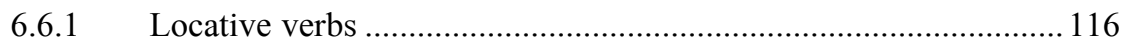

6.6.1.1 le 'be.located' ....................................................................... 116

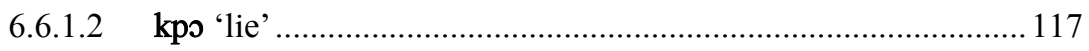

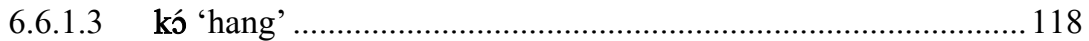

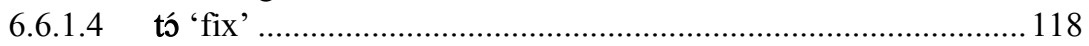

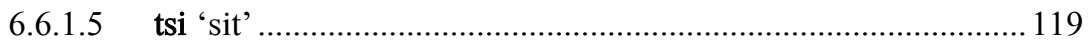

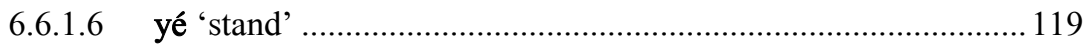

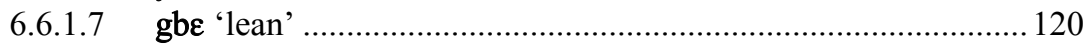

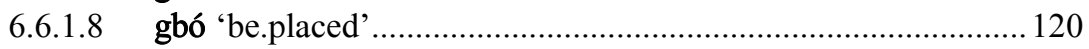

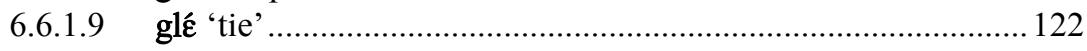




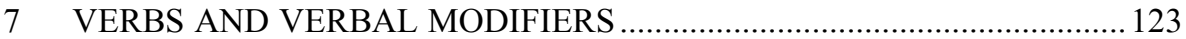

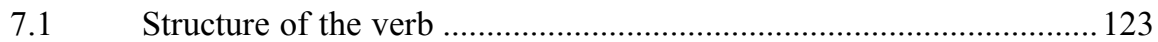

7.2 Verbs and argument structure ......................................................... 124

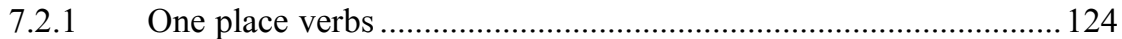

7.2.1.1 Voluntary motion verbs............................................................ 125

7.2.1.2 Verbs denoting emission of vocal sounds ................................. 125

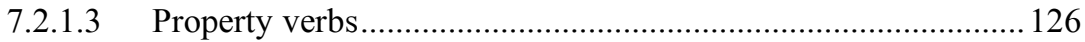

7.2.1.4 Achievement verbs ............................................................... 128

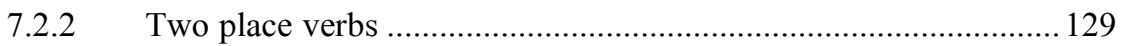

7.2.2.1 Creation verbs........................................................................ 130

7.2.2.2 Caused change of location verbs ............................................. 130

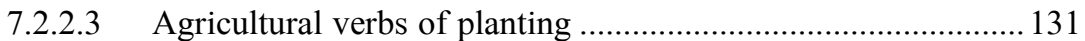

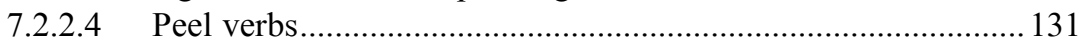

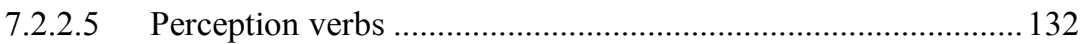

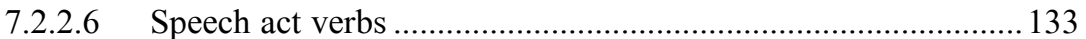

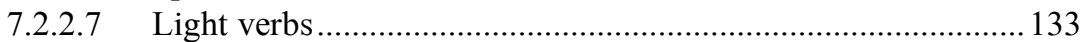

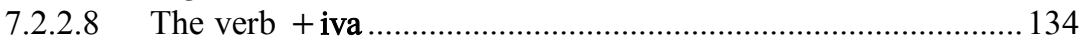

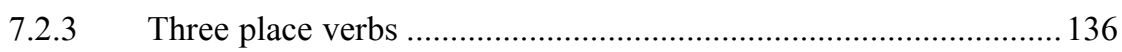

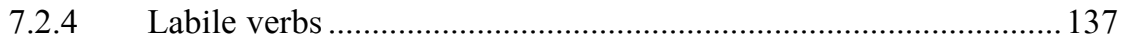

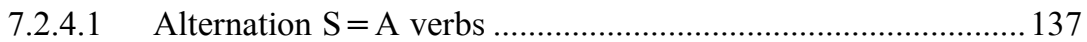

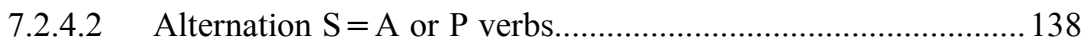

7.2.4.3 Verbs that can be used both as transitive and ditransitive .........139

7.2.4.4 Verbs that are used as intransitive, transitive and ditransitive...139

7.3 Tense, aspect and mood markers ....................................................... 139

7.3.1 Present and past interpretation .................................................. 140

7.3.2 Present progressive................................................................. 140

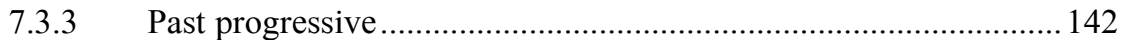

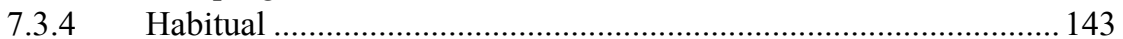

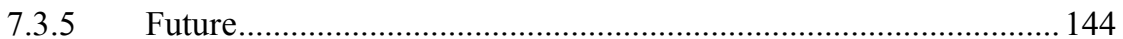

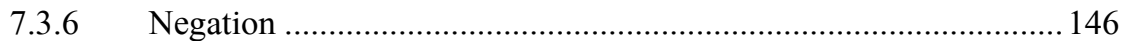

7.3.6.1 Other words which express negation........................................ 149

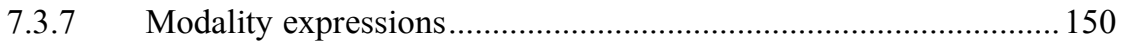

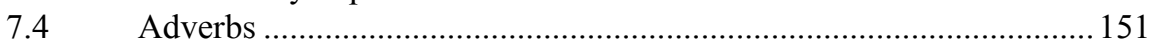

7.4.1 Clause initial and clause final adverbs............................................ 151

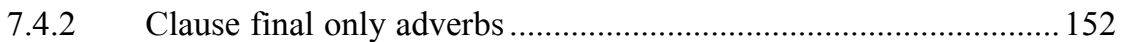

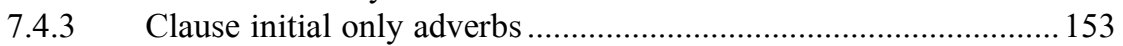

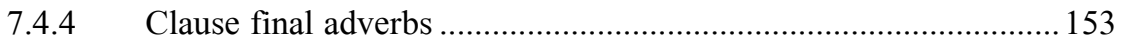

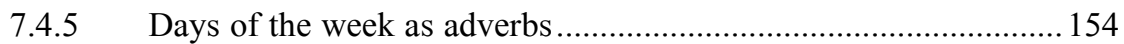

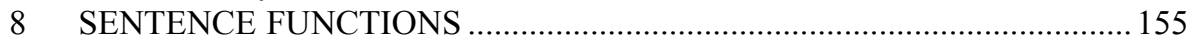

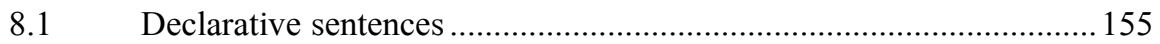

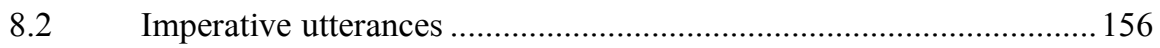

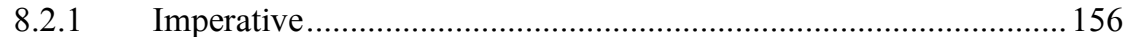

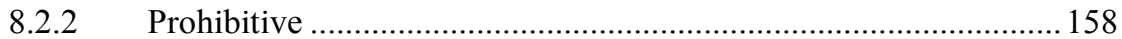

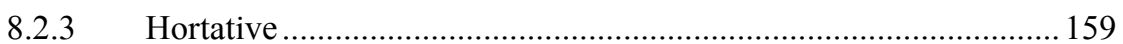

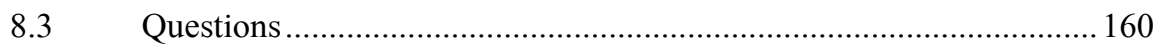




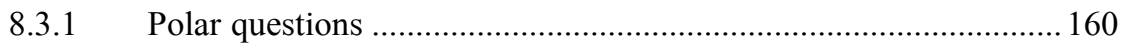

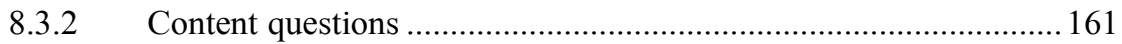

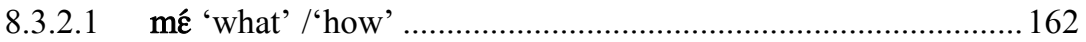

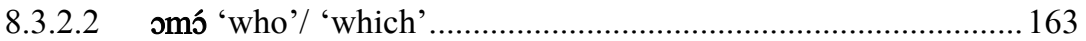

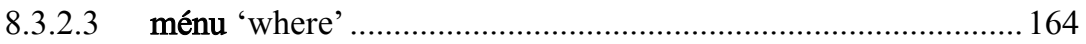

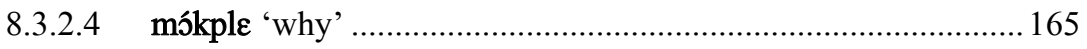

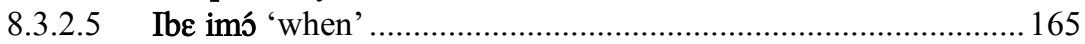

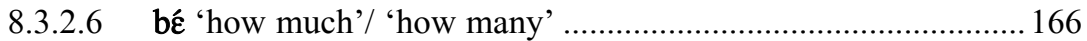

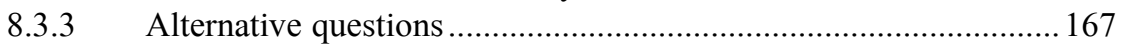

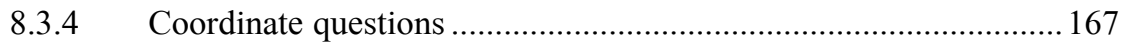

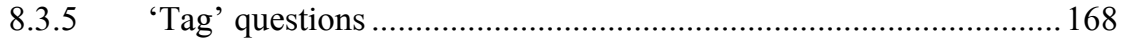

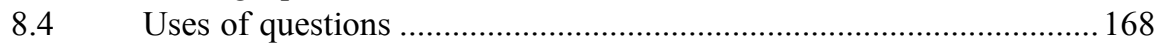

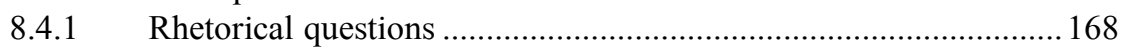

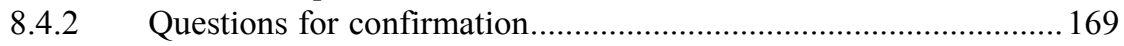

8.4.3 Greeting questions ..................................................................... 170

8.4.4 Question word only questions ....................................................... 171

8.4.5 Questions for more specification................................................... 171

9 DEPENDENT CLAUSES ..................................................................... 173

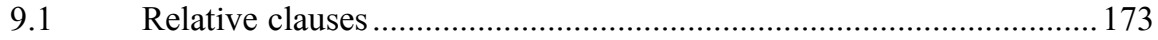

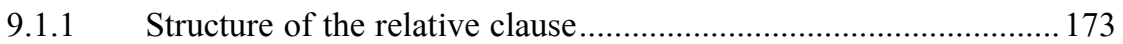

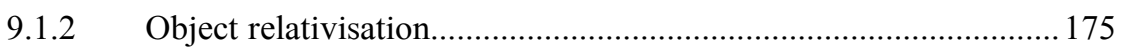

9.1.3 Distribution of relative clauses...................................................... 175

9.1.4 Tense and aspect in relative clauses................................................ 176

9.2 Relativisation hierarchy in Logba ...........................................................

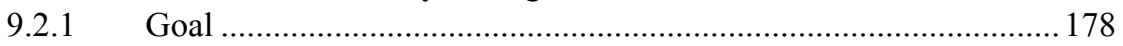

9.2.2 Theme .................................................................................... 178

9.2.3 Objects in a serial verb construction........................................... 178

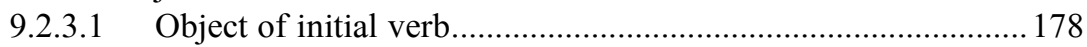

9.2.3.2 Object of second verb in an SVC............................................. 179

9.2.4 Prepositional phrase with postpositions ......................................... 179

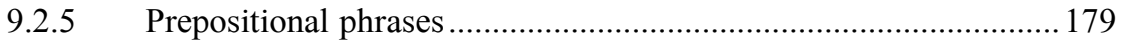

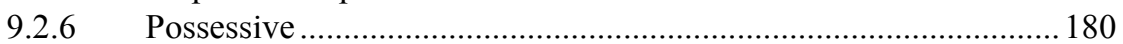

9.3 Complement clauses......................................................................... 181

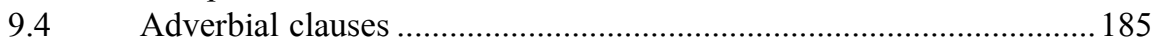

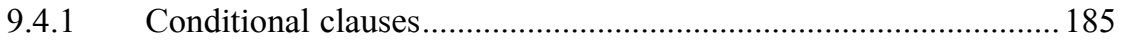

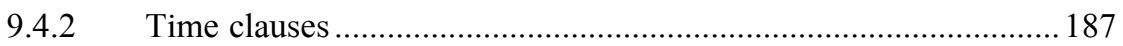

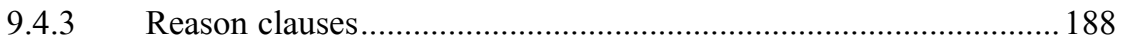

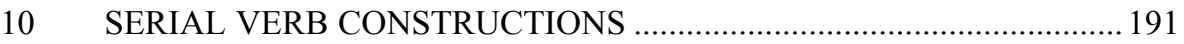

$10.1 \quad$ Serial verb constructions................................................................... 191

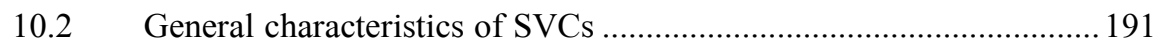

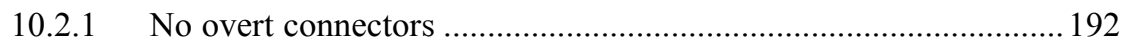

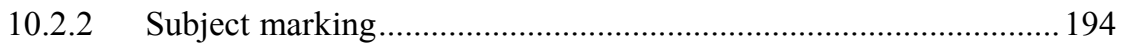

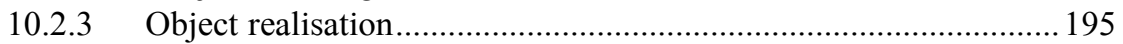

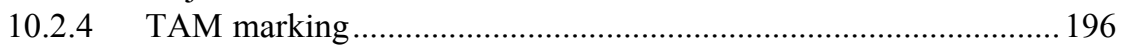

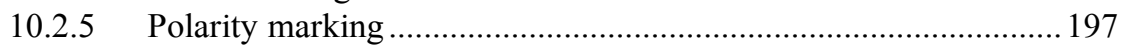




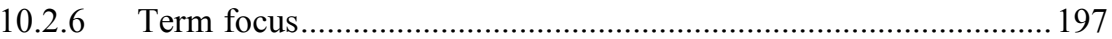

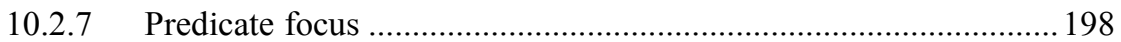

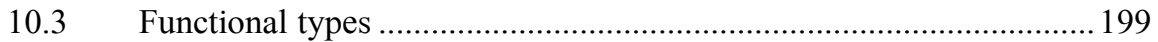

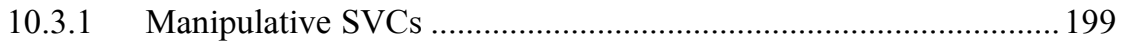

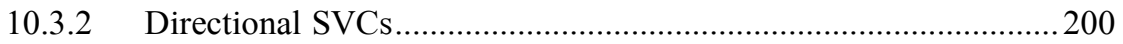

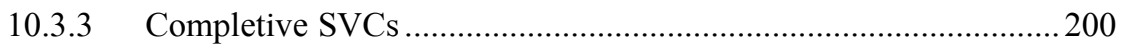

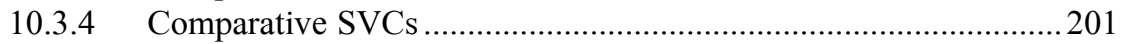

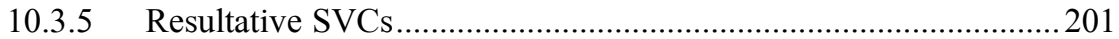

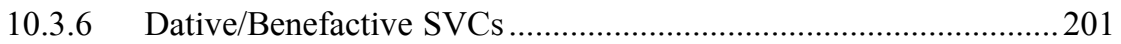

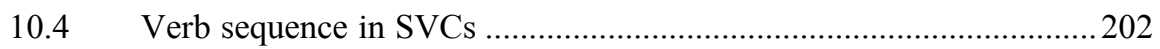

10.5 Lexicalised verb sequences ...........................................................204

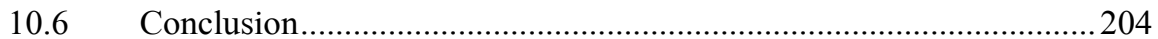

11 REPORTED SPEECH, REFLEXIVE AND RECIPROCAL

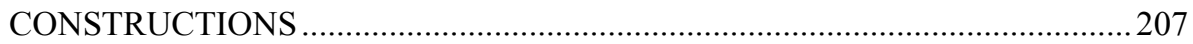

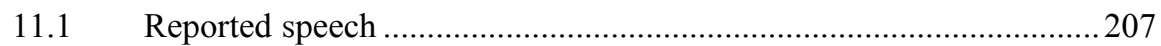

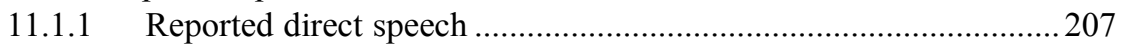

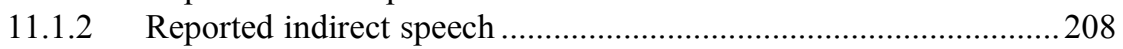

11.1.3 Reported imperative ………………………….............................209

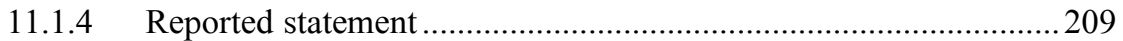

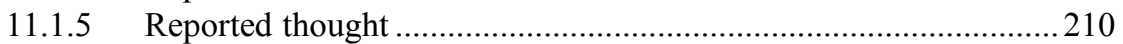

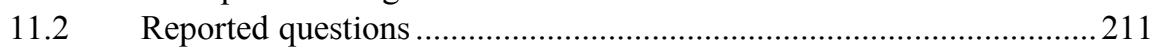

11.2.1 Reported polar questions ............................................................221

11.2.2 Reported content questions ........................................................... 212

11.3 Logophoric pronoun in reported speech ............................................2.213

11.4 Reflexive and reciprocal constructions .............................................2. 214

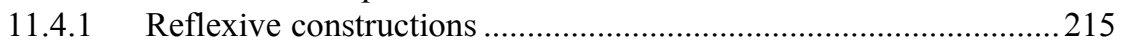

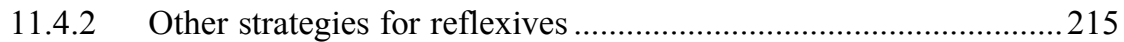

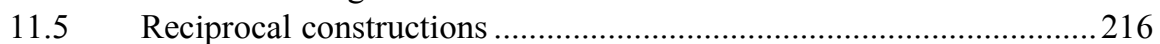

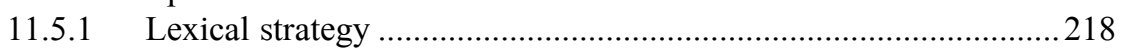

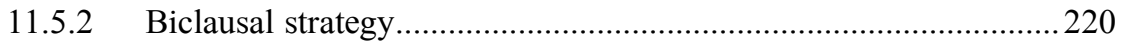

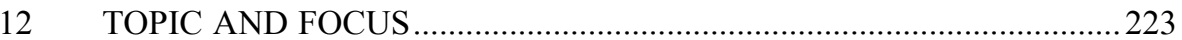

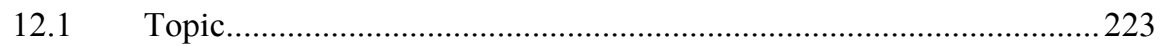

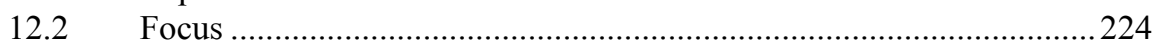

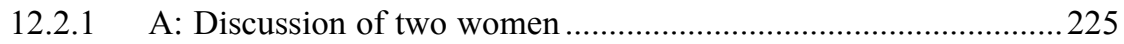

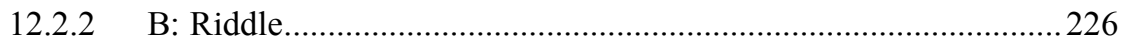

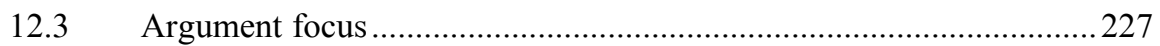

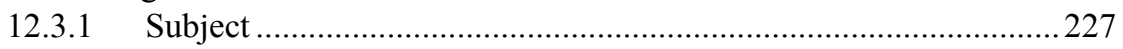

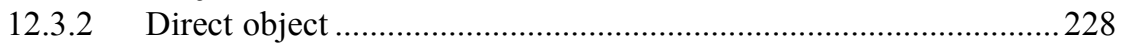

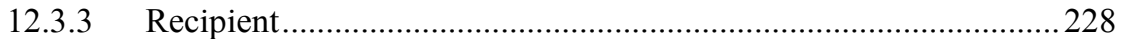

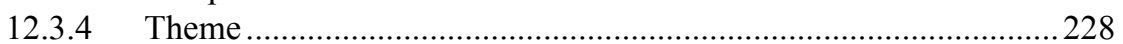

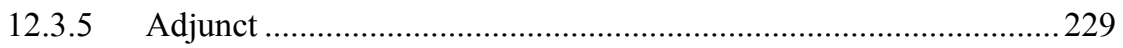

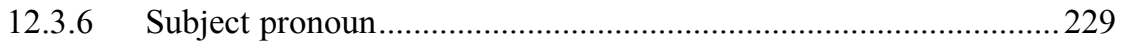

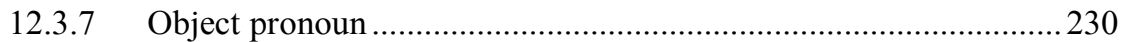

12.3.8 Focusing clause initial adverbials ..................................................231

12.3.9 Focusing arguments in a copula clause........................................231 
12.3.10 Focus in possessive constructions .......................................232

12.3.11 Focusing postpositional phrases .......................................... 233

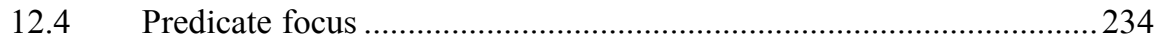

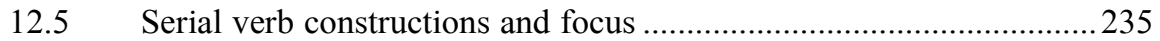

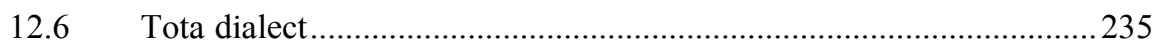

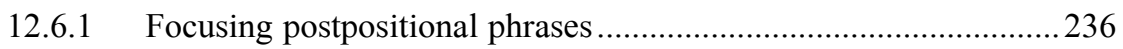

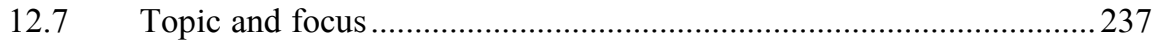

13 IDEOPHONES, INTERJECTIONS AND PARTICLES ..........................2239

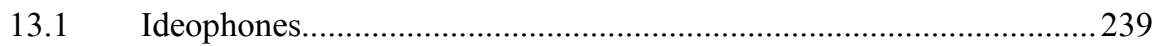

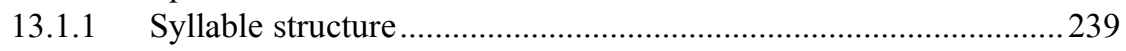

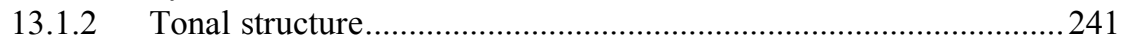

13.1.3 Grammatical categorization of ideophones.................................2 242

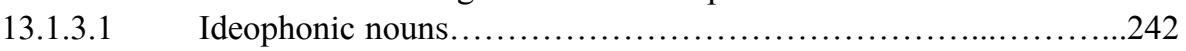

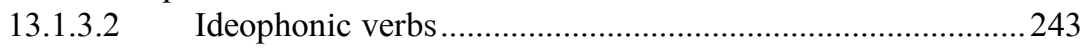

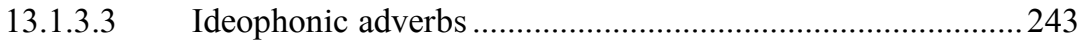

13.1.3.4 Ideophonic adjectives...................................................... 244

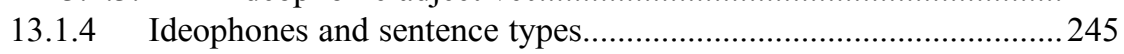

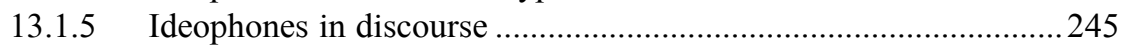

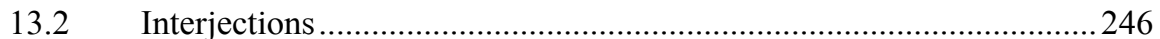

13.2.1 Primary interjections .............................................................. 247

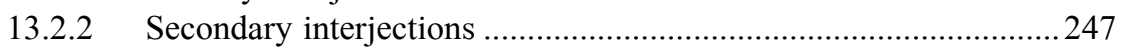

13.2.3 Expressive interjections ............................................................ 248

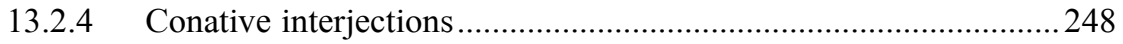

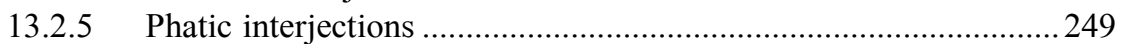

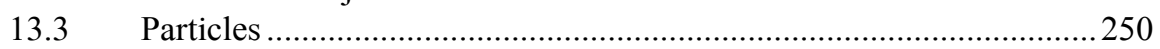

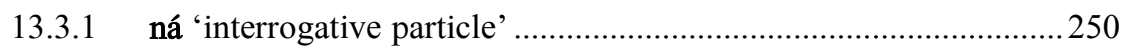

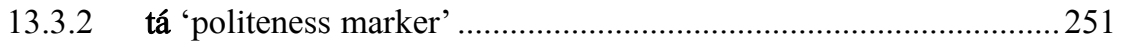

13.3.3 ló 'addressive particle' .................................................................. 252

13.3.4 loo 'addressive particle' ...............................................................2. 253

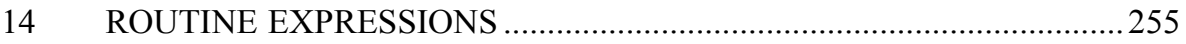

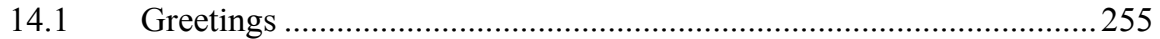

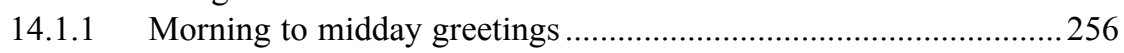

14.1.2 Midday to evening greetings .......................................................256

14.1.3 The greeting response: Yawoen................................................. 257

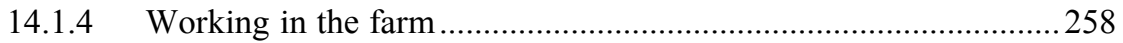

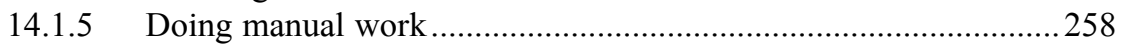

14.1.6 Greeting when people are eating.................................................260

14.1.7 Welcoming people................................................................... 261

14.1.8 Acknowledgement of the priest's return after libation prayer ....... 263

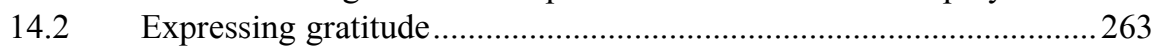

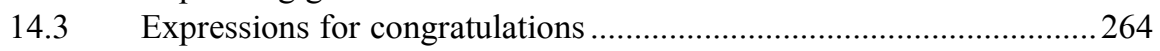

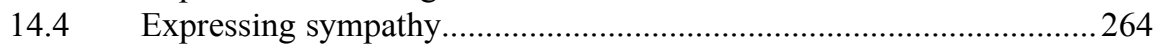

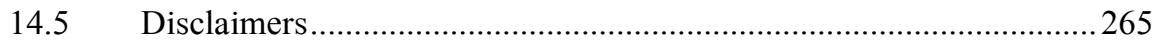

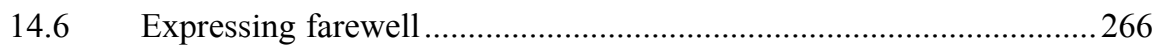

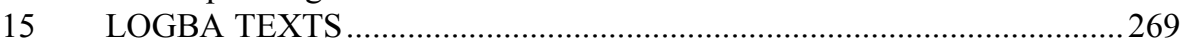




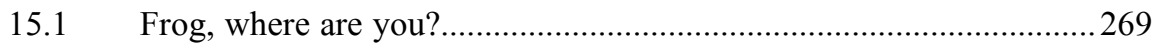

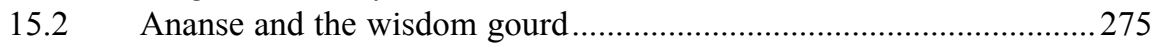

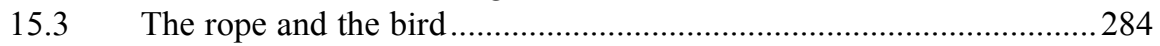

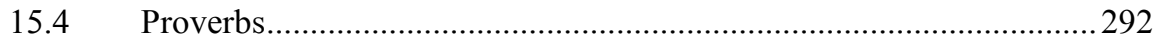

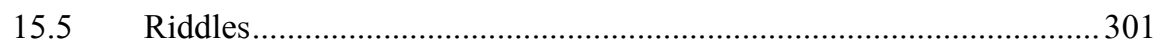

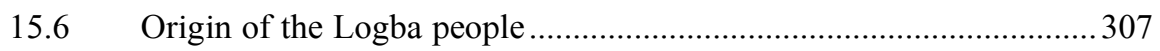

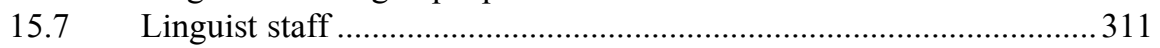

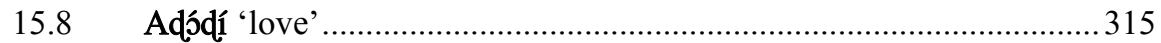

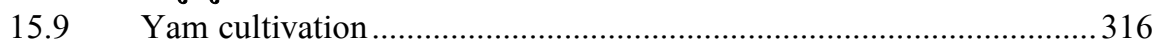

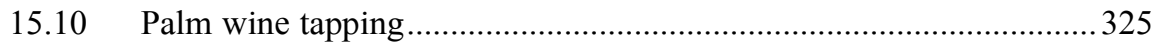

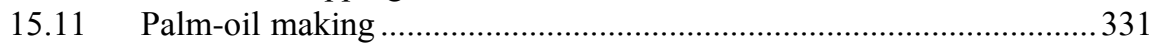

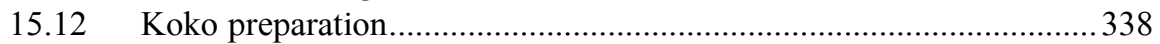

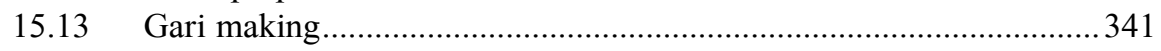

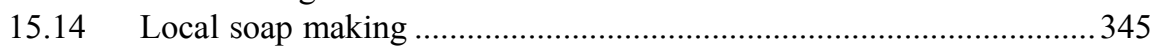

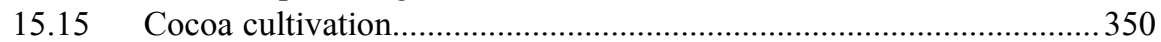

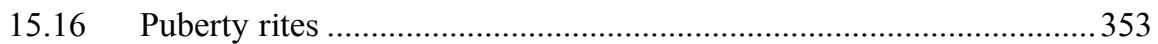

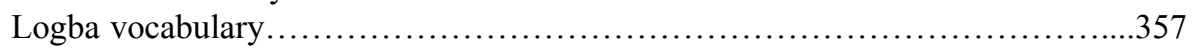

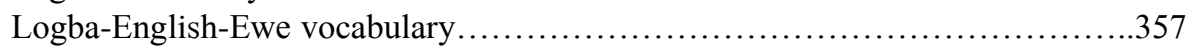

English - Logba index................................................ 403

References..........................................................4 427

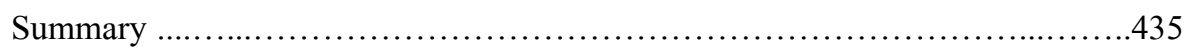

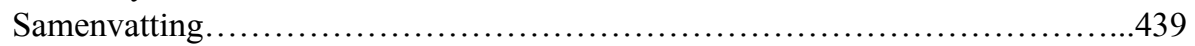

Curriculum vitae.......................................................... 443 


\section{List of abbreviations used}

\begin{tabular}{|c|c|c|c|}
\hline $\mathrm{AFF}$ & Affirmative & OBJ & Object \\
\hline ADR & Addressive particle & ORD & Ordinal \\
\hline $\mathrm{AM}$ & Agreement Marker & PART & Particle \\
\hline$[+\mathrm{ATR}]$ & Advanced tongue root & PLU & Plural \\
\hline [-ATR] & Unadvanced tongue root & PM & Politeness marker \\
\hline $\mathrm{C}$ & Consonant & POSS & Possessive \\
\hline CBP & Cut and break pictures & Post & Postposition \\
\hline CFM & Clause final marker & PROG & Progressive \\
\hline $\mathrm{CM}$ & Class Marker & PRS & Present \\
\hline COMPL & Complementizer & PT & Past \\
\hline COND & Conditional & PV & Positional verbs \\
\hline CONJ & Conjunction & Q & Question word \\
\hline DEM & Demonstrative & QP & Question particle \\
\hline DET & Determiner & REAS & Reason \\
\hline EMPH & Emphatic & $\mathrm{RP}$ & Relative pronoun \\
\hline EXCL & Exclamation & SG & Singular \\
\hline FOC & Focus marker & SM & Subject marker \\
\hline FUT & Future & SUBJ & Subject \\
\hline HAB & Habitual & TOP & Topic marker \\
\hline IDEO & Ideophone & TRPS & Topological relation pic- \\
\hline IMP & Imperative & & ture series \\
\hline IND & Independent & UFP & Utterance final particle \\
\hline INDEF & Indefinite & $\mathrm{V}$ & Vowel \\
\hline INTJ & Interjection & $\mathrm{V}_{1}$ & Initial verb in SVC \\
\hline INTP & Interrogative particle & $\mathrm{V}_{2}$ & Second verb in SVC \\
\hline JUXT & Juxtaposition & $1 \mathrm{SG}$ & First person singular \\
\hline LOC & Locative & $2 \mathrm{SG}$ & Second person singular \\
\hline MOD & Modal & $3 \mathrm{SG}$ & Third person singular \\
\hline NEG & Negative & 1PLU & First person plural \\
\hline NOM & Nominalising suffix & 2PLU & Second person plural \\
\hline & & 3PLU & Third person plural \\
\hline
\end{tabular}





\section{List of grammatical morphemes}

\begin{tabular}{|c|c|}
\hline á /alé & 3PLU.IND \\
\hline a- & $2 \mathrm{SG}$ \\
\hline$=a ́$ & 3PLU.OBJ \\
\hline amú & 1SG.IND \\
\hline ani- & 2PLU \\
\hline anú & 2PLU.IND \\
\hline ati- & 1PLU \\
\hline atú & 1PLU.IND \\
\hline awú & 2SG.IND \\
\hline bó-/bó-/bá & FUT \\
\hline dzue & CONJ \\
\hline é-/ê-/á- & 3PLU \\
\hline$=\hat{\varepsilon} /=\mathrm{e} /=\mathrm{a}$ & DET \\
\hline -go & NOM \\
\hline i- & SM \\
\hline $\mathrm{kp} \varepsilon$ & CONJ \\
\hline$=(1) \hat{\mathrm{e}} /=\hat{\varepsilon}=\mathrm{n} \varepsilon$ & 3SG.OBJ \\
\hline ma- & $1 \mathrm{SG}$ \\
\hline$=\mathrm{m}(\mathrm{u})$ & 1SG.OBJ \\
\hline$=$ nú & 2PLU.OBJ \\
\hline mV...nú & NEG \\
\hline $\mathrm{n}-$ & SM \\
\hline nu & in/containing region (postposition) \\
\hline o /ole/ iyé & 3SG.IND \\
\hline $0-/ 0-$ & $3 \mathrm{SG}$ \\
\hline (o)kpie & INDEF \\
\hline té & COMPL \\
\hline tsú & on/upper surface (postposition) \\
\hline$=$ tú & 1PLU.OBJ \\
\hline$=w u ́$ & 2SG.OBJ \\
\hline $\mathrm{x} \varepsilon$ & $\mathrm{RP} / \mathrm{COND}$ \\
\hline yと́ & CONJ \\
\hline
\end{tabular}


Map 1: Distribution of Ghana Togo Mountain languages

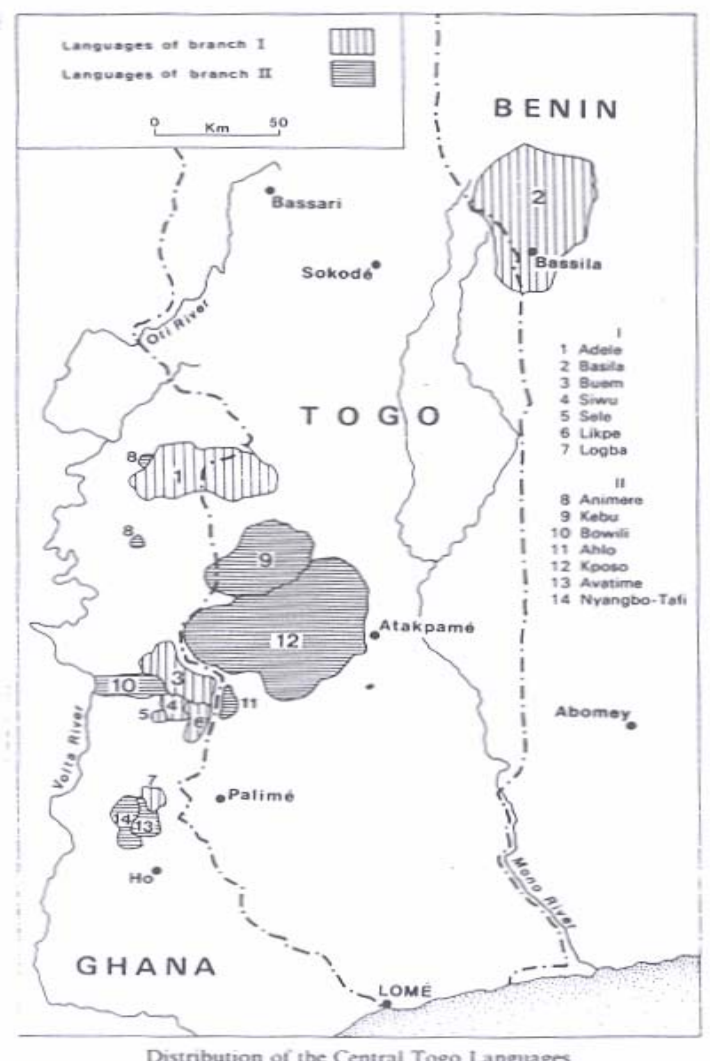

(Source: Bernd Heine, Verbreitung und Gliederung der Togorestsprachen Dietrich Reimer Verlag. Berlin. 1968) 


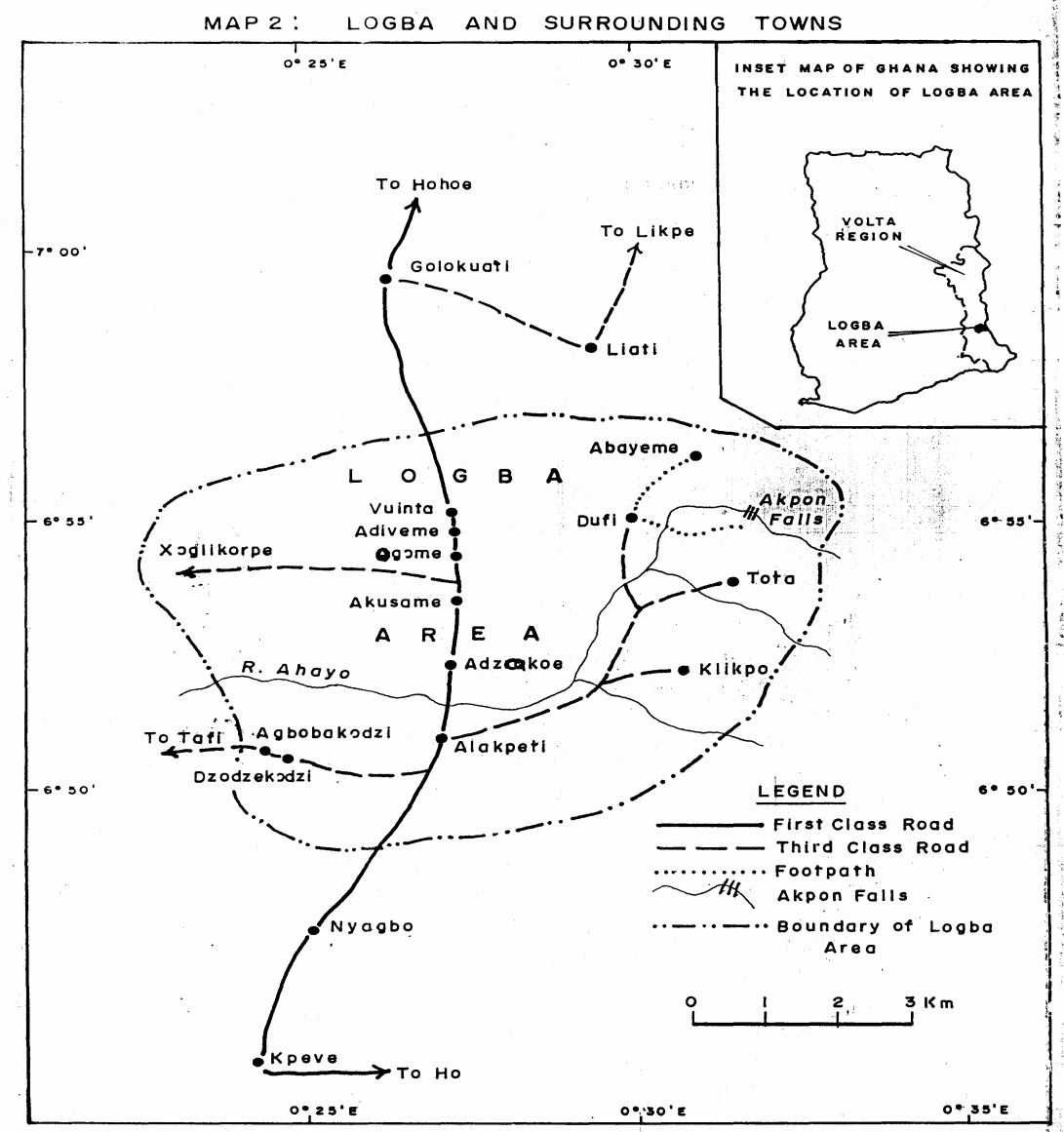





\section{Acknowledgements}

In the course of the study and field research for this publication, I have received immense assistance from many people to whom I want to show appreciation and express my gratitude.

I am greatly indebted to the three anxious and enthusiastic senior citizens I met on my first visit to Logba-Adeline Adiama, Victor Binka and Walter Amedzro-who welcomed me and readily gave me the opportunity to record them and ask them questions on the Logba language. It was this recording that became the preliminary data and the foundation on which I constructed the grammar of Logba.

I wish to thank Prof. Duthie, for extensive comments on an earlier draft, encouragement and support. I shall always remain grateful to him.

I am grateful to James Essegbey who hosted me on my maiden visit to Leiden and formally introduced me to aspects of field techniques.

In addition, I had the opportunity of interacting with many researchers who helped to shape my understanding of field research and African Linguistics to whom I will ever be grateful: They are Enoch Aboh, Azeb Amha, Maud Devos, Connie Kutsch Lojenga, Maarten Kossman, Maggy Konter-Katani, Victoria Nyst, Chris Reinges, Christian Rapold, Thilo Schaedeberg, and Arie Verhagen.

The ideas expressed in the thesis, the methodology employed and the analysis presented benefited immensely from my participation in discussions, talks, meetings and comments from colleagues and researchers in the Leiden University Centre for Linguistics for which I am highly appreciative. I wish to thank Jos Pacilly and Rob Goedemans for providing valuable information on the technical aspects of language documentation and archiving. I am also indebted to Daniela Merolla for guidance and also for valuable help and comradeship during our field trips in Ghana.

I will like to express my gratitude to the staff of CNWS especially Ilona BeumerGrill and Sabine Luning for the stimulating seminars and guidance in the cohort discussions which I will continue to cherish.

Thanks to Ines Fiedler, Anne Schwarz, Stefanie Jannedy and Caroline Féry for providing the opportunity for me to learn how to use instruments for the recording and analysis of language data in a language laboratory while I was their guest in Berlin.

I would like to thank Azeb Amha, Caroline Angenent, Anneke Breedveld, Maggy Konter-Katani, Marlous Tamminga, Sylvia Amevor and Chris Hesse for their support during my stay in Leiden. 
I would also like to thank my $\mathrm{PhD}$ colleagues with whom I shared many ideas both bordering on Linguistics and other aspects of social life. They include: Alwin Kloekhorst, Anne-Christie Hellenthal, František Kratochvil, Guus Kroonen, Heleen Smits, Jenneke van der Wal, Juliette Huber, Louisa Muller, Mark Dingemanse, Mercy Lamptey Bobuafor, Mulugeta Seyoum, Ongaye Oda, Oumou DiabyKassamba, Sander Steeman and Tolemariam Fufa.

My main research assistant in Logba was Nelson Howusu. In addition to him, I have had the opportunity to work closely with native speakers of the language from almost all the Logba towns. These people gave me useful advice during the committee meetings. They include: George Ahorhorlu, John Glawu, C.K. Amedzro and Elikem Akusa- all from Alakpeti. The following are from Klikpo: Ophelia Hesse, Mawuli Kahia, Togbe Shiamoah III, Joseph Kahia, Wisdom Kahia and Beauty Bissiwu. From Tota are E.W.G. Agrah and Catherine Bediako. The rest are Asafo $\mathrm{Kudzo}^{1}$ from Adzakoe, Doko Yao Joseph from Ogome and Nelson Asiedu from Vuinta. All these people helped in no small measure and I extend my heartfelt thanks to them.

At the University of Ghana, I wish to thank the Head of Department and staff of the Linguistics Department, the Director and staff of Language Centre for the guidance they offered me both when I was nursing the idea to move into documentary linguistics and for the various seminars they organized which shaped my understanding of Linguistics in general.

The research reported here was funded by the Endangered Languages Programme of the Council of Humanities (GW) and WOTRO of the Netherlands Organisation for Scientific Research (NWO) as part of the project The southern Ghana-Togo Mountain Groups: A description of their languages and cultural heritage (grant $\mathrm{nr}$ 256-00-500) for which I am very grateful.

Throughout the study both in Ghana and the Netherlands, it was the moral support of my extended family that saw me through. For this, I will forever be thankful.

Last but not the least, I wish to thank my wife and children for the moral support.

It will not be possible to express gratitude adequately to all the people for their immense contribution but I know that the good Lord from whose storehouse all good things flow will reward them a thousand fold. To all these people, I say thank you in the Logba language:

\section{Anyintse}

Thank you.

\footnotetext{
${ }^{1}$ I was informed of his death in January 2007 when I went to Logba. May his soul rest in perfect .peace
} 



\section{INTRODUCTION}

This thesis presents a grammar of Logba, one of the fourteen Ghana Togo Mountain (hereafter GTM) languages in the hills of the Ghana-Togo frontier. The work is the outcome of a research based on two periods of a total of fifteen months of fieldwork in the Logba speaking communities. The major concern of this study is to describe the Logba language. This chapter introduces the people, geographical location, classification of the language and some general information about the characteristic features of the language.

\section{$1.1 \quad$ The people}

The Logba people call themselves Akpanawo. A female Logba person is Akpanadze and a male Logba person is Akpananyi. The indigenous term for the language is Ikpana. This is explained by some native speakers as 'defenders of truth'. One can find words in the language which apparently go to support this claim: Ikpá means 'truth'. anaá is a question particle which is used in conversation by a speaker when he wants confirmation about a proposition. This shows that the word may be related to 'truth'.

There are folk etymologies for the name Logba. According to one story from an indigenous Logba speaker, Logba is derived from two Ewe words ló 'collect' gbě 'rubbish' and refers to those people who in the course of migration of the Ewes from Notsie in present day Togo were in front of the group and made the path by literally 'breaking and collecting the thick vegetative undergrowth' to facilitate the movement for the Ewes who followed.

Another account suggests that the name is from two Logba words, la 'to make' and ogbá 'path'. Logba people were supposed to be hunters who were residing outside the great walls of Notsie and at the time of the migration of the Ewes, they helped to make the path for the Ewes. It is believed that this name was a result of the reference that the Ewes made to them when they heard them saying: la ogbáa! la ogbaá! 'make the path, make the path.' From that time they were referred to by the other ethnic groups as the Logba people.

In one folk story, which is apparently different from the others, the claim was that they migrated from Egypt and Sudan and it took them over 200 years to come to the present settlement. The sentence in (1) below is an extract from a story in Logba by one of the elders:

1. Akpana édu ahá xé édo gú Egypt kpe Sudan ivantsiénu.

$\begin{array}{llllll}\text { Akpana } & \text { é-du } & \text { ahá } & \text { xé é-do } & \text { gú } & \text { Egypt } \\ \text { Akpana } & \text { SM.PLU-be } & \text { people RP } & \text { 3PLU-come } & \text { from } & \text { Egypt }\end{array}$




\section{kpe Sudan i-vantsiénu}

CONJ Sudan CM-area

'The Logba people are people who migrated from Egypt and Sudan areas.' [15.6.01]

\subsubsection{Settlement in the GTM area}

The GTM languages in Ghana are in three geographical groups. Ahlo (Igo), Kposo, Kebu and Bassila are in Togo and Benin. The Northern group in Ghana are Animere and Adele. Bowli, Buem, Siwu and Sele are located a little South of Animere. The southernmost group to which Logba belongs are Nyagbo, Tafi, Avatime and Logba (see map for the distribution of the GTM languages).

Concerning the order in which the people came to the area, it was stated in one of the accounts that the Logba and the Nyagbo people came to the area after the Tafi people but the Logba people were in the area even before the Avatime people settled at their present location. It is plausible that the Logba people are one of the groups that migrated to the Ghana Togo Mountain region but one is not certain which groups they moved with and at what time they came to the GTM area. The Ewes might be one of the people they met on their journey to their present settlement. Plehn $(1899: 18-20)^{2}$ reports that:

Avatime people however assured me that their ancestors, upon their arrival in the Togo Mountains, already came across the Logba.

Nugent (1997) suggests that the GTM region has seen ample language shifts and the adoption of languages by whole groups as it served as refuge for populations fleeing from Asante invasions from the West in the nineteenth century and from Dahomean military operations of the nineteenth century (see also Nugent 2005).

Other reports summarised in Dakubu (2006) state that the Logba people possibly are the descendants of the powerful Maks ethnic group, which controlled the greater part of the area and were conquered around 1750. The widespread view now among the Logba is that they migrated from Notsie with the Ewes as a result of the cruel rule of Agorkorli of Notsie. It can be argued that the remaining Mako ethnic group after their conquest was joined by some groups who possibly included some Ewes who migrated from Notsie. Also, it is possible that other ethnic groups who were driven from their homelands came to join the remaining descendants of the Maks ethnic group who found the mountains as a refuge. This can be corroborated by stories I heard from the Logba area maintaining that the early settlements were in the mountains of Aya and that settlements along the road and the lowlands are later developments when the area started to enjoy relative peace.

\footnotetext{
${ }^{2}$ Thanks to Mark Dingemanse for the translations of the German original.
} 


\subsubsection{Geographical location}

Logba falls in the Hohoe administrative district in the Volta Region of Ghana and it is about 200 kilometers from the coast. It is a mountainous region bounded on the North-East by Avatime, the South by Nyangbo-Tafi and on the West by Ve. On the Eastern part is the Ghana-Togo Mountains (GTM) ${ }^{3}$. The 2002 estimates of the Hohoe District Assembly indicate that Logba has 6,400 inhabitants. A survey I conducted in 2006 gives a total population of about 7,500 inhabitants in all the Logba towns and settlements

The Logba people live in the following townships: Vuinta, Ogome, Akusame, Adiveme, Adzakoe, Alakpeti ${ }^{4}$, Tota, and Klikpo, where the paramount seat is located. Other new settlements have sprung up which are small farming communities adjoining these towns and villages: Abayeme and Dufi are villages which are on the outskirts of Tota. Xoglikofe is a small settlement north of Akusame. These new settlements are inhabited mostly by settler farmers who are from other ethnic groups. Agbobakodzi and Dzodzekodzi are new settlements of Ewe speakers founded by settlers from Dzodze, a town in the Ketu District of the Volta Region of Ghana (refer to map 2). These villages are all Ewe speaking with Ewe names. They are close to Alakpeti, the commercial centre of Logba. Andokofe shares a boundary with Adzakoe and it is inhabited mainly by people from Ando, a town in the Southern part of the Republic of Togo. There are a few people in these new settlements who speak Logba as a second language. Some Logba people have moved into these new settler communities and built houses and settled in these areas. This movement of Ewe speakers to the Logba area resulted in a situation commented on by Dakubu and Ford (1988:125) that:

...the Logba have the most extensive local contact with Ewe; for exam-

ple, the Ewes probably now outnumber the Logba on Logba lands.

The Logba towns and villages are located on the trunk road from Accra to Hohoe except Tota, which is on the top of the Aya hills ${ }^{5}$. Climbing the hills, one finds Akpon falls and small caves inhabited by bats. There are pieces of rocks that point upwards from the floor of the caves and other wonderful geographical features that attract tourists to the area.

\footnotetext{
${ }^{3}$ See the map of Ghana and that of Logba for the location.

${ }^{4}$ Alakpa is a name of one of the hills in Logba. etsi means 'ground, under' Alakpeti thus refers to Alakpa hills. It is one of the low lying settlements which has now become a centre for commercial activity.

${ }^{5}$ This is the highest point in Logba. Tota is the Ewe name for Ayotsu /aya-otsu/ 'top of Aya' Aya is one of the early places on the hills where Akusame, Adiveme and Ogome stayed together as one settlement.
} 
The Logba people are peasant farmers. The main agricultural products they cultivate are cassava, maize, yams, rice, plantain, and cash crops like cocoa, coffee, peas and oil palm, whose wine is used in the distillation of Akpeteshie, a local gin 6 .

\subsubsection{Some religious practices}

Christians of various denominations can be found in Logba e.g. Evangelical Presbyterian, Roman Catholic, Pentecost and others. There are others whose form of religion centres around ancestor reverence and the worship of the supreme deity which is known in Logba as Sumafa ${ }^{7}$ but generally called Akpanamo 'Logba god'. The priest, Amowasa/Amonutsiwo is the pillar around whom traditional religious activities revolve. He performs libation during most of the local traditional ceremonies. Ayadzi 'Saturday' is a special day for the priest. He does not go to the farm on this day; rather he is supposed to stay at home and offer prayers in the house of Sumafa. A she-goat is not supposed to be slaughtered in the town. In June, when preparation for the cultivation of rice begins, Amowasa pours libation to the gods. Also, during the yam festival in September, he is called upon to pour libation. Other rites are performed which have religious components. I will talk about two of them. First appeasing the gods after a violation such as suicide, second girls puberty rites.

Libation prayer is also performed to appease the gods when there is a violation. On one occasion when a case of an attempted suicide was reported to the elders, the culprit was brought to the public court of the local chief where he was made to pay a fine of one ram and some kegs of palm wine. The palm wine was used to pour libation and the ram was sacrificed. The ceremony was crowned with advice from elders to the accused person on how to live a socially acceptable life.

Experienced elderly women perform edzezigo 'puberty rites' for the girls. They teach willing young virgins hygiene, home economics, culture and management as a preparation for future marital life. Here also libation prayer is performed for blessing for the young virgins and the family they come from. After the training, there is always an elaborate passing out ceremony which is an occasion of great joy, drumming and dancing.

With funds from the town, the triumvirate of Logba, Odikro ${ }^{8}$, 'a senior statesman' Okyeame, 'the spokesperson' and Amowasa 'local priest' perform the Ogboglego,

\footnotetext{
${ }^{6}$ According to Ghanaian Times January 13, 2007 this was first introduced in Logba in the early 1900s by two West Indians who came to Ghana.

${ }^{7}$ The word Sumafá is made up of three morphemes: osu 'thunder' mo NEG fá 'cross over.' The name indirectly refers to the powers of the god which is so great that thunder, which is feared by many people in the area, cannot pass over.

${ }^{8} \mathrm{He}$ is also referred to as ogbowasa 'town owner'. Odikro is an Akan based term but it is used in Ewe communities as well. The Ewe equivalent Dutor/Afetor translates as 'Lord of
} 
literally 'tying of the town' ceremony which is aimed at invoking spiritual protection for the town against evil forces and saboteurs. These religious activities are generally designed to promote harmonious relationship and continuity with the past and to assure the people of good harvest.

\section{$1.2 \quad$ Language}

Logba is one of the fourteen languages concentrated in the hills of the Ghana-Togo frontier which have been referred to as the Togo Restsprachen (Struck 1912), Togo Remnant $^{9}$ languages or the Central Togo languages (Dakubu and Ford 1988). These languages are now commonly referred to as GTM languages, (Ring 1995).

\subsubsection{Classification}

There are differences in opinion on the classification of GTM languages. Westermann and Bryan (1952) seeing that these languages have vocabulary items which show a relationship to Kwa and a noun class system that is similar to Bantu languages consider these languages as an isolated group. Greenberg (1963a) classifies them among the Kwa sub-group B of the Niger-Congo family. Based on a comprehensive linguistic comparison Heine (1968) sub-classified them into KA and NA, (see map 1). Stewart (1989) submits that the two branches belong to two different branches of Kwa: The KA belongs to the left bank branch together with Gbe including Ewe and the NA group, to which Logba belongs, is in the Nyo branch including Tano which includes Akan and Ga-Adangbe. Williamson and Blench (2000) suggest that the KA and the NA subgroups branch out from Proto Kwa. Blench (2001:5) points out the difficulty in establishing the GTM languages as a group in relation to Kwa, and suggests that these languages may be better seen as a mixture of a single-branch languages and small clusters within Niger Congo.

In all these classifications, the difficulty in getting adequate information on each of the fourteen GTM languages in order to come out with an acceptable classification for scholars of all persuasions is evident. However, it is apparent from the classifications that Logba is consistently in the NA sub group and her geographical neighbours are Nyagbo, Tafi and Avatime which are KA. The linguistic neighbours of Logba are located in the northern cluster of GTM languages. The NA group, to which Logba belongs, has three sub-groups in Heine's classification and Logba and Ani are in separate sub-groups. In Blench's revised tentative classification (Blench 2006 ) the NA group has two sub-groups and Logba is again in its own sub-group with Lelemi, Lolobi and Likpe forming a separate sub-group. I should think a ho-

the town'(see Egblewogbe 1990).

${ }^{9}$ My interactions with most native speakers who are literate and understand the meaning of this term suggest to me that they feel uncomfortable when this word is used to describe their mother tongue. 
listic linguistic description similar to this if it is done for all the fourteen languages will clear the air and help to arrive at the definitive classification and the position of Logba in GTM - Na group.

\subsubsection{Previous studies on the language}

Logba is one of the least studied of the fourteen GTM languages. The only published material exclusively on the Logba language is Westermann (1903) which is a concise grammatical sketch in German. Other works, Bertho (1952), Heine (1968), Greenberg (1968), Egblewogbe (1990) and Dakubu and Ford (1988) are studies on the GTM languages which provide information on Logba as a member of the group. Logba is also reported on in Ladefoged (1964) as part of phonetic linguistic study of West African languages.

\subsubsection{Socio-linguistic situation}

Many native speakers of Logba, speak Ewe, and Twi. Ring (1981) in a sociolinguistic survey of the non-Ewe language communities located between Have and Kadzebi reports the following percentages of language ability claims in Logba $\operatorname{area}^{10}$ :

$\begin{array}{llll}\text { Ewe } & -92 \% \quad \text { Akan } & -28 \% & \text { English - }\end{array}$

From a survey I conducted on the languages spoken in Logba and the number of people who speak these languages, one sees that some of the local residents who have access to basic formal education can communicate and understand basic instructions in English. Out of a total population of 7,500 inhabitants, 7,120 claim to speak Ewe and Logba. There is however no one identified in Logba who claims to speak only Logba.

It is rare to find people who are bilingual in two GTM languages. The few I found in the area who have a fair knowledge of another GTM language in addition to Logba are men / women who married from another GTM community or have either schooled or worked in one of the neighbouring towns. Among the other three GTM languages in the area, Avatime, Tafi and Nyagbo, there are more multilinguals that have Avatime as one of their languages. A survey reveals that the people who claim to have the ability to understand and communicate in Avatime are $11 \%$. This is far greater than the percentage for Tafi and Nyagbo which together is $4.8 \% .{ }^{11}$ The relatively high percentage recorded for Avatime is not surprising: Logba is almost surrounded by Avatime towns. Schools were established by the German missionaries earlier in Avatime. Because there were no schools in Logba

\footnotetext{
${ }^{10}$ Logba was one of the communities on which Ring's sociolinguistic survey touches.

${ }^{11}$ This is based on the 2006 population survey I conducted.
} 
at that time people went to school in Avatime. Some of the early scholars from Logba are said to be alumni of these schools where they were informally exposed to the Avatime language. This suggests that there was a long standing social interaction between the people of the two towns.

There are eight primary schools, three junior secondary schools and one senior secondary school in Logba. Children speak the Logba language in their homes but Ewe is spoken in school because it is the de facto medium of instruction in the primary school in Logba. It is observed that many of the children cannot speak English before they enter school. In the senior secondary school, the English language is used but one can hear Logba, Ewe and Twi as one interacts with the students.

Because the people live in eight settlements next to each other, the dialectal variation is not pronounced. Native speakers with whom I interacted acknowledge that the Tota dialect, spoken mainly by people on the hills is distinct from the linguistic variety used for communication in the settlements in the low lying areas, especially in Alakpeti, the commercial centre. The differences between the varieties exist more in the phonology than in the other aspects of the grammar. In this study, an effort is made to point out these differences where they occur and offer an explanation where possible. In a number of instances where it is apparent, I have made the attempt to differentiate between not only the dialectal differences but also the difference in careful word for word speaking and connected discourse.

\section{$1.3 \quad$ Brief outline of the language}

This section is aimed at giving a summary of the main grammatical features which will then be discussed in greater depth in the chapters that follow. There are three syllable types in Logba. These are: peak only, which can be a vowel or a nasal, onset and peak, and an onset made up of two consonants plus peak. Logba is a tone language with two basic tones: These are High and Low with falling and rising tones generated phonetically. Each syllable bears a tone of its own. In this book, a High tone is marked (' $)$ and Low tone is unmarked. Rising tone which is phonetically realized on a single syllable peak is represented as $\left({ }^{\checkmark}\right)$. Tone is realized on vowels and syllabic nasals. Logba has twenty-two consonant phonemes and seven vowels. There are no phonemically nasalised vowels in the language. The nasalised vowels are a result of assimilation. It has a stem controlled Advanced Tongue Root (ATR) vowel harmony system where the stem determines the [ATR] value of the affixes.

Logba is an SVO language. The subject is cross-referenced on the verb in the form which agrees with the subject in class. The noun modifiers follow the head and there is agreement between the demonstrative and interrogative with the head noun. Among the numerals, it is the numbers, one to six that show agreement with the head noun. 
The verb roots take prefixes which are subject pronominal prefixes or aspect markers. In three place constructions with a single verbal element, the Recipient precedes the Theme.

In kin possession, the kin term is not marked with its class prefix.

Logba has five prepositions and quite a large number of postpositions. There are three question words in Logba which are used to form six question expressions to ask content questions.

Logba is a verb serialising language. In Serial verb constructions, the initial verb is marked for the subject and the subsequent verbs are not marked. Sentences are not overtly marked for tense. Four morphological preverbal markers are identified in Logba. They are present progressive, past progressive, habitual, and future markers. There are few underived adjectives in Logba. Some intransitive verbs have adjectival meanings in addition to other derived adjectives and ideophones. Negation is expressed using a bipartite negative marker; the first part which is obligatory occurs before the verb and the second after it. In a Serial verb construction, the first part occurs before the initial verb and the second after it. Where a lexical noun is used, the subject marker comes in between the verb and the first negative morpheme.

The term focus marker is ka and follows immediately the constituent that is focused. Focusing the verb is done by placing the bare form of the copy of the verb immediately before the verb word. Speakers of the Tota dialect use another strategy: For term focus, the prominent NP is fronted and is recapitulated by the independent pronoun followed by the rest of the clause.

\section{$1.4 \quad$ Data collection}

Data for this study was collected during fieldwork in Logba for a total of fifteen months divided over two periods living in Logba Alakpeti and regularly visiting the other towns and villages. I familiarized myself with the place and was learning the language. 1 began by eliciting lexical data using as a starting point the Ibadan 400 wordlist, a wordlist including items based on characteristics of West African languages. Other lexical data was extracted from text recordings leading to 1600 entries in Logba-English- Ewe vocabulary (see pages 357-403).

I also elicited syntactic structures to supplement information from other sources. Spontaneous language production was recorded in addition to stimulated data using visual stimuli - A Frog story narrative description, Topological Relation Picture Series, Cut and Break video clips. The last two materials have been designed by the Language and Cognition Group of the Max Planck Institute for Psycholinguistics (some of the elicitated data are the texts in chapter 15). In the collection of 
field data, emphasis is on spontaneous spoken texts of various genres: conversations, proverbs, stories, riddles etc. Supplementary information is obtained from direct elicitation guided by questionnaires for linguistic and cultural fieldwork such as Bouquiaux and Thomas (1992) Comrie and Smith (1977) McKinney (2000), and Payne (1997). Informal interviews were also conducted. The data were recorded using audio (mini disc) and video, after which they were transcribed and interlinearised. These constituted a database for the analysis of the grammar presented.

\subsection{Methodological and theoretical framework}

A holistic anthropological linguistic approach to language documentation is the methodology adopted in this work. My fervent desire is primarily to write a grammar that will show clearly the structure of the language which will serve as a record for the people. This calls for the use of the theoretical concepts that are in line with what Dixon (1997:128) refers to as Basic Linguistic Theory. It is a cumulative framework that employs mainly the techniques of analysis derived from traditional grammar and accepts the influences from other theoretical models developed over the years (see Dryer 2006). In the use of this theory, every part of the language is described with analysis and arguments on how the language is used, taking note of how context and situation contribute to give the particular sense (meaning) that the people share. In addition, a conscious effort is made to explain every grammatical point discussed using terminology and abbreviations that in my estimation will not be beyond the comprehension of linguists and the interested reader.

The elucidation of the meanings of concepts although done in English, is approached from the perspective of Logba speakers rather than from a point of view external to Logba. Some of the data that is collected and used in writing the grammar are provided in chapter 15 with relevant information about the source to serve as reference and guide for future researchers who want to work on other aspects of the language. Also a reader of the grammar can also verify any points of analysis by examining the body of data so as to shed more light on what still remains hidden and eventually facilitate further comparison of the GTM languages.

\subsection{Outline of the grammar and presentation of data}

This book is organised as follows. In chapter 2, I give a description of the phonological system of the language. Chapters 3 and 4 concern nominals: The structure of nouns and noun classes are presented in chapter 3 while the structure and types of noun phrases are discussed in chapter 4 . Chapter 5 discusses adpositions and adpositional phrases. Basic clause structure, non verbal and locative predications are presented in chapter 6 . The next five chapters focus on verbal constructions with different degrees of complexity. Chapter 7 concerns verbs and verbal modifiers and chapter 8 looks at sentence functions and I move on to discuss dependent clauses in chapter 9. Serial Verb Constructions are presented in chapter 10. Re- 
ported speech, Reflexive and Reciprocal constructions are discussed in chapter 11. Information packaging in the clause in terms of topic and focus articulation is described in chapter 12 . The last two chapters relate to constructions that are sometimes considered marginal to grammar (Sapir 1922) but which are very crucial for communication. Chapter 13 discusses ideophones, interjections and particles. The final chapter, chapter 14, presents routine expressions used in social interaction.

In chapter 15, a number of texts which are translated are presented in addition to Logba - Ewe - English and English -Logba wordlists. Logba language texts and their translations in the grammar are presented in four lines as follows:

2. Azuzo fé ale blome ibo

$\begin{array}{lllll}\text { a-zuzo } & \text { f'́ } & \text { ale } & \text { blo-me } & \text { i-bo } \\ \text { CM-housefly } & \text { also } & \text { 3PLU } & \text { make-LOC } & \text { SM-stay } \\ \text { 'Houseflies also have their importance' } & {[15.4 .63]}\end{array}$

The first line is the Logba data showing word divisions. Words belonging to a compound are separated by a hyphen. Clitics are written as separate words. In the second line, the Logba data is presented in bold with morpheme breaks indicated by hyphens (-) and clitics indicated by the equal to sign. (=) The interlinear English gloss is in the third line and a free English translation is provided enclosed in single quotes. The source of the example, if it is available in the texts, is given in square brackets. 


\section{PHONOLOGY}

This chapter provides the features of the phonology of Logba. It begins with syllable structure and moves on to describe consonants and vowels and how they pattern in the language. The chapter concludes with tone, phonological processes and loanword phonology.

\section{$2.1 \quad$ Syllable}

The significant elements in the syllable are vowels, consonants and tone. The syllable has parts: The onset is the initial constituent(s) of the syllable. A vowel, the most sonorous element in the syllable, is the peak.

There are three syllable types in the Logba language. They are as follows:

1. Peak only. (With a tone) The peak can be either a vowel or a nasal.(V/N)

2. Onset and Peak. (With a tone) (CV)

3. Two consonant onset and a Peak. (With a tone) (CCV)

\subsubsection{Peak only (V)}

In Logba, this syllable type is either a pronoun or a prefix to the stem of a word. Vowels can occur as syllables by themselves. The peak only syllable in (1) is a prefix to each noun stem.

\begin{tabular}{|c|c|c|}
\hline \multirow[t]{3}{*}{ 1. $/ \mathrm{i} /$ as in } & i-mó & 'neck' \\
\hline & i-nyo & 'two' \\
\hline & i-be & 'season' \\
\hline /e/ as in & e-ví & 'sun' \\
\hline$/ \varepsilon /$ as in & $\varepsilon-d z \varepsilon ́$ & 'women' \\
\hline \multirow[t]{3}{*}{$/ \mathbf{u} /$ as in } & u-zí & 'door' \\
\hline & u-kú & 'bone' \\
\hline & u-fóto & 'marshy area' \\
\hline \multirow[t]{2}{*}{$/ \mathrm{a} /$ as in } & a-bé & 'oil palm' \\
\hline & á-fúta & 'cloth' \\
\hline \multirow[t]{2}{*}{ /o/ as in } & o-núkpá & 'king' \\
\hline & ó-dró & 'elephant' \\
\hline \multirow[t]{2}{*}{$/ \mathrm{o} /$ as in } & 0-yó & 'tree' \\
\hline & --wó & 'mortar' \\
\hline
\end{tabular}


Peak only syllable also occurs as 3SG or 3PLU object either after a verb or a preposition. It can also occur as a determiner after a noun (see section 2.3.3). This is shown in the following examples.

2. me.á 'sew them'

futo.á 'mix them'

di.é 'suck it'

bu.é 'ask it'

kpi.é 'with it'

féá 'at them'

aklo.é 'the goat'

egbi.é 'the stone'

The vowels which occur as syllables by themselves and function as pronouns are: /ع/, /e/, /i/, /o/, /っ/ and /a/. No close back vowel occurs as vowel only pronoun.

\begin{tabular}{|c|c|c|}
\hline \multirow[t]{2}{*}{ 3. / / / as in } & $\varepsilon$-mó & 'They laughed.' \\
\hline & e-zá & 'They cooked.' \\
\hline /e/ as in & e-kpófú & 'They barked.' \\
\hline$/ \mathbf{i} /$ as in & i-yú & 'It is cold.' \\
\hline$/ \mathrm{o} /$ as in & o-zó & 'He /She went.' \\
\hline & o-bá & 'He /She came.' \\
\hline /o/ as in & o-ké & 'He/She jumped.' \\
\hline$/ a /$ as in & á-bá & 'You came.' \\
\hline & á-gbá & 'You sweep.' \\
\hline
\end{tabular}

A nasal can form the peak of a syllable. It is any of the following nasals: $/ \mathrm{m} / \mathrm{n} /$ and $/ \mathrm{y} /$. The palatal nasal does not occur in this position. These nasals are homorganic with the consonant in the next syllable and occur in word initial or medial position. These are illustrated in (4) below.

4. $/ \mathrm{m} /$ as in nú.ḿ.blé 'fifth'

$\begin{array}{lll} & \text { á-bǔ.ḿ.bá } & \text { 'wing' } \\ & \text { m-gbí.ní } & \text { 'okro' } \\ / \text { n/ as in } & \text { a-ka.ń.dó } & \text { 'milipede' } \\ & \text { a-kó.ń.tí } & \text { 'basket' } \\ & \text { n-dú } & \text { 'water' } \\ / \text { /y/ as in } & \text { y-gbo } & \text { 'rashes' } \\ & \text { a.y-kpá } & \text { 'juju' }\end{array}$

All the words with a syllabic nasal in either initial or medial position are nouns.

Some words appear to have a syllabic $/ \mathrm{n} /$ in word final position. However, the $/ \mathrm{n} /$ in these words is actually an allomorph of $\mathrm{nu}$ 'containing region' (Dorvlo 2004:246). This is shown in (5) below: 
5. afá 'house' afá-nu 'house-in' $\rightarrow$ afạn 'home'

ubo 'farm' ubo-nu 'farm-in' $\rightarrow$ ubon 'farm'

Other examples that are in the language are in (5).
6. kpi-wá-ṇ 'go-shit-in'
bú-zúgbó-ṇ 'count-head-in'
e-kélé-n 'grass-in'

\subsubsection{Onset and peak (CV)}

This is the most common syllable type and it can form a word by itself or it can occur in a polysyllable in any position. In this type of syllable, the peak can only be a vowel.

$\begin{array}{lr}\text { 7. ba } & \text { 'come' } \\ \text { gba } & \text { 'sweep' } \\ \text { go } & \text { 'grind' } \\ \text { ḱ́ } & \text { 'jump' } \\ \text { dzosú } & \text { 'blood' } \\ \text { bisí } & \text { 'cola nut' } \\ \text { ganú } & \text { 'greet' }\end{array}$

\subsubsection{Two consonants onset and a peak (CCV)}

This syllable type can form a word by itself. It can occur in polysyllabic words as a stem of a word in both word initial or word final positions. The onset of this type of syllable is made up of a consonant cluster of two consonants. The second consonant is either $/ 1 /$ or $/ \mathbf{r} /$, or a glide.

$\begin{array}{ll}\text { 8. akló } & \text { 'goat' } \\ \text { aváblowo } & \text { 'native doctor' } \\ \text { ivafli } & \text { '(thing) white' } \\ \text { utróme } & \text { 'work' } \\ \text { tro } & \text { 'refuse' } \\ \text { igla } & \text { 'jaw' } \\ \text { wli } & \text { 'many' } \\ \text { wla } & \text { 'waste something }\end{array}$

The [ + grave] first consonant in a cluster (labial, labial dental, labial velar or velar consonants) selects $/ 1 /$ as the second consonant. On the other hand, $/ \mathrm{r} /$ is selected by a [-grave] (alveolar, alveo palatal or palatal) first consonant. Many words containing these syllables are loan words. 
Another type of two consonant onset has a glide as second consonant. The glide is either $/ y /$ or $/ \mathbf{w} /$. The central vowel /a/ goes with both glides. This syllable can form a word by itself. It can occur in polysyllabic words as a stem of a word. This is exemplified below:

$\begin{array}{ll}\text { 9. gwókpo } & \text { 'fight with blows' } \\ \text { ebítwó } & \text { 'children' } \\ \text { ywé } & \text { 'pound' } \\ \text { bwá } & \text { 'fold' } \\ \text { bwé } & \text { 'animal' } \\ \text { nen.tswi } & \text { 'cow' } \\ \text { onzyé } & \text { 'owls' } \\ \text { byá } & \text { 'boil' } \\ \text { abyá } & \text { 'chair' } \\ \text { fyé } & \text { 'exceed' } \\ \text { fyé } & \text { 'dehust corn' } \\ \text { gokwadu } & \text { 'nine' }\end{array}$

A palatal nasal / $\mathrm{n} /$ does not occur before a consonant (or glide) hence the digraph /ny/ is unambiguously [n] and phonemically never/ny/. As a result, /ny/ is always considered a single consonant.

\section{2}

Consonants

The following are the consonant sounds of Logba including allophonic variants. The pair of sounds in bold only occur as allophones. The sound in italic is a dialect variant. In the discussion, we differentiate allophonic variation and phonemic opposition. Phonetically /y/ is palatal approximant [j].

Table 2.1: Consonant sounds

\begin{tabular}{|c|c|c|c|c|c|c|c|c|}
\hline & 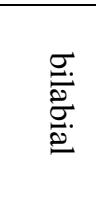 & 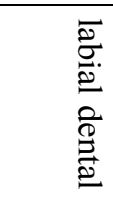 & 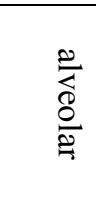 & 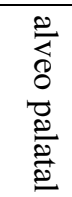 & 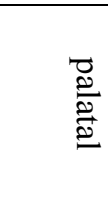 & 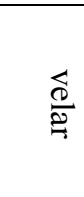 & $\begin{array}{l}\overline{0} \\
\overrightarrow{0} . \\
\frac{0}{2} \\
\stackrel{0}{0} \\
\stackrel{0}{2}\end{array}$ & $\frac{\infty a}{\stackrel{\infty}{\circ}}$ \\
\hline plosive & (p) b & & $\mathrm{td}$ & d & & $\mathrm{kg}$ & $\mathrm{kp} \mathrm{gb}$ & \\
\hline fricative & & f $\quad \mathrm{v}$ & $\begin{array}{ll}\mathrm{S} \\
\mathrm{Z}\end{array}$ & & $\int 3$ & $\mathrm{x}$ & & h \\
\hline affricate & & & ts $\mathrm{dz}$ & & t & & & \\
\hline nasal & $\mathrm{m}$ & & $\mathrm{n}$ & & $\mathrm{n}$ & y & & \\
\hline lateral & & & 1 & & & & & \\
\hline approximant & & & $r$ & & $\mathrm{y}$ & & $\mathrm{W}$ & \\
\hline
\end{tabular}




\subsubsection{Plosives}

All Plosives occur as onset in a CV and CCV syllable type with all vowels. All Plosives except /d/ have a voice opposition. The Voiceless Bilabial Plosive /p/ is found in very few lexical items in the language. It occurs in initial position in words which are ideophones or loan words.

$\begin{array}{llll}\text { 10. pepepe } & \text { 'exactly' } & \text { pété } & \text { 'all' } \\ \text { pro } & \text { 'wet' } & \text { peya } & \text { 'pear' } \\ \text { pépa } & \text { 'paper' } & \text { pépi } & \text { 'harmattan' }\end{array}$

In Ewe, a similar situation exists where /p/ also occurs in loan words and ideophones. The words, peya and pepa can be traced to English. It is not clear whether they came to Logba through Ewe or they were borrowed into Logba directly from English.

The Voiced Bilabial Plosive occurs with all vowels in a CV syllable structure and with $/ 1 /$ as the second consonant in a CCV syllable. The following examples illustrate this:

$\begin{array}{rlll}\text { 11. ba } & \text { 'come' } & \text { bo 'stay' } \\ \text { bé } & \text { 'season' } & \text { bisí } & \text { 'cola' } \\ \text { bo } & \text { 'make' } & \text { bli } & \text { 'break' }\end{array}$

ba 'come' has cognates in other Ghanaian languages. For example, in Ewe, it is vá 'come' and Akan is ba; 'come'

The Alveolar Plosives /t/ and /d/ occur with all vowels in a CV syllable and with /r/ in a CCV syllable. The examples below illustrate this:

$\begin{array}{clll}12 \text { dá } & \text { 'open' } & \text { do } & \text { 'follow' } \\ \text { dre } & \text { 'dirty' } & \text { odró } & \text { 'elephant' } \\ \text { tóle } & \text { 'push' } & \text { ta } & \text { 'give' } \\ \text { tro } & \text { 'refuse' (v) } & \text { tró } & \text { 'carry' (load) }\end{array}$

Apical Alveo Palatal Plosive $/ \mathrm{d} /$ is articulated with the tongue slightly curled backwards with the tip touching lightly the upper teeth ridge. It is the only plosive without a voiceless counterpart and occurs in CV stems with all vowels except the half-open front vowel. This is considered to be an accidental gap. The following examples illustrate this:

$\begin{array}{llll}13 \text { ndú } & \text { 'water' } & \text { idíwago } & \text { 'day' } \\ \text { adabakutó } & \text { 'eyebrow' } & \text { doka } & \text { 'reserve' (v) } \\ \text { deblekú } & \text { 'fog' } & \text { detsiflú } & \text { 'cotton' }\end{array}$


The Velar Plosives occur in many words in Logba. They are found in both CV and $\mathrm{CCV}$ stems. The second consonant is /1/ since the Velar Plosives are [+ grave] sounds. The following are examples:

$\begin{array}{rlll}\text { 14. kla } & \text { 'hide' } & \text { aklo } & \text { 'goat' } \\ \text { gla } & \text { 'pour' } & \text { glé } & \text { 'tie' }\end{array}$

The Voiceless Velar Plosive exceptionally occurs with /r/ in the word akró 'boat' in the Logba language. This word is used in the dialects of Ewe which are linguistic neighbours of Logba. It is not used in the other dialects of Ewe.

/k/ occurs intervocalically. It can occur with any vowel before or after it immediately. However, front vowels do not occur immediately after /g/ (unless it is followed by /1/ as in glé 'tie'). This is illustrated in (15) below.

$\begin{array}{clll}\text { 15. uku } & \text { 'bone' } & \text { iku } & \text { 'song' } \\ \text { akóntí } & \text { 'basket' } & \text { akúkóli } & \text { 'fingernail' } \\ \text { kake } & \text { 'part' } & \text { kélékélé } & \text { 'first' } \\ \text { aga } & \text { 'valley' } & \text { ugú } & \text { 'husband' } \\ \text { ifúgo } & \text { 'flowers' } & \text { nqúgo } & \text { 'thirst' }\end{array}$

$/ \mathrm{kp} /$ and $/ \mathrm{gb} /$ have a wide distribution in the language. The close back vowel $/ \mathrm{u} /$ does not come after either of them. The following are examples:

$\begin{array}{clll}\text { 16. ikpe } & \text { 'one' } & \text { gba } & \text { 'sweep' } \\ \text { kpita } & \text { 'stumble' } & \text { igbe } & \text { 'arrow' } \\ \text { akpá } & \text { 'leg' } & \text { agbé } & \text { 'dog' } \\ \text { ukpóku } & \text { 'knee' } & \text { ogbomi } & \text { 'monkey' } \\ \text { kpe } & \text { 'and' } & \text { agbigloms } & \text { 'spider' } \\ \text { kpo } & \text { 'lie' } & \text { mgbó } & \text { 'rashes' }\end{array}$

In CCV syllables both $/ \mathrm{kp} /$ and $/ \mathrm{gb} /$ have $/ \mathrm{l} /$ as the second consonant in the cluster. The following are the examples:

$\begin{array}{llll}\begin{array}{c}\text { 17. kplo } \\ \text { akpakpla }\end{array} & \text { 'fry' } & \text { gblele } & \text { 'many' } \\ \text { ékplé } & \text { 'now' } & \text { gbla } & \text { 'teach' }\end{array}$

\subsubsection{Fricatives}

All the fricatives in Logba have voice opposition. They can occur in syllable initial position in $\mathrm{CV}$ and CCV syllables. This is illustrated below: 
A. Syllable initial

$\begin{array}{rlll}\text { 18. fo } & \text { 'wash' } & \text { flé } & \text { 'fly' } \\ \text { he } & \text { 'pull' } & \text { sa } & \text { 'leave' } \\ \text { zo } & \text { 'sell' } & \mathbf{z u} & \text { 'descend' } \\ \text { sú } & \text { 'pierce' } & \text { xé } & \text { Relative particle } \\ \text { vu } & \text { 'castrate' } & & \end{array}$

B. Stem of nouns and word medial

$\begin{array}{llll}\text { 19. a-f́s } & \text { 'egg' } & \text { a-fé } & \text { 'comb' } \\ \text { a-vá } & \text { 'deer' } & \text { a-vu } & \text { 'porridge' } \\ \text { a-só } & \text { 'pot' } & \text { u-su } & \text { 'urine' } \\ \text { u-zí } & \text { 'door' } & \text { u-zúgbó } & \text { 'head' } \\ \text { u-hé } & \text { 'knife' } & \text { o-ha } & \text { 'pig' } \\ \text { a-xixlánu } & \text { 'difficulty' } & & \end{array}$

C. Medial position of polysyllabic words

These words are mainly verbs. They appear to involve reduplication of different sorts.

\begin{tabular}{|c|c|c|}
\hline 20. vuvo & 'spoil' & xoxu \\
\hline & 'break' & susu \\
\hline zuzo (asó) & 'roast (pot)' & húhú \\
\hline
\end{tabular}

In all, fricatives occur in many words. However, the velar fricatives $/ \mathbf{x} /$ and glottal fricative $/ \mathrm{h} /$ have a limited occurrence. The Voiceless Velar Fricative does not occur with the half open front vowel $/ \varepsilon /$.

$\begin{array}{llll}\text { 21. xe } & \text { Relative particle } & \text { xoxu } & \text { 'gather' } \\ \text { xoxoe } & \text { 'already' } & \text { xátsáxlá } & \text { 'rough' } \\ \text { axíxlánu } & \text { 'difficulty' } & \text { okutexoe } & \text { 'funeral' }\end{array}$

The Alveolar Fricatives /s/ and /z/ are palatalized as / $/$ and / $3 /$ when they occur before the high front vowel /i/. / $/$ sounds like the initial consonant of the English word 'she' and the / 3 / sounds like the beginning of the French word for 'day' /jour/. These are found in the following words in the language:

$\begin{array}{lll}\text { Underlying } & \text { Surface } & \\ \text { 22. /si/ } & / \int / & \text { GLOSS } \\ \text { isíkpe } & \text { ishíkpe } & \text { 'ring' } \\ \text { inasína } & \text { inashína } & \text { 'everybody' } \\ \text { okusiokú } & \text { okushiokú } & \text { 'everywhere' } \\ \text { ikpesikpe } & \text { ikpeshikpe } & \text { 'everything' }\end{array}$




\begin{tabular}{|c|c|c|}
\hline Underlying & Surface & \\
\hline $23 . / \mathrm{zi} /$ & $/ 3 /$ & GLOSS \\
\hline onzie & onzhie & 'owl' \\
\hline zí & zhí & 'carry' \\
\hline zi & zhi & 'good' \\
\hline
\end{tabular}

The palato-alveola fricatives only occur as allophones of the alveolar fricatives before $/ \mathrm{i} /$.

\subsubsection{Affricates}

/ts/ [t] $]$ and /dz/ [\$] are the only affricates in the language. /ts/ occurs in the following words:

$\begin{array}{clll}\text { 24. tsítsí } & \text { 'turn' } & \text { tsíyí } & \text { 'maize' } \\ \text { atsá } & \text { 'horn' } & \text { átsi } & \text { 'night' } \\ \text { tsímí } & \text { 'crack' } & \text { tsibi } & \text { 'small' }\end{array}$

/dz/ occurs in the following words:

$\begin{array}{rlll}25 \mathrm{dzu} & \text { 'arrive' } & \text { odzá } & \text { 'fire' } \\ \text { dze } & \text { 'look' } & \text { dzuanú } & \text { 'like' } \\ \text { adzi } & \text { 'bird' } & \text { idzó } & \text { 'yam' }\end{array}$

/ts/ and /dz/ are independent phonemes in their own right in Logba including Tota. However, when the alveolar plosive $/ t /$ is followed by a close vowel $/ \mathbf{i} /$ or $/ \mathbf{u} /$ it is realised as an affricate in the Tota dialect.

\begin{tabular}{cll}
$\begin{array}{c}\text { OTHER DIALECTS } \\
\text { 26. tú }\end{array}$ & TOTA & GLOSS \\
atí & tsú & 'on' \\
utí & atsí & 'night' \\
otú & utsí & 'father' \\
odzátume & otsú & 'hill' \\
\hline & odzátsume & 'kitchen'
\end{tabular}

This is a phonological process which occurs in some dialects of Ewe, one of the major languages spoken in Logba. Duthie (1996:15) reports this indicating that it is the southern speakers of Ewe who use the palatalized form. Although, this is not uncommon, I assume that this is an influence from Ewe on the Logba spoken in Tota. It is interesting to note that whereas the Logba speakers palatalize before $/ \mathbf{u} /$, the southern Ewe dialect speakers do not. The Tota dialect speakers are applying the palatalization to both front and back high vowels. It could be argued that the palatalization before $/ u /$ is not due to the influence of the back high vowel but rather because of the presence of an alveolar affricate in the language. 


\subsubsection{Nasals}

All the nasals except the palatal nasal can occur in the peak of syllables. They can also be found in word initial position. The bilabial nasal $/ \mathrm{m} /$ occurs with all vowels. There are co-occurrence restrictions of the other nasal consonants and mid-vowels. Mid vowels are rare after nasals, no /o/ after $/ \mathrm{n} /$ and no $/ \mathbf{e} / / \mathbf{o} / / \boldsymbol{\varepsilon} / / \mathbf{o} /$ after $/$ ny/ and no $/ \mathbf{e} / / \mathbf{o} / / \boldsymbol{\varepsilon} /$ after $/ \mathbf{y} /$ occur. With other vowels these nasals do occur.

\begin{tabular}{|c|c|c|c|}
\hline 27. nya & 'live' (v) & anye & ‘so’ \\
\hline anys & 'louse' & fonyi & 'peel' (v) \\
\hline inyui & ‘juju’ & akpananyi & 'a Logba person' \\
\hline yú & 'see' & gonyi & 'write' \\
\hline anáná & 'rib' & on.kpá & 'rope' \\
\hline toý.ká & 'pepper' & j.gbíní & 'okro' \\
\hline $\mathrm{n} \varepsilon$ & 'buy' & nen.kpi & 'cow' \\
\hline no & 'drink' & & \\
\hline
\end{tabular}

In connected discourse, all the nasals that have a consonant following are syllabic and homorganic with the consonant that follows them. There are no consonant clusters involving the palatal nasal /ny/. The following are examples:

\begin{tabular}{|c|c|c|}
\hline 28. o-bu & 'wing (of bird)' & a.y-kó \\
\hline & 'liquor' & n-tró \\
\hline n-gbo & 'rashes' & 0.m-bwé \\
\hline
\end{tabular}

There is a class of nouns that form their plural by a syllabic nasal prefix realized homoganically with the stem noun. This is exemplified in (29).

$\begin{array}{ll}\text { 29. PLURAL } & \text { GLOSS } \\ \text { m-byá } & \text { 'chairs' } \\ \text { m-futa } & \text { 'clothes' } \\ \text { n-lága } & \text { 'speeches' } \\ \text { y-kpo } & \text { 'farm bags' } \\ \text { y-gúwo } & \text { 'antelopes' }\end{array}$

\subsubsection{Lateral}

The Alveolar lateral, /1/ is widely distributed. It occurs as onset in a CV syllable. It also occurs as a second consonant in a CCV consonant cluster when the first consonant is a grave sound. This is attested in the following examples:

$\begin{array}{clll}\text { 30. agblenú } & \text { 'hoe' } & \text { agbígloms } & \text { 'spider' } \\ \text { la } & \text { 'beat' } & \text { gla } & \text { 'pour' } \\ \text { le } & \text { 'buy' } & \text { kla } & \text { 'hide' } \\ \text { lo } & \text { 'weed' } & \text { mla } & \text { 'bring' }\end{array}$




$\begin{array}{llll}\text { lí } & \text { 'hold' } & \text { alá } & \text { 'scorpion' } \\ \text { wlíwlí } & \text { 'small parts' } & \text { ohloyí } & \text { 'throat' } \\ \text { yayí } & \text { 'search' } & \text { yíré } & \text { 'wait' }\end{array}$

The 3rd Person Singular Object Pronoun is $1 \varepsilon$ or le depending on the [ATR] value of the vowel in the verb root. In fast speech, Tota dialect speakers elide the $/ 1$. Speakers from other Logba towns maintain it both in fast speech and in careful speech. This is exemplified below:

31a. OTHER DIALECTS

$$
\text { ma-zí=le }
$$

1SG-carry 3SGOBJ

'I took it'

31b. ว-blí=le

3SGSUBJ-break $=3$ SGOBJ

'He/She broke it'
TOTA

ma-zí=é

$1 \mathrm{SG}$-carry $=3 \mathrm{SGOBJ}$

'I took it'

ó-blí= $=\mathfrak{\varepsilon}$

3SGSUBJ-break = 3SGOBJ

'He/She broke it'

The Voiced Alveolar Trill [r] is restricted in its distribution. It occurs as a second consonant in a consonant cluster and in that position is in complementary distribution with [1]. It also occurs as a syllable initial consonant once where it alternates with $/ 1 /$, in the word rí 'hold'. In the Tota dialect, the speakers say [rí] 'to hold' while the other dialects use [lí].

In CCV syllables / $\mathrm{r}$ / occurs as the second consonant when the first consonant is a coronal or non-grave sound. Examples are:

$\begin{array}{llll}\text { 32. adrú } & \text { 'mound' } & \text { adruva } & \text { 'Thursday' } \\ \text { dre } & \text { 'dirty' } & \text { atruí } & \text { 'hearth' } \\ \text { odró } & \text { 'elephant' } & \text { ntró } & \text { 'breast' } \\ \text { tro } & \text { 'refuse' (v) } & & \end{array}$

All the words that have a syllable with /r/ as onset contain the syllable rí 'hold' It is unclear whether they are all historically derived from ri. Examples are:

$\begin{array}{ll}\text { 33. urímé } & \text { 'handle' } \\ \text { ntsurí } & \text { 'ladder' } \\ \text { rí } & \text { 'hold' }\end{array}$

\subsubsection{Approximants}

The Palatal approximant /y/ occurs intervocalically and in initial position of syllables. It occurs with all vowels. 
Examples:

$\begin{array}{clll}\begin{array}{c}\text { 34. ayé } \\ \text { əý́ }\end{array} & \text { 'grandmother' } & \text { azayi } & \text { 'beans' } \\ \text { yé } & \text { 'tree' } & \text { oyubitsi } & \text { 'thief' } \\ \text { yáyí } & \text { 'search' } & \text { yó } & \text { 'skin' }\end{array}$

The Palatal approximant $/ y /$ occurs as second element in a consonant cluster as illustrated in (35).

$\begin{array}{ll}\text { 35. [byá] } & \text { 'boil' } \\ \text { [a-fyá] } & \text { 'pain' } \\ \text { [fyé] } & \text { 'dehusk corn' } \\ \text { [fyéc] } & \text { 'exceed' }\end{array}$

The Labial velar approximant, /w/ occurs intervocalically and in initial position of words and stem of nouns before back vowels and central vowel, /a/. This is shown in (36). There is a phonemic opposition between $/ \mathrm{y} /$ and $/ \mathrm{w} /$ before back vowels.

$\begin{array}{llll}\text { 36. wa } & \text { 'say' } & \text {-wo } & \text { plural clitic } \\ \text { wo (bi) } & \text { 'give birth' } & \text { wasa } & \text { 'owner' } \\ \text { iwo } & \text { 'bee' } & \text { owś } & \text { 'mortar' } \\ \text { awó } & \text { 'snake' } & \text { awu } & \text { 'garment' }\end{array}$

The Labial velar approximant /w/ occurs as second element in a consonant cluster. These are exemplified in (37).

$\begin{array}{ll}37 \text { [ywé] } & \text { 'pound' } \\ \text { [bwá] } & \text { 'fold' } \\ \text { [a-bwé] } & \text { 'animal' } \\ \text { [o-m-bwé] } & \text { 'orange' }\end{array}$

\section{$2.3 \quad$ Vowels}

Logba has a seven vowel system which is in two groups. The grouping is based on the Advanced Tongue Root feature.

Table 2.2 Vowel Phonemes

\begin{tabular}{|c|c|c|c|c|c|}
\hline & \multicolumn{2}{|c|}{ FRONT } & CENTRAL & \multicolumn{2}{|c|}{ BACK } \\
\hline & {$[+\mathrm{ATR}$} & [-ATR] & & [+ ATR $]$ & [- ATR] \\
\hline Close & $\mathrm{i}$ & & & $\mathrm{u}$ & \\
\hline Mid & e & $\varepsilon$ & & o & 0 \\
\hline Open & & & $\mathrm{a}$ & & \\
\hline
\end{tabular}


All the seven vowels are phonemic. This is exemplified below with some of the near minimal pairs of words. Examples of near minimal pairs are shown in (38).

\begin{tabular}{clllll} 
38. & SOUND & \multicolumn{3}{c}{ MINIMAL PAIRS } & \\
a. & $\mathrm{a} / \mathrm{o}$ & na & 'walk' & no & 'drink' \\
b. & $\mathrm{u} / \mathrm{o}$ & $\mathrm{du}$ & 'extinguish' & do & 'follow' \\
c. & $\mathrm{u} / \mathrm{o}$ & ukú & 'drum' & okú & 'place' \\
d. & $\varepsilon / \mathrm{a}$ & té & COMPL & tá & 'shoot' \\
e. & $\mathrm{e} / \mathrm{i}$ & me & 'here' & mi & 'take' \\
f. & $\mathrm{i} / \mathrm{a}$ & iny & 'two' & anyo & 'louse'
\end{tabular}

There are no phonemically nasalized vowels in Logba. Generally, all the vowels become nasalised when they occur immediately after a nasal consonant. The spreading of the nasalisation is rightwards. Examples are:

\begin{tabular}{|c|c|c|c|}
\hline 39 ubonũ & 'farm' & imว̃ & 'neck' \\
\hline inỹ̃ & 'two' & yṹ & 'see' \\
\hline $\mathrm{m} \tilde{\varepsilon}$ & 'swallow' & nyã & 'live' \\
\hline $\begin{array}{l}\text { mẽn.gba } \\
\text { mõ }\end{array}$ & $\begin{array}{l}\text { 'bowl' } \\
\text { NEG }\end{array}$ & ədzátsumẽ & 'kitchen' \\
\hline
\end{tabular}

The front vowel $/ \varepsilon /$ has a limited occurrence in initial position in the language. In the data I have collected, it occurs as prefix for a small number of nouns. One of

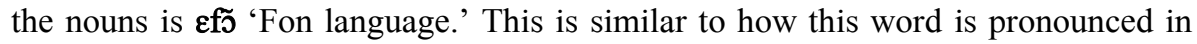
Ewe. The stem of the word has a back vowel, $/ \mathrm{s} /$, and $/ \varepsilon /$ as the class prefix. This harmonizes with the vowel in the noun stem. Nasalisation in the noun is an influence from Ewe since I have observed that nasalization occurs only after nasal consonants in Logba. / $\varepsilon$ / also occurs as a prefix in the nouns in (40):

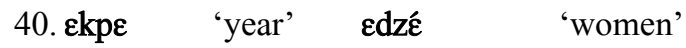

There is free variation between [I] and [i] and [v] and [u] except for a small number of words for a number of speakers

[I] to the exclusion of [i] occurs in a few words in initial position. All examples are in $(41)$ :

$\begin{array}{lll}\begin{array}{l}\text { 41. I.nfwo } \\ \text { Inó }\end{array} & \text { 'worm' } & \text { 'meat' }\end{array}$

[v] to the exclusion of [u] occurs in only the initial position of a small number of nouns as prefix. These nouns are in (42).

42.

$$
\begin{array}{llll}
\mathbf{v} \text {-foto } & \text { 'marshy area' } & \mathbf{v} \text {-wló } & \text { 'Sunday' } \\
\mathbf{v} \text {-nyí } & \text { 'name' } & \boldsymbol{v} \text {-menta } & \text { 'salt' }
\end{array}
$$


One fact which comes out clearly is that while some of the native speakers consulted produce words which have these unadvanced vowels to sound close to their [+ ATR] counterparts, others produce these vowels as if they were the [+ ATR] vowels. To many people these [-ATR] vowels are perceived as the [+ATR] vowel close to them.

I assume that this situation is the outcome of a nearly completed sound change in which

$/ \mathrm{I} /$ has shifted to $/ \mathrm{i} /$ and $/ \mathrm{v} /$ has shifted to $/ \mathrm{u} /$

It is for these reasons that I now claim that Logba has seven vowels ${ }^{12}$. The close unadvanced vowels have merged with their advanced counterparts and what is evident now is the trace that it was once a nine vowel system.

The assertion that these unadvanced vowels have undergone a merger with their advanced counterparts is similar to the observation of Harry Van der Hulst and Smith (1986) that these are the vowels which most commonly undergo changes as a result of the difficulty in their production and may eventually be lost or merge with other close vowels in a language (Stewart 1970, Casali 2003).

\subsubsection{Vowel harmony}

Logba has seven vowels (see Table 2.2). All vowel affixes have two forms, one [+ATR] and the other [-ATR]. Selection of either of the forms depends on which harmony set the vowels in the lexical stem belong. If the stem is [+ATR], one of the following vowels will be chosen: /o $\mathrm{u} \mathrm{i} \mathrm{e} \mathrm{/.} \mathrm{If} \mathrm{on} \mathrm{the} \mathrm{other} \mathrm{hand,} \mathrm{it} \mathrm{is} \mathrm{[-ATR]} \mathrm{it}$ will come from the following set: $/ \mathrm{o} \varepsilon /$. This is illustrated in the words below:

\begin{tabular}{|c|c|c|c|}
\hline $\begin{array}{l}\text { 43. e-tsí } \\
\text { e-ke }\end{array}$ & $\begin{array}{l}\text { 'down' } \\
\text { 'root' }\end{array}$ & $\begin{array}{l}\text { e-bí } \\
\text { e-ví }\end{array}$ & $\begin{array}{l}\text { 'cocoa beans' } \\
\text { 'sun' }\end{array}$ \\
\hline 44. $\varepsilon-\mathrm{dz} \varepsilon$ & 'women' & $\varepsilon-\mathrm{kp} \varepsilon$ & 'year' \\
\hline $\begin{array}{c}\text { 45. o-tsú } \\
\text { o-kú }\end{array}$ & $\begin{array}{l}\text { 'forehead' } \\
\text { 'place' }\end{array}$ & $\begin{array}{l}\text { o-fú } \\
\text { o-vu }\end{array}$ & $\begin{array}{l}\text { 'guest' } \\
\text { 'market' }\end{array}$ \\
\hline $\begin{array}{l}\text { 46. o-kpe } \\
\text { o-gbっ }\end{array}$ & $\begin{array}{l}\text { 'one' } \\
\text { 'town' }\end{array}$ & $\begin{array}{l}\text { o-dzá } \\
\text { o-da }\end{array}$ & $\begin{array}{l}\text { 'fire' } \\
\text { 'lowest part of a valley' }\end{array}$ \\
\hline
\end{tabular}

The stems of the words do not change. They impose a restriction on the vowels in the affixes making them to undergo a change. This is referred to as stem-controlled Vowel Harmony (Clements 2000).

\footnotetext{
${ }^{12}$ In my earlier work which is a preliminary report, I state that Logba has a nine vowel system (Dorvlo 2004:241).
} 
Looking at the vowels in Logba, it is evident that the central vowel /a/ and the two close [+ATR] vowels have no harmonic partners. They harmonize with either [+ ATR] or [-ATR] vowels in a word. In (47a) all the stems have [+ ATR] vowels and in (47b) the stems have [-ATR] vowels. The first two words in each group have the central vowel $/ \mathrm{a} /$.

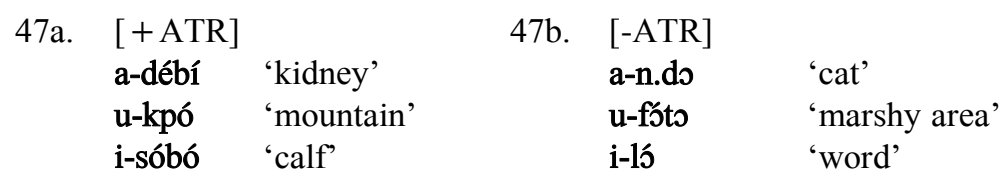

Mid vowels in stems are either [+ ATR] or [-ATR]. This is exemplified in (48a) and (48b).

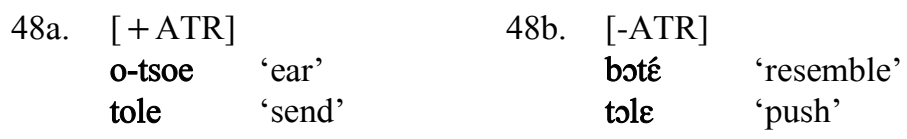

Stems with [+ATR] mid vowels trigger [+ATR] affixes. In (49) bodze 'come.look' has $[+$ ATR] mid vowels and the subject marker is a prefix $/ o /$.

49. Ebitsi é óbodze akpaiva nu.
ebitsi $=$ é
ó-bo-dze
akpa iva nu
Child=DET SM-SG-come-look boot in

'The child came to look in the boot.' [15.1.06]

Stems with [-ATR] mid vowels in the stem vowel trigger [-ATR] affixes. In (50), the verb stem zó ' go' has the prefix /o/.

50. Ee! Ye ózó...

ee! ye ว́ -zó

Yes! CONJ 3SG-go

'Yes! As he goes...' [15.2.49]

All stems in which there is either [+ATR] or [-ATR] mid vowels take affixes containing $/ \mathrm{a} / / \mathbf{i} /$ and $/ \mathrm{u} /$. The following words in (51a) and (51b) illustrate this.

$\begin{array}{llll}\text { 51a. }[+ \text { ATR }] & \text { 51b. } & \text { [-ATR] } & \\ \text { a-fé 'comb' } & \text { a-bé } & \text { 'palmnut' } \\ \text { a-lo 'or' } & \text { a-kló } & \text { 'goat' } \\ \text { u-gbe 'voice' } & & \text { u-mé } & \text { 'this' } \\ \text { i-té 'front' } & \text { iyé } & \text { 3SG.IND }\end{array}$

The vowel harmony is root controlled but $/ \mathrm{a} /, \mathbf{i} /$, and $/ \mathbf{u} /$ have no harmonic counterpart. (52) exemplifies roots with /a/, (53) roots with /i/, and (54) roots with /u/. 


$\begin{array}{clll}\begin{array}{r}\text { 52. a-da } \\ \text { a-fá } \\ \text { o-fá }\end{array} & \begin{array}{l}\text { 'lizard' } \\ \text { 'house' } \\ \text { 'fence' }\end{array} & \begin{array}{l}\text { o-dzá } \\ \text { o-ba }\end{array} & \begin{array}{l}\text { 'fire' } \\ \text { 'mud' }\end{array} \\ \begin{array}{c}\text { 53. o-mi } \\ \text { e-ti }\end{array} & \begin{array}{l}\text { 'he takes' } \\ \text { 'soil' }\end{array} & \begin{array}{l}\text { o-kpí } \\ \text { e-vi }\end{array} & \begin{array}{l}\text { 'he went' } \\ \text { 'sun' }\end{array} \\ \begin{array}{r}\text { 54. o-kú } \\ \text { o-tú }\end{array} & \begin{array}{l}\text { 'place' } \\ \text { 'gun' }\end{array} & \text { e-bú } & \text { 'They asked' }\end{array}$

/a/ is [-ATR] because it takes a [-ATR] prefix. (55) and (56) illustrate this.

55. Jlá ḿ.

$$
\text { ふ-lá=ḿ }
$$

'She/He beat me.'

56. Jsá ndú é.

$$
\begin{array}{ll}
\text { `́ -sá } & \text { n-dú=é } \\
\text { 3SG-fetch } & \text { CM-water }=\text { DET }
\end{array}
$$

'She/He fetched the water.'

$/ \mathbf{i} /$ and $/ \mathbf{u} /$ are $[+$ ATR] because each triggers [ + ATR] prefix. The verb stem in (57) has $/ \mathbf{i} /$ and (58) has / $\mathbf{u} /$. They all trigger /o/ as the $3 \mathrm{SG}$ subject.

57. órí agbi é ka óyó

$$
\begin{aligned}
& \text { ó-rî agbi=é } \quad \text { ka ó-yó } \\
& \text { 3SG-hold dog =DET put CM-skin } \\
& \text { 'he holds the dog close' [15.1.03] }
\end{aligned}
$$

58. óyú oble ka anyi.
ó-yú o-ble ka anyi
3SG-see 3SG-own putface
'he identified his.' [15.1.41]

There are stems in which there are vowels from [+ ATR] and [-ATR]. The following words in (59) and (60) are examples:
59. mikpe 'choose'
shídé 'leave someone'
60. zúzo aso 'roast pot'
fútó 'mix'


These words futo and shídé trigger [+ ATR] vowel prefix as can be seen in (61) and (62) and they harmonize with the nearest root vowel.

61. Ófuto amøwe mengba á nu.

ó-futo amowe mengba=á nu

3SG-mix dough bowl=DET in

'He mixed dough in the bowl.'

62. Óshídé ebítsi é afa á nu.
ó-shídé
e-bítsi =é
a-fa =á
$\mathrm{nu}$
3SG-leave $\quad$ CM-child $=$ DET
$\mathrm{CM}$-house $=\mathrm{DET} \quad$ in
'He left the child in the house.'

There are some words in which the [+ATR] and [-ATR] mid vowels occur together. This is exemplified in (63):

$\begin{array}{clll}\text { 63. i-vaflego } & \text { 'insect' } & \text { o-dzogbenyi } & \text { 'northerner' } \\ \text { u-mokue } & \text { 'there' } & \text { a- } \text {-gblue } & \text { 'pipe for smoking' } \\ \text { u-trome } & \text { 'work' } & \text { fotete } & \text { 'green edible leaves' }\end{array}$

\subsubsection{Vowel sequencing in roots}

Long vowels, ee as in pétée 'completely', aa as in dzáa 'only' are loans from Ewe. This expressive length is not considered phonemic. There are no vowel sequences in roots. Apparent vowel sequences in roots are better analysed as two margins plus a nucleus. The second margin is a glide (see section 2.7). The following are examples:

$\begin{array}{cl}\text { 64. [o-ń.zye] } & \text { 'owl' } \\ \text { [a-byá] } & \text { 'chair' } \\ \text { [a-bwé] } & \text { 'animal' } \\ \text { [a-fyé] } & \text { 'comb' } \\ \text { [nen.tswi] } & \text { 'cow' }\end{array}$

\subsubsection{Vowel sequences across morpheme boundaries}

When words beginning in a vowel are preceded by words terminating in a vowel they trigger vowel sequences which do not lead to diphthongs since they belong to different syllables. Another context in which this occurs is when the object of a verb is the 3PLUOBJ -á. This is illustrated in (65).

$$
\begin{array}{cccc}
\text { 65. la } & \text { á } & \rightarrow \text { [la.á] } & \text { 'beat them } \\
\text { blo } & \text { á } & \rightarrow \text { [blo.á] } & \text { 'make them' } \\
\text { dze } & \text { á } & \rightarrow \text { [dze.á] } & \text { 'look them' }
\end{array}
$$




$\begin{array}{lll}\text { do } & \text { á } \rightarrow \text { [do.á] } & \text { 'build them' } \\ \text { fli } & \text { á } \rightarrow \text { [fli.á] } & \text { 'cut them' } \\ \text { bú } & \text { á } \rightarrow \text { [bu.á] } & \text { 'ask them' }\end{array}$

There is a constraint in which two front mid vowels $/ \mathrm{e} /+/ \mathrm{e} /, / \varepsilon /+/ \varepsilon /$ do not occur in a sequence in Logba even across word or syllable boundaries. When it occurs, it is phonetically realised as /ie/, /ie/. There are a number of contexts in which this occurs. When the determiner is realised as /e/ and it is preceded by a noun or number word ending in /e/, this process is triggered (see the last two words in example (66). Also, a 3SGOBJ pronoun and a preposition ending in /e/ as shown in (67) or $3 \mathrm{SGOBJ}$ pronoun and a verb ending in /e/ as shown in (68) can trigger this process.

\subsubsection{Noun + determiner}

The determiner is realised as / $/ \hat{\varepsilon} /$ and /á/. These are allomorphs which are morpho-

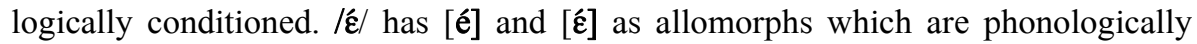
conditioned. The following phrases in (65) are examples.

$\begin{array}{lll}\text { 66. okla } & \text { é } \rightarrow \text { [okla.á] } & \text { 'the mat' } \\ \text { uklo } & \text { é } \rightarrow \text { [u.klo.é] } & \text { 'the lorry' } \\ \text { dzosú } & \text { é } \rightarrow \text { [dzosú.é] } & \text { 'the blood } \\ \text { igbedi } & \text { é } \rightarrow \text { [i.gbe.di.é]' } & \text { 'the cassava } \\ \text { aklo } & \text { é } \rightarrow \text { [a.klo.á] } & \text { 'the goat' } \\ \text { agbe } & \text { é } \rightarrow \text { [a.gbi.é] } & \text { 'the dog' } \\ \text { egbe } & \text { é } \rightarrow \text { [e.gbi.é] } & \text { 'the stone' }\end{array}$

\subsubsection{Preposition and object pronoun}

The prepositions $f \varepsilon$ 'at' and kpe 'with' end in / $\varepsilon$ / and trigger /i $\varepsilon /$ when they occur with the 3 SGOBJ pronoun $/ \varepsilon /$. They are shown in (67).

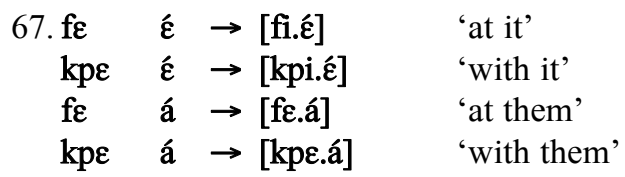

\subsubsection{Verb and object}

The $3 \mathrm{SGOBJ}$ is é/દ. In the examples below, verbs ending in all the vowels possible are used.

$\begin{array}{ccll}\text { 68. la } & \text { ć } & \rightarrow \text { [la.é] } & \text { 'beat him/her' } \\ \text { blo } & \hat{\varepsilon} & \rightarrow \text { [blo.éc] } & \text { 'make it' } \\ \text { dze } & \text { é } & \rightarrow \text { [dzi.é] } & \text { 'look it' }\end{array}$




$\begin{array}{lll}\text { do } & \text { é } \rightarrow \text { [do.é] } & \text { 'build it' } \\ \text { fli } & \text { é } \rightarrow \text { [fli.é] } & \text { 'cut it' } \\ \text { bú } & \text { é } \rightarrow \text { [bú.é] } & \text { 'ask it' }\end{array}$

\section{$2.4 \quad$ Tone}

Tone is distinctive in Logba. Two tones are identified in the lexical data compiled on Logba. High tone is marked (') and Low tone is unmarked. A third tone, Rising tone is phonetically realised on a single syllable peak and is represented as $\left({ }^{\bullet}\right)$. This tone is found on a limited number of borrowed words from Ewe with the inland Ewe dialect tone (see 82). Tone is realised on vowels and syllabic nasals. The meaning of a word depends on the tone of each syllable as well as the vowels and consonants of which the word is made. In the examples in (69), the pairs of words have the same consonants and vowels and they are in the same sequence. However, the difference in their meanings is brought about by tone.

\begin{tabular}{|c|c|c|c|}
\hline 69 zo & 'sell' & z’́ & 'go' \\
\hline avi & 'axe' & aví & 'groundnut' \\
\hline dzi & 'tie firmly' & dzí & 'stand' \\
\hline ubi & 'wound' & ubí & 'child' \\
\hline fõ & 'brother' & fó & 'wash' \\
\hline
\end{tabular}

Monosyllabic words can either be Low tone or High tone. (70) are examples of Low tone verb roots and (71) High tone verb roots respectively.

Low tone

$\begin{array}{clll}\text { 70. ba } & \text { 'kill' } & \text { da } & \text { 'become fat' } \\ \text { ka } & \text { 'put' } & \text { le } & \text { 'buy' } \\ \text { mi } & \text { 'take' } & \text { sa } & \text { 'leave' } \\ \text { fli } & \text { 'cut in pieces' } & \text { blo } & \text { 'make' }\end{array}$

High tone

$\begin{array}{rlll}\text { 71. bú } & \text { 'ask' } & \text { wó } & \text { 'prick' } \\ \text { yú } & \text { 'see' } & \text { rí } & \text { 'hold' } \\ \text { sé } & \text { 'finish' } & \text { tsí } & \text { 'sit' } \\ \text { yé } & \text { 'stand' } & \text { tró } & \text { 'carry' }\end{array}$

Monosyllabic noun roots can also be Low tone or high tone. They have a vowel prefix attached to the root. This is exemplified in (72) and (73)

Low tone

$\begin{array}{clll}\text { 72.i-so } & \text { 'faeces' } & \text { i-va } & \text { 'thing' } \\ \text { o-ks } & \text { 'custom' } & \text { u-bi } & \text { 'wound' } \\ \text { a-bu } & \text { 'valley' } & \text { a-gli } & \text { 'wall' } \\ \text { a-dzi } & \text { 'bird' } & \text { u-dzi } & \text { 'heart' }\end{array}$




$\begin{array}{lll}\text { a-gu } & \text { 'top' } & \text { n-wu }\end{array}$

High tone

$\begin{array}{rlll}\text { 73.u-kú } & \text { 'bone' } & \text { o-dzá } & \text { 'fire' } \\ \text { a-bí } & \text { 'palm kernel' } & \text { o-tú } & \text { 'gun' } \\ \text { a-dí } & \text { 'frog' } & \text { a-fé } & \text { 'comb' } \\ \text { u-hé } & \text { 'knife' } & \text { a fó } & \text { 'egg' } \\ \text { a-drú } & \text { 'mound' } & \text { á-fá } & \text { 'house' } \\ \text { n-dú } & \text { 'water' } & \text { n-tó } & \text { 'ash' }\end{array}$

All possible tonal patterns, LL, HH, LH, and HL, are attested in disyllabic roots.

The examples in (74), (75) (76) and (77) are these tone combinations in disyllabic verb roots.

74. LL

$\begin{array}{llll}\text { dase } & \text { 'thank' } & \text { klanu } & \text { 'hide' } \\ \text { fifi } & \text { 'break' } & \text { doka } & \text { 'reserve' }\end{array}$

75. $\mathrm{HH}$

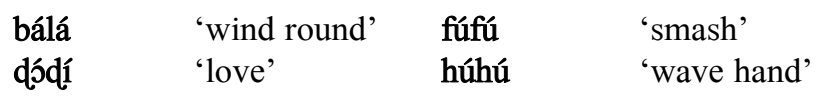

76. $\mathrm{LH}$

$\begin{array}{llll}\text { tolé } & \text { 'send' } & \text { ganú } & \text { 'greet' } \\ \text { mumú } & \text { 'complete' } & \end{array}$

77. HL

$\begin{array}{llll}\text { dónu } & \text { 'shrink' } & \text { dzúba } & \text { 'return' } \\ \text { núma } & \text { 'fall down' } & \text { húho } & \text { 'bathe lazily' }\end{array}$

The examples in (78), (79) (80) and (81) are these tone combinations in disyllabic noun roots.

78. LL

$\begin{array}{llll}\text { a-druva } & \text { 'Thursday' } & \text { i-same } & \text { 'happiness' } \\ \text { a-buba } & \text { 'termite' } & \text { e-bleta } & \text { 'left hand' } \\ \text { a-dzago } & \text { 'millet' } & & \end{array}$

79. $\mathrm{HH}$

$\begin{array}{llll}\text { a-búkpá } & \text { 'shoulder' } & \text { e-bítsí } & \text { 'child' } \\ \text { a-débí } & \text { 'kidney' } & \text { i-suso } & \text { 'thatch' } \\ \text { a-bótí } & \text { 'corpse' } & \text { o-túlí } & \text { 'mosquito' }\end{array}$




$\begin{array}{lll}\text { a-dzímí } & \text { 'mudfish' } & \text { o-lómí 'testis' } \\ \text { a-gáné } & \text { 'scorpion ' } & \text { y-gbíní }\end{array}$

Also included in the $\mathrm{HH}$ tonal pattern is an adjective which is derived from the reduplication of a noun stem: o-bí 'child' bíbí 'small'

80. $\mathrm{LH}$

$\begin{array}{llll}\text { a-dzayí } & \text { 'firewood' } & \text { u-zugbó } & \text { 'head' } \\ \text { a-dodí } & \text { 'love' } & \text { o-gloyí } & \text { 'knee cap' } \\ \text { a-gutó } & \text { 'bat' } & \text { i-tibí } & \text { 'finger' } \\ \text { e-kelé } & \text { 'grass' } & \text { kutó } & \text { 'hat' }\end{array}$

81. HL

$\begin{array}{llll}\text { a-fása } & \text { 'landlord' } & \text { i-kádza } & \text { 'black berries' } \\ \text { i-kpóli } & \text { 'toe' } & \text { o-zúme } & \text { 'tomorrow' } \\ \text { o-kúmi } & \text { 'garden egg' } & \text { u-dóbe } & \text { 'afternoon' } \\ \text { u-kpóku } & \text { 'knee' } & & \end{array}$

The LH tonal sequence on a single syllable peak can be found on a limited number of loan and ideophonic words. This is attested in the examples in (82). fõ 'brother' akpǒ 'sack' zenklă 'pot stand' are loans with the inland Ewe dialect tone and tǒ 'to fell palm tree' sounds like an ideophonic word referring to the sound made when a palm tree is felled.

82. fõ 'brother' tǒ 'to fell palm tree'

$$
\text { akpǒ 'sack' zenklă 'pot stand' }
$$

\subsubsection{Change of tone in low tone monosyllabic verbs}

Monosyllabic verbs which have a low tone in citation form change to a high tone when inflected. All verbs are high in this frame, irrespective of the tone of the preceding subject prefix. The lexical tonal difference is evident in the citation form. The following low tone verbs are used in sentences to illustrate this:

83. ko 'hang'

Awu é ákó aglié yó.
$\mathrm{A}-\mathrm{wu}=\mathrm{é}$
á-kó
a-gli =é
yó
CM-dress $=$ DET SM.SG-hang CM-wall=DET skin
'The dress hangs on the wall.' 
84. kpe 'know'

Okpé inashína.

ó-kpé i-nashína

3SG-know CM-everybody

'He knows everybody.'

85. ba'kill'

Mabá agbi é.

ma-bá agbi =

1SG-kill dog $=$ DET

'I kill the dog.'

86. la 'beat'

Jgblawo é ólá ebítsi é.

o-gblàwo =é ó-lá e-bítsi=é

CM-teacher $=$ DET $\quad$ SM.SG-beat $\quad$ CM-child $=$ DET

'The teacher beats the child.'

There is no change in the pitch of monosyllabic verbs which are pronounced with high tone in citation form. This is illustrated below:

87. zó 'go'

Mazó ovu é nu.

ma-zó o-vu=é nu

1SG-go CM-market in

'I went to the market.'

88. blí 'break'

Ati blí aso á.

ati blí a-so=á

1PLU break CM-pot=DET

'We broke the pot.'

\subsubsection{Register raising in polar interrogatives}

Polar interrogatives are marked by a final High tone. The effect of this is that the level of such an interrogative is raised in comparison to its counterpart statement. For instance, in the affirmative statement, akpé iva 'you have eaten', the tones of the syllables are as shown below. In particular, the last word has an underlying LL 
tone. However, in the interrogative, the tones on this last word are realised as LHH where the last $\mathrm{L}$ becomes $\mathrm{HH}$. The final vowel is lengthened or doubled.

This is illustrated below supported with tracings from Praat: ${ }^{13}$

89a. Statement: A-kpe i-va

L H L L

2SG-eat thing

'You have eaten'

89b. Interrogative: A-kpe i-va-a

L $\quad \mathrm{H} \quad \mathrm{L} \mathrm{H} \quad \mathrm{H}+$

2SG-eat thing

'Have you eaten?'

The final tone of a polar interrogative can also be realised as extra High for emphatic reasons. This phenomenon of rising for questions occurs in Akan as well (see Dolphyne 1988].

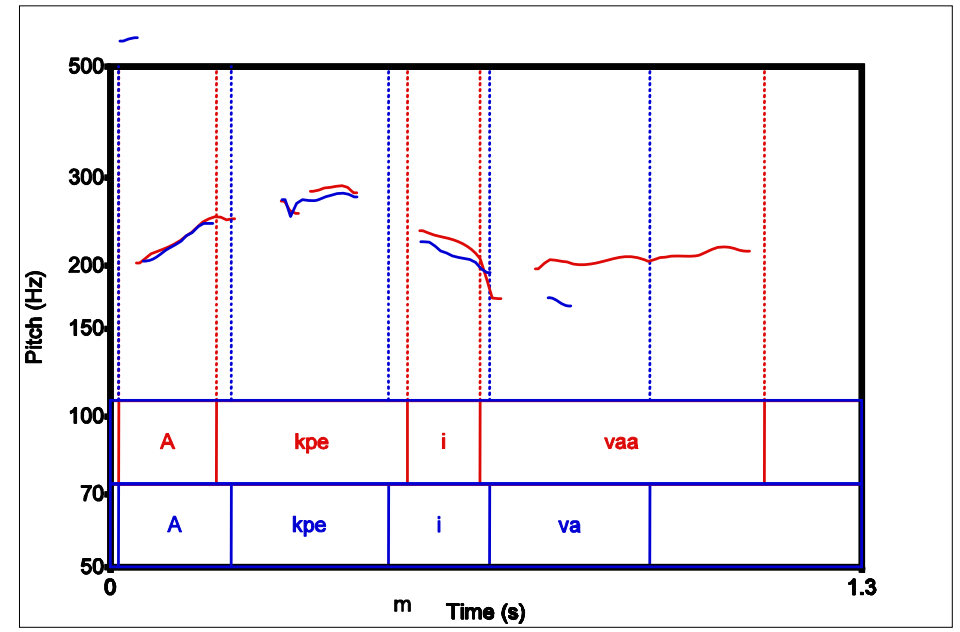

\subsubsection{Tonal morphemes: aspect marked by tone}

Tone is used to indicate the difference between Habitual aspect tu and the Past Progressive aspect marker tú. The former is said with a Low pitch and the latter with a High pitch. In (90) tú has a high tone and it is Past Progressive but in (91) tù has a low tone and it is Habitual.

\footnotetext{
${ }^{13}$ Software for acoustic analysis by Paul Boersma and David Weenink, University of Amsterdam, Netherlands.
} 
90. Matúkpí ubón adzísiadzí

ma-tú-kpí u-bón adzísiadzí

1SG-PTPROG-go CM-farm everyday

'I was going to farm everyday'

91. Matukpí ubón adzísiadzí.

ma-tu-kpí u-bón adzísiadzí

1SG-HAB-go CM-farm everyday

'I go to farm everyday.'

\subsubsection{Nominalising suffix -go}

Qualifiers often contain the -go nominalising suffix produced with a low tone. A syllabic nasal which is homorganic with the nasal and acts as a binder for the two morphemes is produced with a low tone. It has been observed that this binder consistently occurs where the preceding syllable has a high tone, as shown by the following words in (92):

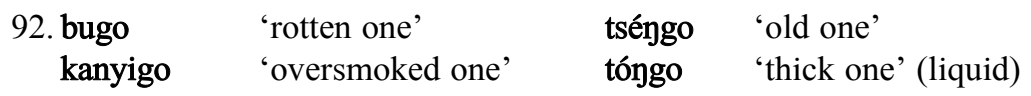

However, when the determiner, [-é], is suffixed to the nominal with the low tone -go suffix, it raises the pitch level of -go a little bit but phonologically it is still low.

This is shown in (93a) below:

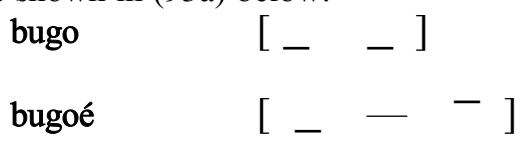

The following words in (93b) illustrate this.

$\begin{aligned} & \text { 93. bugo.é } \\ & \text { kanyigo.é 'the rotten one' }\end{aligned}$ 'the oversmoked one' tséngo.é 'the old one'
tóngo.é

2.5 Phonological processes

The following phonological processes are common in the Logba language.

\subsubsection{Final vowel deletion}

This phonological process is more easily observed in most CVNV syllable structure. When the NV is - nu, the final vowel undergoes deletion. The tone of the 
vowel remains and docks on the alveolar nasal on the left. The following are examples:

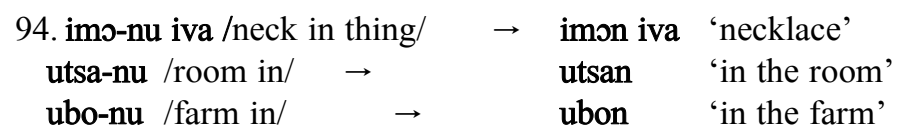

This also happens when mú 1SGOBJ pronoun is suffixed to the verb. In this context, the tone of the deleted vowel is high. It moves leftwards and docks on the bilabial nasal.

$\begin{array}{clll}\text { 95. gbla-mú } & / \text { teach me } / \rightarrow & \text { gbla ḿ } & \text { 'teach me' } \\ \text { tá-mú } & / \text { give me } / \rightarrow & \text { ta ḿ } & \text { 'give me' } \\ \text { dzé-mú } & / \text { look me } / \rightarrow & \text { dze ḿ } & \text { 'look at me' }\end{array}$

\subsubsection{Palatalization of consonants}

Palatalization is the raising of the body of the tongue as in the production of the initial consonant in the English word, she. The following alveolar consonants /s/, $/ \mathrm{z} /, / \mathrm{t} /, / \mathrm{d} /, / \mathrm{n} /$ are palatalized when each of them occurs before high vowels.

$\begin{array}{clll}\text { 96./t/ } & \text { /otú/ } & \text { [otsú] } & \text { 'hill' } \\ \text { /d/ } & \text { /odú/ } & \text { [odzú] } & \text { 'river' } \\ \text { /s/ } & \text { /isikpe/ } & \text { [ishikpe] } & \text { 'ring' } \\ \text { /z/ } & \text { /zi/ } & \text { [zhi] } & \text { 'good' } \\ \text { /n/ } & \text { /ani/ } & \text { [anyi] }{ }^{14} & \text { 2PLU SUBJ. }\end{array}$

\subsubsection{Vowel elision and labialization}

(Palatalization of consonant is restricted to the Tota dialect.) When the plural morpheme is suffixed to nouns which end with a close front vowel, this vowel undergoes deletion and the rounding of lips which is associated with the semivowel /w/ of the suffix remains. The following words in (97a) attest to this:

$97 \mathrm{a}$.

\begin{tabular}{|l|l|l|l|l|}
\hline etsi & 'parent & etsi-wo & 'parents' & etf's \\
\hline uklontsi & 'book' & uklontsi-wo & 'books' & uklont' ${ }^{\text {w } ~}$ \\
\hline
\end{tabular}

A further reduction is the optional realisation of tsiwo as [ $\left.\mathbf{t}^{\mathrm{w}} \mathrm{o}\right]$ in the word etsí 'parent.' This also occurs in ebitsí -wo [ebit ${ }^{\mathrm{w}} \boldsymbol{0}$ ] 'children'. This is illustrated in (97b) below.

\footnotetext{
${ }^{14}$ This is found to be peculiar to the speech of Vuinta speakers.
} 
$97 b$.

\begin{tabular}{|l|l|l|l|l|}
\hline ebitsí & 'child' & ebitsí-wo & 'children' & ebit $^{\mathrm{w}} \mathbf{0}^{15}$ \\
\hline etí & 'parent' & etí-wo & parents' & et $^{\text {wo }}$ \\
\hline
\end{tabular}

\subsubsection{Pronoun + verb stem + object pronoun}

[ATR] harmony operates across the word. The affixes have the same value based on the [ATR] value of the root. The spread is bidirectional. That is, from the verb and moves regressively to the bound form of the subject pronoun and from the verb to the bound form of the object pronoun. Example (98) shows [+ ATR] harmony spread on the suffix and the prefix and (99), (100) and (101) illustrate [-ATR] harmony spread on the prefix and the suffix of the verb. (99) is an example of a multi syllabic verb with a combination of [+ATR] and [-ATR] vowels in the verb stem. It triggers [-ATR] harmony with the value of the vowels at the edges.

98. ófó é

$$
[+\mathrm{ATR}]
$$

ó-fó =é

3SG.SUBJ-wash = 3SG.OBJ

'He/She washed it.'

[-ATR]

99. ałkpáwasa á ó-falife é

a-pkpáwasa =á ó-falif $\varepsilon=\hat{\varepsilon}$

CM-jujuman =DET 3SG.SUBJ-charm =3SG.OBJ

'The jujuman charmed him/her.'

100.ósrá $\varepsilon$

ó-srá $=\hat{\varepsilon}$

3SG.SUBJ-sieve $=3 \mathrm{SG}$.OBJ

'He/She sieved it.'

101.j́blo ع́

ว-blo $=\mathbf{\varepsilon}$

3SG.SUBJ-make $=3 \mathrm{SG} . \mathrm{OBJ}$

'He/she made it.'

\footnotetext{
${ }^{15}$ In the case of ebitwo some native speakers pronounce it in a way that the semi vowel is not audible at all.
} 


\subsubsection{Assimilation of tense and aspect markers}

\subsubsection{Present progressive}

The present progressive morpheme is $\mathbf{l u}$. The underlying vowel is $/ \mathbf{u} /$ because this is the vowel quality that surfaces after a consonant subject prefix such as $/ \mathbf{n} /$ for $1 \mathrm{SG}$, and after a open vowel subject prefix such as /a/ for 2SG. For example, nlu alu. The $/ \mathbf{1} /$ of the progressive morpheme completely assimilates to become $/ \mathbf{n} /$ after the nasal of 1SG. in the Alakpeti dialect. The /1/ however, becomes a stop /d/ in the Tota dialect ${ }^{16}$.

In other cases, (non nasal, non-low prefix), the $/ \mathrm{u} /$ vowel of present progressive assimilates in closeness and in frontness to the vowel of the subject prefix and for the mid-vowel in [ATR] to the vowel of the stem. In the 3SG, the progressive morpheme assimilates to the vowel of the pronoun [o] / [o] to become 10, lo. Similarly, the underlying vowel of the present progressive morpheme assimilates to the vowel of the 3PLU morpheme to be realized as e/e, $\varepsilon / \varepsilon$. In the 1PLU and the 2PLU the pronouns are two syllable words which have $/ \mathrm{a} /$ and $/ \mathrm{i} /$ in the first and second syllables respectively. The $/ \mathrm{i} /$ in the second syllable influences the underlying vowel $/ \mathrm{u} /$ to become $/ \mathrm{i} /$. This makes the vowel of the progressive morpheme in the $1 \mathrm{PLU}$ and $2 \mathrm{PLU}$ to change to $/ \mathrm{i} /$.

102.

$\begin{array}{ll}\text { 1SG Nnúlé afúta (Alakpeti) } & \text { 'I am buying cloth.' } \\ \text { 1SG Ndúlé afúta (Tota) } & \text { 'I am buying cloth.' } \\ \text { 2SG Alúlé afúta } & \text { 'You are buying cloth.' } \\ \text { 3SG Jlólé afúta } & \text { 'He /She is buying cloth.' } \\ \text { 1PLU Atililé afúta } & \text { 'We are buying cloth.' } \\ \text { 2PLU Anililé afúta } & \text { 'You (PLU) are buying cloth.' } \\ \text { 3PLU Elélé afúta } & \text { 'They are buying cloth.' }\end{array}$

103. 1SG Nnúdó utsaá'(Alakpeti) 'I am building the house.'

1SG Ndúdó utsaá (Tota) 'I am building the house.'

2SG Alúdó utsa á 'You are building the house.'

3SG Ólódó utsa á

1PLU Atilídó utsa á

2PLU Anilídó utsa á

3PLU Élédó utsa á

'He /She is building the house.'

'We are building the house.'

'You (PLU) are building the house.'

'They are building the house.'

The example sentences in (104) and (105) illustrate further that the verb stem controls the harmony spread. The verb selects one of the ATR pairs of the vowel prefixes that harmonises with the aspect marker. In (104), kpomi the main verb, has

\footnotetext{
${ }^{16}$ It is for this reason that there are two forms for the $1 \mathrm{SG}$ present progressive in the paradigms below. Alakpeti:Nnú za iva 'I am cooking' but in the Tota dialect Ndú za iva 'I am cooking.'
} 
[+ ATR] vowels. This results in the selection of o-lo. However, in (105) where the main verb zo has a [-ATR] vowel stem $\mathbf{0}-\mathbf{l}$ o is selected.

104.ólokpomi kla ko

ó-lo-kpomi kla ko

3SG-PRSPROG-collect hide only

'he is collecting it and only hide it only' [15.2.20]

105.Adzi ع́ ólózó ikú.

adzi $=\varepsilon$ é ó-ló-zó i-kú

bird = DET SM.SG-PRSPROG-sing CM-song

'The bird is singing' [15.3.31]

\subsubsection{Habitual and past progressive}

The Habitual is represented by tu with a low tone. It has other forms depending on the harmony in the verb stem and the pronoun following the same rules as established for lu. These are: ti, te, to, to. The Past Progressive uses the same segmental form but only the vowel carries a high tone.

106. Habitual

$\begin{array}{lll}\text { 1SG } & \text { matuzó } & \text { 'I go' } \\ \text { 2SG } & \text { atuzó } & \text { 'you go' } \\ \text { 3SG } & \text { ’́tozó } & \text { 'she/he goes' } \\ 1 \mathrm{PLU} & \text { atitizó } & \text { 'we go' } \\ \text { 2PLU } & \text { anitizó } & \text { 'you go' } \\ \text { 3PLU } & \text { ćtezó } & \text { 'they go' }\end{array}$

107. Past Progressive

$\begin{array}{lll}\text { 1SG } & \text { matúyé } & \text { 'I was standing' } \\ \text { 2SG } & \text { atúyé } & \text { 'you were standing' } \\ \text { 3SG } & \text { otóyé } & \text { 'she/he was standsing' } \\ \text { 1PLU } & \text { atitíyé } & \text { 'we were standing', } \\ \text { 2PLU } & \text { anitíyé } & \text { 'you were standing', } \\ \text { 3PLU } & \text { étéyé } & \text { 'they were standing' }\end{array}$

The proverb in (108) demonstrates further that the [ATR] harmony spread is controlled by the verb root. The verb, kpe 'know' has a [+ATR] vowel stem /e/. This makes the $3 \mathrm{SG}$ pronoun to select /o/ which is the [+ ATR] form of the pronoun.

108. 'Antényi té mkpónyi moóma olé f’é otokpé afágba.'

$\begin{array}{llllll}\text { Antenyi } & \text { té } & \text { mkponyi } & \text { moóma } & \text { o-le } & \text { f } \varepsilon \\ \text { earthworm } & \text { say } & \text { eye } & \text { NEG have } & \text { 3SG-be } & \text { also }\end{array}$


ó-to-kpe afa-gba

AM-HAB know home-path

'Earthworm says that even without eyes it knows the home path.' [15.4.24]

\subsubsection{Future}

The underlying form of the future marker is bá with a high tone. The same assimilation rules apply as established for lu. That is complete assimilation to preceding (non-open) vowel. The form for $1 \mathrm{SG}$ is ma with a low tone. This is exemplified in (109) and (110).

109.

SINGULAR

1. mabázó 'I will go'

2. abázó 'You will go'

3. obózó 'She/He will go'
PLURAL

1. atibízó 'We will go'

2. anibízó 'You will go'

3. ebézó 'They will go'

110. SINGULAR

PLURAL

1. atibífó 'We will wash'

2. anibífó 'You will wash'

3. ébéfó 'They will wash'

\subsection{Loanword phonology}

Ewe and Akan loan words are used profusely in the Logba language. Heine (1968:131) writing on loanwords in Togo Remnant languages, notes that 'The southern and eastern Togo Remnant languages borrowed mostly from Ewe and the western languages of this group borrowed from Twi'. He further notes that loan words of European origin have entered the language through the African lingua franca. What I have observed is that Ewe-Logba bilinguals with Ewe dominance and younger speakers especially those in the 'diaspora' use words from Ewe, Akan and English freely when they are speaking Logba. ${ }^{17}$ When Ewe nouns which have a mid tone prefix are borrowed in Logba, they are pronounced with a low tone prefix. With some words not only the tone changes but also a different noun class prefix is selected. The Ewe words and the Logba borrowings in (111) illustrate this:
111.
Ewe
èló
Logba
Gloss
òló
'crocodile'

\footnotetext{
${ }^{17}$ Before my initial fieldwork, I met two persons on University of Ghana Campus, on separate occassions. They are natives of Logba and they offered to describe some pictures which are part of the elicitation tools. These recordings were later played to a number of adult speakers on one of my visits to Logba. Surprisingly, the evaluation they gave is below the standard I expected
} 


$\begin{array}{lll}\text { ākpónò } & \text { àkpónò } & \text { 'biscuit' } \\ \text { ēglà } & \text { ìglà } & \text { 'jaw' } \\ \text { êdù } & \text { ìdù } & \text { 'gunpowder' } \\ \text { àká } & \text { ìká } & \text { 'charcoal' } \\ \text { ēsó } & \text { òsó } & \text { 'horse' }\end{array}$

Also there is a change of consonants of the Ewe loans in Logba. With some Ewe loan words with a CVCV stem, there is a change in the place of articulation of the consonant without a change in the vowel and the tone. fofú 'gather' in Ewe is realised as xoxú in Logba. Labialised velar fricative replaces the Ewe bilabial fricative which is absent in Logba. Example is ekutefe 'funeral' in Ewe, and in Logba the prefix is changed to $/ \mathrm{o} /$ and the bilabial fricative is replaced with velar fricative. Also the vowel in the final syllable becomes /oe/ in Logba instead of /e/ in this particular example. Other examples show that some words which are loaned have the same form and they do not undergo any change at all. The word xé is an example. It is used in inland Ewe dialects as relative particle and a particle that introduces the conditional clause. It has the same function in Logba.

A handful of words are identified with nasalised vowels that are loaned from Ewe. The nasalised vowels can be prolonged on the same pitch to show intensity. They can be analysed as ideophonic adverbs. Otherwise nasalisation only occurs allophonically in the context of nasal consonants in Logba. This is exemplified in (112):

112. tsỹ̃ 'for a long time'

fãã 'freely'

Akan loan words do not show any significant change except that high tone monosyllabic verbs change to a low tone in the uninflected citation form (see section 2.4.1). The citation form is formed by backformation on the basis of this rule. This is shown in the verb wò 'give birth in (113):

$\begin{array}{lll}\text { 113. Akan } & \text { Logba } & \text { Gloss } \\ \text { abé } & \text { abé } & \text { 'palm nut' } \\ \text { opété } & \text { opété } & \text { 'vulture' } \\ \text { wó } & \text { wò } & \text { 'give birth' }\end{array}$

English is a stress-timed language and has syllable types which are not found in the Logba language. Because of these facts, loan words from English to Logba undergo many changes. Consonant clusters and diphthongs are reduced to simple CVCV syllable with each vowel given a significant tone. Loans from English to Ewe have similar phonological features. It is not certain whether Logba borrowed via Ewe. The English loan words and how they are pronounced in the Logba language are shown in (114). Ewe pronunciations are also provided to show that they are identical with the Logba ones. 


$\begin{array}{llll}\text { 114. English } & \text { Ewe } & \text { Logba } & \text { Gloss } \\ \text { plate } / \text { pleit/ } & \text { pirénté } & \text { pirénté } & \text { 'plate' } \\ \text { pear } / \text { peə(r)/ } & \text { péya } & \text { péya } & \text { 'pear' } \\ \text { school } / \text { sku:l/ } & \text { sukú } & \text { sukú } & \text { 'school' }\end{array}$

\section{$2.7 \quad$ Logba orthography}

Considering the structure of words in Logba and their phonology, some of the orthographic conventions have been adopted and used in the grammatical description. The following consonant phonemes are written with the same character as their phonetic representation.

\section{5. f, v, s, z, t, d, k, g, kp, gb, x, h, ts, dz, m, n, y}

The phonetic representation [ $\mathrm{n}]$ and $[\mathrm{j}]$ have the orthographic form as 'ny' and ' $\mathrm{y}$ ' respectively. The apical post alveolar is written with character ' $d$ '. The glottal fricative is written with the character ' $h$ '.

The vowels, /a, i, e, $\varepsilon, \mathrm{u}, \mathrm{o}, \mathrm{o}, /$ are written as a, i, e, $\varepsilon, \mathrm{u}, \mathrm{o}, \mathrm{o}$. High tone is marked with an acute accent on the segment (á) and low tone is unmarked. Rising tone which is phonetically realised on a single syllable peak is represented with a haček as in ( $\check{a})$.

The palatal glide / $y$ / is written with the character ' $\mathrm{i}$ ' in the second margin in a CCV syllable (see section 2.3.2 - 2.3.3 for a discussion of this). This is illustrated in (116).

\section{6. [bya] bia 'boil' \\ [a-fye] afie 'comb'}

In the nucleus in a CV syllable, the close front vowel / $i$ / is written as ' $i$ ' as shown in the following words in (117)

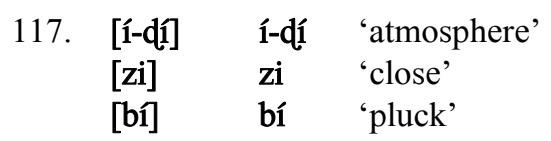

The labial-velar approximant /w/ as a second element in a CCV syllable structure is written with the character ' $u$ ' (see section 2.3.3). This is illustrated in (118).

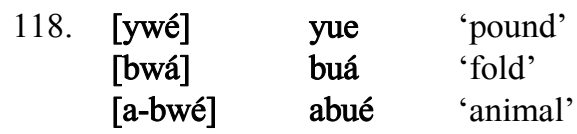


[fu-fwi] fufuí 'pounded yam / cassava'

However, in the onset in a CV or CCV syllable the sound /w/ is written as ' $\mathrm{w}$ ' as shown in (119).

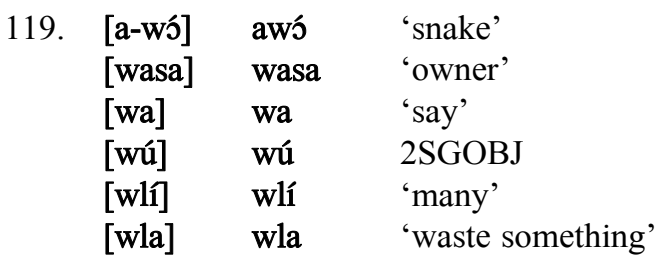

The subject markers are written together with the verbs they are attached to. In (120) the subject marker / $\mathrm{i} /$ is attached to du 'be'

120.Adð́dí îdu ikago kelekele.

A-dódí î-du i-kago kelekele
CM-love SM-be CM-law first
'Love is the first law' [15.8.02]

Also monosyllabic preverbal markers and the first pair of the negative marker are written together with the verb. This is illustrated in (121)

121. amolónú ojkpe
a-mo-ló-nú
o-ıkpe
3PLU-NEG-PRSPROG-see
CM-nothing
'they are not getting anything' [15.10.26]

Compounds are written with a hyphen while verb and object, noun and determiner are written separately.

Some of these conventions, for example, the use of the vowel symbols for the $\mathrm{C}_{2}$ glide consonants, are inspired by Ewe orthographic practice since some of the Logba speakers are literate in Ewe and are familiar with written Ewe. 



\section{NOUNS AND NOUN CLASSES}

This chapter is in three major parts. The first part describes the noun class system and goes on to discuss noun compounds in part two and pronouns in part three.

\subsection{Nouns}

Nouns in Logba have a low-tone vowel prefix. There are also nouns with nasal prefix and some loan words which are prefixless. All vowels are used as prefix on nouns. Out of a total of 1,635 words in my lexical data base, 1,069 are nouns out of which 799 have a vowel prefix, which is 75 per cent of the nouns in the data. The distribution of the noun with singular prefix is in Table 3.1 below:

Table 3.1 Frequency of Noun Prefix in lexemes

\begin{tabular}{|l|l|l|}
\hline PREFIX & NUMBER & PERCENTAGE \\
\hline $\mathrm{a}$ & 258 & 32.3 \\
\hline $\mathrm{i}$ & 153 & 19.2 \\
\hline $\mathrm{u}$ & 138 & 17.2 \\
\hline $\mathrm{o}$ & 104 & 13.2 \\
\hline $\mathrm{o}$ & 101 & 12.6 \\
\hline $\mathrm{e}$ & 43 & 5.3 \\
\hline$\varepsilon$ & 2 & 0.2 \\
\hline TOTAL & 799 & 100.0 \\
\hline
\end{tabular}

In Table $3.1 / \mathrm{a} /$ has the highest frequency because it is capable of being attached to stem with both [+ ATR] and [-ATR] vowels. The least frequent vowel prefix is / $\varepsilon /$. Prefixes are used with nouns in citation form. In some cases, these prefixes are elided or changed to other vowels when they combine with other nouns or words. Another observation from the study of the data is that there are 32 lexical items which are descriptive noun compounds with [iva-] 'thing'. When this is added, the total will be 831 nouns and the /i-/ prefix nouns will have the frequency of 22.3 per cent.

\subsubsection{Noun classes}

While some languages have two or three genders, others have a detailed system by which they arrange their nouns according to the features they have in common. Anderson (1985:175) reports that the number of groups may range from two (as in French) three (as in Latin) four (as in Australian language, Dyirbil) to as many as twenty or so (in the noun class languages of Africa). 
According to Schuh (1995:128) the term, noun class has been used in at least two senses in African languages. In one use, it refers to 'a single set of morphological concords'. In another sense, it refers to 'a paired set of morphological concords' where the member of the pair refers to singular and the other member is its plural equivalent. I use noun class in the first sense.

In a noun class language of the Niger Congo family generally, nouns have a particular prefix in the singular, and form their plural through the use of a different prefix. There are some nouns especially mass nouns which, as a result of their meaning do not have a number differentiation. Also, there is a system of morphological concord between a nominal and the verb. The GTM languages are reported by most researchers to have noun class systems and Logba is no exception.

A close examination of the noun class system reveals three interconnected systems. These are:

a. The prefix classes

b. The singular and plural pairings

c. The agreement classes.

\subsubsection{The prefix classes}

The largest number of nouns has an a- prefix. These nouns have the nasal prefix as their plural. Nouns that have $u$ - in the singular have e-/ $\varepsilon$ - in the plural and those that have $\mathrm{e}-/ \varepsilon$ - in the singular have a nasal prefix in the plural. There are some nouns with the nasal prefix which are liquid nouns. The nouns that have o-/o-prefix in the singular have i-prefix in the plural. A group of nouns with the i-prefix are mass nouns. There is another group of nouns which do not have a prefix. These zero prefix nouns are identified as borrowed words.

\subsubsection{Singular plural pairings}

Another system that comes up is the singular and plural pairings. This is shown in table 3.2 below:

Table 3.2: Singular and plural pairings.

$\begin{array}{ll}\text { SINGULAR } & \text { PLURAL } \\ \text { a- } & \text { N- } \\ \text { u- } & \text { e- } / \varepsilon \\ \text { e- } / \varepsilon & \text { N- } \\ \text { o- } / \mathrm{o}- & \text { i- }\end{array}$




\subsubsection{Agreement classes}

It is a grammatical requirement in Logba to cross reference the subject on the verb as concord. This is used to put the nouns into agreement classes. The nouns which have the o-/o- verbal concord are by far the largest group of nouns. They comprise nouns with the following prefixes. o-/o-, $\mathbf{u}-$, e-/ $\mathbf{\varepsilon}-$, and a- prefix nouns ${ }^{18}$. These are all singular nouns. Nouns that trigger the i- verbal concord are those that take inoun prefix. Nouns whose stems belong to the o-/o- noun prefix take the o-/o- singular class. Nouns that are cross referenced by the $\mathrm{N}$ - prefix as verbal concord are those nouns that take the $\mathrm{N}$-noun prefix. Nouns with the e-/ $\varepsilon-$ plural noun prefix trigger the concord of the same form.

\section{2}

\section{Subject agreement markers}

The Subject agreement classes of all the Noun classes are further illustrated with example sentences in Table 3.3.

Table 3.3: Subject Agreement classes with example sentences

\begin{tabular}{|c|c|c|}
\hline $\begin{array}{l}\text { NOUN } \\
\text { PREFIX }\end{array}$ & $\begin{array}{l}\text { VERBAL } \\
\text { CONCORD }\end{array}$ & EXAMPLE SENTENCE \\
\hline \multirow[t]{2}{*}{ a- } & ó- & $\begin{array}{l}\text { A-gbi }=\hat{\varepsilon} \quad \text { ó-yú } \quad \text { n-wo } \quad \text { u-tsa. } \\
\text { CM-dog=DET SM.SG-see CM-bee } \\
\text { CM-home } \\
\text { The dog saw a bee hive. }\end{array}$ \\
\hline & ó- & $\begin{array}{l}\text { A-ndo-=á ó-zó o-dzátsúme. } \\
\text { CM-cat=DET SM.SG-go CM-kitchen } \\
\text { The cat went to the kitchen. }\end{array}$ \\
\hline N- & Ń- & $\begin{array}{l}\text { N-kó=á ń-dó. } \\
\text { CM-fowl=DET SM.PLU-go.out } \\
\text { The fowls went out. }\end{array}$ \\
\hline a- & á- & $\begin{array}{l}\text { A-fútá á-kó a-gli=é } \quad \text { yó. } \\
\text { CM-cloth SM.SG-hang CM-wall=DET skin } \\
\text { The cloth hangs on the wall. }\end{array}$ \\
\hline \multirow[t]{2}{*}{$\mathrm{u}-$} & ó- & $\begin{array}{l}\text { U-dzi }=\hat{\varepsilon} \quad \text { ó-glé } \quad \text { belet. } \\
\text { CM-girl= DET SM.SG-tie belt } \\
\text { The girl has a belt on her waist. }\end{array}$ \\
\hline & ó- & $\begin{array}{l}\text { U-nansá=á ó-zó } \quad \text { Tota. } \\
\text { CM-chief=DET SM.SG-go Tota } \\
\text { The chief went to Tota. }\end{array}$ \\
\hline
\end{tabular}

${ }^{18}$ A small group of a-prefix nouns, which I describe as artefacts because they are - wood, clay, cotton and metal objects, take a-prefix as agreement marker in the singular. In the plural, they fall in the class of nasal prefix nouns and take $\mathrm{N}$ - as agreement marker. 


\begin{tabular}{|c|c|c|}
\hline e- & é- & $\begin{array}{ll}\text { E-nansá é-bá } & \text { Klikpo. } \\
\text { CM-chief SM.PLU-come } & \text { Klikpo } \\
\text { Chiefs came to Klikpo. } & \\
\end{array}$ \\
\hline \multirow[t]{2}{*}{ e- } & ó- & $\begin{array}{l}\text { E-feshi-=é o-bo u-tsá nu. } \\
\text { CM-sheep=DET SM.SG-stay CM-house in } \\
\text { The sheep is in the room. }\end{array}$ \\
\hline & ó- & $\begin{array}{l}\text { E-bitsí=é } \quad \text { ó-fónyí koduatsia. } \\
\text { CM-child=DET SM.SG-peel banana. } \\
\text { The child peels banana. }\end{array}$ \\
\hline e- & á- & $\begin{array}{l}\text { E-kele-wo á-lé a-fá=á } \quad \text { nu. } \\
\text { CM-grass-PLU SM.PLU-be AM-house=DET in } \\
\text { Grasses are in the house. }\end{array}$ \\
\hline \multirow[t]{2}{*}{ o- i- } & ó- & $\begin{array}{l}\text { O-ló } \quad \text { ó-rí=é. } \\
\text { CM-crocodile SM.SG-hold=3SGOBJ } \\
\text { crocodile caught him. }\end{array}$ \\
\hline & ó- & $\begin{array}{l}\text { O-gblawò=é ó óla } \quad \text { Kofi. } \\
\text { CM-teacher =DET SM.SG-beat } \\
\text { The teacher beat Kofi. }\end{array}$ \\
\hline i- & í- & $\begin{array}{l}\text { I-wo i-bo a-fá=á } \quad \text { nu. } \\
\text { CM-mortar SM.PLU-stay CM-house = DET in } \\
\text { Mortars are in the house. }\end{array}$ \\
\hline N- & Ń- & $\begin{array}{l}\text { N-dú } \quad \text { ń-tó } \quad \text { u-zí-e } \quad \text { yó. } \\
\text { CM-water } \\
\text { Water pours on the door. }\end{array}$ \\
\hline i- & i- & $\begin{array}{ll}\text { I-no fítsi } & \text { futsu=é nu. } \\
\text { CM-meat SM-be.in } & \text { soup=DET in } \\
\text { Meat is in the soup. }\end{array}$ \\
\hline
\end{tabular}

The verbal subject marker is specified as SM.SG when it refers to a singular noun and SM.PLU when it refers to a plural noun. The subject marker is left unspecified for singular or plural when it refers to liquid and mass nouns. For liquid and mass nouns, SM is used. No class distinction is indicated in the glossing of the subject marker.

The prefixes on the noun are glossed as CM for both singular prefix and plural prefix. The additional suffix -wo attached to some nouns is glossed as PLU. Other noun class agreement markers such as those on demonstratives and quantifiers are glossed with AM (agreement marker).

There is an agreement relation between the noun and the demonstrative. In the singular, o-/o- is used as a prefix to the demonstrative, a- for plural, $\mathbf{i}$ - for mass nouns and other i-prefix nouns. $\mathrm{N}$ - is the agreement marker for liquid nouns and any other N-prefix nouns. 
The agreement relation between the noun and question word bé 'how much' is identical to that of the demonstrative but restricted to the plural classes so the plural agreement marker a- is used, i- for mass nouns and for other i-noun prefix nouns and $\mathrm{N}$ - for liquid and $\mathrm{N}$-prefix nouns. Other question words which combine with singular nouns use o-/o- as a prefix to the question word.

In respect of numbers, when used as modifiers the numbers one to six which have i-prefix when counting, exhibit variation in the prefix to show agreement with the head noun. But it is only when the head noun is individuated that the agreement is shown. With the singular prefix classes, nouns belonging to $\mathbf{u}-, \mathbf{e}-\mathbf{\varepsilon} \mathbf{\varepsilon}-, \mathbf{o}-/ \mathbf{o}-$ take the o-/o- agreement on the number. Countable nouns belonging to the $\mathrm{N}$-class take the $\mathrm{N}$ - agreement marking on the number. The a-prefix class of artefacts takes aagreement marker. The a- noun prefix class of animates take o-/o-. The e-/ $\mathbf{\varepsilon}$ - plural nouns take the a- agreement marking on the number. The choice between e-/ $\varepsilon$-, and o-/o- depends on the [ATR] harmony in the word. The agreement systems are shown in Table 3.4 .

Table 3.4: Agreement systems.

\begin{tabular}{|c|c|c|c|}
\hline NUMBER & PREFIX & VERB AGREEMENT & DEMONSTRATIVE \\
\hline I & a- SG & o-/0- & $0-/ 0-$ \\
\hline II & N- PLU & $\mathrm{N}-$ & N- \\
\hline III & $\mathrm{u}-\mathrm{SG}$ & $0-/ 0-$ & $0-/ 0-$ \\
\hline IV & e-/ع-PLU & $\mathrm{e}-/ \varepsilon$ & $\mathrm{a}-$ \\
\hline $\mathrm{V}$ & $\mathrm{e}-/ \varepsilon-\mathrm{SG}$ & o-/o- & $0-/ 0-$ \\
\hline VI & N- PLU & $\mathrm{a}-$ & N- \\
\hline VII & o-/o- SG & $0-/ 0-$ & $0-/ 0-$ \\
\hline VIII & i- PLU & i- & i- \\
\hline IX & a- SG & a- & a- \\
\hline
\end{tabular}

A combination of external verb agreement and noun phrase internal agreement results in nine different agreement classes: five singular and four plural classes. Two of the 'plural' agreement classes also contain nouns that have no number distinction. These are mass nouns with a noun prefix $\mathrm{i}-$ in class VIII and liquid nouns with a nasal prefix in class II. There are two singular noun classes with a noun prefix a-. These are distinguished in verb agreement only. There are two plural noun classes with a noun prefix $\mathrm{N}$-. These too are distinguished in verb agreement only. The singular classes I, III, V, and VII have identical agreement patterns but different noun prefix and different plural pairings

\subsubsection{Further statements about the nouns}

The following statements can be made about nouns in Logba: 
With some plural nouns in class II and VI with a nasal noun prefix there is additional suffixation of the plural marker -wo. The following nouns attest to this:

$\begin{array}{lll}\text { 1. a-gutó } & \text { n-gutó-wo } & \text { 'bat' } \\ \text { a-dzimi } & \text { n-dzimi-wo } & \text { 'mudfish' } \\ \text { e-féshí } & \text { n-féshí-wo } & \text { 'sheep' }\end{array}$

Some nouns have only [-wo] attached to them without the alternation of the noun prefix. These nouns are loans either from Ewe or can be traced to other languages in the area. The plural morpheme in Ewe is [wó]. It is probable that the Logba form [-wo] is based on this morpheme. These nouns show the same agreement as their singular counterparts. The following nouns are examples:

$\begin{array}{lll}\text { 2. a-kpóno } & \text { a-kpónó-wo } & \text { 'biscuit' } \\ \text { u-kpló } & \text { u-kpló-wo } & \text { 'table' } \\ \text { a-kó } & \text { a-kó-wo } & \text { 'parrot' }\end{array}$

There is another group in the e- class (IV/V) which makes use of no plural prefix. They appear to form a class because they are nouns relating to the things in the environment.

$\begin{array}{lll}\text { 3. e-ví } & \text { e-ví } & \text { 'sun' } \\ \text { e-tsí } & \text { e-tsí } & \text { 'land' } \\ \text { e-gbe } & \text { e-gbe } & \text { 'stone' } \\ \text { e-ke } & \text { e-ke } & \text { 'root' }\end{array}$

There are other prefixless nouns which take the plural suffix -wo and without prefix. These nouns can be traced to Ewe. Some of the words, for example, a-bladzo have prefixes in Ewe.

$\begin{array}{lll}\text { 4. mango } & \text { mango-wo } & \text { 'mango' } \\ \text { bladzó } & \text { bladzó-wo } & \text { 'plantain' } \\ \text { fesre } & \text { fesre-wo } & \text { 'window' } \\ \text { sefófó } & \text { sefófówo } & \text { 'flowers' }\end{array}$

There is a simplification of the singular-plural prefix system going on. In an elicitation session in Jim Borton Memorial Secondary School in Adzakoe on nouns and their plurals from students who are native speakers between 16 to 21years of age, the students added the suffix -wo to nouns. When I presented the data to older speakers in Klikpo, Adiveme and Alakpeti, they frowned on these forms describing them as ungrammatical and a careless adulteration of the language.

This simplification and generalisation is common among the younger speakers. One can infer that in a not too distant future, when the present generation of adult population passes away, what will remain of the class system will be difficult to 
notice. This does not mean that the -wo suffix is inappropriate. There are many nouns for which this suffix is the accepted form.

In nouns referring to peoples there can be singular suffix parallel to the plural suffix. A good candidate to exemplify this point is the noun A-kpana-nyi, which means 'a person who hails from Akpana'. There is a template for prefixing and suffixing on the noun in the language and that there is an internal shift in the language in favour of the suffix, -wo. In addition, I propose that the noun prefix is a language internal grammatical feature and the wo suffix is a product of the contact with Ewe (see Bertho 1952:1051). It is probable that this process will continue until a large number of the prefixes will be 'bleached out' of the language.

There are nouns which attract neither plural prefix nor plural suffix. These are nouns which are non-count or mass nouns. They also include undifferentiated nouns like 'stone', 'land' and nouns like 'sun' and 'moon'. It is probable that the world knowledge of the people makes them conceive these nouns as having no identifiable plural. Some examples are in $(5 a-5 d)$.

5a. a-

$\begin{array}{ll}\text { a-bobí } & \text { 'moon /month' } \\ \text { a-bu } & \text { 'valley' } \\ \text { a-débí } & \text { 'kidney' } \\ \text { A-drúva } & \text { 'Thursday' } \\ \text { a-nú } & \text { 'mouth' }\end{array}$

5b. u-

$\begin{array}{ll}\text { ú-sú } & \text { 'urine' } \\ \text { u-súsofolí } & \text { 'bladder' } \\ \text { u-ménta } & \text { 'salt' } \\ \text { u-múshi } & \text { 'smoke' }\end{array}$

5c. e-

$\begin{array}{ll}\text { é-gbe } & \text { 'stone' } \\ \text { e-tsí } & \text { 'land' } \\ \text { e-ví } & \text { 'sun' } \\ \text { e-ke } & \text { 'root' }\end{array}$

5d. o-/o-

$\begin{array}{ll}\text { o-dóntí } & \text { 'waist' } \\ \text { o-dzá } & \text { 'fire' } \\ \text { o-kúnu } & \text { 'anus' } \\ \text { o-lómí } & \text { 'testis' }\end{array}$

There are a few nouns that have suppletive and compound plurals. The stem of the plural a-ha 'persons' is closely similar to the Ewe word for group ha. The plural for 
'man' and 'woman' are compounds using the word ina- as the first word of the compound followed by the word for man or woman. This is illustrated in (6):
6. i-na 'person'
a-há
'persons'
o-sá 'man'
i-ná-sá ${ }^{19}$
'men (literally: person men)'
u-dzé 'woman'
i-ná-dz $\hat{\varepsilon}^{20}$
'women (literally: person women)

Noun classes may have semantic bases. This has been demonstrated for some languages (see Breedveld 1995, Aikhenvald 2000). However, the patterns displayed in languages are not universal, there are marked language specific differences.

A rough semantic range is typical of each noun class. Each class has other nouns which are not easily accounted for by a single semantic feature.

a- class as Class I and Class IX

The a- class hosts a large number of nouns. Three sub-semantic groups emerge. These are: a. Animals. b. Body parts c. Artefacts.

The semantic subgroup of Animals contains nouns referring mostly to animals, and insects. The o- / o- prefix is used to refer to them.

7a. Animals

$\begin{array}{llll}\text { a-n.do } & \text { 'cat' } & \text { a-gbé } & \text { 'dog' } \\ \text { a-n.kó } & \text { 'chicken' } & \text { a-kló } & \text { 'goat' } \\ \text { a-gú } & \text { 'antelope' } & \text { a-lá } & \text { 'scorpion' } \\ \text { a-kpakpla } & \text { 'frog' } & \text { a-gbíglomo } & \text { 'spider' }\end{array}$

7b. Insects

a-zuzs 'housefly' a-nyo 'louse'

akpakpla 'frog' is borrowed from Ewe and it is integrated in this class. This is based on the form and the meaning in Ewe and Logba.

b. Nouns referring to visible parts of the body form a second semantic group within this class. These terms can be applied to parts of animals as well.
8. a-tró 'breast' a-nana 'rib'
a-fuí 'thigh' a-gbashi 'arm'
a-kukóli 'finger nails'

c. Nouns in this group are things made from e.g. clay or wood or cotton by humans for use in their daily activities. They constitute class IX and have an a- verbal agreement prefix.

\footnotetext{
${ }^{19}$ There are some speakers who have the plural as asáwo.

${ }^{20}$ There are some speakers who have the plural as $\varepsilon d z \varepsilon w o$.
} 
$\begin{array}{llll}\text { 9. a-lé } & \text { 'clay-bowl' } & \text { a-kóntí } & \text { 'basket' } \\ \text { a-kpó } & \text { 'farm-bag' } & \text { a-só } & \text { 'pot' } \\ \text { a-biá } & \text { 'chair' } & \text { a-fúta } & \text { 'cloth' }\end{array}$

u- class Class III

This class contains at least four semantic clusters, namely: 1. Kinship terms, 2. Social organisation terms, 3. Human category terms and 4. Important socio-cultural possessions.

10a. Kinship terms

$\begin{array}{llll}\text { u-gusa } & \text { 'brother' } & \text { u-tí } & \text { 'father' } \\ \text { u-gu } & \text { 'husband' } & \text { u-má } & \text { 'mother' }\end{array}$

10b. Social group terms

$$
\begin{array}{ll}
\text { u-sá } & \text { 'clan' } \\
\text { u-nánsa } & \text { 'chief' (status) } \\
\text { u-bome } & \text { 'town' }
\end{array}
$$

10c. Human category terms

$$
\begin{array}{ll}
\text { u-dzé } & \text { 'woman' } \\
\text { u-bí } & \text { 'child }
\end{array}
$$

Socio-culturally salient entities and their parts (or things that belong to them) belong to this class. It could be argued that $\mathbf{u}$-tsa 'house' is the bridge between the social organisation and these socio-culturally important terms. Among these, barn, grinding stone can be found in the home and in some cases in the farm:

$\begin{array}{clll}\begin{array}{c}\text { 11. u-tsá } \\ \text { u-bo }\end{array} & \text { 'house' } & \text { u-loégbé } & \text { 'grinding stone' } \\ \text { u-mútsí } & \text { 'barn' }\end{array}$

e- class Class V

This is a small class comprising natural elements and items relating to ritual and religious practices

$\begin{array}{clll}\text { 12. e-ví } & \text { 'sun' } & \text { e-gbe } & \text { 'stone' } \\ \varepsilon \text {-kpé } & \text { 'year' } & \text { e-kelé } & \text { 'grass' } \\ \text { e-tsí } & \text { 'ground' } & \text { e-fiéyí } & \text { 'calabash' } \\ \text { e-feshi } & \text { 'sheep' } & \text { e-te } & \text { 'tooth' }\end{array}$

While in the field I observed a ritual caried out for the expiation for an attempted suicide in one of the Logba villages ${ }^{21}$. For example, some of the items listed above

${ }^{21}$ The ritual is recorded on a DVD and is available for viewing. 
were used or referred to during the ceremony confirming that they are a functional class.

\section{o- class Class VII}

The nouns in this class refer to God, man, important people, big animals and soft and attached human body parts. This class can be referred to as the augmentative class, the class of important things. This class includes the words related to male gender including specific body parts such as testis. The nouns belonging to the different sub-groups include:

13a.God and important people

$\begin{array}{ll}\text { O-kpaya } & \text { 'God' } \\ \text { o-núkpá } & \text { 'king' } \\ \text { o-sá } & \text { 'man' }\end{array}$

\section{3b.Big animals}

$\begin{array}{ll}\text { o-sámínángo } & \text { 'leopard' } \\ \text { o-dró } & \text { 'elephant' } \\ \text { o-gbómí } & \text { 'monkey' } \\ \text { o-só } & \text { 'horse' } \\ \text { o-ló } & \text { 'crocodile' }\end{array}$

13c.Soft and attached body parts

$\begin{array}{ll}\text { o-lómí } & \text { 'testis' } \\ \text { o-tsóe } & \text { 'ear' } \\ \text { o-tó } & \text { 'cheek' }\end{array}$

o-núkpá 'king' is perhaps loaned from Ga: o-ló the word for 'crocodile' is similar to Ewe e-ló but the prefix is different. The word for horse could also be borrowed from Ewe: esó. In fact, in some Ewe dialects the word has o- prefix. For example in the Peki dialect, it is o-só

N-class

This class is dominated by nouns referring to non-individuated entities especially liquids. Some of the members are:

$\begin{aligned} \text { 14. n-da } & \text { 'liquor' } \\ \text { n-dú } & \text { 'water' } \\ \text { n-fú } & \text { 'oil' }\end{aligned}$

i-class

In this class are non-count nouns which refer to either abstract entities like peace or masses made up of particles such as rice or sand.

15. i-be 'time' i-yóyú 'peace' 


$\begin{array}{llll}\text { i-n-fieyi } & \text { 'sand' } & \text { i-yánu } & \text { 'air' } \\ \text { i-tsí } & \text { 'soil' } & \text { i-múnyí } & \text { 'hair' } \\ \text { i-kágo } & \text { 'rule' } & \text { i-hanágo } & \text { 'indiscipline' } \\ \text { i-m-bí } & \text { 'rice' } & & \end{array}$

\subsection{Compounding}

\subsubsection{Compounding of nouns}

When two nouns are compounded the vowel prefix of the second noun is elided with the low tone it carries. If the second noun has a nasal prefix, it maintains its position forming a syllabic consonant. The order in compounds is head final. Examples are in (16):

$\begin{array}{rllll}\text { 16. idzó } & \text { iyó } & \text { 'yamstick' } & \text { idzóyó } & \text { 'yam-pole' } \\ \text { iwó } & \text { nqú } & \text { 'bee water' } & \text { iwóndú } & \text { 'honey' } \\ \text { ankó } & \text { afó } & \text { 'hen egg' } & \text { ankófó } & \text { 'hen egg' } \\ \text { agbí } & \text { afúta } & \text { 'spider cloth' } & \text { agbífúta } & \text { 'spider web' }\end{array}$

\subsubsection{Compounding of postpositional phrase + noun}

A noun may be added to a noun and postposition to form a compound. The vowel prefix of the noun is elided with the low tone it carries. Examples in (17):

17. ukpló tsú afúta

$\begin{array}{ll}\text { table on cloth } & \text { ukplótsúfútá 'table cloth' } \\ \begin{array}{l}\text { udzi tsú imúnyî } \\ \text { heart on hair }\end{array} & \text { udzitsúmúnyí 'chest hair' }\end{array}$

\subsubsection{Compounding of noun + wasa}

The lexical formative wasa 'owner' is added to a noun stem to form a new nominal as in (18)

18. ajkpá wasa 'juju owner' aykpáwasa 'jujuman'
adzé wasa 'witch owner' adzéwasa 'witch’

\subsubsection{Compounding of noun + sex-determining word}

A noun can be compounded with a root of o-sá 'man' or u-dzé 'woman' The prefix of the sex determining word is elided, as exemplified in (19). 
19.

$\begin{array}{llll}\text { afá udzé } & \text { 'house woman } & \text { afádze } & \text { 'landlady' } \\ \text { afá osá } & \text { 'house man' } & \text { afása } & \text { 'landlord' } \\ \text { akló osá } & \text { 'goat man } & \text { aklósá } & \text { 'he-goat' } \\ \text { abué udzé } & \text { 'animal woman' } & \text { abuédze } & \text { 'female animal, goat' }\end{array}$

In (19) the compound word, abuédze is used in most cases to refer to nanny-goat. This is a sacred animal to the Logba people. They are not supposed to kill it or inadvertently eat a meal prepared with it.

\subsubsection{Compounding of noun + verb}

Another compound which is common is a sequence of noun and verb. The verb denotes a property. The following are examples:

$\begin{array}{llll}\text { 20. iyó yú } & \text { 'skin cold' } & \text { iyóyú } & \text { 'peace' } \\ \text { asó druí } & \text { 'pot red' } & \text { asódruí } & \text { 'unmentionable' }\end{array}$

asódruí is used to give a fore-warning if one of the interlocutors in a speech situation is making a remark which is considered by the other to be malicious and uncomplimentary. The colour, red symbolises danger. In the sentence below, a child makes a statement about one of the funeral customs in Logba and the mother warns:

21. Abózí asó druí ló!

a-bó-zí $\quad$ a-só-druí ló!
2SG-FUT-lift $\quad$ CM-pot-red warning (I warn you)
'You should be careful not lift the red pot.'

\subsection{Nominalisation}

Nominalisation is a process of forming a noun from some other word class (see Comrie and Thompson 1985). The following are nominalisation processes in Logba.

\subsection{1 $[\mathrm{V}+-\mathrm{go}]$ nominalisation}

A noun can be formed by the suffixation of the -go nominalising suffix to the verb. The -go nominalising suffix is produced with a low tone and it is invariant for vowel harmony. A syllabic nasal which is homorganic with the velar nasal and acts as a linker for the two morphemes is produced with a low tone. It has been observed that this linker consistently occurs where the preceding syllable is a high tone, as shown by the stems below: 


$\begin{array}{clll}\text { 22. na } & \text { 'walk' } & \text { na-go } & \text { 'walking' (journey) } \\ \text { gle } & \text { 'tie' } & \text { gle-go } & \text { 'tied' } \\ \text { sa } & \text { 'leave' } & \text { sa-go } & \text { 'leaving'(migration) } \\ \text { blo } & \text { 'make' } & \text { blo-go } & \text { 'making' } \\ \text { bu } & \text { 'be rotten' } & \text { bu-go } & \text { 'rotten one' } \\ \text { tó } & \text { 'become thick' } & \text { tó-n-go } & \text { 'thick one' (liquid) } \\ \text { tsé } & \text { 'be old' } & \text { tsé-n-go } & \text { 'old one' }\end{array}$

These nominalised verbs can function as a subject in a sentence. The verb, yú 'be cold' is converted to a nominal, iyúgoe 'coolness.' It has taken i- prefix, thus entering the group of non-count mass nouns. All derived nouns in -go use the noun prefix i- when functioning as an independent noun. This is illustrated in (23)

23. iyúgo é xe íbo etsienu izi

$$
\begin{array}{llll}
\text { i-yú-go=é } & \text { xe î-bo } & \text { e-tsienu } & \text { i-zi } \\
\text { CM-cold-NOM=DET } & \text { RP SM-stay } & \text { CM-soil } & \text { SM-be.good }
\end{array}
$$

'The coolness (moisture) in the ground is good'

The nominal with -go suffix can also function as an object of a sentence iglegoe 'tied one' is the object of the verb yú 'see' in the sentence below in (24).

24 Ovanukpiwo é ónú iglegoé
O-vanukpiwo $=$ é
ó-yú
i-gle-go-é
CM-hunter $=$ DET
SM.SG-see
$\mathrm{CM}$-tie-NOM $=$ DET

'The hunter saw the tied one'

The nominalising suffix -go makes these words, which are used to qualify other nouns, morphologically nominals. When they are used as qualifiers or modifiers they do not take the i-prefix. In (25a), bugo 'rotten one' qualifies avúdágo 'leaf' and in (25b) tséngo 'old one' qualifies amúgunedzé 'my sister'

\section{5a.Avúdágo bugo móózí \\ a-vudago bugo mó-ó-zi \\ CM-leaf rotten one NEG-3SG be.good \\ 'Rotten leaf is not good'}

25b.Nkpé bé amúgunedzé tséngo ólé?
$\mathrm{N}-\mathrm{kp} \varepsilon \dot{\varepsilon}$
bé amú-gunedzé
tséngo
ó-lé
CM-year Q 1SGPOSS-sister old_one AM-be
'What is the age of my old sister?' 


\subsubsection{Nominalisation involving nominalised verbs}

A nominalised verb can further form a compound with a noun. The nominalised verb occupies the final position and the noun class is determined by the first nominal.

$\begin{array}{clllll}\begin{array}{c}\text { 26. ogbá } \\ \text { aś́ }\end{array} & \begin{array}{l}\text { 'road' } \\ \text { 'pot' }\end{array} & \text { [nago]N } & \text { 'walking' } & \text { ogbánago } & \text { 'journey' } \\ \text { otá } & \text { 'war' } & \text { [gugo]N } & \text { 'broken' } & \text { asóblígo } & \text { 'broken pot' } \\ & \text { [gling' } & \text { stágúgo } & \text { 'fighting war' }\end{array}$

There is an alternative analysis in which the verb and object as its constituent are permuted and a nominalising suffix - go added to the VP to be permuted to form a nominal. According to Ameka and Dakubu (in press), this appears to be an areal phenomenon as nominalized verb is everywhere in Kwa preceded by its object.

\subsubsection{Agentive nominalisation [V+ -wo]}

-wo is invariant for vowel harmony and marks the agent. It is suffixed to the verb which is usually an action verb. The resulting noun has the o-/o- noun class prefix. (27) is an illustration of agentive nominalisation.

$\begin{array}{clll}\text { 27. blo } & \text { 'make' + wo } & \text { oblowo } & \text { 'creator; maker' } \\ \text { gbla } & \text { 'teach' + wo } & \text { ogblawo } & \text { 'teacher' } \\ \text { kp } \varepsilon & \text { 'eat' + wo } & \text { okpewo } & \text { 'eater' } \\ \text { mé } & \text { 'sew' + wo } & \text { oméwo } & \text { 'seamstress' } \\ \text { zo } & \text { 'sell' + wo } & \text { ozowo } & \text { 'seller' }\end{array}$

As the object requires an object to be expressed, either the word iva 'thing' or a noun which can occupy the object slot for the verb in question may be used. The result is a compound consisting of the object noun plus the verb with wo, in this order. The resulting compound has the noun class prefix of the noun object but the agreement of class I. In this case, agreement is according to the semantic feature of [+ human]. Examples are in (28).

$\begin{array}{cllll}\text { 28. iva } & \text { 'thing' } & \text { ogblawo } & \text { ivagblawo } & \text { 'teacher' } \\ \text { ina } & \text { 'person' } & \text { okpewo } & \text { inakpewo } & \text { 'eater' } \\ \text { utsá } & \text { 'house' } & \text { dówo } & \text { utsadowo } & \text { 'mason' } \\ \text { avá } & \text { 'medicine' } & \text { blowo } & \text { aváblowo } & \text { 'herbalist' }\end{array}$

\subsubsection{Instrumental nominals $\quad[\mathrm{iva}+\mathrm{V}+-\mathrm{N}]$}

Some Instrumental compounds involve the generic noun iva 'thing' to which a verb and a noun are added in this order. The instrumental noun follows the verb and the generic noun iva 'thing' precedes it. The noun formed refers to things used for the 
activity described by the stem. It is possible to have elision of vowels at stem boundaries in rapid speech. This is shown in the first and second examples in (29).

29. iva za asó

thing cook pot ivazásó 'cooking pot'

$\begin{array}{lll}\text { iva } & \text { mé } & \text { iva } \\ \text { thing } & \text { sew } & \text { thing' ivaméva 'needle' }\end{array}$

iva go egbe

thing grind stone' ivageegbe 'grinding-stone'

\subsubsection{Locative nominals [VO +- me]}

Nominals with locative meaning are derived when a locative, [-me] 'place' is suffixed to the verb which is preceded by the associated nominal.

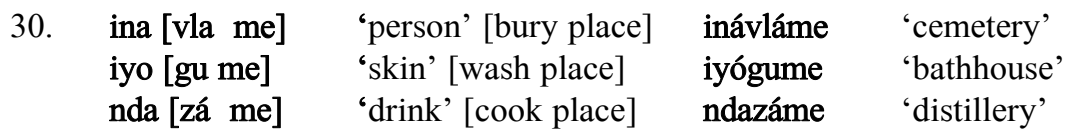

\subsection{Pronouns}

Table 3.6 represents pronoun and the pronominal affixes in Logba.

Table 3.6

\begin{tabular}{|c|c|c|c|}
\hline & INDEPENDENT & SUBJ. PREFIX & OBJ. SUFFIX \\
\hline SING. 1 & amú & ma- $(\mathrm{N})$ & $-\mathrm{m}(\dot{u})$ \\
\hline 2 & awú & a- & -wú \\
\hline 3 & ó lé iyé & ó-/ó- a- & -(l)é $\quad-(1) \hat{\varepsilon} \quad-n \varepsilon$ \\
\hline NON COUNT & & N- i- & \\
\hline $\begin{array}{ll}\text { PLU. } 1 \\
\end{array}$ & atú & ati- & -tú \\
\hline 2 & anú & ani- & -nú \\
\hline 3 & á alé & é- $\varepsilon-$ á- í-Ń- & -á \\
\hline
\end{tabular}

The term 'independent' is used to refer to pronominal words that function as nominals and can constitute a whole utterance (see Siewierska 2004:17). The independent person markers are used as single word responses to questions and emphatic forms in utterances. The bound form, on the other hand, is attached to the verb 
stems. The example sentences in (31a), (32a), and (33a), below are connected discourse and (31), (32), and (33) are careful word for word versions of each of them.

31. Jla $\mathfrak{\varepsilon}^{\circ}$

ว-la $=\hat{\varepsilon}$

3SG-beat $=3 \mathrm{SGOBJ}$

'He/She beat him/her.'

32. Gbla mú.

gbla $=$ muh

teach $=1 \mathrm{SGOBJ}$

'teach me.'

33. Mađú ubonukpíwo.

ma-dú u-bonukpiwo

1SG-be CM-farmer

'I am a farmer.' 31a. गlé.

ว $-1 \varepsilon=\hat{\varepsilon}$

3SG-beat $=3 \mathrm{SGOBJ}$

'He/She beat him/her.'

32a. Gbla ḿ.

gbla $=$ m

teach $=1 \mathrm{SGOBJ}$

'teach me.'

33a. Ndú ubonukpíwo.

n-dú u-bonukpiwo

1SG-be CM-farmer

'I am a farmer.'

(34) illustrates how pronouns combine with the negative marker. In the sentence below, the $2 \mathrm{SG}$ pronoun, a combines with mo the negative marker.

34 amolónu ojkpé gu abégoénu
a-mo-ló-nu
o-ykpe
gu a-bégoé-nu
2SG-NEG-again-see
CM-nothing from CM-dead.palm.tree-in

'You see nothing again from the dead palm tree' [15.10.26]

Pronouns substitute for nouns in a sentence. While the major defining criterion of grammatical relations is constituent order there are different forms of the personal pronouns depending on their syntactic function. The $3 \mathrm{SG}$ subject pronouns are prefixed to the verb and they choose the variant depending on the [ATR] value of the verb stem. The 3SG bound object pronoun has no class agreement and is [-(1)é] or $[-(1) \hat{\varepsilon}][n \varepsilon]$ as the object. If the vowel in the verb stem is [+ ATR], then [-(l)é] will be selected. On the other hand, if the vowel in the verb stem is [-ATR], [-(1)é] will be selected. (35) and (36) are examples:

35.nyitamble adzi é abóyi é abózó gatetsi.

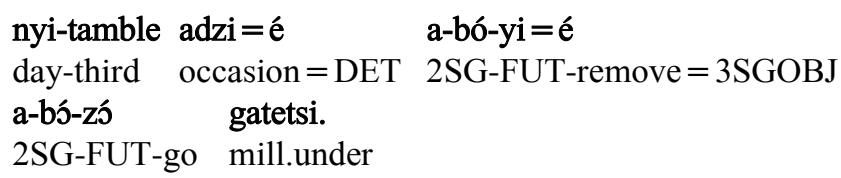

'The third day you will remove $\mathrm{it}^{22}$ and go to the mill' [15.12.02]

\footnotetext{
${ }^{22}$ It refers to tsiyi 'corn' class III
} 
36. Xé ato $\varepsilon$...

$$
\begin{array}{ll}
\text { xé } & \mathbf{a}-\mathbf{t} \boldsymbol{0}=\boldsymbol{\varepsilon} \\
\text { COND } & \text { 2SG-process }=3 \text { SGOBJ }
\end{array}
$$

'If you process $i^{23} \ldots$ '

Where the speaker wants to be emphatic the full form of the $3 \mathrm{SG}$ object pronoun $-l \varepsilon /-l e n \varepsilon$ is used. In (37) $l \varepsilon$ refers to linguist staff and in (38) $n \varepsilon$ refers to palm oil.

37. anitimi $1 \varepsilon$ tá tsami mango

$\begin{array}{llll}\text { ani-ti-mi }=1 \varepsilon & \text { tá } & \text { tsami } & \text { mango } \\ \text { 2PLU-HAB-take = 3SGOBJ give } & \text { linguist } & \text { another } \\ \text { '..you give it to another linguist' } & & \end{array}$

38. Abólóblu ne nu tsyэo.
A-bó-lo-blu $=\mathrm{n} \varepsilon$
nu tsyos
2SG-FUT-PROG-stir $=3$ SGOBJ in IDEO
'You will be stirring in it for some time.' [15.11.35]

When the bound form of the pronoun is used no word can come between the pronoun and the verb. However, the independent form of the pronoun, when used in emphatic speech, is not attached to the verb. (40) is ungrammatical because the independent form of the pronoun stands alone without the support of its corresponding bound form as can be seen in (41) below:

39. Máfó mémgbá á nu udántsí me

$\begin{array}{llll}\text { má-fó mémgbá=á nu u-dántsí } & \text { mé } \\ \text { 1SG-wash plate=DET in } & \text { CM-morning } & \text { this } \\ \text { 'I washed the plate this morning' } & & \end{array}$

40. *Amúfo memgba á nu udantsi me
* amú-fo memgba =á
1SG.IND-wash plate $=$ DET
$\mathrm{nu}$ u-dantsi $\mathrm{m} \varepsilon$
in CM-morning this

'I washed the plate this morning'

Amú mafó memgba á nu udantsi me

$\begin{array}{lllll}\text { amú ma-fó memgba=á nu u-dantsi } & \text { me } \\ \text { 1SG.IND SG-wash plate=DET in CM-morning } & \text { this } \\ \text { 'I washed the plate this morning' (Emphatic) } & \end{array}$

The independent form is used in listing when the items to be listed are in the subject. The independent form of the pronoun functions like any other noun and has to

\footnotetext{
${ }^{23}$ It refers to idzó 'yam' class VIII
} 
be indexed on the verb with an agreeing pronoun when it is subject. The agreeing pronoun is a bound form of the pronoun. In (42) and (43) ati 1PLU is used. ani '2PLU' is used in (44). (43) is ungrammatical because the bound form of the pronoun is used in listing instead of the independent form.

42. Amu, Gameli kpe Selorm atikpé ímbí

$\begin{array}{lllll}\text { amu, } & \text { Gameli } & \text { kpe } & \text { Selorm } & \text { ati-kpé ímbí } \\ \text { 1SG.IND } & \text { Gameli } & \text { CONJ Selorm } & \text { 1PLU-eat CM-rice }\end{array}$

'I, Gameli and Selorm ate rice'

43. *Ma, Gameli kpe Selorm atikpé îmbî

*ma, Gameli kpe Selorm ati-kpé î-mbî

1SG Gameli CONJ Selorm 1PLU-eat CM-rice

'I, Gameli and Selorm ate rice'

\section{Anu kpe Esi anisa}

$\begin{array}{lll}\text { anu } & \text { kpe Esi } & \text { ani-sa } \\ \text { 2PLU.IND CONJ Esi } & \text { 2PLU-leave } \\ \text { 'You and Esi left' } & \end{array}$

The independent form can occur as head of an expanded NP and be modified by an adjective or a demonstrative. The adjective and the demonstrative come after the independent pronoun. In (45) okpukpe 'alone' is used to modify the 1SG.IND pronoun whereas in (46) the adjective kloyi 'small' and the demonstrative 'o-me 'this' are used. It can also be pointed out that ebítsí 'child' is a noun in apposition to the 2SG.IND pronoun.

45. Amú okpukpe ko mázó ubo é nu
amú okpukpe
1SG.IND alone only
má-zó
u-bo=é $\quad \mathrm{nu}$
'I alone went to the farm'

46. Awú ebítsí kloyi óme alé oyó nángo ómoá tsú

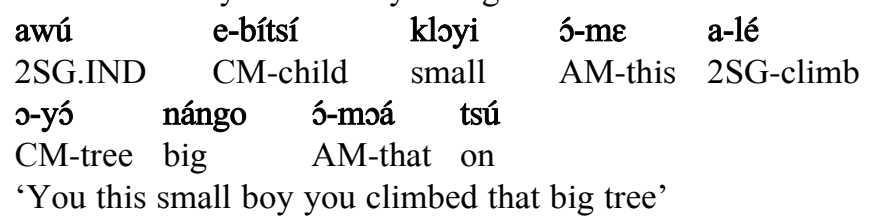

The 1SG SUBJ pronoun ma has another form $\mathrm{N}$. This is the result of the elision of the central vowel / $\mathbf{a}$ / and the assimilation of the nasal to the place of articulation of the following consonant. Clitics normally share properties of their host (see Siewierska 2004:26). The underlying pronoun clitic in sentences (48) and (49) below then become homorganic with the consonant adjacent to it. 
47. Mátá adzi ع́

má-tá a-dzi $=\hat{\varepsilon}$

1SG-shoot CM-bird = DET

'I shoot the bird.'

48.Mbázó Uge

m-bá-zó U-ge

1SG-FUT-go CM-Accra

'I will go to Accra'

49. Ndú ebítsí

n-dú e-bítsí

1SG-be CM-child

'I am a child'

[a-] is the second person singular subject form and [-wú] is the object form. The subject form of the second person is in (50) and the object form is in (51).

50. aךú agbé únáme
a-yú a-gbé
ú-náme
2SG-see CM-dog CM-yesterday
'You saw a dog yesterday'

51. Mbá lá wú

m-bá-lá= wú

1SGSUBJ-FUT-beat $=2$ SGOBJ

'I will beat you'

The 1PLU and 2PLU subject pronouns are disyllabic with low tones. Their counterpart in the object form is however monosyllabic with a high tone. The 1PLU subject is used in (52), 2PLUOBJ in (53) and 1PLUOBJ in (54).

52. Ati tró idu fé atilígbe atamá
ati
tró i-du

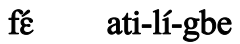
1PLU carry CM-gunpowder also 1PLU-PRSPROG-smoke a-tamá
CM-tobacco
'We carry gunpowder yet we are smoking tobacco' [15.4.25]

53. Jyú nú sukukpo é tsú
ว-ทú= nú
sukukpo $=$ é
tsú
$3 \mathrm{SG}-\mathrm{see}=2 \mathrm{PLUOBJ}$
school.compound $=$ DET on
'He saw you on the school compound' 
54. Etonam obú tú ilo á nu
Etonam ó-bú=tú
i-lo=á
$\mathrm{nu}$
Etonam SM.SG-ask = 1PLUOBJ
$\mathrm{CM}$-word $=\mathrm{DET}$ in
'Etonam asked us about the matter'

On further investigation it has been observed that the choice of pronouns is evidence of dialectal variation especially for humans in the third person. In the independent singular, [ó] is the form used mostly by native speakers from Tota. [olé] is used by speakers of the Alakpeti dialect. In the plural native speakers who speak the Alakpeti dialect use the [alé] for the 3PLU.IND in their descriptions. [Iy $\varepsilon$ ] is used when reference is made to a noun that is [-HUMAN] in the $3 \mathrm{SG}$ in all dialects as shown in (57). Those who speak the Tota dialect, use [á-] for the 3PLU SUBJ. (55) below is for Tota dialect. In (56) ebitsikloyi okpe 'a small child' agbé 'dog' and akpakpla 'frog' are nouns introduced in a narration. The grammar requires that an agreeing pronoun has to be indexed on the verb when it is subject. The 3PLU SUBJ pronoun used in the Alakpeti dialect is [é-].

55. Ami mpáni wo fé péya nu

$\begin{array}{lllll}\text { a-mi } & \text { m-páni } & \text { wo f́c } & \text { péya } & \text { nu } \\ \text { 3PLU-take } & \text { CM-needle } & \text { pierce }(\text { put in) } & \text { peas in }\end{array}$

'They take needle and pierced through the peas' [TRPS.70]

56. Ebítsíkloyi okpe, agbé kpé akpákplá ényá
e-bítsí-kloyì
o-kpe
a-gbé
kpé a-kpákplá
é-nyá
CM-child-small CM-one CM-dog CONJ CM-frog
SM.PLU-live
'There lived a small child, dog and a frog.'
$\left[15.1 .01^{24}\right]$

57. Iyé ámá yé awó zúgbó kótsú
iyé ámá yé
a-wó
zúgbó kótsú
3SG back CONJ 2SG-move
head hospital
'After it you head towards hospital'
[15.14.20]

In the 3PLU.OBJ pronominal form is á in all dialects. And for all classes (58) and (59) are examples.

58. Mané á Uge

$$
\begin{array}{ll}
\text { ma-né }=\text { á } & \text { U-ge } \\
\text { 1SG-buy =3PLUOBJ } & \text { CM-Accra } \\
\text { 'I bought them in Accra.' }
\end{array}
$$

\footnotetext{
${ }^{24}$ Even though this speaker Roselyn Adzah is a native of Tota, she resides in Alakpeti. This is apparently the reason for using a mixture of Tota and Alakpeti varieties.
} 
59. Kofi lá á gbaygbay
Kofi lá=á
Kofi beat $=3$ PLUOBJ
severely
'Kofi beat them severely.'

\subsubsection{Possessive pronouns}

Pronominal possession (where the possessor is a pronoun) is expressed using the independent form of the pronoun. This is juxtaposed to the possessed noun phrase without any overt marker. The vowel of the possessed noun is maintained except for kinship terms. In the examples in (60), and (61) ugusa 'brother' and ntsurí 'ladder' are used with all the independent pronouns and in (62) the possessor is a pronoun and each of the possessed item has a different vowel as class marker and modified by a qualifier.

$\begin{array}{cl}\begin{array}{c}\text { 60. amígusa } \\ \text { awú gusa }\end{array} & \begin{array}{l}\text { 'my brother' } \\ \text { ó gusa }\end{array} \\ \begin{array}{l}\text { atú gusa brother' } \\ \text { anú gusa }\end{array} & \text { 'our brother brother' } \\ \text { alé gusa } & \text { 'your brother' } \\ & \text { 'Their brother' } \\ \text { 61. amú ntsurí } & \text { 'my ladder' } \\ \text { awú ntsurí } & \text { 'your ladder' } \\ \text { ó ntsurí } & \text { 'his/her ladder' } \\ \text { atú ntsurí } & \text { 'our ladder' } \\ \text { anú ntsurí } & \text { 'your ladder' } \\ \text { alé ntsurí } & \text { 'Their ladder' }\end{array}$
62. awú idzófó bíbí 'your small yam slice' aḿ efiéyí kojklo 'my old calabash'

When a pronominal possession is expressed using a kinship term with the 1SG pronoun, both the vowel of the pronoun and the possessed noun are deleted. The tone of the vowel of the pronoun which is deleted moves leftwards and docks on the bilabial nasal (see section 2.5.1). The words in (63) illustrate this:

63. amú-ugune-udzé-tséngo amgunedzetséngo 'my older sister' 1SG.IND-sister-woman-old 
amú-ugusa-kloyi

1SGIND-brother-small

aḿú-utí

1SGIND-fahter amǵgusakloyi 'my small brother'

ańtí 'my father'

\subsubsection{Reflexive pronouns}

In Logba, a reflexive pronoun is expressed when yó 'skin' is suffixed by the independent pronoun. However, in the 1PLU, and the 2PLU, yó 'skin' occurs after the bound form of the pronoun. Another analysis that is plausible is that in the singular, yó is suffixed to the independent pronoun but in the plural it is suffixed to the bound form. This is illustrated in (64)

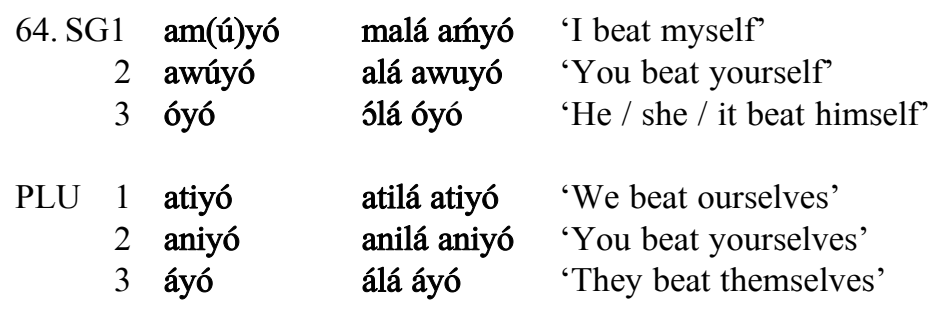

In a sentence, the subject NP which is normally the pre-verbal argument controls the reflexive expression. In (65) because the agentive NP, Binka is singular o yó '3SGIND skin' is selected. However, in (66) a coordinate NP, Setor kpe Akpene caused 3PLU.IND to be used.

65. Binka ólá o yó

$\begin{array}{lll}\text { Binka ó-lá } \quad \text { o } & \text { yó } \\ \text { Binka SM.SG-beat } & \text { 3SG.IND } & \text { skin } \\ \text { 'Binka beat himself' } & \end{array}$

66. Setor kpe Akpene álá á yo.

$\begin{array}{lllll}\text { Setor kpe } & \text { Akpene } & \text { á-lá } & \text { á } & \text { yó. } \\ \text { Setor CONJ } & \text { Akpene } & \text { SM.PLU-beat } & \text { 3PLU.IND } & \text { skin } \\ \text { 'Setor and Akpene beat themselves' } & & \end{array}$

The emphatic form of the reflexive is a construction involving a juxtaposition of independent pronoun and nta 'own' which comes before yó. The independent form of the pronoun precedes nta. This is illustrated in (67) below:

67. amú nta am(ú) yó

1SG own 1SG skin 'my own self' 


$\begin{array}{lllll}\text { awú } & \text { nta } & \text { awú } & \text { yó } & \\ \text { 2SG } & \text { own } & \text { 2SG } & \text { skin } & \text { 'your own self' } \\ \text { o } & \text { nta } & \text { o } & \text { yó } & \\ \text { 3SG } & \text { own } & \text { 3SG } & \text { skin } & \text { 'his / her own self' }\end{array}$

These are used in (68) and (69):

68. Malá amú nta amú yó

$\begin{array}{llll}\text { ma-lá amú ntá } & \text { amú } & \text { yó } \\ \text { 1SG-beat } 1 \mathrm{SG} . I N D & \text { own } & \text { 1SG.IND } & \text { skin } \\ \text { 'I beat my own self' } & & & \end{array}$

69. dơdí awúgúne bóté awú nta awú yó

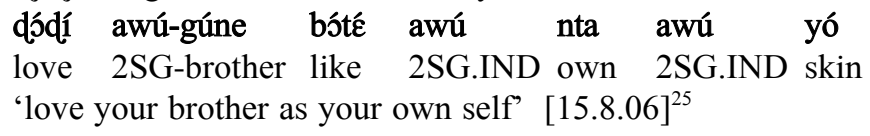

nta 'own' can also be used to emphasise the bare pronoun. This is shown in (70).

70. Asiedu ónú ole nta

Asiedu ó-nú $\quad$ ole nta
Asiedu SM.SG-see 3SG.IND own
'Asiedu saw the very one'

The use of nta shows further that Asiedu saw him personally and not that he met someone else in the house and left a message for him.

\subsubsection{Reciprocal pronouns}

Reciprocal pronoun is formed with the plural pronouns ati, ani, á before the noun nda 'companion'. The antecedent is plural and the verbs used in constructions involving reciprocals are generally two argument verbs. In (71) there is a coordinate NP Udzi é kpe osa á 'the woman and the man' and a 3PLU is used to agree with it. In (72) Amú kpe Esi 'Esi and I' is used and this triggers 1PLU. (73) is however marked as ungrammatical because a singular agentive NP is used with 3PLU.

71. Udzi é kpe osá a ádodi á nda.
udzi $=$ é
kpe osá $=\mathrm{a}$
á-dodi á nda Woman $=$ DET CONJ man=DET SM.PLU-love 3PLU companion 'The woman and the man loved one another.'

\footnotetext{
${ }^{25}$ This line is taken from Adodi 'love', a song composed by T.K. Bediako. This is one of the first attempts to compose a song in Logba (see 15.8).
} 
72. Amú kpe Esi ati yáyí ati ndà.
amú
kpe Esi
ati-yáyí
ati
nda
1SG.IND CONJ Esi SM.PLU-look.for
1PLU
companion

'Esi and I looked for one another.'

73.*Binka óyayi á nda

\begin{tabular}{|c|c|c|c|}
\hline *Binka & '-yayi & á & nda \\
\hline Binka & SM.SG-search & 3PLU & companion \\
\hline
\end{tabular}

The noun akpakplawo, and nda are used in (74) below to indicate literally that the frogs line up behind each other's body. The sentence is a description of the picture in the last page of the frog story. To show there is a physical contact with each of them yó 'skin' is used as a compound with nda 'companion'. This shows the reciprocal is used for sequence relationship between entities.

74. akpakplawo étsídí ánda yó úmókóe

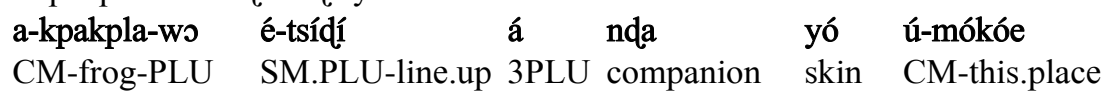

'The frogs line up behind each other at this place'

The form: ati-nda '1PLU-companion' ani-nda '2PLU-companion' a-nda '3PLUcompanion' are identified with some native speakers who use the Alakpeti dialect. However, in the Tota dialect a-nda '3PLU-companion' is used for 1PLU, 2PLU and 3PLU.

Westermann (1903) records that the reciprocal is expressed with the independent form of the plural pronouns: atu '1PLU', anú '2PLU', and á '3PLU' with andakame $^{26}$ 'companion.' Both dialects replaced andakame with anda and replaced the independent pronoun with the bound form. One can deduce from this point that the Alakpeti dialect is close to what Westermann recorded. Based on this assumption, it can be said that Tota dialect, in this regard, has simplified the grammar by using the 3PLU-nda throughout.

\subsubsection{Logophoric pronoun}

Some languages have special pronouns that are used in indirect speech complement clause to show that the noun in the clause is co-referencial with the subject in the main clause. Logba is no exception. In sentence (75), ó- that is prefixed to ká 'put' is the $3 \mathrm{SG}$ pronoun that refers to another person who is not the speaker. In (76), (77) and (78) the logophoric pronoun blo refers to the subject NP, the speaker who is being quoted.

${ }^{26}$ In my fieldwork, I have recorded anda 'one another' and andakame 'friend' This can be found in the texts in chapter 15 . 
75. Guadi ówá te óká koko eví ubo é nu
Guadi ว-wá
té
óká
koko e-ví
u-bo =é
nu

Guadi SM.SG-say COMPL 3SG-put cocoa CM-sun CM-farm=DET in 'Guadi said he (not the speaker) dried cocoa in the farm'.

76. Guadi ówá te óloká koko evi ubo e nu

Guadi ó-wá té ólo-ká koko e-vi u-bo-=e

Guadi SM.SG-say COMPL LOG-put cocoa CM-sun CM-farm=DET in 'Guadi said he (Guadi, the speaker) dried cocoa in the farm'.

77. Jwa te ólolózó ubo é nu
ग-wa té
ólo-ló-zó
u-bo =é
$\mathrm{nu}$
3SG-say COMPL LOG-PRSPROG-go
$\mathrm{CM}-\mathrm{farm}=\mathrm{DET}$ in

'He says he (the speaker) is going to farm'

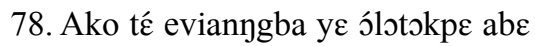
A-ko
té
e-vianygba
ye ว́lo-to-kpe
a-be
CM-parrot COMPL CM-noon
CONJ LOG-HAB-eat
CM-palmfruit
'Parrot says it is noon that it (parrot) eats palmfruit' [15.4.50] 



\title{
4 NOUN PHRASES
}

The head of the noun phrase in Logba may be a noun or an independent pronoun. The head is followed by constituents that modify it. The types of NPs and the structure of NP are discussed in this chapter.

\subsection{Noun phrases}

The structure of a simple Noun Phrase (NP) is as follows:

[NOUN]- QUALIFIER - QUANTIFIER - DETERMINER - INTENSIFIER [PRO]

A nominal word is minimally made up of a stem. For most nouns, there is a class prefix $(\mathrm{CM})$ which also signals number ${ }^{27}$. This depends on the class to which the noun belongs. The plural morpheme -wo comes immediately after the stem of most plural nouns. In (1a) the noun, u-klontsî, has a vowel class prefix and -wo. In (1b) adzayi has only a class prefix.
1a. book
u-klontsí
u-klontsí-wo
CM-book
CM-book-PLU

1b. firewood a-dzayi
CM-firewood

\author{
n-dzayi \\ CM-firewood
}

The only element obligatory in the NP is the head which is either a noun or a pronoun. In (2) the NP is atele 'ant'. The other elements in the NP can only support the head. This implies that none of them can be the only element in the NP slot.

2. Atele óta ebîtsi é
a-tele ó-ta
e-bîtsi $=$ é
CM-ant SM.SG-sting
CM-child $=$ DET
'The ant stings the child'

The Qualifier is either an adjective or a derived nominal. This is followed by the Quantifier. There is no agreement between the adjective and the head noun but some numbers that function in the Quantifier slot and the Determiner are marked for agreement with the noun head. In (3) the singular headword E-bitsi makes o$\mathrm{kp} \varepsilon$, the quantifier and $\mathrm{o}-\mathrm{m} \varepsilon$ the determiner to have the $\mathbf{0}$ - prefix, which is singular. On the other hand, in (4) because the head word E-bit-wo is plural the quantifier anyo and the determiner a-me have the a- prefix which is also plural.

\footnotetext{
${ }^{27}$ A detailed discussion of this is in chapter three under Noun classes.
} 
3. Ebitsi kloyi okpe omé

e-bîtsi kloyi o-kpe o-mé

CM-child small AM-two AM-those

'That (one) small child'

4. Ebîtwo kloyi anyo amé

e-bít-wo kloyi a-nyo a-mé

CM-child-PLU small AM-two AM-those

'Those two small children'

Another element in the NP is the intensifier. Other examples of intensifiers are ko 'only', blibo 'whole' gblélé 'many' An intensifier occupies the final boundary of the NP. After the intensifier, any element that follows does not belong to the NP. The intensifier petee 'all' can be added to the NP in (4). This is shown in (5) below:

5. Ebîtwo kloyi anyo amé peteé
e-bît-wo
kloyi a-nyo
a-mé
peteé
CM-child-PLU small AM-two AM-those all
'All those two small children'

\subsubsection{Types of noun phrases}

The types of noun phrases are discussed in the sub-sections below:

\subsubsection{Conjoined noun phrase}

NPs are linked using the conjunction kpe 'and, with' to indicate addition. In (6) Agbiglomo 'spider' and adzì 'bird' are linked with kpe 'and'. In (7) three nouns are joined and the conjunction is between the second agbé 'dog' and akpakpla 'frog' the third noun.

6. Agbíglomo kpe adzi

a-gbíglomo kpe a-dzi

CM-spider CONJ CM-bird

'Spider and bird'

7. Ebîtsi kloyi okpe, agbé kpe akpakpla ényá
e-bîtsi kloyi o-kpe
a-gbé
CM-child small CM-one CM-dog
kpe a-kpakpla é-nyá
CONJ CM-frog SM.PLU-live

'A small child, a dog and a frog lived'. [15.1.01] 


\subsubsection{Alternate noun phrase}

When alternate possibility is to be expressed aló 'or' is used to link the NPs. In (8), the nouns pampro 'bamboo' and iyó 'stick' are linked with aló forming an NP.

8. ákpo tso pampro aló iyó

$\begin{array}{lllll}\text { á-kpo tso pampro } & \text { aló } & \text { i-yó } \\ \text { 2SGFUT-go cut } & \text { bamboo } & \text { or } & \text { CM-stick } \\ \text { 'you cut bamboo or sticks;' } & {[15.9 .27]}\end{array}$

It is worth noting that the NP conjunctions used in Logba, kpe 'and, with' and alo 'or', are similar to the ones used in Ewe. The only difference is that the form for 'and' used in Ewe is kple. In the Ga language alo is used with the same meaning. The linker for clauses is different from the NP conjunction in Ewe and many languages in the GTM area.

\subsubsection{Possessive noun phrase}

Possession is expressed by the juxtaposition of the possessor and the possessed. A determiner obligatorily occurs on the possessed entity. The class marker of the possessed noun is maintained except for kinship terms. In (9a) - (9d) the possessed entities are non-human nouns and the class markers are maintained. However, in (10a) and (10b) where the possessed entities are kinship terms ma $=\mathrm{a}$ 'the mother' and tsi- $\varepsilon$ 'the father' the class markers are elided.

9a. Kodzo aklo a

$$
\begin{aligned}
& \text { Kodzo } \quad \text { a-klı=a } \\
& \text { Kodzo } \quad \text { CM-goat=DET } \\
& \text { 'Kodzo's goat' }
\end{aligned}
$$

9c. Ubonukpíwo abueklonti é

u-bonukpíwo a-bueklonti =é

CM-farmer $\quad \mathrm{CM}$-animal .skin $=\mathrm{DET}$

'Farmer's animal skin'

10a.Kofi ma a

Kofi $\mathrm{ma}=\mathrm{a}$

Kofi mother $=$ DET

'Kofi's mother' 9b. Kofi эу a

$$
\begin{aligned}
& \text { Kofi } \quad \text { o-y }=a \\
& \text { Kofi } \quad \text { CM-tree= DET } \\
& \text { 'Kofi's tree' }
\end{aligned}
$$

9d. ivanuvo otu é

$$
\begin{array}{ll}
\text { i-vanuvo } & \text { o-tu=é } \\
\text { CM-hunter } & \text { CM-gun }=\text { DET }
\end{array}
$$

'hunter's gun'

10b.Kofi tsi e
Kofi $\quad$ tsi $=\mathrm{e}$
Kofi father $=$ DET
'Kofi's father' 


\subsection{Nominal modifiers}

\subsubsection{Adjectives}

Most languages distinguish easily between verbs and nouns but in some languages what are called adjectives are a small number or many which are derived from other word classes. In Ewe, for example, Ameka (1991:78) identifies five underived adjectives and quite a large number which are adjectives derived from verbs and nouns. This situation possibly informs Welmers (1973:274) to warn that one should be circumspect in making judgements about words which are adjectives and those which are not because according to him 'what one may consider an adjective may not be an adjective after all. Dixon (2004:1) suggests that "a distinct word class 'Adjectives' can be recognised for every human language" He goes on to offer an elaborate explanation:

In some languages, adjectives have similar grammatical properties to nouns, in some to verbs, in some to both nouns and verbs and in some to neither. I suggest that there are always some grammatical criteria sometimes rather subtle - for distinguishing the adjective class from other word classes.

Similarly, Bhat (1994:12) notes that attempts to define adjectives as a distinct category and differentiate them from other categories have been met with many problems and linguists have been debating on which criteria will be applicable to all languages. From the above discussion, I think to get the adjectives in any language apart from using language internal semantic and morphosyntactic evidence, one also has to consider the word category from a typological functional perspective. Dixon (2004:3) argues for an internal morpho-syntactic definition for adjectives and then notes that there are seven major semantic types linked to the adjective class. He also observes that there are four core semantic types associated with both large and small adjective class. These are Dimension, Age, Value and Colour. He then points out that the other semantic types- Physical property, Human propensity and Speed are typically associated with medium sized and large adjective classes.

My objective in this section is to describe how property concepts or qualities are expressed in Logba and present their grammatical properties. An adjective in Logba is a class of words which occurs after the head noun in the noun phrase, does not show any agreement relation with the head noun but specifies its attributes. Logba has a number of adjectives which is relatively small when one considers other word classes like nouns and verbs.

Adjective occurs after the referent noun. There is no agreement between the head noun and the adjective. In (11a) the head noun ifiami 'cutlass' is followed by the adjective koyklo 'old'. In (11b) vuvo 'new' is the adjective and occurs after the 
head noun mfúta 'clothes' (11c) gbali 'bad' modifies iva 'thing' and kloyi 'small' in (11d) is the adjective and occurs after ebitwo 'child'.

11a. Ebémi ifiami konklo xé mivenu da ye ébémi fonyi koko é.

\begin{tabular}{|c|c|c|c|c|}
\hline é-bé-mi & ifiami & konklo & xé & mi-ve-nu \\
\hline 3PLU-FUT-take & cutlass & old & $\mathrm{RP}$ & NEG-pass-NEG \\
\hline
\end{tabular}

'They will take an old cutlass that is not too big to break the cocoa.' [15.15.13]

11b. Ekpe vuvo matá wú

ekpe vuvo ma-tá = wú

year new $1 \mathrm{SG}$-give $=2 \mathrm{SGOBJ}$

'I wish you new year.'

11c. Iva gbálî pétée tá îzó ime lo!

iva gbálî pétée tá î-zó $\quad$ i-me

thing bad all let SM.SG-go AM-DEM ADR

'All the bad things should leave here, I tell you!' [LIBATION]

11d. Ibote atsúe ebîtwo kloyi ko atsidú

$\begin{array}{llllll}\text { ibote } & \text { atsú-e } & \text { e-bit-wo } & \text { kloyi } & \text { ko } & \text { atsi-dú } \\ \text { reason } & \text { 1PLU-EMPH } & \text { CM-child-PLU } & \text { small only } & \text { 1PLU-be } \\ \text { 'for us only small children we are' } & {[15.7 .20]} & & \end{array}$

Out of over 1635 words in my lexical database only one is an underived and nonideophonic adjective. It is shown in 4.2.2 specifying its semantic class.

\subsubsection{Non-derived adjective and its semantic type}

One non-derived adjective is identified in the data. It is shown in (12) specifying its semantic class. It can neither occur as a noun nor as a verb.

\section{VALUE gbálí 'bad'}

\subsubsection{Derived adjectives and processes of their derivation}

Derived adjectives are words expressing adjectival concepts which are derived from other categories. Three processes are identified by which lexical adjectives are derived. The derived adjectives occupy the same syntactic position in the NP as their non derived counterparts. A number of adjectives are derived from verbs and nouns. They are placed into three groups based on their process of derivation: 


\subsubsection{Suffixation of -yi to value property verb}

Adjectives are formed by the suffixation of -yi to value property verbs. (13a) and (13b) below show that adjectives derived using the suffix -yi are adjectives of colour and dimension. The stem klo does not exist. It is possible that either this might have been used in the past or kloyi 'small' is borrowed into Logba and not that it is derived by using the suffix -yi

$\begin{array}{lllll}\text { 13a. COLOUR } & \text { drui 'become red' } & \text {-yi } & \text { drui-yi } & \text { 'red' } \\ & \text { fli 'become white' } & \text {-yi } & \text { fli-yi } & \text { 'white' }\end{array}$

13b. DIMENSION kisa 'become long' -yi kisa-yi 'long' *klo 'become small' -yi klo-yi 'small'

In (14a) druiyi 'red' qualifies memgba 'bowl' and in (14b) kisayi 'long' qualifies the noun ogbá 'road' These nouns are heads of the NP memgbá druiyi ome 'that red bowl' and ogbá á kisayi 'the long road' respectively. (14b) and (15b) show that the verbs drui 'become red' and kisa 'become long' unlike the adjectives have vowel prefix to show agreement with the respective head noun.

14a. Memgbá druiyi omé óbli.

[memgbá druiyi o-mé $]_{\mathrm{NP}}$ ó-bli

Bowl red AM-that SM.SG-break

'That red bowl broke.'

14b. Mango é odrui

$$
\begin{aligned}
& \text { mango }=\text { é o-drui } \\
& \text { mango }=\text { DET SM.SG-become .red } \\
& \text { 'The mango is ripe' }
\end{aligned}
$$

15a. Jgbá á kisayi ózó Klikpo.

$$
\begin{array}{lll}
\text { o-gbá=á } \quad \text { kisayi ó-zó } & \text { Klikpo } \\
\text { CM-road=DET long SM.SG-go } & \text { Klikpo } \\
\text { 'The long road goes to Klikpo.' } &
\end{array}
$$

15b. Jgbá á okisa

ogbá =a o-kisa

CM-road = DET SM.SG-become.long

'The road is long'

\subsubsection{Compounding of an intransitive verb root and a noun}

Deverbal adjectives are also derived from the compounding of an intransitive verb root and a noun. In the examples below kpi 'go' forms a compound with nouns like etsi 'ground' otsi 'down' and agu 'top' 
16. kpî 'go' etsi 'ground' $\rightarrow$ kpírtsi 'deep'

kpî 'go' otsi 'down' $\rightarrow$ kpóntsi 'short'

kpî 'go' agu 'top' $\rightarrow$ kpî-agu 'tall'

In (17a) kpóntsi 'short' is used to qualify the head noun ina 'person', kpiagu 'tall' qualifies osá 'man' in (17b) and kpietsi 'deep' qualifies vuti 'hole' in (17c). As usual, these qualifiers do not exhibit any agreement relation with the head nouns. These derived adjectives are used attributively and not predicatively.

17a.Udzé xé óbá ódu ina kpóntsi.

u-dzé xé ó-bá ó-qu [i-na kpóntsi $]_{\mathrm{NP}}$

CM-woman RP SM.SG-come 3SG-be CM-person short

'The woman who came is a short person.'

17b Psá kpíagu óbóba núm.
[o-sá
kpíagu $]_{\mathrm{NP}}$ ó-bó-ba
ᄁú $=\mathbf{m}$
CM-man tall
3SG-FUT-come see $=1 \mathrm{SGOBJ}$

'A tall man will come to see me.'

17c.Vuti kpíctsi óle unansá ubo é nu.

[vuti kpíctsi] $_{\mathrm{NP}}$ ó-le u-nansá u-bo=é $\quad$ nu

hole deep SM.SG-be(located) CM-chief CM-farm = DET in

'A deep hole is in the chief's farm.'

\subsubsection{Derivation via reduplication}

Another process by which adjectives are formed is reduplication. It can be either a full reduplication of the stem of a noun as in u-bí 'small child' or a partial reduplication of a property verb, bli 'black'.
18. bli 'become black'
bí-bli 'black'
u-bí 'small child'
bíbí 'small'

The forms in (19) are likely to be reduplicated but vó 'become spoilt' and vo 'become new' do not exist in Logba. It is possible that these words were used in the past in Logba but have lost their position in the lexicon to other words. vévé 'important' is likely to be a borrowing from Ewe. Interestingly, the base form of the Ewe verb vé 'become scarce' which yields vévé 'important' does not seem to have been borrowed into Logba. Essizewa (2007) in a conference paper reports similar borrowing from Ewe into Kabye.

19. *vó 'become spoilt'

*vo 'become new'

vúvó 'spoilt'

vuvg 'new' 
*vé 'become scarce'

veve 'important'

In (20a) bíbli 'black' the derived adjective qualifies the head noun afúta 'cloth' and in (20b) bíbí 'small' qualifies idzó 'yam'.

20a. Afúta bíbli afuí.
a-fúta
bíbli a-fuí
CM-cloth black AM-lost

'The black cloth is lost.'

20b. Idzó bíbí óbo umutsi nu.

i-dzó bíbí ó-bo $\quad$ u-mutsi nu
CM-yam small SM.SG-stay
'The small yam is in the barn.'

\subsubsection{Derived nominals}

Derrived nominals are words that can be used to qualify another noun in an NP structure. They therefore occupy the slot for adjectives. They can also occur by themselves as nouns and maintain a class prefix. These words are not in the real sense lexical adjectives.

\subsubsection{Adding nominalising suffix [-go] to a verb}

The qualifiers are derived from the compounding of a verb and a -go nominalising suffix.

$\begin{array}{ll}\text { 21. tó-n-go } & \text { 'thick one' } \\ \text { tsé-n-go } & \text { 'old one' } \\ \text { ná-n-go } & \text { 'big one' } \\ \text { bu-go } & \text { 'rotten one' }\end{array}$

The qualifier tóngo 'thick one' in (21) above may possibly be based on a loan from Ewe because Ewe has the word to which means 'thick and slimy'. tsé is a verb 'become old' to which -go is suffixed thereby becoming a noun. Also bu 'become rotten' is in the data but there is no word na related semantically to nángo. The nominalised verb is then used to modify another noun. The nominalising suffix go makes these words, which are used to qualify other nouns, morphologically nominals. In (22), bugo 'rotten one' qualifies avúdago 'leaf' and in (23) tséngo 'old one' qualifies amugunedze 'my sister'

22. Avúdago bugo móózí.
a-vúdago bugo
mó-ó-zî
CM-leaf rotten-NOM NEG-SM.SG be.good
'Rotten leaf is not good.' 
23. Nkpé bé amúgunedzé tséngo ólé?
$\mathrm{n}-\mathrm{kp} \varepsilon$
bé amú-gunedzé
tsé-ngo
ó-lé
CM-year Q SGIND-sister
old-NOM
SM.SG-be
'What is the age of my old sister?'

The -go derived forms can occur by themselves as nouns. They usually take the /i-/ prefix. In the example sentences below ibugoé 'rotten one' itséngoé 'old one' are used as noun heads in sentences (24) and (25).

24. Ibúgoé îlé akólíkpo é tsú.
i-bugo-é
î-lé
a-kólí-kpo =é
tsú
CM-rotten =DET SM.SG-be CM-refuse-hill=DET upper.surface

'The rotten thing is on the refuse dump.'

25. Itséngo é îđú Setor óblé.
i-tséngo =é
i-dú
Setor ¡́-blé
CM-old.one $=$ DET SM.SG-be
Setor 3SG-own
'The old one is Setor's own.'

\subsubsection{Compounding the stem wasa to a noun}

Human property terms are derived from the compounding of a noun stem and wasa 'owner' (see section 3.3.3). These are nouns which can function as qualifiers to the head noun. Each of these property nouns takes a class marker except kufiowasa 'lazy owner' which is without a class marker possibly because it is borrowed from Ewe $^{28}$.
26. kúfió 'lazy' wasa 'owner' $\rightarrow$ kúfiówasa 'lazy'
ałkpá 'juju' wasa 'owner $\rightarrow$ aykpáwasa 'jujuman'
adzé 'witch' wasa 'owner $\rightarrow$ adzéwasa 'witch'

In (27a) ałkpáwasa 'jujuman' modifies osá 'man' and in (27b) kufiówasa 'lazyowner' and ebîtwo 'children' form an N-N structure in which the former modifies the latter.

27a. Osá aךkpáwasa á óbá.
o-sá
a-ykpá-wasa =á
óbá
CM-man CM-juju-owner $=$ DET SM.SG-come
'The jujuman came.'

\footnotetext{
${ }^{28}$ The southern Ewe speakers say kuvia. The form in Logba kufio is the same as how the inland Ewe speakers pronounce it.
} 
27b. Ebîtwo kufiówasa inú ábo ubo é nu.

E-bît-wo kufió-wasa a-nú á-bo u-bo=é nu

CM-child-PLU lazy-owner AM-five SM.PLU-stay CM-farm=DET in

'Five lazy children are in the farm.'

These property terms can be used as noun heads independent of the head nouns. For example, the noun head in both (27a) osá 'man' and (27b) Ebîtwo 'children' can be removed and the sentences will be grammatical.

It is noted that these human property terms can be modified by other qualifiers. In (28a) kpiagu 'tall' qualifies ankpawasa ‘jujuman' and in (28b) kuviawasa 'lazy one' is qualified by kpontsi 'short'.

28a.Ałkpáwasa kpiagu é óbá.

a-ykpá-wasa kpiagu é ó-bá

CM-juju-owner tall=DET SM.SG-come

'The tall jujuman came.'

28b. Kufiówasa kpontsi é osá.

kufió-wasa kpontsi=éo-sá

lazy-owner short=DET SM.PLU-leave

'The short lazy man left.'

This clearly shows that nominal qualifiers are not in the real sense adjectives. Rather, they only function as adjectives when they modify a head noun.

\subsubsection{The use of ideophones}

Ideophones are another group of qualifiers used in the language to modify nouns. They are also not marked for agreement. Some of these ideophonic words are in (29a) below:

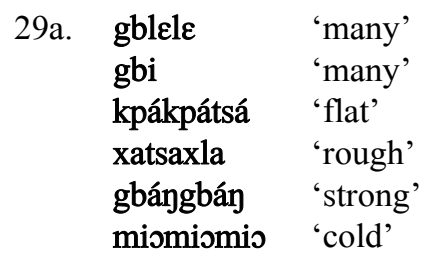

Out of the five ideophonic words above, the last two are borrowed from Ewe. gbángbán 'strong' is an Ewe word but it is used as an intensifier to describe extreme hotness. miomiomis 'cold'on the other hand, has the same meaning in Ewe as in Logba. In fact, these borrowed words are used widely in the languages in Southern Ghana. 
gblele 'many' is used as an adjective to qualify ina 'person' in (29b)

29b.Ina gblele adaju izi fié ina okpe.

$\begin{array}{llll}\text { [I-na } & \text { gblele }]_{N P} & \text { a-daju } & \text { i-zi } \\ \text { CM-person } & \text { many } & \text { CM-advice } & \text { SM-good } \\ \text { fíc } & \text { i-na } & \text { o-kpe } & \\ \text { exceed } & \text { CM-person } & \text { AM-one } & \end{array}$

'The advice of many people is better than the advice of one person.' [15.4.80]

It is possible to find some of these ideophones used as verbs or adverbs in a sentence in addition to their use as adjectives. The examples in (30a) and (30b) attest to this:

miomiomiı used as an adjective to qualify nqú

30a.Mba no nđú miomiomio.

$\begin{array}{lll}\text { M-ba no } \quad \text { n-dú } & \text { miomiomio }]_{\mathrm{NP}} \\ \text { 1SG-come drink } & \text { CM-water } & \text { fresh.cold } \\ \text { 'I drank fresh and cold water.' } & \end{array}$

miomiomio used an adverb to modify the verb ná 'walk' 30b. Ahointsa óná miomiomis.

$\begin{array}{lll}\text { a-hointsa } & \text { [’o-ná } & \text { miomiomiı }]_{\mathrm{NP}} \\ \text { CM-chameleon } & \text { 3SG-walk } & \text { slow }\end{array}$

'Chameleon walks slowly.'

\subsubsection{Verb phrase for expression of quality concepts}

Adjectives cannot be complements of the verb 'to be'. Instead, a predicative possessive construction is used with the verb bo 'stay' which translates in English as a predicative use of an adjective. In sentence (31) and (32) below, the subject NP is the possessor and the object is a quality that is possessed. In (31) the possessed quality is intse 'strength' and in (32) it is iló 'bitterness'. Both are marked with /i/, a class marker noted for abstract nouns.

31. Kopu $\varepsilon$ obo intsé

$$
\begin{array}{lll}
\text { Kopu }=\varepsilon & \text { o-bo } & \text { i-ntsé } \\
\text { cup = DET } & \text { 3SG-stay } & \text { CM-strength } \\
\text { 'The cup is strong' }
\end{array}
$$

32. Ava á obo iló
$\mathrm{A}-\mathrm{va}=\mathrm{á}$
o-bò i-ló
$\mathrm{CM}$-medicine $=\mathrm{DET}$
3SG-stay CM-bitterness
'The medicine is bitter' 
Adjectives may be nominalised by adding a nominal class prefix to the substantive functioning in argument slots as head of NP. Once the adjective is nominalised it may function as a nominal, either in subject or object position in a sentence. In (33a) ovuvos 'the new one' is used as subject in (33b) obiblii is the object of the verb yú 'see'. In (33c) ifliyié 'the white one' is subject in an intransitive construction.

33a. Ovuvo ś óbom.
o-vuvs =ó
ó-bo-m
CM-new $=$ DET SM.SG-stay-1SGOBJ
'I have the new one.'

33b. Mayú obíblié Ugé.
ma-nú o-bíbli-é
U-gé
1SG-see CM-black = DET CM-Accra

'I saw the black one in Accra.'

33c. Iflíyi é ikú.

$$
\begin{aligned}
& \text { i-flíyi=é i-kú } \\
& \text { CM-white=DET SM-die } \\
& \text { 'The white one died.' }
\end{aligned}
$$

It is possible to express quality concepts using relative clauses. In (34), ekpe 'year' is specified as the coming year.

34. Abó mié dóká ta ekpe é xé alába nu.

$$
\begin{aligned}
& \text { a-bó mi é dóká ta e-kpe=é } \\
& 2 \mathrm{SG}-\mathrm{FUT} \text { take }=3 \mathrm{SGOBJ} \text { reserve give } \mathrm{CM} \text {-year }=\mathrm{DET} \\
& \text { xé a-lá-ba nu } \\
& \text { RP 2SG-PRSPROG-come in } \\
& \text { 'You will reserve it for the next planting season.' [15.9.75] }
\end{aligned}
$$

It can be argued that though Logba has one underived adjective, it has processes by which adjectives can be derived from other categories and structures which are used to express quality concepts. These findings confirm that Logba is not too different from the other neigbouring languages in terms of the adjective class and its properties.

\subsection{Numerals}

Numerals include cardinal and ordinal numbers. They are used as post head modifiers and occur in an NP after an adjective but before the determiner. 


\subsubsection{Cardinal numbers}

Logba uses a base ten (decimal) number system. The cardinal numbers one to six have the prefix when they are used in counting. When used as modifiers they show variation in the prefix signalling agreement with its head noun. The cardinal numbers from one to ten are in (35):

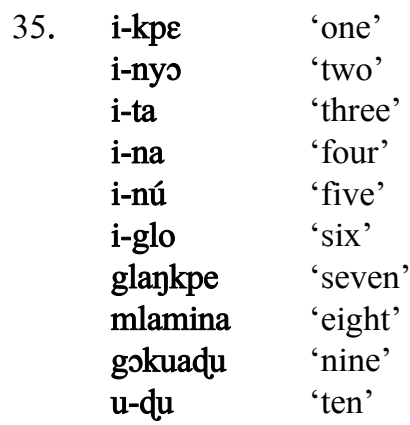

In (36) below the prefix of the cardinal numbers agree with the nouns. However, when used independently in counting, it is only the i- prefix that is used regardless of the class of the noun (see 35 above for numbers $1-6$ ). When o-sa 'man' a singular noun is used, the prefix for o-kpe 'one' is [0-]. It agrees with the head noun. For plural, the prefix of a-nyo 'two' becomes a- to agree with a-sa 'men'

36. Psá okpe 'one man'

Asá anyo 'two men'

Asá ata 'three men'

Asa aná 'four men'

Asá anú 'five men'

Asá agló 'six men'

In (37), afúta 'cloth' is the head noun and druyi 'red' is the qualifier. The singular prefix is [a-] the agreement marker for class IX. [N-] is the marker for the plural class, to which mfúta 'clothes' belongs.

37. Afúta druyi akpe 'one red cloth'

Mfúta druyi nnys 'two red clothes'

Mfúta druyi ntà 'three red clothes'

Mfúta druyi nná 'four red clothes'

Mfúta druyi nnú 'five red clothes'

Mfúta druyi ygló 'six red clothes'

In (38), agbé 'dog' attracts [0-] in the singular and [N-] in the plural. 
38. Agbé okpe 'one dog'

Ngbé nnyə 'two dogs'

Ngbé nta 'three dogs'

Ngbe nná 'four dogs'

Ngbe nnú 'five dogs'

Ngbe ngló 'six dogs'

The prefix of i-kpe 'one' agrees with the noun head. In (39a) the noun head is abó 'ball' a singular noun so the prefix is 0-. The prefix becomes a- in (39b) to agree with the head noun afúta 'cloth'.

39a. Abó okpe ókpó etsi
a-bó
o-kpe
ó-kpó
etsi
CM-ball AM-one SM.SG-lie ground
'One ball lies on the ground'. [PV 07]

39b. Ami afúta drui akpe na akóntsi é anú.
a-mi
a-fúta
drui a-kpe
na
a-kóntsi =é
a-nú
3PLU-take
CM-cloth red AM-one for
CM-basket $=$ DET
mouth

'They take one red cloth and put on top of a basket'. [PV.16]

In (40) the head noun adzi 'day' is singular but the numeral quantifier has a nasal prefix $\mathrm{n}$-kpe and not $\mathrm{okp} \varepsilon$. The nasal prefix is normally used for plurals. Adzi $\mathrm{jkp} \varepsilon$ 'one day' is a popular expression used in the opening of stories.

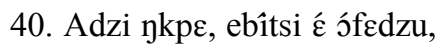
a-dzi
$\mathrm{n}-\mathrm{kp} \varepsilon$
e-bîtsi $=\mathbf{\varepsilon}$
ว-fédzu
CM-day AM-one CM-child=DET SM.SG-sleep
'one day, the child slept'
[15.1.03]

okpe 'one' is used to mark nouns indefinite. In (41), the use of okpe 'one' after udze tsengo 'old woman' is an indication that the old woman is not known earlier to the speaker.

41. Mayú udze tsengo okpe

$\begin{array}{llll}\text { mayú } \quad \text { u-dze } & \text { tsengo } & \text { o-kpe } \\ \text { 1SG-see } & \text { CM-woman } & \text { old } & \text { CM-one } \\ \text { 'I saw an old woman' } & & \end{array}$

Where the person unknown earlier to the speaker is more than one, it is marked with an a- to replace the class marker. In (42) a-kpe 'one' is juxtaposed with ina 'person'. akpe has an a- prefix indicating that the person is indefinite and plural. ina belongs to class VIII mass nouns. This is a semantic agreement with a plural equivalent of the head noun. 


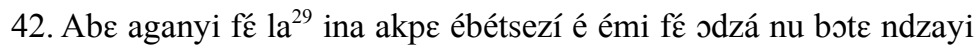

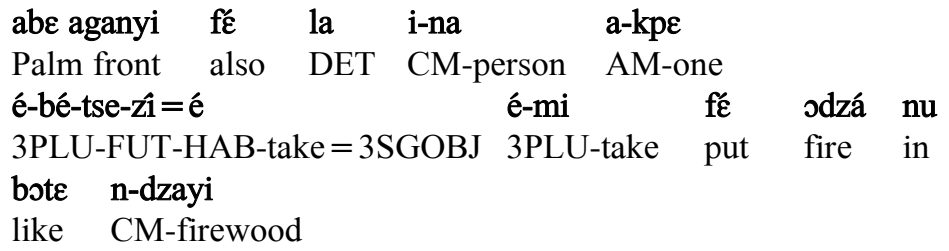

To form the numerals between eleven and nineteen, the numerals conjoin the stem of ten to tsa and the prefix of $\mathbf{u}-\mathbf{d u}$ 'ten' is elided.

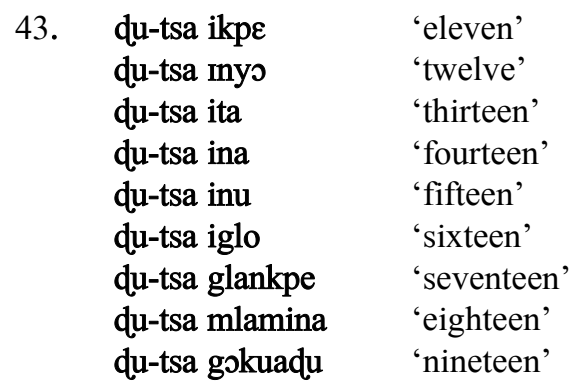

Numbers which are multiples of ten are formed by compounding the stem of the numbers: ita 'three', ina 'four', inu 'five', iglo 'six', glankpe 'seven', mlamina 'eight', gokuadu 'nine' to the stem of udu, the word for ten.

$\begin{array}{ll}\text { 44. odo } & \text { 'twenty' } \\ \text { udata } & \text { 'thirty' } \\ \text { udana } & \text { 'forty' } \\ \text { udanú } & \text { 'fifty' } \\ \text { udaglo } & \text { 'sixty' } \\ \text { udoglankpe } & \text { 'seventy' } \\ \text { udumlamina } & \text { 'eighty' } \\ \text { udugokuadu } & \text { 'ninety' } \\ \text { uga } & \text { 'hundred' }\end{array}$

In forming the compound with the stem of the numbers, - $u$ the final vowel of $\mathbf{u d u}$ is replaced with /a/, a vowel which can go with both [+ ATR] and [-ATR] vowels. In the pronunciations of some native speakers, /o/ is heard. It is possible that this is used to maintain a rounding harmony.

\footnotetext{
${ }^{29}$ la is a determiner in Ewe. This is evidence of code mixing. It is common to hear most speakers using Ewe words when speaking Logba
} 
Numbers which come after multiples of ten are expressed by placing the number after the multiple of ten as is done when counting eleven to nineteen. The word tsa is used as a linker (conjunction).

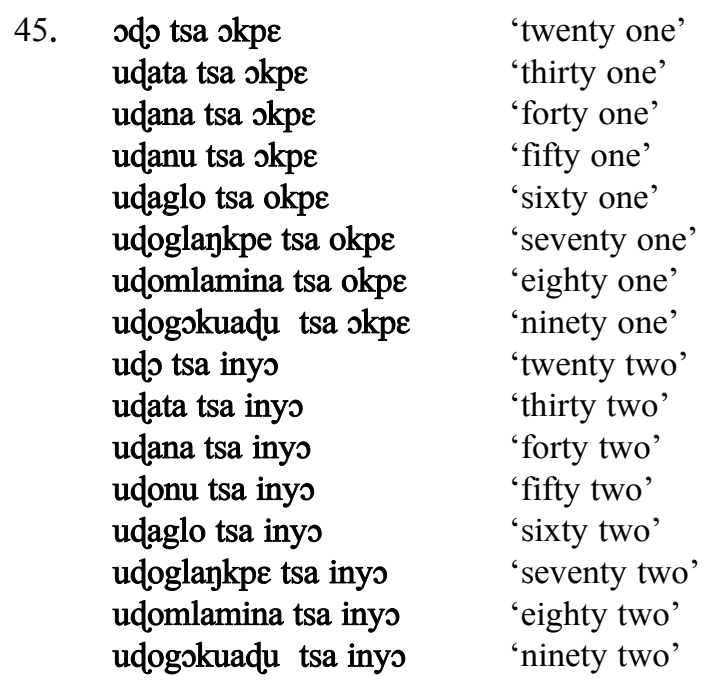

The expression for one thousand is a calque involving the Ewe word akpe 'thousand' and $\mathrm{okp \varepsilon}$, the Logba word for 'one' as in (46)

46 . akpi okpe thousand one 'one thousand'

igamoga is the word for million but the word milionu okpe, 'million one' which is a loan translation from English into Logba appears to be more frequently used. sTo express the frequency that an event has occurred, the verb that denotes the state of affairs is nominalised by a prefix $\mathbf{u}$ - and this nominal is modified by a cardinal number. It is exemplified in (47a), (47b) and (47c) how ' $n$ times' is expressed:

47a. Obíná úbíná ata

o-bíná ú-bíná a-ta

3SG-roll CM-roll CM-three

'He rolled three times'

47b. Aléć úlá glánkpe
a-lé $\varepsilon$
ú-lá glánkpe
3 PLU-beat $=3$ SGOBJ
CM-beat seven
'They beat him seven times' 
47c. Abó kpe á ukpe anys
a-bó-kpe =á
u-kpe
a-nyo
2SG-FUT-tap $=3$ PLUOBJ CM-tap CM-two
'You will tap them two times'

For half, the word used is okpenútsigo which is a compound of four words:

okpe 'one' nú (Ewe) 'thing'

tsi 'share out' go NOM.

Some speakers also use the Ewe word afa 'half'. The following examples in (48a) and (48b) illustrate the use of okpenútsigo 'half' and afa 'half'

48a. Atino adenklui asoti okpenútsigo.

$\begin{array}{llll}\text { ati-no } & \text { a-denklui } & \text { a-soti } & \text { o-kpenútsigo } \\ \text { 1PLU-drink } & \text { CM-fresh palm.wine } & \text { CM-pot.small } & \text { CM-half } \\ \text { 'We drank half pot of fresh palm wine.' } & \end{array}$

48b.Peya akóntsi afa ole ukpló á tsú.

\begin{tabular}{|c|c|c|c|c|}
\hline peya & a-kóntsi & afa & o-le & u-kpló=á \\
\hline pear & CM-basket & half & SM.SG-be.located & $\mathrm{CM}-$ table $=\mathrm{DET}$ on \\
\hline
\end{tabular}

\subsubsection{Units of measure}

Cardinal numerals are used in measurement of items in the environment. For example, the foot or the arm of an average adult person is used as a standard for measurement. In estimating distance, a distinction is made between mkpa udú 'ten feet' as against yovu mkpa udú 'white man foot ten'. In a discussion, I am reliably informed that the later refers to the imperial system. Some of the people especially those who have had formal education sometimes use the metric system of measurement.

\subsubsection{Ordinal numbers}

The ordinals are formed by suffixing the morpheme -mble to the cardinal numerals. The word for first and last have different forms. The vowel prefix in the cardinals from two to six and ten is normally deleted. The following examples in (49) attest to this:

$\begin{array}{ll}\text { 49. kelekele / gbants / gbã } & \text { 'first' } \\ \text { nyomble } & \text { 'second' } \\ \text { tamble } & \text { 'third' } \\ \text { namble } & \text { 'forth' }\end{array}$




$\begin{array}{ll}\text { numble } & \text { 'fifth' } \\ \text { glomble } & \text { 'sixth' } \\ \text { glamkpemble } & \text { 'seventh' } \\ \text { mlaminamble } & \text { 'eight' } \\ \text { gokuadumble } & \text { 'ninth' } \\ \text { dumble } & \text { 'tenth' } \\ \text { igango } & \text { 'last' }\end{array}$

gbants 'first owner' and gbã 'first' are expressions borrowed from Ewe. However, kelekele is a Logba word.

Syntactically, the ordinal numbers are adjectives and they do not have any agreement relation with the head noun. In (50) the head noun is abobî 'moon' and the ordinal number gokuádú mblé 'ninth' is used as a quantifier.

50. yédzé abobí gokuádú mblé nué ...

$\begin{array}{llll}\text { yédzé a-bóbí } & \text { gokuádú } & \text { m-blé } & \text { nu-é } \\ \text { then CM-month nine } & \text { CM-ORD } & \text { in-EMPH } \\ \text { 'then in the ninth month...' } & {[15.9 .52]} & \end{array}$

The ordinal number can also be complement of the verb du 'be'. This is exemplified in (51).

51. Kofi ódu tamblé.
Kofi ó-qu
ta-mblé
Kofi SM.SG-be
three-ORD
'Kofi is the third.'

The word dza 'lead' is used in expressions to imply first. This is clearly exemplified in the proverb in (52).

52. Avagbaliféwo ódza no.
a-va-gbali-f'́c-wo
ó-dza
no
CM-medicine-bad-put-owner SM.SG-lead drink

'The owner of bad medicine leads in drinking.' [15.4.69]

nyomblé 'second' is used in some contexts to mean 'friend' or 'partner' This usage appears to be a calque of the Ewe expression (e)velia 'second' or 'friend'. In (53) the paramount chief is telling Hayse, one of the informants, to inform his friend, nyomblie 'the second'

53. tátá té áwú nyombli ع́
tátá té
áwú nyo-mbli $=\hat{\varepsilon}$
inform COMPL 2SG two-ORD $=$ DET
'inform your friend' [15.7.13] 
adzí and unyì are used to refer to day. adzi cannot be used with cardinals numerals. For this reason, it is not grammatical to say (56)

54. abó f’é tsiyi nđú unyí nta
a-bó
fं́
tsiyi n-dú
unyí-nta
2SG-FUT put maize CM-water
day-three

'You will put maize in water for three days' [15.12.01]

55. unyitamblé adzi ع́ abóyié
u-nyi-ta-mblé
$\operatorname{adzi}=\varepsilon$
a-bó-yi-é
CM-day-three-ORD period $=$ DET $2 \mathrm{SG}$-FUT remove $=3 \mathrm{SGOBJ}$

'on the third day you remove it'

56. * omi utrome adzi ita

*o-mi u-trome a-dzi i-ta

3SG-take CM-work CM-day CM-three

'he works for three days'

57. omi utrome unyi ita
o-mi
u-trome
u-nyi i-ta
3SG-take CM-work
CM-day CM-three

'He works for three days'

It is noted that there is one instance in which adzi 'day' collocates with the deviant cardinal $\mathrm{n}$-kpe 'one' to introduce the setting in stories as in (58):

58. ye adzi Đkpe iva me petee xé madzî unyi me

\begin{tabular}{|c|c|c|c|c|}
\hline$y e$ & a-dzi & n-kpe & i-va-me & pétée \\
\hline J & CM-day & CM-one & CM-thing-this & all \\
\hline & all CM-n & ame & & \\
\hline
\end{tabular}

'then, one day all the things whose names I have called here' [15.3.18]

\subsection{Determiner}

Determiners are clitics that show whether the noun refers to a particular example (definite). In Logba, a determiner is a clitic and occurs after a quantifier and before intensifier in a fully expanded noun phrase. 


\subsubsection{Definiteness marker}

The determiner is realised as / $\mathfrak{\varepsilon} /$ and /á/. These are allomorphs which are morphologically conditioned. $/ \hat{\varepsilon} /$ has [é $]$ and $[\hat{\varepsilon}]$ as allomorphs which are phonetically conditioned (see section 2.3.5).

Nouns that end with the vowel -á take -á as a definiteness marker.

59. akpakpla -á akpakpla á 'the frog' okla -á okla á 'the mat'

Those that take -e as determiner are nouns with the final syllable ending in [-o]

60. Akpana-wo -é Akpana-wo é 'The Logba people' Avie-wo -é Avie-wo é 'The Ewe people'

Another group of nouns which take the suffix -é as determiner are nouns with the final syllable ending in [-u]

$\begin{array}{llll}\text { 61. déblékú } & \text {-é } & \text { débléku é } & \text { 'the cloud' } \\ \text { dzósú } & \text {-é } & \text { dzósu é } & \text { 'the blood' } \\ \text { fútsú } & \text {-é } & \text { fútsu é } & \text { 'the soup' }\end{array}$

Nouns with the final syllable ending in $-\mathbf{i}$ select $-\varepsilon$

62. akontsi - $-\varepsilon$ akontsi $\varepsilon \quad$ 'the basket'

igbedi $\quad-\hat{\varepsilon}$ igbedi $\hat{\varepsilon} \quad$ 'the cassava'

Either -o or a is selected for nouns with the final syllable ending in $\mathbf{- 0}$. In the Tota dialect $-\mathrm{a}$ is used while $-\mathrm{o}$ is used in the Alakpeti dialect.

63. aklo-ó aklo-ó/á 'the goat'

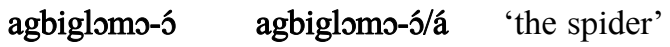

There is a constraint in which two front mid vowels $/ \mathrm{e} /+/ \mathrm{e} /, / \varepsilon /+/ \varepsilon /$ do not occur in a sequence in Logba. When it occurs, it is phonetically realised as /ie/, /ie/ (see section 2.3.3 for a discussion of this).

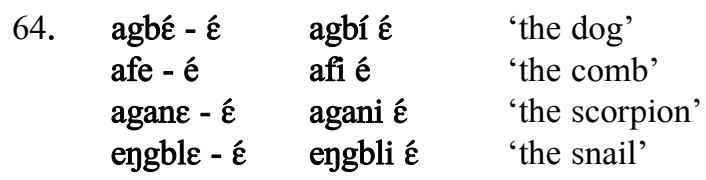

Definiteness is an obligatory category. Words that are known from the context have to be marked for 'definiteness.' 
For generic reference, no determiner is suffixed to the noun. In the sentence below, asangbla refers to any member of a class of 'tortoise' so it is used without a determiner.

65. asángblá ótsó ná blewuu

a-sangblá ó-tsó-ná blewuu

CM-tortoise SM.SG-HAB-walk slowly

'A tortoise walks slowly'

\subsubsection{Indefiniteness marker}

If the noun refers to a particular member of a class which is however unknown to the adressee, the word, o-kpi- $\varepsilon$ 'CM-one DET' which functions as a specific indefinite marker is used to modify the noun. With nouns already modified by an adjective, o-kpié 'one' comes after the adjective. In (66) the head of the NP Adzakoe is modified by another noun kófé 'village' and then okpié 'one ${ }^{30}$. In (67) okpí lows the head noun osá 'man' and the qualifier tséngo 'old.one'

66. Kpaita, ápété ányá Adzakoe kófé skpié nu

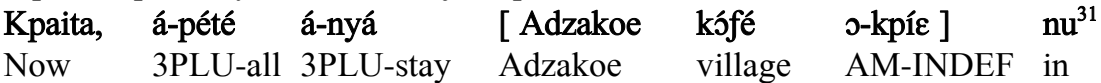

'Now, they all stayed in one of the villages in Adzakoe' [15.2.12]

67. Osá tséngo okpíc ó-tsi mó

o-sa tsengo o-kpie ó-tsi mó

CM-man old AM-INDEF 3SG-sit there

'An old man sat there'[15.2.75]

\subsubsection{Demonstratives}

Diesel (1999) defines demonstratives as deictic expressions serving specific syntactic functions. He notes that from a broader perspective it entails not only their use as pronouns and noun modifiers but also they are used as locational adverbs and help to focus the attention of the hearer to an object or location in the speech situation. Demonstratives can be used independently as anaphoric pronoun referring to nouns. Two forms of demonstratives are distinguished in Logba: proximal demonstrative and distal demonstrative. The former denotes a referent that is near the deictic centre and the latter refers to an entity that is a distant location from the deitic centre. This is shown in (68).

\footnotetext{
${ }^{30}$ Adzakoe is one of the Logba towns; see chapter one and the Logba map for the location

${ }^{31} \mathrm{nu}$ 'in'is a postposition. The whole NP can be said to be inside the postpostional phrase. See chapter 5 for a discussion of adpositional phrases.
} 
$\begin{array}{ll}\text { 68. Proximal } & \mathrm{m} \varepsilon \\ \text { Distal } & \mathrm{m} \varepsilon\end{array}$

There is however a dialectal variation in the use of demostratives. The Tota dialect uses mó for the distal demonstrative.

There is concord between the noun and the demonstrative. In the singular, o-/o- is used as a prefix to the demonstrative, a- for plural, i- for mass nouns and other iprefix nouns. $\mathrm{N}$ - is the agreement marker for liquid nouns and any other $\mathrm{N}$-prefix nouns.

In (69) the head noun uklontsi 'book' is a singular count noun so o- prefix is selected. The book is before the speaker and the speaker holds the book and shows it to the addressee. In (70) aha 'people' a plural count noun triggers the selection of a- as the prefix for the distal demonstrative. The people in the story world are mentioned by the story teller to the children. In (71) and (72) where ilo 'news' and ibe 'time' mass nouns are the heads, so the prefix i- is selected. In (72) the news being referred to is known to the audience so the proximal demonstrative is used. One thing that should be noted is that the post verbal NP in (73), Egemi uzúgbó umó 'mount Gemi there' is an N-N compound followed by a distal demonstrative to show that Logba market in the story world is far away on the top of mount Gemi.

69. Uklontsi ome ozi

$\begin{array}{lll}\text { u-klontsi } & \text { o-m } \varepsilon & \text { o-zi } \\ \text { CM-book } & \text { AM-DEM } & \text { AM-be.good }\end{array}$

'This book is good'

70. Ahá (á)me péteé xe ma-dzi-e

aha a-me pété-e xe ma-dzi- $\varepsilon$

People AM-DEM all-EMPH RP 1SG-call-CFM

'All these people I call,' [15.2.11]

71. iló ime ikpé lé ámé

i-ló i-me i-kpé lé á-mé

CM-news AM-DEM SM-eat 3SGOBJ CM-stomach

'This news eats up his stomach' (This idea disturbed him) [15.2.63]

72. ibé Imé nu Akpana ovu é enyá Egemi uzúgbó umó
i-bé i-mé
nu Akpana o-vu=é
e-nyá
CM-time AM-DEM
in Akpana
CM-market $=$ DET
SM.SG-stay 
$\begin{array}{ll}\text { egemi u-zúgbó } & \mathbf{u}^{32} \text {-mó } \\ \text { egemi CM-head } & \text { AM-there }\end{array}$

'That time Logba market was on top of Mount Gemi there'[15.2.24]

Also, demonstratives can be coreferencial to the NP that is already introduced in the discourse and therefore known to the discourse participants. In (73) ofonyi é 'the gourd' is one of the instruments in the story. By using a demonstrative after the noun the story teller is informing the audience that the gourd he is making reference to is the same gourd which is already introduced.

73: aha, tee ofonyi é ome de tee ole amántsi

$\begin{array}{lllll}\text { aha, tee } \quad \text { o-fonyi=é } & \text { o-me de } & \text { téé } \\ \text { AFF may be CM-gourd=DET } & \text { AM-this } & \text { COND } & \text { maybe } \\ \text { ole } & \quad \text { a-mántsi } & & \\ \text { 3SGIND CM-back } & & \end{array}$

'yes, may be if this gourd were at his back' [15.2.44]

Demonstratives can be used independently as pronouns with a noun prefix referring to the unexpressed noun. In (74) ime 'this' is the post verbal NP to the verb ri 'hold'. ime 'this' is coreferencial in the story to the song (tune) which the bird is blasting and as a result, disturbing the other animals in the forest. The story teller repeats this for emphasis.

74. Ori ime omi ka,...

$\begin{array}{lll}\text { o-ri } & \text { i-me } \varepsilon & \text { o-mi } \\ \text { 3SG-hold } & \text { AM-this } & \text { 3SG-take put.down } \\ \text { 'It takes this tune and puts it down, ...' [15.3.42] }\end{array}$

The demonstrative can be used to show the relationship between the speaker and the entities he wants to talk about. In stories, the story teller is situated in the deictic centre and the entities that he refers to are in the story world which is his artistic creation. In both (75) and (76) mó 'distal demonstrative' is used. An indication that the story world the story teller is refering to is located far away from him.

75. osá tsengo okpié ótsi mó

$\begin{array}{lllll}\text { o-sá } \quad \text { tsengo } & \text { o-kpí́ } & \text { ó-tsi } & \text { mó } \\ \text { CM-man } \quad \text { old } & \text { AM-INDEF } & \text { SM.SG-sit } & \text { there } \\ \text { An old man sat there } & {[15.2 .75]} & & \end{array}$

\footnotetext{
${ }^{32} \mathbf{u}$ - prefix is selected here instead of i-prefix because the preceding noun, uzugbo 'head' has back vowels.
} 
76. yé ápetee équ egusa yé énya mó
yé
á-petee é-qu
e-gusa
yé é-nya
mó
CONJ 3PLU-all 3PLU-be PLU-friend CONJ 3PLU-stay there
And they all were friends and stayed there. [15.3.20]

\subsection{Intensifiers}

Intensifiers add emphasis or precision to the meaning of a word. In Logba, an intensifier functions as a modifier in a fully expanded NP. The intensifiers identified are as follows:

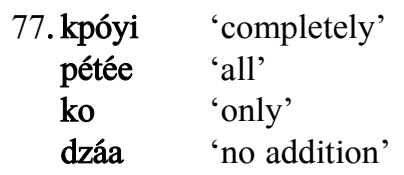

The object noun phrase in (78) has all the slots filled: mfúta vuvo nnyə mmê petee 'all these two new clothes' is an NP in which the head noun is mfúta 'clothes', vuvo 'new' is the qualifier, nnyo 'two' is the quantifier mme 'these' is the determiner and pétee 'all' is the intensifier. In (79) the subject NP iva gbali pétée 'all the bad things' the noun head iva 'thing' is modified by a qualifier gbali 'bad' and an intensifier pétée 'all'

78. Manc mfúta vuvə nnyə $\mathrm{mm \varepsilon}$ pétée Ugé

$\begin{array}{lllll}\text { Ma-ne m-fúta vuvo n-nyっ m-me } & \text { pétée Ugé } \\ \text { 1SG-buy } & \text { CM-cloth new AM-two AM-DEM } & \text { all } & \text { Accra } \\ \text { 'I bought all these two new clothes in Accra' } & & \end{array}$

79. Iva gbali pétée ta izo ime loo!

Iva gbali pétée ta i-zo $\quad$ i-me
thing bad all loo!
'Let all the bad things go away here' [LIBATION]

The intensifiers identified so far are as follows:

$\begin{array}{ll}\text { 80. kpoyi } & \text { 'completely' } \\ \text { péteé } & \text { 'all' } \\ \text { ko } & \text { 'only' } \\ \text { dzáa } & \text { 'no addition' }\end{array}$

I will discuss the use of each intensifier in turn:

kpoyi 'all' and pétée 'completely' are synonymous. They are used almost interchangeably with both count and non-count nouns. It is probable that pétée 'all' is borrowed from Ewe. It is used in Ewe with the same meaning. The intensifier ko 
'only' is used to show that no other thing apart from the one mentioned exists even though it is expected. The use of dzáa 'just' shows that no addtion is expected.

Intensifiers cannot function as head in an NP. It must always be preceded by either a head noun or a modifier in the NP. It only functions as a modifier as such it cannot stand alone as an NP. It is possible to have a sentence in which there is more than one intensifier. In (81), there are two intensifiers dzaa 'just' and ko 'only' modifying oyó nango okpic 'a certain big tree'

81.Ebítsi ع́ okla fé oyว́ nango okpie dzáa ko etsi.

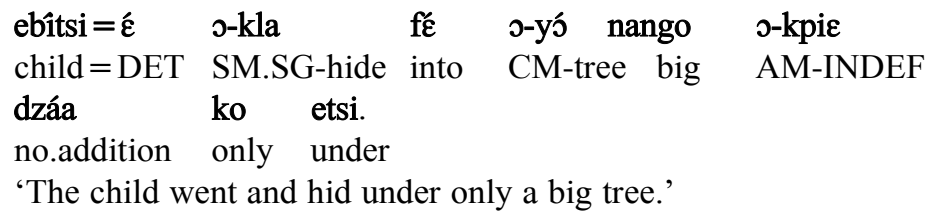





\section{ADPOSITIONS AND ADPOSITIONAL PHRASES}

The discussion in this chapter centres on adpositions looking closely at each of the two classes in Logba - prepositions and postpositions.

\section{$5.1 \quad$ Adpositions}

Adpositions refer to both prepositions and postpositions. They are a closed class of lexical items which may derive diachronically from nouns and verbs (see Ameka \& Essegbey 2006, Payne 1997). Some languages have either of the two but Logba has both prepositions and postpositions.

\subsubsection{Prepositions}

Preposition is a word which precedes a noun or pronoun forming an adjunct. This phrase is usually not a core argument. Preposition in Logba comprises a closed class of five members. They are shown in table 5.1:

Table 5.1 Prepositions

\begin{tabular}{|c|c|}
\hline PREPOSITION & MEANING \\
\hline $\mathrm{f}^{\prime} \bar{\varepsilon}$ & 'at' \\
\hline na & 'on' \\
\hline $\mathrm{kp} \varepsilon$ & 'with, and' \\
\hline $\mathrm{gu}$ & 'about' \\
\hline dzígu & 'from' \\
\hline
\end{tabular}

These prepositions in table 5:1 are used in example sentences (1) - (5)

1. Ina ókla fé abia á amá
i-na
ó-kla
fé a-bia =á
a-má
CM-person SMSG-hide at CM-chair=DET CM-back

'The person hides behind the chair' [TPRS.64]

2. Aklá pepa na agli é yó
a-klá
pepa na a-gli =é
yó
3PLU-paste paper on CM-wall=DET skin
'They paste paper on the wall' [TRPS.44] 
3. Udzi é óglé uzugbo kpe afuta

udzi=é ó-glé $\quad$ uzugbo kpe a-futa

CM-woman =DET SM.SG-tie CM-head with CM-cloth

'The lady tied her head with a cloth' [TRPS.46]

4. Nkpe okpe gu avietsozzágo yó

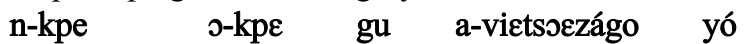

1SG-know AM-one about CM-local.soap skin

'I know something about how to make local soap' [15.14.01]

5. Dzîu nkpe nglo lízó glankpe yedze edze nyí

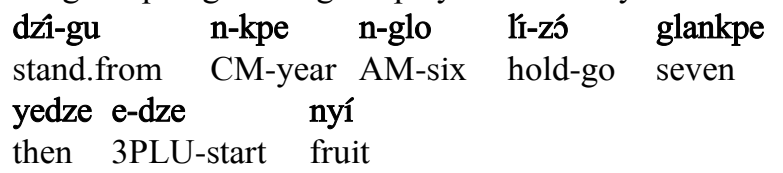

'from six going to seven years then it begins to bear fruit'

Most prepositions are verbs which have undergone grammaticalization.

na 'on' in (2) is a preposition and shows the relation of the figure 'paper' and the ground 'wall.' The paper rests on the wall. An alternative interpretation is that na is a verb in a serial verb construction with kla 'paste' and this literally translates as 'They paste paper put wall skin'. na however, does not occur on its own as a verb.

$\mathrm{f}^{\prime} \dot{\varepsilon}$, unlike na can function both as a verb and a preposition. It functions as a verb with the agreement marker prefixed to it. This is shown in (6):

6. Udzi $\varepsilon$ ófé afokpa.

$\begin{array}{lll}\text { u-dzi }=\dot{\varepsilon} & \grave{o}-f \hat{\varepsilon} & \text { a-fokpa } \\ \text { CM-woman=DET } & \text { SM.SG-put } & \text { CM-shoe }\end{array}$

'The woman wears a shoe.' [TRPS.21]

As a preposition, it is preceded by the finite verb kla 'hide' in (1). The person is covered by the chair; he is not on its surface. As such, he can not be seen easily. It can therefore be argued that $f^{\prime} \dot{\varepsilon}$ has undergone a semantic restriction as a result of its collocation with the adjacent finite verb.

In another context, f' ' $^{\prime}$ has an adverbial function meaning 'also' and it is in sentence final position modifying mo imo 'laugh a laugh'. This is illustrated in (7):

7. Udzi ع́ ólókpe akpon ólóny le ondzi ye óló mo imo fé.
$\mathrm{u}-\mathrm{dzi}=\boldsymbol{\varepsilon}$
ว-ló-kpe
a-kpono
$\mathrm{CM}-$ woman $=\mathrm{DET}$
SM.SG-PRSPROG-eat
CM-biscuit
ว-ló-ny = $=1 \varepsilon$
o-ndzi
3SG-PRSPROG-stay = 3SGOBJ
3SG-sweet 


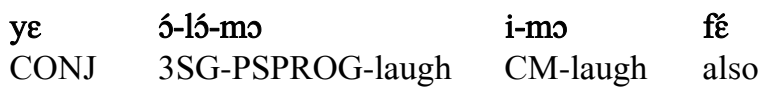

'The woman is eating biscuits it is sweet for her she is laughing also.'

The words f'́ 'also' f'́ 'put' and f' ' 'at' have high tone. The semantic relationship is not clear to suggest that they share the same meaning. I therefore suggest that they are homonyms.

gu 'about' and dzigu 'from' are closely related. dzigu 'from' is a stronger form of gu 'about'. dzigu 'from' is used when the boundaries between what one wants to refer to are clearly defined. gu 'about' is used when the relationship to be expressed is either an approximation or is unclear.

$\mathrm{kp} \varepsilon$ is both used to join additive NPs and mark instruments. The use of $\mathrm{kp} \varepsilon$ is common with Ewe, ${ }^{33}$ Gbe languages and other GTM languages. (8a) and (8b.) illustrate this:

8a. Ama ókpa akukoli kpe uhe

\begin{tabular}{|c|c|c|c|}
\hline Ama & o-kpa & a-kukoli & $\mathrm{kp} \varepsilon$ \\
\hline Ama & SM.SG-cut & CM-fingernail & with \\
\hline
\end{tabular}

8b. Esi óblí uzi é kpe hama

\begin{tabular}{|c|c|c|}
\hline ó-blí & $\mathrm{u}-\mathrm{zi}=\mathrm{e}$ & hama \\
\hline SM.SG-break & CM-door $=$ DET with & hammer \\
\hline
\end{tabular}

From this discussion, one can say that the words which are used as prepositions in Logba have other grammatical functions; they can function as verbs, conjunctions, or adverbs.

\subsubsection{Postpositions}

Postposition forms a constituent with a preceding NP adjacent to it. It is a word that heads a phrase and its dependent is the NP. Ameka \& Essegbey (2006) point out that even though postpositions in Ewe evolve diachronically from nouns they constitute a distinct class. Postposition in Logba is a closed class of nine members of which five are body part terms that have grammaticalised. The grammaticalization is considered to be cognitively motivated (see Heine 1997). Table 5.2 shows the postpositions in Logba.

\footnotetext{
${ }^{33}$ The form in Ewe is [kple] but the functions are similar. Kofi kple Yawo yi suku 'Kofi and Yawo went to school' Yawo bla ta kple avo 'Yawo tied the head with cloth.'
} 
Table 5.2 Postpositions

\begin{tabular}{|l|l|}
\hline POSTPOSITION & GLOSS \\
\hline nu & 'containing region' \\
\hline etsi & 'under' \\
\hline tsú & 'on' \\
\hline ité & 'front' \\
\hline zugbó & 'head', 'on' \\
\hline yó & 'skin', 'surface contact' \\
\hline anú & 'mouth' 'tip' 'edge' \\
\hline otsoe & 'ear', 'side' \\
\hline amá & 'back' 'behind' \\
\hline
\end{tabular}

In sentences $(9)-(16)$, postpositions are used. The postpositions add meaning to the location of the figure. For example, in (12), tsú 'on' can be used in the syntactic position of zugbó 'head', 'on'. When this is done, the native speaker will have a subtle semantic difference in the sentence. ukpu é zugbó refers to 'the peak of the mountain' while ukpué tsú refers to 'any position on the mountain top'

9. Afúta átsi bagi é nu

a-fúta á-tsi bagi=é nu

CM-cloth SM.SG-be.in bag = DET containing.region

'Cloth is in the bag' [TRPS AV 14]

10. Idatoa îtsi afútaá etsi
i-dato-a
i-tsi
a-fúta-á
etsi

$\mathrm{CM}$-spoon $=\mathrm{DET} \quad$ SM.SG-be.in CM-cloth $=$ DET under

'The spoon is under the cloth' [TPRS.24]

11. Odzutsuklo e óle ndú é tsú
o-dzutsuklo =e ó-le
n-đú-é
tsú
CM-river $=$ DET SM.SG-be CM-river $=$ DET on

'The boat is on the water' [TRPS.11]

12. Dyoa óle ukpu é zugbó
o-yəa
óle
$\mathrm{u}-\mathrm{kpu}=$ é
zugbó

CM- tree SM.SG be CM-mountain=DET head

'The tree is on top of the hill' [TRPS.65]

13. Awu e áko agli é yó
$\mathrm{awu}=\mathrm{e}$
á-ko
a-gli =é
yó
dress $=$ DET SM.SG-be.hang
CM-wall $=$ DET skin
'The dress hangs on the wall'

[TRPS.09] 
14. Jykpa óle akontsi é anú

$\begin{array}{llll}\text { o-nkpa } & \text { ó-le } & \text { a-kontsi=é } & \text { anú } \\ \text { CM-rope } & \text { SM.SG-be } & \text { CM- basket=DET } & \text { mouth }\end{array}$

'A spinned rope is on the tip of the basket' [PV.19]

15. Odzúnúinó óle memgba otsoe

o-dzú-nú-inó ó-le memgba o-tsoe

CM-river-in-animal SM.SG-be plate CM-ear

'Fish is on the side of the plate'

16. Amúti ózutsi ofafego é ité

$\begin{array}{lll}\text { amú-ti } \quad \text { ó-zutsi } \quad \text { ofafzgo=é } & \text { it } \varepsilon \\ \text { 1SG-father } & \text { SM.SG-sit } \quad \text { CM-fence=DET } & \text { front } \\ \text { 'My father sits in front of the fence' } & \end{array}$

In sentences (9) - (16) above, the postpositions contribute greatly in showing the location of the figure. In sentence (9), the figure occupies the containing region. The bag is a container and the cloth occupies the space in it. nu is therefore selected as the postposition to delimit the space the object occupies. In (10), there is a space under the cloth where the spoon is located. So the cloth is above the spoon and covers it. Another situation in which etsi can be used is illustrated in sentence (17):

17. Ando á ótsi ukplo á etsi
a-ndo=á ó-tsi
u-kplo=á
etsi
CM-cat $=$ DET SM.SG-be.sit
$\mathrm{CM}$-table $=$ DET under

'The cat sits under the table'

[TRPS.31]

In (17), the body of the table does not touch the cat as one can visualise in (10) where the cloth touches the spoon. The 'under' relation is not sensitive to whether the figure is visible or touching the ground. The same postposition is used to describe the location of the two figures.

In sentence (11), tsú 'on' is the postposition used. It describes a horizontal surface with support from below. This contrasts with (13) where the ground is a vertical wall and yó 'skin' is selected. tsú 'on' is used for similar situations like a cup on a table, a pen on a desk, a dog on a mat and yó 'skin' is used for a handle on a door, a spider on the wall and a handle on a bag. In (16) ite 'front' is used to show the position of the 'father' in relation to ofafego é 'the fence' This contrasts with amá 'behind' in sentence (1).

In sentence (12), the postposition used is zugbó. This example is a description of a figure that is positioned on a ground that is either vertical or horizontal but above the view of the speaker. The outer edge of a plate - the sides bordering it is referred to as otsoe 'ear' as in (15) memgba otsoe 'the ear of the plate' and anú 
'mouth' refers to the tip as in (14) akontsi é anú 'the mouth of the basket' It is evident that the postpositions used in sentences (12), (13), (14) and (15) are body part nouns which are transferred to entity parts.

It can be argued that yó 'skin' and zugbó 'head' are postpositions because they have lost their prefixes which they would have if they were nouns and for that matter can be said to have undergone grammaticalization. The others, otsoe 'ear' anú 'mouth' amá 'back' are spatial nominals that function as postpositions but they have not grammaticalised to become postpositions.

Postpositions are used in expressions that refer to time and other abstract concepts. In (18) ibe ime nu 'in this time' the postposition nu 'containing region' heads the phrase and its dependent is the NP ibe ime 'this time' In (19) tsú 'on' is used with the abstract NP ofu 'pain'

18.ibime(ibe $m \varepsilon)$ nu Akpana ovu é énya Egemi

$\begin{array}{llll}\text { ibi-me nu Akpana } \quad \text { o-vu=é } & \text { é-nya } & \text { Egemi } \\ \text { time-this in Akpana } & \text { CM-market=DET } & \text { SM.SG-stay } & \text { Egemi } \\ \text { 'This time the Akpana market is in Egemi' } & {[15.2 .24]} & \end{array}$

19. inadzi é óle ofu tsú

$\begin{array}{lll}\text { inadzi =é ófule } & \text { o-fú } & \text { tsú } \\ \text { woman =DET SM.SG-be } & \text { CM-pain on } \\ \text { 'The woman is in distress' } & & \end{array}$

There are fixed expressions in which, the postposition is present with a preceding NP. These expressions are shown in Table 5.3 with the literal translations and meaning. Some of these expressions are fossilised.

Table 5.3: Postpositional Expressions

\begin{tabular}{|l|l|l|}
\hline EXPRESSION & LITERAL MEANING & GLOSS \\
\hline iyé tsú & it on & 'be certain' \\
\hline ofu tsú & pain on & 'in distress' \\
\hline imo amá & neck back & 'after that' \\
\hline ogbá amá & road back & 'late' \\
\hline anyi nu & face in & 'texture' 'presence' \\
\hline idie nu & world the in & 'in the world, in life' \\
\hline
\end{tabular}

The postpositional expressions are used in sentences. (20) shows the use of idienu $\boldsymbol{\varepsilon}$ 'in the world' and (21) exemplifies anyinu 'face' or 'presence'

20. Ekple ina okp xé óbo idienu $\varepsilon$ toto susu té ole kpe iva fiéc.
Ekple i-na
o-kpe $\quad$ xé
ó-bo i-dienu $=\boldsymbol{\varepsilon}$
Now CM-person
CM-one RP 3SG-stay CM-world=DET 
to-to susu té ole kpe iva fié - $\varepsilon$

never-never think COMPL 3SGIND know thing exceed=3PLUOBJ

'Now a single person in this world should not think that'he is wiser than all.' [15.2.78]

21. Idzówasa anyinu idzó inú bé

$\begin{array}{lllll}\text { I-dzó-wasa } \quad \text { anyi-nu i-dzó i-nú } & \text { bé } \\ \text { CM-yam-owner face-in } & \text { CM-yam } & \text { SM-see } & \text { well.cooked } \\ \text { 'Yam gets well-cooked in the presence of the owner' [15.4.07] }\end{array}$

Postposition can also be used metaphorically. In the example sentence (22), etsi 'under' is a postposition to the NP, Ayotsú nansa 'Tota chief' and shows that the subject NP, Asafohene is subordinate in status to the Tota chief.

22. Asafohene ótsi Ayotsú ${ }^{34}$ unansa etsi
A-safohene
ó-tsi
Ayotsú
u-nansa
e-tsi
CM-asafo.chief SM.SG-sit Ayotsu
CM-chief CM-under

'The Asafo chief is under the Tota chief'

\footnotetext{
${ }^{34}$ Ayotsú is the local name for Tota. It means on the top of Aya. Tota is the Ewe name which means top of mountain (see explanation in section 1.1.2).
} 



\section{BASIC CLAUSE STRUCTURE, NON-VERBAL AND LOCATIVE CONSTRUCTIONS}

The chapter is about basic clause structure in Logba and some specific verbal and non-verbal constructions. It opens with an overview of the basic clause structure and discusses grammatical relations and the syntactic properties of the constituents of the clause. Copula structures and non-verbal structures are then discussed. This is followed by comparative constructions and verbless predications. The chapter concludes with a discussion on basic locative constructions.

\subsection{Constituent order}

Logba has a strict SVO constituent order. The subject is followed by the verb and in a transitive clause; the verb is followed by a direct object. In a double object construction, the Goal comes before the Theme. The adjunct occurs at the final position of the clause but before utterance final particles eg. loo. The linear order of constituents in a simple double object clause is shown in (1)

\section{SUBJECT - VERB - GOAL - THEME - ADJUNCT}

Table 6.1 presents a simple clause in which all the slots are filled.

Table 6.1: Simple double object clause

\begin{tabular}{|l|l|l|l|l|}
\hline SUBJECT & VERB & GOAL & THEME & ADJUNCT \\
\hline osá á & ógbla & ebîtwo ó & akonta & afánu \\
\hline o-sá-á & o-gbla & e-bít-wo-ó & a-konta & a-fá-nu \\
\hline CM-man-DET & SM.SG-teach & CM-child-PLU-DET & CM-maths & CM-house-in \\
\hline
\end{tabular}

This clause structure is typical of most Kwa languages spoken in the area especially Akan and other GTM languages. The basic constituent order is modulated for topicalisation and focalisation. In topic constructions, a noun phrase or a postpositional phrase may be fronted to the left periphery as an external constituent of the clause. In focus constructions, a non-verbal constituent in the clause can be front shifted to the left periphery in pre subject slot. Temporal nouns and ideophonic adjectives can sometimes function as adjuncts.

When Topic and focus slots are filled a simple clause is as shown in (6.2)

6.2: Simple clause with topic and focus slots filled

$(\mathrm{TOPIC}) \rightarrow($ FOCUS $) \rightarrow$ SUBJECT $\rightarrow \mathrm{V} \rightarrow(\mathrm{OBJECT})$ 
Logba is a configurational language. That is grammatical relations are defined by the order in which they occur relative to the verb. Every clause has subject obligatorily expressed. The subject is cross referenced on the verb in the form of a vowel prefix. Subject and object are nominals. Adverbs can occupy the immediate post verbal slot when an intransitive verb is used. Semantic roles are imposed on its nominal arguments, the roles linked to the grammatical relations may be different. The subject in a two argument clause is normally Agent and the object is Patient. It is possible to have a transitive clause with Theme and Location in Subject and Object positions respectively. In an intransitive clause, the only argument subject is in preverbal position. (1a) below, is a transitive clause with two arguments: Gameli, which is in preverbal position and Kofi, a post-verbal NP. In (1b) there is a clause in which the preverbal argument Kopu ' $\varepsilon$ 'the cup' is the Theme and the postpositional phrase ukplo á tsu 'on the table' is the Location. In (1c) the postpositional phrase, ukplo á tsu 'on the table' is the subject. (1d) is an intransitive clause and the only argument, which is in pre-verbal position, is Selorm.

1a. Gameli ólá Kofi.

$\begin{array}{lll}\text { Gameli ólá } & \text { Kofi } \\ \text { Gameli } & \text { SM.SG-beat } & \text { Kofi } \\ \text { 'Gameli beat Kofi.' } & \end{array}$

1b. Kopu é óle ukplo á tsú.

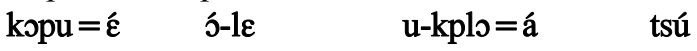

$$
\begin{aligned}
& \text { Cup }=\text { DET SM.SG-be CM-table }=\text { DET on } \\
& \text { 'The cup is on the table.'[TPRS.01] }
\end{aligned}
$$

1c. Ukplo á tsú ídre

$$
\begin{aligned}
& \text { u-kplo=á tsú í-dre } \\
& \text { CM-table=DET on } \\
& \text { 'The table is dirty' }
\end{aligned}
$$

\section{1d. Selorm ózó.}

\section{Selormó-zó}

Selorm SM.SG-go

'Selorm went.'

The subject argument may have different semantic roles to the verbs. This is because the verb determines the semantic role of the arguments. The subject in (2a) is Agent, in (2b) it is Theme and in (2c), it is Experiencer. 
2a. Senanu óbá awó á.
Senanu ó-bá
awó=á
Senanu SM.SG - kill snake $=$ DET
'Senanu kills the snake.'

2b. Agbí é ólé agli é yó.
Agbí=é
ó-lé
spider = DET SM.SG-be
agli=é $\quad$ yó
'Spider is on the wall.'
wall $=$ DET skin

\section{2c. Osá á ónúm.}
o-sá=á
ว-yú-m
CM-man = DET SM.SG-see-1SGOBJ
'The man saw me.'

In Logba, there are no special markers for subject and object on the NPs. However, there are distinct forms of pronouns for the subject and object (refer chapter 3 ).

The NPs in (3a) and (4a) are replaced with pronoun affixes in (3b) and (4b) below to illustrate this.

3a. Kofi ólá Ama

\section{Kofi ó-la \\ Kofi SM.SG-beat Ama \\ 'Kofi beat Ama'}

4a. Setor ókpe igbedi é.
Setor ó-kpe
i-gbedi $=$ é
Setor SM.SG-peel CM-cassava $=$ DET
'Setor peeled the cassava.'

$$
\begin{aligned}
& \text { 3b. गlá } \varepsilon \\
& \text { '-lá =é } \\
& \text { 3SG-beat = 3SGOBJ } \\
& \text { 'He beat her' } \\
& \text { 4b. Ókpe é } \\
& \text { ó-kpe =é } \\
& \text { 3SG-peel = 3SGOBJ } \\
& \text { 'He peeled it' }
\end{aligned}
$$

Independent pronouns behave like nouns. When an independent pronoun is used, an agreeing pronominal prefix has to be prefixed to the verb. (5a) is grammatical because a corresponding bound pronoun ma ' $1 \mathrm{SG}$ ' is prefixed to the verb in addition to the independent pronoun amú '1SGIND' (5b) is marked as ungrammatical because the independent form is used without the bound form, that is the subject noun is not cross referenced on the verb.
5a. Amú maz(a)iva
amú ma-z(a)-i-va
1SGIND 1SG-cook-CM-thing
'I cooked,(no one else)'

\author{
5b.*Amú z(a)iva \\ amú $\quad z(a)-i-v a$ \\ 1SGIND cook-CM-thing \\ 'I cooked, (no one else)'
}


There is a fixed order of the constituents in which the first object is the Recipient and the second one is the Theme. In Logba both the Theme and the Goal can be preposed. Even the postpositional phrase in adjunct slot can be fronted.

Object 1 and Object 2 differ with respect to pronominalization. Sentences in which both objects are pronominalised are considered ungrammatical. The Goal is the first object and it can be pronominalised. In (6) the two objects: Goal and Theme are shown in a sentence. However, in (7) a pronoun is used in place of the first object. In (8) a pronoun is used to replace the second object and it is considered to be ungrammatical. In (9) the position of the second object pronoun is changed and in (10) both objects have been pronominalised. They are all ungrammatical.

6. Stá Yaku mango

D-tá Yaku mango

3SG-give Yaku mango

'He gave Yaku mango'

7. Dtá é mango

O-tá $=\varepsilon \quad$ mango

3SG-give $=3 \mathrm{SGOBJ}$ mango

'He gave him mango'

8. * Otá Yaku é

*o-tá Yaku-é

3SG-give Yaku=3SGOBJ

'He gave Yaku it'

9. * Jtá éYaku

*o-tá= ع́ Yaku

3SG-give $=3$ SGOBJ Yaku

'He gave it Yaku'

10. * Jtá ع́ ع́

*o-tá=c

3SG-give $=3 \mathrm{SGOBJ} 3 \mathrm{SGOBJ}$

'He gave him it'

This implies that the second object is barred from pronominalisation. The question is how to get a construction that will make it possible to pronominalise the second object; that is the Theme. To pronominalise the second object, a manipulative SVC is normally employed in which the Theme is used as the object of $\mathrm{V}_{1}$. Similar behavior of second object in double object construction is reported in Stewart (1963) and Saah \& Eze (1997) for Akan and Igbo. The pronominalisation of the second object in an SVC is illustrated in (11) 
11. Omi é tá Yaku

O-mi=é tá Yaku

3SG-take $=3$ SGOBJ give Yaku

'He take it give Yaku'

Another property that distinguishes object 1 from object 2 is the use of the objects in relative clauses. While a gap strategy is used to relativise object 1 , a marker strategy is used for object 2. This is attested in (12) and (13).

12. Yaku xe Amozi ótá $\varnothing$ mango

$\begin{array}{llll}\text { Yaku xe Amozi } & \text { ó-tá } & \varnothing & \text { mango } \\ \text { Yaku RP Amozi } & \text { SM.SG-give GAP } & \text { mango } \\ \text { 'Yaku who Amozi gave mango' } & \end{array}$

13. Mango xe Amozi ótá Yakue

$\begin{array}{lllll}\text { Mango } & \text { xe } & \text { Amozi } & \text { ó-tá } & \text { Yaku-e } \\ \text { Mango } & \text { RP } & \text { Amozi } & \text { SM.SG-give } & \text { Yaku-MARKER } \\ \text { 'Mango which Amozi gave } & \text { Yaku' }\end{array}$

From these, one sees that there is a difference between the objects in respect of pronominalisation and relativisation. These tests have shown that Object 1 (Goal) and Object 2 (Theme) are different.

\subsection{Copula constructions}

In this section, I intend to show copula constructions in Logba and describe them.

\subsubsection{Equative constructions}

In equative constructions the verb dú 'be' is used. The pre-verbal NP is definite and either has a proper noun or a noun and a demonstrative. There is an agreement marker prefixed on the verb. The structure of the construction in Logba is in 6.4 below:

\section{4: Structure of equative construction}

$$
\begin{aligned}
& \left(\mathrm{NP}_{1}\right)-(\mathrm{SM}-\mathrm{Cop})-\left(\mathrm{NP}_{2}\right) \\
& + \text { definite }
\end{aligned}
$$

The sentences below are examples of equative constructions. The order of NPs in (14a) and (15a) are permuted to get (14b) and (15b). The initial subject has to be definite. 
14a.Kofi ódú ubonukpíwo.
Kofi ó-dú u-bonukpíwo
Kofi SM.SG-be
CM-farmer
'Kofi is a farmer.'

14b.Ubonukpíwo é ódú Kofi.
u-bonukpiwo $=$ é
ó-dú
Kofi
CM- farmer $=$ DET SM.SG-be Kofi

'The farmer is Kofi.'

15a. Kədzo ódú avabləwo.
Kodzo
ó-dú
a-vablowo
Kodzo SM.SG-be
CM-herbalist
'Kodzo is a herbalist.'

15b.Avablowo é ódú Kodzo.
a-vablowò =é
ó-dú
Kodzo
CM-herbalist $=$ DET SM.SG-be Kodzo
'The herbalist is Kodzo.'

dú 'be' in its bare form has a present time reference. When a speaker intends to express future time, the future marker bó is prefixed to the verb. This is exemplified in (16).

16. Kofi óbódú ubonukpíwo.
Kofi ó-bó-dú
ubonukpíwo
Kofi SM.SG -FUT-be farmer
'Kofi will be a farmer.'

đú cannot be used in the progressive. Sentence (17) is ungrammatical because ló 'PRSPROG' is attached to dú 'be'.

17. *Kofi olódú ubonukpíwo.
*Kofi o-ló-dú
obonukpíwo
Kofi SM.SG -PRSPROG-be farmer
'Kofi is being a farmer.'

When a past time is to be expressed, the adjunct expression dzé 'ago' is used. (18) shows dze in clause final position:

18. Kofi odú obonukpíwo dzé.
Kofi o-dú
obonukpíwo dzé
Kofi SM.SG -be farmer ago
'Kofi was a farmer.' 
This implies that he was once a farmer but he is not a farmer at speech time

\subsubsection{Predicative possessive constructions}

This construction is expressed by a clause whose nucleus is filled by the verb bo 'stay'. The possessed NP is the subject and the possessor NP is the object. The literal meaning of the clause is that the possesed item stays with the possessor. This is shown in the sentences below. Sentences (19a-c) are examples of material things and (20a-b) are non-material things.

19a.Awu ábowú.

$$
\begin{array}{ll}
\text { a-wu } & \text { á-bo-wú } \\
\text { CM-dress } & \text { SM.SG -stay-2SGOBJ }
\end{array}
$$

'You have a dress.'

19b.Ukló óbo é.

$$
\begin{array}{ll}
\text { u-kló } & \text { ó-bo }=\text { é } \\
\text { CM-car } & \text { SM.SG -stay }=3 \text { SGOBJ }
\end{array}
$$

'He has a car.'

19c.Ambué anyo ábo ḿ.

$$
\begin{array}{lll}
\text { a-mbué } & \text { a-ny } & \text { á-bo=ḿ } \\
\text { CM-orange } & \text { AM-two } & \text { SM.PLU-stay = 1SGOBJ } \\
\text { 'I have two oranges.' } &
\end{array}
$$

20a.Asusú dúkpá ábo Esi.

$$
\begin{aligned}
& \text { a-susú dúkpá á-bo Esi } \\
& \text { CM-brain good SM.SG -stay Esi }
\end{aligned}
$$

'Esi has good ideas.'

20b.Ugune okpe óbo é.

$$
\begin{array}{cll}
\text { u-gune } & \text { o-kpe } & \text { ó-bo=é } \\
\text { CM-sister } & \text { AM-one } & \text { SM.SG -stay=3SGOBJ }
\end{array}
$$

'She has one sister.'

bo is used generally to refer to present and future possessive situations. For past time reference nyá is used as the verb in the predicative possessive constructions. This means that at the time of talking the speaker is without the item in question. In (21), the object complement $-\mathrm{m}$, the possessor, has no car. This is illustrated below:

21. Ukló ónyá ḿ.

$$
\begin{array}{ll}
\text { u-kló } & \text { ó-nyá = ḿ } \\
\text { CM-lorry } & \text { SM.SG -stay.PAST = 1SGOBJ } \\
\text { 'I had a car.' } &
\end{array}
$$


nyá is also used to express sensation that one had experienced in the following expressions :

22. Jgo ónyá mé.
o-go
ว-nyá =m
CM-hunger SM.SG-stay.PAST $=1 \mathrm{SGOBJ}$
'I had hunger.'

23. Ndúgo ónyá ḿ.

$$
\begin{array}{ll}
\text { n-dúgo } & \text { ó-nyá =m ḿ } \\
\text { CM-thirst } & \text { SM.SG-stay.PAST = 1SGOBJ }
\end{array}
$$

'I had thirst.'

The present progressive collocates with nyá to give a progressive sense, it is grammatical in this attested expression in (24):

24. Jgo ólónyá ḿ.
o-go
ว-ló-nyá ḿ
CM-hunger SM.SG -PRSPROG stay.PAST = 1SGOBJ
'I have been having hunger.'

This implies that the person making the statement was suffering from the pangs of hunger some time before speech time and it is continuing. On the other hand, ogò onyám 'I had hunger' will imply the speaker was hungry at a particular time in the past but not at the time he was making the statement. So when óló nyám is used, the possession of the NP argument in the subject is from the past and it is progressive in speech time. It can also be used in the construction involving du 'be' as $\mathrm{V}_{1}$ and nyá 'stay' as $V_{2}$ to mean the feeling of a current sensation. (25) attests to this fact.

25. Nqúgo nqú ónyá ḿ.
nđú-go
n-dú
ว-nyá = ḿ
water-hunger
SM.SG-PRSPROG.be 3 SG-stay = 1SGOBJ
'I am thirsty.'

\subsection{Comparative constructions}

A Comparative Construction has a semantic function of assigning a graded position on a predicative scale to two objects: The entity that is compared and the standard to which it is compared. This construction is strategically used in discourse by a speaker to get a mental picture of the quality of an object that is compared to the quality that has been described. 
Comparative construction according to the terminology used by Stassen (1985) involves the following elements: Standard; the NP which indicates the object that serves as the yardstick of the comparison; Comparee, the object that is compared. The parameter, is the property on which the comparison is based and the index is the type of comparison. Both the parameter and the index are referred to as the scale. The verb fié 'exceed' comparative construction illustrated in (26) and (27) is by far the most widely used comparative construction in the language. The NP Binka, 'name' is the comparee and the parameter is kpontsi 'be.short' and Howusu 'name' is the standard:

26. Binka ókpontsi fié Howusu.

$\begin{array}{lll}\text { Binka ó-kpontsi fié } & \text { Howusu } \\ \text { Binka SM.SG -be.short exceed } & \text { Howusu } \\ \text { 'Binka is shorter than Howusu.' } & \end{array}$

In (27) below, the standard abia 'chair' is the object complement of fie which is the index. The parameter is kpiagu 'be.high'

27. Ukpló ókpiagu fíé abia.

$\begin{array}{lll}\text { u-kpló ó-kpiagu fié } & \text { a-bia } \\ \text { CM-table SM.SG -be.high exceed } & \text { CM-chair } \\ \text { 'The table is higher than the chair.' }\end{array}$

From the structure, it is evident that 'more than' comparison is expressed by using a Serial Verb Construction in which $V_{2}$ fié 'exceed' is the index on the scale of comparison and the $\mathrm{V}_{1}$ kpontsi 'be.short' and kpiagu 'be.high' are the parameters. The comparative verb, $\mathrm{V}_{2}$ fíe 'exceed' can occur as a simple predicate. When it occurs in a sentence as the main verb the subject NP is cross referenced on it. This is illustrated in (28) where it is cross referenced but no parameter is expressed and the value is referred to as parameter: However, when the index of (the comparee) fié 'exceed' occurs in $V_{2}$ as in (29) it is not cross referenced.

28. Amu peya áfié jkontsi inyo.

$\begin{array}{llll}\text { amu peya á-fíc } & \text { y-kontsi } & \text { nny } \\ \text { 1SG IND peas } & \text { SM.SG-exceed } & \text { PLU-basket } & \text { AM-two } \\ \text { 'My peas are more than two baskets.' } & \end{array}$

The comparee is subject NP and the parameter is in $\mathrm{V}_{1}$

29. Awú awu óbibi fié Esinam.
awú
a-wu
ó-bibi
fí
Esinam
2SG IND CM-dress
SM.SG -be.smallexceed
Esinam
'Your dress is smaller than Esinam's.' 
In sentence (30) below, Comparee is the event manc uklontsi 'I bought books' fié 'exceed' is the index. udze (ne uklontsi) 'woman bought books' is the standard.

30. Mané uklontsi fié udzi é.

\begin{tabular}{|c|c|c|c|}
\hline ma-né & u-klontsi & fié & $\mathrm{u}-\mathrm{dzi}=\hat{\varepsilon}$ \\
\hline 1SG-buy & CM-book & exceed & $\mathrm{CM}-$ woman $=\mathrm{DET}$ \\
\hline
\end{tabular}

In sentence (31) below, Parameter is V1 - Object mî utrome 'work'. inashina (ómi utrome). 'everybody works' is the standard.

31. Osa á ómí utrome fié inashina.
o-sa $=\mathrm{a}$
ó-mí
u-trome
fíé
i-nashina
CM-man $=$ DET SM.SG-take
CM-work
exceed
CM-everybody
'The man works more than everybody.'

When the standard is plural or compound the interpretation of the construction would be superlative. That is the comparee is the highest degree among the members of the standard. The standard is Kwaku kpe Kwadzo 'Kwaku and Kwadzo' The comparee is Kuma 'name'. (32) shows that Kuma is bigger than Kwaku and Kwadzo. Thus, degree is not grammaticalised in the exceed construction.

32. Kuma ódá fié Kwaku kpe Kwadzo.

$\begin{array}{lllll}\text { Kuma ó-dá } & \text { fié } & \text { Kwaku } & \text { kpe } & \text { Kwadzo } \\ \text { Kuma SM.SG-big } & \text { exceed } & \text { Kwaku } & \text { CONJ Kwadzo } \\ \text { 'Kuma is bigger than Kwaku and Kwadzo.' }\end{array}$

Apart from the 'exceed' comparative constructions which is dominant in the language, there are other strategies employed to express comparison. These are discussed below:

\subsubsection{Structures expressing superlative}

The superlative is expressed using the verb dú 'be' and NP with a determiner suffixed to it + 3PLU-nu 'in them'. The 3PLU could be replaced with a noun. (33) and (34) illustrate this. The standard of comparison is expressed in an NP with the containing region postposition nu 'in' resulting in a superlative interpretation.

33. Seli ódú otsengo e ánu.

\begin{tabular}{|c|c|c|}
\hline ó-dú & otsengo $=\mathrm{e}$ & á-nu \\
\hline SM.SG-be & old.one $=\mathrm{DET}$ & 3PLU-containing.region \\
\hline
\end{tabular}


34. Seto ódú obibi é ebítwo nu.
Seto ó-dú
obibi $=$ é
e-bít-wo-nu
Seto SM.SG-be small.one = DET CM-child-PLU-containing.region
'Seto is the smallest one among the children.'

\subsubsection{Structures expressing equality}

Equative structure where the copula complement is ikpe 'one' is used to express egalitarian comparison. This expression is used as a predicate of the $\mathrm{NP}(\mathrm{s})$ that is used in the comparison. The example sentence (35) below is an explanation given by the Klikpo chief about the state regalia:

35. katawəe pétée îdu ikpe

katawəe pétée $\hat{\mathbf{1}}$-du $\quad$ i-kpe
parasol all SM-be AM-one
'all parasols are one' $[15.7 .20]$

\subsubsection{Comparisons expressing semblative}

The word bote 'like' is used in expressions of semblance. The index of similarity is either expressed in a verb preceding bote 'like' as in (37) or in a verb following bote 'like' which in that case is preceded by a form of du 'to be' as in (36). The comparee is in a form of the subject and the standard follows the verb.

36. anye ko îqu bote tsitsi menu ami kerosene xé ami tsú odzá

$\begin{array}{llrllll}\text { anye } & \text { ko } & \hat{\mathbf{1}}-\mathrm{du} & \text { bote tsitsi } & \text { menu a-mi kerosene } \\ \text { this } & \text { only } & \text { SM-be } & \text { like overturn } & \text { where } & \text { 2SG-take kerosene } \\ \text { xé } & \text { a-mi } & \text { tsú } & \text { o-dzá } & & \\ \text { RP } & \text { 2SG-take on } & \text { CM-fire } & & \end{array}$

'this is like how you will take kerosene and pour it into fire' [15.11.58-59]

37. Avá óndzi bote iwóndú.
avá
ว-ndzi
bote i-wó-n-dú
CM-medicine SM.SG -be.sweet
like CM-bee CM-water

'The medicine is sweet like honey.'

Verbless predications involve two NPs juxtaposed without a verb linking them. The first NP function as the topic and the second as a comment on it. Some emphatic expressions are said using verbless predication. It can be said that inadzengo 'human being' is the topic and okpe 'something' is the comment in (38). The topic seems to be emphatic since it is marked with an intensifier ko 'only'. Structures 
like these express a kind of similarity between the topic and the comment. This expression is used in an answer to a question in emotional situations. (38) and (39) are examples. (38) has the structure as: NP + ko 'only' NP. (38) is usually a statement made to emphasise the unique role that human beings are perceived to play in all that is done in Logba

\section{Inadzengo ko əkpe. \\ inadzengo ko o-kpe \\ human.being only AM.one \\ "Human being is something."}

The expression, in (39) on the other hand, appears to be tautological. afánu 'home' is mentioned twice. It is first used as a topic and second as a comment. This is a statement that is often made to show the importance of the land of birth to the Logba people. As a result, they believe that all that they own come from the land which is their final resting place.

39. Afánu ko afánu.

afánu ko afánu

home only home

"Home is home." (There is no place like home)

\subsection{Basic locative constructions}

Basic Locative Construction (BLC) is the construction that is used in answer to when a where question is posed. When the question where is $x$ is posed the answer is a construction in which there is a locative verb and an NP - Postposition indicating the location. The elicitation tool employed in this research is the Topological Relation Picture Series (TPRS) (Bowerman and Pederson 1993). This book is designed to help researchers to identify the resources that languages have for encoding static topological relation between Figure and Ground (Talmy 1983). Figure is the entity whose location is at stake and Ground is where the figure is located. For example, in picture 1 of TPRS, there is a picture of a cup on a table. The cup is the Figure and the table is the Ground. Another elicitation tool used is Picture Series for Positional Verbs. (Ameka et al. 1999). In this manual, there are different pictures of objects in different positions and a question was posed to consultants: where is $x$ and they had to provide full clause answers to describe the pictures they see especially the position of the figure to the ground. The data from elicitation tools and those from what I will refer to as semi-natural responses were used as a basis for the discussion on locative constructions.

The description of BLC is made up of a reference object and a search domain or part of the reference object where the figure is located. Based on these criteria, Levinson and Wilkins (2006) identify four language types using the verbal compo- 
nent in the BLC. In the first group, there is no verb in the BLC. In the second group are languages that use a copula in all the BLC. This verb may either be a copula as in English or a locative verb as in Ewe. There is also a third group which has a large set of dispositional verbs of which Akan and Likpe are examples. In addition, Dutch is cited as belonging to a group that has a small contrastive set of positional verbs (see Levinson and Wilkins 2006). Judging from this grouping, I propose that Logba belongs to the same group with Akan and Likpe. This is because, in addition to the locative verb le 'be located' which is the unmarked form, there are about eleven other dispositional verbs used in the BLC. Table 6.3 below shows the verbs used in locative constructions in Logba.

Table 6.3: Locative verbs

\begin{tabular}{|l|l|}
\hline VERB & GLOSS \\
\hline le & be.located \\
\hline kpo & lie \\
\hline ko & hang \\
\hline to & fix \\
\hline tsi & sit \\
\hline ye & stand \\
\hline gbe & lean \\
\hline gbo & fall \\
\hline tsoga & lie across \\
\hline buá & turn upside down \\
\hline glé & tie \\
\hline dzi & tie firmly \\
\hline
\end{tabular}

The fixed order of elements in a locative construction is:

40a.

$$
\text { NP V [LOC] [NP Postp] PostpP }
$$

The subject noun phrase position is filled by the FIGURE. This is followed by the locative verb and postposition. A postposition phrase denotes the GROUND where the figure is located. The postposition is in most cases a grammaticalised body part noun.

Other variations of the locative construction have come up in the elicitation which is worth mentioning. In all, the subject noun phrase position which is filled by the Figure and the position of the locative verb do not change. In the first variation, there is a preposition before the NP-Postposition. In the second variation, a body part NP follows the locative verb immediately.

\section{FIGURE GROUND}

40b. NP V[LOC] Prep [NP Postp] PostpP

40c. NP V [LOC] [NP ] Body Part 
It has been observed that when some consultants were questioned they used a Serial Verb Construction to describe the location of the pictures. These constrcutions describe more than the basic location. The $\mathrm{V}_{1}$ helps $\mathrm{V}_{2}$, the locative verb to provide information about the manner in which figure is located as shown in (41).

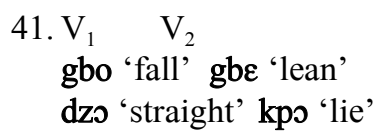

From the analysis of the data, one is able to arrive at the following as the interpretation of the verbs found in the data collected:

\subsubsection{Locative verbs}

\subsubsection{1 le 'be.located'}

le is the unmarked locative verb. It appears Logba has borrowed this verb from Ewe. This is because the same form is in Ewe. For example:

42. Ewe Kopua le kploa dzi.

$\begin{array}{lll}\text { kopu-a le } & \text { kplo-a } & \text { dzi } \\ \text { cup-DET be.located table-DET } & \text { upper surface } \\ \text { 'The cup is on the table.' } & \end{array}$

43. Logba Kopu é óle ukplo á tsú.

$$
\begin{aligned}
& \text { kəpu=é ó-le u-kplo=á tsú } \\
& \text { cup }=\text { DET SM.SG-be.located CM-table }=\text { DET upper.surface } \\
& \text { 'The cup is on the table.' }
\end{aligned}
$$

le is able to collocate with a wide number of postpositions. This is shown in (44) (45), (46), and (47). For example in (44) below, zugbó refers metaphorically to a body part and implies that the person wears the hat. In (46), it refers to the top of an item. This is used when the speaker does not want to specify anything about the portion of the figure but only the general location.

44. Kutó óle osá á zugbó.

$$
\begin{aligned}
& \text { kutó ó-le o-sá=á } \\
& \text { hat SM.SG.be CM-man=DET head } \\
& \text { 'The hat is on the man's head.' [TRPS 05] }
\end{aligned}
$$

45. Udzutsuklo é óle nqú é tsú.

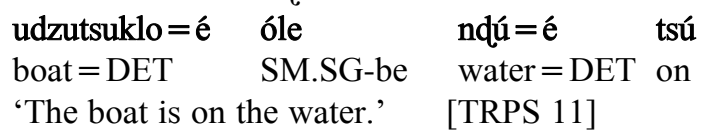


46. गyó óle ukpu é zugbó.
o-yó
ó-le
$\mathrm{u}-\mathrm{kpu}=\mathrm{e}$
zugbó
CM-tree SM.SG -be
CM-mountain $=$ DET head

'The tree is on the top of the hill.' [TRPS 65]

47. Agbí é óle agli é yó.
agbí=é
ó-le
a-gli=é
yó
spider $=$ DET SM.SG- be CM-wall=DET skin
'The spider is on the wall.' [TRPS 07/2]

\subsubsection{2 kpo 'lie'}

kpo is used to signal that an item is located somewhere in a horizontal position with its whole body touching the ground. kpo is used when reference is made to a human being lying on a mat. It is also used for a bottle that is not on its base but is in a flat position. Other flexible objects and objects without a base (eg. pot) for sitting or standing are also described as lying in relation to the ground. kpo 'lie' is also used in greetings expression. ite îkpá? 'front lies' as in (51) is used as a form of greeting to find out whether the person addressed is in good condition. (48), (49), (50) and (51) are examples:

48. Bol ókpó abiaá etsi.

$\begin{array}{llll}\text { bol } & \text { o-kpó } & \text { a-bia-á } & \text { etsi } \\ \text { ball } & \text { SM.SG- lie } & \text { CM-chair } & \text { under }\end{array}$

'The ball is under the chair.' [TRPS.16/2]

49. Agbi é ókpó utsa á yó.
a-gbi $=\dot{\varepsilon}$
ว-kpó
u-tsa =á
yó
$\mathrm{CM}-\operatorname{dog}=\mathrm{DET} \quad$ SM.SG-lie $\quad \mathrm{CM}$-house $=\mathrm{DET} \quad$ skin
'The dog lies near the house.' [TRPS.06/2]

50. Osá a ókpó okláá tsú.
o-sá =a
o-kpó
o-klá=á
tsú
CM-man=DET SM.SG-lie
CM-mat $=$ DET on
'The man lies on the mat.'

51. Ité ikpó loo?
i-té
i-kpó
100
CM-front
SM.SG-be.lie
ADR

'You are in front?' Lit: The front lies there. 


\subsubsection{3 kó 'hang'}

This verb is used for figures which are attached to their referenced objects by suspension making the lower part of the figure to be loose and possibly dangle. It could be a dress on a hook (TPRS 9) or drying line, (TPRS 37) a picture on a wall, (TPRS 44) or a light on a ceiling. (TPRS 52) In an answer to a question with respect to a flag hoisted, in (56) a non locative impersonal construction is used involving the verb ko 'hang' but the answer does not specify the ground on which it is hanged. In (52) and (53) the verb is used with the postposition yó 'skin' which refers to only part of the ground. agu 'top' refers to a location meaning 'above'. This is exemplified in (54), (55)

52. Awu ع́ ákó ivakuivaá yó.

a-wu $=\hat{\varepsilon} \quad$ á-ḱ $\quad$ ivakuiva $=$ á yó

CM-dress = DET SM.SG-be-hang thing.hang.thing $=$ DET skin

'The dress hangs on the hanger.' [TRPS.09]

53. Ivatago é íks agli é yó.
i-vatago $=\hat{\varepsilon}$
í-ko
a-gli =é
yó
CM-picture $=$ DET SM.SG-hang CM-wall $=$ DET skin
'The picture hangs on the wall.' [TRPS.44/2]

54. Debleku óks agu.
debleku ó-ko
a-gu
cloud SM.SG-hang
CM-top
'Cloud is above.' [TRPS 36]

55. Flagi é óko agu.
flagi $=$ é
ó-ko
a-gu
Flag = DET SM.SG-hang CM-top

'The flag hangs up.'

56. Áko flagi é.

$$
\begin{aligned}
& \text { á-ko flagi=é } \\
& \text { 3PLU-hang flag=DET } \\
& \text { 'They hang the flag.' }
\end{aligned}
$$

\subsubsection{4 tó 'fix'}

tó is used to describe situations in which a figure is attached to a referent object so firmly that it will be difficult to remove it. 'A handle on a door' or 'a writing on a dress' are typical examples of situations for which tó is used. tó suggests that the figure is pasted on the entity by someone. For a fruit in a tree some speakers describe it with the verb, to signalling that the fruit is somehow fixed in the tree. 
Some speakers use ks 'hang' focusing on the suspended nature of the fruit in the tree. (57) and (58) exemplify the use of tó:

57. Urime é ótó bagi é yó.

\begin{tabular}{|c|c|c|}
\hline $\mathrm{u}$-rime $=$ é & ó-tó & bagi =é \\
\hline CM-handle = DET & SM.SG-fix & $\mathrm{bag}=\mathrm{DET}$ \\
\hline
\end{tabular}

58. Uzidaiva ótó uzi é yo.

\begin{tabular}{llll} 
u-zi-da-iva & \multicolumn{1}{c}{ o-t́́ } & u-zi=é & yó \\
CM-door-open-thing & SM.SG-fix & CM-door=DET & skin \\
'The handle is fixed on the door, & [TRPS.61]
\end{tabular}

'The handle is fixed on the door.' [TRPS.61]

\subsubsection{5 tsi 'sit'}

The locative verb tsi 'sit' is used for figures on their base supported from below. A good example of figures for which tsi is used is those that are able to support themselves like humans and animals. (59), (60) illustrate this:

59. Ando a ótsî ukplo á etsi.
A-ndo $=\mathbf{a}$
ó-tsî
u-kplo=á
etsi
CM-cat $=$ DET SM.SG-sit
CM-table $=$ DET under

'The cat sits under the table.'

[TRPS.31]

60. Ando á ótsî utsa á yó.
A-ndo=á ó-tsî
u-tsa =á
yó
CM-cat $=$ DET SM.SG-sit
CM-house $=$ DET skin
'The cat sits near the house.'
[TRPS.06]

\subsubsection{6 yé 'stand'}

yé 'stand' is used for living things that have to support themselves on the horizontal surface because they are designed or naturally made to be in a vertical position. Human beings and some animals stand in a vertical position. Inanimates that have vertical dimension eg. houses, trees, are also perceived to be 'standing' when they are in a vertical position. In the case of a pole, yé 'stand' is used to describe it when it is upright on a horizontal surface. The sentences (61), (62), and (63) are illustrations of the use of these expressions.

61. Jyó a óyé ukpo é yó.
--уว́= a
ó-yé
u-kpo=é
yó
CM-tree $=$ DET
SM.SG-stand
$\mathrm{CM}$-mountain $=\mathrm{DET} \quad$ skin
'The tree stands on the hill.' [TRPS.17] 
62. Utsá á óyé ofáfegu é nu
u-tsá =á
ó-yé
o-fáfegu $=\boldsymbol{\varepsilon}$
$\mathrm{nu}$
CM-house $=$ DET $\quad$ SM.SG - stand $\quad \mathrm{CM}$-fence $=\mathrm{DET} \quad$ in
'The house is inside the fence' [TRPS.60]

63. Dsá á óyé utsá á zugbó.
o-sá =á
ó-yé
u-tsá =á
zugbó
CM-man $=$ DET SM.SG-stand
CM-building $=$ DET head

'The man stands on the top of the building.' [TRPS.34/2]

\subsubsection{7 gbe 'lean'}

gbe 'lean' is used for figures that do not stand straight but rather are touching the body of the reference object at the upper part and it is supported at the two parts. A ladder is a classic example because it can not stand without resting part of its body on a wall or a fence. yo 'skin' is the postposition that is usually selected when gbe 'lean' is used. (64) and (65) attest to this:

64. Ntsodi ógbe agli e yó.
n-tsodi
ó-gbe
a-gli $=\mathrm{e}$
yó
CM-ladder SM.SG -lean CM-wall=DET skin

'The ladder leans against the wall.' [TRPS.58]

65. Jyó á ógbe fesri-é yó.
o-yó =á
ó-gbe fesri=é
yó
CM-stick $=$ DET AM-lean window $=$ DET skin

'The stick leans on the window.'

\subsubsection{8 gbó 'be.placed'}

When a figure is partially on its base and it does not lean on anything, the verb gbó is used. This verb is sometimes used for the figure, for example a bottle, when it makes an acute angle with the ground as if it were lying on the ground. (66) is an example.

66. Tumpa ógbó na egbi é tsú.
tumpa ó-gbó
na e-gbi =é
tsú
bottle SM.SG-be.placed
on $\mathrm{CM}$-stone $=\mathrm{DET}$ upper surface

'A bottle lies on the stone.'

[PV.26]

If the figure is neither standing nor leaning a Serial Verb Construction is used in order to give an accurate description of the situation. The Serial Verb Construction is mainly two verbs; the initial verb takes the agreement marker and no word comes in between the two verbs. The initial verb, gbo 'be placed' describes the 
manner of the location and the second verb gbe 'lean' concentrates on the position in (67), and (68) or kpo 'lie' in (69).

67. Jyótsi ع́ ógbó gbe oyó á yó.
o-yótsi =
ग-yว́=á
yó
CM-Stick = DET SM.SG-be.placed lean
$\mathrm{CM}$-tree $=\mathrm{DET} \quad$ skin
'The stick leans against the tree.' [PV.01]

68. Afúta druiyi ógbó gbe akontsi ع́ nu.
a-fúta
druiyi ó-gbó gbe
a-kontsi $=\mathfrak{\varepsilon}$
$\mathrm{nu}$
CM-Cloth red SM.SG-be.placed lean CM-basket $=$ DET in 'red cloth is leaning in the basket.' [PV 02]

69. Tumpa okpe ógbó kpo oyótsigbo é tsú.

$\begin{array}{llll}\text { tumpa } 0 \text {-kpe } & \text { ó-gbó kpo } & \text { o-yótsigbo=é } & \text { tsú } \\ \text { bottle AM-one } & \text { SM.SG-be.placed-lie } & \text { CM-stump=DET } & \text { on }\end{array}$

'One bottle lies on the stump.' [PV.26]

A figure may lie down in a straight line or lie across a horizontal surface. When it lies straight, a compound dzokpo 'straight lie' which comprises a word borrowed from Ewe dzo 'straight' and the Logba word kpo 'lie' is used to describe the position of the figure. dzu yé 'straight stand' is used when the figure is standing straight. The vowel in dzu should be a half open back vowel /o/ but I suggest that this has changed to $/ \mathrm{u} /$ partly because of the [ATR] vowel harmony. Example (70) shows the use of dzuyé.

70. Jyótsibi $\varepsilon$ odzuyé itite oyótsigboe tsú.

\begin{tabular}{lll} 
o-yótsi-bi $=\varepsilon$ & \multicolumn{1}{c}{ o-dzu-yé } & i-tite \\
CM-stick-small=DET & SM.SG-straight & 3SG-stand \\
o-yótsigbo-e & tsú & \\
CM-stump=DET & on
\end{tabular}

'The small stick is standing straight on the stump.' [PV.38]

The expression, tsoga 'placed across' is borrowed from Ewe. It is used to describe a figure that is streched or situated over a ground from one side to the other. It may be a stick lying over the mouth of the basket or a log on a path or road situated from one edge to the other. (71) is an example,

71. Idato a ótsoga memgba nu.
$\mathrm{i}-\mathrm{dat} \mathbf{0}=\mathrm{a}$
ó-tsoga
memgba $\mathrm{nu}$
CM-spoon $=$ DET SM.SG-lie.across
bowl
containing.region
'The spoon lies across the bowl.' 


\subsubsection{9 glé 'tie'}

The verb glé 'tie' is used to describe a situation in which a rope or a ropelike figure eg. thread, twine, etc is used around an object including a human being as in TRPS 42 glé belet 'wear belt'.

72. Udzi $\varepsilon$ óglé belet.
$\mathrm{u}-\mathrm{dzi}=\varepsilon$
ó-glé
belet
CM-girl = DET SM.SG-tie belt
'The girl 'ties' belt.'

In contexts involving things worn on the body the locative verb is at times not used. Instead, a verb meaning 'to wear' is used. Examples are (73) and (74):

73. Ina a óf́́ ishikpe.
i-na $=\mathbf{a}$
ว-f́
i-shikpe
CM-person=DET SM.SG-wear CM-ring
'The person wears a ring.'

74. Osá a óbua kuto.
o-sá = a
ó-bua
kuto
CM-man =DET SM.SG-put.on hat

'The man put on a hat.'

As these are part of a common cultural knowledge, it is redundant using a locative construction. Things worn on the body are therefore described with a verb 'to wear' or 'put on'. 


\section{VERBS AND VERBAL MODIFIERS}

This chapter discusses verbs and verbal modifiers. It is in four parts: the first part deals with the structure of the verb and the verb phrase. The second part discusses the inherent semantic features of verbs and how they are used to classify verbs. The third part links the discussion to tense, aspect, mood and negation. The final part deals with adverbs.

\subsection{Structure of the verb}

The verb cluster can be marked for various features. The sequence of the markers with respect to the verb root is as follows: The negative (NEG) is doubly marked in pre and post verb form. The verb stem (STEM) usually has a pronominal vowel prefix, the subject marker (SM) which signals agreement with the noun phrase that functions as subject to the verb in the clause. This is followed by tense aspect and mood (TAM) markers and then followed by the verb stem. This is represented in (1)

\section{NEG [SM - TAM - STEM] NEG}

In the sentences below, the verb stem is preceded by the following: SM, PTPROG, FUT, and PRSPROG. In (2a), the SM o- and the the Past progressive aspect, tsú are used. In (2b), the SM á- and the Future marker, -bá- are used. In (3), the SM oand the Present progressive aspect marker, -ló are used.

2a. Binka ótsókpe fufui afánu.
Binka ó-tsó-kpe
fufui a-fă-nu
Binka SM.SG-PTPROG-eat fufu CM-house-in
'Binka was eating fufu in the house.'

2b. Kofi kpe Ama ábázó ubonu.
Kofi kpe Ama á-bá-zó
u-bo-nu
Kofi CONJ Ama SM.SG-FUT-go CM-farm-in
'Kofi and Ama will go to the farm.'

3. Ebitsi é ólóyuedî.
e-bitsi $=\tilde{\varepsilon}$
ó-ló-yuedî
CM-child = DET SM.SG-PRSPROG-cry
'The child is crying.' 


\subsection{Verbs and argument structure}

The verb is central in the clause. The semantics of the verb have participants and some of these participants are realised as arguments in the syntax. The verb expresses states of affairs and determines the number of arguments with which it combines to make a simple proposition. All the arguments in a clause gravitate around the verb. For example, an intransitive verb basically has one argument; a transitive verb, two and a ditransitive verb, three. These arguments have semantic roles in the state of affairs. Following Essegbey (1999), I classify the verbs in Logba according to the number of core arguments that they require.

\subsubsection{One place verbs}

These verbs are intransitive and are used in one argument clause. The simple argument of such a verb functions as the subject and is realised as a pre verbal constituent in terms of order. It is also cross referenced on the verb by a pronominal prefix that agrees with the class of the noun and the harmony of the verb stem. Some one place verbs can participate in causative alternation in which the subject of an intransitive verb becomes the object of the transitive clause. In the example sentence below, the verb blí 'break' and fáshí 'tear, be torn' are used. asó 'pot' in (4) and afúta 'cloth' in (6) are the subjects and in (5), and (7) these NPs have become the object and Asafo and osá 'man' have become the subjects.

4. Asó á ábli.

$$
\begin{array}{ll}
\text { a-só=á } & \text { á-bli } \\
\text { CM-pot=DET } & \text { SM.SG-break }
\end{array}
$$

'The pot broke.'

5. Asafo óblí asó á.

$$
\begin{array}{ll}
\text { Asafo ó-blí } & \text { a-só=á } \\
\text { Asafo SM.SG-break } & \text { CM-pot=DET } \\
\text { 'Asafo broke the pot.' } &
\end{array}
$$

6. Afúta áfáshí.

$$
\begin{array}{ll}
\text { a-fúta } & \text { á-fáshí } \\
\text { CM-cloth } & \text { SM.SG-be.torn }
\end{array}
$$

'The cloth is torn.'

7. Osá ófáshí afúta.
o-sá ó-fáshí a-fúta
CM-man SM.SG-tear CM-cloth
'The man tore the cloth.' (C\&B) 


\subsubsection{Voluntary motion verbs}

The semantic types of verbs that are one place are varied. They include some activity verbs which can be described as voluntary motion verbs involving moving entities. Examples are in (8):

8. gbígbe 'crawl'

ké 'jump'

léntá 'fall'

In the following sentences, (9) ebitsi e 'the child' (10) osá a 'the man' are agentive subjects:

9. Ebîtsi é óló gbígbè.
e-bîtsi =é
ó-ló-gbígbè

CM-child = DET SM.SG-PRSPROG crawl

'The child is crawling.'

10. Osá á óké.
o-sá=á
ó-ké
CM-man = DET SM.SG-jump
'The man jumped.'

\subsubsection{Verbs denoting emission of vocal sounds}

Another set of one place verbs are those that describe the emission of vocal sounds. These verbs take an argument which is an agentive subject. They are in

\section{1. fálí 'bleat, of a goat' \\ yuédí 'cry' \\ kpófú 'bark, of a dog'}

The sentence below is an illustration of verbs that describe emission of vocal sounds.

12. Kweku ólóyuédî.

Kweku ó-ló-yuédî

Kweku SM.SG-PRSPROG-cry

'Kweku is crying.'

13. Agbí é ókpófú.
Agbí=é
ó-kpófú
$\operatorname{dog}=$ DET SM.SG-bark
'The dog barked.' 


\subsubsection{Property verbs}

Property verbs are verbs which express non-dynamic situations. They are mainly intransitive verbs and are used in a clause with a preverbal argument and denote properties or qualities. These verbs are predicated of entities that are said to possess the properties. They are inchoative verbs (BECOME x) (see Van Valin \& La Polla 1997) They can be assigned stative verb (BE x ) interpretation in some contexts. Examples of such verbs are in (14)

\begin{tabular}{|c|c|c|c|}
\hline 14. drui & 'be/become red' & dre & 'be/become dirty' \\
\hline bli & 'be/become black' & flí & 'be/become white' \\
\hline kisa & 'be/become long' & dzo & 'be/become straight' \\
\hline tsá & 'be/become tired' & $\mathbf{z i}$ & 'be/become good' \\
\hline mú & 'be/become dark' & yi & 'be/become full' \\
\hline yú & 'be/become cold' & & \\
\hline
\end{tabular}

In the sentence (15) below, the verb kisa 'be/become long' is a property verb. Using it in the clause makes the pre verbal argument ogbá 'road' the possessor of the quality that the verb denotes.

15. ogbá á ókísá.
o-gbá=á
ó-kîsá
CM-road=DET SM.SG-be.long
'The road is long.'

The following verbs are used in some contexts to express entry into a state and in some cases they show further that there is a dynamic change in the state into which the entity that is being referred to has entered. I have indicated the context in which the following verbs can be used with this sense.
16. dá 'become big' lià 'become hard'
yi 'beome weedy' yi 'beome full'

\section{7.dá 'big'}
Akpene uvu é ólódá.
Akpene u-vú=é ó-ló-dá
Akpene CM-stomach $=$ DET SM.SG-PRSPROG-big
'Akpene's stomach is becoming big.'

This is said when a reference is made to the belly of a pregnant woman. Akpene is pregnant and her belly is developing. 
18. yi 'weedy'

ubo é nu ílíyí.

u-bo=é nu í-lí-yí

$\mathrm{CM}-$ farm $=\mathrm{DET}$ in SM-PRSPROG-be.weedy

'The farm is becoming weedy.'

This statement is made with reference to the fast growth of weeds on a fertile piece of farmland.

19. lia 'be hard'

Igbedi ع́ îlîlia.

i-gbedi $=\hat{\varepsilon} \quad \hat{\varepsilon}$-lî-lia

CM-cassava = DET SM-PRSPROG-be.hard

'The cassava is becoming hard.'

This statement is made when cassava which is cooked for the preparation of fufu is becoming hard contrary to what is expected.

20. yì 'full'

nqú é nnyí.

n-qú=é n-nu-yi

CM-water $=$ DET $\quad$ SM-PRSPROG-full

'The water is becoming full.'

This was overheard at the public stand pipe when the container that is put under the tap is getting full. The person whose turn it will be in the queue makes this statement for the owner to get ready and carry the bowl of water away.

It has been observed that there are limited contexts in which dre 'become dirty' yî 'become full', dzo 'become straight' can be used in a two argument clause with an agentive pre verbal argument in a causative alternation. This is illustrated (21), (22) and (23).

21. Kwaku ódre utsá nu.

Kwaku ó-dre u-tsánu

Kwaku SM.SG-dirty CM-room.in

'Kwaku dirties the room.'

22. Akpene óyî ndú e.
Akpene ó-yî
n-dú =é
Akpene SM.SG-full CM-water $=$ DET
'Akpene fills the water.' 
23. Kahia ódzo pampro é.
Kahia ó-dzo
pampro $=$ é
Kahia SM.SG-straighten bamboo = DET
'Kahia straightens the bamboo.'

The causative counterpart of some other verbs is expressed periphrastically using the verb blo 'make' or tá 'give' plus the nominalised form of the verb. (24) blo 'make' is used with the nominalised form bli $\rightarrow$ iblí 'blackness' (25) tá 'give' is used followed by a postposition phrase as object with the nominalised form of yú $\rightarrow$ iyú 'coldness' following the object.

24. Kofi óblo asó á iblí.
Kofi ó-blo
a-só=á
i-blí
Kofi SM.SG-makes
CM-pot $=$ DET CM-blackness
Kofi makes the pot black.'

25. Seto ótá utsánu iyú.

Seto ó-tá u-tsá-nu i-yú

Setor SM.SG-give CM-room-in CM-coldness

'Setor makes the room cold.'

\subsubsection{Achievement verbs}

The one place verbs also include some achievement verbs. The subject argument that is used with the verbs in this group undergoes a change. The following are examples: ku 'die' pró 'be wet' bú 'spoil 'fashi 'torn' dónu'shrink'

26. Abego é ókú.
a-be-go=é
ó-kú
CM-palm-trunk=DET SM.SG-be.die
'The palm trunk is dead.'

27. Avudago é ódónu.
a-vudago = é
ó-dónu
CM-leaf $=$ DET SM.SG-shrink
'The leaf shrank.'

There are however expressions in the language in which ku 'die' and bú 'spoil' are used in two argument constructions. When a person pretends not to hear what he is told because he feels the speaker is bothering him, the expression (28) is used. 
28. Óku ntsoe fé iló á nu.
ó-ku
n-tso
fé i-ló=á
$\mathrm{nu}$
3SG-die PLU-ear in CM-word $=$ DET in
'He/She turned a deaf ear to the case.'

When an item is spoilt and one gets to know that someone or thing has contributed in a way to it the verb: bu 'spoil' may be used in a two argument construction. This is attested in (29).

29. Pepí óbu koko á.

pepí $\quad$ ó-bu $\quad$ koko=á
harmattan $\quad$ SM.SG-spoil koko=DET
'Harmattan spoils the cocoa.'

\subsubsection{Two place verbs}

Two place verbs have two arguments, For example an Agent, a preverbal NP and a Patient, a post verbal NP. These arguments function as subject and object respectively. Of the two arguments, it is the subject argument that is cross referenced on the verb. These verbs express dynamic states of affairs in which the Agent does something which affects the Patient. Examples of these verbs are in (30).

$\begin{array}{llll}\text { 30. no } & \text { 'drink' } & \text { fáshí } & \text { 'tear' } \\ \text { ba } & \text { 'kill' } & \text { tsó } & \text { 'cut' } \\ \text { dá } & \text { 'open' } & \text { yué } & \text { 'pound' } \\ \text { la } & \text { 'beat' } & & \end{array}$

These verbs are used in sentences (31), (32) and (33).

31. Osei ónó ndú.

Osei ó-nó

n-dú

Osei SM.SG-drink CM-water

'Osei drank water.'

32. Howusu óbá ada.

Howusu ó-bá a-da

Howusu SM.SG-kill CM-lizard

'Howusu killed lizard.'

33. Agbi ع́ ódá uzí é.
$\mathrm{A}-\mathrm{gbi}=\hat{\varepsilon}$
ó-dá
$\mathrm{u}-\mathrm{zi}=\mathbf{e}$
CM-dog $=$ DET SM.SG-open CM-dooor $=$ DET
'The dog opened the door.' 


\subsubsection{Creation verbs}

There are many types of verbs used in two place constructions. Creation verbs are one group of two argument verbs. The agent is realised as the subject and does something to an entity to create a new entity. For these verbs either the material that is used to create or the product of the creating activity may function as the second argument of the verb and occupy the object slot. Examples of these verbs are in (34):

$\begin{array}{llll}\begin{array}{l}\text { 34. yənyi } \\ \text { do }\end{array} & \text { 'write' } & \text { mé } & \text { 'sew' } \\ \text { glé } & \text { 'tie'eg. thread, } & \text { lo } & \text { 'weave' 'plait' }\end{array}$

The subjects in (35) and (36) Ama, Esi are Agents. afúta a 'the cloth' and onkpáá 'the thread' are the created entities and they occupy the object slot.

35. Ama ómé afúta á.
Ama う́-mé
afúta =á
Ama SM.SG-sew cloth $=$ DET

'Ama sewed the cloth.'

36. Esi óglé onkpá á.
Esi ó-glé
o-ykpá-á
Esi SM.SG-weave
CM-thread $=$ DET

'Esi wove the thread.'

The material used for the creation which is not the Agent NP can be realised as the subject in a two place construction. This is illustrated in (37) and (38). afúta 'cloth' and onkpa 'thread' which are in the object slot in (35) and (36) are in the subject slot in (37) and (38)

37. Afúta á áme nwu ata.

$\begin{array}{llll}\text { a-fúta }=\text { á } & \text { á-me } & \text { n-wu } & \text { a-ta } \\ \text { CM-cloth=a } & \text { SM.SG-sew } & \text { PLU-dress } & \text { AM-three }\end{array}$

'The cloth sewed three dresses.'

38. Oykpá á óglé imunyi pétée.

$\begin{array}{llll}\text { oykpá=á } & \text { ó-glé } & \text { imunyi } & \text { pétée } \\ \text { rope=DET } & \text { SM.SG-tie } & \text { hair } & \text { all }\end{array}$

'The thread tied all the hair.'

\subsubsection{Caused change of location verbs}

Another set of two place verbs are caused change of location verbs. Examples are in (39): 
39. he 'pull' to 'push'

zí 'carry'

The agent which occupies the pre verb position moves the NP in object postion from one location to the other. In (40) ukplo á 'the table' the object undergoes a movement which is caused by ebitsi é 'the child' the NP that fills the subject slot.

40. Ebítsi é óhe ukplo á.
e-bítsi=é ó-he
u-kplo=á
CM-child $=$ DET SM.SG-pull CM-table $=$ DET
'The child pulls the table.'

\subsubsection{Agricultural verbs of planting}

Also in the set of two place verbs there are verbs that can be classified as agricultural verbs of planting. The NP in the object slot is the material that is planted by the agent which occupies the preverbal subject position. Examples of the verbs are in $(41)$
41. f'́ 'plant'
nunya 'broadcast seed'
du 'sow'

In the sentence below, the postverbal object argument koko é 'the cocoa' is placed in a location in the soil by the agent, the preverbal argument.

42. akpe ejúnyá koko é f'é ubo é nu
a-kpe
koko $=$ é
fe u-bo $=$ é
$\mathrm{nu}$
CM-one SM.PLU-broadcast cocoa $=\mathrm{DET}$ in $\mathrm{CM}$-farm $=\mathrm{DET}$ in
'some broadcast the cocoa in the farm' [15.15.07]

\subsubsection{Peel verbs}

A number of two place verbs express removal of outer covering with either the hands or an instrument from the Patient. The removal depends on the nature of the outer covering and the instrument that is used. Example of peel verbs are in (43):
43. gba 'shave'
vlo 'peel (cassava)'
fónyí 'peel (banana, orange)' kpe 'peel (yam)'

gba 'shave' collocates with the following post-verbal NP. gba idzi 'shave beard', gba uzugbó 'shave hair on the head', gba imunyí 'shave hair on the body'. fónyí is used to refer to removing the peel off banana and plantain. Interestingly, this same verb is used for the removal of the cocoa pod, which is comparatively harder. 
There is a difference in the meaning of 'peel verbs' based on the nature of the outer covering of the item to be peeled. Banana has a soft outer covering that can be removed with the hand almost effortlessly. The outer covering of cassava and yam are layered differently and therefore require different strategies in the use of an Instrument, such as for banana, cassava and yam. So, fonyi, vlo and kpe are used respectively. In (44) fonyi 'break open' is used for cocoa. The same verb is also used for banana and orange. In respect of cocoa, a cutlass is used, but the hand is used to remove the outer covering of banana and orange. The use of knife in respect of orange depends on the type of orange. In (45) vlo is used for cassava because cassava has a harder inner layer in addition to the outer one and in (46) kpe is used for yam as it has only one layer which is not as hard as that of cassava. This difference in the outer layer of cassava and yam accounts for the choice of vlo for one and kpe for the other.

44. Guadi ófonyi koko é.
Guadi o-fonyi
koko $=$ é
Guadi SM.SG-break.open
cocoa $=\mathrm{DET}$
'Guadi breaks the cocoa.

45. Sefe óvlo igbedi é.
Sefe ó-vlo
i-gbedi $=$ é
Sefe SM.SG-peel CM-cassava $=$ DET
'Sefe peels the cassava.'

46. Sefe okpé idzó ó.
Sefe ó-kpe
i-dzó =ó
Sefe SM.SG-peel CM-yam =DET

'Sefe peels the yam.'

\subsubsection{Perception verbs}

Perception verbs also are two place verbs. They involve the experiencer that is coded as subject, and the object slot is filled by the entity that is perceived. Examples of these verbs are in (47):

$\begin{array}{cccc}\text { 47. nu } & \text { 'hear' } & \text { dze } & \text { 'look' } \\ \text { yú } & \text { 'see' } & \text { kloa } & \text { 'smell', }\end{array}$

These verbs are illustrated in (48) and (49) below:

48. Kahia óyú mé.
Kahia ó-yú =m
Kahia $\quad 3 \mathrm{SG}-$ see $=1 \mathrm{SGOBJ}$
'Kahia saw me.' 
49. Esi ólódze akpá asó á nu.
Esi ó-ló-dze
a-kpá
a-só=á
$\mathrm{nu}$
Esi SM.SG-PRSPROG-look
CM-fish $\quad$ CM-pot $=$ DET
in
'Esi is looking at the fish in the pot.'

\subsubsection{Speech act verbs}

Speech act verbs are two argument verbs that involve a speaker and an addressee. The subject position is the NP that refers to the speaker and the object slot is filled by the addressee or the content of speech. (50) are examples of speech act verbs.
50. klóá 'insult'
wá 'tell/say'
dzu (gbe) 'pray'

Speech act verbs are used in the sentences below. When positive consequences are expressed, the direct object is a benefactive because the addressee is a recipient of the compliments expressed by the speaker. It is however malefactive when a negative consequence is expressed. The example sentence in (51) expresses malefactive and (52) expresses benefactive. The verb in (52) is gbe 'voice' which is compounded with the verb dzu 'sound' to give the meaning 'pray'

51. Udzi ع́ óklóá ebítsi ع́.
$\mathrm{U}-\mathrm{dzi}=\hat{\varepsilon}$
ว-klóá
e-bítsi $=\hat{\varepsilon}$
CM-woman $=$ DET SM.SG-insult
$\mathrm{CM}$-child $=$ DET

'The woman insulted the child.'

52. Abiasa ódzugbe Ayadzi.

$\begin{array}{lll}\text { abiasa } & \text { ó-dzu-gbe } & \text { A-yadzi } \\ \text { Logba priest } & \text { SM.SG-Sound-voice } & \text { Saturday } \\ \text { 'Logba piest prayed on Saturday.' } & \end{array}$

\subsubsection{Light verbs}

Another class of two argument verbs are the so called 'light verbs' with relatively little semantic content which take a specified object. The object of these verbs contributes greatly to the semantics of the verb phrase. Without the verb, the object cannot be used independently. mi 'take' plus utrome 'work' means 'to work'. la 'beat' plus alága 'speech' means 'to speak'. These verbs are referred to as light verbs (Lefebre and Brousseau 2002) or inherent complement verbs (Essegbey 1999). Examples of some of the verbs are in (53): 


\begin{tabular}{|c|c|c|c|c|c|}
\hline 53. a. & $\mathrm{mi}$ & 'take' & utrom $\varepsilon$ & 'work' & 'to work' \\
\hline b. & zo & 'move' & ikú & 'song' & 'to sing' \\
\hline c. & la & 'beat' & alága & 'speech' & 'speak' \\
\hline d. & la & 'beat' & iló & 'word' & 'explain' \\
\hline e. & gu & 'make' & otá & 'war' & 'fight (battle)' \\
\hline f. & $\mathrm{gu}$ & 'make' & ima & 'fist' & 'fight (fist)' \\
\hline g. & dó & 'say' & dase & 'thank' & 'to express thanks' \\
\hline h. & gá & 'give out' & anú & 'mouth' & 'to greet' \\
\hline i. & di & 'enjoy' & onúkpá & 'chief' & 'reign' \\
\hline j. & tso & 'cut' & ilo & 'word' & 'end ones speech' \\
\hline $\mathrm{k}$. & to & 'fix' & etsí & 'ground' & 'start speaking or work' \\
\hline
\end{tabular}

In the example sentence in (54) a light verb la ilo 'explain' is used. This is an expression of gratitude by Ophelia to the chief after he explained the use of the linguist staff to them

54. Anyintse té alá iló ime wá tsú.

anyintse té a-lá i-ló i-me wá tsú.

Thanks COMPL 2SG-beat CM-word AM-this tell 1PLUOBJ

'Thanks that you have explained this to us.' [15.7.19]

\subsubsection{The verb + iva}

The verb expression involving the verb and noun express a verb idea. These verb expressions in their citation take a generic verb + iva 'thing'. Below are examples.

$\begin{array}{clll}\text { 55. V-N (iva) } & & & \\ \text { ta-iva } & \text { [tiva] } & \text { swear thing } & \text { 'swear' } \\ \text { kpe-iva } & \text { [kpiva] } & \text { eat thing } & \text { 'eat' } \\ \text { za-iva } & \text { [ziva] } & \text { cook thing } & \text { 'cook' } \\ \text { du-iva } & \text { [diva] } & \text { plant thing } & \text { 'plant' }\end{array}$

The verb cannot occur alone even though it has meaning by itself. iva 'thing' is used as a complement when the speaker expresses the general activity encoded by the verb without reference to any particular undergoer. A phonological process results in the deletion of the final vowel of the verb word. iva can be replaced by specific complements. ta 'swear' can take complements like Biblia 'Bible', Akpanams 'Logba god' and other words referring to things that one can swear by. The verb du 'plant' can be used with complements which refer to items that can be planted like idzo 'yam' and igbedi 'cassava'. The reason they are cited with iva is that they require an object. These verbs fall under the class described as obligatory complement verbs (Essegbey 1999:13). 
In sentences (56) and (59), iva 'thing' is used as the complement of the verb. It is replaced by the complement idzó bugo é 'the rotten yam' in (57) and imbí bibi é 'the small rice' in (60) for specificity. (58) and (61) are ungrammatical because the object position is left unfilled.

56. Kofi ódu iva.

Kofi ó-qu i-va

Kofi SM.SG-plant CM-thing

'Kofi planted.'

57. Kofi ódu idzó bugo é

Kofi ó-du i-dzó bugo=é

Kofi SM.SG-plant CM-yam rotten $=$ DET

'Kofi planted the rotten yam'

58. * Kofi ódu

Kofi ó-du

Kofi SM.SG-plant

*'Kofi planted'

59. Ntsu zá iva.

n-tsu-zá iva

1SG-HAB-cook thing

'I cook.'

60. Esi ózá imbí bibi é.

Esi ó-zá i-mbí bibi=é

Esi SM.SG-cook CM-rice small=DET

'Esi cooked the small rice.'

61. *Esi ózá

Esi ว́-zá

Esi SM.SG-cook

*'Esi cooked'

For the expression of certain verbal ideas, the verbs take specific complements. For example, the verb bu 'count' takes the postposition complement zugbó nu 'head in' The verb word bu-zugbó-nu which will literally be translated as 'count-head-in' but means 'to think' appears to be a calque from the Ewe phrase bu tame 'think' which also literally translates as 'count head in'.

Another class of verbs requires complements which are related in some way to them. They do not take iva 'thing' as an obligatory complement. Rather, they take objects that semantically repeat the information in the verb. These are referred to as cognate objects. 
In (62) imó, iyó and okugbali are semantically dependent on the action expressed by mó, yó. and kú. In addition, the objects share the morphology of the verb.

62 i. mó 'laugh' imó 'laugh'

ii. yó 'dance' iyó 'dance'

iii. ku 'die' okugbali ${ }^{35}$ 'bad death'

(63), (64) and (65) are example sentences in which yó iyó and ku okugbali are used. (65) is ungrammatical because gbali is not attached to oku 'death'

63. Udzi é óyó iyó.
u-dzi =é
ó-yó
i-yó
CM-woman=DET SM.SG-dance
CM-dance

'The woman danced.'

64. Ebitsi kləyi ókú okugbali.
e-bitsi kloyi ó-kú
o-ku.gbali
CM-child small SM.SG-die CM-death.bad

'The small child died a bad death.'

65. *Ebitsi kloyi ókú oku.
e-bitsi
kləyi ó-kú
o-ku
CM-child
small SM.SG-die
CM-death

'The small child died a death.'

\subsubsection{Three place verbs}

A large number of verbs in Logba are two place verbs. Three place verbs are few. Examples are gbla 'show', bú 'ásk', tá 'give' They take a pre-verbal NP (Agent), and two post-verbal arguments, Goal and Theme. There is a restriction on the order of the two complements in the immediate post verbal slot. Goal precedes the Theme. In the illustrated sentences below, those in which the Theme precedes the Goal (67) and (69) are ungrammatical:

66. Kofi ógbla Seto Akonta.
Kofi ó-gbla
Seto Akonta
Kofi SM.SG-show Seto Akonta
'Kofi taught Seto Mathematics.'

\footnotetext{
${ }^{35}$ Culturally, some unnatural deaths are regarded as evil and bad. Certain customs are performed to prevent a re-occurrence. This is however, not peculiar to the Logba people. The Ewes who are their neighbours also hold on to this belief.
} 
67. *Kofi ógbla Akonta Seto.
Kofi ó-gbla
Akonta
Seto
Kofi SM.SG-teach Akonta
Seto

68. Howusu ótá Asafo efeshi.
Howusu ó-tá
Asafo e-feshi
Howusu SM.SG-give Asafo CM-sheep
'Howusu gave Asafo sheep.'

69. *Howusu ótá efeshi Asafo.
Howusu ó-tá
e-feshi
Asafo
Howusu
SM.SG-give CM-sheep
Asafo

\subsubsection{Labile verbs}

From the discussion of one place, two place and three place verbs, it can be inferred that there are some verbs that belong to more than one group depending on the way they are used in a clause. These are called labile verbs (see Payne 1997:216). Those found in Logba are placed into two main groups depending on a change of semantic function of the subject or not.

\subsubsection{Alternation $\mathrm{S}=\mathrm{A}$ verbs}

This group of verbs can occur in both one place and two place constructions but in both cases the Subject of one place construction remains the agent in the two place construction. In the sentences below the verbs teni 'escape' and buetsi 'fall' are used. In (70) and (72), they are used in one place constructions with Sowu as the Subject. (71) and (73) are two place constructions but the Subjects do not change their semantic roles or syntactic positions. The object slot is filled by a postpositional phrase which is a Locative.

70. Sowu óténí.

Sowu ó-téní

Sowu SM.SG-escape

'Sowu escaped.'

71. Sowu óténí afá á nu.

Sowu ó-téní a-fá=á nu

Sowu SM.SG-escape CM-house $=$ DET in

'Sowu escaped from the house.'

72. Sowu óbuetsí.

Sowu ó-buetsí

Sowu SM.SG-fall

'Sowu fell.' 
73. Sowu óbuetsi oyó á nu.

Sowu ó-buetsi o-yó=á nu

Sowu SM.SG-fall CM-tree $=$ DET in

'Sowu fell from the tree.'

\subsubsection{Alternation $\mathrm{S}=\mathrm{A}$ or $\mathrm{P}$ verbs}

Another group of verbs that can occur in one place and two place constructions have the NP that functions as object in a two place construction surfacing as the single argument in an intransitive clause. The following verbs in (31) are examples.

74. bu 'be spoil' kú 'die'

When they are used in an intransitive construction, the subject NP is the patient. This is illustrated in (75) and (76)

75. Koko é óbu.
koko $=$ é
ó-bu
cocoa $=$ DET SM.SG-be.spoil
'The cocoa is spoiled.'

76. Amuzu otsoe ókú.
Amuzu otsoe ó-kú
Amuzu ear SM.SG-die
'Amuzu is deaf.'

On the other hand, these verbs can be used in transitive constructions with the subject NP as the Agent and the object NP as the patient. This is shown in (77). In (78) the subject is the Patient and the object okugbali is a cognate object.

77. Ubonukpíwo é obu koko é.

$$
\begin{aligned}
& \text { ubonukpíwo=é o-bu koko=é } \\
& \text { farmer=DET SM.SG-spoil cocoa=DET } \\
& \text { 'The farmer spoiled the cocoa.' }
\end{aligned}
$$

78. Amuzu okú okugbali.
Amuzu o-kú
o-kugbali
Amuzu SM.SG-die CM-death.bad
'Amuzu died a bad death.' 


\subsubsection{Verbs that can be used both as transitive and ditransitive}

It is also observed that there are some verbs that can be used in transitive and ditransitive constructions. The verb gbla 'teach/show' is an example. In a transitive construction it translates as 'show' and in some contexts it means 'punish'. However, in a ditransitive construction, it means 'teach'. (79) and (80) illustrate this:

79. Masta ógbla amú bî intá.

$\begin{array}{llll}\text { masta ó-gbla } & \text { amú } & \text { bî̀ intá } \\ \text { Masta SM.SG-show } & \text { 1SGIND child } & \text { well }\end{array}$

'Master punished my child severely.'

80. Masta ógbla amú bî akónta intá.

$\begin{array}{llll}\text { masta ó-gbla } & \text { amú } \quad \text { bí akónta intá } \\ \text { Masta SM.SG-show } & \text { 1SGIND child mathematics } & \text { well } \\ \text { 'Master taught my child mathematics well.' } & \end{array}$

\subsubsection{Verbs that are used as intransitive, transitive and ditransitive}

There is one verb identified that can be used in intransitive, transitive and ditransitive constructions without any shift in meaning. This verb is bú 'ask'. In the use in transitive and ditransitive contructions $\mathrm{O}_{1}$ and $\mathrm{O}_{2}$ can either be NP or a postpositional phrase This is demonstrated in (81), (82) and (83)

81. Mabú.

ma-bú

1SG-ask

'I asked.'

82. Mabú iló á nu.

$$
\begin{aligned}
& \text { ma-bú i-ló=á nu } \\
& \text { 1SG-ask CM-word=DET in } \\
& \text { 'I asked about the matter.' }
\end{aligned}
$$

83. Mabú Kofi iló á nu.

$$
\begin{aligned}
& \text { ma-bú Kofi i-ló=á } \quad \text { nu } \\
& \text { 1SG-ask Kofi CM-word=DET in } \\
& \text { 'I asked Kofi about the matter.' }
\end{aligned}
$$

\subsection{Tense, aspect and mood markers}

Four morphological preverbal markers are identified in Logba. They are present progressive, past progressive, habitual, and future markers. 


\subsubsection{Present and past interpretation}

There is no clear cut present tense in Logba. The bare form of the verb indicates the simple past tense when dynamic verbs including achievement verbs like dónu 'shrink' in (27) are used. However, inchoative verbs and verbs that express quality concepts have present time interpretation.

On one of my field trips in Logba, I visited a cocoa farm to record the processes involved in cocoa production in Alakpeti ${ }^{36}$. The example sentence (84) is one of the sentences recorded. The tenseless form of the verb gba 'cover' is used. The action of covering cocoa beans in the farm with leaves was completed and the chief farmer was narrating how it was done. The bare form of the verb was therefore used. What is evident is the result of the cocoa that is covered in the farm. One sees a past action with traces in the present. A similar interpretation is found in the data in the use of many dynamic verbs that are unmarked for tense. In a sense, since there is no overt marking for tense on the verb, adverbials in the context are used where there appears to be an ambiguity.

84. Ebonukpiwo é ágbá avudago na koko é tsú
e-bonukpiwo $=$ é
á-gbá
a-vudago na
koko $=$ é $\quad$ tsú
$\mathrm{CM}$-farmer $=\mathrm{DET} \quad$ SM.PLU-cover CM-leaf put cocoa $=\mathrm{DET}$ on

'The farmers covered the cocoa with leaves'

In (85), an inchoative verb gbé 'become dry' is used. It gives the quality that the NP argument possesses. The change of state took place before speech time but the state is present. The translation equivalent is present. The 'end state' of what happened is what is talked about. In (86), temporal adverbials ekpebe vé nu 'in the year past' is used to locate the time of the drying of the river in the past.

\section{Ado ógbé.}

Ado ó-gbé

Ado SM.SG-dry

'River Ado is dry.'

86.Ado ógbé ekpebe vé nu.

Ado ó-gbé ekpebe vé nu

Ado SM.SG-dry year.time pass in

'River Ado dried last year.'

\subsubsection{Present progressive}

The present progressive describes an event that is going on simultaneously to the speech reference time. The progressive morpheme is [lu] with a high tone. It is also

\footnotetext{
${ }^{36}$ See appendix for an extract of the text collected from Mr. Guady.
} 
realised as [ló, lí, lé] depending on the quality of the pronominal prefix vowel and the [ATR] quality of the vowel of the verb stem (see section 2.5.7.1). (87) and (88) are examples of the progressive using the verb, no 'drink' and a complement nqú 'water' and fó 'wash' and the complement memgba a 'the plate'

\section{1SG Nnú no nqú.(Alakpeti) \\ 1SG Ndú no nqú.(Tota) \\ 2SG Alú no ndú. \\ 3SG Jló no ndú. \\ 1PLU Atilí no ndú. \\ 2PLU Anilí no nđú. \\ 3PLU Elé no nqú.}

88. 1SG Nnú fó memgbá á.'(Alakpeti)

1SG Ndú fó memgbá á. (Tota)

2SG Alú fó memgbá á.

3SG Óló fó memgbá á.

1PLU Atilí fó memgbá á.

2PLU Anilí fó memgbá á.

3PLU Elé fó memgbá á.
'I am drinking water.'

'I am drinking water.'

'You are drinking water.'

'He /She is drinking water.'

'We are drinking water'

'You (PLU) are drinking water.'

'They are drinking water.'

'I am washing the plate.'

'I am washing the plate.'

'You are washing the plate.'

'He /She is washing the plate.'

'We are washing the plate.'

'You are washing the plate.'

'They are washing the plate.'

(89), (90) and (91) are examples in which the present progressive is used in sentences.

89. Jkple, zãa ko ivanukpíwo ólóba.

$\begin{array}{llll}\text { o-kple, } & \text { zãa } & \text { ko } & \text { i-vanu-kpí-wo } \\ \text { CM-reason } & \text { for.a.while } & \text { only } & \text { CM-bush-go-NOM } \\ \text { o-ló-ba } & \end{array}$

'Because only after a while, the hunter is coming.' [15.3.27]

90. Ankó té ólókpo atsa nu fé ale uvi é okpó ónyuí.
a-nko té
o-ló-kpo
a-tsa nu f'
CM-hen COMPL SM.SG-PRSPROG-lie CM-coop in also
ole u-vi=é ó-kpó onyui
3SG CM-tail=DET SM.SG-lie outside

'The hen says it is lying in the coop but its tail lies outside.'

91. Atitro iđu fé atilí no atama.
ati-tro
i-du
$\mathrm{f}^{\prime} \varepsilon$
1PLU-carry CM-gunpowder also
ati-lí-no
a-tama
1PLU-PRSPROG-smoke CM-tobacco

'We carried gunpowder but we are also smoking tobacco.' [15.4.25] 
The Present progressive is also used for imminent actions and situations that are about to happen and there is assurance that the said action will take place. For example, a man who plans to travel to Have, a town near Logba, is indoors making the final preparations to start the journey. When I entered the house and asked his wife about him: 'Where is your husband?' The answer she gave was:

92. Obo utsá nu gake ólózó Have.

$\begin{array}{lll}\text { o-bo u-tsá nu gake ó-ló-zó } & \text { Have } \\ \text { 3SG-stay CM-room in CONJ SM.SG-PSPROG-go } & \text { Have } \\ \text { 'He is in the room but he is going to Have.' } & \end{array}$

\subsubsection{Past progressive}

The Past progressive and the Habitual are segmentally identical but tonally different. Past progressive describes situations that go on at some past time. Habitual refers to an event that is customary, regular or an action that is perceived as lasting for a period of time.

The only distinction between the Past progressive and the Habitual is that a high tone is attached to the morpheme [tu] that marks the former while the latter has a low tone. The underlying form of the Past progressive morpheme is [tu] (see section 2.5.7.1). This is shown below using the verb no 'drink' and a complement nqú 'water':

$\begin{array}{ll}\text { 93. 1SG Ntú no nqú. } & \text { 'I was drinking water.' } \\ \text { 2SG Atú no ndú. } & \text { 'You were drinking water.' } \\ \text { 3SG Dtó no ndú. } & \text { 'He /She was drinking water.' } \\ \text { 1PLU Atití no ndú. } & \text { 'We were drinking water.' } \\ \text { 2PLU Anití no ndú. } & \text { 'You (PLU) were drinking water.' } \\ \text { 3PLU Eté no ndú. } & \text { 'They were drinking water.' }\end{array}$

94. 1SG Ntú fó memgbá nu. 'I was washing the plate.'

2SG Atú fó memgbá nu. 'You were washing the plate.'

3SG Otó fó memgbá nu. 'He /She was washing the plate.'

1PLU Atití fó memgbá nu. 'Wewere washingthe plate.'

2PLU Anití fó memgbá nu. 'You (PLU) were washing the plate.'

3PLU Eté fó memgbá nu. 'They were washing the plate.'

Below are other examples:

95. Oyubitsi ótólé agli é unáme.
O-yubitsi ó-tó-lé
a-gli =é u-náme
CM-thief SM.SG-PTPROG-climb
CM-wall $=$ DET CM-yesterday
'The thief was climbing the wall yesterday.' 
96. Atitífiní atsá unánsánango afánu.

Ati-tí-finí $\quad$ a-tsá u-nánsánango
1PLU-PTPROG-blow CM-horn CM-paramout.chief
a-fá-nu
CM-house-in
'We were blowing horn in the paramount chief's house.'

97. Ntudo amfǒ ogbámá zó suku.

\begin{tabular}{|c|c|c|c|}
\hline N-tú-do & am-fõ & o-gbá-má & zó suku \\
\hline 1SG-PTPROG-follow & 1SG-brother & CM-road-back & go school \\
\hline
\end{tabular}

\subsubsection{Habitual}

The habitual refers to an event that is customary; regular or an action that is perceived as lasting for a period of time or have occurred over and over again. The habitual morpheme is [tu] with a low tone. The vowel of this aspectual prefix may change to any of these vowels: $\mathbf{u}, \mathbf{o}, \mathbf{i}$, or $\boldsymbol{\varepsilon}$ depending on the [ATR] value of the vowel of the verb stem (see section 2.5.7.1). This is illustrated below using the predicate expression $\mathrm{kp} \varepsilon$ imbí 'eat rice':

$\begin{array}{lll}\text { 98. 1SG } & \text { Ntu kpe imbí. } & \text { 'I eat rice.' } \\ \text { 2SG } & \text { Atu kpe imbí. } & \text { 'You eat rice.' } \\ \text { 3SG } & \text { Jto kpe imbí. } & \text { 'He /She eat rice.' } \\ \text { 1PLU } & \text { Atiti kpe imbí. } & \text { 'We eat rice.' } \\ \text { 2PLU Aniti kpe imbí. } & \text { 'You eat rice.' } \\ \text { 3PLU } & \text { Ete kpe imbî. } & \text { 'They eat rice.' }\end{array}$

(99) and (101) are questions aimed at eliciting answers that make use of the habitual. (100) and (102) are the answers offered by the addressee.

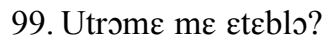

u-trom $\varepsilon \quad \mathrm{m}(\varepsilon) \quad \varepsilon$-te-blo

CM-work Q 3PLU-HAB-make

'Which work do they do?'

100. Etckpí ubonu.
ع́-te-kpi
u-bo-nu
3PLU-HAB-go CM-farm-in
'They go to farm.' 
101. Me atublo udántsí xé adzí etsí?
$\mathrm{me} \quad$ a-tu-blo
u-dántsí
xé a-dzí
e-tsí
Q 2SG-HAB-make CM-morning RP 2SG-stand
CM-ground

'What do you do in the morning when you wake up?'

102. Ntufo anyinu.
n-tu-fo
a-nyi-nu
1SG-HAB-wash CM-face-in
'I wash my face.'

Proverbs are generic statements that are assumed to articulate habitual happenings and timeless truths. One general type of expression in which habitual occurs is the proverb as in (103).

103.Antenyi té mkponyi momá ole fé ótokpe afágba.

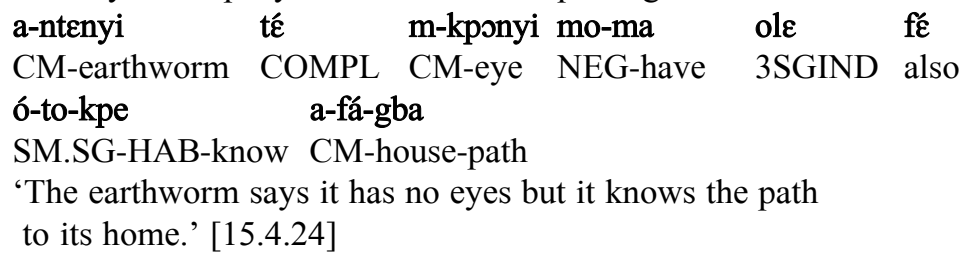

\subsubsection{Future}

The future locates a situation in time that will occur after the time of speaking. It is marked morphologically with bá bó bí bé á which precedes the verb. This depends on the quality of the vowel in the first syllable of the verb and the vowel of the SM. The vowel in the future morpheme may change to either /o/ or $/ \mathrm{o} /$. In (46a) because the verb stem of zo 'go' is [-ATR], /o/ is selected. /o/ is selected in (46b) to harmonise with the stem of the verb fó 'wash'. However, in the 1PLU and 2PLU the future morpheme becomes [bi]. In the 3PLU, because the stem of the verb is [-ATR] and the pronominal prefix is $[\varepsilon]$, the future morpheme becomes [be]. In rapid speech, this morpheme may lose the bilabial plosive leaving only /á/. In environments where this vowel also undergoes deletion, the high tone remains only to hang on the vowel which comes to take that position. The conjugation below illustrates the future using the verb: zó 'go' fó 'wash'

$\begin{array}{llll}\text { 104. } & \text { mázó } & \text { mbázó } & \text { 'I will go' } \\ \text { 2SG } & \text { aázó } & \text { abázó } & \text { 'you will go' } \\ \text { 3SG } & \text { ośzó } & \text { óbózó } & \text { 'he /she will go' } \\ \text { 1PLU } & \text { atibízó } & & \text { 'we will go' } \\ \text { 2PLU } & \text { anibízó } & & \text { 'you will go' } \\ \text { 3PLU } & \text { ćbézó } & & \text { 'they will go' }\end{array}$




\begin{tabular}{|c|c|c|c|}
\hline $1 \mathrm{SG}$ & máfó & mbáfó & 'I will wash' \\
\hline $2 \mathrm{SG}$ & aáfó & abáfó & 'you will wash' \\
\hline $3 \mathrm{SG}$ & óófó & óbófó & 'he /she will wash' \\
\hline 1PLU & atibífó & & 'we will wash' \\
\hline 2PLU & anibífó & & 'you will wash' \\
\hline 3PLU & ébéfó & & 'they will wash' \\
\hline
\end{tabular}

(106) is in the future. The speaker is issuing a warning of what he thinks will happen. The future marker bó is used and it comes before the main verb, kpe 'eat'

106.Agbé óbókpe wú.
A-gbé ó-bó-kpe
wú
CM-dog SM.SG-FUT-eat
2SGOBJ
'A dog will bite you.'

Generally the future is used in procedural discourse in the apodosis of the conditional clause. Future is also used in describing procedures in conditional hypothetical contexts. Thus the future has modal qualities of marking non-actuality or intention. Sentence (107) is a description of how to make palm oil. It is not an actual event. The speaker is narrating the various processes involved in palm oil making. She has used a conditional clause in the main clause in which the future abó gla 'will pour' is used.

107.Abóna abe odzá xé abe ébeé abó gla fé akontsi nu.

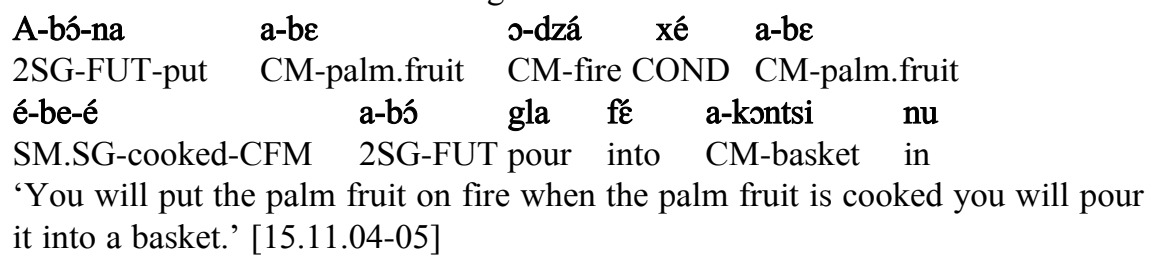

The future can be used with other TAM markers. The future morpheme is used with the present progressive aspect marker -lu to express the state of affairs which will be in progress at a certain future time. The future morpheme precedes the progressive morpheme. The following sentences are examples:

108.Esi óbólózó Agbo.
Esi ó-bó-ló-zó
Agbo
Esi SM.SG-FUT-PRSPROG-go Tafi
'Esi will be going to Tafi.'

109.Asafo kpe oga ébélezó afán.
Asafo kpe o-ga
ع́-bé-le-zó
a-fá-n
Asafo CONJ CM-wife SM.PLU-FUT-PRSPROG-go CM-farm-in
'Asafo and his wife will be going to farm.' 
Where one wants to express a habitual that will occur in the future, the future morpheme is used with an adjunct phrase that has a habitual sense. Examples of these phrases are adzisiadzi 'everyday', ibesibenu 'always'. Adzi-sia-dzi 'day-every-day is similar to the Ewe expression gbe-sia-gbe 'day-every-day. There is a high probability of it being a calque. ibe-shí-be-nu 'time-every-time-in' is also similar but in the Ewe expression, ye-sia-yi 'time-every-time' there is no postposition as the final morpheme. The following sentences are examples:

110. Yawo óbózá iva adzísíadzí.

Yawo ó-bó-zá ivà a-dzísíadzí

Yawo SM.SG-FUT-cook thing CM-everyday

'Yawo will cook everyday.'

111.Setorwu óbófó memgbá ibeshíbenu.

$\begin{array}{lll}\text { Setorwu ó-bó-fó } & \text { memgbá } & \text { i-beshibenu } \\ \text { Setorwu SM.SG-FUT-wash } & \text { plate } & \text { CM-always } \\ \text { 'Setorwu will wash plate always.' } & \end{array}$

\subsubsection{Negation}

A negative proposition is a denial of an assumed or a presupposed assertion. This contradiction is created because of the presence of a word, a morpheme or a particle in the structure which has a negative (John Payne, 1985, Thomas Payne, 1997 and Croft and Cruse 2004). In Logba, there is a negative particle that is used to indicate negation on the verb. A bipartite morpheme $\mathrm{mV}$....nu is used similar to Ewe me....o and French ne....pas. While in Ewe no constituent comes after o, except utterance final particles, in Logba, an NP or a pronoun which is object can come after nu. This is represented in (112).

$$
\text { SUBJ NEG -V - NEG (OBJ) }
$$

The structure is used in examples (113) and (114). In (113) the pre verb form of the NEG morpheme is mo and in (114) it is ma. In both example sentences the object pronoun occurs after nu the post verbal NEG marker.

\section{Iyé blowo é moókpé nu é.}
iyé
blo-wo =é
mo-ó-kpé nu=é

3SGIND make-owner =DET NEG-SM.SG-eat NEG $=3$ SGOBJ

'He who owns it does not benefit from it.' [15.4.30].

114.Adze okushieku gake maáyúnú akpakpla á
a-dze
okushieku
gake
3PLU-search everywhere
CONJ 
ma-á-pú-nú a-kpakpla=á

NEG-SM.PLU-see-NEGCM-frog = DET

'They searched everywhere but they did not see the frog.'[15.1.09]

It is evident from the examples that there is a bipartite negative marker $\mathrm{mV}$...nu. The first part occurs before the verb cluster and the second occurs after it. The negative particle in (113) and (114) is tied to the subject pronoun. The first pair comes before the verb. If a lexical noun is used in the clause, a subject marker comes in between the verb and the first negative morpheme. In (113) the SM.SG is -ó- referring back to the NP, iyé blowoe 'the person who makes it'. The -a attached to ma in (114) is however, the SM.PLU prefix. The SM.SG and the SM.PLU are illustrated in the example sentences in (113) and (114).

(115) shows the negative marker as it is used with various subjects. The verb used is kpi 'go'. The negative markers are underlined:

\section{AFFIRMATIVE \\ SG:1 ma kpi 'I went' \\ 2 a kpi 'You went' \\ 3 ó $\mathrm{kpi}$ 'He/She went'}

\author{
NEGATIVE \\ ma kpi nú 'I did not go' \\ a mo kpi nú 'you did not go' \\ mo ó kpi nú 'he/she did not go' \\ ati mi kpi nú 'we did not go' \\ ani mi kpi nú 'you did not go' \\ me kpi nú 'they did not go' \\ me kpi nú 'They did not go'
}

In the negative, when the $1 \mathrm{SG}$ Pronoun [ma] is used only the post verb NEG is used; the first negative marker of the pair mo is deleted. This is exemplified further in the sentences below. In the 3PLU, the pronoun fused with the vowel of the pre verb NEG and in the $2 \mathrm{SG}$ there is a syntactic reversal making the pronoun to occur before the pre verb NEG morpheme. Sentence (118) is ungrammatical because the whole pair $\mathrm{mV}$...nú is used in the $1 \mathrm{SG}$.

116. Maminú fiofio.

ma-mi-nú fiofio
1SG-take-NEG broom
'I did not take broom.'

117. Mazónú ovu é nu.
ma-zó-nú o-vu=é
$\mathrm{nu}$
1SG-go-NEG-CM-market=DET in
'I did not go to the market.' 
118.*Mamozonú ovu e nu
ma-mo-zo-nú
$\mathrm{o}-\mathrm{vu}=\mathrm{e}$
$\mathrm{nu}$
1SG-NEG-go-NEG CM-market $=\mathrm{DET}$ in
*'I did not go to the market.'

In the $3 \mathrm{SG}$, the whole pair mo...nu is used. (121) is ungrammatical because the second negative marker of the pair nu is not used.

119. Seto moólánú ebîtsi ع́.

Seto mo-ó-lá-nú e-bîtsi $=\hat{\varepsilon}$

Seto NEG-SM.SG-beat-NEG CM-child $=$ DET

'Seto did not beat the child.'

120. Ida miînyánú Asiedu.

i-da mi-i-nyá-nú Asiedu

CM-money NEG-SM-stay-NEG Asiedu

'Asiedu has no money.'

121.*Ida miînya Asiedu
i-da
mi-í-nya
Asiedu
CM-money NEG-SM-stay Asiedu
*'Asiedu did not have money'

However, when bo 'stay' is to be used in the 3SG negative, only the the first part of the negative marker mo is used with negative suppletive verb stem ma 'not.stay'. (123) is the negative form of (122) in which ma is used with mo, the first part of the negative.

122.Awutí óbo afánu.
awu-tí ó-bo
a-fá-nu
2SG-father SM.SG-stay CM-house-in
'Your father is in the house.'

\section{Awutî moóma afánu.}
awu-tî mo-ó-ma
a-fá-nu
2SG father NEG-SM.SG-stay
CM-house-in
'Your father is not in the house.'

Sometimes only one of the parts is used. Where one negative morpheme is used it is $\mathrm{mV}$, the first part, and it precedes the verb. This happens sometimes in more ritualized sayings or proverbs. This is shown in examples (124), (125) and (126) below: 
124.Mé́go mmua dovu etsí.
me-é-go
m-mua dovu e-tsí
NEG-3PLU-grind CM-flour pour.out CM-ground

'One does not grind flour and pour it on the ground.' [15.4.31]

125. Iló miikla iyóguasó.
i-ló
mi-i-kla
i-yó-gu
a-só
CM-testis NEG-SM-hide CM-skin-wash CM-pot

'The testis is not hidden from the pot used for bathing.' [15.4.32]

126. Odzú moókpali lé ukpó.
o-dzú
mo-ó-kpali
lé u-kpó
CM-river NEG-SM-flow climb CM-mountain

'A river cannot flow climbing a mountain.' [15.4.33]

Since the first part (mo) is always maintained, it can be said that it is the obligatory negative element. The first part of the negative element can lose its vowel. When it does, the nasal becomes homorganic with the initial consonant of the following verb. The position of the negative marker is between the future marker and the verb stem. The nasal which is syllabic retains the tone of the morpheme.

127. Maámmí utrome.

$$
\begin{array}{ll}
\text { ma-á-m-mí } & \text { u-trome } \varepsilon \\
\text { 1SG-FUT-NEG-take } & \text { CM-work }
\end{array}
$$

'I will not do the work.'

128. Maán-klá.

ma-á-n-kla

1SG-FUT-NEG-hide

'I will not hide.'

129. Maánzí uzié.
ma-á-n-zí
u-zié
1SG-FUT-NEG-close CM-door
'I will not close the doo.'

\subsubsection{Other words which express negation}

It is possible to form the negative by using the following negative polarity item to 'never' and negative implying word vui 'cease.' These are prefixed to the verb. (130) and (131) illustrate this: 
130. todze okúnyié

to-dze o-kúnyié

never-see CM-that.place

'never see that place'

131. té ani (tani) vui blo

té ani vui blo

COMP 2PLU cease make

'...that you should not do that' [ C.74]

\title{
7.3.7 Modality expressions
}

Modals are forms that express necessity, ability, and possibility. In addition to the modal uses of the bá FUT, three verbal expressions are identified as modals in Logba. They are: ibote + te 'have to', indú 'may be', kadu iyé tsú 'to be certain'. These expressions do not occur alone but rather they are used with other verbs to express these moods. They are exemplified below:

Obligation is expressed using ibote 'because' with the complementizer clause. The sentence below exemplifies this.

132. Xe abózá nfú, gbã ibote tá (te á) yayi aso.

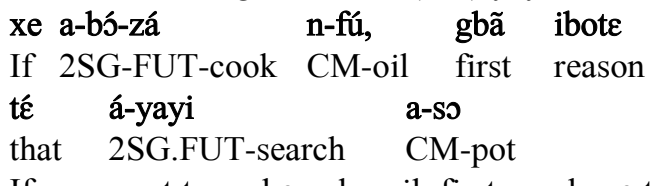

If you want to make palm oil, first you have to search for pot. [15.11.01]

Necessity is expressed by a clause with expletive subject form and the verb zia 'be necessary' which takes a complement clause. When a report was made to one woman that her in-law is dead in one of the villages her response was (133):

133. Iziá té nzó.
té $\quad$ n-zó
3SG-be.necessary COMPL 1SG-go
'It is necessary that I go.'

Uncertainty may also be expressed by the adverbial expression indú 'may be' in a clause with the future tense marker bá. Normally, a pause is heard after indu. This is illustrated below:

\author{
134.Indú, mbázó \\ indu m-bá-zó \\ may.be 1SG-FUT-go \\ 'May be, I will go.'
}


135. Jbóbá, indú

ó-bó-bá $\quad$ indú
3SG-FUT-come may.be
'He will come, may be.'

One of the ways to express a strong belief in something or an event is to use the verb, kadu 'believe' with the complement iyé tsú 'on it'. This precedes a complementizer clause which introduces the main clause. (136) is a response to an earlier question whether the community health nurse will come. The speaker wants to show that she strongly believes that the nurse will come. So she makes use of the expression kaqu iyé tsú 'believe on it.' Since kaqu iyé tsu is a complement taking predicate it is followed by the actual information which normally starts with a complement té. (136) illustrates this.

136. Makadu iyé tsú té óbóbá

$\begin{array}{lllll}\text { Ma-kadu iyé tsú té } & \text { ó-bó-bá } \\ \text { 1SG-believe } & \text { 3SG on COMPL } & \text { 3SG-FUT-come } \\ \text { 'I am certain that he will come' }\end{array}$

\subsection{Adverbs}

An adverb is a word that modifies the action expressed by the verb or the event expressed in the clause. Logba has comparatively few adverbs. As a result, a number of words from other grammatical categories like nouns, ideophones, and postpositional phrases usually fill the adjunct slot in a clause, the syntactic position that the adverb occupies. Adverbs and words that express an adverbial concept may be classified into five semantic groups: manner, degree, time, place and mood. The following ideophones function as manner adbverbials: boboboi 'shout for help' dzaa 'stealthily'/'only'. Postpositional phrase: utsa yo 'attached to the house' and nouns-days of the week adrova 'Thursday', deictic expressions Etsietsi 'south', uname 'yesterday', mekoe 'here' function as temporal adverbials. Below are some of the words which function as adverbs.

\subsubsection{Clause initial and clause final adverbs}

These are mainly temporal adverbs. They include some adverbial expressions indicating location.

$\begin{array}{lll}\text { 137. Temporal } & \text { kpata } & \text { 'at once, immediately' } \\ \text { kpane 'now' } & \text { 'bnanyi 'before yesterday' } \\ & \text { ozume 'tomorrow' }\end{array}$


Deictic adverbial mekoe 'here'

mó 'there'

In (138) kpane is used as a clause initial adverb and (139) mekoe is used clause finally.

138. Kpane, Binka óbózó.

kpane Binka ó-bó-zó

now Binka SM.SG-FUT-go

'Now, Binka will go.'

139. Enya mekoe.

é-nya mekoe
3PLU-stay here
'They stayed here.'

\subsubsection{Clause final only adverbs}

Some adverbs occur only clause finally. These include some temporal adverbials and degree adverbs. They are illustrated in (140), (141) and (142):

140. Temporal: adzisiadzi 'always'

$\begin{array}{ll}\text { ebiasia } & \text { 'all the time' } \\ \text { li } & \text { 'again' } \\ \text { anyile } & \text { 'early' } \\ \text { xoxoe } & \text { 'already' }\end{array}$

141. Frequency zi iyé tsú 'again'

tibi tibi 'bit by bit'

tadze ko 'immediately'

142. Degree enzi 'very much, well'

tututu 'exactly'
pepepe 'exactly'

In (143), (144) and (145) anyile 'early' xoxoe 'already' and enzi 'well' are used respectively in clause final position.

143. Kofi ózó suku anyile.
Kofi ó-zó
suku anyile
Kofi SM.SG-go school early
'Kofi went to school early.' 
144. Ebua oklá xoxoe.

é-bua o-klá xoxoe

3PLU-fold CM-mat already

'They folded the mat already.'

145. Emi utrome enzi.

é-mi u-trome enzi
3PLU-take work well
'They did the work well.'

\subsubsection{Clause initial only adverbs}

Some adverbs only occur clause initially. These include modal adverbials. They are exemplified in (146):

146. Modals ndzódu 'perhaps'

ikpá 'truly'

\subsubsection{Clause final adverbs}

Manner adverbs occur clause finally. These include some ideophonic expressions. The following in (147) and (148) are examples:

147

$\begin{array}{lll}\text { Manner } & \text { kpoo } & \text { 'quietly' } \\ & \text { kpe uzi } & \text { 'loudly, violently' } \\ & \text { kpatakpata } & \text { 'quickly' } \\ & \text { iklángo nu } & \text { 'secretly }\end{array}$

$\begin{array}{lll}\text { 148. (Ideophones) } & \text { dzaa } & \text { 'stealthily'/ 'only' } \\ & \text { blewuu } & \text { 'slowly' } \\ & \text { intá } & \text { 'very' } \\ & \text { boboboi } & \text { 'loudly' } \\ & \text { tsibitsibitsibi } & \text { 'a little, a little' } \\ & \text { gbangbay } & \text { 'fast' }\end{array}$

Ideophones function as adverbials. They normally follow the verb and its arguments as exemplified in (149), (150) and (151).

149. Inashina ókpe onkpe tsibitsibitsibi.

$\begin{array}{lll}\text { i-na-shi-na } & \text { ó-kpe } & \text { o- } y k p \varepsilon \\ \text { CM-person-every-person } & \text { SM.SG-know } & \text { CM-something } \\ \text { tsibitsibitsibi } & & \\ \text { small.small.small } & \\ \text { 'Everybody knows a very small bit of something.' [15.2.80] }\end{array}$


150. ofufo tá ólié tsibi

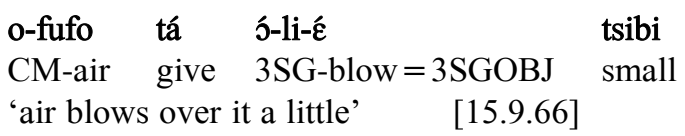

151. Asangbla moóná gbangbay.
a-sangbla
mo-ó-ná
gbángbán
CM-tortoise NEG-AM-walk fast
'Tortoise does not walk fast.'

\subsubsection{Days of the week as adverbs}

Logba language has names for days of the week and is culturally relevant in relation to worship and the performance of rituals. One thing worth commenting on in the example sentence below is the mixing of the Logba name for the days of the week and those of Ewe. The days of the week are in (152). (153) shows the use of days of the week in a sentence.

152. Days of the week

$\begin{array}{ll}\text { uwló } & \begin{array}{l}\text { 'Sunday' } \\ \text { uwláté }\end{array} \\ \text { uwó } & \text { 'Tuesday' } \\ \text { mambliwó } & \text { 'Wednesday' } \\ \text { adruva } & \text { 'Thursday' } \\ \text { uva } & \text { 'Friday' } \\ \text { ayádzi } & \text { 'Saturday' }\end{array}$

153. Kwasida imé ámogba iyé pétée f́é le ayádzi ć.

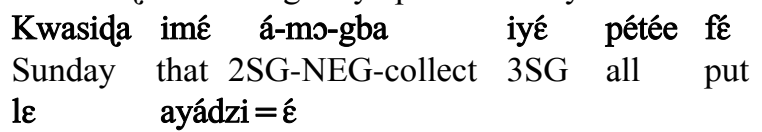

3SGOBJ Saturday $=$ DET

'That Sunday you did not collect all things for her to wear on the Saturday.'

The up-coming youth are either unaware of the names of the days of the week or they have forgotten it. For example, ayadzi 'Saturday' is the day for spirit worship. This is the knowledge that the youth do not have or they are losing it. Thus in conversation one hears the words for the Ewe seven-day week which according to Westermann (1930:102) are borrowed from 'Twi and are rapidly becoming naturalized in Ewe'. 


\section{SENTENCE FUNCTIONS}

The chapter is in three main parts. The first part provides a brief background on the notion of sentence functions and goes on to discuss declarative sentences. The second part is on imperatives and the final part focuses on interrogative sentences concentrating on polar, non-polar and complex questions.

A sentence will have a particular structure and the rules of interaction and interpretation of the sentence in a particular speech community will influence the choice of the structures in the language to be used to say something or/and perform particular actions. A sentence can be used to perform different tasks. This includes giving information, asking permission, asking a question, issuing a command, and instructing other people. Sentences can be distinguished based on their function and can be marked prosodically, syntactically or morpho-lexically.

\subsection{Declarative sentences}

Declarative sentences are usually unmarked as such and are used for making statements. There is no special marker for a declarative sentence. The example sentences (1), (2), (3), and (4) are declarative sentences:

1. Akpakpla á óké fé ndzú é nu.

$\begin{array}{lllll}\text { a-kpakpla=á } & \text { ó-ké } & \text { f́é } & \text { n-dzú=é } & \text { nu } \\ \text { CM-frog=DET } & \text { SM.SG-jump } & \text { into } & \text { CM-river=DET in }\end{array}$

'The frog jumped into the river.'

2. Ebitsi é ótsu atsoli ka etsi.

\begin{tabular}{lllll} 
e-bitsi $=$ é & \multicolumn{1}{c}{ ó-tsu } & a-tsoli & ka & e-tsi \\
CM-child=DET SM.SG & -spit & CM-spittle & put & CM-ground
\end{tabular}

'The child spit on the ground.'

3. Amu nqú ivagblawo ogbo á nu.

amu n-dú i-vagblawo o-gbo=á nu

1SGIND 1SG-be CM-teacher CM-town=DET in

'I am a teacher in the town.'

4. Jsa á óbá abue á.
o-sa =á
o-bá
a-bue =á
CM-man =DET SM.SG-kill
$\mathrm{CM}$-animal $=\mathrm{DET}$

'The man killed the animal.' 
The whole complex sentence, comprising the dependent and the independent clauses can be a declarative sentence. (5) and (6), are examples of complex sentences which function as declarative sentences.

5. Ivagblawo ólá ebitsi é xé ógbama.
i-vagblawo ó-lá
e-bitsi $=$ é
xé
ว-gbama
CM-teacher SM.SG -beat CM-child=DET RP SM.SG-be.late

'The teacher beat the child who was late.'

6. Selorm ósusu té óbá yú Kofi.

\begin{tabular}{lllll} 
Selorm ó-susu & \multicolumn{1}{c}{ té } & ó-bá & yú & Kofi \\
Selorm SM.SG-think & COMPL & 3SG-come & see & Kofi \\
'Selorm thought that he would come and see Kofi.' &
\end{tabular}

Declarative sentences can also be quoted. In quotative sentences, the SVO structure is maintained. The tag that introduces the quotation has a verb of 'saying'. In sentences (7) and (8) below, the verbs dzi 'call' and da 'tell' and wá 'say' are examples of verb of 'saying' used.

7. Đekanyo ódzi é, "amgusa midu anye éteblo ć."
Đekanyo ó-dzi=é, "aḿ-gusa
Đekanyo SM.SG-call =3SGOBJ 1SGIND-brother
mi-du anye é-te-blo= $=$ "”
NEG-be this.way 3PLU-HAB-make $=3 \mathrm{SGOBJ}$
'Đekanyo called him, "my brother this is not the way
they do it."',[15.2. 55-56]

8. Gameli dá wá Kofi, "texo bibi óbo ḿ."”37,
Gameli dá wá Kofi, “te-xっ
bibi ó-bo $=\mathrm{m}$ "
Gameli tell say Kofi yam-house small SM.SG-stay=1SGOBJ
'Gameli told Kofi, "I have a small yam barn.",

\subsection{Imperative utterances}

\subsubsection{Imperative}

Imperative sentences are used to express the wants of a speaker to an addressee(s) to get them do something. It is an important speech act in social relations. Imperatives are formed by using verb forms without expressing the subject. In example sentence (9a), the verb sa 'leave' is followed by an adverb mokoe 'there'; in (9b) the verb za 'cook' is followed by the obligatory complement, the object imbî 'rice'

\footnotetext{
${ }^{37}$ There is no verb which translates as 'have' It is expressed as ' $\mathrm{x}$ stays with me' where $\mathrm{x}$ is the entity that is possessed.
} 
and in (10a) the verb rî 'hold' is followed by the object memgba 'plate' and the adverb, gbangbay 'firmly'. Sentence (10b) is ungrammatical because the basic word order does not allow this. The adverb cannot precede the object.

9a. Sá mokoe!

sá mokoe

leave there

'Leave there!

10a. rí mengba gbaygbay

rí mengba gbangbay

hold plate firmly

'Hold plate firmly!' 9b. Zá imbî!

zá i-mbî
cook CM-rice
'Cook rice!'

10b. *rí gbangban mengba

*rí gbangban mengba

hold firmly plate

'Hold firmly plate!'

In the plural imperative, the independent form of the pronoun is used without a cross reference of the subject on the verb. In (11a) anu 2PLU independent pronoun occurs before the verb sa 'leave' followed by adverb, mokoe 'there'. (11b) is considered unacceptable because ani 2 PLU bound pronoun is indexed on the verb.

11a. Anu sá mokoe!

11b. *Anu anisá mokoe

$\begin{array}{lllll}\text { anu } & \text { sá mokoe } & \text { *anu } & \text { ani-sá } & \text { mokoe } \\ \text { 2PLU.IND } & \text { leave there } & \text { 2PLU.IND } & \text { 2PLU-leave there } \\ \text { 'Leave there! (You plural) } & \text { *'Leave there! (You plural) }\end{array}$

Imperative can also involve serial verb constructions. In the singular, a serial verb involving two verbs can be used to express imperative. In the singular the imperative is expressed like any imperative without a subject but in the plural the 2PLU independent pronoun comes before the initial verb. The verb vui 'stop' and blo 'make' are used in the imperative. (12a) is singular and (12b) is plural. This is used if the speaker wants to prevent the hearer from doing something.

12a. Vui blo!

vui blo

stop make

'stop' (to one person) 12b. anu vui bló

$\begin{array}{lll}\text { anu } & \text { vui } & \text { bló } \\ \text { 2PLU.IND } & \text { stop } & \text { make } \\ \text { 'you (plural) } & \text { stop' } & {[15.3 .74]}\end{array}$

To sound more polite, imperatives are prefaced with certain formula or even address terms. These are:

13. Á́ gusa lá alága

$\begin{array}{llll}\text { aḿ } & \text { gusa lá } & \text { alága } \\ \text { 1SG.IND } & \text { brother } & \text { beat } & \text { CM-speech } \\ \text { 'My brother } & \text { speak!' }\end{array}$


14. Unánsa ba!

u-nánsa ba

CM-chief come

'Chief, come!'

15. Ma tá wú (u)zugbó, na kábákábá!

ma-tá-wú-zugbó, na kábákábá

1SG-give-2SGOBJ-head walk fast

'I give you my head, walk fast!' (I doff my hat)

Sometimes, the benefactive prepositional phrase tám 'for the benefit of me' is added to the imperative to reduce the force further.

16. Ma tá wú (u)zugbó, dá uzi é tá m?

ma-tá wú '(u)-zugbó dá u-zi=é tá=ḿ

1SG give 2SG CM head open $\mathrm{CM}$-door $=$ DET give $=1 \mathrm{SGOBJ}$

'I give you my head, open the door for the benefit of me!'

\subsubsection{Prohibitive}

Prohibitive is a negative imperative in which the speaker does not want the addressee to do something. In Logba to 'never' is used with the bare form of the verb when prohibition is expressed. It is a proclitic on the verb and therefore agrees with the stem in [ATR] since generally it is the stem of the verb that controls the [-ATR] harmony spread. The vowel, /o/ in the word to 'never' may change to its [-ATR] counterpart, $/ \mathrm{o} /$ if the initial vowel in the stem of the verb is [-ATR]. In (18) the verb ba 'come' controls the harmony spread. /a/ triggers [-ATR] value (see section 2.5.4). So, the vowel /o/ in the word, to 'never'changes to to. This is illustrated with the following sentences.

17. To dó!

to $=$ dó

never $=$ go.out

'Do not go out!'

18 To bá afánu!

to = bá a-fá-nu

never $=$ come $\quad$ CM-house-in

'Do not come to the house!'

19. Tə lo zó iku!
to $=10$
zó iku
never $=$ PRSPROG sing song
'Do not be singing song!' 
20. To zó ubo e nu!

$$
\begin{array}{ll}
\text { to=zó } & \mathbf{u}-\mathbf{b o}=\mathrm{e}
\end{array}
$$

'Never go to the farm!'

\subsubsection{Hortative}

This is a form of the imperative in which the speaker invites the addressee to do something together. The use of the plural imperative is a strategy used to reduce the perlocutionary effect so as not to hurt the feelings of the addressee. tá 'let' + the bound subject pronoun occupies the initial position of hortatives. This is followed by the bare form of the verb. The following sentences in (21) and (22) are examples:

21. Tá atizó ubonu.
tá ati-zó u-bo-nu
let 1PLU-go CM-farm-in
'Let us go to farm!'

22. Tá atikpe fufui.
tá ati-kpe fufui
let 1PLU-eat fufui
'Let us eat fufu!'

In some instances, the 2SG or 2PLU pronoun after tá 'let' is used when the speaker invites a spiritual force such as God to assist the addressee in his wish. Examples are travelling mercies, pleas for good health etc.

23. Tá ana enzî.

tá a-na enzî

let 2SG-walk well

'Let the journey be good.' (safe journey)

24. Dmawu taá óvé awú yó.
o-Mawu tá-á
ó-vé
awú yó
CM-God let-PART SM.SG-guard
2PLU skin
'Let God guard you.' 


\subsection{Questions}

Questions are types of sentences used by a speaker to elicit information from an addressee. Different strategies are used for various types of questions in Logba. These are discussed below:

25. a. Prosodic pitch raising of final syllable (see section 2.4.2).

b. The use of a question word eg. mó

c. The use of special tags

\subsubsection{Polar questions}

Polar questions are used to seek specific affirmative or negative answers from the addressee. It is possible to have, apart from the yes/no answers, elaborate answers, or a sentence like 'I do not know', 'perhaps' etc. A case that comes to mind is an interaction between a mother and her children: She came back from the farm at around noon and asked the children Akpe iváá? 'Did you eat?' A 'yes' or 'no' answer was what she expected. However, one of the children answered Aḿtí moótám ida 'my father did not give me money'.

To form a polar question a raised pitch is added to the final syllable of what would have otherwise been a simple declarative sentence (see section 2.4.2). With some people the rise is higher than with others. (26), (27) and (28) are examples of polar questions using different verb structures: aorist, negative, and present progressive.

26. Kofi osáá?

Kofi o-sá-á

Kofi SM.SG-leave-Q

'Did Kofi leave?'

27. Kofi moósanuú ?

Kofi mo-ó-sa-nu-ú

Kofi NEG-SM.SG-leave-NEG-Q

'Did Kofi not leave?'

28. Alózó Haveé ?

a-ló-zó Have-é
2SG-PRSPROG-go Have-Q
'Are you going to Have?'

When the questioner wants to make the question emphatic, the particle anáa is added to it. This suggests an angry mood of the questioner, most often. anáa is said with a rising pitch. Each of the sentences (21-23) can be said with anáa sentence 
finally. The final vowel of anáa may be lengthened. When it is lengthened, it is an indication that the questioner is impatient with the person addressed.

\subsubsection{Content questions}

Content questions are used to seek information about a particular part of the proposition from an addressee. The semantics of a content question is that the constituent that is questioned is what is most important and the answer is the information that the questioner wants. The answer fills the empty slot that is in the question. The addressee has much room to offer an elaborate answer when asked this type of question (Ameka 1986; Sadock \& Zwicky 1985).

In Logba, the question word has two forms mé 'what' and mó 'which'/'who'. Apart from these, there is another word bé 'how many/how much'. Sentences (2932) illustrate how the question word operates. The pitch level of a content question is not different from that of a declarative statement ${ }^{38}$. The question constituent can remain in situ as in sentences (29) and (30) or can occur in clause initial position. In sentence (30), udze 'woman' the NP that is questioned is at the initial position followed by the question word mó. ó-mó is prefixed with o- agreement marker. If the questioned constituent is moved to the initial focal position it is optionally marked with the focus marker (see section 12.2). In sentence (32), utsa is questioned. The questioned phrase comes to initial position and is marked for focus.

29. Mayú udzé ómó ?

$\begin{array}{lll}\text { ma-yú } & \text { u-dź́ } & \text { ó-mó } \\ \text { 1SG-see } & \text { CM-woman } & \text { SM.SG-Q }\end{array}$

'I see which woman?'

30. Mayú udzi ع́ utsá ómó nu?

$\begin{array}{llll}\text { ma-yú } & \text { u-dzi }=\hat{\varepsilon} & \text { u-tsá } & \text { ó-mó nu } \\ \text { 1SG-see } & \text { CM-woman = DET } & \text { CM-room } & \text { SM.SG-Q containing.region } \\ \text { 'I see the woman in which room?' } & \end{array}$

31. Mayú udzi é utsá á nu.

ma-yú u-dzi=é $\quad$ u-tsá=á $\quad$ nu

1SG-see CM-woman =DET CM-room $=$ DET containing.region

'I saw the woman in the room.'

32. Utsá ómó ká nu ayú udzi ع́?
u-tsá
ó-mó ká
$\mathrm{nu}$
a-nú $\quad$ u-dzi $=\varepsilon$
CM-room AM-Q FOC containing.region
2SG-see CM-woman $=\mathrm{DET}$
'In which room did you see the woman?'

\footnotetext{
${ }^{38}$ In the orthographic representation, I add a question mark to distinguish the question from the statements.
} 
If a noun from a group is questioned, the collective noun for that may replace the word in the interrogative. To be more specific, the question could be 'On which Monday did you see the woman as in (35). Sentence (33) is a declarative sentence from which the interrogative sentence (34) is derived. In (34), adzi 'day' is used instead of uwlate 'Monday'

33. Mayú udzi ع́ uwlate.

$$
\begin{array}{lll}
\text { ma-yú } & \mathbf{u}-\mathbf{d z i}=\hat{\varepsilon} & \mathbf{u}-\text { wlate } \\
\text { 1SG-see } & \mathrm{CM} \text {-woman =DET } & \mathrm{CM} \text {-monday } \\
\text { 'I saw the woman on Monday.' }
\end{array}
$$

34. Adzi ómó ká ayú udzi ع́?

$$
\begin{array}{llll}
\text { a-dzi ó-mó ká } & \text { a-nú } & \text { u-dzi=é } \\
\text { CM-day } & \text { AM-Q FOC } & \text { 2SG-see } & \text { CM-woman=DET } \\
\text { 'On which day did you see the woman?' }
\end{array}
$$

35. Uwlate ómó ká ayú udzi ć?
u-wlate
ó-mó ká
a-yú
$\mathrm{u}-\mathrm{dzi}=\boldsymbol{\varepsilon}$
CM-monday AM-Q FOC 2SG-see CM-woman=DET
'On which Monday did you see the woman?'

\begin{tabular}{|c|c|c|c|}
\hline EXPRESSION & STRUCTURE & MEANING & GLOSS \\
\hline 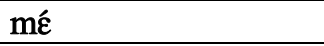 & general question word & what, how & what / how \\
\hline mó & AM-mó & which & $\mathrm{Q}$ \\
\hline mé-nu & Q-in & where & where \\
\hline $\mathrm{m}(\varepsilon)$ ó-kple [mokple] & what-CM-reason & why & what reason \\
\hline ibe Imóa & CM-time-Q-FOC & when & which time \\
\hline bé & quantity & how many & $\mathrm{Q}$ \\
\hline
\end{tabular}

There are six expressions used to ask content questions in Logba. mó, mé and bé are the underived forms mé is derived from mé A noun or pronoun may come before the question word or a particle may be suffixed to the question word. A list of these expressions is in the table 8.1 below:

Table 8.1 Question words

The following are examples of the use of these expressions (The question expression is in bold face).

\subsubsection{1 mé 'what' /'how'}

mé is used in questions which generally probe for information about a constituent that the speaker does not know. It is also used in questions that are asked to find out about the manner in which something is done. mé occurs utterance initially followed by the rest of the clause. It is used to ask about a constituent eg. What did 
Kofi buy? or What bit Kofi? or It is used to talk about the manner of the entire clause, 'how'. The following sentences attest to this:

36 Mé Kofi ónع?

mé Kofi ๖-nє?

what Kofi SM.SG-buy

'What did Kofi buy?'

37 Mé ózá imbí?
mé ó-zá
i-mbî
what 3SG-cook CM-rice

'How does one cook rice?'

38 Mé ézá idzó?

mé ع́-zá i-dzó

what 3PLU-cook CM-yam

'How do they cook yam?'

39 Mé udzi $\varepsilon$ ózá idzó?
$\mathrm{m} \varepsilon \quad \mathrm{u}-\mathrm{dzi}=\varepsilon$
ó-za idzó
what CM-woman=DET SM.SG-cook CM-yam
'How did the woman cook yam?'

\subsubsection{2 omó 'who'/ 'which'}

omó is used in asking questions about animate and inanimate entities. The /o-/ is an agreement marker prefixed to mó to function as a question word if the questioner has no referent in mind or the referent is singular. When the head of the NP in such question is generic, it is unexpressed as in (40). (40) can be paraphrased as 'which people = who' In (43), the agreement marker changes to a- if the referent whose identity the speaker is questioning is plural. This is exemplified in the questions (Q) and answers (A) adjacency pairs below:

40. Q: ómó ami ع́ tá?

$$
\begin{array}{ll}
\text { ó-mó } \quad \text { a-mi-ć } & \text { tá } \\
\text { 3SG-Q } 2 \text { SG-take=3SGOBJ } & \text { give } \\
\text { 'Who did you give it to?' } &
\end{array}
$$

41 A: Ivagblawo é.

i-vagblawo =é.

$\mathrm{CM}$-teacher $=\mathrm{DET}$

'The teacher' 
42. Q: Ebítsi ómó omié tá?

e-bîtsi ó-mó o-mi- $\varepsilon \quad$ tá

CM-child AM-Q SM.SG-take $=3$ SGOBJ give

'Which child did you give it to?'

42a. A: Selorm.

'Selorm'

43. Q: Ebítwo amś ami ع́ tá?
e-bít-wo
a-mó
a-mi-é
tá
CM-child-PLU AM-Q 2SG-take=3SGOBJ give

'Which children did you give it to?'

\section{3a. A: Esinu kpe Gameli}

'Esinu and Gameli'

44. Q: Ando ómó ayáyí?
a-ndo ó-mó
a-yáyí
CM-cat AM-Q 2SG-search

'Which cat did you search for?'

$$
\begin{aligned}
& \text { 44a. A: Amú ando á } \\
& \text { amú a-ndo=á } \\
& 1 \text { SG } \mathrm{CM}-\mathrm{cat}=\mathrm{DET} \\
& \text { 'My cat' }
\end{aligned}
$$

\subsubsection{3 ménu 'where'}

ménu is a question expression which is a compound comprising the question word mé and nu 'containing region' a postposition (see section 5.1.2). This question expression can be either clause initial or in situ. The semantic / pragmatic difference between the use of ménu 'where' in situ and in sentence initial position is not clear. It is however noted that when ménu 'where' is used in situ as in (46) it either shows an expression of surprise or the speaker expects a further clarification from the addressee.

45. Ménu ólózó?
ménu ó-ló-zó?
where 3SG-PRSPROG-go
'Where is he going?'

46. ólózó ménu?
ว́-ló-zó
ménu?
3SG-PRSPROG-go where
'He is going where?' 
In conversation, when the interlocutors share some knowledge about the topic that is under discussion ménu can be used alone in elliptical questions. (47a) and (47b) illustrate this.

47a. Ménu Kofi? 'Where, Kofi?'

47b. Kofi ménu? 'Kofi where?'

\subsubsection{4 mókple 'why'}

mókple is used to question the reason for the occurrence of something or the attitude of someone. This question expression occurs sentence initially as in (42). mókple may be used without any other word. The morpheme ókple literally translates as reason. Sometimes a statement may be made and after a pause mókple may be added as a tag as in (49) below:

48. Mókple Kofi ólóté adzi ع́ egbe?
mó-kple Kofi ว́-ló-té
a-dzi $=\dot{\varepsilon} \quad$ e-gbe ?
Q_reason Kofi SM.SG-PRSPROG-throw
CM-bird $=$ DET CM-stone
'Why is Kofi throwing stone at the bird?'

49. Kofi ólóté egbe agbé, mókple?
Kofi ó-ló-té
a-gbé,
e-gbe
mó-kple?
Kofi SM.SG-PRSPROG-throw
CM-dog CM-stone
which-reason

'Kofi is throwing stone at the dog, why?'

\subsubsection{Ibe imó 'when'}

This question expression is made up of two words: i-be 'time' i-mó AM-Q usually occurs at sentence initial position. The actual question word follows the head word ibe. Because ibe belongs to the class of mass nouns, the agreement marker i- precedes the question word. This contrasts with questions about [ + animate] nouns which have 0 - in singular and a- for plural (see section 8.3.2.2). Examples in (50) and (51) illustrate this:

50. Ibe imśa Kofi ózó suku?

\begin{tabular}{|c|c|c|c|}
\hline $\mathrm{i}-\mathrm{b} \varepsilon$ & i-mó-a & Kofi & ó-zó \\
\hline CM-time & AM-Q-FOC & Kofi & SM.SG-go \\
\hline
\end{tabular}


51. Ibe imóa atú vla aboti?

i-be i-mó-a atú-vla a-boti

CM-time AM-Q-FOC 1PLU-bury CM-corpse

'When do we bury the corpse?'

When the question expression is used with -a suffixed to it, it has added information about the speaker's frustrations about the situation he or she is questioning.

\subsubsection{6 b’́ 'how much'/ 'how many'}

bé is the question word used to find out the quantity or the amount. For questions like How old are you? How much is X? the question word bé is the appropriate choice. This question word has a high tone like other question words. The question word follows the head noun and there is an agreement relation between them. The agreement marker refers to the class of the plural equivalent of singular noun. mbé is used when $\mathrm{N}$ - class nouns are used in the sentence. The a- agreement marker is used for all other noun classes. The noun asked about is assumed to be a quantity, that is either plural or mass and hence the question word takes one of the plural agreement markers. This is attested in (52) where $\mathrm{N}$ - class noun $\mathrm{nkp \varepsilon}$ 'years' is used and (53) where a plural noun aha 'people' is used. The other examples in (54) and (55) show the a- agreement marker.

52. Nkpe mbé anć?

y-kpe m-bé a-né

CM-year AM-Q 2SG-get

'How old are you?' (Lit: How many years have you got?)

53. Ahá abé abo utsá nu?

$\begin{array}{lllll}\text { a-há } & \text { a-bé } & \text { a-bo } & \text { u-tsá } & \text { nu } \\ \text { CM-people } & \text { AM.-Q } & \text { SM.PLU-stay } & \text { CM-house } & \text { in } \\ \text { 'How many persons stay in the house?' } & \end{array}$

54. Ovi ábé?

o-vi á-bé

CM-amount AM-Q

'How much?'

55. Utsá ábé?

u-tsá á-bé

CM-house AM-Q

'How many houses?' 


\subsubsection{Alternative questions}

These are questions in which the questioner offers two possibilities as answers to the addressees to choose from. The question has two clauses joined by the alternative conjunction aló 'or'. The high tone that indicates that a polar question is posed occurs at the final position of both clauses. If the two clauses have the same verb, the verb in the first clause is not repeated in the second clause.

In (56) the first clause has different verbs: zó 'go' and fó 'wash' so they are repeated in the two clauses.

56. Abózó ubonu aló abófó mengba nu?

$\begin{array}{llll}\text { a-bó-zó u-bo-nu aló a-bó-fó } & \text { mengba } & \text { nu } \\ \text { 2SG-FUT-go CM-farm-in or } & \text { 2SG-FUT-wash } & \text { bowl } & \text { in } \\ \text { 'Will you go to farm or will you wash the bowl?' } & & \end{array}$

In (57), both clauses have the same verb: kpe 'eat' The verb therefore occurs once only in the first clause.

57. Abókpe idzó ó aló imbi ع́?

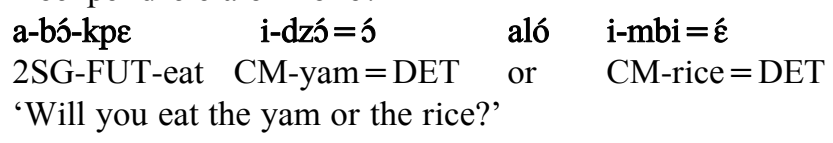

\subsubsection{Coordinate questions}

Questions can also be coordinate. Coordinate clauses are two clauses each containing a question word and linked by a coordinator ye 'and'. (59) is a coordinate question derived from (58).

58. Kofi əzá iku ye Ami oyo iyó.

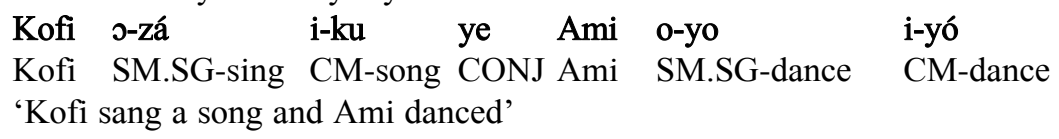

59. Iku ímóa Kofi ózá ye iyó omóa Ami oyó?
i-ku
í-mó-a
Kofi う́-zá
ye i-yo
CM-song SM.SG-Q-FOC Kofi SM.SG-sing CONJ CM-dance
o-mó-a
Ami o-yó
SM.SG -Q-FOC Ami SM.SG-dance
'Which song did Kofi sing and which dance did Ami dance?' 


\subsection{5 'Tag' questions}

These are questions containing the negative tag miqu anyć. The tag is used to seek confirmation about a proposition. This is normally a negative polar question tagged on a positive statement. In (60) below two brothers are going to the farm. They are walking fast because they are carrying planting materials which are heavy. The one ahead asked this question to find out whether the brother who was trailing far behind was coming. In (61), a mother searched the bag of her son and saw balloons and she asked whether the child bought them with the money that was to be used for food in school.

60. Al॰ ba, midu anyé

$$
\begin{aligned}
& \text { a-lo-ba mi-du anyé } \\
& \text { 2SG-PRSPROG-come NEG-be so } \\
& \text { 'You are coming, is it not so?' }
\end{aligned}
$$

61. A-li $\varepsilon$, midu anyé

$$
\begin{array}{lll}
\text { a-li= }=\hat{\varepsilon} & \text { mi-du aný } \\
\text { 2SG-bought }=3 \text { SGOBJ NEG-be } & \text { so } \\
\text { 'You bought it, is it not so?' } &
\end{array}
$$

\subsection{Uses of questions}

\subsubsection{Rhetorical questions}

These are questions for which no response is anticipated from the addressee by the questioner. Both polar questions and content questions can be used as rhetorical questions. In the adjancency pairs below, the polar rhetorical question in (63) and (65) is a response to the statement in (62) and (64)

62. Jkpe idzó ó pétée

$$
\begin{aligned}
& \text { o-kpe i-dzó=s pétée } \\
& \text { 3SG-eat } \quad \mathrm{CM} \text {-yam }=\mathrm{DET} \text { all }
\end{aligned}
$$

63. Izí?

$$
\begin{aligned}
& \text { i-zí } \\
& \text { 3SG-good } \\
& \text { 'Is it good?' }
\end{aligned}
$$

64. Owusu ólé fesre zó utsá nu
Owusu ó-lé
fesre
zó u-tsá
$\mathrm{nu}$
Owusu SM.SG-climb window go CM-room
containing.regionin

'Owusu climbed the window and entered the room' 
65.Izí té inadzengo óblo anyé
i-zí té i-nadzengo
o-blo anyé
3SG-good COMPL CM-person SM.SG-make so
'Is it good for a human being to behave this way?'

The content questions in (67) and (69) are rhetorical and a reaction by another person to the statement in (66) and (68) below.

66. Amú mbázó Ugé ozume
amú
m-bá-zó
U-gé
o-zume
1SG:IND SG-FUT-go
CM-Accra
CM-tomorrow
'I will go to Accra tomorrow'

67. Ménu ayayi tánya kpane

ménu a-yayi té a-nya kpane

where 2SG-want COMPL 2SG-live now

'Where do you want to live now?'

68.Amú maánzó suku idze

$\begin{array}{llll}\text { amú } & \text { ma-á-n-zó } & \text { suku } & \text { i-dze } \\ \text { 1SG:IND } & \text { 1SG-FUT-NEG-go } & \text { school } & \text { CM-today } \\ \text { 'I will not go to school today' } & & \end{array}$

69. Mé ayayi té mablo tá wú
mé a-yayi
té
ma-blo
tá wú
what 2SG-want COMPL 1SG-make give you
'What do you want me to do for you?'

\subsubsection{Questions for confirmation}

Closely related to rhetorical questions is a type of indirect question which is normally an affirmative statement with a high pitch question intonation on the final vowel of the last word just like polar questions. This type of question is a suggestion to the hearer to agree with the speaker. Often, this construction is used when the speaker is soliciting the support of the addressee as his witness. In sentence (70) a girl was complaining to a member of the family that her mother had been shouting on her in public. The mother in sentence (71) defended herself using a conducive question by soliciting the support of the addressee who is not the aggrieved person. 
70.Amú má ótófé uzí na amú zugbó.

$\begin{array}{lll}\text { amú } \quad \text { má } & \text { o-tó-f'́ } & \text { u-zí } \\ \text { 1SG:IND mother } & \text { SM.SG-PTPROG-put.in } & \text { CM-noise } \\ \text { na amú } & \text { zugbó } & \\ \text { put 1SG:IND } & \text { head } & \\ \text { 'My mother was shouting on me.' } & \end{array}$

71. Mafé uzí na uzugbó?
ma-f̌́
u-zí
na u-zugbó
1SG-put.in CM-noise
give LOC-head
'Did I shout on her?'

In sentence (72), a child came home from school and complained that he had not had any meal the whole day. The mother, who had been working all day in the house, directed the question in (73) to him in the presence of his grandmother as follows:

72. Amú majkpe okpesiokpe.

$$
\begin{array}{lll}
\text { amú } \quad \text { ma-n-kpe } & \text { onkpesiokpe } \\
\text { 1SG:IND } 1 \text { SG-NEG-eat } & \text { nothing } \\
\text { 'I did not eat anything.' } &
\end{array}
$$

73. Amú makpe iva afá nú?
amú ma-kpe i-va
a-fá- nú
1SG.IND 1SG-eat CM-thing
CM-house-in

'Did I eat something in the house?'

\subsubsection{Greeting questions}

Questions function prominently in greetings. In the exchange of greetings, the interactants ask questions about the health not only of one another but also of the members of each others' family. Both polar and content questions are used in greetings. The sentences which are used as examples below are taken from greetings recorded in Alakpeti. Each of (74) and (75) is a polar question.

74. Adzí?

a-dzí

2SG-wake

'Are you awake?'

75. Afán aha ádzí?
a-fá-n
a-ha
á-dzí
CM-house-in CM-people SM.PLU-wake
'Did the people of the house wake up?' 
(76) is a content question used in greetings generally. (77) is also a content question but it is specifically used by well-wishers when they pay a visit to a sick person.

76. Mé afán aha ádzî tá ?
mé a-fá-n
a-ha
á-dzí
tá
Q CM-house-in CM-people SM.PLU-wake PART
'How are the people of the house?'

77. Mé iđú awú iyó nu?

$\begin{array}{lllll}\text { mé } & \text { i-dú } & \text { awú } & \text { i-yó } & \text { nu } \\ \mathrm{Q} & \text { 3SG-be } & \text { 2SG } & \text { CM-skin } & \text { containing.region }\end{array}$

'How do you feel in your body?' ie. How are you?

\subsubsection{Question word only questions}

Questions which are asked in informal situations are full of elision because the interactants have information that is known to them. Sometimes the whole clause may be left out leaving the question word alone. This type of question is used when one wants to know the actual person being talked about, a place, or the reason for which something is done. Consider the following examples:

$\begin{array}{cl}\text { 78. Omś } & \text { 'Who?' } \\ \text { Mókplé } & \text { 'What reason (why)?' } \\ \text { Ménu } & \text { 'Where?' }\end{array}$

\subsubsection{Questions for more specification}

Questions are also asked in conversation for confirmation of an aspect of a statement that a previous speaker has made. In the examples below, the speaker A, makes a point and the addressee $\mathbf{B}$ does not know what or which of the things he is referring to. He therefore asks about it for more specification to facilitate the identification of the entity that is being talked about.

79A uklontsi druyi

u-klontsi druyi

CM-book red

'red book'

80A: idzó nango a-mé

i-dzó nango a-mé

CM-yam big AM-Q

'those big yams'
79B uklontsi druyi omóa?

u-klontsi druyi o-mó-a

CM-book red AM-Q-FOC

'which red book?'

80B idzó nango amóa?

i-dzó nango a-mó-a

CM-yam big AM-Q-FOC

'which big yams?' 
81A: jgbé n-ta

y-gbé n-ta

CM-dog AM-three

'three dogs'
81B: y-gbé n-ta m-móa?

n-gbé n-ta m-mó-a

CM-dog AM-three AM-Q-FOC

'which three dogs?'

In these contexts, the modifier that occurs in the NP is presupposed knowledge to the interactants. So speaker A has to answer the question using other modifiers to make his point to be understood. For example, A can continue the conversation by adding the modifier koyklo 'old' to the NP as in (82A) below

82A: uklontsi kojklo druyi

$\begin{array}{ll}\text { u-klontsi koyklo } & \text { druyi } \\ \text { CM-book old } & \text { red } \\ \text { 'red old book' } & \end{array}$

From the discussions so far, it is evident that the question word can occur in situ and also at the initial position of the sentence. Declarative sentences can become questions when the pitch of the final syllable of the sentence is raised. Also, the non singular, that is the $\mathrm{N}$-class, $\mathrm{i}$-class and a-class nouns take plural agreement when quantity is expressed. 


\section{DEPENDENT CLAUSES}

In this chapter, I discuss clauses that are embedded in other structures or are adjoined to other clauses in complex sentences. These clauses are peripheral to other structures with which they form higher structures that makes them subordinate to the others which are referred to as main clause in the sentence. Because of the structures of these dependent clauses, they cannot make complete sense without being joined with a semantically related independent clause (Keenan 1985, and Dixon 2006). The first part is centred on relative clauses and it is followed by a section on complement clauses. The final part deals with various types of adverbial clauses.

\subsection{Relative clauses}

In this section, I introduce the structure of the relative clause and illustrate how it interacts with other modifiers of NPs. I then discuss the relativizability of different arguments and show how relative clauses are related to focus and questions.

\subsubsection{Structure of the relative clause}

A relative clause provides further modification about a nominal within an NP. Generally, a distinction is made between 'restrictive' and 'non-restrictive ${ }^{39}$ relative clauses. However, such a distinction is not universal. Logba for instance, does not make such a distinction. The relative clause is a postnominal clause introduced by a relativizer xé. This particle is used in the northern Ewe dialects surrounding Logba as relativizer and also as temporal and conditional introducer.

I refer to it as a relative particle instead of a relative pronoun because it is invariable in form (Keenan 1985, Payne 1997). Furthermore, an anaphoric pronoun, a nominal prefix is attached to the verb in the relative clause in case of subject relative clauses. A determiner occurs between the head noun and the relative particle.

The relative clause occurs after the noun it modifies; the same position in which adjectives and numerals occur in the sentence. In Logba, the head of the relative clause always precedes the relative clause. The relative particle xé follows the head noun and precedes the relative clause. In (1) xé follows the head noun, osa'á 'the man', and introduces the relative clause. The same can be said of (2) where the head is iyóyu é, a mass noun. However in (3), the head ebitws 'children' is followed by the modifier: ime 'this' (demonstrative) and pétée 'all', an intensifier, all these precede the relativizer xé.

\footnotetext{
${ }^{39}$ Other linguists use the term: defining and non-defining relative clauses Keenan and Comrie (1977).
} 
The position of the head in the subject relative clause is filled by an anaphoric pronoun. In (1) the agreeing pronoun is prefixed to $n \varepsilon$ 'buy' in (2) to nya 'stay' and in (3) du 'be'. However, in (4) the head ebitwo 'children is followed by the following modifiers ame 'these' demonstrative pétee 'all' intensifier. All these precede the relativizer xé.

1. Osa a xé óne imbi é ogá gú.

$\begin{array}{llll}\text { o-sa =a } & \text { xé [ó-ne } & \text { i-mbi=é ] } & \text { o-gá gú } \\ \text { CM-man=DET } & \text { RP SM.SG-buy } & \text { CM-rice=DET } & \text { 3SG-pay price } \\ \text { 'The man who bought the rice paid.' } & \end{array}$

2. Iyoyu é xé inya ibisé.
i-yoyu $=$ é
xé [i-nya ] i-bi-sé
CM-peace $=$ DET RP SM-stay 3SG-come-end

'The peace that prevailed came to an end.' [15.6.20]

3. iva á xé etemí be uwá idu ifiami
iva =á
xé [e-te-mí
be
u-wá]
i-du
i-fiami
thing $=$ DET RP 3PLU-HAB-take clear CM-forest 3SG-be CM-cutlass
'the thing they use to clear the forest is cutlass' [15.15. 04]

4. Ebitwo ame pétée xé malá suku idze edu akpanawo.
e-bit-wo
a-me
pétée xé ma-lá
suku i-dze
CM-child-PLU AM-this all
RP 1SG-beat school CM-today
e-du
a-kpana-wo
SM.PLU-be CM-logba-PLU
'All these children who I beat today in school are Logba citizens.'

From the illustrative sentences of relative clauses, it can be said that the consttruction of the relative clause in Logba consists of first the head noun, its modifiers and the relativizer, xé. This is then followed by the relative clause. The structure is represented below using the sentence Asa nango inú amé eba 'Those five big men came' in which the subject (head noun) asa 'men' is relativized below:

5. Asá nango ata amé xé éfezi ebá.

$\begin{array}{llllll}\text { a-sá } & \text { nango } & \text { ata a-mé } & \text { [ xé } & \text { e-fezi }] & \text { e-bá } \\ \text { CM-men big } & \text { five AM-those } & \text { REL } & \text { 3PLU-cry } & \text { 3PLU-com } \\ \text { Noun } & \text { ADJ } & \text { QNT DET } & \text { REL } & \text { PRO VERB } & \text { PRO VERB } \\ \text { HEAD } & \text { MODIFIERS } \rightarrow & \text { RELATIVE CLAUSE } \leftarrow \\ \text { 'Those three big men who cried came' } & & \end{array}$

The head noun is subject and the relativised NP is the subject of the relative clause. A pronoun prefix is marked on the verb in the relative clause. In (6), it is marked on ba 'come' and in (7) on bo 'stay' 
6. Ebiti é xé óbaa odu amu bí

$\begin{array}{lllll}\text { [e-biti=é } & \text { [xé } & \text { ó-ba-a ] } & \text { o-du } & \text { amu bí } \\ \text { CM-child=DET } & \text { RP } & \text { SM.SG-come-CFM } & \text { 3SG-be } & \text { 1SGPOSS child }\end{array}$

'The child who came was my child.'

7. Ekple ina $ว$ kpe $\mathrm{x} \varepsilon$ obo idienu $\varepsilon$ toto susu té ole kpe iva fie $\varepsilon$

\begin{tabular}{|c|c|c|c|}
\hline sple & i-na & o-kpe $[\mathrm{x} \varepsilon$ & $\mathrm{i}$-dienu $=\hat{\varepsilon}]$ \\
\hline & CM-person & CM-one RP 3SG-stay & CM-world = DET \\
\hline & & o-kpe & iva \\
\hline
\end{tabular}

'Now a single person in this world should not think that he is wiser than all.' [15.2.78-79]

\subsubsection{Object relativisation}

If the head is co-referential with the object in the relative clause, it is not expressed in the relative clause. A gap is left in the relative clause. The relative clause in (8) is xé ma-ne 'which I buy $\mathrm{x}$ '. The item that is bought, the object, is imbi 'rice'. It is however not expressed in the relative clause.

8. Imbi é xé mane ikanyi.

\begin{tabular}{|c|c|c|c|c|}
\hline$[\mathrm{i}-\mathrm{mbi}=$ é & [xé & ma-ne & $\varnothing]]$ & i-kanyi \\
\hline CM-rice $=$ DET & RP & 1SG-buy & $\varnothing$ & SM-burn \\
\hline
\end{tabular}

\subsubsection{Distribution of relative clauses}

An NP containing a relative clause can function as a topic phrase, Iva ime petee with the head as iva 'thing' as illustrated in (9)

9. Iva ime pétée xé madzi unyi me epétée inya uwa nango nango okpe nu.

[iva ime pété [xé ma-dzi u-nyi
thing this all RP 1SG-call CM-name here 3PLU-all
i-nya u-wa ne-pété
SM-stay CM-forest big big CM-one in
'All the things that I have mentioned here, they all
stayed in a big forest.' [15.3.18-19]

The relative clause can modify the post-verbal argument of the clause. The italized portions of the example sentences (10), (11) and (12) are the relative clauses. The NP modified is boldened in the first line of the examples. In sentence (12) the head of the relative clause is object of the relative clause. 
10. Ivagblawo olá ebitsi é xé ogbamá.
ivagblawo
o-lá
e-bitsi $=$ é
xé o-gbamá.

teacher AM-beat CM-child=DET RP SM.SG-be_late

'Teacher beat the child who was late.'

11. Akpana edú aha xé edo gu Egypte kpe Sudan ivanutsienu.

Akpana e-qú aha xé e-do gu

Akpana AM-be people RP SM.SG-come.out from

Egypte kpe Sudan ivanutsienu

Egypt CONJ Sudan area

'Akpana's are people who are from Egypt and Sudan.' [15.6.01]

12. Malá akló xé amú má ole.

ma-lá a-kló xé amú má o-lé

1SG-beat CM-goat RP 1SG motherSM.SG-buy

'I beat the goat which my mother bought.'

\subsubsection{Tense and aspect in relative clauses}

The same tense aspect distinctions that are found in main clauses are present in relative clauses. The example sentences with relative clauses below are in present progressive, past progressive, future and future progressive.

Present progressive:

13. Osa xé slótro idu odú ovunawo.

$\begin{array}{lll}\text { o-sa } & \text { xé } \quad \text { o-ló-tro } & \text { i-du } \\ \text { CM-man } & \text { RP } \quad \text { SM.SG-PRSPROG-carry } & \text { CM-gunpowder } \\ \text { o-dú } & \text { o-vunawo } & \\ \text { AM-be } & \text { CM-hunter }\end{array}$

'The man who is carrying the gunpowder is a hunter.'

Past progressive

14. Ubí xé otólé agli é odú oyúbitsi

$\begin{array}{lll}\text { u-bí } & \text { xé o-tó-lé } & \text { a-gli=é } \\ \text { CM-child } & \text { RP SM.SG-PTPROG-climb } & \text { CM-wall=DET } \\ \text { o-dú } & \text { o-yúbitsi } & \\ \text { AM-be } & \text { CM-thief } & \end{array}$

'The child who was climbing the wall is a thief.'

\section{Future}

15. Osa xé sbóba odú amu ovui.
o-sa xé
o-bó-ba
o-dú
amu
o-vui
CM-man RP SM.SG-FUT-come SM.SG-be
'The man who will come is my maternal uncle.'
1SGPOSS CM-uncle 
Future progressive

16. Inashina xé obólózó Agbo udantsi mé ánú ogbómiwo.

\begin{tabular}{|c|c|c|c|}
\hline inashina & xé & o-bó-ló-zó & \\
\hline Everyone & $\mathrm{RP}$ & SM.SG-FUT & -PRSPROG-go \\
\hline$-d$ & mé & á-yú & o-gbómi-wə \\
\hline M-morning & this & FUT-see & CM-monkey-F \\
\hline
\end{tabular}

'Everyone who will be going to Tafi this morning will see monkeys.'

Negative

For negative relative clauses, the negative marker occurs before the verb and the subject marker. The pronoun is fused with the vowel of the pre verb negative marker (See section 7.3.6). Sentences (17) and (18) are examples of negative relative clauses:

17. Ebitwo xé maablonu utrome á asá zó afán

$\begin{array}{lll}\text { e-bit-wo } & \text { xé ma-a-blo-nu } & \text { u-trome =á } \\ \text { CM-child-PLU } & \text { RP NEG-SM.PLU-make-NEG } & \text { CM-work=DET } \\ \text { a-sá } & \text { zó a-fán } & \\ \text { SM.PLU-leave } & \text { go CM-home } & \\ \text { 'The child who did not do the work went home.' }\end{array}$

18. Ivagblawo olá udze xé moófó nú memgba nu.

i-vagblawo o-lá u-dze
CM-teacher AM-beat $\mathrm{CM}$-girl
xé mo-ó-fó
RP NEG-SM.SG-wash NEG plate containing_region
'The teacher beat the girl who did not wash the plate.

\section{2}

Relativisation hierarchy in Logba

One of the concerns of most linguists working on relative clauses is the positions that can be relativized on the relativisability hierarchy (Keenan and Comrie 1979). This is aimed at making some cross linguistic generalizations about the positions relativised and the strategies that are employed.

Keenan and Comrie proposed the following positions:

\section{SUBJECT > DIRECT OBJECT > INDIRECT OBJECT > OBLIQUE > POSSESSOR}

Keenan and Comrie (1977) refer to the above as the Accessibility Hierachy. My investigation is based on the positions that are relevant in the Logba language. These are Subject, Goal object, Theme object, Objects of SVC, Locative objects, Prepositional phrases, and Nominal Possessive. A careful study of the relative 
clauses in my data suggests that all the positions can be relativised with either a gap or a marker strategy.

As already demonstrated, the subject and object positions within a relative clause can be relativised (see example 5 for subject and example 8 for object). Subject relativisation involves adding the relativising particle to the subject NP. The subject NP is cross referenced on the verb with an agreeing pronoun like any other clause. The object is relativised with a gap strategy.

In clauses that are three place constructions, for example, in the sentence: Kofi stá Howusu mango 'Kofi gave Howusu mango' both Howusu, the Goal and mango, the Theme can be relativised. The Goal may be relativised using a gap (19) while the Theme uses a marker strategy ie. A marker fills the position of the Theme argument in the relative clause (20)

\subsubsection{Goal}

19. Howusu xé Kofi otá $\varnothing$ mango
Howusu xé Kofi o-tá
$\varnothing \quad$ mango -
Howusu REL Kofi 3SG-give GAP mango
'Howusu whom Kofi gave the mango'

\subsubsection{Theme}

20. Mango xé Kofi otá Howusu é

$\begin{array}{lllll}\text { mango xé Kofi } & \text { o-tá } & \text { Howusu } & \text { é } \\ \text { Mango REL Kofi } & \text { SM.SG-give } & \text { Howusu } & \text { MARKER } \\ \text { 'Mango which Kofi gave to Howusu' } & & \end{array}$

\subsubsection{Objects in a serial verb construction}

Arguments in a Serial Verb Construction can also be relativised. The subject is relativised the same way as in a monoverbal construction. In a multiple object SVC such as Ubonukpiwo omi idzó tá udze 'The farmer gave the yam to the woman', the NP which is object to the 'verb of giving' is relativized with the marker -a in the position from which the NP is moved as shown in (22) while the object of the first verb is relativised using gap as in (21)

\subsubsection{Object of initial verb}

21. idzó á xé omí $\varnothing$ tá udzi ع́
i-dzó =á xé o-mí
$\varnothing \quad$ tá $\quad u-d z i=\varepsilon$
CM-yam $=$ DET REL SM.SG-take
GAP give $\mathrm{CM}$-woman $=\mathrm{DET}$

'The yam which he gave the woman' 


\subsubsection{Object of second verb in an SVC}

22. Udzi ع́ xé ubonukpiwo é omî idzó á táá
$\mathrm{u}-\mathrm{dzi}=\hat{\varepsilon}$
xé u-bonukpiwo =é
o-mí
$\mathrm{CM}$-woman $=\mathrm{DET} \quad \mathrm{RP} \quad \mathrm{CM}$-farmer $=\mathrm{DET} \quad$ SM.SG-take
i-dzó =á
tá-á
$\mathrm{CM}-\mathrm{yam}=\mathrm{DET}$ give MARKER
'The woman who the farmer gave the yam'

Locatives, and instrumental NPs in the sentence can also be relativized.

\subsubsection{Prepositional phrase with postpositions}

A postpositional phrase complement in a locative prepositional phrase can be relativised. A marker is left in its position after the locative preposition. Sentence (24) and (26) are relativised versions of (23) and (25).

23. Kofi omi kəpu é na ukplo á tsú.
Kofi o-mi
$\mathrm{kopu}=$ é
na $\mathrm{u}-\mathrm{kpl}$ ๖=á
tsú
Kofi AM-take cup $=$ DET on CM-table $=$ DET upper.surface

'Kofi put the cup on the table.'

24.ukplo tsú xé Kofi omi kəpu é naá

u-kplo tsú xé Kofi o-mi kopu=é na-á

CM-table on RP Kofi AM-take cup =DET on-MARKER

'the table on which Kofi put the cup'

25. Abá oyubitsi é fé utsá-á nu.
a-bá
o-yubitsi $=\hat{\varepsilon}$
fé u-tsá=á
$\mathrm{nu}$
3PLU-kill $\quad \mathrm{CM}$-thief $=\mathrm{DET}$ at $\mathrm{CM}$-house $=\mathrm{DET}$ containing.region

'They killed the thief in the house.'

26. utsá nu xé ábá oyubitsi ع́ féc
u-tsá
nu xé á-bá
o-yubitsi $=\varepsilon \quad f^{\prime} \varepsilon-\varepsilon[$ fie $]$
CM-house in RP 3PLU-kill
CM-thief $=$ DET at-MARKER
'the house in which the thief was killed'

Note that the preposition remains in its position and hosts the marker.

\subsubsection{Prepositional phrases}

The complement of the preposition kpe 'with' can be instrument and can be relativised using a marker strategy; kpe stays in its position as shown in (28). This explains why example sentence (29) is ungrammatical. 
27. Ama óglé uzugbo kpe afuta.

Ama ó-glé u-zugbo kpe a-futa

Ama SM.SG-tie CM-head PREP CM-cloth

'Ama tied the head with cloth.'

28. afúta xé Ama óglé ozugbo kpé́

a-fúta xé Ama ó-glé $\quad$ o-zugbo kpe-é [kpie]

CM-cloth RP Ama SM.SG-tie CM-head PREP-MARKER

'the cloth which Ama tied the head with'

29. * afúta kpe xé Ama óglé ozugbo ofui

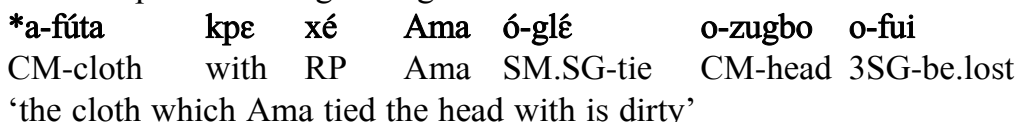

\subsubsection{Possessive}

When possessives are relativised the possessor is followed by the possessed noun and the relative particle. The possessed noun can either be a full NP otu 'gun' as in (30) or a nominal compound abueklonti 'animal-skin' as in (31). The possessed noun is relativised using a marker strategy as in (30) and (31).

30. Ivanuvo otu é xé ovuvoá sbá.

i-vanuvo o-tu=é xé o-vuvo-á o-bá

CM-hunter CM-gun=DET RP SM.SG-spoil-MARKER 3SG-come

'The hunter whose gun is spoilt came.'

31. ubonukpiwo abueklonti é xé mayúé osá.

u-bonukpiwo a-bueklonti=é xé ma-yú-é o-sá

CM-farmer CM-animal.skin=DET RP 1SG-see MARKER 3SG-left

'The farmer whose animal skin I saw left.'

The marker is an invariant form which takes the position of a constituent that is moved. It displays the same phonological pattern to the definiteness morpheme (see section 2.3.3.1). In section 9.2.2 (in example 20), when the Theme is relativised, the marker in its position is -é. When the constituent is plural, the marker does not change in form. It remains an -é. This is shown in example (32) below.

32. Mangowo xé Kofi otá Howusu é apró.

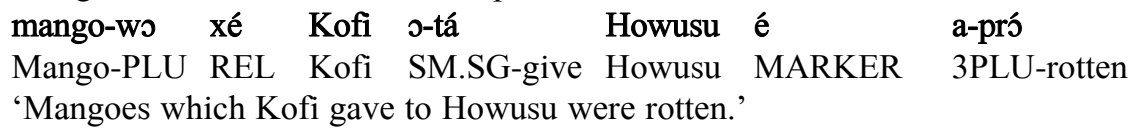


In the relativisation of the prepositional complement, afúta 'cloth' (section 9.2.5 in example 28) the marker -é takes the position of afúta 'cloth'. Even when the relativised constituent is plural, the marker does not change in form. It remains an -é. as shown in (33) below.

33. Nfúta xé Ama óglé ozugbo kpé́ nfui
N-fúta xé Ama ó-glé
o-zugbo kpe-é [kpic] n-fui
CM-cloth RP Ama SM.SG-tie CM-head PREP-MARKER3PLU-lost
'The clothes which Ama tied the head with are lost'

The marker does not function as a clause boundary marker because in clauses where other constituents follow the position of the relativised constituent, the marker retains that position. In (34), the NP Udobe smóa 'that afternoon' follows the position of the relativised constituent that is taken by the marker -é.

34. Nfúta xé Ama óglé ozugbo kpeć udobe oməa nfui.
N-fúta xé
Ama ó-glé
o-zugbo
CM-cloth RP
Ama SM.SG-tie
CM-head

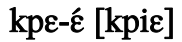
u-dobe
o-moa n-fui
PREP-MARKER CM-afternoon AM-that 3PLU-lost
'The clothes which Ama tied the head with that afternoon are lost.'

The determiner and the invariant marker has allomorphs and are phonologically conditioned (see section 2.3.3).

Positions relativised are summarised in the table below. The $\mathbf{M}$ refers to marker and - indicates a gap.

Table 9.1: Summary of relativisation hierarchy in Logba

\begin{tabular}{|l|l|l|l|l|l|l|l|l|l|}
\hline POSITION & SUBJ & OBJ & GOAL & THEME & OBJ $V_{1}$ & OBJ $V_{2}$ & LOC & PREP & POSS \\
\hline STRATEGY & - & - & - & $\mathrm{M}$ & - & $\mathrm{M}$ & $\mathrm{M}$ & $\mathrm{M}$ & $\mathrm{M}$ \\
\hline
\end{tabular}

From the discussion of topic and focus in chapter twelve it will be evident that the strategies used for relativisation is similar to the strategies used for focusing and content questions.

\subsection{Complement clauses}

A complement clause is a dependent clause which is an argument of a predicate. According to Noonan (1985:42) 'it is a syntactic situation that arises when a notional sentence or predication is an argument of a predicate.' Dixon (2006) argues 
that for all languages there is a restricted set of verbs, $(\mathrm{R})^{40}$ which occupies the main clause and another verb from an unrestricted set (U) which is the predicate of a matrix clause verb (R). He however adds that a semantic compatibility must exist between $(\mathrm{R})$ and $(\mathrm{U})$.

In Logba, a complement clause is introduced by an obligatory particle té. This particle occurs after a set of verbs (R). These verbs are restricted in number and occur in a complex sentence. Some of the verbs in the restricted set (R) are in (35)

$\begin{array}{llll}\text { 35. wa } & \text { 'tell' } & \text { yú } & \text { 'see' } \\ \text { ta } & \text { 'say' } & \text { dzi } & \text { 'call' } \\ \text { gbla } & \text { 'show' } & \text { dze } & \text { 'look' } \\ \text { kpe } & \text { 'know' } & \text { vó } & \text { 'fear' } \\ \text { kanyí } & \text { 'realise' } & & \end{array}$

The complement clause contains one of the unrestricted set of verbs (U) and it is an argument of the matrix sentence. In (36), té óbóbá 'that he/she will come' and in (37) té nfúc ndzi bá agu 'that the oil will come to the top' are complement clauses and are objects of the verb wa 'tell' and yú 'see' respectively.

\section{Kofi owá té óbóbá}
Kofi o-wá
té
ó-bó-bá
Kofi SM.SG-tell COMPL SM.SG-FUT-come
'Kofi said that he will come'

\section{7. abóyú te nfú é ndzí bá agu.}

$\begin{array}{lllll}\text { á-bó-nú } \quad \text { te } & \text { n-fú=é } & \text { n-dzí } & \text { bá } & \text { agu } \\ \text { 2SG-FUT-see COMPL } & \text { CM-oil=DET } & \text { AM-stand } & \text { come } & \text { top } \\ \text { 'you will see that the oil comes up' } & & & \end{array}$

Complement clauses can also occur as the second object to the verb. In these examples the first object is the addressee and the second object, the complement clause represents the context of what is said. When this happens the first object precedes the complementizer t $\varepsilon^{\varepsilon}$. This object may be a noun phrase or a pronoun. In sentence (38), the first object is a full noun phrase, agbé 'dog' followed by the second object, which is the complement clause. In sentence (39), the 1SG object pronoun, $-\mathrm{m}$ is the first object. This is followed by the complement clause which is the second object.

38. Jlowá agbe té ogakrana.
o-lo-wá
a-gbe té o-gakrana
3SG-PRSPROG tell CM-dog COMPL SM.SG-keep.quiet
'He is telling the dog that it should keep quiet.'

\footnotetext{
${ }^{40}$ These are also known as Complement taking predicates.
} 
39. owám té xé mabá suku me...

\begin{tabular}{|c|c|c|c|c|}
\hline o-wá-m & té & xé & ma-bá & suku \\
\hline 3SG-tell-1SGOBJ & COMPL & COND & 1SG-come & school \\
\hline
\end{tabular}

One of the verbs from the set R, tá which translates as 'say' and the complementizer are used in giving reports of what has been said by a third person. This strategy is used in relating not only indirect speech but it is also found in gnomic expressions which are attributed to personified animals in folk stories in Logba. The complementizer can be the only predicating element in a quote frame. The complement taking verb, tá is sometimes omitted in connected discourse. What is omitted will not affect the information the speaker wants to bring to the notice of the addressee. The complement taking verb ta must however be present when the speaker wants to be emphatic.

In (40) and (41), the complement taking verb tá can be omitted.

40. Antenyi (tá) té mkponyi moma olé fé otokpe afágbá.

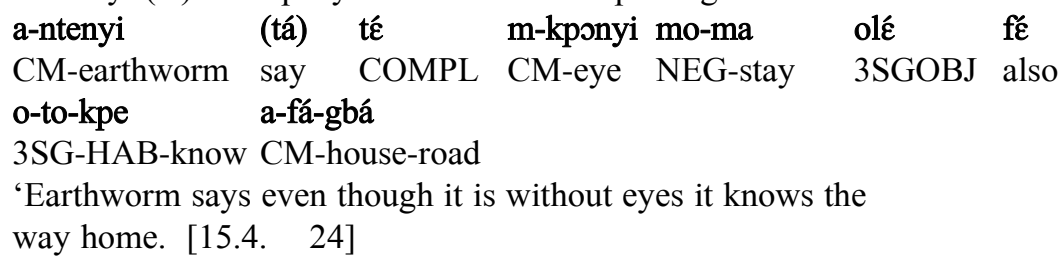

41. Anko (tá) té ólókpo atsa nu f'é ale vie okpo nyui

\begin{tabular}{|c|c|c|c|}
\hline (tá ) & té & ว-ló-kpo & $\mathrm{nu} \mathrm{f}^{\prime}$ \\
\hline say & COMPL & SM.SG-PRSPROG-lie & CM-coop in also \\
\hline T & o-kp & nyui & \\
\hline G tail & SM.SG-lie & outside & \\
\hline
\end{tabular}

'Hen says that it is lying in the coop but its tail lies outside' [15.4.28]

The complementizer can be used to introduce a complement clause which is a polar question. The question in (42) is in every respect like an independent polar question.

42. Agbé ójú nwó utsá ye odze té ojú akpakpla á anáa?

$\begin{array}{lllll}\text { a-gbé } & \text { ó-nú } & \text { n-wó u-tsá } & \text { ye } & \text { o-dze } \\ \text { CM-dog } & \text { SM.SG-see CM-bee CM-house } & \text { CONJ } & \text { 3SG-look } \\ \text { té } & \text { ó-nú } \quad \text { a-kpakpla=á anáa? } & & \\ \text { COMPL } & \text { 3SG-see CM-frog=DET QP } & & \\ \text { 'Dog sees the bee hive and look whether it sees the frog?' }\end{array}$


The complement taking verb can be modified with an adverbial. In (43) inta 'very' shows the intensity of fear using vó 'fear'. In (44) kanyi 'realise' is used as a complement taking verb but in (45) it is used to modify yú 'see' and is an expression of a stronger form of realisation and holding on to a belief.

43. วvó inta te olenta.
o-vó inta te
o-lenta.
3SG-fear very COMPL 3SG-fall
'It was so afraid that it fell.'

44. Kwesi okanyi té Hesse obo Klikpo.
Kwesi
o-kanyi
té
Hesse o-bo
Klikpo
Kwesi SM.SG-realise COMPL Hesse SM.SG-stay Klikpo
'Kwesi realised that Hesse lives in Klikpo.'

45. aðú kanyi té abe midu iva vuvogo kuraa

a-yú kanyi té $\quad$ a-be $\quad$ mi-du
2SG-see realise COMPL CM-palm.oil NEG-be
iva vuvogo kuraa
thing waste at.all
'you realise that palm has no waste at all' [15.11.66-67]

A complement clause can be followed by another complement clause in a discourse. In (46) The complement clause té mbu 'that I ask' is followed immediately by another complement clause. The second complement clause contains an embedded conditional clause xé unansanango afida okunkpe 'if paramount chief (you) meet somewhere' and a main clause which is a content question ogbsta omoá oble utrome áblo? 'which town's (own) will you use?' If a complement clause contains a complement taking predicate it can itself be followed by another complement clause satisfying the argument requirements of the verb.

46. mayayi té mbu té xé unansanango afida okunkpe ogbota omoá oble utrome abló?

$\begin{array}{llcll}\text { ma-yayi } & \text { té } & \text { m-bu té } & \text { xé } & \text { unansa-nango } \\ \text { 1SG-want } & \text { COMPL } & \text { 1SG-ask COMPL } & \text { COND } & \text { chief.big } \\ \text { a-fida } & \text { o-kunkpe } & \text { o-gbota } & \text { o-moá } & \text { o-ble } \\ \text { 2SG-meet } & \text { CM-somewhere } & \text { CM-town } & \text { AM-Q } & \text { 3SG-own } \\ \text { u-trome } & \text { a-bló } & & & \\ \text { CM-work } & \text { 2SG-make } & & & \end{array}$

'I want to ask that if the Paramount Chiefs meet somewhere which town's own will you use?'

A complement clause can also contain an embedded relative clause as shown in (47). The first one is xé Hesse obue 'which Hesse asked' and the second one is. xé unansanango otso naa 'which the paramount chief uses' The second relative clause has a main clause which is a polar question. This is exemplified below: 


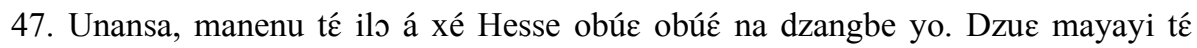
mbú katawəe xé unansanango otsə naa onango gu anukpa ogagoe ible yo?

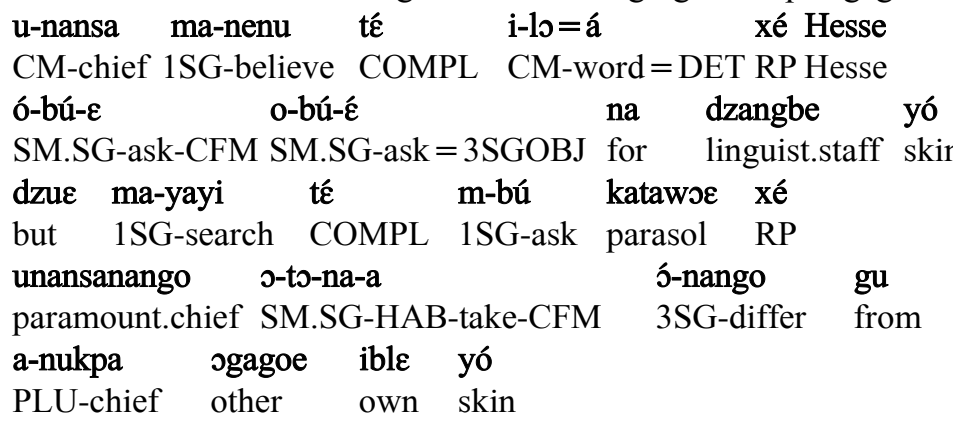

'Chief, I believe that what Hesse asked he asked about the linguist staff. But I want to find out about the parasol which the Paramount chief uses; is it different from that of the other chiefs?' [15.7.15]

An adverbial clause is a subordinate clause which modifies the verb phrase or the entire clause. In reality, an adverbial clause is not a core argument of the main clause but it is in an adjunctive relation with the main clause. Because of this, an adverbial clause can be 'plucked' from the rest of the construction without necessarily affecting the core semantic import of the sentence. Adverbial clauses, however, contribute to the information that the main clause gives by providing answers to questions relating to the time, place, reason, and the manner that the event(s) described in the main clause occur(s).

\subsubsection{Conditional clauses}

A conditional clause is a subordinate clause which expresses the condition for the situation expressed in the main clause to be realised. In Logba, this clause can either precede the main clause or come after it. When it precedes the main clause, it ends with a clause final marker which is a mid vowel $-\mathbf{e} /-\varepsilon, 0-/-0$ suffixed to the final word. This vowel agrees in [ \pm ATR] value with the final vowel of the clause. The conditional clause is introduced by the particle xé. This particle and the relative particle, xé are similar in form. There is a difference in the syntactic position that each of them occurs. xé erl $_{\text {rel }}$ occurs postnominally. Since xé end $_{\text {con }}$ does not modify a noun, it occurs at clause initial position.

In sentences (48), (49), (50) and (51) xé introduces the conditional clause. 
48. Xé ina inys ékeé, ina inys édzeé.
xé
i-na
i-nyo
é-ke-é
COND CM-person AM-two
SM.PLU-set.trap-CFM
i-na
i-nyo é-dze $=$ é
CM-person AM-two SM.PLU-see=3SGOBJ

'If two people set trap, two people watch it.' [15.4.44]

49. Xé mazóó, maánué.
xé
ma-zó-ó,
má-á-nu-é
COND 1SG-go-CFM 1SG-FUT-see = 3SGOBJ

'If I go, I will see him/her.'

50. Xé anú awú dankame zugbó odzogbee tá dzú awoble fé uwa.
xé
a-yú
awú dankame zugbo o-dzogbe-e
COND 2SG-see 2SG friend head CM-grassland-CFM
tá dzú awoble fé u-wa
give return your.own put CM-forest
'If you see your friend's skull in the grassland, take yours into
the forest.'[15.4.23]

51. Xé até adu ina kpewòe metedzi iva.
xé
a-té
á-qu
i-na-kpe-wo-e
COND 3PLU-COMPL 2SG-be CM-person-eat-owner-CFM
me-te-dzi i-va
NEG-HAB-call CM-thing
'If they say you are person eater, you don't swear.' [15.4.72]

In sentences (52) and (53) the conditional clause follows the main clause because of that there is no clause final marker.

52. Esi otedze iva xé ifedzolego ifó iyé tsú.

$\begin{array}{lcll}\text { Esi o-tedze i-va xé } & \text { i-fedzolego } \\ \text { Esi } & \text { SM.SG-learn CM-thing COND } & \text { CM-examination } \\ \text { i-fó } & \text { iý́ tsú } & \\ \text { SM-reach } & \text { 3SG on }\end{array}$

'Esi learns when examination is close.'

53. Kofi óbózó avablome xé odze odu.
Kofi ó-bó-zó
a-vablome xé
o-dze
o-du
Kofi SM.SG-FUT-go CM-hospital COND
SM.SG-see CM-sickness
'Kofi will go to hospital if he falls sick.'

Most aphorisms and proverbs are said in complex sentences which have the subordinate clause as a conditional clause. Sentences (46) and (47) are examples of these proverbs. Another feature of some of these proverbs is that they have conditional 
clause in the negative. The negative marker occurs before the agreement marker which comes after the verb. Below are examples:

54. Xé ámo kpe tenyie ta kpe kla.
xé á-m-o-kpe
tenyi-e
ta kpe kla
COND 2SG-NEG-AM-know escape-CFM let know hide
'If you don't know how to escape, you must know hiding.'

55. Xé idi mi mu nue idi miíwa.
xé
i-di
m-i-mu-nu-e
COND CM-atmosphere NEG-SM-dark-NEG-CFM
i-di mi-í-wa
CM-atmosphere NEG-SM-open
'If the atmosphere is not dark, it will not be bright.'

\subsubsection{Time clauses}

Adverbial clauses of time provide information on how the information about the temporal order in which the actions described in a sentence occur. The actions can occur at the same time or follow the one described in the main clause. The time expression, ibenu 'in the time' is used to describe a general time relation. The time expression occurs on the initial subordinate clauses as in (56) and (57). It is a topic scene setting or background information marking particle. Sentence (58) is a complex structure involving not only the time clause, ibenu xé onu té idzo ś izue 'when he sees that the yam is matured' but also there is another embedded subordinate clause which is a complement clause: té idzo ó izue 'that the yam is mature'

56. ibenu mazós malé uklontsi inys
ibe-nu ma-zó-o ma-lé u-klontsi myo
time-in 1SG-go-CFM 1SG-buy CM-book two
'When I went, I bought two books'

57. Malé uklontsi inyo ibenu mazó.

$\begin{array}{lll}\text { ma-lé } & \text { u-klontsi inyo ibe-nu ma-zó } \\ \text { 1SG-buy } & \text { CM-book two time-in } & \text { 1SG-go } \\ \text { 'I bought two books when I went.' } & \end{array}$

58. ibenu xé onú té idzó ó izue, oglui é.
'When he sees that the yam is matured, he uproots it.' 
However, when time relation is to be expressed to show that the event in the time clause occurs prior in time to the main clause xexé 'before' is used. This is illustrated in (59). The time expression, du ité tá 'be in front of' takes a nominalised complement and is also used in some constructions to express a similar meaning. (60) is an example. Each of these can occur either initially or after the main clause.

59. Xexé ófó afánue, utsi é okú xóxó.

\begin{tabular}{|c|c|c|c|}
\hline xexé & ó-fó & a-fá-nu-e & u-tsi =é \\
\hline Before & 3SG-reach & CM-house-in-CFM & CM-father $=\mathrm{DET}$ \\
\hline o-kú & xóxó & & \\
\hline SM.SG & already & & \\
\hline
\end{tabular}

60. Đu ité tá afánu fogoe, utsi ć ókú xoxo.

\begin{tabular}{llll} 
du ité & tá & a-fá-nu & fo-go-e \\
Be front & give & CM-house-in reach-NOM-CFM \\
u-tsi=ć & \multicolumn{1}{c}{ o-kú } & xoxo \\
CM-father=DET & SM.SG-die & already \\
'Before his reaching the house, the father had died already.'
\end{tabular}

For time relations that involve a terminal point for an event that is durative, the expression bisú ibi- $\varepsilon-n u$ 'till the time' is used. This expression occurs in between the main clause and the subordinate clause. The agentive noun phrase position is filled for both the main clause and the subordinate clause. (61) illustrates this:

61. Ablo utrome bisú ibi é nu xé áfiali.

$\begin{array}{llll}\text { a-blo } \quad \text { u-trome bisú } \quad \text { ibi=毛 nu xé } & \text { á-fiali } \\ \text { 3PLU-make } & \text { CM-work till time=DET in RP } & \text { 3PLU-sweat } \\ \text { 'They worked till the time that they sweated.' } & \end{array}$

\subsubsection{Reason clauses}

Adverbial clauses of reason offer explanation for the event that is expressed in the main clause. They are connected to the main clause using one of these expressions, iboté 'because' okple 'for that reason.' When each of these phrases is used, the clause it introduces cannot be preposed because the discourse anaphoric element has been said already. It is for this reason that the example sentence (63) and (65) are considered ungrammatical.

62. ebîtsi é molónú akpakpla á okple ókebu etsi

$$
\begin{array}{lll}
\text { ebitsi }=\text { é } & \text { mo-ló-yú } & \text { akpakpla=á } \\
\text { child=DET } & \text { NEG-PRSPROG-see } & \text { frog=DET }
\end{array}
$$


okple ó-kebu etsi

REAS 3SG-jump down

'the child is not seeing the frog for that reason he jumped down'[15.1.11]

63.* okple okebu etsi ebîtsi é molóyú akpakpla á

*okple o-kebu etsi ebîtsi=é mo-ló-nú

REAS3SG-jump down child=DET NEG-PRSPROG-see

a-kpakpla =á

CM-frog $=$ DET

*`Because he jumped down the child is not seeing the frog' [15.1.11]

64.safi эme ole эyó ome yó iboté Akpana tsiami əyó ógugo

safi o-me o-le o-yó o-me yó iboté Akpana

Key AM-this AM-be CM-stick AM-this skin because Akpana

tsiami o-yó o-gugo

linguist CM-stick SM.SG-different

'this key is on this stick because the linguist of Logba is different' [15.7.07]

65. *Iboté Akpana tsiami эyó ogugo safi ome ole эyó эme yó

\begin{tabular}{|c|c|c|c|c|c|c|}
\hline iboté & Akpana & tsiami & 0-yó & o-gugo & Safi & o-m $\varepsilon$ \\
\hline because & Akpana & linguist & CM-stick & AM-different & Key & AM-this \\
\hline & ग-yó & o-me & yó & & & \\
\hline M-be & CM-stick & AM-this & skin & & & \\
\hline
\end{tabular}

One point which is worth commenting on is the function of these clauses in the sentences as cohesive devices. Structurally, most of them can be pre-posed and post-posed, except iboté 'because' okple 'for that reason' which has a restricted occurrence; they can only come after the main clause. It is also noted that a careful use of these clauses enhances the overall organisation of the texts providing links and boundaries of the events described in the texts. The way these clauses pattern in the sentences in one way or the other contributes largely to the understanding of the texts. 



\section{SERIAL VERB CONSTRUCTIONS}

This chapter discusses Serial Verb Constructions (SVCs) in Logba. It is organised as follows: After the introduction on the main features of Serial Verb Constructions (hereafter SVCs), the discussion moves on to show the different types and the syntactic and semantic properties that make SVCs stand out from other constructions.

\section{1}

\section{Serial verb constructions}

SVCs are one of the linguistic structures that have been described and analysed in most West African languages. Despite the fact that there is similarity in SVCs, there appears to be some differences. In one of the first works on the subject, Westermann (1930:126) points out the main linguistic features of SVCs in an Ewe SVC which is apparently representative of what happens in many other languages:

....all the verbs stand next to each other without being connected, ... all have the same tense or mood, and ... in the event of their having a common subject and object, these stand with the first, the others remaining bare:...

The main difference between SVCs in Logba and Ewe is that in Logba the subject is cross referenced on $\mathrm{V}_{1}$ as a prefix. I will at this stage offer a definition of SVC in Logba. SVC is a construction in which two or more verbs which are without an overt conjunction share subject, object, aspect and tense markers.

Many scholars have expressed their views on SVCs pointing out the different types and the cross linguistic variation that they exhibit. Notable among them are Lord (1993) for West African Languages, Agbedor (1994) for Ewe, Carlson (1994) for Supyire, Bodomo (2002) for Dagaare, Lefebre and Brousseau (2002) for Fongbe, Osam (2005) for Akan and Ameka (2006) for Ewe.

\subsection{General characteristics of SVCs}

The following are the general characteristics of SVCs in Logba:

a. The verbs are not linked overtly by coordination or subordination.

b. The subject is expressed once on $\mathrm{V}_{1}$.

c. Where the object is shared, it is expressed once with $\mathrm{V}_{1}$

d. The VP's share the same TAM expressed with $V_{1}$

e. Negation is expressed with $\mathrm{V}_{1}$, using a bipartite morpheme.

f. Any term constituent in an SVC can be focused. 
g. The bare form of $V_{1}$ is placed before the initial VP when the predicate is focused.

Logba is an active noun class language and the nouns are prefixed with class markers. If the subject of an SVC is realised as NP, it is cross referenced on $\mathrm{V}_{1}$ as a pronominal affix. Subsequent verbs are not marked with any pronominal prefix. The examples below are taken from two popular Ananse stories ${ }^{41}$. In (1), the verbs, mi 'take' ka 'put.down' are used in an SVC to express the idea in the clause. The subject NP adzi é 'the bird' is cross referenced with a vowel prefix on $\mathrm{V}_{1}$ mi 'take' In (2), three verbs dze 'need' da 'tell' wa 'say' are used. There is only one subject pronoun [o] and it is realised on $\mathrm{V}_{1}$. In (3), three verbs: ba 'come' mi 'take' ko 'hang' are used and the subject pronoun [o ] is prefixed on $\mathrm{V}_{1}$ as well.

1. adzi é ómi ka,

$$
\begin{aligned}
& \text { a-dzi=é } \quad \text { ó-mi } \quad \text { ka, } \\
& \text { CM-bird=DET } \\
& \text { 3SG-take put.down } \\
& \text { 'the bird puts it down,' [15.3.42] }
\end{aligned}
$$

2. me ólódze dá wá adzi $\varepsilon$...

$\begin{array}{llll}\text { me } & \text { ó-ló-dze dá } & \text { wá } & \text { a-dzi=₹́ } \\ \text { Q } & \text { 3SG-PSPROG-need tell } & \text { say } & \text { CM-bird=DET } \\ \text { 'why does he need to tell bird...?' } & {[15.3 .36]}\end{array}$

3. ibote to óbo (ba) mi (l)é ko agu oyó nu

$\begin{array}{lllll}\text { ibote } & \text { to } & \text { ó-ba } & \text { mi }=\hat{\varepsilon} & \text { ko } \\ \text { because } & \text { should } & \text { 3SG-come } & \text { take=3SGOBJ hang } \\ \text { a-gu } & \text { o-yó } & \text { nu } & \\ \text { CM-top } & \text { CM-tree } & \text { in } \\ \text { '... because he has to take it and hang it in a tree at the top' } & \text { [15.2.36] }\end{array}$

I will now have a closer look at the charasteristics of SVCs in Logba in the order in which it is presented in 10.2.

\subsubsection{No overt connectors}

SVCs are not linked overtly by any conjunction. If a conjunction is placed in between the verbs, the constructions will cease to be SVCs. The non-initial verb would then have the subject pronoun cross referenced on it as shown in (4).

\footnotetext{
${ }^{41}$ Ananse stories are popular stories in Logba and the surrounding Ewe and Akan speaking communities. In these stories, Ananse 'spider' is the hero. The name, Ananse is based on the name for spider in the Akan language.
} 
4. adzi é ómi ye oka,
adzi =é ó $\quad$-mi ye o-ka,
bird=DET SM.SG-take CONJ 3SG-put.down
'The bird puts it down,'

In an SVC, the states of affairs of the VPs are perceived as occurring in the same temporal frame. Sentence (5) below is an SVC with $\mathrm{V}_{1}$ as huite 'run' and $\mathrm{V}_{2}$ as bá 'come'; the two verbs denote one action.

5. Selorm óhuite bá afán.
Selormó-huite
bá a-fán
Selorm SM.SG-run come CM-house
'Selorm run home.'

In the sentence (6) below, a conjunction is used to join $V_{1}$ huite 'run' and $V_{2}$. ba 'come'. The verbs in the sentence are considered as actions performed separately. Indeed, it gives the impression that the man engaged in a race and after that he came home.

6. Selorm ohuite ye obá afán

$\begin{array}{lll}\text { Selormo-huite } & \text { ye o-bá } & \text { a-fán } \\ \text { Selorm SM.SG-run CONJ } & \text { 3SG-come } & \text { CM-house } \\ \text { 'Selorm run and came home' } & \end{array}$

In one of the SVCs recorded four verbs are used; the sentence describes a single event with actions expressed by the verbs internal to it.

7. Ebitsi é ohu bi vé lé utu nango okpié tsú.

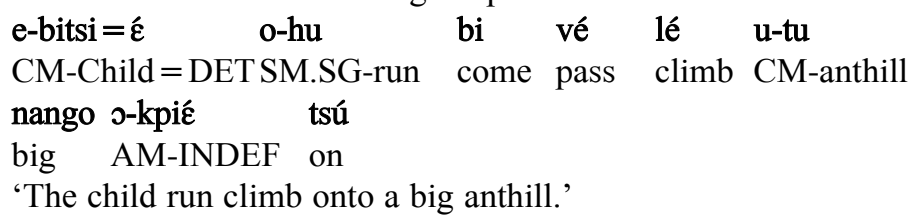

The actions hu 'run' shows movement, bi 'come' indicates the direction ve 'pass' refers to the direction of movement to the landmark. This is followed by lé 'climb'. It is noted that vé 'pass' complements the action expressed when verbs denoting movement are used in an SVC. For example, sentence (6) below was an answer given on one ocassion when I was looking for one of my consultants who works in the local primary school. It contains an SVC using the following verbs bí 'come' vé 'pass' zó 'go'. The speaker implies the man has gone to the master's house. 
8. Anto óbi vé zó master afán.
Anto ว-bi
vé
zó master
a-fá-n
Anto SM.SG-come pass
go master CM-house-in

'Ants has passed to master's house.'

\subsubsection{Subject marking}

SVC is a simple clause. The subject NP is cross referenced on $V_{1}$. If the subject is a pronoun, then it is expressed on $\mathrm{V}_{1}$. Subsequent verbs are not marked with any pronominal prefix. If the full NPs in $(9-11)$ above are deleted the anaphoric pronoun will be on kpo 'hide' in (9) and teni 'escape' in (10). (12) is ungrammatical because the anaphoric pronoun is marked on both $V_{1}$ and $V_{2}$. In (13) the anaphoric pronoun is marked on only $\mathrm{V}_{2}$ which is also unacceptable.

9. Ebitsi ع́ ókpo kla fé oyó nango okpić etsi.

\begin{tabular}{|c|c|c|c|c|}
\hline e-bitsi $=\varepsilon$ & ó & ว-kpo & kla $\quad f \varepsilon$ & 0-ý́ \\
\hline CM-Child & $\mathrm{l}=\mathrm{DET}$ & SM.SG-move & hide into & CM-tree \\
\hline & o-kpié & etsi & & \\
\hline & AM-INDEF & F under & & \\
\hline
\end{tabular}

10. Kofi óteni zó ogbá yó.
Kofi ó-teni
zó o-gbá yó
Kofi SM.SG-escape go CM-road skin

'Kofi run to the road side.'

11. Ogridi óbo dze asaygbla tsú.
o-gridi ó-bo
dze a-sangbla tsú
CM-story SM.SG-come land CM-tortoise on

'The story falls on tortoise.' [15.3.09]

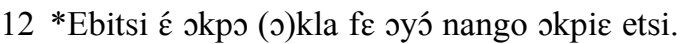
*Ebitsi $=\varepsilon \quad$ é-kpo
o-kla
fย o-yó
Child = DET SM.SG-move
SM.SG-hide into
CM-tree
nango o-kpi-ćc etsi

big AM-DEF under

'The child went and hid under a big tree.'

$13 *$ Ogridi bo odze asangbla tsú
*o-gridi bo o-dze
a-sangbla tsú
CM-story come SM.SG-land CM-tortoise on
*'The story takes off and falls on tortoise' 
It is interesting to note that there are other languages which have the non initial verbs marked with a subject pronominal vowel prefix. One language which is reported to have this feature is Likpe, one of the GTM languages in the NA group.

14 .Ufi ofiamó oklé lísi

$\begin{array}{llll}\text { u-fi } & \text { o-fiamó } & \text { o-klé } & \text { lí-si } \\ \text { 3SG-take } & \text { CM-handkerchief } & \text { 3SG-tie } & \text { CM-head }\end{array}$

'She has used a handkerchief to wrap around her head' Ameka (2005:8)

\subsubsection{Object realisation}

Another important feature of SVCs is that the direct object of the initial verb may be an Instrument of the second verb in the series. In sentence (15), the object of $\mathrm{V}_{1}$ kampe 'scissors' is an instrument for carrying out the action expressed in $V_{2}$ tso 'cut'. In (16), the object of the initial verb uhe 'knife' is used to perform the action of cutting the paper.

15. Omi kampe tso kodiatsya nu

ó-mi kampe tso kodiatsya nu
3SG-take scissors cut banana in
'He took scissors and cut banana' $[\mathrm{CBP}]$

16. Osá á ómi uhe ri pepa...
o-sá=á
ó-mi
$\mathrm{u}-\mathrm{h} \varepsilon$
ri pepa
CM-man =DET SM.SG-take CM-knife hold paper
'The man holds a paper with a knife' [CBP]

Where the verbs share the object, it (the object) is expressed only once with the initial verb. In sentence (17), iva 'thing' is the object of both the initial verb zá 'cook' and the second verb in the series kpe 'eat'. In (18), kop 'cup' is the object of mi 'take' and ri 'hold'. In (19), the two verbs in the series have the same object iva 'thing'. nta 'hand' which occurs immediately after the second verb.

17. Afadze ózá iva kpe
a-fadze
o-zá
iva $\mathrm{kp \varepsilon}$
CM-woman SM.SG-cook
thing eat

'The woman cooked food and ate.'

18. Psá á ómi kəp ri yé óló no nđú
o-sá=á
ó-mi
kəp ri ye
CM-man=DET SM.SG-take cup hold CONJ
ó-ló-no
n-dú
SM.SG-PRSPROG-drink CM-water
'The man holds a cup and is drinking water' CBP 
19. Ómi iva ri ntá ( Omi iva ri iva ntá ).

ó-mi iva ri n-tá

3SG-take thing hold CM-hand

'He holds thing in hand.'

It is also possible to have an SVC in which each verb has its own object. In the sentence (20) below mi 'take' has ukplotsuziva 'table cloth' as its object and ukploá 'the table' is the object of zi 'cover' In sentence (21), oyóti 'stick' and awo 'snake' are objects of the initial verb, mi 'take', and the second verb ba 'kill' respectively

20. Ami ukplotsuziva zi ukplo á tsú.
a-mi
u-kplotsuziva $\quad$ zi
u-kplo=á
tsú
3PLU-take CM-table cloth cover CM-table $=$ DET on
They cover the table with table cloth. TRPS.29

21. Kwaku ómi syótí ba awo.
Kwaku ó-mi
o-yótí
ba
a-wo
Kwaku SM.SG-take CM-stick kill
CM-snake
'Kwaku killed the snake with a stick.'

\subsubsection{TAM marking}

In SVCs in Logba, tense-aspect markers occur only once on the initial verb. In (22) to 'HAB' precedes klé, in (23) bó 'FUT' comes before mí 'take' and in (24) ló 'PRSPROG' precedes né 'buy'.

22 Abobi é ótoklé fie atáwalibi.
a-bobi $=$ é
ó-to-klé
fic
a-táwalibi-wo
$\mathrm{CM}-\mathrm{moon}=\mathrm{DET}$
SM.SG-HAB-shine
exceed
CM-star-PLU
'The moon shines brighter than stars.'

23. abómí ya idzó ó pétée
a-bó-mí
ya i-dzó=ó
pétée
2SG-FUT-take stake CM-yam =DET all
'you will stake all the yams'
[15.9.25]

24. Owusu ólóné afúta tá oga.
Owusu ว-ló-né
a-fúta
tá o-ga
Owusu 3SG-PRSPROG-buy
CM-cloth
give CM-wife

'Owusu is buying cloth for his wife.' 


\subsubsection{Polarity marking}

Logba has a bipartite negative marker $\mathrm{mV}$...nu. The first part occurs before $\mathrm{V}_{1}$ and the second after it. Where a lexical noun is used, the subject marker comes in between the verb and the first negative morpheme as in (25). In (26) the constituent which is negated occurs between the two elements (see section 7.3.6 for a discussion on negation).

25. Odzu moókpali nu lé ukpo.

o-dzu mo-ó-kpali nu lé u-kpo

CM-river NEG-SM.SG-flow NEG climb CM-mountain

'A river does not flow up a hill.' [15.4.33]

26. Mośtanyi nu fufu é me.

$\begin{array}{llll}\text { Mo-ś-tanyi nu fufu=é } & \text { me } \\ \text { NEG-3SG-can NEG fufu=DET } & \text { swallow } \\ \text { 'He could not swallow the fufu.' } & \end{array}$

The difference between Logba and Ewe is that Ewe marks the first part of the NEG me before $V_{1}$ and the second part, $o$ at the end of the whole SVC. Logba is similar to Ewe in marking Tense Aspect and Negation once on $\mathrm{V}_{1}$. In Akan, however, each verb is morphologically marked for the negative if the SVC is negative (see Osam 2004, Dolphyne 1987). Sentences (27) and (28) are Ewe and Akan examples respectively.

\section{EWE}

27. Esi metso gafloa ná fofoa o

$\begin{array}{llll}\text { Esi me-tso gáflo-a ná fofo-a } & \text { o } \\ \text { Esi NEG take fork-DEF give father-DEF } & \text { NEG } \\ \text { 'Esi did not give the fork to the father' } & \end{array}$

\section{AKAN}

28. Araba àǹtó m̀̀pètsea àmmá àbòfrá nó
Araba à-ǹ-tó
m̨̀̀̀tsea à-m-má
àbòfrá nó
Araba COMPL-NEG-buy ring
COMPL-NEG-give child DEF
'Araba did not buy a ring for the child' (Osam 2004:40)

\subsubsection{Term focus}

It is possible to focus each of the arguments in a simple SVC by fronting the constituent and marking it with the appropriate focus marker. (29) is the basic sentence from which the subject is extracted in (30), the object in (31), and the locative in (33) for focus. 
29. Asafo ómí kodiatsya zó ovu é nu
Asafo ó-mí
kodiatsya zó o-vu=e
$\mathrm{nu}$

Asafo SM.SG-take banana go CM-market=DET in

'Asafo took banana to the market'

30. Asafo ká ómí kodiatsya zó ovu é nu

$\begin{array}{llllll}\text { Asafo ká } & \text { ó-mí } & \text { kodiatsya } & \text { zó } & \text { o-vu=é } & \text { nu } \\ \text { Asafo FOC } & \text { SM.SG-take } & \text { banana } & \text { go } & \text { CM-market=DET } & \text { in }\end{array}$

'ASAFO took banana to the market'

31. Kodiatsya ká ómí zó ovu é nu

kodiatsya ká ó-mí zó o-vu=é nu

Banana FOC SM.SG-take go CM-market=DET in

'BANANA he took to the market'

32. Ovu é nu ká ómí kodiatsya zó
ovu $=\mathrm{e} \quad$ nu ká ó-mí
kədiatsya zó
market $=$ DETin FOC SM.SG-take banana go
'MARKET he took banana to'

\subsubsection{Predicate focus}

In an SVC, only the first verb can be focused. To focus the predicate of the sentence, the bare form of the initial verb is placed before the VP then the initial verb occurs with the pronoun prefixed to it followed by the second verb. The initial verb of sentence (33) is focused in sentence (34). Sentence (35) is ungrammatical because it is the bare form of $\mathrm{V}_{2}$ that is placed before VP position. Equally, both $\mathrm{V}_{1}$ and $V_{2}$ cannot be fronted as in (36)

33. Ama óteni zó ogbá yó.
Ama ó-teni
zó o-gbá yó
Ama SM.SG-escape go CM-road skin
'Ama rushed to the road side.'

34.Ama teni óteni zó ogbá yó.
Ama teni ó-teni
zó o-gbá yó
Ama escape SM.SG-escape go CM-road skin
'It is rushing to the road side that Ama did.'

35. *Ama zó óteni zó ogba yó.
*Ama zó ó-teni
zó o-gba yó
Ama go SM.SG-escape go CM-road skin
'It is rushing to the road side that Ama did.' 
36. *Ama teni zó óteni zó ogba yó.
*Ama teni
zó ó-teni
zó o-gba yó
Ama escape go SM.SG-escape go CM-road skin

'It is rushing to the road side that Ama did.'

A similar process is reported in Fon in Lefebre and Brousseau (2002:407). A copy of the initial verb is fronted and occurs in the same position as a fronted argument $\mathrm{NP} / \mathrm{AP}$ and followed by we, a focus marker. (37) is focused in (38).

\section{FON}

37. Kòkú só àsón ó yì àxì mè.

Kòkú só àsón ’́ yì àxì
Kòkú take crab DÈ
'Koku brought the crab to the market.'

38. Só wè Kòkú só àsón ó yì àxì mè.
só wè Kòkú só àsón ó
yì àxì mè
take it.s Koku take crab DEF go market in
'It is bringing the crab to the market that Koku did.' (as opposed to selling it)

Apart from the general characteristics, SVCs can be placed into functional groups. I will describe the functional types in the next section.

\subsection{Functional types}

The greater number of SVCs has one verb in addition to the initial verb. However, there are other SVCs which make use of three or four verbs which express related actions. This relationship becomes evident when the semantics of the verbs are examined. Out of these, the SVCs which have the initial verb as mi 'take' are very common. Sebba (1987:162) notes that cross-linguistically the most common SVCs are those constructions involving a verb which translates as 'take'. Following Durie (1997), I describe the functional types of SVC.

\subsubsection{Manipulative SVCs}

A manipulative verb mí 'take' occurs in initial position expressing a manipulation of the object of $V_{1}$ with different verbs in $V_{2}$ position. In such constructions $V_{2}$ can be placement verb such as na 'put' as in (39) positional verb ko 'hang' in (40) and benefactive ta 'give' in (41).

39. Omí afuta na ukplo á tsú
ó-mí
a-futa
na
u-kplo=á
tsú
3SG-take CM-cloth put
$\mathrm{CM}$-table $=\mathrm{DET}$ on
'He put the cloth on the table.' 
40. Omí awú ko agli é yó.

$$
\text { o-mí a-wú ko a-gli=é yó }
$$

3SG-take CM-dress hang CM-wall=DET skin

'He hangs the dress on the wall.'

41. Omí fufu tá ebiti.

ó-mí fufu tá e-biti
3SG-take fufu give CM-child
'He gives the child fufu.'

\subsubsection{Directional SVCs}

The initial verb in directional SVCs shows movement while $\mathrm{V}_{2}$ are verbs of direction indicating where the object is going. In (42), as a result of the action of $V_{1}$ the NP object umá 'mother' is carried to the hospital. In (43), udze 'woman' moves to the house.

42. Ozí umá zó avablome.

$\begin{array}{lll}\text { ó-zí } & \text { u-má } & \text { zó a-vablome } \\ \text { 3SG-carry } & \text { CM-mother } & \text { go CM-hospital }\end{array}$

'He carried the mother to hospital.'

43. Jhe udzé bá afánu.
o-he u-dze
3SG-pull CM-woman come CM-house
'He pulls the woman to the house.'

\subsubsection{Completive SVCs}

sé 'end' is used as a second verb in a completive SVC. The initial verb expresses the action in the SVC while the completion of the action is indicated by sé, 'end' the second verb in the series. In (44) blo 'make' is the initial verb followed by the object utrome 'work' and in (45) kpe 'eat' is the initial verb and the object idzó 'yam' follows. $V_{2}$ sé 'end' shows that the event has been completed. Since sé occupies the sentence final position, it can be argued that its position is iconic with its semantics.

44. Jblo utrome sé.
ó-blo
u-trome sé
3SG-make CM-work
end
'He finished the work.' 
45. Jkpe idzó sé.
Ђ-kpe i-dzó sé
3SG-eat CM-yam end
'He finished eating the yam.'

\subsubsection{Comparative SVCs}

A two-verb SVC is used to express comparatives in Logba. The initial verb expresses the quality that is being compared. The NP object to which the subject NP is compared follows the second verb, fié 'exceed', the index. In (46) and (47) $V_{2}$ is fie 'exceed' The objects are omóá 'that' in both examples.

46. Amú uklontsi ózi fié amóá.

\begin{tabular}{llll} 
amú u-klontsi fó-zi & \multicolumn{1}{c}{ fié } & a-móá \\
1SG CM-book & SM.SG-be.good exceed & AM-that \\
'My book is better than that.' &
\end{tabular}

47. Abia ame akpiagu fié amóa.
a-bia
a-me
a-kpiagu fié
a-móá
CM-chair
AM-this SM-high exceed
AM-that
'This chair is higher than that.'

\subsubsection{Resultative SVCs}

The action expressed in $V_{1}$ leads to the situation expressed in $V_{2} . V_{1}$ in both (48) and (49) is lá 'beat'. In (48) the action of beating results in the breaking of the object ukú 'drum'. However, in (49), the beating results in the death of agbé 'dog'

48. Jlá ukú bli.

$\begin{array}{lll}\text { o-lá } & \text { u-kú } & \text { bli } \\ \text { 3SG-beat } & \text { CM-drum } & \text { break }\end{array}$

'He beats the drum and it breaks.'

49. Jlá agbé bá.
o-lá
a-gbé
bá
3SG-beat CM-dog kill
'He beat the dog to death.'

\subsubsection{Benefactive SVCs}

Benefactive SVC expresses a notion of something being done 'for the benefit of' someone. The verb, tá 'give' is used as the second verb in a benefactive SVC. The NP that occurs after tá 'give' is the recipient of the NP or the situation characterised in $\mathrm{VP}_{1}$ that is the object of $\mathrm{V}_{1}$. In (50), the singing is done for the benefit of 
the child; the benefactive is ebitsi é 'the child' and in (51), it is -m 1SGOBJ, indicating that the speaker is the intended recipient.

50. Udze ózuiku tá ebîtsi é.
$\mathrm{u}-\mathrm{dz \varepsilon}$
ó-zu.iku
tá e-bítsi =é
CM-woman 3SG-sing.song
give $\mathrm{CM}$-child $=$ DET
'The woman sang for the child.'

51. Yayra óne uklontsi tá ḿ.
Yayra ó-ne
u-klontsi tá=ḿ
Yayra 3SG-buy CM-book give $=1 \mathrm{SGOBJ}$
'Yayra bought a book for me.'

In the next section, I will describe the order in which the verbs occur in SVC and how it influences the overall meaning of the sentence

\subsection{Verb sequence in SVCs}

The sequence in which verbs occur in SVC is a reflection of what the speakers of the language consider as an inseperable coherent unit. (Durie 1997, Essegbey 2004). In instrumental SVCs, the instrument is the first object that follows $\mathrm{V}_{1}$ immediately. Sentence (52) is a grammatical SVC. When yam is to be peeled, the sub-event, mi uhé 'take knife' normally precedes the second sub-event, kpe idzó ó 'peel the yam' (53) is not grammatical; the peeling of the yam comes before taking the knife which is not a natural order of events. The sub-events in (54) are unnaturally ordered so they are considered as separate events. However, the two actions can be placed in a clause and linked by use of the conjunction when the order is reversed. That is, he peels the yams and after that takes a knife. In this situation, the knife may not necessarily be the one used in peeling the yam.

52. Omi uhé kpe idzó ó.

$\begin{array}{llll}\text { ó-mi } & \text { u-hé } & \text { kpe } & \text { i-dzó=ó } \\ \text { 3SG-take } & \text { CM-knife } & \text { peel } & \text { CM-yam=DET }\end{array}$

'He takes knife peel the yam.'

53.*Ókpe idzó ó mi uhé.
*ó-kpe i-dzó=ó
mi u-hé
3SG-peel CM-yam=DET take CM-knife
'He peels the yam takes knife.'

54.Okpe idzó ó yé ómi uhé.

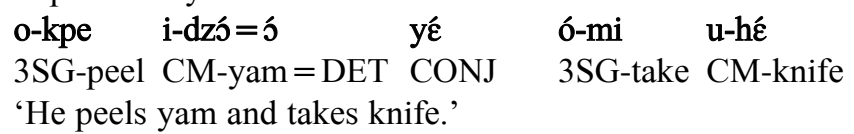


The sentences in (55), (56) and (57) are illustrations taken from a description of agronomic practices in yam cultivation. The farmer needs to take special care for the yam tendrils that will produce the big tubers of yam for him after some months. He holds them and gently ties them together. This is the natural order of events as in (55). It is for this reason that (56) is considered unacceptable. (57) may be appropriate if only it is taken to mean tying the yam tendrils and after that holding the tendrils together. In which case, they are events which occur as separate temporal entities.

55. Ori idzs mba á glé fé anda nu.

$\begin{array}{lllll}\text { ó-ri } \quad \text { i-dzo } & \text { m-ba=á } & \text { glé fé } & \text { a-nda } & \text { nu } \\ \text { 3SG-hold CM-yam } & \text { CM-tendril=DET } & \text { tie into } & \text { CM-friend } & \text { in } \\ \text { 'He holds the yam tendrils into one another.' } & \end{array}$

56* Oglé idzó mba á ri fé anda nu.

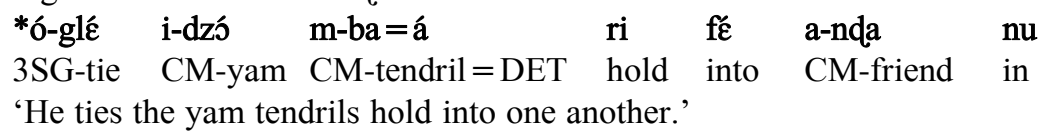

57.Óglé idzó mba á yé óri fé anda nu.

$\begin{array}{llll}\text { ó-glé } & \text { i-dzó } & \text { m-ba-á } & \text { ý́ ó-ri } \\ \text { 3SG-tie } & \text { CM-yam } & \text { CM-tendril=DET } & \text { CONJ 3SG-hold } \\ \text { f́̂́ } & \text { a-nda } & \text { nu } & \\ \text { into } & \text { CM-friend } & \text { in } & \end{array}$

'He ties the yam tendrils and holds them into one another.'

In completive $\mathrm{SVCs}$ the $\mathrm{V}_{2}$ which indicates completion of an action cannot come to the position of $\mathrm{V}_{1}$ even if a conjunction were used because one can not complete something before one starts to do it. In sentence (58), the sequence of the verbs cannot be changed to (59). This also applies to resultative SVC's. The sequence of the verbs in (60) cannot be changed to (61). This is because the action of $V_{1}$ results in $\mathrm{V}_{2}$. One thing that comes up clearly is that if the order of events seems unnatural then a conjunction is used to bind the verbs together and a pronominal vowel prefix is marked on the subsequent verb. However, if $V_{2}$ denotes a natural endpoint of the larger event or a result, then the $\mathrm{V}_{2}$ cannot be brought to $\mathrm{V}_{1}$ position.

58 Jblo utrome sé.

ó-blo utrome sé
3SG-make work finish
'He finished the work.'

$59 *$ フsé utrome (yع) (o)blo.

$\begin{array}{llll}\text { ó-sé } & \text { utrome } & \text { (уع) } & \text { (o)blo. } \\ \text { 3SG-finish } & \text { work } & (\mathrm{CONJ}) & \text { make }\end{array}$

'He finished the work.' 
60 Olá agbé bá.

ó-lá agbé bá

3SG-beat dog kill

'He beat the dog to death.'

61. *Obá agbé (yع) (o)lá.

*ó-bá agbé (yع) (o)lá

3SG-kill dog (CONJ) beat

'He beat the dog to death.'

\section{$10.5 \quad$ Lexicalised verb sequences}

The order in which the verbs occur also affects the semantics of the sentence (see Dorvlo 2007). This comes to light when the verbs mi 'take' ri 'hold' are used in an SVC. (62) translates as 'the man takes the cup.' When mi 'take' is $\mathrm{V}_{1}$ and ri 'hold' is $V_{2}$ as in (63) the sentence is understood by the native speaker as the man holds the cup firmly. When the position is changed and ri 'hold' is $\mathrm{V}_{1}$ and mi 'take is $\mathrm{V}_{2}$ as in (64) the meaning shifts to the man takes the cup as his possession. This points to the fact that all the verbs in the SVC complement each other in the determination of the overall meaning of the sentence.

62. Jsá á ómi kop.

osá=á ó-mi $\quad$ kop
CM-man=DET SM.SG-take
'The man takes the cup.'

63 Dsáá ómi kop ri.

osá-á ó-mi kop ri
CM-man = DET SM.SG-take cup hold
'The man holds the cup firmly.'

64. Jsá á óri kop mi.

$$
\begin{array}{llll}
\text { osá=á } & \text { ó-ri } & \text { kop } & \text { mi } \\
\text { CM-man=DET } & \text { SM.SG-hold } & \text { cup } & \text { take }
\end{array}
$$

'The man takes the cup as his possession.'

\subsection{Conclusion}

In this chapter, I describe SVCs in Logba looking closely at the general characteristics and the functional types. From the discussion so far, it can be said that SVC in Logba is a clause which contains two or more verbs. Each verb in the SVC shares the same subject. Negation tense and aspect are marked only once with $\mathrm{V}_{1}$. If the verbs share an object, it is expressed only once with $\mathrm{V}_{1}$. Only one verb, the 
initial verb can be focused. The focusing follows the pattern of verb or predicate focusing in monoclausal clauses. The bare verb is placed before the first VP in the SVC. All these features indicate that an SVC is a monoclausal structure. 



\section{REPORTED SPEECH, REFLEXIVE AND RECIPRO- CAL CONSTRUCTIONS}

Communication basically involves sending and receiving information. It includes reporting statements which are made by another person at a different time and place or re-asking a question that was asked by another person or reporting a command that someone else had issued to another person at another time. This aspect of communication is discussed in the first part of this chapter. The second part deals with reflexive construction and the final part dwells on reciprocal constructions.

\subsection{Reported speech}

A reported speech is an utterance of another person that is quoted or recast in the reporter's own words. I will discuss the features of reported direct speech and reported indirect speech in Logba.

\subsubsection{Reported direct speech}

In reported direct speech, the actual words of the original speaker are exactly the same as what he had said. The intonation break is after té. Sentence (1a) below is what the headteacher, Mr. Howusu is quoted to have said when a concerned mother brought a delinquent child to school and (1b) the quotes indicate what is said to have been directly uttered by Jesus and is a translated biblical verse by one of the elders of the local church to Sunday school children :

1a. Masta ówá té 'Manu ubi (u)me suku idze.'

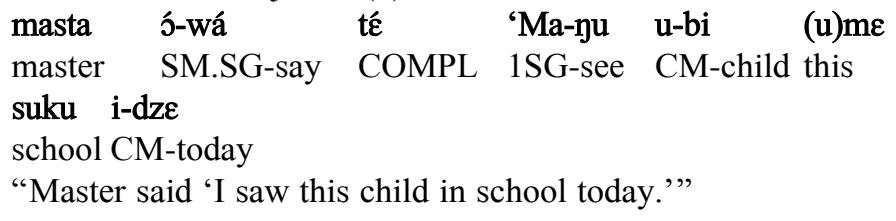

1b. Yesu ówá té 'tá ebitwo te ba amú wá.'

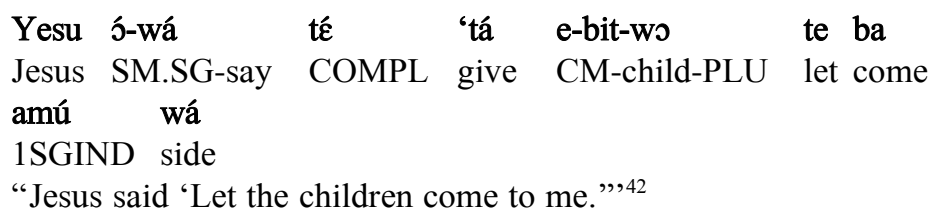

\footnotetext{
${ }^{42}$ This verse is from Matthew 19 verse 14; Luke 18 verse 16.
} 
This is reported direct speech. Quotation marks are used to show that these are the direct words that Mr. Howusu and the church elder uttered respectively.

\subsubsection{Reported indirect speech}

A reported indirect speech is an utterance of another person that is recast in the reporter's own words with a speech report frame. In Logba, the reporting frame precedes what is being reported. There are two report introducers: té and xé. té introduces statements and xé, the relative particle, is used in reported questions. The report frame is a simple clause made up of NP and verb. The verb in the reporting frame is a verb of saying, hearing or any other verb expressing cognitive activity. e.g. thinking, knowing. In addition, there is a 'shift' in the use of the following deictic elements: person, time, place, and demonstratives.

In a reported indirect speech construction, Howusu's speech and that of another teacher are recast in the reporter's own words. The reported speech in (2a) was made the following day when the child was not at the spot. The following shifts have therefore occurred in example sentences (2a) ma ' $1 \mathrm{SG}$ ' becomes 0 - ' $3 \mathrm{SG}$ ',

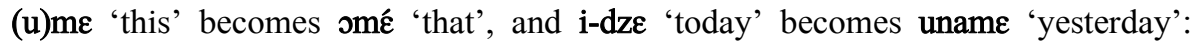
These shifts are however, peculiar to this example. In (2b) Esi, the aunt of the said child is reported to have said that she will advise the child and this is reported by another teacher on the same day. Because of this, idze 'today' has not changed to uname 'yesterday' as in sentence (2a).

2a. Howusu ówá té ónú ubí omé suku uname.

\begin{tabular}{|c|c|c|c|c|}
\hline Howusu & ó-wá & té & o-yú & u-bí \\
\hline Howusu & SM.SG-say & COMPL & 3SG-see & CM-child AM-that \\
\hline $\begin{array}{l}\text { suku } \\
\text { school }\end{array}$ & $\begin{array}{l}\text { u-nam } \varepsilon \\
\text { yesterday }\end{array}$ & & & \\
\hline
\end{tabular}

2b. Esi ówá té óbólá alaga wa é idze.
Esi ó-wá
té ó-bó-lá
a-laga
wa $=\hat{\varepsilon}$
Esi SM.SG-say COMPL 3SG-FUT-beat
CM-speech
say $=3 \mathrm{SGOBJ}$
i-dze
CM-today
'Esi said that she will talk to him today.'

In example sentence (3a) ume 'here' undergoes a deictic shift to become umó 'there' in $(3 \mathrm{~b})$ when it has been reported. 
3a. 'Kofi óba ume.'
Kofi ふ́-ba
$\mathrm{u}-\mathrm{m} \varepsilon$
Kofi SM.SG-come
AM-here
'Kofi came here.'

3b. Enyo ówá té Kofi óba umó.
Enyo ó-wá
té
Kofi う-ba
u-mó
Enyo SM.SG-say
COMPL Kofi 3SG-come
CM-there

'Enyo said that Kofi came there.'

This is an indication that in reported speech there is rephrasing of pronouns, place adverbs and demonstratives that are found in what is to be reported in line with the deictic centre of the reporter.

\subsubsection{Reported imperative}

Imperatives are formed by using the imperative form which is the bare form of the verb with the complements if any without expressing the subject (see 8.2.1). In reported imperative, the imperative form is the constituent that follows the reporting frame. The NP, the person making the order, is only used in the reporting frame. In example (4) only the 3SG pronoun 0- is used but in (5), the NP, umá 'mother' is used. This is illustrated below:

4. Jwá té tsi etsi.
ว́-wá té
tsi e-tsi
3SG-say COMPL stand CM-ground
'He said you should stand up.'

5. Umá ówá té dú odzá.

$\begin{array}{lllll}\text { u-má } & \text { ó-wá } & \text { té } & \text { dú } & \text { o-dzá } \\ \text { CM-Mother } & \text { SM.SG-say } & \text { COMPL } & \text { estinguish } & \text { CM-fire } \\ \text { 'Mother said you should extinguish the fire.' } & \end{array}$

\subsubsection{Reported statement}

To construct a reported statement, one needs to have a speech report frame which precedes the statement that is to be reported. The report frame clause ends with the complementizer té which is probably grammaticalized from the verb ta 'say, tell'. This is a common grammaticalization pattern in African languages (see Heine et al 1991). Examples showing reported statement are shown in (6), (7), (8) and (9) below: 
6. Jwá té atsiba suku ayadzi
ว-wá té
atsi-ba
suku
a-yadzi
3SG-say COMPL 1PLU-come school CM-saturday
'He said that we should come to school on Saturday'

7. Egbla té ๆka koko é evi unyi tamble adzi.

é-gbla té $\quad$ n-ka $\quad$ koko=é e-vi
3PLU-teach COMPL
unyi tamble adzi

8. Awáé té ómi idzó á fé texo á nu.

\begin{tabular}{|c|c|c|}
\hline a-wá-é & té & i-dzó=á \\
\hline 2SG-say-3OBJ & COMPL & 3SG-take CM-yam = DET \\
\hline texo=á & $\mathrm{nu}$ & \\
\hline PREP barn $=\mathrm{D}$ & $\mathrm{T}$ in & \\
\hline
\end{tabular}

9. Jnú té óbóba.
ว-nú té
ó-bó-ba
3SG-hear COMPL 3SG-FUT-come

'He heard that he would come.'

\subsubsection{Reported thought}

Verbalization of ones mental disposition to another person is also considered as another form of reported speech. This usually involves either a person reporting his own thoughts or another person's. Mental process verbs like nenu 'believe' susu 'think' are in the reporting frame. (10), (11) and (12) are the examples.

10. Onenu té Yesu ódu onukpa ikpá.

$\begin{array}{lllll}\text { ó-nenu } & \text { té } & \text { Yesu ó-du } & \text { o-nukpa } & \text { i-kpá } \\ \text { 3SG-believe } & \text { COMPL Jesus } & \text { SM.SG-be } & \text { CM-king } & \text { CM-truth } \\ \text { 'He believes that Jesus is truly a king.' } & \end{array}$

11. Masusu té mikisa kuraa atsibîbl ’ iyé utrome.

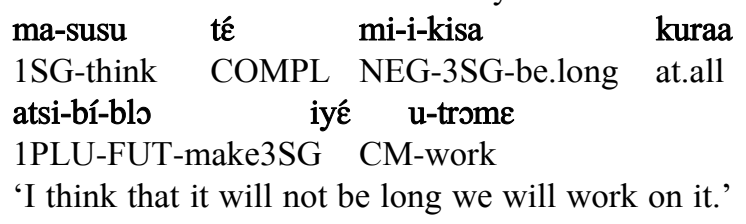


12. Unansa, manenu té anitirî tsiami oyó okpe xé safi óle oyó.

u-nansa ma-nenu té ani-ti-rí tsiami o-yó

CM-chief 1SG-believe COMPL 2PLU-HAB-hold linguist CM-stick

o-kpe xé safi ó-le o-yó

AM-one RP key AM-be 3SG-skin

'Chief, I believe that you usually hold a linguist staff on which

there is a key.' [15.7.01]

\subsection{Reported questions}

\subsubsection{Reported polar questions}

A reported polar question is introduced with té 'say'. Very often, the impersonal pronoun á- is prefixed to té. In my discussion on propositional questions, I stated that the pitch is modified to high or a vowel may be added or lengthened. In indirect propositional questions, the rise is lost. The sentences below, (13) and (14), are examples of reported polar questions.

13. Áté afánu awá?

$\begin{array}{lll}\text { á-té } & \text { a-fá-nu } & \text { a-wá? } \\ \text { 3PLU-say } & \text { CM-house-in } & \text { SM.SG-break.open }\end{array}$

'They asked how your home is?'

14. Áté Kofi obófó?

á-t́́ Kofi o-bó-fó?
3PLU-say Kofi SM.SG-come-reach
'They said that Kofi arrived home?'

With questions involving location ménu 'where' and animacy (o)mó 'who'/'which' the question that is to be reported is complement of the reporting frame até. This is a contracted form of abú té 'they asked that' in which the verb bú 'ask' is omitted. This is illustrated below:

15. Áté ménu ólózó?

á-té ménu ó-ló-zó

3PLU-COMPL where 3SG-PRSPROG-go

'They asked where were you going?'

16. Até omó ólá ebitsi é?

$\begin{array}{lll}\text { á-té } & \text { o-mó } \quad \text { ó-lá } & \text { e-bitsi=é } \\ \text { 3PLU-COMPL } & \text { 3SG-who 3SG-bea } & \text { CM-child=DET } \\ \text { 'They asked who beat the child?' } & \end{array}$




\subsubsection{Reported content questions}

In reported content question the content question function as an argument of bú 'ask' and it is introduced by té 'that'. The question word is prefixed with an agreement marker and occurs after the NP that is being questioned. The following sentences illustrate this:

17. Ubonukpiwo óbú té iva okple koko é matsoe nú?

$\begin{array}{llll}\text { u-bonukpiwo } & \text { ó-bú } & \text { té } & \text { iva o-kple } \\ \text { CM-farmer } & \text { SM.SG-ask COMPL thing reason } \\ \text { koko=é } & \text { ma-tsoe nú } & \\ \text { cocoa = DET NEG-dry NEG } & \\ \text { 'The farmer asked the reason the cocoa is not dry?' }\end{array}$

18. Ebú té iva okple osatsibié ogbamá?

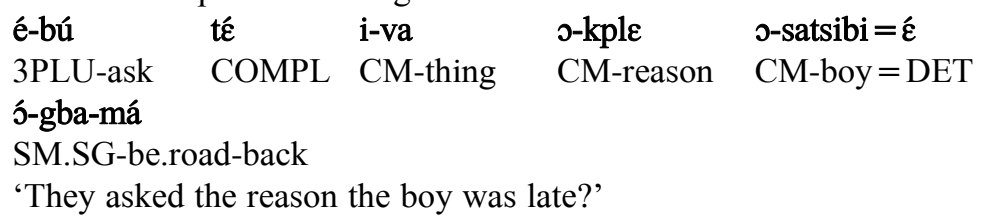

19. Obú té ebitwo abé akpi okutexoe?

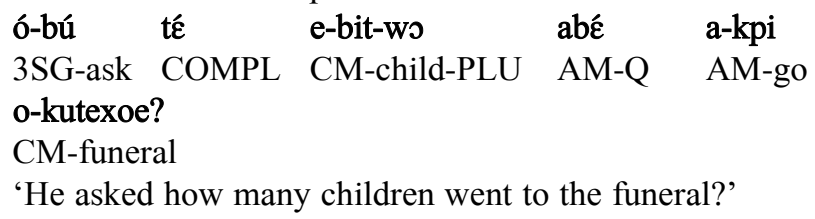

t $\varepsilon$ can be the only predicating element in the quoting frame. It is possible for the complement taking verb tá to be omitted without changing the meaning. Though it is omitted in (21), and (23), it can be determined from the context. Also the pronoun reference on the verb after the NP is elided. In both (20) and (22) there is no pronoun reference on tá since the subject NP ankó 'hen' and abudze 'nanny goat' precede the verb (see section 3.1.4).

20. Ankó tá té ólókpo atsa nu fé ale vie ókpo nyui.

\begin{tabular}{|c|c|c|c|c|}
\hline a-nkó & tá & té & ว-ló-kpo & $\mathrm{nu} \mathrm{f}^{\prime} \dot{\varepsilon}$ \\
\hline CM-hen & say & COMPL & 3SG-PRSPROG-lie & CM-coop in also \\
\hline ole vi & & ว-kpo & nyui & \\
\hline $3 \mathrm{SG}$ ta & & SMSG-lie & outside & \\
\hline
\end{tabular}

21. Ankó té ólókpo atsa nu fé ale vie ókpo nyui.
a-nkó té
ว-ló-kpo
a-tsa nu fé
CM-hen COMPL 3SG-PRSPROG-lie CM-coop in also 
ale vie ว-kpo nyui

3SG tail SMSG-lie outside

'The hen says it lies in its coop but its tail is outside.' [15.4.28]

22. Abudze tá té okunyie îzitawoe ómi ifli é na.

$\begin{array}{llll}\text { a-budze tá té } & \text { o-kunyie } & \hat{1}-\text {-zitawo-e } \\ \text { CM-nanny.goat say } & \text { COMPL } & \text { CM-place } & \text { SM-be.suitable-CFM } \\ \text { o-mi } \quad \text { i-fli=é } & \text { na } & \\ \text { 3SG-take } \quad \text { CM-white=DET } & \text { put } \\ \text { 'The nanny-goat says the place that suits her she puts the } \\ \text { white mark.' [15.4.35] }\end{array}$

23. Abudze té okunyie îzitawoe ómi ifli é na.

a-budze té o-kunyie í-zitawo-e
CM-nanny.goat COMPL CM-place SM-be.suitable-CFM
ó-mi i-fli=é na
3SG-take CM-white= DET put
'The nanny-goat says the place that suits her she puts the
white mark.' [15.4.35]

It has been observed that some speakers suffix dé to té in their speech. Some native speakers claim it is common with speakers of the Alakpeti variety but I find that it cuts across speakers of both the Tota and Alakpeti varieties. I think it is the dé in the reporting frame of some Ewe dialects surrounding Logba that is creeping into the Logba language. In Ewe, dé is added to the complementizer to emphasize what is reported.

\subsection{Logophoric pronoun in reported speech}

Every language has a means of indicating reference to show special pronouns that are used in indirect speech complement clause to show that a noun in the clause is co-referential with the subject in the main clause. Logba is no exception. In sentence (24), the regular third person subject prefix, o- that is prefixed to ká is the $3 \mathrm{SG}$ pronoun that refers to another person who is not the speaker. In (25) (26), and (27) olo refers to the subject NP, the speaker who is being quoted.

24. Guadi ówá té oká koko eví ubonu.
Guadi ó-wá
té o-ká
koko e-ví
u-bo-nu
Guadi SM.SG-say
COMPL 3SG-put cocoa CM-sun
CM-farm-in

'Guadi said he (not the speaker) dried cocoa in the farm.'

25. Guadi ówá té oloká koko evi ubonu.
Guadi ó-wá
té
olo-ká
koko e-vi
u-bo-nu
Guadi SM.SG-say COMPL LOG-put cocoa CM-sun
CM-farm-in
'Guadi said he (the speaker) dried cocoa in the farm.' 
26. Jwá té ololózó ubonu.
ó-wá té
olo-ló-zó
u-bo-nu
3SG-say COMPL LOG-PRSPROG-go
CM-farm-in
'He says he (the speaker) is going to farm.'

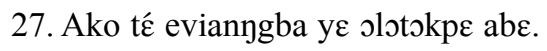
a-ko té
e-vianygba
ye olo-to-kpe
$\mathrm{a}-\mathrm{b} \varepsilon$
CM-parrot say CM-noon CONJ LOG-HAB-eat
CM-palmfruit

'Parrot says it is noon that it eats palmfruit.' [15.4.50]

It is noted in (26) that the present progressive marker is lo with a high tone. There are two other words which have similar forms but pronounced with a low tone. They are 10 'again'.and olo logophoric pronoun. When the three: present progressive, 'again' and logophoric pronoun are used in the same clause one of the lateral sounds is elided. This is attested in the sentence (28) below:

28. Jwá té oloolókpe iva.
o-wá té olo-o-ló-kpe-(i)va
3SG-say COMPL LOG-again-PRSPROG-eat-thing
'He says he (the speaker) is eating again.'

The focus marker occurs after the logophoric pronoun. In (29) what precedes is a discussion over who dried the good quality cocoa: an extension officer wanted to know. One person said Mr. Guadi and another maintained that it was Mr. Kuma. A third person who lives in the house of Mr. Guadi came with a report that he got from Guady himself as in (29).

29.Guadi ówá té oloká ká koko evi.
Guadi ó-wá
té
olo ká ká
koko e-vi
Guadi SM.SG-say COMPL LOG FOC put cocoa CM-sun
'Guadi said he (the speaker and no other person) dried cocoa.

\section{4}

Reflexive and reciprocal constructions

A construction is said to be reflexive if the action it describes goes back to affect the performer; thus semantically making the subject and the object to refer to the same person. A reciprocal construction, on the other hand, refers to an action in which two participants engage in an activity or behave in the same way towards each other or engage simultaneously in symmetric action (see Evans, to appear, Payne 1997). In Logba, apart from the use of pronouns dedicated to the expression of reflexive or reciprocal, other strategies have been identified. These are lexical items, modifiers and conventional bi-clausal descriptions. This section is concerned with these constructions and they are discussed considering the particles that are used to mark them in addition to the strategies that are employed. 


\subsubsection{Reflexive constructions}

Reflexive pronoun is formed when yó 'skin' or 'body' is added to the possessive pronoun (see section 3.5.3). The sentence below is an example:

30 Bansa ólá óyó.
Bansa ólá
ó-yó
Bansa SM.SG-beat 3SG-skin
'Bansa beat himself.'

The subject, Bansa and the object, óyó 'himself' refer to the same person and perform two roles: AGENT and PATIENT. It is possible to introduce the INSTRUMENT argument using kpe + NP after the (reflexive) object NP, amúyó 'myself'. This is exemplified in (31) and (32) below:

31. Máshíbí amúyó.
má-shíbí amú-yó
1SG-cut 1SG-skin
'I cut myself.'

32. Seli óshibi óyó kpe ífíami.

$\begin{array}{lllll}\text { Seli } & \text { ó-shibi } & \text { ó-yó } & \text { kpe } & \text { ífíami } \\ \text { Seli } & \text { SM.SG-cut } & 1 \text { SG-skin with } & \text { cutlass }\end{array}$

Seli cut himself with cutlass.'

\subsubsection{Other strategies for reflexives}

Reflexive concepts are expressed by some nominal compounds. Of importance is the morpheme yó 'skin' the reflexive marker which is always present in these compounds. They are:

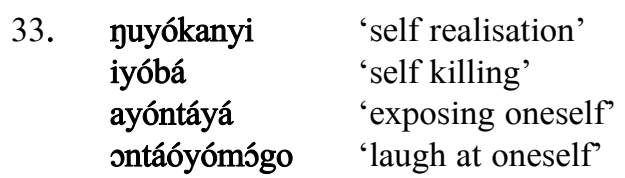

The following in (34) and (35) illustrate the use of these nominal compounds in sentences.

34. Ndánogo ndú iyóbá.
ndánogo
n-dú
i-yóbá
being.drunk SM-be CM-self.killing
'The act of being drunk is self killing.' 
35. Đuyókanyi izi.
yuyókanyi i-zi
self.realization SM-be.good
'Self-realization is good.'

There are also predicates which make the action performed by the subject to affect him and can be perceived as semantically reflexive. Examples are gu iyó 'wash body' gba uzúgbó 'shave head' gba idzi 'shave beard'. These fall under the attributes which Kemmer (1994) refers to as grooming predicates. Of these three predicates, gu iyó 'wash body' is more appealing as a reflexive because the action goes back to affect the whole 'body' of the subject NP. Also, this is an action which normally a person can perform on himself. It is however, the norm that those who are seriously sick have their body washed by another person. Considering the other two predicates, it can be said that it is only part of the body - head; beard that is affected. In addition, one can have his hair cut for him by another person. The sentences below (36), (37) and (38) show the use of these predicates.

36. Kofi ógú iyó.

$\begin{array}{ll}\text { Kofi ó-gú } & \text { i-yó } \\ \text { Kofi SM.SG-wash } & \text { CM-skin } \\ \text { 'Kofi bathed.' } & \end{array}$

37. Kofi ógbá uzúgbó.
Kofi ó-gbá
u-zúgbó
Kofi SM.SG-shave CM-head
'Kofi shaved his head.'

38. Kofi ógbá idzi.
Kofi ó-gbá
i-dzi
Kofi SM.SG-shave
CM-beard
'Kofi shaved beard.'

\subsection{Reciprocal constructions}

In reciprocal constructions, two or more different persons are involved in the same action that is expressed (see 3.5.4 for a discussion on reciprocal pronouns). They willfully perform the same kind of action to one another. The action performed does not have to be at the same time. For example: They visited each other. However, for symmetrical action, it tends to be at the same time. For example: They kissed. In Logba, the subject of the reciprocal construction is plural. The object a nda 'they companion' occurs after the verb. nda is an NP and occurs after a pronoun which agrees with a participant in the clause. The main difference between reflexive and reciprocal is that the participant in a reflexive is the Agent acting on 
himself and in the reciprocal the Agent acts on the Patient and the Patient also acts on the Agent. These actions occur simultaneously. The subject NP for the reciprocal is therefore generally plural.

What is generally acceptable is the structure in which á '3PLU' precedes nda 'companion' for all the plural pronouns: 1PLU, 2PLU and 3PLU; an indication that the 3PLU pronoun has grammaticalised with the reciprocal marker. This is shown in the example sentences (39), (40), and (41):

39. Atikpe ánda.

ati-kpe á-nda

1PLU-eat 3PLU-companion

'We bit each other.'

40. Anidodi ánda.

ani-dodi á-nda
2PLU love 3PLU-companion
'You love each other.'

41. Álá ánda.
Á-lá
á-nda
3PLU-beat 3PLU-companion
'They beat each other.'

Assuming we specify the persons as in (42) by giving the actual names we will have - Bansa and Yabani. This implies that Bansa beat Yabani and Yabani beat Bansa and these events happened simultaneously. In (43) osá kṕ́ údź́ are the participants and it is a requited love relationship.

42. Bansa kpe Yabani álá ándá.
Bansa kpe Yabani
á-lá
á-ndá
Bansa CONJ Yabani SM.PLU-beat
3PLU-companion
'Bansa and Yabani beat one another'

43. Xe mábá Logba máyú té osá á kpé udzi é édódi ánda íntá.
$\mathrm{Xe}$
Logba
má-nú
té o-sá=á
kpé
When 1SG-come Logba 1SG-see COMP
$\mathrm{u}-\mathrm{dzi}=\boldsymbol{\varepsilon}$
é-dódi
á-nda
$\mathrm{CM}-\mathrm{man}=\mathrm{DET}$
CONJ
woman $=$ DET SM.PLU-love
3PLU-companion so.much
'When I came to Logba I saw that the man and the woman loved each other so much.'

In a reciprocal construction, the subject NP is plural. In the example sentences below, ati '1PLU', ani '2PLU'and á '3PLU' are used and they agree with the pronoun which precedes nda 'companion'. This structure is marginally grammatical 
but it is gaining currency as some speakers find it acceptable. This is shown in the example sentences in (44), (45) and (46):

44. Álá á ndạ.

$\begin{array}{lll}\text { á-lá } & \text { á nda } \\ \text { 3PLU-beat } & \text { 3PLU companion }\end{array}$

'They beat each other.'

45. Anidodi ana nda.

ani-dodi ana nda

2PLU-love 2PLU companion

'You love each other.'

46. Atikpe atsá nda.

ati-kpe atsá nda

1PLU eat 1PLU companion

'We bit each other.'

The reciprocal can be used with the possessive as in (47).

47. $\mathcal{E}$ dzé f'é ándá afúta odzá.

$\begin{array}{lllll}\varepsilon \text {-dze } & \text { f } \varepsilon & \text { á-ndá } & \text { a-fúta } & \text { o-dzá } \\ \text { PLU-woman } & \text { put } & \text { 3PLU-companion } & \text { CM-cloth } & \text { CM-fire }\end{array}$

'The women set fire to each others cloth.'

\subsubsection{Lexical strategy}

The semantics of some verbs makes them express reciprocity especially when they are used with plural subjects. Verbs that fall in this category usually have more than one participant when they undergo lexical decomposition. gla 'exchange' can only be used when two items are involved in an exchange. blo anunyi 'make quarrel' always involve more than one person. It is therefore redundant to use the reciprocal nominal ndá 'companion' in the structures in which these verbs are used. However, the expression kpe $\mathrm{N}$ 'with $\mathrm{N}$ ' is sometimes used as complement to the verb expression. The following verbs are identified as having inherent reciprocal semantics. These are:

$\begin{array}{ll}48 \text { gla } & \text { 'exchange' } \\ \text { blo ayunyi } & \text { 'quarrel' } \\ \text { na edí } & \text { 'work for each other }{ }^{43},\end{array}$

\footnotetext{
${ }^{43}$ This refers to working in the farm in turns. This does not necessarily mean to complete working in turns on the same day.
} 
In sentence (49) and (50), and (51) and (52), the verbs gla and blo ayunyi are used in a one place constuction with preverbal plural pronominal argument. The reciprocal noun nda 'companion' is not used because symmetrical action is inherent in these verbs. The sentences can therefore be interpreted as reciprocals.

49. Atu ifíami igla.

atu i-fíami i-gla

1PLU CM-cutlass SM-exchange

'Our cutlasses exchange.' (i.e. they are exchanged)

50. Atu ifiami igla kpe Setor oble.
atu i-fiami i-gla
kpe Setor o-ble
1PLU CM-cutlass SM-exchange
CONJ Setor 3SG-own
'Our cutlass exchange with Setor's.'

51. Ablo ayunyi.
a-blo
a-nunyi
3PLU-make CM-quarrell

'They engaged in a quarrel.'

52. Sena ๖blo ayunyi kpé Kafui.
Sena o-blo
a-yunyi
kpé Kafui
Sena 3SG-make
CM-quarrel CONJ Kafui
'Sena quarrelled with Kafui.'

Sentence (53), expresses a bidirectional action because of the semantics of the verb: na edí 'work in turns' is a way of working not only in the Logba area but also in the Ewe communities. They work in turns for one another. The action of working for each other does not occur at the same time but when the process starts it ends when everyone in the group is equitably served.

53. Ebitwo á ená edí uname.
ebit-wo=á
e-ná
edí
uname
Child-PLU $=$ DET 3PLU-walk work.in.turns yesterday
'The children worked in turns for each other yesterday.'

Reciprocal action is expressed using f'́ anda nu 'into one another'. In local soap making, the soap maker has to stir the ingredients to mix into one another. This expression is used as in (54) and (55) below:

54. mfú kpe adi pétée ibi tsaka fe anda nu.

$\begin{array}{llllll}\text { mfú } & \text { kp } \varepsilon \text { adi pétée i-bi-tsaka } & \text { f́́ } & \text { anda } & \text { nu } \\ \text { oil CONJ soda all } & \text { SM.PLU-FUT-mix } & \text { into } & \text { companion } & \text { in } \\ \text { 'oil an the soda mix into each other' } & & & \end{array}$


55. Xe iblu fé anda nu pétée ko ayú té ndú kú fé ónu.
xe
i-blu
f' $\varepsilon^{\prime} \quad$ anda
nu pétée ko a-yú
COND SM.PLU-stir into companion in all only 2SG-see

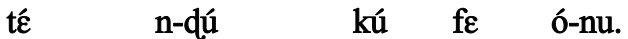
COMPL CM-water die into 3SG-in
'If it all mix then you will see that the water will be dried in it.'

There are some nominal compounds that connote reciprocity. These are:
56. andáyúdogo 'mutual help'
andátsínago 'mutual defamation'
andáwlégo 'mutual deception'
edínago 'working in turns for each other'

The following in (57) and (58) illustrate the use of these nominal compounds in sentences.

57. andátsínago miîzi.
andátsínago
mi-î-zi
mutual.defamation NEG-SM-be.good
'Mutual defamation is not good.'

58. Edinago i-bo veve tá atsú Akpanawo.

$\begin{array}{llll}\text { edinago } & \text { i-bo veve tá atsú Akpanawo. } \\ \text { working.in.turns } & \text { SM-stay important give } & \text { 1PLU Logba.people } \\ \text { 'Working in turns for each other is important for us, Logba people.' }\end{array}$

\subsubsection{Biclausal strategy}

Biclausal descriptions are also used to express reciprocal action but the meaning of some biclausal expressions may not be wholly symmetrical because the action may not have occurred at the same time as we understand prototypical reciprocals to have. Sentences (59) and (60) attest to this:

59. Jlám ye amú fé maléé.
o-lá-m ye
amú fé

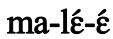
3SG-beat-1SGOBJ CONJ $1 \mathrm{SG}$ also $1 \mathrm{SG}-$ beat $=3 \mathrm{SGOBJ}$
'He beat me and I also beat him.'

60. Ntsi afása nu ye afása fé otsi amú nu.
n-tsi
a-fása
nu ye a-fása
$f^{\prime} \varepsilon \bar{c} \quad$ o-tsi
amú nu
1SG-stay CM-father in CONJ CM-father also 3SG-stay $1 \mathrm{SG}$ in
'I am in the father and the father is in me.' John 14 verse 11 
In sentence (59), A might have beaten B and later B also beats him in retaliation. In sentence (60), the states of affairs of the verb tsi 'stay in' involves continuity. This differs from la 'beat' which expresses a non-durative action. So sentence (60) will be more symmetrical since the action that is expressed in clause A and that in clause B has happened concurrently. 



\section{TOPIC AND FOCUS}

In any communication situation, the interlocutors make a conscious effort to bring out what they intend to say in a way that will be fully understandable to one another. Each of them makes deliberate choices in carefully packaging the information he wants to present in the sentences he constructs. Some of these choices may include what the speaker considers to be the most salient, whether the reference to this element will be directly expressed or other words or referring expressions will be used to imply what the speaker means. Languages have a variety of ways in which these functions are indicated. What the speaker considers to be salient is the focus and what the information is about is the topic. This chapter presents topic and focus in Logba. First, topic constructions are discussed. This is followed with a description of focus constructions. The chapter is concluded with a statement on the relevance of topic and focus.

\section{$12.1 \quad$ Topic}

Topic is a function that is assigned to a constituent considered to be what is talked about in a communication situation. According to Ameka (in press) the sentence initial position in Kwa languages is used for background information topic, the information which the utterance is about and what the hearer should have at the back of his mind to achieve the target of full comprehension of the rest of the utterance.

In Logba, the syntactic arrangement shows the topicality of an element in a clause. In topic constructions, a noun phrase or a postpositional phrase may be fronted to the left periphery as an external constituent of the clause that is to sentence initial position. There is no special marker but this is the constituent that is the starting point and it is what the clause or sentence is about.

In (1), afúta á 'the cloth' is a core argument of the sentence in object position. In (2), Afúta á 'the cloth' is front shifted and its clausal object position is filled by $-\varepsilon$. '3SGOBJ'. In (3) Mfúta á 'the clothes' is placed at clause initial position, and in the rest of the clause it is referred to by an agreeing 3PLUOBJ $-\mathrm{a}$ in the object position.

1. Mane afúta á

$$
\begin{aligned}
& \text { ma-ne a-fúta=á } \\
& \text { 1SG-buy CM-cloth=DET } \\
& \text { 'I bought the cloth' }
\end{aligned}
$$


2. Afúta á mani $\varepsilon$

$$
\begin{aligned}
& \text { a-fúta =á } \quad \text { ma-ni= }=\hat{\varepsilon} \\
& \text { CM-cloth=DET 1SG-buy=3SGOBJ } \\
& \text { 'The cloth, I bought it' }
\end{aligned}
$$

3. Mfúta á mane á

$$
\begin{array}{ll}
\text { m-fúta }=a ́ & \text { ma-ne }=\text { á } \\
\text { CM-cloth=DET } & 1 \mathrm{SG}-\text { buy =3PLUOBJ }
\end{array}
$$

'The clothes I bought them'

Unlike situations where the object is topicalised, when a peripheral argument, such as a temporal NP, or an adverb (manner), or a locative postpositional phrase, is topicalised, there is no pronominal element in the rest of the clause to refer to them. In (4) the marked topic is the NP, Udobe omóa 'that afternoon', (5) the adverb Blewuu 'slowly' and in (6) the locative postpositional phrase Ukpu é zugbó 'the top of the mountain' is the marked topic.

4. Udobe omóa, ónú Amøwasa

$\begin{array}{llll}\text { u-dobe o-móa ónú } & \text { Amowasa } \\ \text { CM-afternoon } & \text { AM-that } & \text { SM.SG-see } & \text { Logba priest } \\ \text { 'That afternoon, he saw Logba priest' } & \end{array}$

5 Blewuu, asangbla ótsona
Blewuu a-sangbla ó-tsっ-na
slowly CM-tortoise SM.SG-HAB-walk
'Slowly, a tortoise walks'

6. Ukpu é zugbó, ivanuvo óyú ogbómiws
$\mathrm{u}-\mathrm{kpu}=\mathrm{e}$
zugbó i-vanuvo
ว-yú
o-gbómi-wo
$\mathrm{CM}$-mountain $=\mathrm{DET}$ head CM-hunter
SM.SG-see
CM-monkey-PLU
'The top of the mountain the hunter saw the monkeys'

These are placed at the initial position of the sentence to facilitate the understanding of the rest of the information (see Chafe 1976).

\subsection{Focus}

Focus is a constituent which is of communicative interest to the interlocutors when compared to what has already been discussed. According to Dik (1997:326) it is the information

which is relatively the most important or salient in the given communicative setting and considered by the S[peaker] to be essential for $\mathrm{A}[\mathrm{ddr}$ essee] to integrate into his pragmatic information. 
There are different ways of marking a focal constituent in Kwa languages. Some move the focused constituent to the pre-core slot in the clause. Others mark focus prosodically or morphologically. The strategy for focusing to a large extent depends on how the language in question marks focus. Focus is marked on an argument which is new and contrasts with what is previously known. This does not mean that the information that is in focus should be entirely new. Dakubu (2005:2) notes that

...newness of information must not be taken as necessarily the introduction of something previously totally unknown... it may more likely mean the assertion of a choice among conflicting possibilities.

In Logba, ká is the focus marker and follows immediately the constituent that is focused. This is mainly used in the Alakpeti dialect. There is a second focus strategy which is primarily used in the Tota dialect and which consists of adding the appropriate independent pronoun to the focused and fronted constituent.

While in Logba doing linguistic fieldwork, two events in which focus came out naturally are: A discussion two women had in a street market, when they both observed a porter who was staggering, and a riddle telling competition. These are presented below:

\subsubsection{A: Discussion of two women}

A porter in the market came around; he was walking with weak unsteady steps as if he was going to fall. He is not known to walk in this way. This is the comment two women, Arku and Amozi made as they observed him:

7. Arku Me obá

me o-bá

Q 3SG-come

'What has happened?'

8. Amozi Ndá á ká ónó
n-dá=á
ká ó-nó
$\mathrm{CM}$-liquor $=\mathrm{DET} \quad$ FOC $3 \mathrm{SG}$-drink
'LIQUOR he drank' 
9. Arku Avúdago é e $^{44}$ iyé ónó
a-vúdago =é iyé
ว́-nó
CM-leaf=DET 3SGIND 3SG-drink
'LEAF he drank' (He smoked wee).

Amozi, in an answer to the question posed by Arku, used the focus particle ka after ndaa 'the liquor' which is the constituent she wants to stress. The whole predicate nó ndá 'drink liquor' is new information. Yet only the object NP is marked for focus. However, Arku's response Avúdago é iyé ónó 'the leaf he drank' is a disagreement with Amozi's claim and therefore presents contrastive information which she marks with another way of marking focus which is used in the Tota dialect. This strategy involves the use of an independent pronoun iyc after the NP that is being focused. Further investigation reveals that Arku speaks the Tota dialect while Amozi speaks the Alakpeti one.

\subsubsection{B: Riddle}

In a riddle telling competition, Akom takes the floor and announces that he is going to present a riddle to the opponent group. After telling the riddle, answers are offered by members in the other group as shown below:

10. Akom Adzo loo!
adzo loo
riddle ADR
'Riddle'

11. Howusu Adzo tóbá (tá óbá)

adzo tá óbá

riddle let SM.SG-come

'Let riddle come'

12. Akom Mádzí mádzi wúu?

má-dzí má-dzi wúu?
1SG-stand 1SG-call 2SGOBJ Q
'I get up, have I called you?'

13. Howusu Abobí iyé nyí

abobí iyé nyí

Moon 3SGIND be.that

'MOON is the answer'

\footnotetext{
${ }^{44}$ The Logba people euphemistically refer to marijuana as avudago 'leaf' Some other people call it ekelé 'grass' In Ewe also it is referred to as gbe 'grass'
} 
14. Festus Vovoli iyé nyí

vovoli iyé nyí

shadow 3SGIND be.that

'SHADOW is the answer'

The riddle is in the form of a question and since the answer is the piece of information that is sought for by the questioner the NP that is presented as new is marked for focus using the Tota dialect. Howusu's answer to the riddle is abobi 'moon'. Since Festus finds the answer to be incorrect, he offers another answer, vovoli 'shadow' which he focused using the same strategy ${ }^{45}$.

Question and answer adjacency pair is one method generally used to determine focus (see e.g. Dik 1978, Ameka 1992). The semantics of a content question is that the constituent that is represented by the question is what is most important and the answer is the information that the questioner wants. The answer fills the empty slot that is in the question. It could be in contrast or a correction of an impression which the addressee thought the speaker had. These can be inferred from the two discourse fragments above.

There are two markers; one for argument focus and the other for predicate focus. The argument focus marker ka is used to show focus on a nominal and an adverbial that are fronted.

\subsection{Term focus}

In (15) below, Seto is the subject and ebitsi is the direct object. The subject, Seto is focused in (16) and the direct object, ebitsi $\varepsilon$ in (17).

15. Seto ólá ebítsi ع́

Seto ó-lá ebítsî $=\hat{\varepsilon}$

Seto SM.SG-beat child $=$ DET

'Seto beat the child'

\subsubsection{Subject}

16. Seto ká ólá ebitsi é
Seto ká ó-lá
ebitsi $=\hat{\varepsilon}$
Seto FOC SM.SG-beat child $=$ DET
'SETO beat the child'

\footnotetext{
${ }^{45}$ The participants in the riddle are from Tota, hence their use of this focusing strategy.
} 


\subsubsection{Direct object}

17. Ebitsi ع́ ká Seto ólá
e-bitsi $=\tilde{\varepsilon} \quad$ ka $\quad$ Seto ó-lá
CM-child=DET FOC Seto SM.SG-beat
'Sets beat THE CHILD'

A complex NP in which a demonstrative omoá 'that' is marked for agreement and modifies the head noun. This NP is focused and is shown in (18) below:

18. Psá omoá ká óbá oga.
o-sá
0-moá
ká
óbá
0-ga
CM-man AM-that FOC SM.SG-kill CM-wife

'THAT MAN killed the wife.'

In a clause with a ditransitive verb, the two post verbal arguments RECIPIENT and THEME can be focused individually. In (19) tá 'give' is a ditransitive verb osá 'man' is the Recipient and efeshi 'sheep' is the Theme. The Recipient is focused in (20) and the Theme in (21) below:

19. Ama śtá osá á efeshi.
Ama ótá
o-sá=á
e-feshi
Ama SM.SG-give CM-man=DET CM-sheep
'Ama gave the man sheep.'

\subsubsection{Recipient}

20. Osá á ká Ama otá efeshi.
0-sá=á
ká Ama o-tá
e-feshi
CM-man=DET FOC Ama SM.SG-give CM-sheep
'THE MAN Ama gave sheep.'

\subsubsection{Theme}

21. Efeshi é ká Ama ótá osáá
e-feshi $=\varepsilon$
ká Ama o-tá
0-sá-á
CM-sheep $=$ DETFOC Ama SM.SG-give CM-man=DET
'Ama gave the man SHEEP'

It is only one constituent that can be focused in a clause. The two post-verbal constitunets (RECIPIENT and THEME) can not be focused in the same clause. Sentence (22) below is ungrammatical because osá á 'the man' Recipient and efeshi 'sheep' Theme are both fronted for focus in the same clause. Nor can ká be after efeshi 'sheep' as in (23) 
22. *Osáá ká efeshi ká Ama ótá
o-sá=á
ká e-feshi
ká Ama ótá
CM-man $=$ DET FOC CM-sheep
FOC Ama SM.SG-give
'Ama gave THE MAN SHEEP'

23. * Osá á efeshi ká Ama ótá
o-sa =á
e-feshi
ká Ama o-tá
$\mathrm{CM}$-man $=$ DET CM-sheep
FOC Ama SM.SG-give
'Ama gave THE MAN SHEEP'

\subsubsection{Adjunct}

The focus marker is placed at the end of the adjunct phrase. The adjunct phrase udántsí me 'this morning' in (24) is focused in (25)

24. Jzó suku udántsí me.

ó-ź́ suku u-dantsi me
3SG-go school CM-morning this
'He/She went to school this morning.'

25. Udántsí mé ká ózó suku.

u-dantsi mé ká ó-zó suku

CM-morning this FOC 3SG-go school

'THIS MORNING he/she went to school.'

\subsubsection{Subject pronoun}

If a pronominal constituent is in focus, be it subject, or object, it will be the independent form of the pronoun that will be used. A gap is left at the site where the object pronoun is extracted. ma ' $1 \mathrm{SG}$ ' in (26) is focused in (27) using amu '1SGIND' in (28) using Awú '2SGIND' and in (29) using ole '3SGIND'

26. Maz(a)iva.

ma-z(a)-iva

$1 \mathrm{SG}$ cook thing

'I cook.'

27. Amú ká ma z(á)iva.

amú ká ma z(a)íva

1SG.IND FOC 1SG-cook-thing

'I cooked, nobody else did.' 
28. Awú ká az(á)iva.

awú ká a-z(a)-îva

2SG(IND) FOC 2SG-cook-thing

'YOU cooked.'

29. गle ka oz(á)iva.

ole ka o-z(a)îiva

3SG.IND FOC 3SG-cook-thing

'HE/SHE cooked.'

\subsubsection{Object pronoun}

1SGOBJ (-m)

In (26) the 1SGOBJ pronoun is focused in (31) using Amú '1SGIND'

30. Ivagblawo é slá ḿ.

i-vagblawo =é $\quad$ o-lá=ḿ

CM-teacher $=$ DET SM.SG-beat $=1$ SGOBJ

'The teacher beat me.'

31. Amú ká ivagblawo é slá.

amu ka i-vagblawo=é o-lá

1SG.IND FOC CM-teacher=DET SM.SG-beat

'I the teacher beat.'

2SGOBJ (-wú)

In (32) 2SGOBJ pronoun is focused in (33) using awú '2SGIND'

32. Ivagblawoé ólá wú.
i-vagblawo $=$ é
ó-lá= wú
CM-teacher $=$ DET SM.SG-beat $=2$ SGOBJ

'The teacher beat you.'

33. Awú ká ivagblawo é ólá
awu
ka i-vagblawo =é
ó-lá
2SG.IND FOC CM-teacher=DET SM.SG-beat
'You the teacher beat.'

3SGOBJ $(-\varepsilon)$

The independent form of the 3SG has these forms: ole for + human nouns and iý for mass nouns especially those in the i-class. 
34. Ivagblawo é óláé. (o-lé-é)

i-vagblawo =é ó-lá- $\varepsilon(0-1 \varepsilon-\varepsilon)$

CM-teacher $=$ DET SM.SG-beat-3SG

'The teacher beat him/her.'

35. Jle ká ivagblawo é ólá

ole ká i-vagblawo=é ólá

3SG.IND FOC CM-teacher $=$ DET SM.SG-beat

'HE/SHE the teacher beat'

3SGIND iyé is used for mass nouns. Examples are: ida 'money' igbe 'spear' iká 'charcoal' ihánago ‘indiscipline' etc

36. Iyé ká ivagblawo é óné.

iyé ká i-vagblawo=é óné

3SG.IND FOC CM-teacher=DET SM.SG-buy

'IT the teacher bought.'

\subsubsection{Focusing clause initial adverbials}

When adverbials are focused, they are fronted and marked with ka the focus marker. This is attested in the following examples:

37. Uname ká óbá.

u-name ka ó-bá
CM-yesterday FOC 3SG-come
'YESTERDAY he came.'

38. Udzikú ká mamí yonyi uklóntsí ć.
u-dzikú
ka ma-mí yonyi u-klóntsí=
CM-annoyance FOC 1SG-take write CM-letter $=$ DET
'WITH ANNOYANCE I wrote the letter.'

\subsubsection{Focusing arguments in a copula clause}

When the copula subject is in focus, it is marked with the focus marker as in (39) However, the complement of the copula can not be focus marked. (see 41).

39. Aku odú ivagblawo.

$\begin{array}{lll}\text { Aku } & \text { o-dú } & \text { i-vagblawo. } \\ \text { Aku } & \text { SM.SG-be } & \text { CM-teacher }\end{array}$

'Aku is a teacher.' 
$40 \quad$ Aku ká ódú ivagblawo.

Aku ká ó-dú i-vagblawo.

Aku FOC SM.SG-be CM-teacher

'AKU is a teacher.'

41. *Ivagblawo ká ódú Kofi.

*i-vagblawo ká ó-dú Kofi.

CM-teacher FOC SM.SG-be Kofi

'Kofi is a TEACHER'

42. Ivagblawo ódú Kofi.

i-vagblawo ó-dú Kofi.

CM-teacher SM.SG-be Kofi

'Kofi is a TEACHER.'

\subsubsection{Focus in possessive constructions}

Possession is expressed by the juxtaposition of the possessor and the possessed. The possessive phrase as a whole can be focused. Sentence (43) contains a possessive phrase Esi afúta á 'Esi's cloth' in subject position. In (44), the possessive phrase is focused with ká. The phrase can be focused but not the possessor. It is not possible to focus part of a constituent of an NP.

43. Esi afúta á abo utsá á nu
Esi a-fúta $=$ á
a-bo
u-tsá =á
$\mathrm{nu}$
Esi $\quad$ CM-cloth $=$ DET SM.SG-stay $\quad$ CM-room $=$ DET in
'Esi's cloth is in the room'

44. Esi afúta á ká abo utsá á nu
Esi a-fúta $=$ á
ká a-le
u-tsá=á
nu
Esi $\quad$ CM-cloth $=$ DET FOC SM.SG-be $\quad$ CM-room $=$ DET in
'ESI's CLOTH is in the room'

The possessive phrase which is in object position can be focused by fronting and marking it with ka. In (45) Esi afúta-á 'Esi's cloth' is in object position. In (46), it is fronted and marked with ka for focus. The object of the clause is in its unmarked position.

45. Ma mé Esi afúta á.
ma mé Esi a-fúta=á
$1 \mathrm{SG}$ sew Esi CM-cloth $=$ DET
'I sewed Esi's cloth.' 
46. Esi afúta á ká ma mé.

Esi a-fúta=á ká ma mé

Esi $\quad$ CM-cloth $=$ DET FOC $1 \mathrm{SG}$ sew

'ESI's CLOTH (no other cloth) I sewed.'

However, neither Esi, the possessor nor afúta, 'cloth' possessum of the same phrase can be extracted and focused individually. Sentence (47) demonstrates the extraction of the possessor Esi and in (48) the possessum, afúta 'cloth' is extracted and focused. These are ungrammatical.

47. *Esi ká ma me afúta
*Esi ká ma-me a-fúta
Esi FOC 1SG-sew CM-cloth
'Esi's I sew cloth'

48. *Afúta ká ma mé Esi
*a-fúta
ká
ma-mé Esi
CM-cloth FOC 1SG-sew Esi
'Cloth I sew Esi's'

\subsubsection{Focusing postpositional phrases}

A postpositional phrase functioning in a clause is focused in the same way like an NP. It is fronted and marked with the focus marker. These are exemplified in sentences (50) and (52).

49. Adzo ózó uti ع́ wá.
Adzo ó-zó
u-ti $=\mathfrak{\varepsilon}$
wá
Adzo SM.SG-go CM-father=DET side
'Adzo has gone to the father's place.'

50. Uti ع́ wá ká Adzo ózó.
u-ti $=\hat{\varepsilon}$
wá ka Adzo ó-zó
CM-father $=\mathrm{DET}$ side FOC Adzo SM.SG-go
'Adzo has gone to THE FATHER'S PLACE.'

51. Obú iló á etsí.
ó-bú
i-lón=á
etsí
3SG-ask CM-word=DET under
'He asked about the information.' 
52. iló á etsi ká óbú.

i-ló=á etsi ká ó-bú

CM-word $=$ DET under FOC 3SG-ask

'THE INFORMATION he asked about.'

In all the examples shown, the constituent that is focused is fronted and marked with the focus marker ka. However, when the constituent to be focused is a pronominal, the independent form of the pronoun in question is used. A gap is left in its normal position in the clause.

\subsection{Predicate focus}

In Logba, focusing of the verb is done by placing the bare form of a copy of the verb before the verb and after the subject. This pattern is different from what is noted in some dialects of Ewe in which a copy of the verb in placed in pre-core position. Duthie (1996:112) writing on linguistic patterns in Ewe, notes that in some dialects, the verb can be front copied' In Logba, however, the real verb occurs with the pronoun prefixed to it in its proper place. The verb bli 'break' in (53) is focused in (54) and kú 'die' in (55) is focused in (56).

53. Tumpa á óblí utsá á nu.

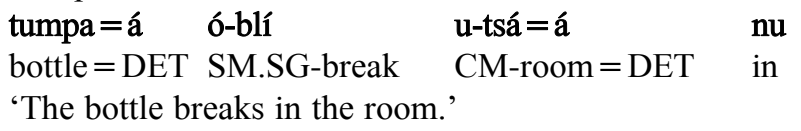

54. Tumpa á blí óblí utsá á nu.

tumpa=á blí ó-blí u-tsá=á nu

bottle $=$ DET break SM.SG-break CM-room $=$ DET in

'The bottle BREAK in the room.'

55. Akpakpla á ókú.

a-kpakpla=á ó-kú

CM-frog = DET SM.SG-die

'The frog died.'

56. Akpakpla á kú ókú.

A-kpakpla=á kú ó-kú

CM-frog = DET die SM.SG-die

'The frog DIED.' 


\subsection{Serial verb constructions and focus}

It is possible to focus the initial verb in an SVC. However, neither the non-initial verb alone nor all the verbs in the SVC can be focused together. The focusing of the initial verb is done by placing the bare form of a copy of the initial verb at the same position between the subject and the verb. In the examples below, the subject is not expressed overtly. The initial verb occurs with the pronoun prefixed to it in its proper place followed by the second verb. The initial verb of sentence (57) below is focused in sentence (58).

57. Otení zó ogbá á yó.

ó-tení zó o-gbá=á yó

3SG-escape go CM-road=DET skin

'He rushed to the road side.'

58. Tení ótení zó ogbá á yó.

teni ó-tení zó o-gbá=á yó

escape $3 \mathrm{SG}$-escape go CM-road=DET skin

'It is rushing to the road side that he did.'

\subsection{Tota dialect}

As indicated at the beginning of the section on focus constructions, the Tota dialect uses a different focusing strategy The prominent NP is fronted and is recapitulated by an independent form of the pronoun followed by the rest of the clause. Sentence (59) illustrates the subject focus and (60), the direct object focus.

59 Seto ole ólá ebitsi é.

$\begin{array}{lll}\text { Seto ol } \varepsilon \quad \text { o-lá } & \text { e-bitsi }=\varepsilon \\ \text { Seto } & \text { 3SG.IND SM.SG-beat } & \text { CM-child=DET } \\ \text { 'SETO beat the child.' } & \end{array}$

60. Ebitsi é olé Seto ólá.

\begin{tabular}{|c|c|}
\hline e-bitsi-ع́ & Seto \\
\hline $\begin{array}{l}\text { CM-child=DET 3SG.IND } \\
\text { 'Sets beat THE CHILD', }\end{array}$ & Seto \\
\hline
\end{tabular}

The pronoun refers to the preposed NP and agrees with it in number. For example, the Plural form of sentence (60) above will use ale '3PLUIND'. This is exemplified below in sentence (61). In sentence (62), imbi 'rice' is a mass noun so iy $\varepsilon$ is the independent pronoun that is selected. 
61. Ebitwo á alé Seto ólá.

$\begin{array}{llll}\text { e-bit-wo=á } & \text { alé } & \text { Seto } & \text { ó-lá } \\ \text { CM-child-PLU = DET } & \text { 3PLU.IND } & \text { Seto } & \text { SM.SG-beat } \\ \text { 'Seto beat THE CHILDREN.' } & & \end{array}$

62. Imbi ع́ iyé ókpé.
$\mathrm{i}-\mathrm{mbi}=\hat{\varepsilon}$
iý́ ว-kpé
CM-rice $=$ DET 3SGIND 3SG-eat
'It is THE RICE he/she eats.

The arguments in the sentence in the Tota dialect behave in similar ways in terms of extraction and focusabilty that is they are fronted and a gap is left in their marked position but postpositional phrases behave in a slightly different way. While in Alakpeti dialect, the focus marker, ka is placed after the NP in the Tota dialect iyé occurs after the head noun.

\subsubsection{Focusing postpositional phrases}

The 3SG Independent pronoun comes in between the NP and the postposition. These are exemplified in sentences (63) and (64), (65) and (66).

63. Adzo ózó utí é wá.

Adzo ó-zó u-tí=é wá

Adzo SM.SG-go CM-father=DET side

'Adzo has gone to the father's place.'

64. Uti ع́ ole wá Adzo ózó.
$\mathrm{u}-\mathrm{ti}=\dot{\varepsilon}$
ole wá Adzo ó-zó
CM-father $=$ DET 3 SG.IND side Adzo SM.SG-go
'THE FATHER HIS PLACE Adzo has gone to.

65. Obú iló á etsí.
o-bú i-ló=
3SG-ask CM-word = DET under
'He asked about the information.'

66 iló á iye etsi óbú.
i-ló=á
iye
etsi ó-bú
CM-word=DET 3SG.IND under 3SG-ask
'THE INFORMATION he asked about.' 


\subsection{Topic and focus}

It is also possible for the topic to coincide with the constituent that is marked for focus. In (67) nqú 'water' is in the unmarked topic position and it is focused.

67 Ndú ká ntsi tumpá á nu.
n-dú ká n-tsi
tumpá=á nu
CM-water FOC SM-be.in bottle $=$ DET in
'It is water (not anything else) in the bottle.'

There are sentences in which the topic and focus are marked on different constituents. In (68) the subject Papa 'father' is the unmarked topic and the predicate lá 'beat' is focused. In (69) the subject oyubitsi 'thief' is the topic and the predicate rî 'hold' is focused.

68. Papa la ólá Kofi ubo é nu.

$\begin{array}{lllll}\text { papa la } & \text { o-lá } & \text { Kofi } & \text { u-bo=é } & \text { nu } \\ \text { father } & \text { beat(FOC) } & \text { SM.SG-beat } & \text { Kofi } & \text { CM-farm=DET in } \\ \text { 'Father, BEAT Kofi in the farm.' } & & \end{array}$

69. Oyubitsi é rí óri ع́ gbaygbay.
o-yubitsi=é
rí
ó-ri $=\hat{\varepsilon}$
CM-thief $=$ DET hold $($ FOC) 3 SG-hold $=3$ SGOBJ fast
'The thief, they DID HOLD him firmly.'

From the discussion, it is clear that topic is the element about which a statement is made and focus, on the other hand, is the element that carries new information. It is also evident that topic and focus actually have special function in the analysis of not only the sentence but the whole discourse (see Payne 1997; Bearth 1999). 



\section{IDEOPHONES, INTERJECTIONS AND PARTICLES}

The chapter is a discussion of three kinds of words: Ideophones, interjections and particles. These categories to a certain extent can be said to share some common features. Ideophone is a word in which the relationship between the sound and the concept is not arbitrary. Interjection and particles are words which express emotion and speaker attitude. Interjections can stand alone but particles and ideophones are dependent on the elements in a clause to express an idea. The discussion opens with ideophones followed by interjections and ends with particles.

\subsection{Ideophones}

Ideophones are depictive of the ideas they express. Westermann (1930) refers to them as 'picture words', Doke (1935) defines an ideophone as a 'vivid representation of an idea in sound' and Duthie (1996) notes that they are 'vocal gestures'. All these statements point to the defining feature of ideophones; that is the sounds that are produced show the concepts that they express. Mostly these sounds are taken from the natural environment based on what people hear and the movements they see around.

Ideophones in Logba also exemplify the general characteristics with some language internal differences which this description hopes to bring out. Some of the features which ideophones display include a unique syllable structure and unique tonal pattern.

\subsubsection{Syllable structure}

Some ideophones have a syllable structure which is different from what is the normal syllable structure of the words. In Logba, there are three syllable types: $\mathrm{C}$, $\mathrm{CV}, \mathrm{CCV}$ (see section 2.1). There is a restriction in the $\mathrm{C}_{1} \mathrm{C}_{2} \mathrm{~V}$ syllable type where $\mathrm{C}_{2}$ is a glide, a liquid or a trill. If the first consonant is a bilabial or velar, the second consonant should be $/ 1 /$. However, most ideophones have the second consonant after labials and velars to be $/ \mathrm{r} /$. The following words in (1) are examples.

$\begin{array}{cll}\text { 1. CC Structure } & \text { WORD } & \text { GLOSS } \\ \text { pr } & \text { pro } & \text { wet, marshy area; spoilt vegetable } \\ \text { gr } & \text { gr } & \text { sound of belching, snoring }\end{array}$

It is possible for the nucleus of the syllable to be lengthened to show the continuity of the action that is being described in the utterance. The $/ \mathbf{r} /$ can function as the nucleus and can be lengthened. The following are examples: 


$\begin{array}{lll}\text { 2. } & \text { WORD } & \text { GLOSS } \\ \text { trrr } & \text { gushing of blood } \\ \text { vrrr } & \text { moving of vehicle } \\ \text { gbrr } & \text { sound of thunder }\end{array}$

Some ideophones have CVC structure where the final $\mathrm{C}$ is normally a nasal. The following are examples:

$\begin{array}{ll}\text { 3. WORD } & \text { GLOSS } \\ \text { gin } & \text { the ring of a bell } \\ \text { glon } & \begin{array}{l}\text { description of lumps on the skin } \\ \text { vim }\end{array}\end{array}$

Sentence (4) below is culled from the introduction of a story illustrating the use of vim 'suddenly' in a sentence as an adverbial.

4. Odze ótsú viim!

$$
\begin{aligned}
& \text { o-dze ó-tsú viim! } \\
& \text { 3SG-land 3SG-on IDEO } \\
& \text { 'It falls on it suddenly!' }
\end{aligned}
$$

Some ideophones have a CVV structure. The final vowel may be lengthened.

Examples are in (5) below:

\begin{tabular}{ll} 
5. WORD & \multicolumn{1}{c}{ GLOSS } \\
shoo & 'noise of flowing river' \\
faa & 'freely' \\
mis & 'without zeal' \\
mii & 'slowly'
\end{tabular}

The final vowel of ideophones can be lengthened to show duration. In the following sentences, the ideophones are in sentence final position and the final vowel is lengthened.

6. Ogridi ódzî tsỹ̃̃̃...
o-gridi ó-dzî
tsyว̃o...
CM-story SM.SG-take.off IDEO.for long

'Story takes off moving for a long time' [15.2.03]

7. Éte gakrana kpoo!
é-te
gakrana
kpoo!
3PLU-HAB keep quiet IDEO.quietly

'They keep quiet!' [15.3.06] 
8. Érí onkpá vlo oyó yó tsyiãa ye ózí asạgbla.

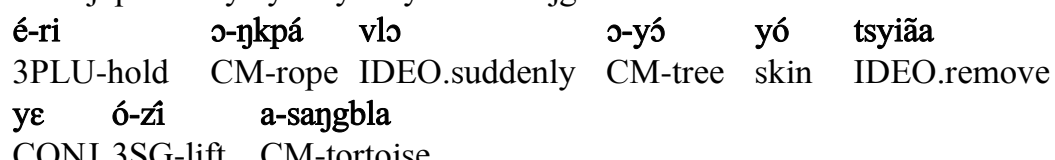

3SG-lift CM-tortoise

'They held rope at once and removed it from the tree and took tortoise.' [15.3.58]

The lenghening depends on the action that is described. The adverbial ideophone vlo 'immediately' is an action that is perceived to have happened suddenly, so the vowel is not lengthened. For example, in story telling, the story is said 'to fall' suddenly on the characters. Odze ótsú wa 'it falls suddenly' odze ótsú vim 'it falls suddenly' wa and vim are ideophones. It is possible for the nucleus vowel to be lengthened for expression.

Some ideophones have an inherent repetitive structure. This structure can permit syllable reduplication or in some cases syllable triplication. The following words are modifiers that are in sentence final position.

9. xe agla fé akontsi ع́ nu sée abo sá nđú miomio
xe a-gla f'é a-kontsi $=\dot{\varepsilon}$
nu sé-e
COND2SG-pour into $\mathrm{CM}$-basket $=\mathrm{DET}$ in finish-CFM
a-bo-sá n-dú miomis
2SG-FUT-fetch CM-water IDEO.cold
If you finish pouring it into the basket, you fetch cold water [15.11.06]

10. Inashina ókpe ojkpe tsibitsibitsibi
i-na-shi-na
ó-kpe
ग-1kpe
CM-person-every-person 3SG-know CM-something
tsibitsibitsibi
IDEO.small small small
Everybody knows small bits about something.' [15.2.80]

11. Binka ódá wa munimunimuni
Binka ๖-dá
wa munimunimuni
Binka SM.SG-talk say
IDEO.undertone
'Binka talks undertone'

\subsubsection{Tonal structure}

Ideophones that have the same segmental form can vary in tone. The tone on an ideophone can either be High or Low. Low tones are associated with bad, unpleasant, amorphous features and High tones refer to things which are nice, pleasant, small and cute. 
12. Ebîtsi ónuma gbágblá
e-bîtsi ó-numa
gbágblá
CM-child SM.SG-fall IDEO.light.small

'The child fell.' (light, small person)

13. Ebîtsi ónuma gbagbla
e-bîtsi ó-numa
CM-child SM.SG-fall IDEO. light.small
'The child fell' (heavy, big person)

14. Udzi ع ózó hlóyíhlóyí
$\mathrm{u}-\mathrm{dzi}=\varepsilon$
ó-zó
hlóyíhlóyí

CM-woman =DET SM.SG-walk IDEO.light.smart.brisk

'The woman walks...' (light, smart, brisk)

15. Udze ózó hloyihloyi
u-dze
ó-zó
hloyihloyi
CM-woman SM.SG-walk IDEO.heavy.slow.dragging movement
'The woman walks...' (heavy, slow, dragging movement)

Other words like pótópótó 'small.marshy' and tóntóntón 'extreme quietness' can have their tones changed to a Low tone potspots 'large marshy' and tontonton 'the sound of water dripping in a container'to introduce a change in meaning. The latter with a high tone suggests that it is a small marshy area but the low tone suggests a bigger wider marshy area.

\subsubsection{Grammatical categorisation of ideophones.}

Ideophonic words can belong to different grammatical categories. The largest number of ideophonic words in Logba belongs to the class of adverbs and adjectives. It is noted that some ideophonic words may have double categorization. This situation is based on how they function in the utterance in which they are found. They normally occur utterance finally.

\subsubsection{Ideophonic nouns}

These are nouns which are most often onomatopoeic and have repetitive $\mathrm{CV}$ or $\mathrm{CVV}$ or $\mathrm{CV}_{1} \mathrm{CV}_{2}$ reduplicative structure. Some examples are:

\section{NOUN GLOSS}

yéné(bi) baby - refers to the noise of a baby when crying (also in Ewe).

fiófió broom - the sound made when sweeping with a broom.

kusekuse peace - tranquility solemnity and orderliness (also in Ewe). 
The morpheme bi which is suffixed to some of the nouns such as jéné(bi) suggests a dimunitive form of the said noun. It is probably taken from the stem of the word u-bi 'child' from which the class prefix is removed. The cognate forms of -bi 'root for child' are found across the languages in the area. Examples are Ewe ${ }^{46}$, Akan and Likpe.

\subsubsection{Ideophonic verbs}

The ideophonic verbs that are attested in the data are mainly intransitive. Two are used in the sentences below:

17. ombue ópro
o-mbue
ó-pro
CM-orange SM.SG-go.bad.IDEO

'The orange had gone bad'

18. avi awlui
a-vi
a-wlui ${ }^{47}$
CM-groundnut SM.SG-be.tiny.IDEO
'The groundnut has small grains'

\subsubsection{Ideophonic adverbs}

Ideophonic adverbs are expressive modifiers to verbs and they occur utterance finally. They are shown in the example sentences below:

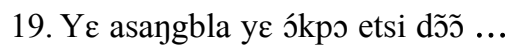
Ye a-sangbla
ує ว-kpo
e-tsi
dก̃
CONJ CM-tortoise CONJ 3SG-lie CM-down motionless.IDEO

'And tortoise then lay under the tree motionless;' [15.3.26]

20. Nkı á ndó hoo.
$\mathrm{n}-\mathrm{k} \mathbf{\jmath}=\mathbf{a}$
n-dó
hoo
$\mathrm{CM}-\mathrm{hen}=\mathrm{DET}$
SM-come.out
many.sudden.IDEO
'The hens came out in large numbers.'

\footnotetext{
${ }^{46}$ Ewe has vi 'small' as the diminutive form that is suffixed to most nouns. This is derived from the word vi 'child' Heine et al (1991), Ameka (1991)

${ }^{47}$ There is a non verb ideophone in Ewe with the inherent iterative structure wluiwluiwlui 'multitude of small particles'
} 
21. Nqúć nyú miómiómiómió.
n-dú- $\varepsilon$
n-yú
miómiśmiśmiś
CM-water SM-be.cold cold.cool.IDEO

'The water is extremely cold.'

22. Futsu $\varepsilon$ óto kpetekpetekpete.
futsu $=\varepsilon$
ó-to
kpetekpetekpete
soup $=$ DET SM.SG-be.thick thick.IDEO

'The soup is very thick.'

23. Oló tso iva á fúnúfúnúfúnú.
ó-ló-tso iva =á
fúnúfúnúfúnú
3SG-PRSPROG-cut thing = DET bit bit bit.IDEO
'He/She cut the thing in bits.'

\subsubsection{Ideophonic adjectives}

Ideophonic adjectives follow the nouns they qualify. This is shown in sentence (24):

24. Mba no nqú miomiomio.
m-ba no n-dú
miómiómió
1SG-come drink CM-water
fresh.cold.IDEO
'I drank fresh and cold water.'

It is possible for these ideophones to function as adjectives or adverbs in an utterance. For example, in (21) miomiomis 'slowly' functions as adverb. The same ideophone is used in (24) as adjective to modify ndú 'water' The difference in context of use brings about the shift in meaning.

mis can be used with a low tone without reduplication. The final vowel is prolonged to show the extent to which a person or thing is weak. In the sentence below, mis 'weak' is an adverbial modifying blo 'make' to express how weak the speaker feels.

25. Amú iyónu iblo miso.
amú iyó-nu i-blo miso
1SG skin-in SM-make weak.IDEO
'I experience bodily weaknesses.' 


\subsubsection{Ideophones and sentence types}

There is a claim that in some languages ideophones occur in certain sentence types Schaefer (2001). ${ }^{48}$ In Logba, however, ideophones can be used in a variety of sentence types. This is shown below:

Imperative

26. gákrana kpoo!

gákrana kpoo

keep quiet serene.IDEO

'Keep quiet!'

Negative

27. Asá gblele maábá okuétéxoé.

a-sá gblele ma-á-bá o-kuétéxoé

CM-man many.IDEO NEG-FUT-come CM-funeral

'Many men will not come to the funeral.'

Prohibitive

28. Vui blo basabasa.

vui blo basabasa

never make unruly.behaviour.IDEO

'Do not put up unruly behaviour.'

Question

29. Nkpakplawo abé ele oystsigbo é ite daa
n-kpakpla-wo a-bé
e-le
o-yotsigbo =é
CM-frog-PLU AM-Q
SM.PLU-be CM-stump = DET
i-t $\varepsilon$ daa
CM-under deep.beneath.IDEO.
'How many frogs are deep under the stump?'

\subsubsection{Ideophones in discourse}

Ideophones are used in different types of discourse. Notably, one finds them in descriptions, conversations and in story telling. In (30) gbun is a simulation of the sound made when a person releases fart and in (31) the sound of swallowing food with force is described by the ideophone glu.

30. Jfíc ifie gbuń
ว-fíe i-fie gbuń
3SG-release CM-fart sound.IDEO
'He farts with a big sound'

\footnotetext{
${ }^{48}$ Ideophones F.K. Erhard Voeltz \& Christa Kilian-Hatz Ideophones 339-355 John Benjamins
} 
31. Jmé fufúi glu.

ว́-mé fufúi glu
3SG-swallow fufu force.IDEO
'He swallowed fufu with force.'

Sometimes, a particular ideophone in a discourse might have two different interpretations and one needs a context to get the meaning. In two different story telling sessions kpoi occurs: In (32) kpoi refers to the sound made when the bird is shot by the hunter whilst the same ideophone in (33) refers to the sound made when the gourd breaks.

32.Tonu (ta onu) kpoi. Etsi vim ye olenta osé

$\begin{array}{ll}\text { to-nu } & \text { kpoi } \\ \text { let-hear } & \text { noise of a certain friction.IDEO. }\end{array}$

E-tsi vim ye o-lenta o-sé

CM-ground sudden.IDEO CONJ 3SG-fall 3SG-cease

'Hear! a noise. On the ground it fell at once. That is the end. [15.3.50]

33.Ye ofonyi é ebli kpoi

ye o-fonyi=é e-bli kpoi

CONJ CM-gourd = DET SM.SG-break noise when a thing breaks.IDEO

'and the gourd break 'kpoi' [15.2.65]

Even though ideophones have unique tonal structure and syllable structure they can be found in the following grammatical categories (noun, verb, adjective, and adverb) of the language. The non-arbitrary relationship between sound and meaning with most of them is what makes them special in the language.

\section{I3.2 Interjections}

Interjections in Logba are words which express overflow of emotion, speaker attitude and are normally not used in a syntactic construction with other word classes. They may occur before a sentence or may constitute a sentence on their own. Because interjections seem to share a close relationship with particles and connectives, their classification is not without some complications. While some linguists consider them as a unit outside the grammatical categories like pre-patterned expressions and multiword expressions others think they belong to the canonical parts of speech.

Ameka (1991, 1992) offers a coherent analysis of interjections which I find relevant to use as a reference point in describing and categorising Logba interjections. He makes a distinction between primary interjections and those words which belong to other grammatical classes but are used in utterances as interjections. The 
former, he refers to as primary interjection and the latter he calls secondary interjections. He then categorised interjections into three. They are:

a. expressive interjection

b. conative interjection

c. phatic interjection

These are discussed in the sections below:

\subsubsection{Primary interjections}

These are little words or in some cases combination of sounds which are not words in the language. They are used mainly to express emotion. The following Logba expressions are known to be used in Ewe with similar meanings and in the same situations:

a. ã $<$ surprise $>$

b. o ó < Negative response; that is not the case $>$

c. oh oh oh <opening for a libation prayer by a priest to get the attention of the ancestors. This is said standing with a calabash in both hands.

d. koó kokoí < praise, and sign of approval. This is said by a man standing at the back of the priest concurring with what the priest demands from the ancestors.

In (34) the interjection ã is an expression of how surprised the hunter was when he saw tortoise in the forest. The story teller uses the interjection artistically to achieve this objective.

34. Ko ã in๖ yayi me ózó

$\begin{array}{llllll}\text { ko } & \text { ã } & \text { i-no } & \text { yayi } & \text { me } & \text { ó-ź́ } \\ \text { Only } & \text { INTJ(surprise) } & \text { CM-meat search } & \text { here } & \text { 3SG-go } \\ \text { Only ah! meat is what he searches for here } & {[15.3 .40]}\end{array}$

\subsubsection{Secondary interjections}

These are words which belong to a syntactic category such as noun or verb etc. It includes expressions that are used to draw the attention of a person to get out of danger. The situation below shows the use of amúmá 'my mother' and Yesu anyintse 'Jesus, thank you' as secondary interjections.

On one occasion, a woman was cooking in the kitchen and was overheard saying amúmá 'my mother'. It was later found out that her child nearly stumbled on a bowl containing hot oil. After we got to the scene and she narrated what happened to us, one woman who came to the scene cried aloud: Yesu, anyintse 'Jesus, thank you.' 


\subsubsection{Expressive interjections}

Expressive interjections are utterances which are expressions of the speaker's mental state at the time of speaking. Some expressive interjections found and used in Logba are stated below and translations are offered in English and the appropriate contexts in which they are used are provided with some comments that will throw light on their meaning.

eí good - this is usually accompanied with a smile.

dzalélé shock! When this is being said the speaker is normally in a trembling mood.

hmm self pity, something is worrying the speaker. This is not addressed to anyone. In most cases, the speaker puts the palm under the chin in a pensive mood.

bóboí grief

áo pain

adzeí a pain at a particular spot.

tsiä contempt for a person

ohóó expression used to ridicule a thief; it is also used to point out to a person that he is lying.

eheé I now know; this is accompanied usually with a smile.

yoo used to indicate that a person has agreed to a request or assent to a demand or a wish

aii / wui used when a person is in physical pain.

\subsubsection{Conative interjections}

Conative interjections are expressions used to get attention of a person or calls directed at an animal or a pet. Some of the expressions are secondary interjections. The following expressions are used to call persons. They show the level of respect in the social relation of the speech participants.

hey call the attention of a person (considered to be impolite) sh order children to be silent. This is said with the forefinger on the lips. 
The following calls are used to get the attention of animals.

kaî drive away goat, sheep

sui drive away fowl/hen

\subsubsection{Phatic interjections}

These are vocal signs used to establish social contact. They are accompanied with non linguistic signs like hugging and movement of the body which is culturally interpreted as acceptable. This includes greetings, welcome, thanks and response to questions as below:

yeyeye expression to welcome a person

ehé a sign that one has remembered a point that is forgotten

yeé response to a call

yoó agreement to something

The following phatic interjective expressions: anyé iqú 'so it is', anyé tá 'so give', yue 'that is it' and yua 'that it is' are said when libation prayer is being recited. The person who is customarily required to stand behind the officiating priest repeats these expressions aloud after every movement.

The word kusekusekuse 'peace' is also a common expression in libation prayer. In one of the routine prayer sessions on ayádzi gbantoá 'the first Saturday' Amowasa 'Logba priest' prays for peace for the people of Logba. He says these words repeatedly in a prayerful mood as he pours the water from the calabash on the ground. As the water is being poured, the person who stands behind the priest responds to the invocation for the ancestors to bring peace by saying betebetebete. This is a solemn wish that they should be soaked in the peace. The water that is being poured on the ground is the symbol of the peace.

ikpá tútútú 'true exactly', la alága 'speak' and zo iyé tsú 'go on it'. These are expressions that women and praise singers use when the chief addresses the people on important occasions. This is aimed at demonstrating that the chief commands great respect and has the full support of the people.

dze iyé nyî <look it be or it is really what should be said> 1́kpó iyé $\operatorname{kpom\varepsilon ~<~it~lies~at~the~place~it~should~lie~or~'It~is~the~right~thing~>~}$

These are emotional responses to demonstrate support for someone who is bold enough to point out the right thing in public in a responsible manner. These expressions above come close to routine expressions (see chapter 14). 


\subsection{Particles}

Ameka (1998) refers to particles as 'little words that are used to encode a speakers attitude towards a proposition or part thereof and are syntactically integrated into the sentence in which they occur'. In Logba, the following words are identified as particles:-

ná 'interrogative particle'

naa 'interrogative particle, confirmation'

anaa 'interrogative particle, alternative view'

tá, 'politeness particle'

ló, 'addressive particle'

loo 'addressive particle'

All the example sentences below are culled from stories and conversations.

\subsection{1 ná 'interrogative particle'}

ná is a clause final interrogative particle that occurs in content questions that contain the initial question particle. In sentence (35) ná is used in what I will call a 'didactic question'. It is used by a story teller to draw the attention of the audience who are children to think about the situation he presents to them. The question can be asked without ná and the sentence will be grammatical. However, the use of ná in this context is to make the children become aware of the dramatic importance of the bird's singing loudly in the forest and the tragic consequences for all the animals who live in the forest. That is, the hunter gets to know where the animals are and he shoots all of them, dead.

35. Mé óló dze dá wá adzi é té gakrana ná?

\begin{tabular}{|c|c|c|c|c|}
\hline $\mathrm{m \varepsilon}$ & ó-ló-dze & dá & wá & $\mathrm{a}-\mathrm{dzi}=\varepsilon$ \\
\hline Q & 3SG-PRSPROG-need & tell & say & CM-bird $=$ DET \\
\hline
\end{tabular}

COMPL keep.quiet IP

'Why is he telling bird to keep quiet?' [15.3.36]

In the example sentence (36) below, the final vowel of ná is lengthened with a rise in pitch. This is an utterance by a head of family who is settling a case involving two brothers. He becomes highly irritated by the attitude of one of the witnesses who is hedging. He fails to provide clear answers to pertinent questions and the head of family explodes with this content question marked by náa at the uttermost boundary directed to him: 
36. Omó ódó utsá á naá?
- -mó
ó-dó
u-tsá=á
naá?
3SG-Q AM-build
CM-house $=$ DET INTP
'Who build the house? (I demand to know from you!)

náa can also be used in a polar question to express ones opinion with an expectation of a response. In the sentence below, the speaker expresses her idea as she sees a picture. She expects an answer or an alternative viewpoint from the addressee. For instance, the speaker of this sentence below is describing what she sees in a picture -Frog Story- and she wants a confirmation from the people seeing the same picture or to agree with her. She nevertheless thinks her point of view is right.

37. Agbi ع ónú nwó utsá ye ódze té óyú akpakpla á nwówo utsá nu náa.

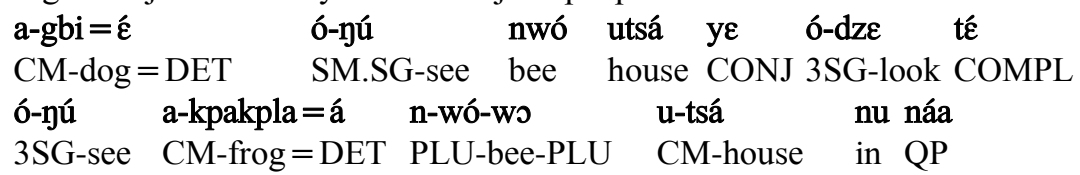

'The dog sees the beehive and look whether It will see frog in the beehive.' [15.2.29/2]

náa may be modified to give another interpretation. This modified form suggests an angry mood of the questioner who expects an alternative response. Most often. anáa is said with a rising pitch. (36) can be said with anáa replacing náa. The final vowel of anáa may be lenghened. When it is lenghened, it is an indication that the questioner is impatient with the person addressed.

\subsection{2 tá 'politeness marker'}

The utterance final particle tá can be viewed as a signal of politeness in semiformal situations. It is only used in questions. This expression is also used when the speaker wants to show deference to the addressee. This becomes evident on the two occassions that I heard it used. In a casual conversation, a Logba citizen who is far younger than the chief wanted the chief to tell him the name of the leader of the Asafohene at Adzakoe. The sentence in (38) is what he said.

38. Unansa, Asafohene gbawo é xé obo Adzakoe me élédzi lé tá?

$\begin{array}{llll}\text { u-nansa, Asafohene } & \text { gbawo=é xé o-bo } & \text { Adzakoe } \\ \text { CM-chief Asafohene leader=DET RP 3SG-stay } & \text { Adzakoe } \\ \text { me é-lé-dzi } & \text { lé } & \text { tá } & \\ \text { Q 3PLU-PRSPROG-call } & \text { 3SGOBJ PM } & \text { PSO } \\ \text { 'Chief, how is the leader of the Asafohene at Adzakoe called?' }\end{array}$


Another example of the use of tá is found in the question posed by my consultant to the queenmother about what was done to the girls who are undergoing puberty rites in the past when there were no churches in Logba.

39. Totokpa, xé okpayadzigo minya mé elebloć tá?

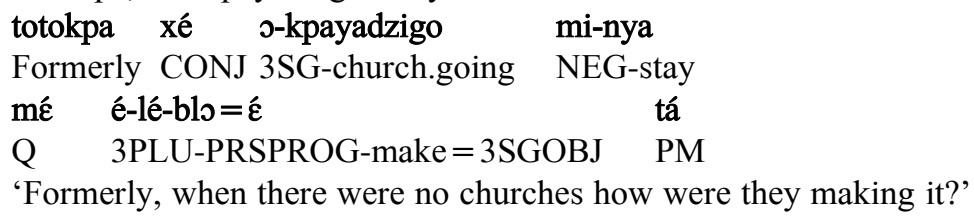

tá is also used in 'get well intention expressions' This is used when a person is bereaved or when something bad happens to someone. (Refer to chapter 14. Expression of sympathy) Expressions of this nature need to show concern and this borders on politeness and affection. Example sentence (40) and (41) are said to a sick person by visitors who went to his house to wish him well.

40. Me akpó tá

$\begin{array}{lll}\text { me } & \text { a-kpó } & \text { tá? } \\ \text { Q } & \text { 2SG-lie } & \text { PM }\end{array}$

'Do you feel well?'

41. Me adzi tá?

$\begin{array}{ll}\text { me } & \text { a-dzi } \\ \mathrm{Q} & \text { 2SG-wake.up PM } \\ \text { 'Do you wake up well?' }\end{array}$

\subsection{3 ló 'addressive particle'}

ló 'addressive particle' either suggests surprise or a warning to the addressee. This particle gives additional information because the sentences are complete without the addressive particle. The examples below illustrate the use of addressive particle in these sentences:

42. Jnta lé (ole) ivakpe nu ló!

$\begin{array}{lllll}\text { o-nta } & \text { ole } & \text { i-vakpe } & \text { nú } & \text { ló } \\ \text { 3SG-self } & \text { 3SG } & \text { CM-knowledge } & \text { in } & \text { ADR }\end{array}$

'According to what he himself thought (I inform you). [15.2.31]

43. Tobá ló!

to-bá ló!
never-come ADR
'never come ( I warn you ).' 


\subsection{4 loo 'addressive particle'}

loo is used to show that the speaker has finished his turn and he is signalling the audience or the addressee to have the floor. It has a low tone and it is used in the final position in greetings as in (48), welcome statements as in (46), in introductions of a story as shown in (47), and to signal an end of a talk as in (49). Sentences (44), (45) and (46) are dialogue from story telling where Papa tells the school children a story. (See chapter 15.2 and 15.3 for the stories).

44. Story teller (Papa): Ebito, Ebito,

E-bi-to $\quad$ E-bi-to
CM-Child-PLU CM-child-PLU
'Children, Children' [15.3.01]

45. Children:

Papa!

papa

Father, (response to an elderly male) [15.3.02]

46. Children:

Anu ani na loo

$\begin{array}{lll}\text { anu } & \text { ani-na } & \text { loo! } \\ \text { 2PLUPOSS } & \text { 2PLUSUBJ-walk } & \text { ADR } \\ \text { 'You are welcome' } & {[15.3 .02]}\end{array}$

47. Story teller: $\quad \mathrm{Nu}$ nu ogridi loo!

$\begin{array}{llll}\text { nu } & \text { nu } & \text { o-gridi loo! } \\ \text { hear-IMP } & \text { hear-IMP } & \text { CM-story } & \text { ADR } \\ \text { 'Hear story!' } & {[15.2 .01]}\end{array}$

48

tá awá loo

tá a-wá loo
give 2SG-greeting ADR
'Greetings to you'

49.

Amú ugbi é ozu etsî loo

$\begin{array}{lll}\text { amú } & \text { u-gbi=é } & \text { o-zu } \\ \text { 1SG } & \text { CM-voice=DET } & \text { SM.SG-descend } \\ \text { etsí } & \text { loo } & \\ \text { down } & \text { ADR } & \end{array}$

My voice has descended. I am done. [15.9.97]

In this chapter, ideophones, interjections and particles are discussed. Ideophones are depictive of the ideas they express, they display unique syllable structure and can belong to different grammatical categories. Interjections are used to express emotion, speaker attitude and intention. Particles are little words that express a 
speaker's attitude towards a proposition and unlike interjections, which may constitute an utterance, particles are intergrated into the sentence in which they occur. 


\section{ROUTINE EXPRESSIONS}

Routine expressions are standardised phrases used for socio-cultural interaction which is speech community specific. This includes greetings, expressions used to show appreciation to someone at work, invitations to someone at dinner and expressions of welcome. In Logba, these expressions are indicative of the goodwill that the interlocutors feel towards one another. There are social and cultural norms associated with these expressions each of which should be strictly observed. These expressions are cultural codes and are given a particular interpretation depending on how and where it is performed.

Routine expressions in Logba are described in this chapter. An attempt is made to explain the circumstances in which these expressions are used and their underlying meanings. The chapter is organized as follows: The chapter opens with greetings and is followed by expressions of welcome. Expressions of gratitude and sympathy are treated next. The chapter is concluded with disclaimers and expressions of farewell.

\subsection{Greetings}

In Logba, like in other African communities, greeting one another is considered an important social behaviour. One hardly sees people passing by without exchanging greetings. People who even reside in the same house are supposed to greet one another when they wake up in the morning. It is not strange to find a family head early in the morning going round the compounds to greet the people in the lineage. $\mathrm{He}$, in turn reproaches the young ones if they do not do likewise. There are a number of non-linguistic features associated with greetings. The following are some of them: When greeting an elderly person one should bend the upper part of the body as a sign of reverence. Men who are in cloth should remove the part covering the left shoulder when they are exchanging greetings with elders in the community. If the person who is about to greet wears a hat, it should be removed in the course of greeting as a sign of respect.

It is also against cultural norms to greet when going to the rubbish heap or toilet. It is permitted on the person's return from the rubbish heap. When one greets on one's way to the rubbish heap or toilet, it is taken as a non-verbal statement which is synonymous with: 'I shit in your mouth' or 'I throw the rubbish in your mouth'. This is regarded as a culturally unacceptable behaviour. As such, fines are imposed on people who go against these rules and they are tagged as 'uncultured'. Similar situations are observed for Ewe in Ameka (1991) and in Ga in Dakubu (1981).

The day is divided into two parts in respect of the type of greeting. The first part is the morning to midday and the second is from midday to the night. 


\subsubsection{Morning to midday greetings}

Below is the greeting and response pair showing the various turns:

1. A: tá awá loo
tá a-wá
100
say 2SG-greeting ADR
'Greetings to you'

2. B: awá zii, afán(u) awá
a-wá zii
2SG-greeting be good CM-house greeting
'Greetings to the home, I greet the house'

3. A: awá, ani dzíi?

$$
\begin{aligned}
& \text { a-wá } \quad \text { ani-dzíi } \\
& \text { 2SG-greeting 2PLU-wake.up } \\
& \text { 'greetings, are you fine?' }
\end{aligned}
$$

4. B: yoo, ani bo enzí?

$$
\begin{aligned}
& \text { yoo ani-bo enzí } \\
& \text { yes, 2PLU-stay well } \\
& \text { 'Yes OK?' }
\end{aligned}
$$

This could be prefaced with the appropriate address term. For example, unansá, 'chief,' am(ú)gusa 'my brother'

\subsubsection{Midday to evening greetings}

Below is the greeting and response pair:

5. A: ngaanu loo

$$
\begin{array}{ll}
\text { n-gaanu } & \text { loo } \\
\text { 1SG-salute } & \text { ADR } \\
\text { 'I salute you' } &
\end{array}
$$

6 B: Yawəen, afan (ahá) etsí

$$
\begin{array}{llll}
\text { yawoen } & \text { a-fan a-há } & \text { e-tsí } \\
\text { yes } & \text { CM-house } & \text { CM-people AM-stay } \\
\text { 'Yes, the people in the house are in good health' }
\end{array}
$$




\subsubsection{The greeting response: Yawoen}

Yawoen occurs only in greetings in Logba and is used in response to greetings from midday to the night. Some speakers use it also as a response for greetings in the morning. All the people consulted could not offer any clear cut meaning for this expression. This does not however mean that it is only phatic. The absence of Yawoen in response to the greeting shows that the person responding to the greeting does not share the love and comradeship wholeheartedly with the person who is greeting him or her. Coincidentally, all the GTM languages surrounding Logba Tafi, Nyagbo, and Avatime use this expression in response to greetings. This is attested in the following greeting response adjacency pairs in the data from the following neighbouring GTM Languages as well as Ewe below: ${ }^{49}$

Tafi

7. $\mathrm{A}_{1}$ : Ayenó o

B: $\quad$ Yawoen, wokónye

$\mathrm{A}_{2}$ : $\quad$ No le mó o.

Nyagbo

8. $\quad \mathrm{A}_{1}$ : Ayigbó o (SG). Ayimó o (PLU)

B: $\quad$ Yawəen woks o / Wopamé o.

$\mathrm{A}_{2}$ : Kpasi o.

Avatime

9. $\mathrm{A}_{1}$ : Ayé

B: Yawoen olókpasi

$\mathrm{A}_{2}$ : $\quad$ TKpasi

It is culturally undesirable to interrupt people who are in the middle of a discussion with greetings. If a person passing by wants to greet these discussants, he has to seek permission with the phrase ani yé loo 'you stand' and when it is granted with the response yoo 'yes' then he can proceed with his greeting. In case the people are sitting A will greet with the expression ani tsii loo 'you sit'. Normally, a shorter version of the greeting is used in situations like this. This is shown (7) and (8) below:
10. $\mathrm{A}_{1}$ : Aniyé loo ani-yé $\quad$ loo
2PLU-stand ADR
'You stand'

\author{
$\mathrm{A}_{2}$ : Anitsí loo \\ ani-tsí loo \\ 2PLU-sit ADR \\ 'You sit'
}

\footnotetext{
${ }^{49}$ In Ewe, what is heard is awəe This word is used by old people and it is dying out.
} 
11. B: Eé awú fé anaa

eé awú f́é a-na-á

yes 2SG also 2SG-walk-Q

'You also you walk?'

A:Yoo

'OK'

12. B: Afánu etsí

a-fánu e-tsí

CM-house 3PLU-stay

'The house is well?' (Is all well at home?)

\section{A: Yoo \\ 'OK'}

There are other forms of greeting which are determined not by the time of day but by the situation or the activity that the addressee is performing.

\subsubsection{Working in the farm}

Apart from being neighbours in the house, much value is placed on healthy social relationship among people who are farming in one area especially those who share boundaries. When one goes to farm, and one's neighbour is already working before one arrives, one is expected to acknowledge the neighbour's presence by greeting him or her thus:

13. A: Dze ntá loo

$$
\begin{aligned}
& \text { dze n-tá loo } \\
& \text { look CM-hand ADR } \\
& \text { 'look hand!' }
\end{aligned}
$$

B: Yoo

'Yes'

The first part uttered by A is a calque on the Ewe phrase: kpo asi loo 'look hand'. which is used in the same situation.

\subsubsection{Doing manual work}

When a person is doing any type of manual work and one sees him, the passer-by can salute him with the expression: Ayekoo. This expression is also used in Ewe and other GTM languages like Nyagbo and Tafi but it is a borrowed word from possibly the Ga language. Another expression used with its response is as below: 
14.A: $\quad$ Awú atsi otsú loo

awú a-tsi o-tsú loo

2SG.IND 2SG-stay CM-top ADR

'You are on top'

B: Yoo

'Yes'

This makes the addressee (person working) aware of the presence of the speaker and also an indication that he appreciates the work he is doing and wants him to continue. This expression is normally heard when people are engaged in communal labour.

Exchange of greeting reflects the order in which interactants come to the work place. Normally, the person who comes later is the initiator of the greeting response pair. It will be noted that words ite 'front' and amá 'back' are used to refer to people who are ahead when coming to a place and the people who are behind at home respectively. One thing that is worth noting is that these words attract the / $\mathbf{i}$ / cross reference on the verb. An indication that ite 'front' and ama 'back' are perceived as mass nouns. This is shown in (15) below:

15. A Ité ikpó loo?

i-té i-kpó $\quad 100$

CM-front SM-lie ADR

'You are in front?' Lit: The front lives there.

B: ikpó; amá ikpó?
i-kpó a-má i-kpó
AM-be.lie CM-back SM-lie
'It lives; the back lives?'
A: ikpó
i-kpó
3SG-be.lie
'it lies'

When a person returns from farm, people in the house will welcome him with the greeting as in (16):

16. People in the house: Awu uwa ókpós?

$$
\begin{aligned}
& \text { awu u-wa ó-kpó-o } \\
& \text { 2SG CM-forest SM.SG-lie-Q } \\
& \text { 'Your forest is fine?' }
\end{aligned}
$$


Farmer: $\quad$ Yoo, ókpó

yoo ó-kpó

OK 3SG-lie

' $\mathrm{OK}$, it is fine'

The person from the farm will then take his turn and greet the people in the house as in (17):

17. Farmer:

Amá íkpó

a-má í-kpó

CM-back SM-lie

'Is the back fine'

People in the house: ikpó

i-kpó

3SG-lie

'It lies'

\subsubsection{Greeting when people are eating}

When a person enters a house and realises that the people in the house are eating, he does not interrupt with a greeting. He must first call their attention by saying the phrase as in (18):

18.

A: $\quad$ Dze ntá loo

dze n-tá loo

look CM-hand ADR

'look hand!'

The expressions that follow are varied. They are all an invitation of the visitor to come and join them in sharing the meal. The four versions of this are shown in (19).

19. $\mathrm{B}_{1}$ : $\quad$ Yoo na ba ume.

$\begin{array}{llll}\text { yoo na ba u-me } \\ \text { yes walk come } & \mathrm{CM} \text {-here } \\ \text { 'Yes come here.' }\end{array}$

$\mathrm{B}_{2}$ : $\quad$ Yoo ba atú wá. (PLU)

yoo ba atú wá

Yes come 1PLU place

'Yes, come to us.' 


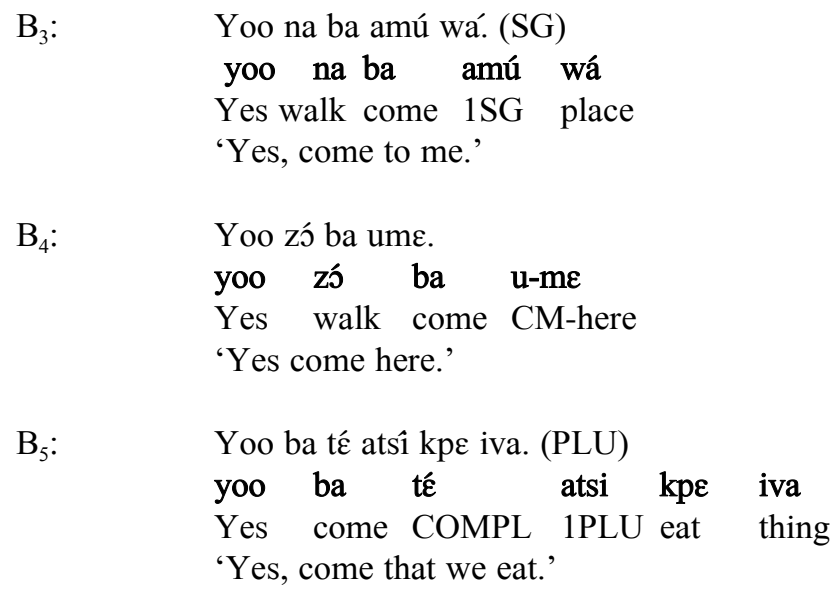

The visitor will then say umokoe izi 'this place is good' which is an indirect reference that the members of the house are enjoying good food and drinks. It is after this exchange that the people in the house will invite the visitor to greet them or ask him to defer the greeting so that they will all enjoy the meal together.

\subsubsection{Welcoming people}

The Logba people have expressions which they use to welcome people who have travelled somewhere and returned. These expressions are also used for strangers when you see them after they have been introduced. It is used to welcome people when the interlocutors have not seen one another for a long time. There are two variants of the welcoming expression: one used when the person to be welcomed is singular as in (20a) and the other when they are more than one as in (20b)

20a. SG: Awa ana loo.

$\begin{array}{lll}\text { awú } & \text { a-ná } & \text { loo } \\ \text { 2SGIND } & \text { 2SG-walk } & \text { ADR } \\ \text { 'You are welcome.' } & \end{array}$

20b. PLU: Aná ni ná loo.

$\begin{array}{lll}\text { anú } & \text { ani-na } & \text { loo } \\ \text { 2PLU.IND } & \text { 2PLU-walk } & \text { ADR } \\ \text { 'You are welcome.' } & \end{array}$

The response in each case is Yoo 'OK'

This greeting suggests that the addressees have walked. It is similar to the Ewe expression woe zo 'you (SG) have walked' miawoe zo 'you (PLU) have walked' 
(see Ameka 1991). It is interesting to note that there is a special welcome when a person returns from farm. This is as in (21) below:

21. People in the house: Awú ogbá dzí ahá etsi

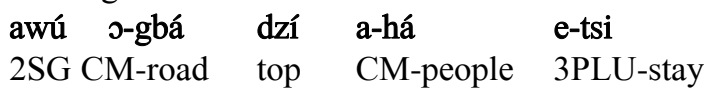

'Are your people on your journey well?'

$\begin{array}{ll}\text { Visitor: } & \text { Etsí } \\ & \text { e-tsí } \\ & \text { 3PLU-stay } \\ & \text { 'They are fine' }\end{array}$

People in the house: Awú (u)gusa otsí

awú u-gusa o-tsí
2SG CM-neighbour 3SG-stay
'Is your neighbour fine?'

In all cases after the welcome response pair, the visitor will be given water to drink to cool off and then the greeting follows. The greeting in this situation is centered on the people and friends of the visitor at where he comes from.

In the plural, Awu egusa atsi is used in the Tota dialect while Awu egusa etsi is the form in the Alakpeti dialect.

22. Visitor:

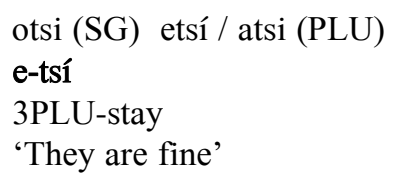

People in the house: $\quad$ Awa na loo (Awú ana loo)

$\begin{array}{lll}\text { awú a-na } & \text { loo } \\ \text { 2SG.IND } & \text { 2SG-walk } & \text { ADR } \\ \text { 'Welcome' }\end{array}$

Visitor: $\quad$ Yoo

'OK'

After the how-are-you questions the oldest of the family in the house at the time of the arrival of the visitor will ask of the visitor's purpose of visit by saying as below: 
23. Elder: Atsú wá iyú

atsú wá i-yú

1PLU side AM-be.cold

'Our place here is cool'(There is peace here)

This expression is used when everything is going on peacefully in the family. If, on the other hand, there is a death or an accident in the family, the expression in (24) is used.

24. Elder:

Atsú wá ibo odzá

atsu wá i-bo o-dzá

1PLU side AM-stay CM-fire

'Our place here is 'hot''(There is misfortune here)

The visitor states his mission and asks them to tell him the iyu 'cold' or the odza 'fire' that is in the family by asking them as follows:

25. Visitor:

Anú wá áblé

anú wá á-blé

2PLU side SM-own

'How is the situation like at your side?'

\subsubsection{Acknowledgement of the priest's return after libation prayer}

The priest, after libation prayer, returns to take his seat with the elders and other family members. They greet him thus:

26. Elders:

Aw(ú) akpi

aw(ú) a-kpi

2SG.IND 2SG-go

'You have gone'

Priest: $\quad$ Yoo

'OK'

The elders welcome the priest because it is believed that he has been to the ancestors to offer prayer on their behalf and come back. The elders then thank the priest for being so caring and patriotic.

\subsection{Expressing gratitude}

When a person is given a present, he is expected to show how grateful he is to his benefactor. The recipient also expresses thanks to God. Some thank the ancestors 
because they believe they are dependable messengers of God and He works through them. The following expressions are used:

27.
Anyîntsé
a-nyîntsé
2SG-thanks
'Thank you'
Okpaya, anyíntsé.
okpaya a-nyintsé
God 2SG-stay-strong
'God, thank you.'

\subsection{Expressions for congratulations}

When a person is fortunate and has won a prize or has given birth to a bouncing baby people in the community troop to the house to share the joy and congratulate the parents especially the mother. The expression below is used most often:

28.

Awú iyó iva inyintse.

awú i-yo iva i-ny(a)-intse
2SG CM-skin thing
'Your luck is strong.'

\subsection{Expressing sympathy}

In a situation where a person is bereaved or when something bad happens to someone, for example, when a person is involved in an accident or is bereaved the members of the family and other well wishers in the community go to the house of the sick person to express their sympathy. The following expressions are used after the usual greetings:

Expressions to the sick:

29

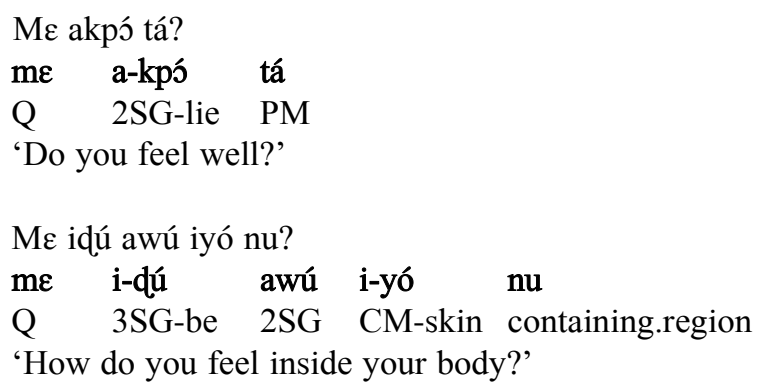


With these empathetic 'get well intention' questions, the sick person tells the visitors the progress and his general state of health and they in turn reply with encouraging words, one of which is:

30.

Ibíkó wú.

i-bí-kó wú

3SG-FUT lift.up 2SGOBJ

'It will be better.' (Lit: It will be lifted up from you.)

The sickness is metaphorically taken as a heavy load placed on the sick person that will be lifted from him. The following expressions are therefore used to console the bereaved person:

Expressions to the bereaved person:

31

$$
\begin{aligned}
& \text { Awú afida é. } \\
& \text { awú a-fida=é } \\
& \text { 2SG.IND 2SG-meet=3SGOBJ } \\
& \text { 'YOU have met it.' } \\
& \text { Awú ayú é } \\
& \text { awú a-yú=é } \\
& \text { 2SG.IND 2SG-see=3SGOBJ } \\
& \text { 'YOU have seen it' }
\end{aligned}
$$

These expressions show that the person they have come to visit has come into contact with something unfortunate. In cases where it is a chain of bereavements, some people use the Present Progressive marker in both expressions: Awú alofida é 'You are meeting it' Awú alonu é 'You are seeing it.' Before the sympathisers leave the house of the bereaved, the person whom they visited will wish them well by saying:

32.

$$
\begin{aligned}
& \text { Anú ani vé ina yó } \\
& \text { anú } \quad \text { ani vé i-na } \\
& \begin{array}{l}
\text { 2PLU.IND } 2 \text { yLU save } \\
\text { 'You have sympathised with a person' }
\end{array}
\end{aligned}
$$

\subsection{Disclaimers}

In Logba, as well as many Ghanaian languages, an adult native speaker is expected to display his knowledge of the social and cultural norms through the way he interacts linguistically with the people. When one wants to enter a person's house one has to announce his presence before he enters by saying Agoo and the response 
from the people in the house is ina to ba 'let the person come'. Agoo is also used when one wants people to give way to him in a crowded market or a farm path. The use of Agoo and the response is the same in many Ghanaian languages.

When one wants to use a word or an expression which one considers to be vulgar or profane one should use the words: taflatse or kafra to preface what one considers to be a socially undesirable expression.

Matá wú zugbo 'I give you head' is used when one wants to ask a favour from someone or wants to speak to an addressee considered to be older, or occupying a social status higher than the speaker. When a person wants to give something to another person, the right hand should be used. It is culturally unacceptable to use the left hand. However, if it becomes necessary to use the left hand, the giver should indicate that he is aware that the left hand is not what he should use. The expression below is used in such situations:

33. Giver: $\quad$ Kafra, eble ló.

$\begin{array}{lll}\text { kafra } & \text { e-ble } & \text { ló } \\ \text { Excuse } & \text { CM-left } & \text { ADR }\end{array}$

'Excuse, it is left.'

Mata wú zugbo eble ló.

ma-ta wú zugbo e-ble ló

1SG-give 2SGOBJ head CM-left ADR

'Your pardon, it is left.'

The recipient will then use the response below as he takes the item:

34. Recipient: $\quad$ Yoo agbashi.

OK a-gbashi

yes CM-hand

'OK hand'

\section{$14.6 \quad$ Expressing farewell}

Normally, when a person is to embark on a journey, he informs his people and they in turn wish him a safe journey to wherever he is going. If he is due to return, they tell him to return on time as in (35):

35.

Ta ba kaba.

ta ba kaba

let come early

'May you come back early.' 
However, if his return is not scheduled, they bid him farewell as in (36) and (37): The examples are singular and plural.

36.

SG

Ta na (e)nzi.

ta ná enzi

let walk well

'Safe journey.'

PLU

Ta aniná enzi.

ta ani-ná enzi

let 2PLU-walk well

'Safe journey.'

SG

37. गkpaya ta ogbáwú.

okpaya ta ogbá wú

God let road 2SGOBJ

'Let God be on your path.'

PLU

Jkpaya ta ogbánú.

okpaya ta ogbá nú

God let road 2PLUOBJ

'Let God be on your path.' 



\section{LOGBA TEXTS}

These texts are collected from native speakers who are resident in the Logba towns to show how the language is really spoken. Stories, proverbs, riddles and folk stories are represented. There are also procedural and socio-cultural organisational texts.. Interlinear English gloss and a free English translation is provided.

\subsection{Frog, where are you?}

This is a story re-telling from Frog story (Berman and Slobin 1994) a popular picture book story used by linguists working on systematic analysis on language and cognition. The story is re-told by Rosalyn Adzah, a student in the Jim Bourton Secondary School, Logba. She is 16 years and a native of Tota. The story was recorded on $12^{\text {th }}$ February 2004.

A child, a dog and a frog which is kept as a pet in a bottle lived in a house. The frog got out of the bottle and the child and the dog were looking for it. They looked in the shoe, bottle and across the house but did not find it. The boy and the dog went to the forest to search for the frog. The boy saw a hole in the ground and looked for the frog inside but only a rat ran out of the hole. In their search, they found a beehive in a tree. They held the tree and the bees scattered and chased them. The boy saw a hole in a tree and looked inside for the frog. An owl came out of the hole and they ran and fell. They saw an anthill and the boy climbed it. When the boy was on the anthill, he saw an antelope at the back of the anthill and he climbed it. The antelope ran, the boy held the horns and the dog followed. The boy fell into a big river. It was there he saw the frog and took it home.

01. E-bîtsi-kloyi o-kpe a-gbé kpe a-kpakpla é-nya CM-child-small CM-one CM-dog CONJ CM-frog SM.PLU live 'There lived a small child, a dog and a frog'

02

$\begin{array}{llllll}\text { A-kpakpla=á } & \text { a-ri-é } & \text { fe tumpa nu ye } & \text { o-du } \\ \text { CM-Frog=DET } & \text { 3PLU-hold-3OBJ } & \text { in } & \text { bottle in } & \text { CONJ } & \text { 3SG-be } \\ \text { i-vavialiva } & \text { ye } & \text { a-tsa-vialiiva } & & \text { a-fá-nu. } & \\ \text { CM-pet } & \text { CONJ } & \text { 3PLU-HAB-pet } & \text { CM-house-in } & \end{array}$

'They took a frog which is a pet and put it in a bottle; they play in a house'

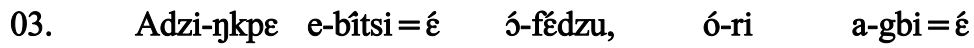
day-one child $=$ DET SM.SG-sleep 3SG-hold $\quad \mathrm{CM}-\operatorname{dog}=\mathrm{DET}$

$\begin{array}{lllll}\text { ka o-yó } & \text { ye akpakpla=a } & \text { xé } & \text { ó-tsi . } \\ \text { put CM-skin CONJ } & \text { frog=DET RP } & \text { SM.SG-stay } \\ \text { tumpa nu ó-dó } & \text { tenyi á-va } & \\ \text { bottle in 3SG-go.out } & \text { escape } & \text { CM-place } & \end{array}$

'One day, the child slept with the dog close to him; the frog which was in the bottle escaped' 
04. Idi i-wa ye a-dze akpakpla=a yáyi

day SM-break CONJ 3PLU-start frog=DET search

'Day broke and they started to look for the frog'.

05. A-yáyi-é

pétée ma-kpe-nú iva etsi.

3PLU-search=3SGOBJ all NEG-know-NEG thing down

'They looked for it for a long time but they could not find it'

06. E-bitsi=é ó-bo-dzé akpaiva nu gake

$\mathrm{CM}$-Child $=\mathrm{DET} \quad$ SM.SG-come-look boot in CONJ

mo-nú-nú akpakpla $=\mathrm{a}$

NEG-see-NEG frog=DET

'The child came to look into the boot but he did not see the frog'

07. Agbé f́é ó-dzé tumpa =a nu xé a-ri akpakpla

$\operatorname{dog}$ also SM.SG-look bottle=DET in RP 3PLU-hold frog

akpakpla =á fi-é gake mo-yú-nú-é.

frog $=$ DET $\quad$ put $=3$ SGOBJ CONJ NEG-3SG see-NEG $=3$ SGOBJ

'The dog looked into the bottle in which the frog was put but it did not see it'

08. Agbé o-zi tumpa na o-fu ye ebitsi=é fé dog SM.SG-lift bottle to CM-nose CONJ child=DET also o-dzu de fesre otsoe ye a-la-yayi

SM.SG-stand to window fringes CONJ 3PLU-PRSPROG-search akpakpla odzogbe.

frog outside

'The dog put the bottle to the nose and the child stood close to the window and they were looking for the frog outside'

09. A-dze okusioku gake ma-yú-nú akpakpla=á 3PLU-look everywhere CONJ NEG-see-NEG frog $=$ DET

'They searched everywhere but they did not see the frog'

10. agbé o-kebu etsi, tumpa =a ó-ló-le

dog SM.SG-jump down bottle=DET 3SG-PRSPROG-be.at

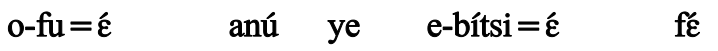

$\mathrm{CM}$-nose $=\mathrm{DET}$ mouth CONJ CM-child $=\mathrm{DET}$ also

ó-ló-dze fé ó-ló-nú akpakpla=á náa

SM-SG-PRSPROG-see also 3SG-PRSPROG-see frog=DET QP

'The dog jumps down, the bottle is on the nose and the child also is searching to see if the frog is there'

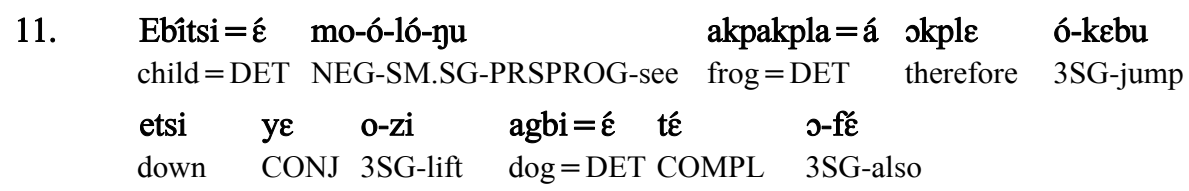


mo-ó-tó-fui.

NEG-3SG-PSTPROG-get.lost

'As the child did not see the frog it came down and carried the dog so that it would not get lost'

12. A ina-nyo a-dzu-ye u-tsa ama fesre etsi. 3PLUperson-two 3PLU-return-stand CM-house back window down 'They, two persons stood up at the back of the house down the window'

13. A-ná kuko tson ye a-ba dzu-ye o-yó 3PLU-walk round long CONJ 3PLU-come return-stand tree

o-kpié etsi té a-yú akpakpla=á náa AM-INDEF down COMPL 3PLU-see frog=DET QP

'They walked round for a long time and came and stood up under a certain tree to see if they could find the frog'

14. A-yayi =é pétée, ma-yú-nú=é.

3PLU-search $=3$ SGOBJ all NEG-see-NEG $=3$ SGOBJ

'They searched all places but they did not see it' $\begin{array}{lllll}\text { 15. Á-lá-na } & \text { kuko tson bi fo uwa nango nango } & \text { ba } \\ \text { 3PLU-PRSPROG-walk } & \text { round long come to forest big big }\end{array}$ o-kpié nu ye á-bá AM-INDEF in CONJ 3PLU-come to CM-tree AM-INDEF below

'They are walking round for a long time into a certain big forest and they came under a big tree'

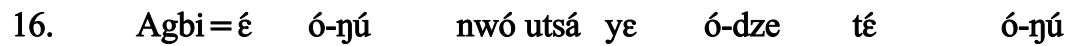
$\operatorname{dog}=\mathrm{DET} \quad$ SM.SG-see bee house CONJ 3SG-think COMPL 3SG-see akpakpla =ánwó-wo utsá nu náa. frog $=$ DET bee-PLU house in QP

'The dog sees the beehive and looks whether is sees the frog in the beehive'

17. Ebîtsi $=\hat{\varepsilon} \quad$ f́c $\quad$ ó-ló-dze $\quad$ vutsi 0 -kpié $\quad$ nu child $=$ DET also SG-PRSPROG-look hole AM-INDEF in té ó-bo-nú akpakpla=á vutsi=é nu náa COMPL 3SG-come-see frog $=$ DET hole $=$ DET in $\quad$ QP 'The child is also looking in a certain hole whether the frog is in the hole'

18. Agbi $=\varepsilon$ ó-ló-dze té $\quad$ ó-yú $\operatorname{dog}=$ DET SM.SG-PRSPROG-look COMPL 3SG-see frog nwó-wo utsá=á nu ye ebítsi=é $\quad$ fé bee-PLU house $=\mathrm{DET}$ in CONJ child $=\mathrm{DET}$ also ó-ló-dze vutsi=é nu ye oglui ó-ké 3SG-PRSPROG-look hole $=$ DET in CONJ mouse SM.SG-jump 
do vutsi $=\varepsilon \quad$ nu

out hole $=$ DET in

'The dog is looking for the frog in the beehive and the child is looking in the hole and a mouse rushed out of the hole'

19. D-vo i-tá té o-dzu tsi etsi

3SG-fear 3SG-result say 3SG-sit stay.in down

'He was afraid, and as a result he sat down'

20. Agbi $=\varepsilon^{\prime} \quad f^{\prime} \varepsilon^{\prime} \quad$ o-tsi etsi ó-ló-yayî $\quad$ akpakpla =á

$\operatorname{dog}=$ DET also SM.SG-sit down 3SG-PRSPROG-look frog $=$ DET

nwó-wo=á nu-é ye nwó-wo u-tsá lenta

PLU-bee-PLU $=$ DET in $=$ DET CONJ bee-PLU CM-house fall

ye n-dó.

CONJ SM-come out

'The dog also sat and was looking for the frog in the beehive but it fell and the bees scattered'

21. $\mathrm{A}-\mathrm{gbi}=\hat{\varepsilon} \quad \mathrm{kp} \varepsilon \quad \mathrm{e}-\mathrm{bîtsi}=\hat{\varepsilon} \quad$ á-hu tenyi.

Dog $=$ DET CONJ CM-child $=$ DET 3PLU-run escape

The dog and the child run for safety.

22. Ebîtsi=é $\quad$ o-kpo kla fُ

child=DET SM.SG-move hide into tree big

o-kpié etsi

AM-INDEF under

'The child went and hid under a big tree'

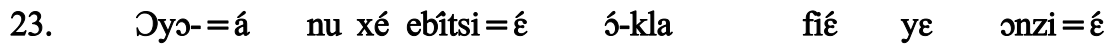

tree $=\mathrm{DET}$ in RP child $=\mathrm{DET}$ SM.SG-hide into $\mathrm{CONJ}$ owl=DET

o-kpié ó-dó.

AM-INDEF 3SG-come out

'The tree into which the child hid was a certain owl which came out'

24. $\quad$ गnzi $=\varepsilon \quad$ ó-du

owl $=$ DET SM.SG-be

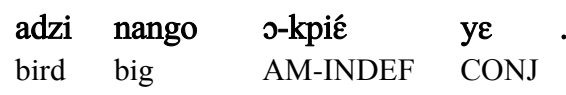

o-tso-fle atsi

3SG-HAB-fly night

'The owl is one big bird which can fly at night'

25. Ye ebîtsi=é ó-nú é la, ó-vo inta

when child $=$ DET $\quad 3$ SG-see $=3$ SGOBJCFM 3 SG-fear greatly

té ó-lenta o-yó=á nu.

COMPL 3SG-fall CM-tree $=$ DET in

'When the child saw it, he became very much afraid that he fell from the tree' 
26. Agbi=毛 fé nwó-wo=á a-do agba-ma té

$\operatorname{dog}=\mathrm{DET}$ also bee-PLU $=$ DET SM.PLU-follow road-back COMPL

a-ba $\quad \mathrm{ti}=\hat{\varepsilon}$

3PLU-come sting $=3 \mathrm{SGOBJ}$

'The dog also, bees followed it to sting it'

27. Ebítsi=é ó-huite bi f́e uwá nango o-kpié child =DET SM.SG-escape come into forest big AM-INDEF in 'The child ran into a certain big forest'

28. $\quad \operatorname{Agbi}=\varepsilon \quad$ f́c $^{\prime} \quad$ nwó-wo=á á-do $\quad$ o-gba-má. $\operatorname{dog}=\mathrm{DET} \quad$ also bee-PLU $=\mathrm{DET} \quad 3 \mathrm{PLU}$-follow CM-road-back 'The dog also the bees followed it'

29. Ebîtsi=é ó-hu bi ve lé u-tu

child $=$ DET 3 SG-run come pass climb CM-anthill

nango o-kpié tsú

big AM-INDEF on

'The child run climb onto a big anthill'

30. Utu=é tsú xe o-yi-é

anthill $=$ DET on RP 3SG-stand-3SG CONJ 3SG-see CM-antelope

u-tu=é amá.

$\mathrm{CM}$-anthill $=\mathrm{DET} \quad$ back

'The hill on which it was standing he saw an antelope at the back of the anthill'

31. Agu ntsa=á dzaa ko ye n-dó ye ó-yú antelope horn $=\mathrm{DET}$ only only CONJ PLU-come.out CONJ 3SG-see 'The animal's horn was only what came out he saw'

32. Ebîtsi = $\varepsilon$ mó-kpe-nú ye ó-rî child=DET NEG know-NEG CONJ 3SG-hold antelope-horn with hand

\begin{tabular}{|c|c|c|c|}
\hline $\mathrm{y} \varepsilon$ & $\mathrm{agu}=\varepsilon$ & $\hat{o}-\mathrm{Z} \hat{1}=\varepsilon$ & ntsa \\
\hline CONJ & antelope $=\mathrm{DET}$ & SM.SG-carry $=3 \mathrm{SGOBJ}$ & horn \\
\hline yع & ó-he & & \\
\hline ONJ & 3SG-pull go & & \\
\hline
\end{tabular}

'The child did not know so he held the antelope's horn with hand and the animal took him on the horn and dragged him'

33. ye ó-bo yú Agbi=é fé ukunkpe ye

CONJ 3SG-come see $\operatorname{dog}=\mathrm{DET}$ also somewhere CONJ

ó-zi o-f́̃ na ntsa tsú

3SG-carry 3SG-also put horn on

'They came to the place where the dog was and took it also on the horn' 
34. ó-bo mi-á lenta fé n-đú nango n-kpié. 3SG-come take-3PLU.OBJ fall in CM-water big AM-INDEF 'It took them to fall in a very big river'

35. Agbi $=\varepsilon \quad \mathrm{kp} \varepsilon \quad$ ebítsi $=\varepsilon \quad$ a-nya $\quad \mathrm{n}$-wa=á $\operatorname{dog}=$ DET $\quad$ CONJ child $=$ DET SM.PLU-stay $\quad$ PLU-forest $=$ DET in

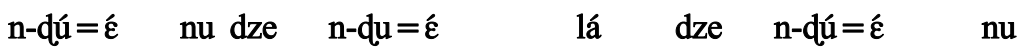
water $=$ DET in start $\quad \mathrm{CM}$-water $=\mathrm{DET}$ swim start $\mathrm{CM}$-water $=\mathrm{DET}$ in kuks té a-yu akpakpla=á náa. round COMPL 3PLU-see frog=DET QP 'The dog and the child stayed in the forest in the water. They started searching in the water to see if they could see the frog'

36. $\mathrm{Agu}=\dot{\varepsilon} \quad \mathrm{f} \dot{\varepsilon} \quad$ ó-le $\mathrm{u}$-kpo o-kpié antelope $=$ DET also SM.SG-be CM-hill AM-INDEF top CONJ ó-ló-dze buyó $\mathrm{n}$-du=é nu. 3SG-PRSPROG-look afar $\mathrm{CM}$-river $=\mathrm{DET}$ in

'The animal also was on a certain mountain top looking in the river'

37. Agbi $=\varepsilon \quad$ u-wasa ó-zî $\quad$ Agbi $=\tilde{\varepsilon} \quad$ fé $\quad$ i-mo-nu $\operatorname{dog}=$ DET CM-owner SM.SG-lift $\quad \operatorname{dog}=$ DET into CM-neck-in ye á-lá-yayi té á-lá-do CONJ 3PLU-PRSPROG-search COMPL 3PLU-PRSPROG-come.out n-dú-ć nu

$\mathrm{CM}-$ water $=$ DET in

'The dog owner carried the dog on his neck searching if it is coming out of the water'

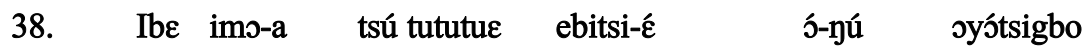
time that $=$ DET on exactly child=DET SM.SG-see stump

\begin{tabular}{|c|c|c|c|}
\hline o-kpié & ว-ló-wa & agbi- $\varepsilon \quad$ ogakrana & té \\
\hline AM-INDEF CONJ & 3SG-PRSPROG-say & dog $=$ DET keep.quiet & COMPL \\
\hline á-lá-yú & akpakpla-á & & \\
\hline & frog $=\mathrm{DET}$ & & \\
\hline
\end{tabular}

'At exactly that time the child saw a stump and was telling the dog to be quiet to see if they could see the frog'

39. Ebitsi $=\varepsilon \quad \mathrm{\varepsilon p} \varepsilon \quad \mathrm{agbi}=\hat{\varepsilon}$ pétée a-dzu zó

child $=$ DET CONJ $\quad \operatorname{dog}=$ DET all SM.PLU-returngo

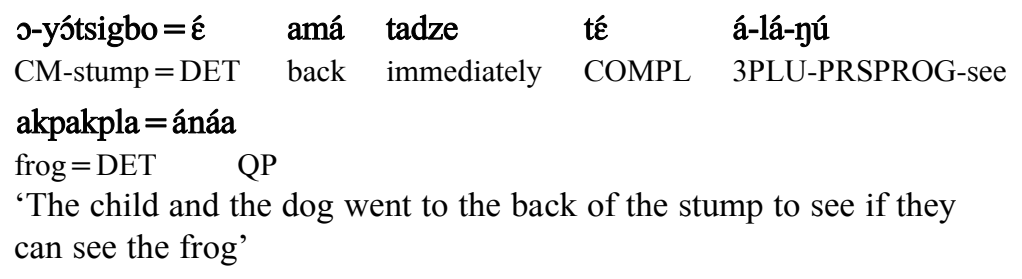


40. Tadze ko n-kpakplawo n-nys n-tsi

mediately only CM-frog-PLU AM-two SM.PLU-stay

o-yótsigbo =é amá.

CM-stump $=$ DET back

'Immediately then they saw two frogs at the back of the stump'

41. ó-yú ó-ble ka anyi 3SG-see 3SG-own put face

'he identified his.'

42. Iyé amá n-kpakpla-wo gblelele n-dó gbi

3SGIND back CM-frog-PLU many SM-come many

ye ebítsi $=\hat{\varepsilon} \quad$ kpe Agbi $=\hat{\varepsilon} \quad$ á-dzuye

CONJ child $=$ DET CONJ dog $=$ DET 3PLU-stand

o-yótsigbo $=\tilde{\varepsilon} \quad$ tsú

CM-stump $=$ DET on

'After that many frogs came out plenty and the child and the dog stood on the stump'

43. ує a-la-dze f́̃ buyó .

CONJ 3PLU-PRSPROG-look from distance

'and were looking at them over there'

44. Ebítsi=é

child $=$ DET SM.SG-walk go come take 3SG-own CONJ 3PLU-CONJ

agbi $=\hat{\varepsilon} \quad$ ye á-ve ye á-sa.

dog $=$ DET CONJ 3PLU-pass CONJ 3PLU leave

'The child went to take his own and they and the dog came passed (and left)'

45. A-kpe agbi=é á-sa ye a-húhú

3PLU-CONJ dog=DET SM.PLU-leave CONJ 3PLU-wave

n-gbashi $=\tilde{\varepsilon} \quad$ yika $\quad$ n-kpakpla $\quad$ n-gango $=\hat{\varepsilon}$

PLU-arm $=$ DET direction $\quad$ PLU-frog $\quad$ PLU-rest $=$ DET

'He and the dog went away and waved hands to the rest of the frogs

\subsection{Ananse and the wisdom gourd}

Asafo Kudjo (Age 56), a native of Adzakoe told this story on $26^{\text {th }}$ March 2004 to pupils of Adzakoe Roman Catholic Primary school where it was recorded. The video recording is available.

Spider and family including his brother Dekanyo live in one of the villages in Adzakoe called Gbamuzo. Spider was selfish and envious of his friends. As a result, he planned to take all the knowledge in the world and hid it in a place which 
will be known to him alone. As part of this plan, he went to Logba market to buy a big gourd, collected all the knowledge and stuffed them into the gourd. Spider then decided to hide the knowledge high up in a tree. He put the gourd on his chest when he was climbing the tree. His brother Dekanyo advised that he should put the gourd at his back. Spider, in his frustration, realized that some of the knowledge remained which he did not collect. Spider then left the gourd and it fell on the ground and broke. Knowledge then returned to everybody's brain.
01. $\mathrm{Nu} \mathrm{nu}$ o-gridi loo!
hear (IMP) hear (IMP) CM-story ADR
"Listen to story"

02. O-gridi tó-ó-ba-a!

CM-story let-SM.SG-come-ADR

"Let the story come"
03. O-gridi ó-dzi tsyõo ye ó-ba dze
CM-story SM.SG-take off IDEO CONJ 3SG-come land
i-die-nu tsú
CM-world-in on

Story takes off for a long time and falls on the world

04. o-dze ó-tsú

3SG-land 3SG-on

'it falls on it'

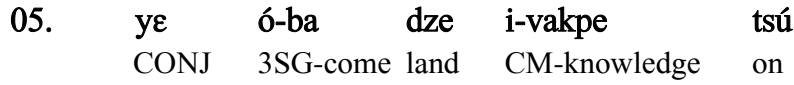

'And it comes and falls on knowledge'
06. o-dze ó-tsú vla
3SG-land 3SG-on IDEO
'it falls on it with vla'

07. ує ó-ba dze a-gbí tsú, a-gbi-glom

CONJ 3SG-come land CM-spider on CM-spider-APPEL

'Then it falls on spider, spider' (APPELATION)

$\begin{array}{llll}08 . & \text { ó-dze ó-tsú } & \text { viim! } \\ \text { 3SG-land } & \text { 3SG-on } & \text { IDEO } \\ \text { 'it falls on it viim!' } & \end{array}$

09. ye ó-ba dze u-gusa Đekanyo tsú

CONJ 3SG-come land brother Đekanyo on

'Then it falls on brother Đekanyo'

10. ó-dze ó-tsú vim

3SG-land 3SG-on IDEO

'It falls on it viim!' 
11. Aha a-me peté-e xé ma-dzi- $\varepsilon$

people AM-DEM all-EMPH RP 1SG-call-CFM

'All these people I call,'

12. Kpaita, á-pete á-nyá Adzakoe kəfe o-kpié nu now 3PLU-all 3PLU-stay Adzakoe village AM-INDEF in 'Now, they all stayed in one of the villages in Adzakoe'

13. xé é-tse-dzi té Gbámuzo nu

RP 3PLU-HAB-call COMPL Gbámuzo in

'Which they used to call Gbamuzo (Lit: put me on go)'

14. I-taté $\mathrm{A}$-gbi $=\varepsilon$ xé ó-nú iva mo-ta i-na AM-result CM-spider $=$ DET when SM.SG-seething NEG-give person 'When the spider gets something, he does not give it out to any person'

15. yé o-kple ye é-nya u-mokoe pétée lá

CONJ CM-REAS CONJ 3PLU stay CM-there all UFP

$\begin{array}{lllll}\text { a-ble } & \text { o-va } & \text { i-ti-kpe } & \text { (l) } \varepsilon & \text { a-me }\end{array}$

3PLU-own CM-behaviour 3SG-PTPROG-eat 3SGOBJ CM-stomach

" And because when they all stayed there he is envious of his friends'

16. уย

CONJ CM-REAS AM-make CM-mind COMPL

ó-ló-ba

fushi

AM-PRSPROG-come take.from

'That is why he made up his mind that he would take away'

17. i-na-shi-na i-zugbo-nu bu-go=é

CM-person-every-person $\quad$ CM-head-in $\quad$ count-NOM $=$ DET

'everyone's thinking. (wisdom)'

18. xé ó-ri-é ónta

RP 3SG-hold=3SGOBJ AM-own

'Which everyone possesses to himself'

19. i-vakpe xé ó-ló-fushi- $\varepsilon$

CM-knowledge RP 3SG-PSPROG-take from-CFM

'Knowledge which he is taking'

20. ó-ló-kpomi kla ko

3SG-PSPROG-collect hide only

'he is collecting it and hide it only'

21. i-nashina mo-ó-ló-kpe

CM-everyone NEG-SM.SG-PRSPROG-know CM-anything 'everyone so that no one knows anything'

22. Ko o-le a-gbigloms o-le wa ko

only 3SG-be CM-spider SM.SG-be side only 
i-vakpe i-nya

CM-knowledge SM-stay

'It is he, spider alone whose bosom that knowledge would stay'

23. Ikpá yé ว́-kpó lé o-fonyi=é

true CONJ 3SG-set out buy CM-guord=DET Akpana

o-vu=é $\quad$ nu

$\mathrm{CM}$-market $=\mathrm{DET}$ in

'Truly, he set out to buy the gourd in the Akpana market'

24. Ibi-me nu Akpana o-vu=é e-nyá Egemi

time-this in Akpana CM-market=DET SM.SG-stay Egemi

u-zugbó u-mó

CM-head CM-there

'This time the Akpana market is on the top of the Egemi mountain there'

25. Té ani kpe okunie é-lé-dzi

Q 2PLU know that.place 3PLU-PRSPROG-call

Egemi- $\varepsilon \quad$ de

Egemi-EMPH Q(Ewe)

'You know that place they are calling Gemi?'

26. I-bo $\quad \mathrm{u}-\mathrm{kpo}=$ é $\quad$ tsú. $\quad \mathrm{y}^{\prime} \varepsilon$ ó-kpo $1 \varepsilon \quad$ o-fónyi 3SG-stay CM-mountain=DET on. CONJ 3SG-go buy CM-gourd 'It is on the mountain. And he went to buy a gourd'

27. nango nango nango o-kpié yé ó-mí mla big big big AM-INDEF CONJ 3SG-take bring very big and brought it'

28. Yé ó-bo fo-e,

CONJ 3SG-come reach-CFM

'When he came back,'

29. yé ó-ri a-ha pété-pété ivakpi- $\varepsilon$

CONJ 3SG-hold CM-people all-all knowledge-EMPH

'then he collected all the people's knowledge'

30. Ye ó-mî f́̂́ o-fonyi $=\hat{\varepsilon} \quad$ nu

CONJ 3SG-take put CM-gourd=DET in

'And put it in a gourd'

31. ग-nta ale i-vakpe nú lo 3SG-self 3SG CM-knowledge mouth ADR

'According to what he himself thought (I inform you)' 
32. Yedze a-ha pété i-vakpi-£́

then CM-people all CM-knowledge-EMPH

'Then all the knowledge of the people'

33. o-fushî- $\varepsilon$

aha nta

3SG-collect 3SGOBJ people hand

'he collected it from the people's hand (from them)'

34. Yर́ o-mi fé $\quad$ o-fonyi $=\hat{\varepsilon} \quad \mathrm{nu}$

CONJ 3SG-take put CM-gourd=DET in

'And put it in a gourd'

35. Ekple xé o-dzi do-e

now COND 3SG-stand go out-CFM

'Now when he went out'

36. O-fonyi=é iboté to ó-ba $\mathrm{mi}=\hat{\varepsilon}$

$\mathrm{CM}$-gourd $=$ DETbecause should SM.SG-come take $=3$ SGOBJ

ko a-gu oyó nu

hang CM-top tree in

'The gourd, because he has to take it and hang it in a tree at the top'

37. Mé ó-blo té xé o-mî o-fonyi=é

Q 3SG-make COMPL if 3SG-take CM-gourd=DET

mi ko a-gu

take hang CM-top

'What does he make if he takes the gourd to hang on the top?'

38. Yedze- $\varepsilon$ iboté ó-lé ग-yó=ó

then-EMPH because $3 \mathrm{SG}$-climb CM-tree $=$ DET

'Then it means, he climbs the tree'

Interlude with song in Ewe

39. $\mathrm{Agbi}=\varepsilon$ xé o-ri ivakpi $=\varepsilon \quad$ pété

spider $=$ DET RP SM.SG-hold $\quad$ CM-knowledge $=$ DET all

'The spider who collected all the knowledge'

40. xé ó-bó-mi lé o-yó

RP 3SG-FUT-take climb CM-tree

'that he will take climb the tree'

41. Menu anu ani kpe té ó-mî Q 2PLU 2PLU know COMPL 3SG-take 3SGOBJ put 'Where do you think he will put it'

42. xé ó-lé o-yó=á-e

RP 3SG-climb CM-tree $=$ DET-Q

'as he climbs the tree?' 
43. Ó-mi (1)é na a-mátsi

3SG-take 3SGOBJ put CM-back

'He puts it at the back'

44. Aha, tee o-fonyi $=$ é ome de téé

AFF may.be CM-gourd=DET AM-this COND maybe

ó-le a-mántsi

3SG-be.located CM-back(of body)

'Yes, may be if this gourd were at his back'

45. i-boté té ó-mi o-fónyi=é na

CM-REAS COMPL 3SG-take CM-gourd=DET put

'Because as he takes the gourd'

46. xé o-mi lé o-yó

RP 3SG-take climb CM-tree

'which he takes to climb the tree'

47. I-boté xé é-lé-lé o-yó=ó

CM-REAS if 3PLU-PRSPROG-climb $\quad \mathrm{CM}$-tree $=\mathrm{DET}$

mi-du o-kótu

NEG-be CM-chest

'Because if they are climbing a tree it is not on the chest'

48. e-te-mi lé o-yó=ふ?

3PLU-HAB-take climb CM-tree $=$ DET

'they use to climb the tree?'

49. Ee! Yé ว́-zó xé ó-bo dze o-yó=ð́ lé yes! CONJ 3SG-go as 3SG-come start CM-tree $=\mathrm{DET}$ climb 'Yes as he starts to climb the tree'

50. yé ó-mi o-fonyi=é

CONJ 3SG-take CM-gourd $=$ DET

'And takes the gourd'

51. Xé ó-mî na a-men yé ó-dze o-yó lé RP 3SG-take put CM-stomach CONJ 3SG-start CM-tree climb 'Which he takes on the stomach and he starts to climb the tree'

52. Ani susu té i-nya lé tsi-i 2PLUthink COMPL 3SG-possible climb stay-Q

'Do you think that it is possible to climb?'

53. Ao! Yé o-dze ग-yó=ð lé O-le-zó no! CONJ 3SG-start CM-tree $=$ DET climb 3SG-PRSPROG-go

o-lenta

3SG-fall

'No! and he starts to climb the tree. He is going, he falls' 
54. O-lé-zó

o-lenta O-lé-zó

ó-lenta

3SG-PRSPROG-go 3SG-fall 3SG-PRSPROG-go3SG-fall

'He is going, he falls. He is going, he falls'

55. Yé u-gusa xé é-lé-dzi Đekanyo- $\varepsilon$

CONJ CM-brother RP 3PLU-PRSPROG call Đekanyo-EMPH

'And his brother who they call Đekanyo'

56. Ó-dzi-é 'aḿ-gusa, mi-1́-qu

3SG-call $=3$ SGOBJ 1 SGIND-brother NEG-SM-be

any $\varepsilon$ é-te-blo- $\varepsilon^{\prime}$

so 3 PLU-HAB-make $=3$ SGOBJ

He called him and said, 'my brother it is not this way it is done'

57. 'Dzú o-fonyi=é ta mí mla a-ma.'

turn back CM-gourd =DET COHOR take bring CM-back

'Turn the gourd to your back Let's bring it to the back'

58. Xé á-mi o-fonyi=é mla a-má=á

if 2SG-take CM-gourd =DET bring CM-back $=\mathrm{DET}$

'If you turn the gourd to the back'

59

$\begin{array}{llll}\text { á-lé } & \text { o-yó=ó } & \text { i-tso } & \text { fíc } \\ \text { 2SG-climb } & \text { CM-tree=DET } & \text { SM-fast } & \text { exceed }\end{array}$

'You climb the tree faster'

Interlude with a song in Ewe
60. Yर́ a-gbi o-tsitsi dze e-tsi tsỹ̃
CONJ CM-spider SM.SG-turn look CM-ground IDEO
$\begin{array}{llll}\text { yé } & \text { o-wá } \quad \text { té } & \tilde{a} \text { ã }\end{array}$
CONJ 3SG-say COMPL MIME

'And spider turns and looks down and said that 'ã ã' (Miming)

61. "Nanєkpa" i-vakpi=é xé ó-ló-fushi-e

then CM-knowledge $=$ DET RP SM-PRSPROG-collect-EMPH

'Then the knowledge he is collecting,'

62. i-na $\mathrm{kp} \varepsilon \quad \mathrm{i}-\mathrm{ble} \quad \mathrm{i}$-ga

CM-person one SM-own SM-remain

'that of one person has remained (uncollected)'

63. I-ló i-me i-kpé (1) $\varepsilon \quad$ a-me

CM-wordSM-this SM-eat 3SGOBJ CM-stomach

'This news disturbed him'

64. $\varepsilon$ ita té A-gbi o-sá nta o-fonyi=é

3SG result COMPL CM-spider SM.SG-leave hand CM-gourd $=$ DET 
yó bu e-tsi

skin fall CM-ground

'This results in the spider leaving the gourd to fall on the ground'

65. Yé o-fonyi=é é-bli kpoi

CONJ CM-gourd=DET SM.SG-break IDEO

'And the gourd breaks 'kpoi'

66. iyé i-taté i-na-shi-na ale ivakpe

3SG SM-result CM-person-every-person 3PLU knowledge

'The result is that the knowledge of everybody'

67. Yé i-dzu f́c ile a-susu nu

CONJ SM-return into 3SG CM-brain in

'has returned to everybody's brain'

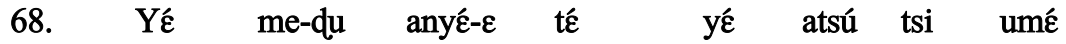
CONJ NEG-be so-EMPH COMPL CONJ 1PLU stay there 'If this had not happened, as we stay there'

69. Te atsú peté atsú i-vakpe té i-bo

COND 3PLU all 3PLU CM-knowledge COMPL SM-stay

agbigloms wá

spider side

'All our knowledge would be with spider'

70. tó awu ona xé ó-ló-yayi ivakpe

COMPL 2SG person RP 3SG-PRSPROG-search knowledge

'If you, a person, want knowledge'

71. i-boté á-zó a-gbi wá

CM-REAS 2SG.FUT-go CM-spider side

'because you go to the spider'

72. a-bó-ta- $\varepsilon$ u-zugbó

2SG-FUT-give $=3$ SGOBJ CM-head

'you give him your head (plead with him)'

73. xé o-ta wú i-vakpe

COMPL 3SG-give 2SGOBJ CM-knowledge

'That he gives you knowledge'

74. Yé n-qú-ba ye ma-fo Ado a-nu=é

CONJ 1SG-PRSPROG-come CONJ 1SG-reach Ado CM-mouth=DET

'As I was coming and I got to the mouth of River Ads'

75. o-sá tsengo o-kpi-é ó-tsi mó

CM-man old AM-INDEF 3SG-sit there

'An old man sat there' 
76. Yर́ a-té ma-ba té CONJ 3PLU-COMPL 1SG-come COMPL AM-tell say 2PLU COMPL 'That when I come (that) I tell you that'

77. Yé ani-yú iva té anu ta a-nda

CONJ 2PLU-see thing give 2PLUOBJ to CM-one another 'And if you have something give to your friend.'

78. Ekple i-na o-kpe xé ó-bo i-dienu=é

now CM-person CM-one RP 3SG-stay CM-world=DET

to-to susu té

never-never think COMPL

'Now a single person in this world should not think that'

79. o-kpe iva fí $=\hat{\varepsilon}$

3SG-know thing exceed $=3$ PLUOBJ

'he is wiser than all'

80. I-na-shi-na ó-kpe

CM-person-every-person SM.SG-know

o-nkpe tsibitsibitsibi

CM-something small small small

'Everybody knows small bits about something.'

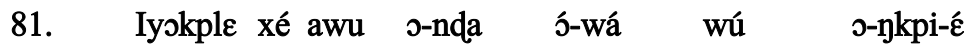

reason if 2PLU CM-friend 3SG-say 2PLUOBJ CM-something-EMPH

'Therefore, if your friend tells you something'

82. ta ke n-tsoe. Xé anu ivagblawo

give open CM-ear If 2PLU teacher

ó-ló-gbla iva

SM.SG-PRSPROG-teach thing

'Listen to him! If your teacher is teaching'

83. Xé o-wá té blo anyé ta ke n-tsoe

if AM-say COMPL make so give open CM-ear

'And he gives instructions, listen to him'

84. ग-na xé o-gridi ome ónyondzi- $\varepsilon$

CM-person RP CM-story this 3SG-live.sweet-EMPH

'The person who enjoys this story'

86. té $\quad$ o-ri $=\tilde{\varepsilon} \quad$ f'́ $\mathrm{n}$-ta 100

COMPL 3SG-hold=3SGOBJ put CM-hand UFP

'Let him hold (keep) it firmly' 


\subsection{The rope and the bird}

Asafo Kudjo, (Age 56) a native of Adzakoe told this story on 26th ${ }^{t}$ March 2004 to pupils of Adzakoe Roman Catholic Primary school where it was recorded. The video recording is available.

Rope, bird, tortoise, tree and hunter all lived in a big forest. Bird who is the leader went to the top of the tree and sang. Rope also climbed to the top of the tree. Because tortoise could not climb, he stayed under the tree. Bird sang aloud unceasingly to disturb the others. Tortoise called rope and asked him to advise bird to keep quiet in the forest. Bird responded that he did not mind whatever happened to anyone in the forest. One day as bird was singing the hunter heard the song. He came to the spot and shot bird, dead. As he came to pick bird, he saw tortoise and collected tortoise and tied it with rope. Bird, tortoise and rope were all taken to the hunter's home and used as food by the hunter.

\section{E-bí-to E-bí-to \\ CM-Child-PLU CM-child-PLU \\ "Children, Children"}

02. Papa! Anu ani-na loo!

father 2PLU 2PLU-walk UFP

"Father, (response to elderly) you are welcome"
03. Anu e-tsí-wo e-boo!
2PLUCM-parent-PLU SM.SG-stay
"Your parents fine?"
04. i-dze ati-bí-ta ogridi wá anda
CM-today 1PLU-FUT-give story say friend
"Today, we shall tell a story to one another"
05. Xé é-lé-ta o-gridi me e-te-blo?
COND 3PLU-PRSPROG-give CM-story Q 3PLU-HAB make
"If a story is being told, what should we do?"
06. E-te-gakrana kpoo!
3PLU-HAB-keep.quiet IDEO
"They keep quiet"
07. $\mathrm{Nu} \mathrm{nu}$ o-gridi loo!
hear-IMP hear-IMP CM-story ADR
"Hear story!"

08. O-gridi to ba

CM-story let come

"Let the story come" 
09. o-gridi o-dzi o-bó-dze a-sangbla tsú

CM-story SM.SG-stand 3SG-come land CM-tortoise on 'The story takes off and falls on tortoise'

10. o-dze o-tsú wa!

3SG-land 3SG-on IDEO

'It falls on it wa!'

11. o-dzi tsỹ̃o yé ó-bo-dze o-nkpa tsú

3SG-stand long CONJ 3SG-come-land CM-rope on

'It moves for long and falls on rope'

12. o-dze o-tsú wa!

3SG-land 3SG-on IDEO

"It falls on it wa!"

13. o-dzi ó-bo-dze a-dzi tsú

3SG-stand 3SG-come-land CM-bird on

'It moves and falls on bird'

14. o-dze o-tsú wa!

3SG-land AM-on IDEO

'It falls on it wa!'

15. o-dzi mokoe yé o-bó-dze o-yó tsú

AM-stand there CONJ 3SG-come-land CM-tree on

'It moves there and falls on the tree'

16. yé o-bó-dze i-vanu-kpi-wo tsú

CONJ 3SG-come-land CM-bush-go-NOM on

'and then falls on the hunter'

17. o-dze o-tsú wa!

3SG-land 3SG-on IDEO

'It falls on it!'

18. Ye a-dzi $\mathrm{y}$-kpe i-va-me pétée xé

CONJ CM-day CM-one CM-thing-this all RP

ma-dzi u-nyi me

1SG-call CM-name here

'Then, one day all the things whose names I have called here'

19. iyé pétée 1̂-nya ú-wá nango nango o-kpe nu

3SG all SM-stay CM-forest big big CM-one in

'They all stayed in a very big forest'

20. Yé á-pétée e-qu e-gusa yé é-nya mó CONJ 3PLU-all 3PLU-be PLU-friend CONJ 3PLU-stay there 'And they all were friends and stayed there.' 
21. Yé ibeshibenu ko é-te-fida yé é-te-la

CONJ always only 3PLU-HAB-meet CONJ 3PLU-HAB make

a-laga wá anda

CM-speech say friend

'always only these three friends meet and talk to one another'

22. Yर́ a-dzi $\mathrm{y}$-kpe e-be-le-fida.

CONJ CM-day CM-one 3PLU-come-again-meet

'Then one day, they came and met again.'

23. Xé é-be-le-fida,

COND 3PLU-come-again-meet

'When they met again'

24. a-dzi=é $\quad$ xé o-tsi $\quad$ a-nu=é $\quad$ yé $\quad a-d z i=\varepsilon$

CM-bird $=$ DET $\quad$ RP SM.SG-stay $\quad 3 P L U-i n=D E T \quad$ CONJ $\quad$ CM-bird $=$ DET

\section{ó-zó a-gu}

3SG-go CM-top

'The bird who is the leader and the bird went to the top'

25. Yर́

CONJ CM-rope CONJ 3SG-also 3SG-climb CM-tree skin

tsõo zó a-gu

IDEOgo CM-top

'Then rope also climbed the tree for long and got to the top'

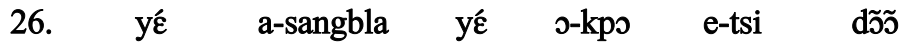

CONJ CM-tortoise CONJ SM.SG-lie CM-down IDEO

mo-tanyi o-yo lé.

NEG-can CM-tree climb

'And tortoise then lay under the tree motionless; it can not climb the tree'

27. J-kple, zãa ko i-vanu-kpi-wo

CM-reason for.a.while only CM-bush-go-NOM

ó-ló-bá

SM.SG-PRSPROG-come

'Because only after a while, the hunter is coming'

28. Yédze i-be-nu xé ó-ló-ba-a

then CM-time-in RP 3SG-PRSPROG-come-EMPH

'Then the time that he is coming'

29

$\begin{array}{lll}\text { yédze } \quad \text { a-dzi }=\hat{\varepsilon} & \text { ó-ló-ź́ } & \text { i-ku } \\ \text { then } \quad \text { CM-bird=DET } & \text { SM.SG-PSPROG-sing } & \text { CM-song } \\ \text { 'then the bird is singing' } & & \end{array}$


30. A-dzi-é ว́-ló-zó

CM-bird-DET SM.SG-PRSPROG-sing CM-song

'The bird is singing'

31. Yé $\mathrm{a}-\mathrm{dzi}=\mathbf{\varepsilon} \quad$ ว-ló-zó $\mathrm{i}-\mathrm{ku}$

CONJ CM-bird=DET SM.SG-PRSPROG-sing CM-song

’́-ló-zó i-ku,

SM.SG-PRSPROG-sing CM-song

'And the bird is singing, it is singing'

32. ग-ló-zó i-ku. A-sangbla o-dzî o-nkpá

SM.SG-PRSPROG-sing CM-song CM-tortoise AM-call CM-rope,

O-nkpá

CM-rope(IMP)

'It is singing. Tortoise called rope: "Rope!'

33. Dá wá a-dzi o-mé té o-gakrana"

tell(IMP) say CM-bird AM-that COMPL 3SG-keep quiet

'Tell that bird to keep quiet'

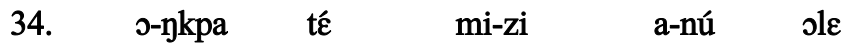

CM-rope COMPL NEG-close CM-mouth 3SGIND

'Rope replied that it did not mind if the bird close his mouth (stop sing ing)'

35. xé a-dzi ó-ló-zó i-ku=á-o

RP CM-bird SM.SG-PRSPROG-sing CM-song=DET-CFP

'if the bird was singing the song'

36. $\mathrm{M \varepsilon}$ ว́-ló-dze dá wá a-dzi=ć

Q 3SG-PRSPROG-need tell say CM-bird=DET COMPL

gákrana ná?

keep.quiet QP

'Why does he need to be telling bird to keep quiet?'

37. ग-ló-mo-dá wó=é $\quad$ i-ku ko

3SG-PSPROG-NEG-tell say $=3$ SGOBJ CM-song only

ó-ló-zó

3SG-PRSPROG-sing

'He is not telling him. Meanwhile, the singing continues'

38. $\varepsilon$-tsú, i-ku ko î-lî-zó

3SGOBJ-on CM-song only 3SG-PRSPROG-sing

iyé-tsú, tsyõo

3SG-on for long

'It continues, only the song continues unceasingly' 
39. Ko i-vanu-kpi-wo=é ó-nu i-ku=é

only CM-bush-go-NOM=DET SM.SG-hear $\quad \mathrm{CM}$-song = DET

'Suddenly, the hunter heard the song'

40. Ko ã i-no yayi me ó-zó

only INTJ(surprise) CM-meat search here 3SG-go

'Only ah! meat is what he searches for here'

41. Yoo yé o-mi i-ku=é vui pétépété

OK CONJ 3SG-take CM-song=DET stop all all

ko fini dódu

only blast out.down

'OK, it takes up a tune and stop all the singing, it rather blasted it down'

42. Ó-ri i-me ó-mi ka, ó-ri i-me

3SG-hold AM-this 3SG-take put.down 3SG-hold AM-this

ó-mi ka,

3SG-take put.down

'It takes this tune and puts it down, it takes this tune, puts it down'

43. Ó-mi ka ã i-vanukpiwo=é

3SG-take put.down INTJ CM-hunter $=$ DET

'Puts it down Ah! As for the hunter'

44. ó-1’ó $\quad$ i-no ’-ló-yayi

3SG-as for him-EMPH CM-meat 3SG-PRSPROG search

'it is meat that he is searching for'

45. Iyo-kple ó-zó xé o-nu i-ku=é ko ý

CM-reason 3SG-go when 3SG-hear CM-song=DET only and

'That is why as soon as he heard the song'

46. o-dze i-ku=é o-gba-má tsi

3SG-start CM-song $=$ DET CM-road-back stay

'He starts to trace where the song was coming from'

47. Yé o-dze i-ku=é o-gba-má do ko-e

CONJ 3SG-start CM-song=DET CM-road-back follow only-EMPH

to-bo dze

let-come see

'As he started to follow the direction of the song; come and see'

48. O! a-dzi nango nango me yé ó-le o-yó tsú

EXC CM-bird big big this CONJ 3SG-be CM-tree on

'Oh! This big big bird is on a tree'

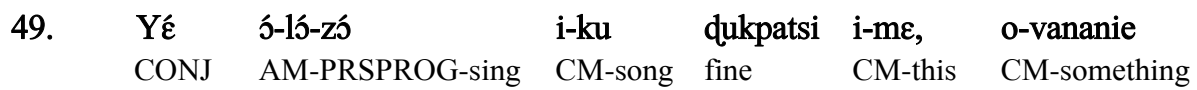


xé ó-le o-yó tsú=é

RP 3SG-be CM-tree on $=$ DET

'Then singing a fine song; this thing on the tree "

50. To-nu kpoi!! E-tsi vim yé o-lenta o-sé let-hear IDEO CM-groundIDEO CONJ 3SG-fall 3SG-cease 'Hear the noise; the ground it fell at once. That is the end'

51. Nta le, yé i-vanukpiwo=é yé ó-zó fall(JUXT) CONJ CM-hunter=DET CONJ SM.SG-go 'It fell! and the hunter went'

52. té ó-ló-kpi zí a-dzi=é

COMPL 3SG-PRSPROG-golift CM-bird=DET

'that he is going to lift the bird'

53. $\mathrm{A}$-dzi=é xé o-zí-é, to-dze ko

CM-bird=DET RP 3SG-lift=3SGOBJ let-see only

a-sangbla he

CM-tortoise this

'As he took the bird he noticed that there was tortoise'

54. xé o-kpo o-yó e-tsi

RP 3SG-lie CM-tree CM-ground

'Which lay under the tree'

55. $\mathrm{O} ! \mathrm{O} ! \mathrm{m} \varepsilon$ ani nénu té ว-blø?

EXCL Q 2PLU believe COMPL 3SG-make

'Oh! Oh! What do you believe that he would do?

O-ž̀-é

kaba

3SG-lift.up $=3$ SGOBJ immediately

He lift it up immediately'

56. A-sangbla=á xé ó-zî lé

CM-tortoise $=$ DET RP 3SG-lift 3SGOBJ Q COMPL make

'The tortoise that he took what should he do?'

57. E-ta fó lé

3PLU-give put 3SGOBJ CM-rope CM-and 1SG-PSPROG

wá wú me

say 2PLU this

'They would tie it with rope. What I am telling you'

58. E-ri o-ıkpa vlo o-yó yó tsyiãa

3PLU-hold CM-rope IDEO CM-tree skin IDEO

ý́ ó-zî a-saygbla

CONJ 3SG-lift CM-tortoise

'They held rope 'vlo' from the tree at once and took tortoise' 
59. Ó-le amá yé ó-mi o-nkpa é-mi fé, 3SG-be back CONJ 3SG-take CM-rope 3PLU-take put

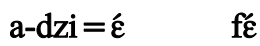

CM-bird $=$ DET also

'After this he took rope and tortoise also'

60. 0-nkpa fé a-pétée i-vanu-kpi-wo=é

CM-rope also 3PLU-all CM-bush-go-NOM=DET

alé a-fánu yrom

3SGIND CM-house IDEO

'Rope also; all ended up in the hunter's home "yrom!",

61. Xé î-fo u-dobe a-dzi=é f'́,

CONJ 3SG-reach CM-afternoon CM-bird=DET also

a-sangbla $=\mathbf{a} \quad \mathrm{f}^{\prime}$

CM-tortoise $=$ DET also

'In the afternoon, the bird also, tortoise also'

62. Yर́ é-mi f'é futsú a-so nu

CONJ 3PLU-take put soup CM-pot in

'They put them in a soup pot'

63. Xé n-dú-ba-a u-dze tsengo o-kpe

as 1SG-PRSPROG-come-CFM CM-woman old CM-one

'As I am coming, an old woman'

64. xé ó-bo anú suku o-kpo=é tsú me

RP SM.SG-stay 2PLU school CM-compund=DET on this

'Who stays on this your school compound'

65. Xé ว-wá-m yé ó-wá-m té

RP 3SG-say-1SGOBJ CONJ 3SG-say-1SGOBJ COMPL

xé ma-ba me

COND 1SG-come here

'Who has told me; and she asks me that when I come here'

66. Ta anu e-bí-to xé ani-bo xé

give 2PLU CM-child-PLU RP 2PLU stay RP

ani-mi-bubu iva

2PLU NEG-respect thing

'Give your children who do not respect anything'

67. xé anú e-tsi-wa é-lé-wá nu

RP 2SGIND CM-parent-PLU SM.PLU-PSPROG-say 2PLUOBJ

'Which your parents are telling you' 
68. té tó-ló-blo-nu anyé xé ani mî nú COMPL never-PRSPROG-make-NEG so COND 2PLU NEG hear 'That never do that so when you do not hear'

69. xé e-tsú ${ }^{50}$ ko ani-tsi xé ani-ti-blo that 3SG-on only 2PLU-stay RP 2PLU-HAB-make 'That you still continue what you do'

70. té ma-mi ka anu a-nyi-nu té dzi kpane tsú COMPL 1SG-take put 2PLU CM-face-in COMPL from now on 'That I should bring it before you that from now on'

71. Xé a-blo 0-nkpe yé awu tsi o-wa if 2SG-make CM-one CONJ 2PLU father 3SG-say 'If you do something and your father says'

72. té o-tó-ló-blo ko-e

COMPL 3SG-never-PRSPROG-make only-EMPH

'You should stop that'

73. Me i-boté ani-blo i-boté

Q CM-REAS 2PLU-make CM-REAS give

nu nu-é

2PLUOBJ hear $=3$ SGOBJ

'What should you do? You have to hear what he says'

74. té anu vui bló

COMPL 2PLUIND stop make

'That you stop'

75. anu andakame xé a-ló-blo o-nkpe

2PLUneighbour if 2SG-PRSPROG-make CM-one

yé ग-wa wú

CONJ 3SG-say 2SGOBJ

'Each one of you, if you are doing something and you are told'

76. té tó-ló-blo COMPL never-PRSPROG-make only give 2PLU stop make

ko ta nu vui blo

only give 2PLU stop make

'that never do what you are doing then stop what you are doing'

77. Yर́ a-briwa yé

CONJ CM-old lady CONJ 3SG-say-1SGOBJ COMPL when

${ }^{50}$ iye-tsú 
ma-fo-e

1SG reach-CFM

'And an old lady told me that when I reach here'

78. té $\mathrm{n}$-da wá nu u-dantsi $\mathrm{m} \varepsilon$ té

COMPL 1SG-tell say 2PLU CM-morning this COMPL

i-nya nu nu tsi-e

CM-own hear 2PLU down-CFM

'that I tell you this morning to the level of your understanding.'

79. té ani rí-é fé nta loo.

let $2 \mathrm{PLU}$ hold $=3$ SGOBJ put hand UFP.

'Take it seriously!'

Yoo a-nyitse

OK CM-thanks

'OK thanks.'

\subsection{Proverbs}

Proverbs are witty sayings which are taken to mean something more than the ostensible form. Normally, proverbs are understood when they are related to the context of use. These proverbs were collected on different occassions during the entire period of my fieldwork in Logba. I have to acknowledge the contribution of Asafo Kudjo (Aged 56) who assisted greatly in the collection of these proverbs.

01

$\begin{array}{llll}\text { A-lo-yó } & \text { i-mutsi } & \text { nu } & \text { i-yó } \\ \text { 2SG-PRSPROG-dance } & \text { CM-barn } & \text { in } & \text { CM-dance }\end{array}$

'You are dancing inside a barn'

02. E-bitsi kloyi ó-ló-la nta anú ale yó

CM-childsmall SM.SG-PRSPROG-beat hand mouth 3PLU skin

'A child shouts according to the size of his mouth'

03. U-bi o-tso a-vu kpó mo-ó-tso i-ló nango

CM-child SM.SG-cut CM-food big NEG-3SG-cut CM-word big

'A child that eats large morsels of food should exercise caution in speech'

04. A-bó-zi a-só drui lo!

2SG-FUT-lift CM-pot red ADR

'You should be careful not to say the unmentionable'

05. U-bí mo-ó-zi a-dzi o-do

CM-child NEG-3SG-pluck CM-bird AM-feather 
mi-1́-gbla o-nukpa tsi

NEG-3SG-teach CM-old.man on

'A child does not pluck a bird's feather to show to the elderly'

06. A-ló-zí-iva

u-menta a-má

2SG-PRSPROG-cook-thing

CM-salt AM-back

'You are cooking food without salt'You are doing something for which an important person who should be present is absent'

07. I-dzó-wasa anyi-nu i-dzó i-nú bé

CM-yam-owner face-in CM-yam SM-see well.cooked

'Yam gets well-cooked in the presence of the owner'

08. O-babie ó-le o-vodzo

CM-small sba.tree 3SG-be CM-ovodzo

'The small tree resembles the sba tree' (The person being talked about is coming)

09. Koku-te-ḿ

Koku- close-1SGOBJ

'Koku is closing in on us' (The person being talked about is coming)

10. A-ha é-bele mo-ó-kpali-é

CM-people 3PLU-clear.forest NEG-3SG-collect $=3$ SGOBJ

'When many people clear the forest, one person alone should not collect the cuttings'

11. Iva wasa mo-ó-wá é xé a-wá o

thing owner NEG-3SG-say Yes then 2SG-AM-say No

'The owner of a thing will not say yes then another person will say no'

12. Dzosú o-tsi a-men f́e e-tsú a-tsolí blood 3SG-stay.in CM-stomach also 3PLU-spit CM-spittle 'Blood is in a person's mouth but we spit out spittle'

13. A-gbé ko ó-dzu i-na-má yé CM-dog only SM.SG-return CM-person- back CONJ

é-nú-kanyi

3PLU-see-light

'It is only a dog that abandons a person and it shows clearly'

14. Bá mo-ó-nya 0-nkpa yó

gift NEG-3SG-stay CM-rope skin

'There is no condition attached to anything that is given for free' 
15. Gblaga ${ }^{51}$ té a-wó mo-ó-fé i-ndzíba gblaga say CM-snake NEG-3SG-wear CM-bead 'Gblaga says that a snake does not wear beads'

16. Me-zi-wú ye awu fé á-lo-zi 1SG-carry-2SGOBJ CONJ 2SG also 2SG-PRSPROG-carry i-na

CM-person

'I carry you and you are also carrying someone'

17. Dze-me té am-f́́ n-dze-me look-here COMPL 1SG-also 1SG-look-here i-ti-gbla o-gbá

SM-HAB-teach CM-path

'We find the path if you look here and I also look here'

18. N-to mo-ó-dzú i-nfieyi a-dzisiadzi

CM-Ash NEG-3SG-become CM-sand CM-everyday

'Ash can never become sand'

19. M-mua mo-ó-sé o-gó tsú

CM-Flour NEG-3SG-finish CM-grinding stone on 'Flour never gets finished on the grinding stone'

20. I-n(a)-osa mo-o-vó u-botsú

CM-person.male NEG-3SG-fea CM-dew

'A man does not fear dew'

21. Agbe té ó-ló-mo-o-du a-nú

CM-dog say 3SG-PRSPROG-NEG-3SG-be.sickCM-mouth

o-dú

CM-sickness

'The dog says it is not attacked with 'mouth-sickness'

22. O-gbá kisayi mo-ó-vé u-bome yó

CM-road long NEG-3SG-pass CM-town skin

'A long road does not pass by a town'

23. Xé a-yú awú o-dankame zugbo

COND 2SG-see 2SGIND CM-neighbour head

$\begin{array}{lllll}\text { o-dzogbe-e ta dzú awú-ble fé (u)wa } & \end{array}$

CM-grassland-CFM let return 2SGIND-own put.in forest

'If you see your neghbour's head in the grassland, you hide yours in the forest'

\footnotetext{
${ }^{51}$ Gblaga is the name of a person to whom the saying is attributed.
} 
24. Antényi té

earthworm COMPL

mkponyi mo-ó-ma

ole fé

ó-to-kpe

eye

NEG-3SG-have

3SGIND also

SM.SG-HAB-know CM-house-path

'Earthworm says that even without eyes it knows the way home'

25

$\begin{array}{llll}\text { Ati-tró } & \text { i-du } & \text { f́e } & \text { ati-lí-gbe } \\ \text { 1PLU-carry } & \text { CM-gunpowder } & \text { also } & \text { 1PLU-PRSPROG-smoke } \\ \text { a-tamá } & & & \end{array}$

CM-tobacco

'We carry gunpowder yet we are smoking tobacco'

26. Xé a-mo-kpé tenyi-é taá kpé kla

COND 2SG-NEG-know run-CFM should know hide

'If you do not know how to escape you should know how to hide'

27. Tó dze a-gádzá m-kpónyí té ó-yótsí

never see CM-crab CM-eye say CM-stick

'Never see crab's eyes like a stick'

28. A-nkó té

o-ló-kpo a-tsa nu f'́

CM-hen COMPL SM.SG-PRSPROG-lie CM-coop in also

ole u-vi=é ó-kpó onyui

3SG CM- tail=DET SMSG-lie outside

'The hen says it is lying in the coop but its tail lies outside'

29. A-gadza té o-nda o-kple u-zugbó

CM-crab COMPL CM-friendship CM-reason CM-head

mo-ó-nyá-nu olé

NEG-3SG-stay-NEG 3SG

'The crab says because of friendship he has no head'

30. Iyé blo-wo=é mo-ó-kpé nu-é

3SG make-owner $=$ DET $\quad$ NEG-3SG-eat $\mathrm{NEG}=3 \mathrm{SGOBJ}$

'He who makes it does not benefit from what he has made'

31. Me-é-go m-mua dovu e-tsí

NEG-3PLU-grind CM-flour pour.out CM-ground

'One does not grind flour and pour it on the ground'

32. I-ló mi-í-kla i-yó-gu a-só

CM-testis NEG-SM-hide CM-skin-wash CM-pot

'The testis is not hidden from the pot used for bathing'

33. O-dzú mo-ó-kpali lé u-kpó

CM-river NEG-SM-flow climb CM-mountan

'A river cannot flow climbing a mountan' 


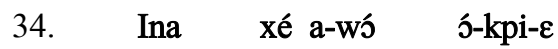

person RP CM-snake SM.SG-eat-CFM

o-tso-bama ta a-ntenyi

3SG-HAB-fear give CM-earthworm

'A person who a snake bites fears earthworm'

35. A-bu-dze té o-kunyie i-zitawo-e

CM-nanny-goat COMPL CM-place SM-be.suitable-CFM

ó-mi i-fli=e na

3SG-take CM-white $=$ DET on

'The nanny-goat says the place that suits her there she puts the white mark'

36. A-gadza té xé a-lo-dze ole vutsi

CM-crab say COND 2SG-PRSPROG-look 3SGIND hole

nu-e o-kpaya fé ó-ló-dze awú o-kunu

in-CFM CM-God also 3SG-PRSPROG-look 2SGIND CM-anus

'The crab says if you look into its hole, God also looks into your anus'

37. Dze a-fá-wá

look CM-home-place

'Look homewards'

38. Zá e-bleta té n-zá a-tukpata yé

row CM-left COMPL 1SGPRSPROG-row CM-right CONJ

o-dzutsúklo o-to-mi zó ité

CM-boat 3SG-HAB-take go front

'Row left and I row right makes the boat to move forward'

39. Xé a-ló-glui o-yó e-tsie in(a)-okpe

COND 2SG-PRSPROG-dig CM-tree CM-under person-one

ó-ló-kpitsi = é a-gu

3SG-PRSPROG-pluck = 3SGOBJ CM-top

'When you are digging under a tree someone is plucking above'

40. I-mo-nu iva kpé o-hloyí-nu iva kpoyi ikpe

CM-neck-in thing CONJ CM-throat-in thing all one

'The thing used for the neck and the one used for the throat are all one

41. A-hoaintsa a-té i-té fर́ i-ná a-má

CM-chameleon 3PLU-say CM-front also CM-walk CM-back

f́̃ i-ná

also CM-walk

'Chameleon says movement is both forward and backwards' 
42. ग-dza yó tsi-wo=é blé i-da be

CM-fire skin stay-owner $=$ DET own CM-ahead well.cooked

'The thing that belongs to the person close to the fire is well cooked ahead of the others'

43. A-klua mo-ó-le y-gbó

CM-insult NEG-SM.SG-be CM-rough.marks.on.skin

'Insult does not result in rough marks on the skin'

44. Xé ina-nyo é-ké-é ina-nyo

COND person-two 3PLU-set.trap $=3$ SGOBJ person-two

e-dzé $=$ é

$3 \mathrm{PLU}-\mathrm{see}=3 \mathrm{SGOBJ}$

'If two people set trap for a thing, the two go to see the trap'

45. To-dze o-kunyie a-kpó boyu dze o-kunyie a-kpitá

never-see CM-place 2SG-lie rather see CM-place 2SG-stumble

'Never watch the place you have fallen look for the place you have stumbled'

46. Xé awú nta-má inyo-wú ondzi tsõ $\tilde{y}$ fé

COND 2SGIND palm-back sweet-2SG sweet long also

mi-î-qu baté awú ntubo nu

NEG-3SG-be like 2SGIND palm in

'However sweet the back of your palm is it will not be equal to the sweetness of the front of your palm'

47. Ina=á xé o-fó-wú-e ó-ke

person $=$ DET RP 3SG-wash-2SGOBJ-CFM 3SG-be.exact

o-bá-la-wú i-vi

3SG-FUT-make-2SG CM-dirt

'The person who cleans you is the same person to make you dirty'

48. A-zuzo té mekoe f́c o-dzuamá mókoe

CM-housefly say here also CM-waterback there

fé o-dzuamá

also CM-water.back

'Housefly says, here is also waterback, there is also waterback'

49. E-ngble té ó-ló-mo-du-nu a-bue xé

CM-snail say 3SG-PRSPROG-NEG-be-NEG CM-animal RP

o-ri iva dzue ó-ló-le atsá

3SG-holdthing but 3SG-PRSPROG-be horn

'Snail says it is not a wild animal but it has a horn'

50. A-ko té e-vianjgba yé olo-to-kpe $\quad$ a-be

CM-parrot say CM-noon CONJ LOG-HAB-eat CM-palmfruit

'Parrot says it is noon that it eats palmfruit' 
51. Mi-zo mi-zo mi-i-nya zo-tsi

take-sing take-sing NEG-3SG-stay sing-HAB

'It is not easy to sing if one is called suddenly to sing'

$\begin{array}{lllll}\text { 52. } & \text { O-pete } & \text { mo-ð́-blı } & \text { u-zugbó-kpa-go } & \text { a-va } \\ \text { CM-vulture } & \text { NEG-SM.SG-make } & \text { CM-head-shave-NOM } & \text { CM-medicine }\end{array}$

'Vulture does not prepare a medicine that prevents baldness for someone'

53. To mi awú bu-me dzú awú kpome never take 2SGIND fall-LOC become 2SGIND home

'Never take the place that you fall to be your home'

54. ว-kponyi ó-bli f́c i-nyui i-tsi o-nu

CM-eye SM.SG-break also CM-sleep SM-in 3SG-in

'Though the eye cannot see, there is sleep in it'

55. Mi-í-bu-nu-e mi-í-klu-a

NEG-3SG-rotten-NEG-CFM NEG-3SG-smell-PART

'If it does not get rotten, it does not smell'

56. Xé i-fie a-gbashi-e a-kpa e-te-zi=e

COND 3SG-exceed CM-arm-CFM CM-foot 3PLU-HAB-take $=3$ SGOB

If it is more than the arm, it is the foot that carries it'

57. O-kunkpe é-susu ka i-dzi vo

CM-place.one SM.PLU-urinate put 3SG-stand foam

'It is one place we urinate for the urine to foam'

58. I-ntse i-bo a-fá i-bo u-wá f́é

CM-strength SM-stay CM-home AM-stay CM-forest also

'Strength is at home and abroad also'

59. M(a)-á-blo m(a)-á-blo mo-ó-blo

1SG-FUT-make 1SG-FUT-make NEG-3SG-make

'Postponing things that one should do does not make the thing to be done'

60. I-yó-yó-me u-kunku i-ti-fida

CM-dance-dance-LOC CM-elbow SM-HAB-meet

'It is at the dancing place that elbow meets elbow'

61. I-dzó i-tsitsi-go kpe iyé

CM-yam SM-move-NOM CONJ 3SGIND CM-strength

'The movement of yam and its strength'

62

\begin{tabular}{|c|c|c|c|c|}
\hline 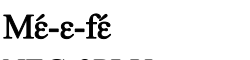 & n-ta & i-na & mángo & $\begin{array}{l}\text { u-kpo-nu } \\
\text { CM-coop-in }\end{array}$ \\
\hline NEG-3PLU-put.in & CM-hand & CM-person & different & CM-coop-in \\
\hline
\end{tabular}

'Never put your hand in another person's coop, you should ask' 
63

$\begin{array}{lllll}\text { A-zuzo } & \text { f } \tilde{\varepsilon} & \text { al } \varepsilon & \text { blo-m } \varepsilon & \text { i-bo } \\ \text { CM-housefly } & \text { also } & \text { 3PLU } & \text { make-LOC } & \text { SM-stay } \\ \text { 'Houseflies also have their importance' } & \end{array}$

64

\begin{tabular}{|c|c|c|c|c|}
\hline Mé-é-nyá & u-ha-nu & u-ha & o-tsoe & é-nyá \\
\hline NEG-3PLU-stay & CM-group-in & CM-group & CM-ear & 3PLU-stay \\
\hline
\end{tabular}

65. O-glui o-tsi i-súsó $\mathrm{nu}$

CM-mouse SM.SG-stay.in CM-thatch in

'There is mouse in the thatch roofing'

66. U-dzi-gbo ma-á-fífí

CM-broom-bunch NEG-FUT-break

'A bunch of broom never breaks'

$\begin{array}{llllll}\text { 67. Xé } & \text { i-kisa } & \text { ts̃̃o } & \text { fُ́ } & \text { o-zúme } \\ \text { COND } & \text { 3SG-become.long } & \text { for.long } & \text { also } & \text { CM-tommorow }\end{array}$

ko é-dzi

only 3PLU-call

'However distant the time is, we say it is tommorow'

68. A-sangbla pu-me e-du ale dze-me

CM-tortoise see-LOC 3PLU-be 3PLUIND look-LOC

'The place tortoise is seen is where it is found'

69. A-va gbali f'́ wo o-da no

CM-medicine bad put.in owner SM.SG-lead drink

'The owner of bad medicine should drink first'

70. Xé i-di mi-í-mu-nu-e

COND CM-atmosphere NEG-SM-be.dark-NEG-CFM

i-di mi-í-wa

CM-atmosphere NEG-SM-open.up

'If night does not fall, day will not break'

71. E-tsí a-fá zó o-kple ati-mi-kpo inyui ló

CM-ground CM-home go CM-reason 1PLU-NEG-lie sleep PART

Is it because of going home under the ground that we are not going to sleep?'

72. Xé á-té a-đú ina kpe-wo=e é ${ }^{52}$

COND 3PLU-say 2SG-be person eat-owner $=$ DET

me-te-dzí iva

NEG-HAB-call thing

'If they say that you are a witch, you do not swear'

\footnotetext{
${ }^{52}$ A person who eats human flesh
} 
73. Ódzú-nu-kpí-wo olé o-to-blí a-só

river-in-go-owner 3SG 3SG-HAB-break CM-pot

'It is the person that goes to river for water who breaks pot'

74. O-dró-yó n-đú=é é-mí za=é(ze)

CM-elephant-skin $\quad \mathrm{CM}$-water $=\mathrm{DET} \quad 3 \mathrm{PLU}$-take $\quad$ cook $=3 \mathrm{SGOBJ}$

'It is the water that comes when steaming elephant meat that is used in its cooking'

75. A-bukpa ó-da me me fé mo-ó-fié $\quad$ o-fui

CM-shoulder 3SG-big great great also NEG-3SG-exceed CM-thigh

'However big a shoulder is, it cannot be bigger than the thigh'

76. Mo-ó-shibi o-dzá dze ina=á xé a-kpe

NEG-3SG-light CM-fire look person=DET RP 2SG-know

e-viangba a-nyi-nu a-tsí

CM-noonCM-face-in CM-night

'One should not light fire in the night to look at the face of a person you know in the day'

77. U-zugbo mo-ó-tró (mo-ó-zi) i-mo

CM-head NEG-3SG-carry (NEG-3SG-lift.up) CM-neck

'The head does not carry the neck'

78. U-zugbó o-kpe mo-ó-blo a-dayu

CM-head AM-one NEG-SMSG-make CM-advice

'One head is not used in taking a decision'

79. A-bobi o-to-klé fié a-táwalibi

CM-moon 3SG-HAB-shines exceed CM-stars

'The moon shines brighter than the stars'

80. I-na gblele a-danu i-zi

CM-person many CM-advice SM-good

fié i-na o-kpe

exceed CM-person AM-one

'The advice of many people is better than the advice of one person'

81. ந-kponyi n-nyo mi-i-dze a-bodiabó nu CM-eye AM-two NEG.SM.look CM-bottle in 'You cannot use two eyes to see in one bottle' 


\subsection{Riddles}

The recording was done on $3^{\text {rd }}$ June 2006 in Alakpeti E. P. Chapel. A group from Tota comprising Prosper Howusu, Prosper Akom, Festus Howusu and Godsway Howusu took active part in the competition.

Riddle or adzo as it is called is a form of recreation. The same term is used in Ewe and both languages have the same procedure of performance. In $\mathrm{Ga}$, nsra is the term used. However, the performance in Logba is almost the same as in Ga and Ewe. For example in Ga the one telling the riddle says Ajenuloo and the audience responds Ajembaa (see Dakubu 1981) while in Ewe, it is Adzo loo and the response is Adzo neva. Telling riddles is a learning situation for the people especially the young ones. It is in situations like this that children are informally exposed to the norms of speaking in a group, how concepts are described concisely and the ability in these brainstorming sessions to figure out what these descriptions refer to. In addition, it is to inform the child of the riddles in the community so that he will also be able to tell it to other people on another occassion.

In a riddle telling competition, there are two teams; one sits facing the other. The distance between the teams is about one meter. One of the contestants (A) takes the floor and announces that he is going to present a riddle to the opposing team. A member of the opposing team, (B) responds by saying that the riddle should come as below:

A

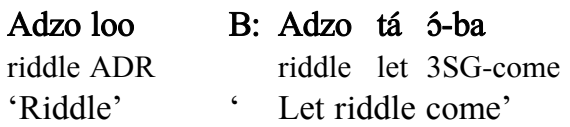

After telling the riddle, answers are offered by members. A member of the team, (C) offers an answer to the riddle and (A) either accepts the answer as correct or rejects it as incorrect. This is shown below:

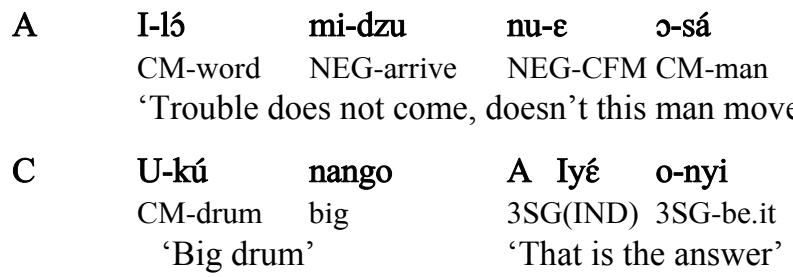

When the answer is not correct, the opportunity is given for other persons to make attempts. It could be a person from the team or any other person outside it. If all the people present are unable to get the correct answer, the riddle is then referred to the one who tells it to offer the right answer. Normally, he gives the answer by explaining why the riddle should have such an answer (meaning). This is shown in the example below: 


\begin{tabular}{llllll} 
Iva & i-kpe & i-bò & té & mi-î-du & iyi- $\varepsilon$ \\
thing & 3SG-one & 3SG-stay & COMPL & NEG-3SG-be & 3SGIND-CFM \\
té & i-na & \multicolumn{2}{c}{ mo-o-kpe } & té
\end{tabular}
té
NEG-3SG-know COMPL
COMPL CM-person
i-dî i-wá
CM-day 3SG-break
'There is something if it were not there no one will know the time day breaks'
B: Soleme idá
'church bell'
A: Oo
No
C: $\quad$ Eví
A: Ao
'sun'
'No'
D: Anko
A: Ankı эmoá
'fowl'
'Which fowl'
E. Ankosá
'cock'
A: Iyé nyi
'That's it'

The riddles collected in Logba and their correct responses are below.

01a. U-dze o-me o-gu i-yó sé o-vé

CM-woman 3SG-this 3SG-wash CM-skin finish 3SG-pass

f'́ o-bà-n

into CM-mud-in

'This woman has finished bathing but has got into mud'

01b. Agadza

'Crab'

02a. Am-tsi o-do u-tsá 0-me tá-ma-a

1SG-father 3SG-build CM-house 3SG-this give-1SGOBJ-CFM

fesre kpe u-zi soyson

window CONJ CM-door many(IDEO)

'My father has built this house for me, it's only windows and doors'

02b. Afie

'sieve'

$\begin{array}{llllll}\text { 03a } & \text { Am-tsi } & \text { o-n } \varepsilon & \text { a-fúta } & \text { a-m } \varepsilon & \text { tá-ma-a } \\ & \text { 1SG-father } & \text { 3SG-buy } & \text { CM-cloth } & \text { 3SG-this } & \text { give-1SGOBJ-CFM }\end{array}$

ma-n-tanyi a-gbá

1SG-NEG-can 3SG-cover

'My father bought this cloth for me but I could not wear it' 
03b. Uklo

'lorry'

04a. U-dze o-me mo-ó-kpi o-dzu-n dzue n-dú

CM-woman 3SG-this NEG-3SG-go CM-river-in but CM-water

n-tsi o-tanki $=\mathrm{e} \quad \mathrm{nu}$

SM-stay $\mathrm{CM}$-tank $=$ DET in

'This woman has not been to the riverside for water but there is water in her tank'

04b. Yovune

'coconut'

05a. N-dú-zó-a

m-bo drui yé

1SG-PRSPROG-go-CFM 1SG-stay red CONJ

n-dú-ba-a m-bo fli

1SG-PRSPROG-come-CFM 1SG-stay white

'When going I am red, when coming I am white'

05b. Indubi kpe ete

'tongue and teeth'

06a. N-dú-zó u-bo-nu-e a-ha á-me

1SG-PRSPROG-go CM-farm-CFM 3PLU-person 3PLU-this

a-lá-blo-ḿ 'bye bye'

3PLU-PRSPROG-make-1SGOBJ bye bye

'I am going to the farm, these people are waving me'

06b. Agbediodo

'cassava leaf'

07a. Yé té mi-î-qu u-tsá

COND COMPL NEG-3SG-be CM-building 3SG-this COMPL

ma-yu a-blotsi

1SG-see CM-overseas

If it were not this building, I should have travelled overseas'

07b. Uvu

'stomach'

08a. Am-tsi o-né a-bue o-me tá-ḿ

1SG-father 3SG-buy CM-animal 3SG-this give-1SGOBJ

a-té n-lá nta o-tsúe-n dzue ma-n-tanyi

3PLU-ask 1SG-beat hand CM-ear-in but 1SG-NEG-can

'My father bought me this animal, he asked me to slap it but I could not'

08b. Abe zugbo

'a bunch of palm fruit' 
09a. O-nukpa o-me o-ku i-sikpi=é i-li-bo

CM-chief3SG-this 3SG-die CM-ring=DET SM-again-stay

'This chief has died, the rings are still there'

09b. Aklando

'centipede'

10a. O-sálokpoto o-me o-sa a-fúta

CM-smallish.man AM-this 3SG-cover CM-cloth

f́e tso o-dzú

on cross CM-river

'This smallish man put on cloth to cross the river'

10b. Asaygbla

tortoise

11a. O-salokpoto o-me o-gle i-da a-wu.

CM-smallish.man 3SG-this 3SG-tie CM-metal CM-dress

'This smallish man put on a metal dress'

11b Abikú

'palm kernel'

12a. Aha a-nyo á-ye o-gba yó nyangbo

people AM-two 3PLU-stand CM-road skin rain

ó-ló-lá o-kpe mo-ó-ló-lá o-kpe

3SG-PRSPROG-beat AM-one NEG-3SG-PRSPROG-beat AM-one

'Two people are standing by the road side rain beats one but not the other one.'

12b. Amewasa

'pregnant woman'

13a. Yé n-dú-zó-a ma-blo fli

COND 1SG-PRSPROG-go-CFM 1SG-make white

ý́ n-dú-ba-a ma-blo drui

COND 1SG-PRSPROG-come-CFM 1SG-make red

'If I am going I am white, if I am coming, I am red'

13b. Abolo

'corn flour bread'

14a. I-va-fle-go i-kpe i-bo a-té

CM-thing-fly-NOM AM-one SM.SG-stay 3PLU-say

o-ló-tso-blo inyémyé iva dzue ole futsú=e

3SG-PRSPROG-make filthy thing but 3SG soup=DET

o-bòndzi

3SG-tasty

'There is a fly which they say it makes things filthy but it makes soup tasty' 
14b. Ankó

'fowl'

15a U-dze o-me o-blo n-tró=a gblayii

CM-woman AM-this 3SG-make CM-breast=DET hanging

'This woman makes her breast hanging loosely'

15b. Bafunuba

'pawpaw'

16a. U-dze o-me ó-tsi

CM-woman AM-this SM.SG-stay 3SG-open 3SG-skin put 'This woman sits and opens herself down'

16b. Atrui

'hearth'

17a. A-nansa o-me o-bo u-tsá-n dzue

CM-old.man AM-this SM.SG-stay CM-toom-in but

i-dzi=é i-bo o-dzogbe

CM-beard $=$ DET $\quad$ SM-stay $\quad$ CM-outside

'This oldman is indoors but his beard is outside'

17b. Umushi

'smoke'

18a. Iva i-me i-bo i-tanyi o-gbo=á

thing AM-this SM-stay SM-can $\quad$ CM-town $=$ DET

pétée iva-kpe-go tá

all thing-food-NOM give

'There is a thing that can give food to the whole town'

18b. Abobí

'moon'

19a. P-gbo=á pétée ó-ku á-vla-á danka

CM-town $=$ DET all SM.SG-die 3PLU-bury-3PLU coffin

o-kpe nu

AM-one in

'The whole town is dead, they bury them in one coffin'

19b. Matsesi

'matches'

20a. Iva i-kpí́ i-bo i-kisa i-tanyi

Thing AM-INDEF SM-stay SM-long SM--can

aha pété zi

people all carry

'There is something that is long; it can carry all people' 
20b. Iyanuklo

aeroplane

$\begin{array}{lllll}\text { U-dze } & \text { o-me } & \text { o-gu } & \text { i-yó } & \text { ó-dó } \\ \text { CM-woman } & \text { AM-this } & \text { SM.SG-wash } & \text { CM-body } & \text { 3SG-come.out }\end{array}$

o-fá-n kpe i-nqu

CM-house-in with CM-tear

'This woman has bathed and came out with tears'

21b. Dtswensa

'sponge'

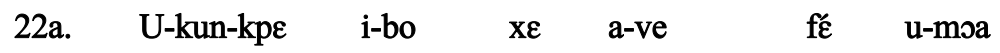

CM-place.one SM-stay COND 3PLU-pass into LOC-there

a-dze i-dawa dzue xé a-do-e

3PLU-contract CM-madness but COND 3PLU-come.out-CFM

i-dawa i-kó-wú

CM-madness SM-get.over-2SGOBJ

'There is a place if you enter, you will become mad but if you come out you will be healed of the madness'

22b. Dfánu

'bath room'

23a. Iva i-kpe i-bo xé n-dú-zó

thing AM-one SM-stay COND 1SG-PRSPROG-go

u-kun-kpi- $\varepsilon$ xé ma-dzi-ni-e

CM-place-one-CFM COND 1SG-call-NEG=3SGOBJ also

i-do-ḿ o-gba-má

SM-follow-1SGOBJ CM-road-back

'There is something, if I am going somewhere and I do not call it too it follows me'

23b. Vovoli

'shadow'

24a. Ma-dzi ma-dzi-wú

1SG-stand 1SG-call-2SGOBJ-Q

'I stand, have I called you?'

24b. Vovoli

'shadow'

25a. Ma-yú o-gbo o-me nu dzue ma-n-tanyi o-nu kpi

1SG-see CM-town 3SG-this in but 1SG-NEG-can 3SG-in go

'I have seen this town but I can not go into it'

25b. Amen

'stomach' 
26a. A-do u-tsa o-me tá-ḿ dzue

3PLU-build CM-house AM-this give-1SGOBJ but

u-zí mo-ó-ma o-yó

CM-door NEG-3SG-stay 3SG-skin

'They build this house for me but it has no door'

26b. Ankofo

'egg'

27a. I-va-nu drui drui drui

CM-thing-in red red red

'The inside of a thing is red throughout'

27b. Tonka

'pepper'

28a. A-dzo o-sé amú n-tá

CM-riddle SM.SG-finish 1SG CM-hand

'riddle has finished in my hand'

28b. Ohoyiebî

'cowry'

\subsection{Origin of the Logba people}

This text was recorded on $6^{\text {th }}$ June 2004. Asafo Kudjo (Age 56) presented his version of the folk story about the origin of the Logba people. This is an extract from a longer conversation.

The Logba people came from Egypt and Sudan. It took the Logba people 200 years to come to their present settlement. They lived with other people on their way and come into contact with Yorubas and the Fon people. As a result, words from these languages entered the Logba language. The Logba people were belligerent. They did not stay in Notsie with the Ewes. The Logbas helped the Ewes when the Ewes were leaving Notsie to show them the way and they called the Akpana's Logba. The Logba peole lived as one people in one settlement but in Awara they started to break into smaller settlements.

01. Akpana é-qu aha xe é-do gu Akpana SM.PLU-be people RP 3PLU-come from

Egypt kpe Sudan i-vantsienu

egypt CONJ Sudan CM-area

'The Logba people are people who migrated from Egypt and Sudan.' 
02. A 0-gbá nago gu Sudan bi-fo o-kpunyie

3PLU CM-route journey from Sudan come-arrive CM-present.place xé e-tsi i-dze í-fo pkpe uga inys.

RP 3PLU-in CM-today SM-about year hundred two

'Their journey from Sudan to their present settlement took about 200years'

03. Akpana á o-gbá nago o-me o-gba bina

Akpana 3PLU CM-route journey AM-this CM-route come.through

Kamalo kpe á-yó

aha xé é-nyams

kamalo CONJ 3PLU-skin

people RP 3PLU-stay-there

$\mathrm{ib}(\mathrm{è})$-im $\varepsilon \quad \mathrm{nu}$

time-this in

'This journey took the Logba people through Cameroon and people resident in the environs at the time'

04. A-kpe ănyenu aha ámé é-nya nkpe gedee (gblele) 3PLU-CONJ particular people these 3PLU-live year many

'They (Logba people) with these people lived together for many years'

05. Akpana é-sa mokoe fé a-yisagoe mo

Akpana SM-PLU-leave there also 3PLU-migration that

i-bi-gu o-ta kpe i-yoyu nya-mo-ó-nya.

SM-come-from CM-war CONJ CM-peace stay-NEG-3SG-stay

'The Logbas left that place too because of wars and lack of peace'

06. A-yisago tamble ime i-ta té a-kpe

3PLU-migration third this SM-give COMPL 3PLU-CONJ

alatawoe f́̃ é-be-fida.

yorubas also 3PLU-come.contact

'Their third migration (journey) made them to come into contact with the Yorubas'.

07. Iva =a xé i-nya Akpanawo=é yó i-qu té

thing $=$ DET that SM-live Akpana $=$ DET skin SM-be COMPL

me-é-dzunu té é-lé-nya ina etsi.

NEG-3PLU-like COMPL 3PLU-PRSPROG-stay person under

'The Logba people did not like to be subordinate to other ethnic groups'

08. Iy(ع)-okple a-kpe alatawo=é fé me-tanyi-nu nya.

3SG-reason 3PLU-CONJ Yoruba $=$ DET also NEG-can-NEG stay

'Because of this, they could not stay together with the Yorubas'

09. Alatawo=é xé etsi kpe Akpana é-qu Yorubawo. alata $=$ DET RP under CONJ Akpana SM.PLU-be Yoruba

'The 'Alatas' who stayed with the Logbas are the Yoruba people. 
10. Akpana i-nya-go kpe Yoruba-wo=é ibita té

Akpana SM-stay-NOM CONJ Yoruba-PLU $=$ DET result COMPL

Yoruba gbe î-bi-vé f́e ikpana.

yoruba language SM-come-pass into Ikpana

'Their stay with the Yorubas made some words from Yoruba language

to come into the Logba language'

11. Efon kpe Ugbe-wa-go ikpé menu xé î-nya

efon CONJ Language-speak-NOM INDEF where RP SM-stay

n-tsi=é mo f́c i-bi vé f́c ikpana nu.

PLU-area $=$ DET there also SM-come pass into Ikpana in

'The Fon language and other languages in that area also entered

the Logba language'

12. Ivi-me ita té Ikpana inta é-dze fui.

thing-this make COMPL Ikpana self 3PLU-start disappear

'This led to the disappearance of the original Logba language.'

13. Iva, xé, ma-yayi té uklontsi o-me

thing RP 1SG-search COMPL book AM-this

gawoe to kpe i-qu té Akpana-wo=é

reader let know 3SG-be COMPL Akpana-PLU $=\mathrm{DET}$

me-é-du-nu ahá yugo

NEG-3PLU-be-NEG people peace

'What I want the reader to note is that the Logba people are not peaceful'

14. E-du o-ta gu-wo é-bime-n.

3PLU-be CM-war make-PLU 3PLU-that.day-in

'They were belligerent in those days'

15. Akpana=á me-é-nyá-nu Notsie kpe Aviewo

Akpana $=$ DET NEG-3PLU-stay-NEG Notsie CONJ Ewe.people

alo Ivi-wa-wo $=$ é

or $\quad$ Ewe-speak-PLU $=$ DET

'The Logbas did not stay at Notsie with the Ewes or the Ewe speakers'

16. Ibe-tsú xé avi=e é-nya Notsie,

time-on RP Ewe $=$ DETSM.PLU-stay Notsie

'At the time the Ewes stayed at Notsie,'

17. Akpana kpe e-gusá xé a-fé e-qu

Logba CONJ PLU-neighbour RP 3PLU-also SM.PLU-be

afiawo $=$ é, é-nya o-kunyie

dialect.speaker $=$ DET $\quad 3$ PLU-stay $\quad$ CM-that.place

'Logba and her allies who were also dialect speakers were staying at that place' 
18. xé ati-lî-dzi idze té eviegbefeme Togo

what 1PLU-PRSPROG-call today COMPL west Togo

ba o-kunyie xé é-lé-dzi Volta Region idze.

come CM-that.place RP 3PLUPRSPROG-call Volta Region today

'what we are calling today the Western part of Togoland to where

is presently called Volta Region.'

19. Avie e-do-go a-gli=é nu ime i-bi

Ewe 3PLU-leave-NOM CM-wall=DET in this SM-come

vúvoiva Akpana kpe anda-wo yó

spoil thing Akpana CONJ friend-PLU skin

'The Exodus of the Ewes affected the Logbas and their allies'

20. Iyóyu=é xé i-nya î-bi-sé o-tá gu-go

CM-peace $=$ DETRP SM-stay $\quad 3 P L U$-come-end CM-war make-NOM

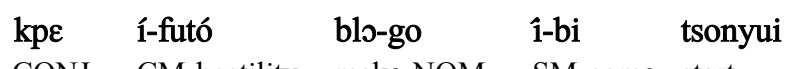

CONJ CM-hostility make-NOM SM-come start

'The peace that prevailed came to an end and war and hostility started'

21. Agli=é nu do-go ibe tsú avie wall $=$ DET-in leave-NOM time on Ewe

é-ta Akpana nyi té Logba.

SM.PLU-give Akpana name COMPL Logba

'It was during the breaking into 'the wall' that the Ewes named the 'Akpanas', Logba'

22. Iboté me-té-nú ikpana xé é-té-wa

CONJ NEG-PSTPROG-understand Ikpana COMPL 3PLU.PTPROG-say

nu té é-la o-gbá=á avie i-ló xé

in COMPL 3PLU-cut CM-path=DET Ewe CM-word RP

é-té-nu-e é-qu Logba

3PLU-PTPROG-understand-CFM 3PLU-be Logba

'The Ewes did not understand what the Logbas were saying, what they heard was Logba'

23. Logba iyé i-bi-dzu Logba idze.

Logba 3SG SM-come-know Logba today

'Logba, which is now Logba today'

24. Akpana édú ina ikpe ibe kpóyi nu bifó ibe tsú

Akpana SM.PLU-be person one time all in uptill time on

$\begin{array}{llll}\text { e-be-fo } & \text { o-kunyi=é } & \varepsilon \text {-té-dzi } & \text { Awara. } \\ \text { 3PLU-come-reach } & \text { CM-place =DET } & \text { 3PLU-PTPROG-call } & \text { Awara }\end{array}$

'The Logbas were one people for a long time up to the time that they came to a place called Awara.' 


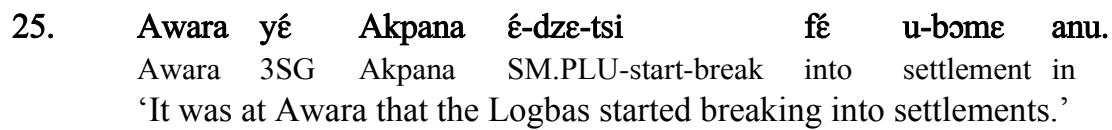

\subsection{Linguist staff}

This text is an extract from a longer converstion which was recorded on $20^{\text {th }}$ May 2004 in Klikpo. Torgbui Asamoah III (A)(Age 60) explained what the linguist staff is to Ophelia (O) (Age 52) and Hayse.(H) (Age 47)

The linguist staff is important in Logba. The key on the linguist staff shows that the paramount chief has the key and he is the person 'who opens the door' for the people. The paramount chief leads the way in everything in Logba. All other chiefs including their linguists are subordinate to the paramount chief.

$\begin{array}{lllllll}\text { 01. } & \text { H: U-nansa } & \text { ma-nenu } & \text { té } & \text { ani-ti-ri } & \text { tsami } & \text { oý́ } \\ \text { CM-chief } & \text { 1SG-believe } & \text { COMPL } & \text { 2PLU-HAB-hold } & \text { linguist } & \text { stick } \\ \text { okpe xé } & \text { safi } & \text { o-le } & \text { o-yó } & & & \\ \text { one REL } & \text { key } & \text { 3SG-be } & \text { 3SG-skin } & & & \end{array}$

'Chief, I believe that you usually hold a linguist staff which has a key on it'

02. A-susu a-me okple xé safi o-me o-le oý́

CM-reason AM-Q reason RP key AM-this SM.SG-be stick

o-me yó iboté Akpana tsami oyó ugugo.

AM-this skin because Logba linguist stick different

'Why is it that this key is on this staff because Logba has different linguist staffs'

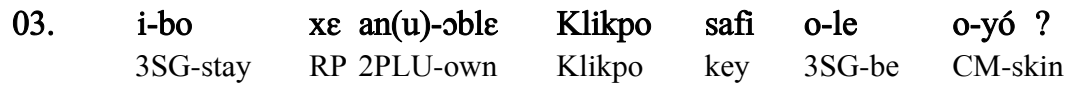

'Why do you have key on your own Klikpo one?'

04. A: Yoo a-bu enzi. Klikpo atu pétée atsi-kpe té OK 2SG-ask well Klikpo 1PLU all 1PLU-know COMPL

i-le i-du o-nukpa nango o-gbonu

SM-be.located SM-be CM-chief big CM-town

'OK You ask well. We all know that Klikpo is the town of the paramount chief'

05. iboté o-nukpa nango=é amá ina o-kpe mo-ó-ma because CM-chief big=DET back person AM-one NEG-3SG-stay xé o-dá uzi ta ina o-kpe té o-vé

RP 3SG-open door give person AM-one COMPL 3SG-pass 
f́̃ okusioku

into everywhere

'Because apart from the paramount chief no one can open the door for anyone to go anywhere'.

06. Xé onkpesiokpe ó-ba u-tudimi $=\tilde{\varepsilon} \quad$ wá fé

COND anything 3SG-come CM-government $=\mathrm{DET}$ side also

u-nansa nango o-bó-dú i-te

CM-chief big 3SG-will-stay CM-front

'If anything happens in the government also the paramount chief will lead'

07. xé a-tani okusioku fo safi o-me o-le

COND 3PLU-can everywhere reach key AM-this SM.SG-be.at

ó-qu эyó xé ó-to-mi-gba Akpana. Safi o-me o-le

3SG-be stick RP 3SG-HAB-lead Logba key AM-this AM-be

o-yó o-me yó iboté Akpana tsiami

CM-stick AM-this skin because Akpana linguist

o-yó o-gugo

CM-stick AM-different

'If they can reach everywhere this key on this staff is what they will use to lead the Logba people 'This key is on this stick because the linguist staff of Logba is different",

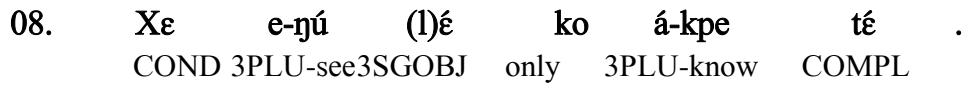

o-le ó-du onukpa nango ta Akpana

3SG-be.at 3SG-be chief big give Logba

'If they see it then they know that it is Logba paramount chief'

09. $\mathrm{H}: \mathrm{M} \varepsilon$ o-du té $\mathrm{x} \varepsilon$ ani-fida okunkpe

Q 3SG-be COMPL when 2PLU-meet somewhere

$\begin{array}{lllll}\text { ani-ti-mi-lé } & \text { tá } & \text { tsami } & \text { mango } & \text { té } \\ \text { 2PLU-HAB-take =3SGOBJ } & \text { give } & \text { linguist } & \text { another } & \text { COMPL }\end{array}$

o-ri ta $=$ anú

3SG-hold give $=2$ PLUOBJ

'Why is it that when you meet somewhere you give it to another linguist to hold for you'

10. Alo ani-dzi lî-zó okunkpe loo ani-dzu- $\varepsilon$

or 2PLU-stand PRSPROG-go somewhere or 2PLU-stand-CFM

ani-ti-mí ta in(a)-okpe té o-ri ta anu?

2PLU-HAB-take give person-one COMPL 3SG-hold give 2PLUOBJ 'or when you are going somewhere do you give it to another person to hold for you?' 
11. Anu tsami vafo di-go okple

2PLUlinguist side rule-NOM reason

$\mathrm{n}-\mathrm{du}-\mathrm{bu}=\boldsymbol{\varepsilon} \quad$ lo!

1SGPRSPROG-be ask $=3$ SGOBJ ADR

'As you are our elder, that is why I am asking'

12.

$\begin{array}{lllll}\text { A: Akpana } & \text { o-kəo } & \text { ó-ló-du } & \text { t'́ } & \text { xé e-ka } \\ \text { Logba } & \text { CM-custom } & \text { 3SG-PRSPROG-be } & \text { COMPL } & \text { COND 3PLU-put }\end{array}$

wú abia tsú ko a-dzu onukpa alo tsami. Tsami

2SGOBJ stool on only 2SG-become chief or linguist linguist

okpesiokpe xé o-bo Akpana o-tsi onukpánango etsi.

everyone REL 3SG-stay Logba 3SG-stay chief.big under

'Logba custom is that if you are put on a stool you become a chief or a linguist. All linguists in Logba are under the paramount chief'

13. Iyé-okple xe a-bo dzi- $\varepsilon$ iboté tátá té awú 3SG-reason COND 2SG-stay stand-CFM reason inform COMPL 2PLU

nyэmbli $=\varepsilon \quad 0-k p \varepsilon \quad$ té $\quad$ abia tátà wú etsi. second $=$ DET 3SG-know COMPL chair inform 2SG ground 'That is why when you will leave you have to inform your partner so that the chair is not empty'

14. Xé Tsami o-kpe ó-dzi té óbó-fé-ntá ${ }^{53}$

COND linguist AM-one 3SG-stand COMPL 3SG-FUT put.in-hand

iboté o-mi=é ta- $\varepsilon$ tsami mango iboté

reason $3 \mathrm{SG}$-take $=3 \mathrm{SGOBJ}$ give3SGOBJ linguist another reason

Tsami okpesiokpe ó-tsi onukpánango etsi

linguist every 3SG-stay chief.big under

'If a linguist stands to go to urinate, its good that he gives it to another linguist because every linguist is under the Paramount chief'

15. O: Unansa ma-nenu té

Chief 1SG-believe COMPL CM-word=DET RP Hesse

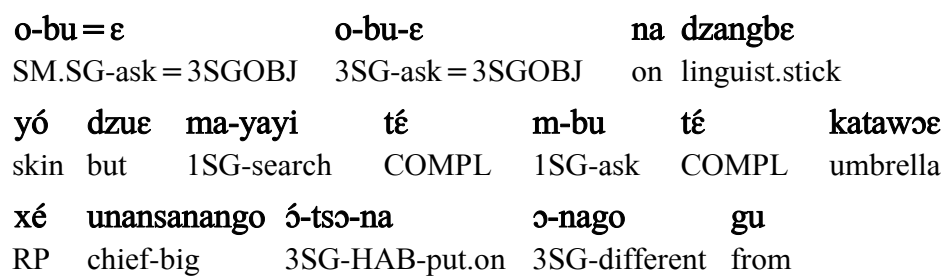

${ }^{53}$ Verbal indirection; an expression used when one wants to say in public that he wants to visit the washroom 
a-nukpa ongago $=\hat{\varepsilon}$ ible yó

PLU-chief other $=$ DET own skin

Chief, I believe the words that Hesse asks he asks about the linguist stick. But I want to ask whether the parasol that the Paramount chief uses is different from that of other chiefs?'

16.
A: Atsú-nta
atsi-kpe
té
unansanango adzi =á
1PLU-own
1PLU-know
COMPL chief.big
day $=$ DET

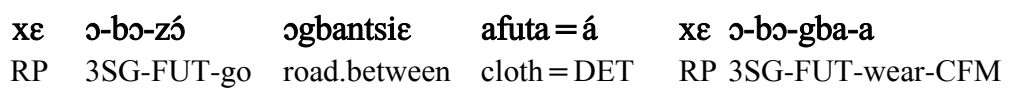

$$
\text { xé i-qu té } \quad \text { a-bo =wu }
$$

COND 3SG-be COMPL 2SG-stay=2SGOBJ too 2SG-NEG-wear-3PLU

'We all know that the day the paramount chief will go out or on a journey, the cloth he will wear you will not wear it even if you have it'

17. Iboté xé a-gba-a i-gbla té a-mó-ló

reason COND 2SG-wear-3PLU 3SG-show COMPL 2SG-NEG-PRSPROG

f́ ugo nango anu kpe unansanango $\mathrm{ntsi}$

put difference big 2PLU CONJ chief.big between

'It shows that there is no great difference between you and the Paramount chief'

18. Iý́

3SG reason COND 3PLU-FUT-make umbrella for $=3$ SGOBJ reason

té o-nago gu a-nukpa angagoe yó .

COMPL 3SG-be.different from PLU-chief others skin

'That is why if they should make umbrella for him, it should be different from that of other chiefs'

19. O: Anyintse té a-lá i-ló i-me wá tsú. thanks COMPL 2SG-beat CM-word AM-this tell 1PLUOBJ 'Thanks that you have explained this to us'

20. Iboté atsú-e ebît-wo kloyi ko atsi-du. Iboté atsi reason 1PLU-EMPH child-PLU small only 1PLU-be reason 1PLU dze té katawəe pétée i-qu ikpe. Awú

see COMPL parasol all SM-be one 2SG

unansanango $=e^{\prime} \quad f^{\prime} \varepsilon \quad x \varepsilon$ a-tsi umi- $\varepsilon \quad k p \varepsilon$ angagoe

chief.big $=$ DET also RP 2SG-sit there-EMPH CONJ others

i-ble té i-du ikpe

3PLU-own COMPL AM-be one

'For we are children. Because we see that all the parasols are the same; You the Paramount chiefs also who are there with the other chiefs should be one' 
Ad’́dí 'love' is a song that is composed by T.K. Bediako, (Age 71) a native speaker of Logba from Tota. Most of the songs sung by the Logba people are in Ewe and Akan. The songs in Logba are sung when certain rituals are to be performed. It is believed that it is forbidden to sing songs which are composed in the Logba language. I am informed that this is the first attempt at writing music in the Logba language. It is amazing how a choir from Tota can sing it with expression.

\section{A-dódí A-dódî A-dódí A-dódí CM-love CM-love CM-love CM-love 'Love, love, love, love'}
02. A-dódí î-du i-kago kelekele CM-love SM-be CM-law first 'Love is the first law'
03. Iyé i-du ग-kpaya i-kago kelekele 3SGIND SM-be CM-God CM-law first 'It is the first law of God'
04. O u-gusa o u-gune o atsú pétépété o CM-brother o CM-sister o 1 PLU all 'Oh brother, o sister o all of us'
05. Yesu o-dá iyé ka té Jesus 3SG-say 3SGIND down COMPL 'Jesus said it that'

$\begin{array}{llllll}\text { 06. dódí awú gusa } & \text { dódí } & \text { awú gune } & \text { boté } & \text { awú } & \text { nta awu-yó } \\ \text { love } 2 S G \text { brother } & \text { love } & \text { 2SG sister } & \text { like } & \text { 2SGIND } & \text { own 2SGIND-skin }\end{array}$ 'love your brother, love your sister like your own self'

07. Yedze a-blo o-kpaya i-kagoe pétée tsú then 2SG-make CM-God CM-rules all on 'Then you will abide by the Lords commandments'

08. Đódî nu andakame loo love 2PLUOBJ each.other ADR 'Love each other (I urge you)'

09. Dze nu golgata u-kpo=é tsú look 2PLU golgata CM-mountain $=\mathrm{DET}$ on 'Look at the Golgata mountains'

10. Ao dzalélélélé me-o-bá- $\varepsilon$ ?

INJ dzalelele(INJ) QP-3SG-come-QP

'Oh what has come to pass?' 
11. Yesu Kristo O-mawu-bí=é

Jesus Christ CM-God-child $=$ DET

'Jesus Christ, the son of God'

12. o-ko atitsoga yó i-yógbe tsú

3SG-hang cross skin CM-misery on

'He hangs on the cross miserably'

13. Awú, amú atsú i-vagbali o-kple

2SGIND 1SGIND 1PLUIND CM-sin CM-reason

'Because of you, I, and our sins'

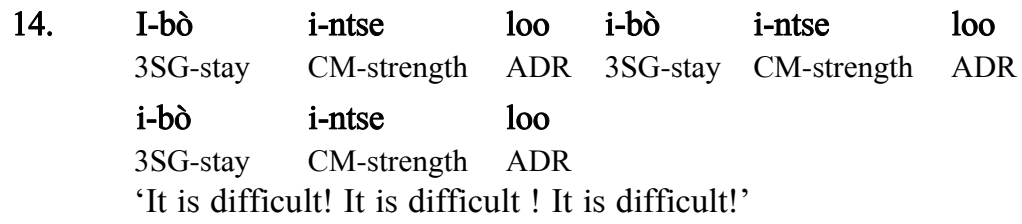
15. Agoo té m-kpa dze iyé texoe ta amu-yó
Agoo let 1SG-go look 3SGIND scene for 1SGIND skin
'Agoo, let me go and watch the scene for myself'
16. I-te na o-tsú inta Vui nu ivagbali blo nu 3SG-press on 3SG-on very stop 2PLU sin make 2PLU
'He is so much disturbed. Stop from your sins'

17. Té tanyi nya u-zúngbá dúkpá

COMPL can stay CM-life good

'that you lead a good life'

\section{$15.9 \quad$ Yam cultivation}

Yam is one of the special food crops in the Logba area. Mr. M. K. Nyalemegbe (Age 53) describes how it is cultivated in Logba. This was recorded on $16^{\text {th }}$ June 2004.

Yam cultivation starts with the selection of a fertile piece of land, clearing, planting and taking care of the young plants up to the time that they are ready for harvest. After harvest, it is stored. Some are sold while a portion is kept as food for the family and another stored as seeds for the planting season that follows.

$\begin{array}{llll}\text { 01. Gbã xé a-lo-yayi } & \text { té } & \text { a-ka } \\ \text { first if } & \text { 2SG-PRSPROG-search } & \text { COMPL } & \text { 2SG-put }\end{array}$ 
i-dzo bo- $\varepsilon$

CM-yam farm-EMPH

'First, if you are willing to cultivate yam'

02. iboté té á-zó té á a-kpó yayi e-tsi dúkpá reason COMPL 2SG-go COMPL 2SG-go search CM-land good 'you have to go and search for a good land'

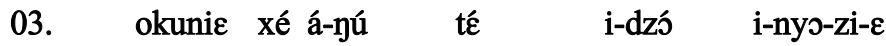

place RP 2SG-see COMPL CM-yam SM-stay-well-CFM

'place where you think that yam will do well'

04. Yédze xé a-yayi e-tsi=é sé a-bo bé iva then if 2SG-search CM-land=DET finish 2SG-FUT clear thing 'Then if you finish searching for land, you clear it'

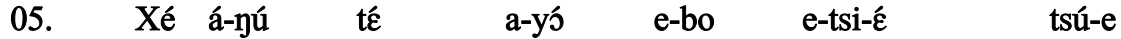
if 2SG-see COMPL PLU-tree 3PLU-stay CM-land=DET on-EMPH 'If you see that trees are on the land'

06. yedze a-tso a-yó=ð pété

then 2SG-cut AM-tree $=$ DET all

'then you cut all the trees'

07. yédze a-bó-ta té iva te i-tsúe then 2SG-FUT-leave COMPL thing get SM-dry 'then you will leave it that the thing get dried'

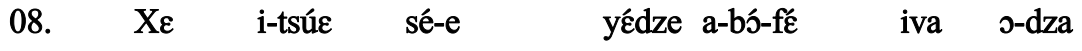
when SM-dry finish-CFM then 2SG-FUT-set thing fire 'After it is dried then you will set fire to it.'

09. Yédze ábó kpali iva, xé a-kpali iva sé-e then 2SG-FUT collect thing when 2SG-collect thing finish-CFM 'then you will collect it. When you finish collecting it'

10. yé nyangbo ग-nっ-っ, yédze a-bó-yayi a-gblenu CONJ rain SM.SG-fall-CFM then 2SG-FUT-search CM-hoe 'and rain falls then you will look for a hoe'

11. A-bó-la a-dru yé a-la $\quad$ a-dru=ć 2SG-FUT-beat CM-mound CONJ 2SG-beat CM-mound=DET finish 'You will prepare a mound and after you finish making the mound'

12. yédze a-bó-mi i-dzo-zugbo =é a-bó-fashi $=\varepsilon$ then $\quad$ 2SG-FUT-take CM-yam-head $=$ DET AM-FUT-split $=3$ SGOBJ 'then you will take the yam head (see) and split it'

13. Yर́ a-fashi $=\mathfrak{\varepsilon} \quad$ sé-e $\quad$ yédze a-bó-dzanyi

CONJ 2SG-split=3SGOBJ finish-CFM then 2SG-FUT-collect 'and after you finish splitting it then you collect' 
14. i-dzó =ó na a-dru=é $\quad$ tsú

$\mathrm{CM}-\mathrm{yam}=\mathrm{DET}$ on CM-mound $=$ DET on

'the yam (seeds) and put them on the mounds'

15. yé a-bó-mi a-gblenu ke yé

CONJ 2SG-FUT-take CM-hoe again CONJ

'and you will take the hoe again and'

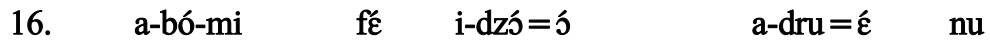

2SG-FUT-take into $\quad \mathrm{CM}$-yam $=$ DET $\quad \mathrm{CM}$-mound $=$ DET in

'you will put into the yam mounds (plant the yam seeds)'

17. yédze i-yóloli kpe e-kele=é

then CM-small sticks CONJ CM-grass $=$ DET

'then the pieces of sticks and weeds'

18. xé a-gba $u-b o=e ́ \quad$ nu- $\varepsilon$

RP 2SG-sweep CM-farm $=$ DET in-CFM

'which you gathered in the farm'

19. a-mi na a-dru $=\hat{\varepsilon} \quad$ tsú té

2SG-take put CM-mound $=$ DET on COMPL reason

i-yóyú aló i-yúgo

CM-moisture or coolness

'you put on the mound to give moisture or coolness'

20. té itaté i-yóyú alo i-yúgo

COMPL reason CM-moisture or coolness

'that moisture or coolness'

21. té i-nya a-dru $=\varepsilon \quad \mathrm{\varepsilon u}$

COMPL AM-stay CM-mound $=$ DET in

'that it stays in the mound'

22. té e-tsi=c nu té

COMPL CM-land=DET in COMPL AM-never dry

'that the mound does not get dried'

23. yé i-dzó=ó i-le-e yédze

CONJ CM-yam $=$ DET SM-germinate-EMPH then

'When the yam germinates, then'

24. a-bó-kpomi a-ganyi

2SG-FUT-remove leaves.CM-palm.branch

'you will remove leaves from a palm branch;'

25. a-bó-mi ya i-dzó=o pétée

2SG-FUT-take stake CM-yam $=$ DET all

'you will use it to stake all the yam' 
26. yé a-ya $=\varepsilon$ sé-é yédze a-zo iva-nu

when 2SG-stake $=3 \mathrm{SGOBJ}$ finish-CFM then 2SG-go thing-in (bush) 'After you stake it then you go to the bush'

27. á-kpo tso pampro aló i-yó

2SGFUT-go cut bamboo or PLU-stick

'you will cut bamboo or stick;'

28. a-glui vutsi yédze a-mi=é fर́

2SGFUT-dig hole then 2SG-take=3SGOBJ in

'you will dig a hole then you will put it in'

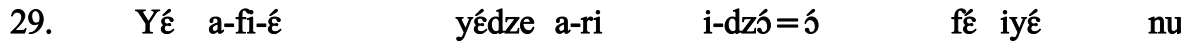

when $2 \mathrm{SG}$-in $=3 \mathrm{SGOBJ}$ then 2SG-hold $\mathrm{CM}$-yam $=\mathrm{DET}$ in 3SGIND in 'when you put it in then you hold the yam on to the stick'

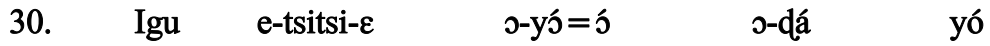

from 3SG-turn-EMPH $\quad$ CM-tree=DET SM.SG-big skin

'It is according to the size of the stick'

31. Yé o-yó=ó o-dá yédze a-ri i-dzó gblele

if $\mathrm{CM}$-stick=DET SM.SG-big then 2SG-hold CM-yam many

'if the stick is big then you hold plenty yam'

32. f́̃ $=\hat{\varepsilon} \quad$ nu iná aló inu

in $=3 \mathrm{SGOBJ}$ in four or five

'on it, four or five'

33. Yé dzue o-yó=ó mo-da-nu-e

if but CM-stick=DET NEG-big-NEG-CFM

'if however, the stick is small'

34. yédze a-ri i-dzó=o iny alo okpe

then 2SG-hold CM-yam $=$ DET two or one

'then you hold two or one yam on it'

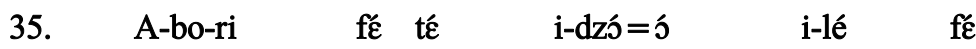

2SG-FUT-hold in COMPL CM-yam $=\mathrm{DET} \quad \mathrm{SM}$-climb in

'You will hold it on it for the yam to climb it'

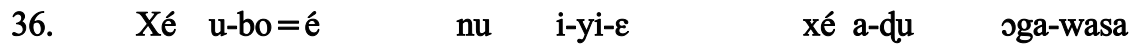

if $\mathrm{CM}$-farm $=\mathrm{DET}$ in $\mathrm{AM}$-weedy-CFM if 2SG-be wife-owner 'If the farm is weedy, if you have a wife'

37. yédze á-wa awú o-ga

then 2SGFUT-say 2SG CM-spouse

'then you will tell your wife'

38. ó-bó-mi a-gblenu aló i-fiami

3SG-FUT-take CM-hoe or CM-cutlass

'she will take hoe or cutlass' 
39. o-bó-ló u-bo=é $\quad$ nu.

3SG-FUT-weed $\quad \mathrm{CM}$-farm $=\mathrm{DET} \quad$ in

'she will weed the farm'

40. Xé i-dzó=ó i-dze m-ba la-a

COND CM-yam =DET SM-start CM-tendril take off-CFM

'If the tendrils start to grow'

41. yédze i-be-shi-be-nu xé a-zo u-bo=é nu- $\varepsilon$

then CM-time-every-time-in COND 2SG-goCM-farm $=$ DET in-CFM

'then everytime when you go to the farm'

42. a-bó-tso-ri i-dzó m-ba=á gle f́́ a-nđa nu

2SG-FUT-HAB-hold CM-yam CM-tendril=DET tie into CM-friend in 'you will have to hold the yam tendrils into one another'

43. té i-ti-ri a-ndakame

COMPL AM-never-hold CM-friend.each.other

'that it will never get into one another'

44. Xé a-blo imo-a tsỹ̃̃

COND 2SG-make that-EMPH IDEO

'If you do that tsyos (for a long time)'

45. yé i-ne boté a-bobí glankpe

CONJ AM-getlike CM-month seven

'and it gets to about seven months'

46. li-zó mlaminá m-ble nu-e

PRSPROG-go eight CM-ORD in-EMPH

'going to the eighth month (in)'

47. yedze a-bó-glu i-dzó=á e-tsi

then 2SG-FUT-dig CM-yam $=$ DET CM-under(ground)

'then you will dig under the yam'

48. I-dzó-etsi-glui i-me- $\quad$ i-dzó i-kpe

CM-yam-under-dig CM-here-EMPH CM-yam CM-one

'This process of digging under the yam, one yam'

49. i-bí-tà boté i-ta aló i-na yedze

SM-FUT-give like CM-three or CM-four then

a-kpitsi iyé yó

2SG-remove 3SG skin

'it will give about three or four; then you will remove some from it'

50. I-be i-kpe menu a-gá o-kpe alo i-ny

CM-time AM-one where 2SG-leave CM-one or CM-two in

'sometimes you leave one or two in' 
51. $\begin{array}{lllllll}\mathrm{kp} \varepsilon & \mathrm{a}-\mathrm{susu} & \mathrm{t} \varepsilon & \mathrm{i}-\mathrm{dzó}=5 & \mathrm{t} \varepsilon & \mathrm{i}-\mathrm{zu} & \mathrm{da}\end{array}$ CONJ CM-reason COMPL CM-yam=DET COMPL AM-be.big fat 'with the reason that the yam becomes big'

52. Yedze a-bobi gokoadu m-ble nu-e then CM-month nine CM-ORD in-CFM 'then in the ninth month'

53. yedze a-dze i-dzó=ó glui then 2SG-start CM-yam $=$ DET harvest 'then you start the yam harvest'
54. Xé á-ló-glui $=\varepsilon \quad$ a-to $=\varepsilon$
COND 2SG-PRSPROG-harvest $=3$ SGOBJ 2SG-remove.part $=3$ SGOBJ 'when you are harvesting you leave part of it'

55. Xé a-to=ź ye i-du té

COND 2SG-remove.part $=3$ SGOBJ CONJ SM-be that

'If in the process you feel that'

56. awú i-dzó=ó i-wlui-ع

2SG $\mathrm{CM}$-yam = DET SM-many-EMPH

'your harvest is great'

57. yedze a-mi ikpe zó o-vu=é nu then 2SG-take one go CM-market $=$ DET in 'then you take some to the market'

58. a-kpi zo alo a-kà $=\varepsilon \quad$ ka $\quad$ o-gba yó 2SG-go sell or 2SG-put=3SGOBJput CM-road skin 'to sell or sell it by the road side'

59. á-zó ta u-klo nu a-há 2SGFUT-sell give CM-lorry in CM-people 'you will sell to those who travel in lorries'

60. dzue xé a-mo-du i-dzó gblele du-wo=é but COND 2SG-NEG-be CM-yam many sow-NOM=DET 'but if you are not a commercial yam farmer'

61. yedze a-mi $=\hat{\varepsilon} \quad$ mla a-fánu

then 2SG-take $=3$ SGOBJ bring CM-house

anyi-li-zá kpe

2PLU-PRSPROG-cook eat

'then you take it to the house to be using for food'

$\begin{array}{lll}\text { 62. Iva anyi-li-zá } & \begin{array}{l}\text { etsitome } \\ \text { thing 2PLU-PRSPROG-cook }\end{array} & \begin{array}{l}\text { beginning } \\ \text { CM-yam=DET }\end{array}\end{array}$ 
mi-tsé-nu

NEG-grow-NEG

'things you are cooking; in the beginning the yam is not developed'

63. $\quad$ okpli- $\varepsilon$

$\begin{array}{lllll}\text { okpli- } \varepsilon & \text { a-há } & \text { gblele } & \text { i-vafo } & \text { ko } \\ \text { REAS-EMPH } & \text { CM-people } & \text { many } & \text { CM-slice } & \text { only }\end{array}$

e-tse-mi

zá

3PLU-HAB-take cook

'therefore many people use it only for slice'

64. dzue xé i-dzó=ó i-dze tse-e

but COND CM-yam $=$ DET AM-start grow-EMPH

é-tse-mi yue fufu f́

3PLU-HAB-take pound fufu also

'but if the yam is developed it is used to prepare fufu also'

65. dzue xé a-zi- $\varepsilon$ sé a-bo-mi

but COND 2SG-remove $=3 \mathrm{SGOBJ}$ finish 2SG-FUT-take

ywe fufu- $\varepsilon$

pound fufu-EMPH

'but when you remove it from fire and use it to pound fufu'

66. $\mathrm{a}-\mathrm{ka}=\varepsilon \quad \mathrm{e}-\mathrm{vi}$ té $\mathrm{e}$-fufo tá

2SG-put=3SGOBJ CM-sun COMPL CM-air give

ó-li $=\varepsilon \quad$ tsibi

3SG-blow $=3$ SGOBJ small

'you leave it open so that air blows over it a little'

67. iý́ ko $\mathrm{x} \varepsilon$ a-ywe $=\varepsilon$

that only COND 2SG-pound $=3$ SGOBJ

'only that when you pound it'

68. iyé ko i-dzó=う fufui=e o-nyo-zi

3SGIND only CM-yam $=$ DET fufu=DET AM-stay-good 'only that you will have a good yam fufu'

69. xé a-to $=\varepsilon \quad$ xé a-yú kanyi

COND 2SG-harvest $=3$ SGOBJ COND 2SG-see light

'If you harvest and you realise'

70. té i-dzo=ó mi-da-nú

COMPL $\quad$ CM-yam $=$ DET NEG big-NEG

'that the yam is not big'

71. té a-mi-zó a-fá-nu a-kpo $\mathrm{kpi}=\boldsymbol{\varepsilon}$

COMPL 2SG-take-go CM-house-in 2SG-go eat=3SGOBJ

'to take home and use for food' 
72. yedze a-fle a-dru=é a-má yedze

then 2SG-break CM-mound=DET CM-back then

$\mathrm{a}-\mathrm{mi}=\hat{\varepsilon} \quad$ fi- $-\tilde{\varepsilon}$

2SG-take $=3 \mathrm{SGOBJ} \quad$ into $=3 \mathrm{SGOBJ}$

'then you dig the back of the mound then you put it into it'

73. I-dzó i-me menu anyé xé i-fo

CM-yam AM-this type so COND 3SG-reach

i-dzó-zugbo la-a

CM-yam-head time-CFM

'this type of yam at the time of harvesting the yam seeds'

74. Iyé atsi-tsi-dzi té panshia

3SG 1PLU-1PLU-call COMPL panshia

'It is the one we call panshia'

75. A-bó-mi-é doka ta e-kpe=é

2SG-FUT take $=3 \mathrm{SGOBJ}$ reserve for $\mathrm{CM}$-year $=\mathrm{DET}$

xé a-lá-ba nu

RP 2SG-PRSPROG-come in

'You will reserve it for the next planting season'

76. Yedze xé i-fo i-dzó du e-kpe=é

then COND 3SG-get CM-yam plant CM-year $=\mathrm{DET}$

a-la-ba nu

2SG-PRSPROG-come in

'then when you are entering the planting time'

77. yedze a-fashi- $\hat{\varepsilon} \quad$ a-mi-du

then 2 SG-cut $=3$ SGOBJ $\quad$ SSG-take-plant

'then you split it for planting'.

78. Iyє́ f́̃ i-bî-le pepepe boté i-dzó-zugbo-e

3SG also AM-FUT-germinate exactly like CM-yam-head-EMPH

'It will also germinate exactly like the yam seed'

79. Xé a-blo-é anyé yé i-fó

COND 2SG-make $=3$ SGOBJ so CONJ SM-reach

'If you do it this way and it is up to'

80. a-bobi dutsanyo-ble nu=e i-be i-mo-a nu

CM-month twelve-ORD in=DET CM-time AM-that-EMPH in

'the twelve month it is that time'

81. xé i-dzó o-nkpa i-ku sé-e

COND CM-yam CM-creepers SM-die finish-EMPH

'if the leaves of the yam are dead' 
82. yedze a-bó-la i-dzó-zugbo

then 2SG-FUT-take.off CM-yam-head 'then you will harvest the yam seeds'

83. Dzue xé a-bó-la i-dzó-zugbo=é

but COND 2SG-FUT-take.off CM-yam-head =DET

a-há a-kpe

CM-people CM-one

'but when you harvest the yam tubers, some people'

84. e-blo texo ka boté e-tsitsi- $\varepsilon$

3PLU-make yam.barn put like SM-sit down-EMPH

'they make yam barn like the one that sits here'

85. anyi-li-nú me kpanie anyé

2PLU-PSPROG-see here now so

'you are seeing here now'

86. A-bó-blo awú texo xé $a-b l o=e ́$

2SG-FUT-make 2SG yam.barn COND 2SG-make=3SGOBJ

'You will make your yam barn. When you make it'

87.

\begin{tabular}{|c|c|c|c|}
\hline a-la & i-dzó-zugbo & A-há & $\mathrm{a}-\mathrm{kp} \varepsilon$ \\
\hline 2SG-take.off & CM-yam-head & CM-people & AM-one \\
\hline & בא & & \\
\hline NEG-make & yam.barn-E & & \\
\hline
\end{tabular}

'you harvest the yam seeds. Some people who do not make the barn'

88. é-tse-blo i-dzó a-gba yedze xé e-glui

3PLU-HAB-make CM-yam CM-stand then COND 3PLU-dig

i-dzó=ó sé

$\mathrm{CM}-\mathrm{yam}=\mathrm{DET}$ finish

'they make yam shed then when they finish harvesting the yam'

89. yedze e-bé-gba na a-gba=á tsú

then 3PLU-FUT-collect $\quad \mathrm{CM}$-yam $=\mathrm{DET} \quad$ to $\mathrm{CM}$-stand $=\mathrm{DET}$ on

'then they will put the yam on the stand'

90. yedze e-tso iva na iyé tsú té é-mi doka then 3PLU-cut thing to 3SG on COMPL 3PLU-take reserve 'then they cut thing (grass) on it to reserve it'

91. ta e-kpé e-le-ba nu ta iva du-go give CM-year 3PLU-PRSPROG-come in give thing plant-NOM 'for planting in the coming year.'

92. Xé a-blo ime sé ko yedze awu ló COND 2SG-make this finish only then 2SG part 'When you finish making this then as for you' 


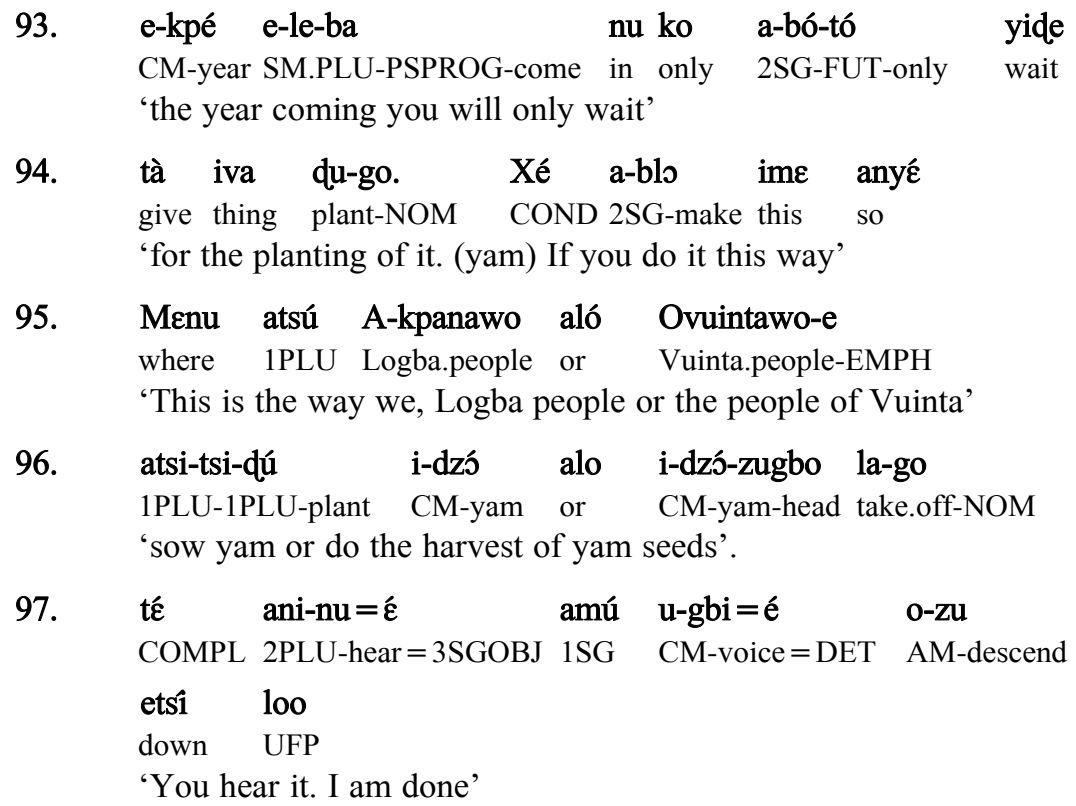

\subsection{Palm wine tapping}

Palm wine is used in almost all socio-cultural ceremonies in Logba. As a result, it has high demand in the area. Enos Adiamah (Age 53) is a well known palmwine tapper in Logba. His description of palmwine tapping was recorded on $27^{\text {th }}$ April 2006 in Alakpeti.

Palm wine tapping involves felling the palm trees and leaving them for two to three weeks before removing the palm fronds. A hole is made in the soft tender upper part of the trunk with a knife and a hollow object in the shape of a pipe is inserted in the hole. The wine flows through this hole and a pot is placed under the trunk to collect the wine. The wine is sold to the people in the town and part of it is distilled into a local gin called Akpeteshie. The tree stops giving wine after about a month. Palm wine is very useful to the Logba people.

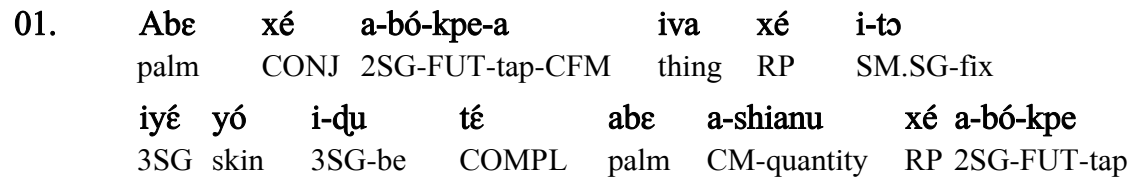


ibote ta kpe iyé i-gago

reason give know 3SG CM-number

'Palm tree, when you want to tap it, the things involved are, the quantity that you will tap, that is you know the number'

02. Iyé i-gago ime té a-yayi iva xé a-bó-mi

3SG CM-number this COMPL 2SG-search thing RP 2SG-FUT-take

kpe abe Iyé i-qu shafi, aflandza, uzu, asotiwo xé

tap palm 3SG SM-be 'ohafi' cutlass 'uzu' small.pots RP

a-bo-mi kpe abe.

2SG-FUT-take tap palm

'This number, you will search for things that will be used to tap the palm tree. They are: "ohafi", cutlass "uzu", small pots"

03. Xé i-flo-っ yé a-bó-dze abe tǒ.

COND 3SG-reach-CFM CONJ 2SG-FUT-start palm fell

Xé a-bó- tǒ abe ibòté ta yayi ina té

COND 2SG-FUT-fell palm reason COMPL search person COMPL

o-bá tǒ-a ta wú

3SG-come fell-3PLU give 2SGOBJ

'If they are ready then you start to fell the palm tree. If you will fell the palm you have to search for a person to help'

04. xé i-qu té awú-nta a-mo-tanyi a-pétée

COND 3SG-be COMPL 2SG-own 2SG-NEG-can 3PLU-all

tǒ $=\mathrm{e}$

fell $=3 \mathrm{SGOBJ}$

'If you yourself you cannot fell all'

05. Ayé i-wli-go nu yé a-bó-mi tǒ-a xé

3PLUCM-many-NOM in CONJ 2SG-FUT-take fell-3PLU COND

a- tǒ abe mê sé-e e-bé-nya

2SG-fell palm this finish-CFM 3PLU-FUT stay week

inys alo ita

two or three"

you have to consider its quantity when you want to fell it. After felling they (palm tree) will stay for two or three weeks.'

06. Ta-mble nu-e yé a-bó-la aganyi.

three-ORD in-CFM CONJ 2SG-FUT-remove palm.fronds.

xé a-bó-la aganyi f’e a-bó-zí ohafi

COND 2SG-FUT-remove palm.fronds also 2SG-FUT-take shafi,

aflandza iyé a-bó-mi là aganyi.

cutlass 3SG 2SG-FUT-take remove palm.fronds

'In the third week, you remove the palm fronds. It's "ohafi" and 
cutlass that you will use'

07.

\begin{tabular}{|c|c|c|c|c|c|c|}
\hline $\begin{array}{l}\text { Ye } \\
\text { then }\end{array}$ & $\begin{array}{l}\text { a-la } \\
\text { 2SG-remove }\end{array}$ & $\begin{array}{l}\text { aganyi } \\
\text { palm.frond }\end{array}$ & $\begin{array}{l}\text { pétée, } \\
\text { ish all }\end{array}$ & $\begin{array}{l}\text { a-bó-z } \\
\text { 2SG-F }\end{array}$ & $\begin{array}{l}\text { zuzo } \\
\text { UT-roast }\end{array}$ & . \\
\hline & Ibe & nu la, & ilubu & kpe & asoti & \\
\hline & t time & blo- & small.por & CUNJ & smant.pot & \\
\hline & ROG-take & $\mathrm{ke}=3 \mathrm{SGOH}$ & & & & \\
\hline
\end{tabular}

'After removing the palm fronds, you will roast the pots; those days it was pots and small pots that we used'

08. Kpane ko ma-á-wá té ima iva ime i-bo now only 1SG-FUT-say COMPL rubber thing this 3SG-stay

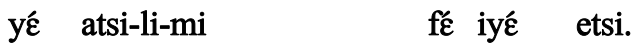

3SG 1PLU-PRSPROG-take put 3SG under

'Now I will only say that we use rubber containers to put under them'

09. Iyé okple yé a-blo anye-nu iva sé pétée

3SG reason CONJ 2SG-make so-in thing finish all

ý́ a-bó-tso anu pétée a-bó-mi izú= $\varepsilon$

CONJ 2SG-FUT-cut mouth all 2SG-FUT-take iron=DET

yé a-bó-súa.

CONJ 2SG-FUT-bore.hole

'Because of this if you finish doing this you will cut the soft tender branches and bore hole in the trunk with an iron'

10. Yé a-bó-to=á asó. Yé a-to=á

CONJ 2SG-FUT-put $=3$ PLUOBJ pot CONJ 2SG-put $=3$ PLUOBJ

asó sé pétée yé a-bó-dze $=\mathrm{a} \quad \mathrm{kpe}$.

pot finish all CONJ 2SG-FUT-start-3PLUOBJ tap

A-bo-kpe-a ukpe anyo

2SG-FUT-tap-3PLUOBJ CM-tap two

'As you finish putting the pot under all then you start tapping. You will tap it twice'

11. Adenklui la a-kpe okpe. Yé a-lo-kpe-a

fresh palm.wine CFM 3PLU-tap one CONJ 2SG-PRSPROG-tap-3PLU

ukpé $\quad$ kpe

tap one

'Fresh palm wine you will tap once. As you are tapping once'

12. yedze adenklui ne-me la atsi-tsi-mi-ne mla then fresh.wine 3SG-this CFM 1PLU-1PLU-take=3SGOBJ bring

o-gbo nu aha pétée e-tse-nó

CM-town in people all 3PLU-HAB drink 
'then we take the fresh wine to the town for the people to drink'

13. Dzue akpeteshi zá-go kpe i-mé i-bi-vé f́e

CONJ akpeteshi cook-NOM CONJ AM-that 3SG-come-pass into

iyé nu okple atsi-mi-li $\mathrm{mi}=\tilde{\varepsilon} \quad \mathrm{mla}$.

$3 \mathrm{SG}$ in reason $1 \mathrm{PLU}-\mathrm{NEG}$-again take $=3 \mathrm{SGOBJ}$ bring

'But akpeteshi distilling we do not take it there again'

14. Atsi-li-zi=é pétée uzá 1PLU-again-distill=3SGall distill one CONJ 1PLU-make this pétée boté unyi n-nu amá yedze atsi-dze-ne vu. all like day AM-five back then 1PLU-start=3SGOBJ blow 'We distill all once. When we do this after five days we start blowing it.'

15. A-bó-vu=a té $\quad$ nda =á té 2SG-FUT-blow =3PLU COMPL palm.wine =DET COMPL AM-cut

anu okple m-bú-nyá boté u-nyi n-nú mouth therefore 1SG-FUT-stay like CM-day AM-five

'You will blow for the palm wine to have a good taste; it will therefore stay for about five days'

16. xé nda m-bo tsó anú xé a-bó-dze =ne

CONJ palm.wine SM-stay cut mouth COND 2SG-FUT-start=3SGOBJ

zî ta ba-ahá

take give bar-people

'when the palm wine has good taste then you start giving it to the bar people (sellers).'

17. xé a-ló-zi-ne ta ba-ahá ale

CONJ 2SG-PRSPROG-carry=3SGOBJ give bar people 3PLU

é-bé-tse-ga awú gú

3PLU-FUT-HAB-pay 2PLU price

'When you are giving it to the sellers, they will be paying you'

18. Abe ko xé é-kpo etsi xé a-dze kpe la palm itself COND 3PLU-lie down COND 2SG-start tap CFM

é-vé nya la abóbi o-kpe kpe kosida o-kpe aló

3PLU-pass stay CFM moon AM-one CONJ week AM-one or

a-bobi o-kpe tututu la é-boté té

CM-moon AM-one exactly CFM 3PLU-have.to COMPL die

'Palm tree, when it is felled and you start tapping, it will last for one month and a week or after one month exactly they have to die.'

19. yedze xé nda mu-lu-ri anú enzi, then CONJ drink NEG-PRSPROG-hold mouth well

xé i-qu ve fé awú anú nu xé mu-nyo 
COND 3SG-be pass into 2PLU mouth in COND NEG-stay

ondzie ne utrome-mi-go i-dze vé

sweet 3SG work-take-NOM 3SG-start pass

'Then if the palmwine has no good taste then it is no longer useful'

20. Yedze ibote ta yó-nta ne yó tá kpeteshi then have.to COMPL skin-own 3SG skin give local.gin

ahá té a-mi zó

people COMPL 3PLU-take go

'Then you have to leave it and give it to local gin distillers'

21. i-mo ama nda xé atsi-lí kpe ume xé i-qu

AM-that back drink RP 1PLU-again tap here RP AM-be

abe nda =á m-bò veve ta atsú Akpanawo.

palm wine $=$ DET SM-stay important give 1PLU Logba.people

'After that palm wine that we tap here is important for us, Logba people'

22. Abenda ka i-bo veve ta ojkpesiokpe

palm.wine FOC 3SG-stay important COMPL everything

blo-go. Xé i-qu té kpane a-wo ubî

make-NOM COND SM-be COMPL now 2SG-born child

atsi-bî-la ubî do onyui abenda $\mathrm{n} \varepsilon$.

1PLU-FUT-take child go.out outside palmwine 3SG

m-bú-du ite

SM-FUT-be front

'Palmwine is important for doing everything, if a child is born and he is to be outdoored ${ }^{54}$ it is palmwine that will be an essential item'

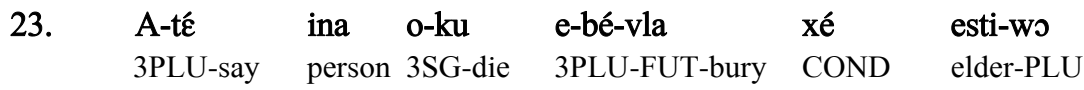

pétée e-tsi etsi e-bé-blo oykpe abenda

all 3PLU-sit down 3PLU-FUT-make something palmwine

m-bú-du ite

AM-FUT-be front

'They say if a person dies and they will bury him; when elders sit and they will do something, palmwine will be an essential item'

24. xé गjkpe o-ba kpata é-dzi aha pétée fida

COND something 3SG-come suddenly 3PLU-call people all meet

xé e-bé-bu nda gu umokoe la abenda yé

COND 3PLU-FUT-ask drink from that.place CFM palmwine 3SG

\footnotetext{
${ }^{54}$ This is the naming ceremony of the child according to Logba custom
} 
m-bú-du ite

AM-FUT-be front

'If something happens suddenly and they call people to meet and they ask for drink palmwine is essential'

25. Iyəkple ma-nú té abenda m-bo veve tá therefore $1 \mathrm{SG}$-see COMPL palmwine AM-be important give atsú Akpanawo $\mathrm{kp \varepsilon}$ atsú utsintsie me pétée. 1PLU Logba CONJ 1PLU surroundings here all 'Therefore, I see that palmwine is essential for the Logba and all her surroundings'

\section{QUESTION}

26. Yedze kpane yé abe a-kú ko la yedze then now COND palm SM.PLU-die only CFM then a-mó-ló-nú o-nkpe gu abźgo=é nu? 3PLU-NEG-PRSPROG-see CM-nothing from dead.palm=DET in 'Then if a palm tree dies, are they not getting anything from the dead palm trunk?'

ANSWER

27. Ikpa xé abe true COND palm.tree

é-kú

SM.PLU-die

a-bó-yu 3PLU-FUT-see thing many

Gbã xé abe e-kú first COND palm.tree

SM.PLU-die

la

e-bé-ba

SM.PLU-FUT-come

'True, if the palm tree dies you get many things, first edible worms come'

28. A-bó-la agblamido. xé a-la agblamido 2SG-FUT-remove edible.worms COND 2SG-remove edible.worms

$\begin{array}{lllll}\text { ame xé } \quad \text { abe } & \text { e-zu } & \text { fé } & \text { etsi } & \text { la } \\ \text { these COND palm.tree } & \text { SM.PLU-stop.yielding into } & \text { ground } & \text { CFM } \\ \text { tókpótókpó } & \text { e-bé-lé } & \text { a-bó-zí } & & \\ \text { short.mushroom } & \text { 3PLU-FUT-germinate } & \text { 2SG-FUT-uproot } & \end{array}$

\section{tókpótókpó}

fé.

short.mushroom also

'You will harvest the edible worms. After harvesting, short mushrooms will germinate and they will also be uprooted and used for food.'

29

$\begin{array}{lllll}\text { Anangba } & \text { m-bú-lé } & \text { a-bó-zí } & \text { ne } & \text { f́e. } \\ \text { broad.mushroom } & \text { SM-FUT-germinate } & \text { 2SG-FUT-uproot } & \text { 3SGOBJ } & \text { also } \\ \text { 'Broad mushroom } & \text { will germinate and it will also be harvested.' } & \end{array}$

\footnotetext{
${ }^{55}$ Edible worms is a delicacy in the Logba area.
} 


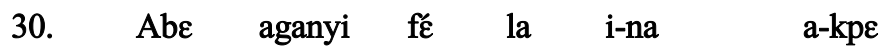

palm front also CFM CM-person AM-one

e-tse- zî-é e-mi fé odzá nu boté ndzayi

3PLU-HAB-take $=3$ SGOBJ 3PLU-take put fire in like firewood

'Palm front also some people put it into fire like firewood'

\section{$15.11 \quad$ Palm-oil making}

Palm oil making is an important occupation mainly for women in Logba. Mama Bakata Challote (Age 52) gives an account and it was recorded on $8^{\text {th }}$ July 2004 in her home, Adzakoe.

Palm oil is generally used for cooking. Its preparation involves cooking the palm fruit and leaving it to cool. After that, the palm fruit would be pounded. Warm water is poured on the pounded palm fruit and it is stirred for the oil to come above the water and the chaff to remain below. The oil is collected into a bowl and then cooked. When it is well cooked, the oil is taken from the fire and allowed to cool. The chaff and other parts of the palm fruit are useful.

01. xé a-bó-zá n-fú, gbã iboté té

if 2SG-FUT-cook CM-oil first reason COMPL

á-yayi a-só alo gaze

2SG.FUT-search CM-pot or iron pot

'If you want to make palm oil, first you have to search for pot or iron pot'

02 .
nu xé a-bó-za
$\mathrm{a}-\mathrm{b} \varepsilon$,
$a-b \varepsilon$
a-shianu
in RP 2SG-FUT-cook
CM-palm.fruit CM-palm.fruit CM-quantity
xé a-bó-zá
RP 2SG-FUT-cook
'in which you cook the palm fruit; the quantity you will cook'

03. i-boté e-wli tsibi boté memgba nango o-kpe

CM-REAS 3SG-plenty small like bowl big CM-one

'because it should be plenty a bit, it should be about a big bowl'
04. A-bó na a-be o-dzá. Xé a-be
2SG-FUT put CM-palm.fruit CM-fire. COND CM-palm fruit
e-be
SM.PLU-cooked
'You will put the fruit on fire. If the palm fruit is cooked'
05. a-bó-gla f'é a-kontsi nu
2SG-FUT-pour into CM-basket in
'you will pour it into a basket'


06. xé a-gla f́e a-kontsi $=\tilde{\varepsilon} \quad$ nu sé-e

COND 2SG-pour into CM-basket=DET in finish-CFM

a-bó-sá n-dú miomì

2SG-FUT-fetch CM-water cold

'If you finish pouring into the basket, you fetch cold water'

07. yunya o-tsú té té a-dzi=é té o-yú

sprinkle 3SG-on COMPL 2SG-see=3SGOBJCOMPL AM-cold

'sprinkle on it to see that it is cold'

08. E-be-ye tsyõ̃̃ i-di i-bî-wá

3SG-FUT-wait IDEO CM-day 3SG-FUT-break

'It will stay for long till day break'

09. Yé-dze i-disabe a-bó-yue a-be

and-look CM-dawn 2SG-FUT-pound CM-palm fruit

'Then at dawn, you will pound the palm-fruit'

10. xé a-sé a-be yue a-bó-mi f'e

if 2SG-finish CM-palm.fruit pound 2SG-FUT-take into

memgba nango nu

bowl big in

'If you finish pounding the palm fruit, you put it in a big bowl'

11. A-bó sá n-qú fé o-tsú tsibi yé

2SG-FUT fetch CM-water into 3SG-on small CONJ

a-bó-ló-hodo=á A-bo-hodo=á tsỹ̃̃

2SG-FUT-PRSPROG stir=3PLUOBJ 2SG-FUT-stir=3PLUOBJ IDEO (long)

'You will fetch water on it for a while and you will be stirring them; You will stir the palm fruit for a long time;'

12. $a-b \varepsilon \quad$ e-be-dzi enzi

CM-palm.fruit 3PLU-FUT-come.up AM-well

it will come up well'

13. Xé a-be e-dzi-e a-bo-tso oyó

if CM-palm fruit SM-come up-CFM 2SG-FUT-pour 3SG-skin

f'́ memgba mango nu

into bowl another in

'If the palm fruit comes up you will pour part of it in another bowl'

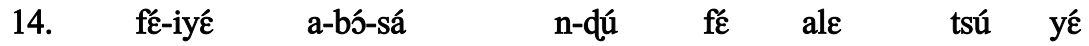

in-3SGIND 2SG-FUT-fetch CM-water into 3SGIND on CONJ

a-bó-la a-be

2SG-FUT-beat CM-palm.fruit

'Now you will pour water on it and you will beat the palm fruit' 
15

A-bo-la tsyo i-bisa

ikpe menu i-bî-zo

etsi

2SG-FUT-beat

IDEO CM-palm.chaff

INDEF like SM-FUT-go

under

'You will beat for a while. Some palm chaff will go under'

16. yé $\mathrm{n}$-fú=毛 m-bu-nya agu kpe i-bisa

then $\mathrm{CM}=\mathrm{DET}$ SM-FUT-stay top with CM-palm.chaff

i-kpić menu $\mathrm{f}^{\varepsilon}$

AM-INDEF like also

'Then the oil will be on top with some of the chaff also'

17. xé a-blo=ć se-e a-bó-yé

if $2 \mathrm{SG}-\mathrm{make}=3 \mathrm{SGOBJ}$ finish-CFM 2SG-FUT-remove

i-bisa i-me

CM-palm.chaff AM- DEM

'If you finish making it you will remove this palm chaff'

18. $\mathrm{kp \varepsilon} \mathrm{nfu}=\mathrm{é}^{\prime} \mathrm{f}^{\prime} \varepsilon$ memgba mango nu

CONJ oil $=$ DET into bowl another in

'with the oil into another bowl'

19. yé a-bó-ló-sá n-đú fú iyé tsú yé

CONJ 2SG-FUT-PROG-fetch CM-water into 3SG on CONJ

a-bó-la iyé pétée

2SG-FUT-beat 3SG all

'and you will be pouring water on it and stir all'

20. la n-ta iyé tsú i-bisa ikpe menu

beat CM-hand 3SG on CM-chaff INDEF like

i-bí-li-zo e-tsi

AM-FUT-PROG go CM-down

'Beat the top with your hand (palm) some of the chaff will be going down'

21. xé i-bisa i-zó e-tsi-e a-bó yú

COND CM-chaff SM-go CM-down-EMPH 2SG-FUT-see

'When the chaff goes down you will see'

22. té nfú=毛 n-dzi ba a-gu

COMPL oil=DET SM-rise come CM-top

'that the oil rises to the top'

23. yédze a-bó-kpa iyé fर́ gazi $=\tilde{\varepsilon} \quad \mathrm{nu}$

then 2SG-FUT-collect 3SG into iron.pot=DET in

xé a-bó-zá iyé

RP 2SG-FUT-cook 3SGOBJ

'Then you will collect it into the iron pot and you will cook it' 
24. xé a-kpa-iyé fé gazi=é

when 2SG-collect-3SG into iron.pot=DET in

xé a-bó-zá iyé

RP 2SG-FUT-cook 3SG

'when you collect it in the iron pot in which you will cook it'

25. yédze a-zí-iyé na o-dzá tsú a-fُ́

then 2SG-lift-3SG put CM-fire on 2SG-make CM-fire

iý́ e-tsi

3SG CM-under

'Then you lift it and set the fire under it'

26. i-bi-bia iyé nta o-kpié tsyo kpe i-bisa

3SG-FUT-boil 3SG self AM-INDEF IDEO with CM-chaff

'it will boil on its own for some time with the chaff'

27. yé i-bia yé a-bó-ló-gla iyé

CONJ AM-boil CONJ 2SG-FUT-PROG-pour 3SGIND

'As it boils then you will pour it'

28. fُ asu $\varepsilon$ nu A-bo-tsúro iyé enzi té

into sieve in 2SG-FUT-sieve 3SGIND well COMPL

i-bisa ikpesikpe mi-li-na n-fú=é nu

CM-chaff all NEG-stick-on CM-oil=DET in

'into a sieve.You will sieve it well to prevent all the chaff from being in the oil'

29. a-bó-do gazi=e nu fo yé

2SG-FUT-again iron.pot $=$ DET in wash CONJ

'you will wash the iron pot again and'

30. á-dzu $\mathrm{n}-\mathrm{fú}=\varepsilon \quad \mathrm{f}^{\mathrm{\varepsilon}} \quad \mathrm{gazi}=\varepsilon^{\varepsilon} \quad \mathrm{nu}-\varepsilon$

2SGFUT-return CM-oil $=$ DET into iron.pot $=\mathrm{DET}$ in-EMPH

'put the oil back in the iron pot'

31. $\quad$ á-dzu $=\mathfrak{\varepsilon}$

2SGFUT-return $=3 \mathrm{SGOBJ}$ on CM-fire 2SGFUT-make CM-fire

ne yó

3SG skin

'you will put it back on the fire and set it under it'

32. xé a-fé o-dzá ne yo-e m-bu-bia

CONJ 2SG-set CM-fire 3SG skin-EMPH AM-FUT-boil

'When you set the fire under it, it will boil'

33. yédze á-mi u-klui á-ló-mi

then 2SGFUT-take CM-cooking.stick 2SGFUT-PRSPROG-take 
blu $\mathrm{n} \varepsilon \quad \mathrm{nu}$

stir 3SG in

'Then you will take a cooking stick and be stirring in it'

34. té n-tu-kanyi, f́c n-tu-ri

COMPL NEG-HAB-burn also NEG-HAB-hold on

a-so=á etsi

CM-pot $=$ DET under

'that it should not burn so that it does not stick under the pot'

35. A-bó-ló-blu-ne nu tsyos a-bó-nú

2SG-FUT-PROG-stir $=3$ SGOBJ in IDEO 2SG-FUT-see

'You will be stirring in it for some time and you will see'

36. té $n$-fú $=\varepsilon \quad n$-dú-dzi

COMPL CM-oil=DET AM-PRSPROG stand foam

'that foam will come to the top of the oil'

37. Xé n-dú-dzi i-vo a-bó-nú té

when AM-PROG-stand CM-foam 2SG-FUT-see COMPL

n-du-dzi zó agu tsyos

AM-PRSPROG-stand go top IDEO

'when it is foaming you will see that it is rising to the top for some time'

38. xé $\mathrm{n}$-dze be- $\varepsilon \quad \mathrm{m}$-bu-dzu f́́ etsi

when AM-start cooked-EMPH SM-FUT-return into down

'When it starts to cook well, the foam will settle down'

39. yédze beku=ć xé ó-tsi n-fú=é nu- $\varepsilon$

then beku=DET RP SM.SG-stay $\quad \mathrm{CM}$-oil $=\mathrm{DET}$ in-EMPH

'then the beku (thick sediments in the oil) which is in the oil'

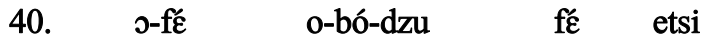

3SG-also 3SG-FUT-return into down

'also will settle down'

41. xé a-yú té

when 2SG see COMPL beku=DET SM.SG-return lie

'When you see that the "beku" is settled'

42. té a-kpe té $\mathrm{\varepsilon} \quad \mathrm{n}$-fú $=\tilde{\varepsilon} \quad$ m-be

COMPL 2SG-know COMPL CM-oil=DET SM-cooked

'then you know that the oil is cooked'

43. mokoe a-bó-gla $\mathrm{n}=$ fú-é.

there 2SG-FUT-pour CM-oil=DET

'There, you will pour the oil' 
44. a-gla $=n \varepsilon \quad$ kaba té $\quad$ n-tu kanyi 2SG-pour =3SGOBJ quickly COMPL NEG-let burn 'You pour it quickly that it should not burn'

45. yé a-gla n-fú=é fé memgba nu sé CONJ 2SG-pour CM-oil=DET into bowl in finish 'After you finish pouring the oil in the bowl,'

46. yédze a-za-ne sé then $2 \mathrm{SG}-\mathrm{cook}=3 \mathrm{SGOBJ}$ finish 'then you finish cooking it.'

47. yédze i-bisa=á xé a-ye mo ikpié then CM-chaff=DET RP 2SG-remove there INDEF 'Some of the chaff which you remove there'

48. a-tanyi-mi blo iva ikpié é-te-dzi 2SG-can-take make thing INDEF 3PLU-HAB-call té kpelebe

COMPL kpelebe

"can be used to make something they used to call "kpelebe""

49

$$
\begin{aligned}
& \text { a-bó-mi }=\varepsilon \quad \text { } \varepsilon \tilde{\varepsilon} \quad \text { a-kóntsi nu } \\
& \text { 2SG-FUT take }=3 \mathrm{SGOBJ} \text { into CM-basket in } \\
& \text { yedze } \quad \mathrm{n}-\mathrm{dú}=\varepsilon \\
& \text { then } \quad \mathrm{CM} \text {-water }=\mathrm{DET} \\
& \text { 'You will put it into a basket then the water' }
\end{aligned}
$$

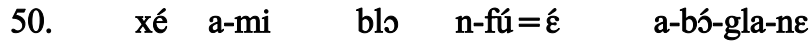

RP 2SG-take make CM-oil=DET 2SG-FUT pour 3SGOBJ

'which you used to make the oil you will pour it'

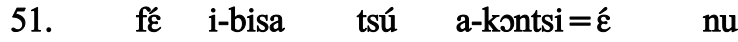

into $\mathrm{CM}$-chaff on $\mathrm{CM}$-basket $=\mathrm{DET}$ in

'onto the chaff in the basket'

52. N-dú kotsoe m-bú-dovu. M-bú-do i-bisa nu CM-water only SM-FUT-pour.out AM-FUT-comeCM-chaff in 'Water only will come out. It will come out of the chaff'

53. yé i-bí-gá n-dú tongue fé i-bísa tu CONJ 3SG-FUT-remain CM-water thick in CM-chaff on 'and it will remain the thick water on the chaff'

54. mokoe n-dzi n-ta a-má=á a-bó-bo

there CM-day AM-three CM-back=DET 2SG-FUT-press

iyé pétée

3SGIND all

'There after three days you will press it all (in bits)' 
55
$\mathrm{a}-\mathrm{b} \mathbf{o}=\hat{\varepsilon}$
a-mi
ka e-vi
2SG-press $=3$ SGOBJ
2SG-take put
CM-sun
'You press it; you put it in the sun'

$\begin{array}{llllllll}\text { 56. xé } & \text { a-ka } & \text { iyé } & \text { e-vi } & \text { boté } & \text { Kosida } & \text { okpe } & \text { a-má } \\ \text { if } & \text { 2SG-put } & \text { 3SGIND } & \text { CM-sun } & \text { like } & \text { week } & \text { one } & \text { CM-back }\end{array}$ 'If you dry it after a week'

57. xé i-tsoe iva ime a-mi $=\mathbf{\varepsilon}$ tsu o-dzá when SM-dry thing this 2SG-take $=3$ SGOBJ set CM-fire 'when it dries, this thing you use it to set fire.'

58. anyé ko i-du boté tsitsi- $\varepsilon$ menu a-mi keresine so only SM-be like turn-EMPHlike 2SG-take kerosine 'So, it only turns like using kerosene'

59. xé a-mi tsú o-dzá=á

RP 2SG-take set $\quad \mathrm{CM}$-fire $=\mathrm{DET}$

'which you take set fire'

60

$\begin{array}{lllll}\text { aný́ } & \text { kee } & \text { i-du } & \text { a-biku=é } & \text { xé a-la } \\ \text { so } & \text { also } & \text { SM-be } & \text { CM-palm.kernel=DET } & \text { RP 2SG-remove } \\ \text { a-be } & & \text { nu=é } & & \\ \text { CM-palm.fruit } & \text { in=DET } & & \end{array}$

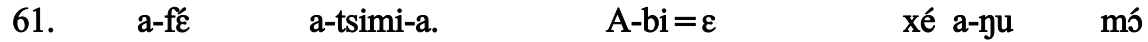

'So also is the palm kernel which is removed from the palm fruit'

2SG-also 2SG-crack=3PLUOBJCM-palm.fruit=DET RP 2SGM-see DEM

'you also crack it. The palm fruit that you get from making the oil'

62. a-bó-kplo a-fé á-mi blo a-bi

2SG-FUT-fry 3PLU-also AM-take make CM-palm.kernel CM- oil 'you will fry. They also take the palm kernel to make palm kernel oil'.

63. Iyé f́́ i-du o-fifie o-kpe xé e-tse-mi zá iva 3SG also SM-be CM-oil AM-one RP 3PLU-HAB-make cook thing 'It is also one kind of oil which is used for cooking'

64. E-tse-mi 3PLU-HAB-take make pepper 3PLU-take fry gawu

kpe iva mango-wo

and thing different-PLU

'They use it to make stew, fry beans pastry and different things'

65. anyé ke i-du a-bifo=o á-fé

so also SM-be CM-kernel.shell =DET 3PLU-also

a-mi =á tsu o-dzá.

AM-take $=3$ PLUOBJset $\quad$ CM-fire

'So is the palm kernel shell, they use it to set fire' 


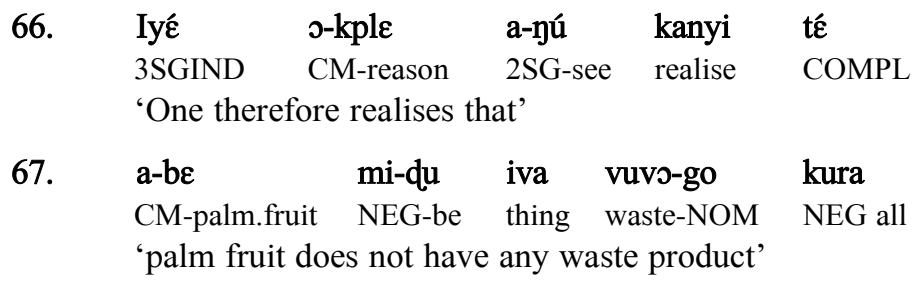

$\begin{array}{lllll}\text { 68. iý́ okusioku mi-ma xé á-mi } & \text { bofi } \\ \text { 3SGIND all } & \text { NEG-stay } & \text { RP } & \text { 3PLU-take } & \text { throw.away } \\ \text { 'No part of it is thrown away' } & & \end{array}$

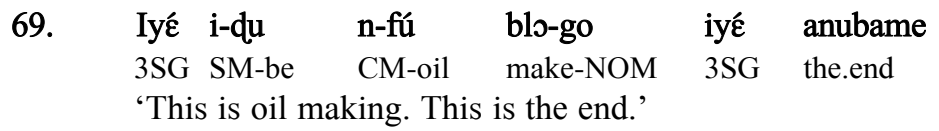

\section{Koko preparation}

Koko is a local porridge prepared with corn. It is taken as breakfast in Logba and other surrounding communities. Mercy Antor(Age 34) recounts how it is prepared. This was recorded on $15^{\text {th }}$ May 2006

In the preparation of koko, corn is soaked for three days. Pepper and other spices are mixed with the corn after it is removed from the water. It is taken and milled to become a dough. Water is put on fire. When the water is hot, the dough is mixed with water and poured on the one on the fire. When the koko is well-cooked, it is seived and poured into a pot. Koko is then ready to be sold to the members of the community.

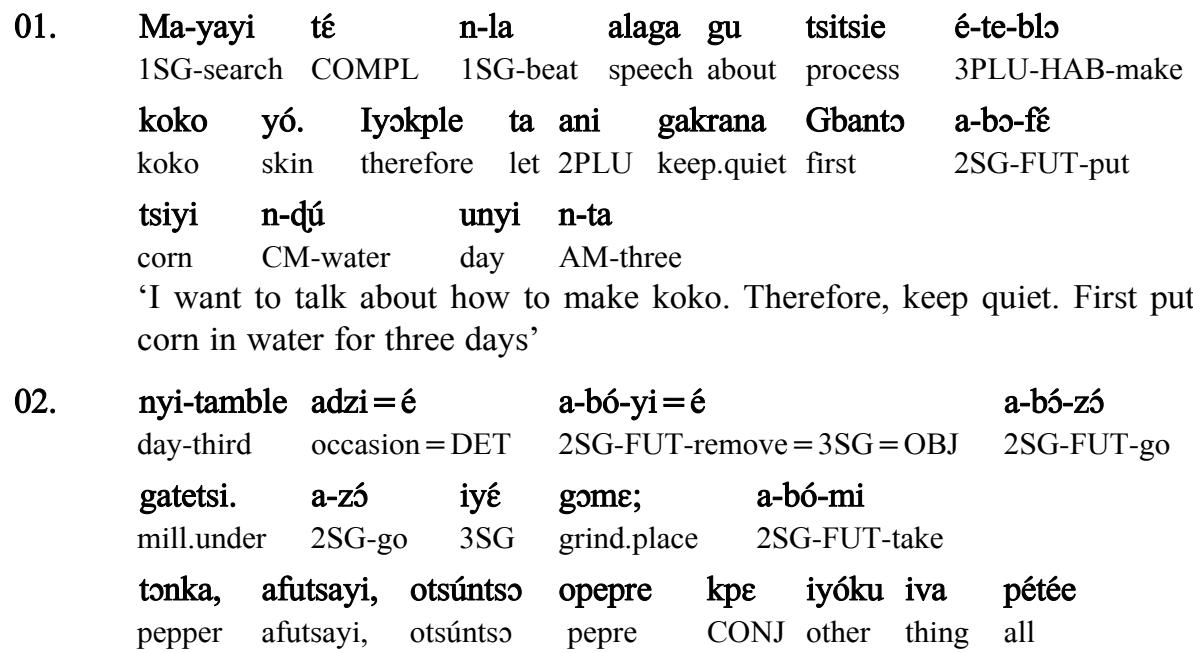


yé a-bó-zí zó go kpe iyé

CONJ 2SG-FUT-carry go grind COM 3SG

'The third day you remove it and go to the mill and grind it; you will take pepper, "afutsayi", "otsúntso", "pepre" and other things to grind with it.'

03. Xé a-go=é sé a-bó-mi iva=á

COND 2SG-grind $=3 \mathrm{SG}$ finish $2 \mathrm{SG}$-FUT-take thing $=\mathrm{DET}$

pétée mlá afán. Xé a-mí-mla afá-nu=é

all bring house COND 2SG-take-bring house-in $=$ DET

$\begin{array}{llll}\text { a-bó-fut }=\boldsymbol{\varepsilon} & \text { ka. } & \text { Xé } \quad \text { a-fut }=\varepsilon & \text { ka } \\ \text { 2SG-FUT-mix }=3 \text { SG } & \text { down } & \text { COND 2SG-mix =3SG.OBJ } & \text { down }\end{array}$

nyəmble adzi $=\varepsilon \quad$ a-bó-tsó anyemenu mawəe yé

second occasion $=$ DET 2SG-FUT-cut such.kind dough CONJ

a-bó-do lé futo.

2SG-FUT-again 3SG mix

'If you finish grinding you bring it home; you take part of the said dough and you will mix it again'

04

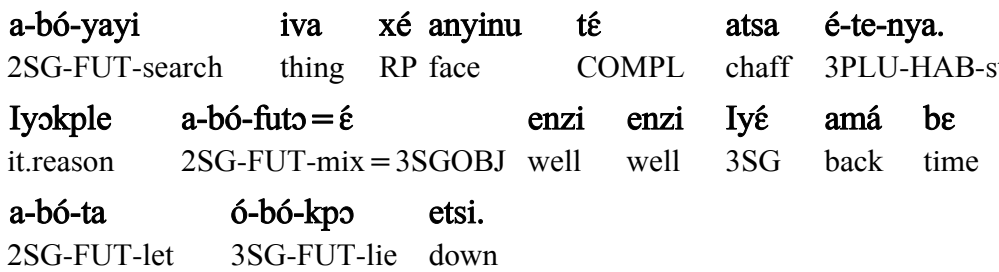

'You will search for the thing which is smooth that takes the chaff. That is why you mix it well; after some time it will settle down'

05 .

\begin{tabular}{llllllll} 
a-bó-na & \multicolumn{2}{l}{ nqú-dzá. } & Xé & nqú=é & n-dze & bia \\
2SG-FUT-put & water-fire & COND water=DET & SM-start & boil \\
a-bó-tsúdo & nqú & n-me & xé & a-mi & futo & mawəe \\
2SG-FUT-sieve & water & AM-DEM & COND & 2SG-take & mix & dough
\end{tabular}

a-tsúdo ne a-mi dodu nqú odzá tsú.

2SG-sieve 3SG 2SG-take pour water fire on

'You will put water on fire. When the water starts to boil, you will sieve that water that you use to mix the dough and pour it on the boiling water'

06. xé ne-məa n-bi-e mawəe xé o-kpo

COND AM-DEM SM-well.cooked-CFM dough RP 3SG-lie

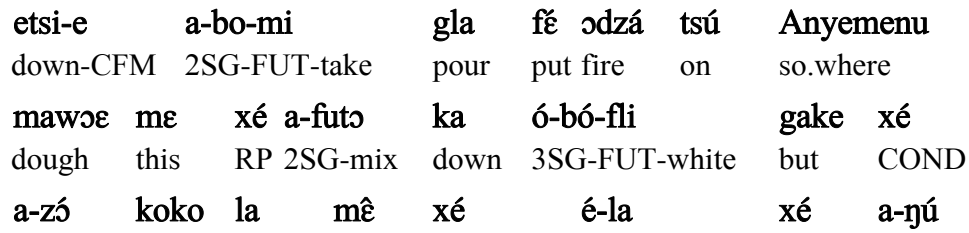


2SG-go koko beat DEM COND 3PLU-beat COND 2SG-see

té ó-ló-bé-e. anyinu i-bí-drui

COMPL 3SG-PRSPROG-well.cooked-CFMface-in SM-FUT-be.red

'If that one is well cooked, the dough which is down you will put it on fire. The said dough which you mix down will be white but if you use it to prepare koko it will be red'

07.

\begin{tabular}{|c|c|c|c|c|c|}
\hline i-gbla & té & anyemenu & kóko =é & o-bé. & Xé \\
\hline SG-show & COMPL & so.where & koko $=\mathrm{DET}$ & 3SG-well.cooked & COND \\
\hline & & a-bó-zi & sieve & TT_sieve & \\
\hline
\end{tabular}

kókó=é fé asó-nu.

koko $=$ DET put pot.in

'It shows that the said koko is well cooked. If it is well cooked you will sieve it into a pot'

08

\begin{tabular}{|c|c|c|c|c|c|}
\hline xé & a-tsúdo & kókó=é & & asónu sé-e & a-bó-yú \\
\hline COND & 2SG-sieve & koko $=$ DET & put pot.in & finish-CFM & 2SG-FUT-see \\
\hline kanyi & té & iv(a)ikpe & i-tsi & sanu-é & nu xé mi-ma \\
\hline alise & COMPL & thing.one & 3SG-remain & sieve $=\mathrm{DET}$ & in RP NEG-stay \\
\hline té & i-vé & asó & nu. & atsúd $\rho=\varepsilon$ & \\
\hline MPL & SM-pass & into & COND & $2 \mathrm{SG}$-sieve $=3$ & SGOBJ \\
\hline & Po & zó & ogbá yó & & \\
\hline sh & all & G-take go & road skin & & \\
\hline
\end{tabular}

'When you finish sieving into the pot you will realise that some will stay in the sieve which does not pass through to the pot. If you finish all, you take it to the road side'

09. xé a-mi zó ogbá=á yó-e ahá xé e-bo

COND 2SG-take go road=DET skin-CFM people RP 3PLU-stay

ogbo=á nu-a a-te-né $\quad$ koko=é f́e efieyî nu.

town $=\mathrm{DET}$ in-CFM 2SG-HAB-buy koko=DET put calabash in

$\begin{array}{llllll}\text { Aló iva } & \text { xé i-qu afán utrome } & \text { mi } & \text { iva a-bá-né } \\ \text { or thing } & \text { RP SM-be house } & \text { work } & \text { take } & \text { thing } & \text { 2SG-FUT-buy }\end{array}$

koko=é $\quad f^{\prime} \varepsilon$ iyé nu

koko $=$ DET put it in

'When you take it to the road side you sell it to people in the town in calabash or in the thing that use to make house work; they buy the koko in it'

10. dzue aha xé é-zó okú kisayi $\varepsilon$-té-né but people RP SM.PLU-go place long 3PLU-HAB-buy

koko=é f́e ima fliyi xé i-gbla té

koko $=$ DET put rubber white RP AM-show COMPL 
ع́-lé-zó

okú kisayi xé é-bé-no

3PLU-PRSPROG-go place long RP 3PLU-FUT-drink

'but people who go distant places, they buy in white rubber containers which show that they are going to distant places where they will drink'

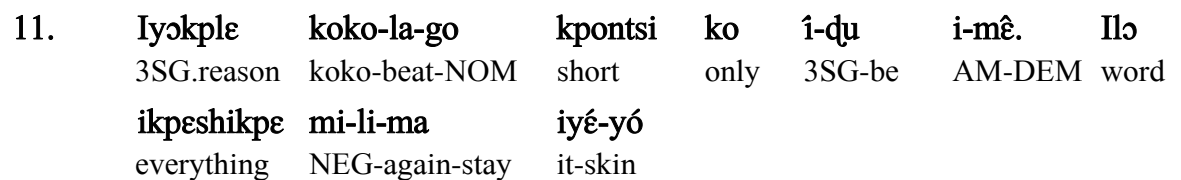

'Therefore this is in short koko preparation. There is nothing again about this'

$\begin{array}{lllll}\text { 12. Iyokple } & \text { ma-tso } & \text { amu } & \text { iló } & \text { nu } \\ \text { 3SG-reason } & 1 \text { SG-cut } & \text { my } & \text { word } & \text { in }\end{array}$

'Therefore, I end here

13. Anyintse

'Thanks'

14. yóo dase moma.

OK thanks NEG-stay

'OK, not at all'

\subsection{Gari making}

Gari is roasted cassava flour used as food in Ghana and most West African countries. Vivian Ankah (Age 37) describes how it is prepared. This was recorded on $10^{\text {th }}$ May 2006.

Cassava is used in the preparation of Gari. Cassava is peeled, washed and taken to the mill. After milling, the cassava dough is pressed for the water in the dough to come out. The cassava dough is sieved and fried. The person frying has to listen to the sound the gari makes in the bowl and taste it as a test to find out whether the gari is fried well. When the gari is well-fried, it is fetched out of the bowl, sieved to remove the large grains before storing in bags.

01. Etsine xé atsi-tsi-kplo gali tá iyé-yó ma-la process RP 1PLU-HAB-frygali COMPL 3SG-skin 1SG-beat

alaga gu

speech about

'The process of making gari is what I talk about'

02. Gbã ati-bî-glui igbedi=é mla afán;

first 1PLU-FUT-uproot cassava $=$ DET bring house 
atsi-bî-vlo $=\hat{\varepsilon} \quad$ pétée, atsi-bî-fo =é.

PLU-FUT-peel $=3$ SGOBJ all 1PLU-FUT-wash $=3$ SGOBJ

'First, we shall uproot cassava to the house, we shall peel it and wash it'

03. Yedze atsi-bî-mi=é

then 1PLU-FUT-take $=3$ SGOBJ go mill on or COND

agbelilili-idá i-bo=é atsi-bî-lili iyé afán.

cassava.grater-iron SM-stay $=3$ SGOBJ1PLU-FUT-grate $3 \mathrm{SG}$ house

'Then we will take it to the mill or if one has cassaava grating material we will grate it in the house'

04. Iyé ama atsi-fé le egbe tsi pétée pétée Yedze

3SG back 1PLU-put 3SGOBJ stone under all all then

ati-ta té nqu=é ta n-do iyé nu pétée.

1PLU-give COMPL water=DET let SM-come.out 3SG in all

'After this we put all of it under stone. Then we let the water to come out from it all'

05. Xé n-do sé-e, yedze ibote ta tsi

COND AM-get.out finish-CFM then have.to let 1PLU

sra $=\hat{\varepsilon} \quad$ ta tsi sra $=\hat{\varepsilon} \quad$ agbadze tsú.

sieve $=3 \mathrm{SGOBJ}$ let $1 \mathrm{PLU}$ sieve $=3 \mathrm{SGOBJ}$ sieve on

Atsi-sra $=\hat{\varepsilon} \quad$ enzi enzi.

1PLU-sieve $=3$ SGOBJ well well

'If it comes out completely then one has to sieve it on a sieve very well'

06. Yedze iyé amá atsi-tsú odzá. Ekple yedze atsi-mi

then 3SG back 1PLU-set fire now then 1PLU-take

galikploale na odzá tsú Yedze atsi-dzudzu onfie iyé nu pétée. gari.frying.bowl put fire on then 1PLU-smear oil 3SG in all

'Then after that we set fire. Now then we take gari frying bowl and smear oil in it'

07. Yedze i-lé odzá mo-vé intse nya yedze atsi kutsi then 3SG-be fire NEG-pass strength stay then 1PLU fetch iyé fé mengba nu.

3SG into bowl in

'Then the fire should not be too strong and you fetch it and put in a bowl'

08. Yedze atsi-dze iyé nu kplo kpe efieyitsifo yé then 1PLU-start 3SG in fry CONJ calabash.crack CONJ

atsi-mi $\quad$ kplo $=\varepsilon \quad$ tsitsi $=\boldsymbol{\varepsilon} \quad$ nu tsyõ̃ om

1PLU-take fry $=3$ SGOBJ turn $=3$ SGOBJ in long this 
asianu o-bo-bé.

quantity 3SG-FUT-well.cooked

'Then we start frying with cracked calabash turning it till this quantity is well fried'

09. Yedze atsi-bî-lí kutsí ongo f’e o-tsú ke yedze then 1PLU-FUT-again fetch uncooked into 3SG-on again then

atsi-li-dze iyé nu kplo anyé.

1PLU-PRSPROG-start 3SG in fry so

'Then we will be fetching the uncooked one into it again; then we start frying it in that manner'

10. Atsi-bî-li-kplo=é

yedze xé atsi-nú té

1PLU-FUT-PRSPROG-fry $=3$ SGOBJ then COND 1PLU-see COMPL

1-fó awú kplo agbasi anu yedze a-bó-vui fé

3SG-reach 2SG fry hand mouth then 2SG-FUT-stop put

'We shall be stiring it; then if we see that the quantity is sufficient for your hand then you stop putting more in it'

11. Yedze kpane a-bó-fé odzá=á gbangbay té

then now 2SG-FUT-put fire=DET strong COMPL

i-mi bé enzi enzi. Yedze kpane a-bó-blu iyé

3SG-take cooked well well then now 2SG-FUT-stir 3SG

nu; a-bó-kplo iyé nu.

In 2SG-FUT-fry $3 \mathrm{SG}$ in

'Then now you will set the fire to be strong that it will fry well; then you will be stiring it and you will be frying it'

12. A-bó-tso-kplo iyé nu zó tsyso xé a-nú kanyi 2SG-FUT-HAB-fry 3SG in go for.long COND 2SG-see realise

té i-dze tsoe. Yedze a-bó-lo-he

COMPL 3SG-start dry then 2SG-FUT-PRSPROG-pull

odzá=á mla amá.

fire $=\mathrm{DET}$ bring back

'You will be stiring inside for long. If you realise that it is dry then you pull the fire back'

13. A-he odzá=á mla amá sé yedze a-ló-dze

2SG-pull fire $=$ DET bring back finish then 2SG-PRSPROG-start

iyé nu kplo té i-ti-tá té mo-ó-kanyi

3SG in fry COMPL 3SG-HAB-give COMPL NEG-3SG-burn

'You move the fire back then you start to fry so that it will not burn'

14. A-kplo iyé nu tsyoo yedze a-kutsi iyé na 2SG-fry 3SG in for long then 2SG-fetch 3SG put 
\begin{tabular}{lllllll} 
efieyi-tsifo & tsú & \multicolumn{1}{c}{ té } & \multicolumn{2}{c}{ a-ló-dze } & té & alaga \\
calabash.crack & on & COMPL & 2SG-PRSPROG-look & COMPL & speech \\
oməa & o-bó-dzú & ale & tsú & náa? & & \\
DEM & 3SG-FUT-sound & 3SG & on & QP & &
\end{tabular}

'You stir it for long then you collect it on the cracked calabash to hear if it makes some noise'

15. Alaga xé a-bó-mi gu ile tsú té a-bó-mi soundRP 2SG-FUT-make from 3SG on COMPL 2SG-FUT-take kpe té o-bé loo aló mo-ó-bé nú know COMPL 3SG-well.cooked ADR or NEG-3SG-well.cooked-NEG aló a-bó-kutsi $\quad l \varepsilon \quad$ fé anú nu or 2SG-FUT-fetch 3SG put mouth in 'The sound that it makes will make you know that it is well cooked or not or you taste some'

16. Uməkoe f́e a-bó-nú té o-bé loo aló there also 2SG-FUT-see COMPL 3SG-well.cooked or or mo-o-bé nú Yedze xé o-be-é

NEG-3SG-well.cooked NEG then COND 3SG-well.cooked-CFM a-gbé $=\hat{\varepsilon} \quad$ fé memgba nu; xé ó-yu=é

2SG-cover $=3$ SGOBJ put bowl in COND 3SG-cold $=3$ SGOBJ a-bó-do-le sra ke agbadze tsú ke 2SG-FUT-again-3SG sieve again sieve on again There too, you see that it is alright or not. Then if it is alright then you collect it in a pan. Then if it is cool, you sieve it'

17. Yedze a-la ykponyi=é xé i-du gali jkponyi=é then 2SG-remove eye $=$ DET RP SM-be garieye $=$ DET

a-bó-li-é ka yedze gali ontá xé o-dú nkponyi 2SG-FUT-remove-3SG down then gariown RP SM.SG-be eye witsi-witsi xé ó-bo=é a-bo-ta ó-bó-yú pétée. small-small RP 3SG-stay $=3$ SGOBJ 2SG-FUT-let 3SG-FUT-cool all 'Then you remove the eye which is gari's eye; which are small small eyes; you will leave it to cool'

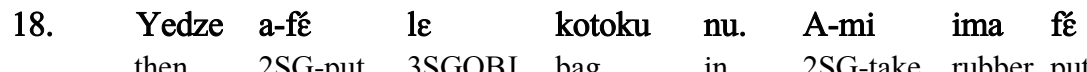
then 2SG-put 3SGOBJ bag in 2SG-take rubber put $\begin{array}{llllll}\text { kotoku=é } & \text { nu a-á-gbe } & \text { f́é } & \text { o-nu } & \text { té } & \text { xé } \\ \text { bag }=\text { DET } & \text { in } 2 \text { 2SG-FUT-cover } & \text { put } & \text { 3SG-in } & \text { COMPL } & \text { COND }\end{array}$ $\begin{array}{lllllll}\text { i-du } & \text { t́́ } & \text { o-bó-nya } & \text { kisa } & \text { fé } & \text { ale } & \text { iyu. } \\ \text { SM-be } & \text { COMPL } & \text { 3SG-FUT-stay } & \text { long } & \text { also } & \text { 3SG } & \text { SM-cold }\end{array}$ 
Iyé amá a-mi lé zó ovu nu

3SG back 2SG-take 3SGOBJ go market in

'Then you put it in a bag. You put rubber in bag to cover it that it takes long before it is cold. After that you take it to the market'

19.

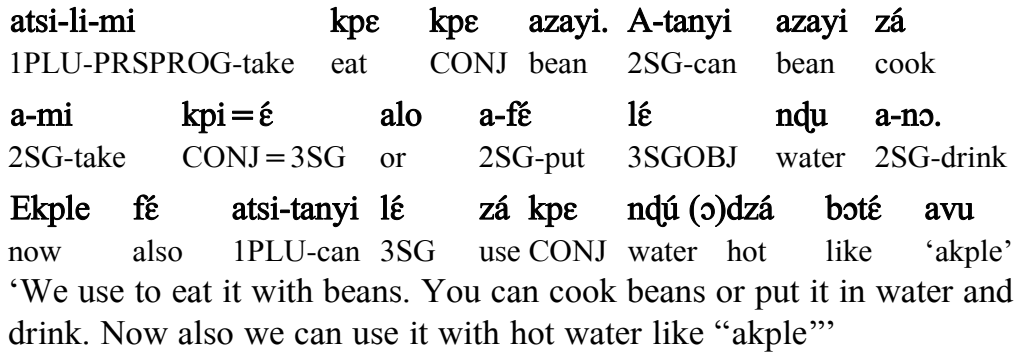

\subsection{Local soap making ${ }^{56}$}

Ophelia Hesse (Age 52) recounts the preparation of local soap. This was recorded on $1^{\text {st }}$ June 2006

The Logba people use palm oil, or coconut oil and caustic soda to manufacture soap. In place of caustic soda, some people use dry cocoa pod, plantain peels and palm husk which are roasted to become like ash. Water is poured on the mixture which is sieved and boiled for a long time. Oil is poured on the solution on the fire and stirred to mix well. When the water evaporates from it, then the soap is ready for use.

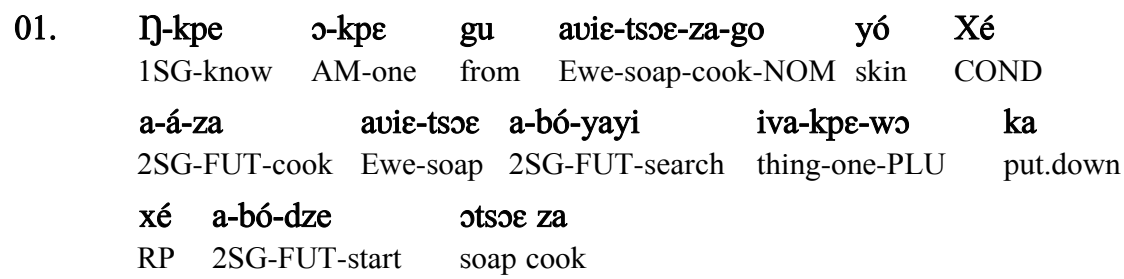

'I know something about local soap making. If you want to make local soap, you have to search some things down before you will start to prepare the soap'

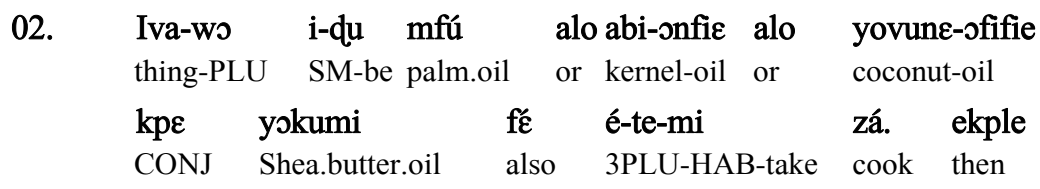

\footnotetext{
56 The people call it avietsoe 'Ewe soap' the Ewe's call it ameyibo dzalẽ 'black man's soap' The impression one gathers is that the people are comparing this soap with the imported ones in these areas.
} 


\begin{tabular}{|c|c|c|c|}
\hline lyi & $\begin{array}{l}\text { Adi }=\varepsilon \\
\text { Soda }=\text { DET }\end{array}$ & $\begin{array}{l}\text { o-me } \\
\text { AM-DEM }\end{array}$ & $\begin{array}{l}\text { o-du } \\
\text { 3SG-be }\end{array}$ \\
\hline 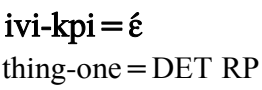 & $\begin{array}{l}\text { xé atsi-tsi-nú } \\
\text { 1PLU-HAB-see }\end{array}$ & $\begin{array}{l}\text { kókó afotsi } \\
\text { cocoa pod }\end{array}$ & $\begin{array}{l}\text { tsúeyi aló } \\
\text { dry or }\end{array}$ \\
\hline n peel & alm.husk roas & $\mathrm{OM}$ & \\
\hline
\end{tabular}

'The things are palm-oil or kernel oil or coconut oil. They use shea butter oil also to make it. Then you will search for soda. We get the soda from cocoa pod which is dry or plantain peel and palm husk which is roasted.'

03. a-bó-zuzo kókó afotsi=é kpe iva i-me-wo

2SG-FUT-roast cocoa peel $=$ DET COM thing AM-DEM-PLU

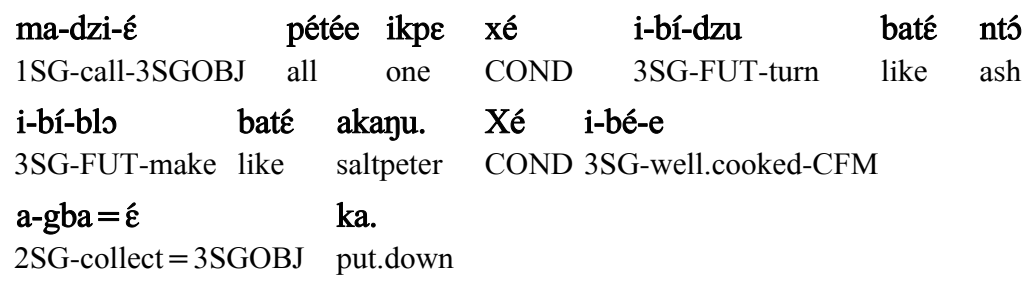

'You will roast the cocoa pod that is peeled and all those things that I have called. They will become like ash; it will be like saltpetre. If it is well cooked you will collect it and put it down'

04. a-bó-fé nđú nto na-(i)me tsú bokiti alo memgba 2SG-FUT-put water ash put-this on bucket or bowl

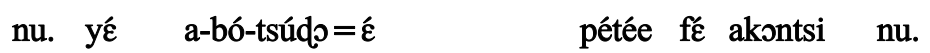

in. CONJ 2SG-FUT-sieve $=3$ SGOBJ all in basket in

'Yo u will pour water into that ash in bucket or bowl. Then you will sieve all into a basket.

05. Akontsi=é a-bó-mi ala xé etsi i-do yé basket $=$ DET $\quad$ 2SG-FUT-take type RP under SM-come.out CONJ

a-bó-mi kotoku kpágo fé iyé nu xé a-bó-gla

2SG-FUT-take sack torn put 3SG in RP 2SG-FUT-pour

adi kpe nqu=e kpe iyé pétée f'́ xé i-bî-tsudo

soda CONJ water $=\mathrm{DET}$ CONJ $3 \mathrm{SG}$ all put RP 3SG-FUT-sieve

f' $\bar{\varepsilon}$ iyé nu.

put $3 \mathrm{SG}$ in

A basket which has a loose under is what you will use. You will then use a torn sack and put in the basket. You will pour the soda and the water and all will be sieved into it'

\begin{tabular}{llcc|} 
06. Iyé amá a-bó-gla & $\begin{array}{c}\text { ndú=é } \\
\text { water=DET }\end{array}$ & $\begin{array}{r}\text { xé } \text { i-du } \\
\text { RP 3SG-be }\end{array}$ & $\begin{array}{r}\text { adi } \\
\text { soda }\end{array}$
\end{tabular} 
nqú=é fé gaze nu xé a-mí na odzá.

water $=$ DET put metal.pot in RP 2SG-take put fire

'After this you will pour the water which is the soda water into the metal pot and you will put it on fire'

07. A-bó-zi $=\hat{\varepsilon}$

tsyoo nqú m-bî-bé

iyé nu.

2SG-FUT-cook =3SGOBJ for.long water SM-FUT-well.cooked 3SG in

'You will cook it till the water will be well cooked in it'

08. Nqú=é y-gbé pétée gake xé i-bé-e

water $=$ DET NEG-evaporate all but COND 3SG-well.cooked-CFM

'The water will not evaporate completely but when it is well-cooked'

09. a-bó-yu kanyi té gaze nu pétée i-dze fli 2SG-FUT-see realize COMPL metal.pot in all 3SG-look white 'you will realise that inside of the pot will be white'.

10. Yedze a-bó-yú kanyi té i-bé ko a-gla then 2SG-FUT-see realize COMPL 3SG-well.cooked only 2SG-pour

mi yida A-bó-nu kanyi té ta gla mfú kpe take down 2SG-FUT-see realize COMPL give pour oil CONJ adí nqú=é pétée na odzá ikpe. i-tsi vuvo soda water $=\mathrm{DET}$ all put fire one 3SG-stay spoil

ibe gblele

time many

'Then you will realise that it is well cooked and you will pour it down.

You will realise that you pour the oil and soda water all on fire at once. It wastes so much time'

11. Kpane anyi da nu-e xé a-zá adi ka now face open in-CFM COND 2SG-cook soda put.down

iva a-kpe na odzá ${ }^{57}$ kura. Xé a-dze iva thing 2SG-peel put fire even COND 2SG-look thing

zá otsoe a-mi na odzá

cook soap 2SG-take put fire

'In this modern world, if you cook soda you can as well cook.

12. xé a-ló-blu o-nu-e. kpane ko té iva

COND 2SG-PRSPROG-stir 3SG-in-CFM now only COMPL thing tá i-bé. गtsəe fé ko o-bé

give well.cooked soap also only 3SG-well.cooked

\footnotetext{
${ }^{57} \mathrm{kpe}$ na odza 'peel put fire' this phrase refers to peeling yam or cassava to put on fire as one of the steps in the preparation of yam or cassava slice or fufu.
} 
a-nú awú otsoe.

2SG-see 2SG soap

'as you are stirring by the time the food is well cooked, the soap

will also be well cooked and you will see your soap'

13. Jtsəe xé a-mi na odzá, a-bó-tso-blu o-nu.

soap RP 2SG-take put fire 2SG-FUT-HAB-stir 3SG-in

A-tso-blu o-nu tsyõ ̃ xé mfu kpe adi pétée

2SG-HAB-stir 3SG-in for.long RP oil CONJ soda all

i-bi-tsaka f́c anda nu

3SG-FUT-mix into companion in

'The soap that you put on fire, you will be stirring it. You will sitr it until the time that the oil and the soda mix into each other'

14. Xé i-blu fé anda nu pétée ko a-yú

COND 3SG-stir into companion in all only 2SG-see

té nqú $\quad \mathrm{ku} \quad \mathrm{f}^{\varepsilon} \quad \mathrm{c} \quad \mathrm{o}$-nu.

COMPL water die into 3SG-in

'If it all mixes into each other then you will see that the water will be dried in it'

15. o-bó-dze tsoe ale tsiban pétée i-bî-dze tsoe.

3SG-FUT-start dry 3PLU under all 3SG-FUT-start dry

tsỹ̃̃ té o-bó-tsoe sé la ó-pétée o-bó-dzú

for.long COMPL 3SG-FUT-dry finish CFM 3SG-all 3SG-FUT-turn

wesee bate gali

coarse like gari

'It will start drying from the bottom and all will dry. Up till the time it finished drying, it will become like gari.'

16. Yédzę awu tsoe o-béé Yé i-du

then 2SG soap 3SG-well.cooked CONJ 3SG-be

iva $\mathrm{n}$-kpe gu ina bibli stsəezago yó-e.

thing 1SG-know from person black soap.cooking skin-CFM

Then your soap is well cooked. This is all that I know

about "black mans" soap making'

\section{QUESTION}

17. Atsa-wa té xé iva baté oganyi

1PLU-say COMPL COND thing like palm.frond

$\begin{array}{llll}\text { kpe avudago } & \text { xé á-lá-dzi } & \text { té } \\ \text { CONJ leaf } & \text { RP 3PLU-PRSPROG-call } & \text { COMPL } \\ \text { acheampon oyó } & \text { xé } & \text { o-wo-wú-e } & \text { atsa-wá } \\ \text { Acheampong.tree } & \text { COND } & \text { 3SG-prick-2SGOBJ-CFM } & \text { 1PLU-say }\end{array}$


té xé a-mi aviestsoe glí-e

COMPL COND 2SG-take local.soap tie $=3$ SGOBJ

adi á-tsa-ku ikpá

poison 3PLU-HAB-die true.Q

'It is said that if something like palm frond and a leaf like Acheampong ${ }^{58}$ tree pricks you, they say that if you tie it with local soap the poison die, is it true?'

\section{ANSWER}

18. E! î-du

\begin{tabular}{|c|c|c|c|}
\hline $\begin{array}{l}\text { E! î-du } \\
\text { Yes3SG-be }\end{array}$ & $\begin{array}{ll}\text { ikpá } & \text { Adi=é } \\
\text { true } & \text { poison=DET }\end{array}$ & $\begin{array}{l}\text { xé ó-tsi } \\
\text { RP SM.SG-be.in }\end{array}$ & $\begin{array}{ll}\text { avieotsoe } & \text { nu-e } \\
\text { local.soap } & \text { in-CFM }\end{array}$ \\
\hline ó-tso-bá & mango & baté & $\operatorname{ad} \mathbf{i}=\hat{\varepsilon}$ \\
\hline 3SG-HAB-kil & poison different & 3PLU-in & soda $=$ DETthis \\
\hline ó-bo & intse & & \\
\hline 3SG-stay & & & \\
\hline
\end{tabular}

'Yes it is true. The poison which is in local soap kills other poisons because this poison is strong'

19. iboté ebi abe xé kotsú iló mi-nya-nú

reason past time RP hospital word NEG-stay-NEG

kpe atsú ka atsi-bo kəfe-wo nu-e xé iva

CONJ 1PLU FOC 1PLU-stay village-PLU in-CFM COND thing

i-wo=wú-e a-tanyi avietsoe mi gli-e

$3 \mathrm{SG}$-prick $=2 \mathrm{SGOBJ}-\mathrm{CFM}$ 2SG-can local.soap take tie $=3 \mathrm{SGOBJ}$

unyi-nys unyi-nta

day-two day-three

'This applied to the past time that people did not understand going to hospital and also those of us who are in villages. If you are pricked by something you can use local soap to tie it for two days or three days'

20. ivi-me xé i-w $=$ =ú-e

thing-this RP 3SG-prick=2SGOBJ-CFM 3SG-FUT-pull=3SGOBJ

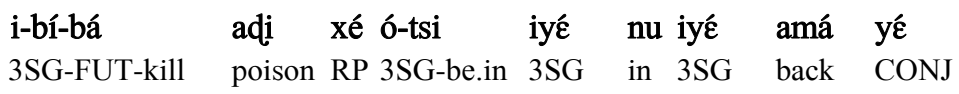

$\begin{array}{lllll}\text { a-wo } & \text { zugbo kotsú } & \text { i-ta } & \text { té } & \text { i-du } \\ \text { 2SG-move } & \text { head hospital } & \text { 3SG-show } & \text { COMPL } & \text { 3SG-be } \\ \text { ava } & \text { f'́c. } & & & \end{array}$

medicine also

'The thing that pricks you, it will pull it out, it will kill the poison that is in it. After this then you head towards the hospital. This shows that it is medicine also'

\footnotetext{
${ }^{58}$ A grass named after one of the former military heads of state in Ghana
} 


\subsection{Cocoa cultivation}

Cocoa is the main cash crop in Ghana and Logba is one of the areas in the Hohoe district where it is cultivated. This text is culled from a longer account of cocoa cultivation. Guady R.K. (Age 61) a chief farmer, describes how cocoa is cultivated. This was recorded on $5^{\text {th }}$ April. The video version is available.

Cocoa does well in forest areas. Cultivation of cocoa involves clearing of the forest and setting fire to the bush to make the land clean and ready for use. Mounds are made on which the cocoa bean is planted. Alternatively, the seeds are broadcast. It takes six to seven years for cocoa to bear fruits. Cutlass or ope is used to pluck cocoa from the trees. When the cocoa pods are plucked, they are broken to take out the seeds. The seeds are then heaped and covered to ferment. They are dried in the sun to make them ready for sale.

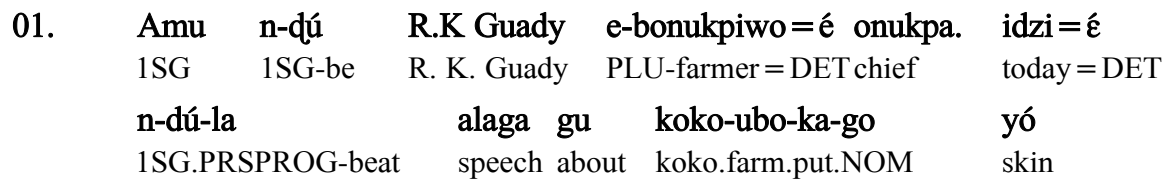
'I am R.K. Guady chief farmer. Today I am speaking about cocoa farming'

02. Koko koy o-zi tá owábo. Koko cocoa mainly 3SG-be.good give forest.area cocoa

$\begin{array}{llll}\text { mo-ó-nyo-n-zi } & \text { odzogbe } & \text { nu. } & \text { i-ta-té } \\ \text { NEG-3SG-stay-NEG-well } & \text { savanna } & \text { in } & \text { 3SG-give-COMPL }\end{array}$

atsú etsi=é xé i-qu Ghana ume koko

1PLUland=DET RP 3SG-be Ghana here cocoa

mo-ó-nyo-n-zi odzogbe nu.

NEG-3SG-stay-NEG-well savanna in

Cocoa mainly does well in forest areas. Cocoa does not do well in savanna areas. It is that our land here, in Ghana, cocoa does not do well in the savanna'

03. Ubo-ka-go=é me e-tse-blo $1 \varepsilon \quad$ ta?

farm-put-NOM=DET this 3PLU-HAB-make 3SGOBJ PART

\begin{tabular}{|c|c|c|c|c|c|}
\hline E-bé-z’́ & yé & e-bé-dze & okunie & xé i-zi & té \\
\hline 3PLU-FUT-go & CONJ & 3PLU-FUT-see & place & RP SM-good & COMPL \\
\hline $\begin{array}{l}\text {-be } \\
\text { J-FUT-clea }\end{array}$ & & & & & \\
\hline
\end{tabular}

'This farming, how is it done? They will go and see a place which is good so they will clear the forest. 
04. iva=á xé é-tse-mî be uwá î-du ifiami thing =DET RP 3PLU-HAB-take clear forest 3SG-be cutlass

E-bémí ifiami bé uwa pétée yé é-bé-dza a-yó. 3PLU-FUT-take cutlass clear forest all CONJ 3PLU-FUT-cut PLU-tree 'The thing they will use to clear the forest is cutlass. They will use cutlass clear all the forest and they will cut the trees'

05 .

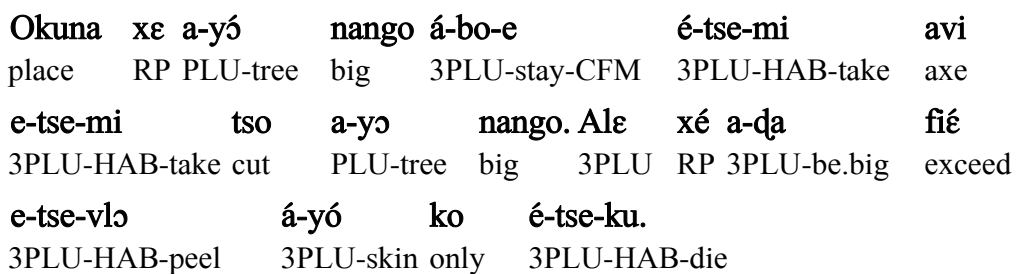

'Where there are big trees they use axe to cut the big trees. Those which are bigger they remove their barks so that they die'

06. Xé é-lo iva sé-e xé é-fe iva=á

COND 3PLU-clear thing finish-CFM COND 3PLU-set thing $=$ DET

odzá=á xe é-kpali iva=á sé-e

fire $=$ DET $\quad$ COND 3PLU-collect thing $=$ DET finish-CFM

'If they finish clearing, set fire to the bush, and finish gathering the things,

07. xé $u b o=e ́$ nu î-ko xe é-lá

COND $f a r m=D E T$ in 3 SG-clean COND 3PLU-make mound $=$ DET

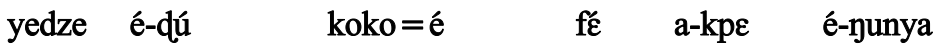

then 3PLU-plant cocoa $=\mathrm{DET}$ also CM-one 3PLU-broadcast

koko $=$ é fé ubo=é nu.

cocoa $=\mathrm{DET}$ in farm $=\mathrm{DET}$ in

if the farm is clean, they make mounds, then they plant cocoa; some broadcast the cocoa in the farm'

08. Koko=é ibe-imo-nu xé odzá ba-a iyé i-qu

Cocoa $=$ DET time-that-in RP ahead come-CFM 3SG 3SG-be

Tettey Quashie. I-qu koko o-kpe xé ó-tso-nyi.

Tettey Quashie. 3SG-be cocoa AM-one RP 3SG-HAB-fruit

Cocoa, at that time which came first is Tettey Quashie. It is a type of cocoa which bears many fruits.'

09. Ekple xé ó-nyi unyi okpe ko-e o-sé. now COND 3SG-bear fruit one only-CFM 3SG-finish

nyagbo ó-lo-no f́̃ mo-ó-ló-nyi

rain 3SG-again-fall also NEG-3SG-PRSPROG-fruit

'Now if it bears fruit only once then it is finished. Even if it rains again it will not bear fruits' 
10. Dzigu ole i-dú-be from 3SG 3SG-plant-time tsyoo

for.long bito a-dze bi-e

up.to 3PLU-start harvest-CFM

3SG-up.to CM-year AM-six CONJ seven then 3PLU-start-fruit 'From the planting up to its time of harvesting is up to six and seven years then it begins to bear fruit'

11. Xé koko=é é-dze drui iva atsi-tsi-mî

COND $\operatorname{cocoa}=\mathrm{DET}$ 3PLU-start red thing 1PLU-HAB-take

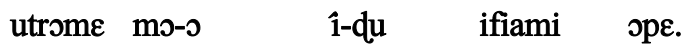

work there-CFM 3SG-be cutlass ope"

"If cocoa starts to ripe the things we use to work are cutlass and "ope"

12. эpe atsi-tsi-mi tole na oyó anú xé atsi-tsi-mi

"ope" 1PLU-HAB-take fix on tree mouth RP 1PLU-HAB-take

bî koko $=$ é $\quad$ ifiami $=\boldsymbol{\varepsilon} \quad$ é-tso etsi á-ble.

pluck $\quad$ cocoa $=$ DET $\quad$ cutlass $=$ DET 3PLU-pluck ground 3PLU-own

agu a-bli=ć atsi-tsi-mi op $\varepsilon \quad$ tso=á

top 3PLU-own=DET 1PLU-HAB-take "op $\varepsilon$ " cut $=3$ PLUOBJ

"ope" we use to fix on the tree which we use to pluck the cocoa. The cutlass plucks those under; the top ones, we use "ope" to pluck them'

13. Xé atsi-tso=á sé pétée é-bé-gba=á

COND 1PLU-cut-3PLU finish all 3PLU-FUT-heap=3PLUOBJ

xoxu e-bé-mi ifiami kojklo xé mi-ve-nu

gather 3PLU-FUT-take cutlass old RP NEG-pass-NEG

da ye é-bé-mi fonyi koko=é.

big CONJ 3PLU-FUT-take break cocoa=DET

'If we finish plucking, they heap them. After heaping all of them we use a cutlass that is old but not too big to break the cocoa'

14. Xé a-fonyi koko=é sé-e yedze e-bé-bua

COND 2SG-break cocoa=DET finish-CFM then 3PLU-FUT-heap

yedze atsi ka ado

then 1PLU put fermentation

'If you finish breaking the cocoa then you will keep it to ferment'

15. E-bé-ka ogayo avudago kpe kodiatsa avudago ka

3PLU-FUT-put plantain leaf CONJ banana leaf put

etsi ina-kpe fर́ a-tsa-ka agbado

ground person-one also 3PLU-HAB-put shed

xé me-zó agu

RP NEG-go top

'They put plantain leaf and banana leaf on the ground. Some people make a shed which is not high' 


\subsection{Puberty rites}

According to custom, girls on reaching puberty have to undergo some rites. Mama Ella Semidi IV (Age 70) recounts what she knows about puberty rites. This is taken from a longer account that was recorded on $13^{\text {th }}$ June 2006.

During the time of our ancestors, they discuss with parents and then inform the girls of the time for the puberty rites. The time is usually fixed three weeks before the actual date. On the day of the ceremony, a prayer is offered and the girl will be adorned with special beads by the aunt. The girl is expected to wear the beads for three months. Food is provided by the girls' parents for the feasting and merry making.

01. amu unyi o-du Mama Ella Semidi na-mble. Ma-bá-la

1SG name SM.SG-be queen Ella Semidifour-ORD 1SG-FUT-beat

alaga gu edze-zigo yó.

speech about women-puberty skin

'My name is queen mother Ella Semidi IV. I shall talk about puberty rites'

02. Gbã iva etsie é-tse-to etsi-wo kpe

first thing under 3PLU-HAB-start male.ancestor-PLU CONJ

ama=á xé á-nya ibe- $\varepsilon$ blo

female.ancestors $=\mathrm{DET}$ COND 3PLU-stay time-CFM make

ikago ta edze-zigo =é é-bé-tsi é-bé-la alaga

rule give women.puberty=DET 3PLU-FUT-sit 3PLU-FUT-beat speech

gu iyé yó

about 3SG skin

'First thing is that the ancestors(both male and female) when they lived they arranged for puberty rite, they sat down to discuss it'

03. xé é-ri=é ka-a yedze é-bé-ta

COND 3PLU-hold=3SGOBJ put-CFM then 3PLU-FUT-give

edzebî=é é-bé-yáyîi ámú uma=á o-bó-yáyî

girls $=$ DET 3PLU-FUT-search rice mother $=$ DET 3SG-FUT-search

ámú edzebî=é e-bé-yuع ámú=é.

rice girls $=$ DET 3PLU-FUT-pound rice $=$ DET

'After they discussed it, they will inform the girls to find local rice; their mothers will find local rice; the girls will pound the unshelled rice'

04. Kwasida ita lî-zó abobî yedze adzi=é tsú week three PRSPROG-go month Then day=DET on 


$\begin{array}{llllll}\text { tututu } & \text { xé } & \text { e-bé-blo } & \text { oks=o } & \text { ta } & \text { nu } \\ \text { exactly } & \text { RP } & \text { 3PLU-FUT-make } & \text { custom=DET } & \text { give } & \text { 2PLU } \\ \text { ubî̀=é } & & \text { é-ki- } \varepsilon & \text { ka. } & & \\ \text { daughter }=\text { DET } & \text { 3PLU-tell=3SGOBJ } & \text { put } & & \end{array}$

'Three weeks going to a month then the exact date that the custom will be performed for the girl will be given'

05

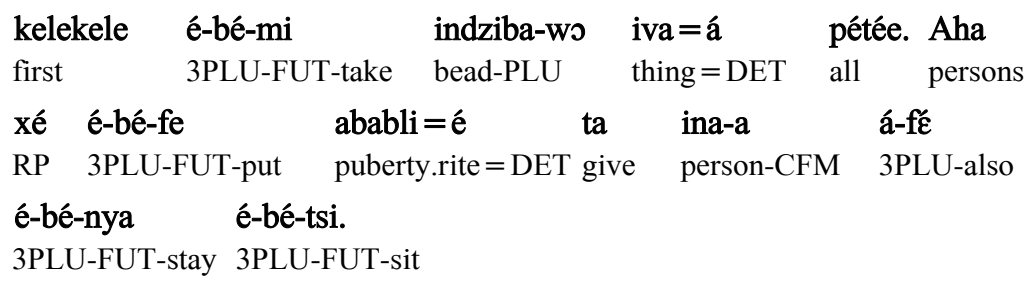

'First they will take all beads of different kinds. The people who will perform the rites will also be seated there'

06

\begin{tabular}{|c|c|c|c|c|}
\hline $\begin{array}{l}\text { Ina = á } \\
\text { person = DET }\end{array}$ & $\begin{array}{l}\text { xé é-bé-dze } \\
\text { RP 3PLU-FUT-look }\end{array}$ & $\begin{array}{ll}\text { iva } & \text { tá } \\
\text { thing } & \text { give }\end{array}$ & $\begin{array}{l}\text { ina=á } \\
\text { person = DET }\end{array}$ & $\begin{array}{l}\text { a-f'́ } \\
\text { 3PLU-also }\end{array}$ \\
\hline $\begin{array}{l}\text { é-bé-tsi. } \\
\text { 3PLU-FUT-sit }\end{array}$ & $\begin{array}{l}\text { Yedze xé } \\
\text { then COND }\end{array}$ & $\begin{array}{l}\text { é-bé-tsi-e } \\
\text { 3PLU-FUT-sit-CFM }\end{array}$ & $\begin{array}{l}\text { é-bé-dzi } \\
\text { 3PLU-FUT }\end{array}$ & $\Gamma$-call \\
\hline $\begin{array}{ll}\text { kpaya } & \text { té } \\
\text { od } & \text { COMPL }\end{array}$ & 3PLU-FUT-fix & $\begin{array}{l}\text { iva }=\text { á } \\
\text { thing =DET }\end{array}$ & ground & \\
\hline
\end{tabular}

The supporter of the celebrant will also be seated. As they are all seated, they will call God (pray) for the start of the ceremony'

07.

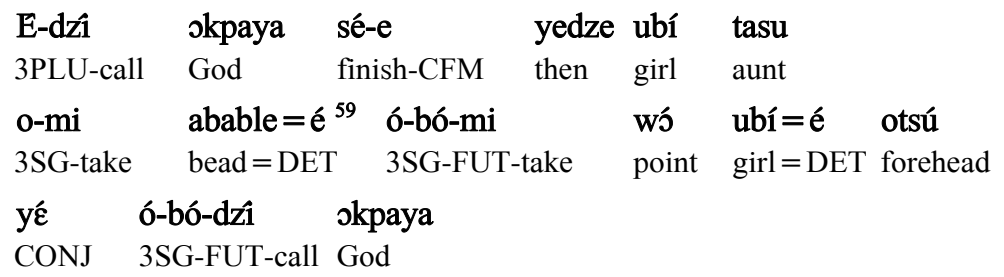

'After calling God, the girl's aunt will take the bead and point it to the forehead and will call God(pour libation)'

08. iblo-go=é nu ugbedzugo=énu-e xé é-dzi

\begin{tabular}{llll} 
make-NOM=DET in & prayer=DET & \multicolumn{1}{c}{ in-CFM COND 3PLU-call } \\
okpaya sé-e & iva xé é-bé-lé-blo \\
God finish-CFM & thing RP & 3PLU-FUT-PRSPROG-make \\
iva kelekele iyé & í-bí-du & ifuwe \\
thing first & $3 \mathrm{SG}$ & 3SG-FUT-be & 'ifuwe'
\end{tabular}

'In the process, when the prayer in which they call God is said the first thing they will be doing is to take a special bead, "Ifuwe" for her to wear'

\footnotetext{
${ }^{59}$ Abablee is used here to refer to the representative items like beads used for puberty rites

${ }^{60}$ Ifuwe is a type of bead; other beads are komegogoe avatsogenge and bluwe.
} 
09. Ifuwe ime yé é-bé-mi le xé î-du kelekele.

'ifuwe' this 3SG 3PLU-FUT-take 3SGOBJ RP 3SG-be first 'This "ifuwe" is what they will give her to wear first'

10. E-bé-mi komegogoe, avatsogenge kpe bluwe.

3PLU-FUT-take "komegogoe, avatsogenge" CONJ "bluwe"

"They give her other beads like "komegogoe", "avatsogenge" and "bluwe" to wear'

11. indziba ime ita=á î-bî-nya ole imo-nu boté bead this three $=$ DET 3SG-FUT-stay 3SG neck-in like

abobî a-ta ó-bó-to-gu iyó kpi=ce.

moon AM-three 3SG-FUT-HAB-wash skin with=3SGOBJ

'These three beads will stay on her neck for about three months. She will be bathing with it'

12. Xé é-blo sé-e yedze é-bé-kuks ogbo-nu

COND 3PLU-make finish-CFM then 3PLU-FUT-go.round town.in

'When they finish they will go round the town'

13. Ubí-ma kpe ubí-tsi é-bé-zá iva mla

girl-mother CONJ girl-father 3PLU-FUT-cook thing bring

ababléfewo-wo kpe iva-dze-wo=é pétée

puberty.performer-PLU CONJ thing-look-PLU = DET all

'The girls mother and the girls father will cook and bring to those performing the rite and all the onlookers.

14. é-bé-za iva mla é-bé-mi nda tá

3PLU-FUT-cook thing bring 3PLU-FUT-take drink give

ababléfewo =é

puberty.performer $=\mathrm{DET}$

'They will cook and bring drink to those who are performing the puberty rites' 



\section{Logba vocabulary}

\section{Logba-English-Ewe vocabulary}

The order in which words (roots) are presented in the Logba-English-Ewe vocabulary is similar to how entries are made in an English dictionary with some modifications. The order is as follows:

$$
\text { a,b,d,d,e,c,f,g,h,i,k,l,m,n,y,o,o,p,r,s,t,u,v,w,x,y,z. }
$$

Every entry is specified for the part of speech it belongs to. For nouns, plural is also indicated. This is followed by the English gloss and the Ewe gloss. The example sentence in Logba is provided for some of the entries with a translation equivalent (work is still in progress). Where a dialectal equivalent is available in the language, it is provided indicating the Logba area in which the particular word is used. Both low tone and high tones are marked on all the entries. The following abbreviations are used.

$\begin{array}{llll}\text { adj } & \text { adjective } & \mathrm{n} & \text { noun } \\ \text { adv } & \text { adverb } & \text { prep } & \text { Preposition } \\ \text { Conj } & \text { conjunction } & \text { Pro } & \text { Pronoun } \\ \text { DET } & \text { determiner } & \text { Pl } & \text { Plural } \\ \text { FUT } & \text { future } & \text { Subj } & \text { Subject } \\ \text { IMP } & \text { imperativ } & \text { V } & \text { verb } \\ \text { Obj } & \text { object } & 3 \mathrm{SG} & 3^{\text {rd }} \text { Singular pronoun }\end{array}$

\section{A - a}

a Pro 2SG.Subj. è

-a DET the (I)a

á FUT RED. -ge

á pron $3 P L U$ wó

abàbléfewò $n$ performers of puberty

rites amesiwo woa leke na

tugbedzewo Ebezá iva mlá

ababléfewo They will cook and bring to those performing puberty rites.

abé

Pl:abé n palmnut dě Abe ezi inta The palmnut is very good. abego $n$ dead palm tree trunk edekpe Amolonú onkpe gu abego e nu They are not getting anything from the dead palm trunk

abéndà $n$ palmwine deha Kofi ono

abénda Kofi drank palmwine

abéyuewó $n$ mortar for pounding palm fruit edetoto Abeyucwo adre The mortar for pounding palmfruit is dirty.

\section{abézúgbó}

$\mathrm{Pl}: a b \varepsilon ́ z u ́ g b o ́$ $n$ the fruit on the palmtree edeta Abézugbo odrui The palm fruit is ripe 
abí

Pl:abí n palm kernel nefi Mane abí I bought palm kernel

abí

Pl:abí $n$ palm kernel nefi

abiá

Pl:mbia $n$ chair zikpi, ablengo Ntsi

abia tu I am sitting on the chair

abiasà $n$ Logba fetish priest Logba

trõnua Abiasa odzí okpaya Ayadzi

Logba fetish priest prayed (poured libation) on Saturday

\section{abífó}

Pl:abifo $n$ palm kernel shell nefito

abifó ole odza nu palm kernel shell is in the fire

abíofifie

Pl:abîofie $n$ palm kernel oil nefimí

Mazò abíofifie I sold palm kernel oil

Tota: abíonfie

\section{àbobí}

Pl:àbobí $n$ moon dzinu Abobi vuvo

odó New moon appears

abólózágò

Pl:abolo $n$ 'abolo' abolo Mané

abólozágo I bought abolo

abótí

Pl:mbótiwo $n$ corpse amekuku evla

aboti uname They buried the corpse yesterday Tota: abotsi

abotiatá

Pl:mbotiatá $n$ flies that swarm after rainfall eko Mbotiata nle nque nu

Flies are in the water

abodiabó
Pl:abodiabó $n$ bottle atukpá nkponyi nny midze abodiabo nu You cannot use two eyes to see in one bottle.

abù

$\mathrm{Pl}$ :abu $n$ valley, precipice abu, balime Esi olenta $f \varepsilon$ abu é nu Esi fell into the valley.

\section{abùbà}

Pl:mbùbà $n$ termite baba Mbùbà

nkpe afuta termites ate the cloth

abúdze

Pl:mbúdze $n$ she-goat gboñ̃ Dze

abudze omé Look at that she-goat

abuéklontí

Pl:mbowoklontsi $n$ hide, skin of ani-

mal elãgbalẽ abuéklonti izi The hide

is good Tota: abweklontsi

abúkpá

Pl:abúkpa $n$ shoulder abotá

abukpákú

Pl:abukpákú $n$ shoulder bone abotafu abué

Pl:mbówó n animal lã つvanuvo obá abué The hunter killed the animal Tota:aboc

ádà

Pl:ndà $n$ lizard adoglo áda ole aglie yo lizard is on the wall

\section{adébí}

Pl:adébí n kidney ayiku

Adenkluí $n$ fresh palm wine deha yeye si vivina Adenklui mbondzi Fresh palm wine is sweet. adí $n$ frog akpokplo Onu adí ndue nu He saw frog in the water 
Adò $n$ River in Logba tosisi ade le

$\log b a$

adrú

Pl:ndrú $n$ mound etekpó Abóla adru

kpe agblenu You will prepare mound with a hoe.

\section{adrú kisai}

Pl:ndru kisai $n$ ridge kpo iyoyu inya adrú kisai nu There is moisture in the ridge.

\section{Àdrùvà}

n Thursday Yawoda Ewom Adruva I was born on Thursday.

ádzáfô $n$ chaff atsa

\section{adzàgò}

$\mathrm{Pl}$ :adzago $n$ millet efo

adzàyí

Pl:ndzàyí n firewood nakè Ndzayí ntsi odzá nu Firewood is in the fire adzexé

Pl:ndzexé $n$ bird possessed with evil spirit adzexe Adzexe ole utsa zugbo Owl is on the top of the building adzewàsà

Pl:ndzewasa $n$ witch adzeto Ari adzewàsà idze They caught a witch/wizard today

adzì

Pl:ndzì $n$ bird xevi Mari adzì I caught a bird

adzi

Pl:ndzí $n$ day, occasion -gbe Mabá zo adzi nkpe I will go one day. Used with ordinal numbers adziá $a d v$ that day, previously

yemayi

adzímí

Pl:ndzímíwo $n$ mudfish adeye adzími oda fie akpá mudfish is bigger than tilapia

adzìsà

Pl:ndzìsà $n$ birds' nest xevi fe at̀̀

ndzìsà nle syś á nu birds' nests are in the tree

adzísiádzí adv everyday gbesiagbe

Adzísiádzi stuzó suku Everyday he goes to school

adzíyí

Pl:ndzíyí $n$ kite ayisu Atinú adziyi e agu We saw the kite above Tota:

adzíi

adzòkloyì $n$ rice molu Ebitsi é okp adzokloyi The child ate rice

\section{adàbàkùtó}

$\mathrm{Pl}$ :adàbàkùtó $n$ eyebrow adzugo

Adabakutó bíbli obò Kafui Kafui has black eyebrow

adạù $n$ advice adayù Adanu dukpa obo Esi Esi has good advice adí $n$ soda adí Abógla adi nqu é fe gaze nu You will put the water containing soda into a metal pot adí $n$ poison adi Kofi omi adi bá oglui Kofi used poison to kill the mouse

adódí $n$ love 1ōlo Adódí iqu ikago kélékélé Love is the first law afã $n$ half afã Afa ole futsu é nu. Half is in the soup 


\section{áfá}

Pl:mfá $n$ house afeme Awu tsi obò

áfá á nu? Is your father in the house?

\section{afádze}

Pl:afádzewo $n$ madam afeno Afádze obo afán The madam is in the house áfán

Pl:mfán $n$ compound xoxonu Manu udze afán I saw the girl in the house afáoblé $n$ citizen of a particular town dumevi

afásà

Pl:afásàwo $n$ landlord, man afetó

Afásaa osá The landlord left

afé

Pl:mfé $n$ comb ayida Mané afé akpe I bought one comb

afiá $n$ pain vevesese

afiánugò

Pl:afiánugo $n$ bitterness, agony vevesese

\section{afiáwo}

Pl:afiáwo $n$ speakers of other dialects egbe bubu gblolawo

afié

PI:mfié n strainer nutsyónu

aflandzá $n$ big cutlass used for harvesting tree crops and cutting big trees eyiga

afó

Pl:mfó $n$ egg koklozi

afokpá

Pl:mfokpá $n$ shoe afokpa

afowui
Pl:mfowui $n$ socks afowui

\section{afúnùimúnyí}

Pl:afúnùimúnyí $n$ pubic hair eh̃̃

Tota: afunumuni

afútà

Pl:mfútà $n$ cloth (material) avo

Afútaa ale ukploa tsú The cloth is on the table

afútàtsì

Pl:mfútàtsi $n$ rag, duster dovú afûtsáì

Pl:afûtsái $n$ black pepper atadi

àgà

Pl:àgà $n$ valley agàme

\section{agaànu}

Pl:agaànu $n$ valley agame

\section{agádzà}

Pl:ygádzà $n$ crab agala

agáné

Pl:agánéwo $n$ scorpion ahग̃

\section{Aganxoé}

PL:Aganxoé $n$ Avatime name for

Tota Alesi Avatimetowo yoa Totae

agànyì

Pl:ngànyì $n$ palm branch devaya

agányì $n$ fish tomelã, nudonui

agbà

Pl:agbà $n$ yam barn etexo

agbádzé $n$ sieve agbadze

agbàshì

Pl:ngbàshì $n$ arm abo

agbashìanú

Pl:ygbashìnú $n$ wrist alotsinu Tota:

agbashianu 


\section{agbashiawù}

$\mathrm{Pl}$ :agbashiawù $n$ glove asiwui

àgbèdì

Pl:igbédì $n$ cassava agbèlì

agbelìlì idá $n$ instrument for grating cassava agbelililigà

agbé

Pl:mgbé $n$ dog avu Agbé olófali The dog is barking

agbí

Pl:mgbíwo $n$ grasscutter exつ, nukpui agbìafútà

Pl:ygbìfútà $n$ spider's web ayiyido agbíglomว̀

Pl:ngbíglomò n spider ayiyi Ogridi ódze agbigloms tsú The story falls on spider Tota: agbíhlõmo

agbímà

Pl:ngbímà $n$ spider's web ayiyido agblàmìdó

Pl:ngblàmìdó $n$ edible worms

gbamido

agblènú

Pl:ygblènú $n$ hoe kodzi, agblenu agbógbló

Pl:ngbógbló $n$ ladder antsroe

\section{agbógbló}

Pl:ngbogblo $n$ ladder, instrument for getting access to high buildings atrakpui

agbòté

Pl:mgbòté $n$ pant avete Tota: agbota Agbذ̀
Pl:Agbò $n$ Logba name for Tafi Tafi

Ogbomiws elé Agbo Monkeys are in Tafi

Agbònyì $n$ Tafi citizen Tafito

àglì

Pl:àglì $n$ wall (of a house) glì

agù

$\mathrm{Pl}$ :agù $n$ top dzifo

agú

Pl:ngúwo $n$ antelope avugbe, aklatsu ágù $n$ yam plant which fruits on the top of the plant ete si wona de kanu àgùtó

Pl:ngùtówo $n$ bat agutó ahointsà

Pl:nhointsà $n$ chameleon agama akandó

Pl:nkando $n$ milipede ahliha

akankabi

Pl:akankabi $n$ clitoris lukutsi

akàtàmá

Pl:nkàtàmá n parasol xexi lolo si fiawo zana Anansanango obo akatama fliyi Paramount chief has a red parasol

ákló

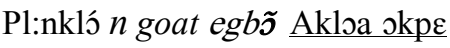
igbedimawor The goat ate the cassava dough

akó

Pl:akóws $n$ parrot ako

akóngrotsí $n$ small cutlass used for weeding eyi sue ade si wotsona ploa nue 
akóntsí

Pl:ykóntsí $n$ basket kusi Dnkpá á olé

akontsi anú The rope is on the tip of the basket

àkpá

Pl:mkpá $n$ fish akpá

ákpá

Pl:mkpá $n$ leg ata

akpá iva

Pl:mkpá iva $n$ ball, shoes bolu,

afokpa

akpadzìdzí

Pl:mkpadzìdzí $n$ heel afokpodzi

akpáfló-ivà

Pl:mkpáfló-ivàwo $n$ ball bolu

àkpàkplà

Pl:mkpàkplà $n$ toad (frog) akpjkplì

Akpakpla á oklá egbi é tsu The frog hid under the stone

akpákpò

Pl:mkpákpò $n$ heel afokpodzi

akpàlí

Pl:mkpàlí $n$ grasshopper gbagblamì akpámandzò

Pl:mkpámandzò $n$ heel afokpodzi

\section{Akpananyi}

Pl:Akpanawo Fem:Akpanadze $A$ native of Logba Logbato

àkpàntà $n$ shed agbado

akpánkpàyìdàdà

Pl:ykpánkpàyìdàdà $n$ black ants; live in coffee trees anyidi yibo, enoa

kofetsi me

akpázúgbó
Pl:ykpázúgbó $n$ top of foot afota

akpétsí

Pl:ykpétsí $n$ sole afogome

akpetsíklontsi

Pl:ykpetsíklontsi $n$ sole afofome

akpe $n$ some (ame)dewo akpe ejúnyá koko é fé ubo é nu. Some broadcast the cocoa in the farm

akpì $n$ local war dance aflì

akpí $n$ thousand akpe (deka)

akpí okpè $n$ one thousand akpe deka akpitagò $n$ fork stick for roofing $a$ thatch house gbegblevi si wozana na xogbagba akpítágò

Pl:ykpítágò $n$ stick for playing talking drum agblovufotsi

\section{ákpívà}

Pl:ykpívà $n$ shoe afòkpà

akpǒ

$\mathrm{Pl}:$ kpǒ $n$ farm bag agblekotoku

akpòyì

Pl:nkpòyì n bag bagi, kotoku

akpò $n$ kenkey kónù

akpónó

Pl:akpónówo $n$ biscuits akpono(vivi)

akpónyíblìgo

Pl:ykpónyíblìgo $n$ blind pkugbagbato

akró

Pl:akrówo $n$ boat todzivu

Akrobonyi $n$ Krobo citizen Akloboto akukólì

Pl:ykukólì $n$ finger nails fetsú 
alá

Pl:nlá $n$ scorpion aho

\section{àlă}

Pl:nlă $n$ dream drõe

alágà

Pl:alágà $n$ speech nufo

Alata

Pl:Alatawo $n$ Person from Yoruba land Anago

Alàtàwò

Yoruba $n$ Yoruba Alata

alebe conj that, COMPL be, alebe

àlélé

Pl:nléléwo $n$ rat alegeli

alé

Pl:nlé n claybowl vegba

alćhàdzàhlà

Pl:nléhàdzàhlà $n$ clay bowl for grinding pepper vegba

aléwò $n$ buyer nuflela

alo conj or alo

amá $n$ back of body megbe

ámántí $n$ back dzimegbe Ofonyi é ome óle amanti This gourd is at the back Tota: amantsi

amantsikú $n$ backbone dzimefu

Amazon $n$ Amazonia variety of cocoa koko si wona kaba awu Tete

Koshi

amé $n$ the belly of a pregnant woman fufodo

amenfiá $n$ stomach-ache domequ àmènù $n$ stomach fodo améwasà $n$ pregnant woman efúnò àmgùnédzékloi

$\mathrm{Pl}$ :àmgunédzékloiwo $n$ sister

(younger) novinyonu

\section{àmgùnédzetséngo}

$\mathrm{Pl}$ :àmgùnédzetséngowo $n$ sister elder dáwò tsitsito

àmgùsàklıi

Pl:àmgùsàkloiws $n$ brother younger novi yutsu

amò

Pl:mmó $n$ idol vodu

amó $n$ disgrace kòkòe

amóblé pron my own tonye Amóble ízi Mine is good Tota: amible

amònù $n$ fetish shrine trõfe

ámú $n$ unshelled rice molu makle-

makle

amú ntá pron my own(self) tonye

amú yó pro myself dokuinye

amúávú $n$ 'porridge' made from

local rice molukplẽ

ánándzè

$\mathrm{Pl}$ :énéndzè $n$ old lady nyagadedi

anàngbà $n$ type of mushroom that is

broad evlo si lolo

anànsà

$\mathrm{Pl}$ :enànsà $n$ old man putsu tsitsi

ánánsá $n$ ancestors togbi, mama wo nutefe si wo $\mathrm{ku}$

anasábiá $n$ ancestral stool togbizikpi 
andà $n$ one another wo noewo

Anidodi anda You love each other

Tota: ndà

andàkàmè $n$ friend, companion novi

Đodi nu andakame Love each other

\section{ànd’̀}

Pl:nńdò $n$ cat dadi ańdoá oyudo ino á

The cat stole the meat

anì Pro 2nd. Pers. Plu. Subj. mi

\section{ànkó}

Pl:ykó $n$ chicken (domestic fowl)

koklo Ankó olo ta anú Fowl is crowing

ankó òkà $n$ cock comb atotsu

\section{ànkófó}

Pl:nkófó n egg koklozi

\section{ànkósá}

P1:nkósǎn cock koklotsu

ankósálìmè $n$ poultry house kok-

lokpo

antènyì

Pl:ntenyi $n$ earthworm voklui

ànú $n$ mouth nú

ánú $n$ fringes (e)tó Aganyi ole

mengba ánú Fish is on the fringes of the plate

anuáykà $n$ moustache nutafu

anúbámè $n$ end nuwuwu

ányé conj so ekema

ányéménù conj as a result eyata

anyénù det so, particular esia

anyìdágò $n$ civilisation pkuvuvu

anyikléwò
Pl:nnyinkléwò $n$ greedy person

nuklẽla

anyilé adv early kaba, blá

anyinù $n$ face pkume

anyintsé $n$ thanks, used to say one is grateful akpe Anyintse te alá iló ime wa tsú Thanks that you have explained this to us

ànyว̀

Pl:nnỳ̀ n louse yo

Ányò $n$ river in Logba Tota passes through Klikpo and enters the Havor river Ánỳ̀

anyúnyuí

Pl:nnyúnyuí $n$ traditional broom abaya

an(u) oble pron your PLU own

miàto

ạàyà $n$ rib agbafitsime

ạàyàkú

Pl:ayànàkúwò $n$ rib (bone) agbafit-

simefu

aygbloe

$\mathrm{Pl}$ :angbloews $n$ pipe for smoking

tobacco ezi

ạkpá $n$ medicine, juju atike, edzo

Ałkpá á onyó zi The medicine is sweet

ałkpá wàsà

$\mathrm{Pl}$ :ałkpá wàsàwo n jujuman edzoto

ạj̀nyìbì $n$ writing nuplonlo

ayùnyì $n$ quarrel dzre Ablo anunyi

They engaged in a quarrel

àsàngblà 
Pl:nsangbla $n$ tortoise eklò Asangbla otoná blewuu Tortoise walks slowly ashiánú $n$ quantity gbosusu

ásó

Pl:nsó $n$ pot ze

\section{ásóblìgò}

Pl:nsóblìgò $n$ broken pot ezegbãgbã

asว

Pl:nsoé $n$ seive sranuí Abó tsudoe

kpe asoc You will sieve it with a

seive Tota: afie

\section{asórívà}

Pl:nsórívà $n$ instrument for supporting pot on fire zelenu

asósó

Pl:nsósó $n$ instrument for plucking cocoa ati si wogbea kokoe

asótí

Pl:nsótí $n$ small pots ahakpazíwo

asùsú $n$ brain, idea susu

átá

Pl:ntá $n$ hand asi

atahányí $n$ comrade evelia

atàmá

$\mathrm{Pl}$ :atamá $n$ tobacco atama

atamakpékpé $n$ small gourd into

which grounded tobacco is kept

atamagui

atándré

$\mathrm{Pl}$ :atandrewo $n$ pineapple atoto

àtàwólíbí

Pl:àtàwòlìbíwo $n$ star yletivi

atélé ateléwo $n$ ant anyidi Atelé stá ebítsié An ant stung the child ati Pro 1PERS. PLU. we mie Atibò kofews nu We live in villages Tota: atsi

àtó

Pl:atówo n laddle detsifogatsi, detsikugatsi

atró

Pl:ntrówo $n$ breast eno

átró

$\mathrm{Pl}:$ ntró $n$ breast eno

átróanú

Pl:ntróanu $n$ nipple enonu

átruí

Pl:ntruí $n$ hearth emlekpui

atruifietsí $n$ red clay for renovating the hearth ekodzi

àtsá

Pl:ntsá $n$ horn elãdzo Mafini atsá á unánsa afánu I blow the horn in the chief's house

átsá $n$ tiredness dediteamenu

átsá $n$ chaff atsá

átsí $n$ night ză Manu é atsí I saw him /her in the night

atsíablé

$\mathrm{Pl}$ :ntsiable $n$ driver ant zanuvo

átsìnì

Pl:ntsìnì $n$ scythe ebewuhe

atsintsinyó $n$ midnight zãtitina

àtsòlí $n$ saliva etá Mizi te atsú atsolí

ka etsi It is not good to spit (saliva)

on the ground 
atsú pron 1 PERS PLU SUBJ mí

atsú sblé pron our own miáto

atu ntá pron our own miaqokui

Tota: atsu nta

atúkpá $n$ right qusime

átúkpàtà $n$ right (side) dusime Taع

(tie) buyó atúkpata Throw it to the right hand side

atútó $n$ confusion toto, masomaso

àvà

$\mathrm{Pl}: \mathrm{mvà} n$ medicine atike

àvá

Pl:mvá $n$ deer ahloe

áváblòmè

Pl:nváblòmè $n$ hospital atikewəfe,

Đokita, Kodzi

àvàblòwò

Pl:mvablòwò $n$ medical officer, na-

tive doctor gbedala Odu avablowo

ogboán He is a native doctor in the town

avàdzé $n$ water yam avadze

àví $n$ groundnut azí Mane aví ko-

toku okpe I bought a bag of ground-

nut

avù

Pl:mvù $n$ porridge dzogbo

àvúdàgò

Pl:mvúdàgò $n$ leaf angba Kpitsi

avúdago mlam Pluck leaf for me

awówòe $n$ parents amedzilá

àwó

Pl:nwówo n snake dã Jba awó á kpe

syóti He killed the snake with a stick awóete $n$ fangs eda fe adu

\section{awóindrubì}

Pl:awóindrubì $n$ snake's tongue eda fe ade

awù

Pl:nwù $n$ dress awu

\section{awùrívà}

Pl:nwuriva $n$ hook, for dress awu-

kunu

axìxlánù $n$ difficulty xaxame

axlàmàkpá $n$ broad green leaves

used as wrapper amakpa si wozana

bla nu de eme

axoe $n$ native, house afe

Áyádzí $n$ Saturday Memleda

Amowasa odzugbe Áyádzí gbanto á

The Logba priest prayed on the first Saturday

ayè

Pl:ayèwo $n$ mother mama

áyó pron themselves wódokui

ayó sáprádá $n$ galic ayo

ayóntá ayó $v$ expose oneself $q$ de asi

ameqokui pu

ayóébígà $n$ gari gali

ayuebí $n$ cocoa, coffee, cash crop

koko,kofi, agblemenuku si hea ga ve

àzàyì $n$ beans ayí

àzùzò

Pl:nzùzò $n$ housefly tagbatsutsu

àvì

Pl:nvì $n$ axe fiá

avíenyì

aviewò $n$ Ewe Evegbeto 
$\mathrm{B}-\mathrm{b}$

bà $v$ come va

bà v kill, slaughter wù Amutí oba

aklosá okpe ekpe vuvo á tsú My

father killed a he goat in the new year

bá bi be be bo $v F U T-a$

ba anú $v$ come to an end va do nu-

WUWU

\section{bàfúnúbá}

Pl:bàfúnúbáws n pawpaw aqiba

bálá $v$ wind, tie sth round bla

bàmá $v$ fear ṽ̃ ótsobamá ta antenyi

$\mathrm{He} / \mathrm{She}$ fears earthworm

basabasa adv unruly behaviour

basabasa Vui blo basabasa Do not put up unruly behaviour

bàté v like abe

bató n owner of restaurant bató

báyá $n$ person who works in the company that buys cocoa and coffee amesi woa do le dowofe si flea Koko kple Kofi

bè $v$ well-cooked dádá (nyuie)

bé ivà $v$ clear forest fo ave

bé úwá $v$ clear forest fo ave

Benuegba $n$ Tafi name for Logba

Alesi Tafitowo yoa Logbatowoe

Benugba $n$ Avatime and Nyagbo

name for Logba Alesi A vatimetowo

kple Nyagbotowo yoa Logbatowoe

bé

Pl:bewo $n$ puff adder efã

bí $v$ bend bi, bobo bí $v F U T$

bí $v$ pluck gbe atikutsetse le ati dzi

bíbí adj small sue

bíblì adj black yibo

bíná $v$ move through yi to

bìsí

Pl:bìsíwo n cola nut agodo

bító prep up to vasede

blankó

Pl:blankówo $n$ mushroom evlo evlo

blànyé n present time yeyiyi sia

-blé $n$ ordinal suffix to number -lia

blekété $n$ palm mat on which cocoa is dried dabé si dzi wosia koko do blewu $a d v$ slowly blewu Maná blewuu mó I walk slowly there blé n own eto Anú wá áblé How about your own side?

blí v break gba Ebitsi ع oblí tumpá á The child broke the bottle

blí $v$ be black yibo

blò v make; used also to congratulate someone for doing a great thing wo

Esi óblo imoa tsỹ̃̃ Esi did that for a long time

blògò $n$ the act of making something nuWอW

blù $v$ stir blù

bò $v$ stay, be in no

bò íntsé $v$ be very difficult sese, mele boboe $o$ 
bo (o)dzá $v$ be hot (fire) xo dzo Evi

ع obodzá udátsí me The sun is hot

this morning

bòsò ífú $n$ candle bosomikadi

bó v press zí, te de anyi

bófí $v$ throw away dodá

\section{bókìtì}

Pl:bokitiwo $n$ bucket baketi

\section{bذ̀lú}

Pl:bòlúwo $n$ lobster bolu

bote $v$ look like, resemble le abe, dze

abe nane ene Obodzú wesee bate

gali It will turn coarse like gali Tota:

bàté

bù $v$ (be) rotten gblẽ, fafa Pepí obu

koko á Harmattan spoiled the cocoa

bù $v$ give an account wo akonta

bú v ask bia Jbú enzi You have

asked well

bú vask (request) bia Yoo, abú enzi

OK, you ask well

bú v open $v u$ bù $v$ respect bu

bù (koko) $v$ ferment bu

buágò $n$ folded fofo

búbò $v$ bend bobo

bùétsí $v$ fall dze anyi la osá buétsi He/She knocked the man down

búgù $v$ rise $d z e$

búidú $v$ be heavy ekpe Ubí obúidu

The child is heavy

bùsú $n$ abomination busu

búyó $n$ distance adzoge

bùzúgbóǹ $v$ think bu tame

Mábuzúgbónu gu amú ogbá yó I

shall think about my ways

bua $v$ wear eg. hat do (kuku) Psá

obua kuto The man put on a hat

buá $v$ coil, fold xatsa, fo Pbuá afúta

á He folds the cloth

biá $v$ boil, of water fie

$D-d$

dá $v$ open $v u$ Madá uzie I opened the door

dá v tell someone sth. gblo nya na ame Da wa osá omé Tell that man dá $v$ marry de srõ

dà nó $n$ first tefe gbãto Tota: dzà nó dàdá

Pl:dádáwo $n$ sister (elder) dá dèglètsú $n$ thumb degblefetsú Tota: deglevetsu dìlé v call (summon) yo Tota: dzie dò $v$ build tu (Xo) dóqù $v$ pour kj̀ Ómí iku ko fini dóqu He/She blasted the song and the sound poured down dògò $n$ the act of leaving dzodzo, dodo

dónù $v$ shrink mia dònklui $n$ moss adru dóvù $v$ pour out tro nu ako de nu me 
dò $v$ give discount de nu dzi

dò conj in addition to that kpede

eңua

dó adv again, also ga, ake

d’̀ óyó $v$ to help someone kpeqe ame $\eta u$ Ma do Kofi yó I helped Kofi help someone

dò (ógbámá) v follow kplo ame do

Mado ógbámá zó suku I followed him to school

drè $v$ be dirty fodi

druí $v$ be red $d z \varepsilon$

druí $v$ to be ripe $d i$

druyi adj red dze

dzà $v$ be ahead do ngo

dzaa adv only $k o$

dzáá $v$ cut sé

dzálélé expression of pain, grief

vevesese ylidodo

dzányì v collect lo nu, le kpodenu

me, lo ete le agble me

dzata

Pl:dzatawo $n$ lion dzata

dze $v$ look kpo (nu)

dze $v$ start $d z e$

dze $v$ contact dze

dzé $v$ belch fâ

dzé adv ago kpo

dzì $v$ call yo ame

dzì v tie firmly $d z i$

dzí $v$ stand tsó Madzíye xé manú

ivagblawo é afánu I stood up when I

saw the teacher in the house dzì ivà $v$ swear ta nu, yo nu

dzídzé $v$ measure dzidze

dzígù prep from, reference to time tso

dzìkú $n$ annoyance dziku

dzinkle $n$ bowl containing assorted clothes to show the wealth of a clan kesinonu si dea asixoxo fometowo pu These clothes are displayed on special occasions, festivals, funerals.

dzòsú $n$ blood vù Dzosu gblele ódo oyó Much blood has come out from his body

dzótú $v$ forget plo bé Omi ilo á

dzótú He/She forgets the word Tota:

dzòtsu

dzò $v$ be straight $d z$ o

dzoe $v$ vomit $d z$ ó

dzòlèafé $n$ indegene afevi

dzóshí $v$ sneeze nye

dzù $v$ sound $q i$

dzú $v$ return tro

dzú $v$ arrive, happen gbo

dzú $v$ become $z u$

dzùanú $v$ like nyo ame nu

dzúbà $v$ return to speaker trová

dzúdzú v smear sìsì

dzué conj but gake Mayayie dzue

manúnué I searched for it but I did

not see it Tota: dzue

dzùgbè $v$ pray do gbeda

dzúgbè $v$ take and lean tso nane na

zis de nu $\mathrm{pu}$

dzuídé $v$ stand tso Tota: dzuye 
dzúsà $v$ return (away from the dzúzó $v$ return tro

speaker) trodzo

dzútsí $v$ sit down (IMP) no anyi

$Đ-d$

dà v fat, big lolo

dánkídá

Pl:dankidawo $n$ nail gatagbadze

dàsè $n$ thank akpe Đase moma

There is no thanks. (Don't mention it)

deblekú $n$ fog afù

\section{dèblekú}

Pl:dèblekúwo $n$ cloud alîlikpo Đe-

bleku ógle idien Cloud has covered the sky

detsiflu $n$ cotton detsifu Tota:

detsifu

di $v$ suck nyí

dí v eat; suck qu; nyi

do adv again ake

dódí v love 1̃ Odợí oga intá He

loves his wife very much d’̀kà $v$ reserve something dzra nane do

dù $v$ extinguish tsi

dù $v$ be heavy kpè

đú v leak

dú $v$ be (is) enye Iyé ídu Dkpaya

ikago kélékélé It is the first law of

God

dù ivà $v$ sow (seeds in a hole) plant

fa nu dó Dsá oqú aví gblele The man planted plenty of groundnuts

dúkpá v be good nyo Nya uzungba

dukpa lead a good life

dúkpátsì $v$ good enyo

dúkùbí $n$ handkerchief takuvi

dutsa $\mathrm{okp} \varepsilon$ n eleven wuideke

$\mathrm{E}-\mathrm{e}$

ebí $n$ beans of cocoa koko

ebiábè $n$ past time etsã

ebíasiá adv always jesiayi

ébínyígò

$\mathrm{Pl}$ :ebinyigows $n$ fruit atikutsetse

èbítí

Pl: ebító $n$ child qevi

èblètà $n$ left miame

edítàfâ $n$ place where dirges are sung tefe si wo dzia konyifaha le edí $n$ na edi working in the farm in turns in groups of three or four. efidodo èfêshì

Pl:nfêshìwò $n$ sheeàlẽ efietsìfò $n$ piece of cracked calabash etrekake Udze ókplo gali kpe efieyitsifo The woman fried gali with cracked calabash

èfiéyí 
Pl:nfiéyí $n$ calabash etré Efieyie alé ndú tsú The calabash is on the water égbè $n$ stone ekpe Dtá egbe aklo á yó He/She threw stone at the goat égbè vùtí $v$ cave agado Otenyi $\mathrm{f} \varepsilon$ egbe vutsí nu He ran into a cave egbètàtsì $n$ pebble kpekui

èkè $n$ root eke Tota: syóloli

\section{èkèlé}

Pl:ekèléwò $n$ grass egbe

\section{èkèléǹ}

Pl:nkèlén $n$ bush, outside egbeme, gota used in the Alakpeti dialect to mean outside.

ékpé $n$ harmattan pepi

ékpébè $n$ dry season dzomejolĩ

ékplé $a d v$ now azo

ékúanú $n$ joints (in the human body)

kpefekpefewo

endengle $n$ incomplete nusi mede $o$ endeńglé $n$ naked amama

entsì $n$ porridge made for babies

akplẽ si woda na deviwó

énzí adv well nyuie

\section{èngblé}

Pl:èngbléwo $n$ snail abj̀b̀̀ Manú engblé vutsi nu I saw snail in a hole étè

étèwo $n$ tooth aqú

étèkùshì $n$ gum enyè étí

Pl:étíwo $n$ earth (soil) anyigba $\underline{\text { Ando }}$ á ótsi ukplo á eti The cat sits under the table Tota: etsĩ etíkótsoé $n$ ground anyigba Afúta á akpó etíkótsoé The cloth is on the ground

étsí $n$ under, down ete

Etsiagù $n$ North Dziehe

etsíbàn $n$ under of a thing nane te étsieonkpá

Pl:etsieonkpawo $n$ snake edã

Etsíetsí $n$ South Anyihe

etsífíní $n$ snake that has two heads

eda si eta eve le esi

étsíné $n$ way, process alesi

étsíntsié $n$ middle, environment

dome, nutome

étsítómé $n$ begining gomedzedze

etsivíní

Pl:etsivíníwo $n$ snake edã

èví $n$ fever pudza

èví $n$ sun ye Eví óbo odzá idze The sun is hot today

èviángbá $n$ noon ndo Mbázó ubonu eviángbá I shall go to farm at noon

Evibúmè $n$ East Yedzefe

Eviègbefémè $n$ West Yetodofe 


\section{$\varepsilon-\varepsilon$}

$\varepsilon$ DET the la, -a

غ̀ Pro 3rd. Pers. Plu. Subj. wó

ع́ Pro 3rd Pers. Sg. Obj. -e, -i

$\varepsilon$ f̃̃ $n$ Fon language Efŏgbe

\section{Ékpé}

Pl:ykpé $n$ year efe $\underline{\varepsilon}$ kpé vuvo tá wú

New year to you ékpé

$F-f$

fãã $a d v$ freely fãã

fálí $v$ make noise, bleating of a goat wó, do yli Agbi $\varepsilon$ ofali The dog barks

fálífe $v$ charm $q u d z o$ ame

fámvè $v$ step over sth. dá ata nu

fáshí $v$ tear vuvu Afúta ofashi The cloth is torn

fêkè $v$ to have hicups dzidze na tso

ame

fésré

Pl:fésréwo $n$ window fesre

fézí $v$ shout do yli Ivá blogo té mafé

uzí The act has made me to shout

fe prep put in $q$ e...

f́̃ $v$ wear eg. dress do (awu) Ina ófє

ishikpe The person wears a ring

f'́ adv also hã

fé ánú v greet do gbe Mazó té nfé

anú I go that I greet him

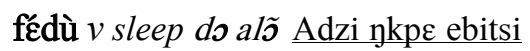

é jfedu One day the child slept Tota:

fedzu

f́vù̀ $v$ frighten do vovodzi na ame

fia $v$ hurt ve ame fídà $v$ meet, assist carry a load do go, kpe ame kple efe agba fídágò $n$ confluence tefe si tosiwo dogo le fié $v$ dehusk corn nyo ebli fi $\varepsilon v$ smear pomade on body si ami fì̀ $v$ dehusk corn kle ebli fiè $v$ drink soup kplo detsi fíc $v$ exceed wú fífi $v$ break $\eta$ e (ati) Udzigbo maáfifi A bunch of broom does not break fíní fifindù $v$ whistle lia akui fiòfió

Pl:fiofiowo $n$ broom atsixali

flé $v$ fly dzò Adzi óflé fé oyóanu A bird flies into the tree flì $v$ cut sth. in parts se nane flí $v$ be white le yie Idienu petée iflí All the sky is white flíyì adj white yi fló $v$ play ball fo bol fló $v$ reach the required number de, flo

flófló adj light hodzoe

fô $v$ reach dó 
fõ

Pl:fǒwo $n$ brother (elder) fŏ

fô (ivà) $v$ wash (thing), clean nyà nú,

klo つzź té ófó iva odzún He/She has gone to wash in the river

fónyí $v$ breaking cocoa pods to remove beans gbã koko aqe ku le eme fónyí v peel, remove cocoa pod for the beans de tsro le nu pu ófonyi koko é. ófonyi kodiatsya He breaks the cocoa. He peels the banana fótètè $n$ green edible leaves ama si wo dana duna

fû̀ flower fo se fûfô j̀lólá $v$ blow (of wind) gbo ya

fúfú $v$ smash gba nu le to me

fûfuí $n$ fufu fufu

fuí $v$ to lose way, direction, get lost bu mo lose way, direction; get lost fúní $v$ eat in bits du nu vivivi fútó $v$ mix blu

fûtsù $n$ old farm futsu, agble хохо Tota: fùtù

fútsú $n$ soup detsi

\section{fútsúsàtó}

$\mathrm{Pl}$ :fútsúsàtówo $n$ laddle detsikugatsi

$\mathrm{G}-\mathrm{g}$

ga adv also hã

gà (ivà) $v$ count xlẽ Suku ebítwo á

eléga iva The school children are reading

gà (ugú) v pay xe fe Ga (u)gu tá

ebítsi é Pay the child

gadamè $n$ place where cocoa is weighed afisi wodaa koko le na gákráná keep quiet zi dodoe Ebítwo o égákráná kpoo The children kept quiet

gàli $n$ gari gali

galikplòálé $n$ earthen bowl for frying gari galitogba Galikplòálie ablí The earthen bowl for frying gali is broken gàmágbá $v$ trouble someone defu na ame gànú $v$ greet (salute) in the morning do gbe na ame Ngaanu loo I salute/greet you gànú(bî) pl:gànú(bí)wo $n$ tin ganu(vi) gàykú $n$ pair of spectacles gankui gàsó $n$ bicycle gasó gàté $n$ mill gate gàzé Pl:gazewo $n$ metal pot gaze gàzérívà

Pl:gàzérívàwo $n$ metal for supporting metal pot on fire gazeleyu gbà $v$ sweep kplo tefe Udzi ع́ ogbá afánu The woman swept the house gbà v lead kplo ame yi tefe ade ogba gbadza ogbá nú zó Ugé The broad way takes you to Accra 
gbã $n$ first gbã Pmó ole gbãto anu nu Who had the first position among you? gbãto

gbá (afútà) v put on (cloth) ta (avo)

gbàgblaà $a d v$ flat gbadzaa

gbálí adj bad gbegble Iva gbali

petée tá ízo ime loo All the bad

things should leave here

gbàntó $n$ first gbãto

gbángbáy adv fast sesie

gbè $v$ evaporate nò nqú é petée nggbé All the water evaporated

gbèdzègbèdzè $n$ red ants; live in

fruit trees. gbedze Gbèdzègbèdzè ole

oyś á nu Red ants are in the tree

gbéngeé adj broad, especially of

leaves gbadzaa

gbe v lean zio de nu pu Magbé

agbógbló agli é yó I lean the ladder on the wall

gbégbánfó $n$ bread yevubolo Mane

gbégbánfó I bought bread Tota:

gbegbafo

gbéñgbé $n$ praying mantis

gbi adj many sugbo Nkpakplawo gbi

ndó Many frogs came out

gbígbè $v$ crawl tá Ebítsie óló gbígbè

The child is crawling

gblà $v$ teach fia

gblele adj many gede Ina gblele adanu izi fie ina skpe Advice from many people is better than advice from one person

gbó $v$ fall $m u$ gbógbè $v$ sth. fall and lying down mu de anyi

gbòkà $n$ line, forming a line le fli me gbòkà $n$ line efli

gbómá $n$ green edible leaves gboma

gbǒntá $v$ touch (with hand) de asi

nane $\eta u$

gbókj̀kò $n$ goitre avo

gbòmògbòmò $a d v$ ill-treat a child fia fu devi

gedee det many gedee

glà $v$ pour ko tsi le nane me Gla nfú

é f'́ abodiabo nu Pour the palm oil into the bottle

glà $v$ exchange doli Atu ifiami igla

Our cutlasses exchanged

glànykpe $n$ seven adre Tam egbe

glangkpe Give me seven stones

glé $v$ become sticky, liquid turning to solid as a result of boiling etò he blá glé v tie (rope) sa (eka) Udzi ع́ ogle belet The girl 'ties' belt glé (imunyi) v plait (hair) fo (da) Udze ológlé imunyi The woman is plaiting hair glui $v$ uproot, dig ho Ma glui idzo's I uprooted the yam.

-go $n$ nominalising suffix the act of this suffix collocates with action verbs (nu)Wow

gògògó adj diferent vovovo

gò $v$ grind tu Mago tonka egbe tsú I grind pepper on the stone gòk̀̀áqu $n$ nine asiek $\varepsilon$ 
gonií adv sticky le de nu pu

gongó adv expression used to tease a person that what happens fits him gón gù $v$ fight wo ava, wo dzre

gù prep from tso

gù $v$ pour kj̀

gù ímà v fight da kó Ebítwo elegú

íma The children are fighting

gù otá $v$ make war, wage war wo ava

Akpanawoé egu otá nkpe gedee The

Logba people fought for many years gù (iyó) $v$ wash (body) le tsi ’mo

ologu wu iyó é? Who is going to

bathe you? gùdù $v$ nurse a seed wu núkú

gùdzù $v$ nurse seeds eg. tomatoes, pepper, garden egg wu nukuviwo abe tomatos, atadi, agbitsa gùmè $n$ origin, source dzotsofe gunè $n$ sister novinyonu guokpò $v$ fight, esp. fist to fist, exchange of blows. wo avu Seli oguokpo kpé Kafui Seli fought with Kafui Tota: guima, takpo, gusà $n$ brother novinutsu

$\mathrm{H}-\mathrm{h}$

hàdzàhlà adj rough flatsa

haibrid $n$ hybrid especially of Tetteh

Quashie and Amazonia haibrid Hai-

brid iqu koko xé otso nyi intá Hai-

brid is cocoa which bears fruits well

hàliwá $n$ clove haliwoe

hàntàhìnì $n$ tiny red ants anyidi $d z \tilde{I}$ sue (wo)

hè DET here yi, si Kofí he here is

Kofi

hè $v$ pull he He abia bá ite Pull the chair forward

hòdう̀ $v$ stir (palm oil) blu nane me

Abóhodoa tsỹ̃̃̃ abe ebédzi You will be stirring for long; oil will come up

$\mathrm{I}-\mathrm{i}$

ibè $n$ season yeyiyi, (yi)

ibèbibiع $n$ minor season kele ibètsú $n$ time, period yemayi, gamame hù tényí $v$ run for safety sisi Ohu tenyi ogbá yó He/She run to the road side

húhò v bathe lazily hũhõ

húhú $v$ wave hands vuvu asi

húhú ágbàsì $v$ wave (hands) vuvu asi

Ahúhú ngbashi yika ebítwo á They waved hands to the children

húhúví $v$ escape si

hùíté $v$ run fu $d u$ Mahuité zó afánu I run to the house

ibènángò $n$ major season adà 
ibè n time game Ibè imóa atu vla

aboti? When do we bury the corpse?

ibé how much, how many nenie Ovi

abć? Utsa á abé? How much? How many houses?

íbí $n$ faeces emi

ibíkpà n palm-husk deklêkpotso

ibísà $n$ palm-chaff edel̃

ibòté conj because elabena

idágò $n$ marriage srodede

idzè adv today, till today egba

Mbázo suku idze I shall go to school today

ìdzì $n$ beard gè Kofi ógbá idzi Kofi shaved beard

idzòwà $n$ riches kesinonu

ídzó

Pl:idzó n yam ete Mokpenu idzó He does not eat yam

idzófó

idzófó $n$ yam slice eteks Idzófó iny

ele mengba á nu Two slices of yam

are in the bowl

idzońkpá

Pl:idzónkpa $n$ yam tendril eteka

idzóyว̀

Pl:idzóỳ̀ n yam-pole etetsí

idzózúgbó $n$ seed yam etetá

idá $n$ money, metal gá

idá ógó n corn mill gate

idábí n small measuring tin nudzidze

ganuvi

idácbi

Pl:idácbiwo $n$ nail gatagbadze ídákpà $n$ gun etu

idàsó $n$ metal pot gaze

idásórívà

Pl:idásórívàwò $n$ metal for supporting a pot on fire ezelegá

idàtó

Pl:idàtó $n$ metal spoon gatsi Idato

ótsoga memgba á nu The spoon lies across the bowl

idáwá $n$ madness aqava

idáwàsà $n$ rich man egato

ídí $n$ atmosphere xexeame

ídí $n$ day pu(keke)

ídí imú darkness xexeame tsyo

ídí íwá day break pu ke

ídíenù $n$ world, weather xexeame

ídicidzèmú $n$ dusk asifomebuyi

ídísàbè $n$ dawn fọlui Mbázó ovafo

idísabe I will go to him at dawn

ídíwágò $n$ day nkeke

idù $n$ gunpowder equ

ífé $v$ be...stain wo qe enu

ifédzolego $n$ examination dodokpo ífiámì

Pl:ífiámì $n$ cutlass eyi klante Pbóló ubo é nu kpe ifiami He will weed the farm with cutlass

ifié $n$ fart ฤo (si wo nye na)

ifióní $n$ end nuwuwu

ífú $n$ fat ami

ifùgò $n$ flower sefofo

ifûtó $n$ hostility, behaving badly

dzrewəwo 
igàgò $n$ number xexleme

igàmoga $n$ million million

igàngò $n$ last mamleto

igbè $n$ arrow edà

ígbè $n$ spear akplo Ígbe iwó abuع

Spear has pierced the animal

igbìsò $n$ plant that causes the body to itch awlo; egbe si fia yuti na ame

igbònyì $n$ snoring afanono

igbòtà $n$ different towns in the same

traditional area duta vovovo le du

me

ìglà $n$ jaw glã

igló $n$ six adé Pkpe abolo ifó igló

He has eaten about six loaves of bread

ihánágò $n$ indiscipline ehadede

ihègòdú $n$ convulsion dogladza

iká $n$ charcoal aka Iká mewlin

odzán Charcoal is insufficient in the

fire

ikádzà $n$ black berries atitoe

ikágò $n$ plan, law ese, dodo Adódí

iqu ikago kelekele Love is the first law

ikintànyì $n$ daughter stone for grind-

ing nutukpe sue

ikpá $n$ truth nyatefe

ìkpà $n$ skin rashes krusakrusá

ikpádágó n justice dzodzoenyenye

ikpálígo $n$ act of collecting unburnt

sticks in the farm ati siwo mebi o fofo

le agble me
Ikpána Logba language Logbagbe

Efon ibi vé fé ikpana nu. Efวn mixed with the Logba language

ikpèté $n$ the sediments after the kernel oil making nefimiba

ikpètèivá $n$ watery stool kpetá

ikpè $n$ one deka

ikpèshìkpè $a d v$ everything desiade

Ikpeshikpe izi Everything is good

ikpóskpómé adv exactly tututu

1́kpólì

Pl:ikpoliwo $n$ toe afobide Ikpoli ikpe ida fié ikpe One toe is bigger than the other

ikú

Pl:ikú $n$ song ha Ko, ivanukpiwo é

ónu iku é Suddenly, the hnter heard the song

ilàlí $n$ scent of something veve

ilíkloà $v$ smell vé

ililívá $n$ grater nuliliga

iló

Pl:iló $n$ word enya Inqubi itifé ina ilo

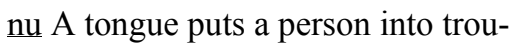
ble

ilówáme $n$ place where cases are

settled nyadrofe

ìlùbù $n$ small pots for palm wine

tapping ahakpazi

ìmà $n$ rubber ane

ímbí $n$ rice molu Seli ozá imbi Seli

cooked rice

imó n laughter nukoko

ímó $n$ neck ko Joe ofifi imó Joe

broke his neck 
ímóámá conj after that emegbe ímoánú $n$ chieftaincy fiaqudu

imómà $n$ back of the neck eko megbe imónìvà

Pl:imonivawo $n$ necklace komènu

imúnyí $n$ hair eqa

imúnyíblòwò $n$ hairdresser dawola imúnyífùgò $n$ grey hair wò

iná $n$ four ene Jga iva iná He has counted four

ìnà

Pl:ahá $n$ person ame Ina gblele abo afánu Many people are in the house íná $n$ walk azoli

ìnà j̀kpè $n$ somebody ame aqe inàdzengò $n$ person, human being amegbeto

ìnàdź

Pl:edzé $n$ woman nyonu inánágo $n$ the act of walking zozo inàshínà $n$ everybody amesiame inàvlámè $n$ cemetery amedibome iǹdzíbà

Pl:ìdzíbàwo $n$ bead dzonu Awó

moófe indzíba A snake does not wear beads

indzódú $a d v$ may be dewohi indáblogò $n$ friendship noviwowo ìndù $n$ tears adatsì ínqú $a d v$ may be dewohi ìnqùbí $n$ tongue aqé Awo óbo inqubi nny $\mathrm{A}$ snake has two tongues Alakpeti: indrubi infièyìgbàmè $n$ sandpit ekeveme infièyì

Pl:mfièyì $n$ sand eke Infieyi iqu bate gali Sand is like gali

infío

Pl:infíowo $n$ worm ęó

ínindzí $n$ lie alakpa Adzo okpe inindzí ga intá Adzo knows how to tell lies

inindzígawò $n$ dishonest person alakpato

ìnó $n$ meat lã Ino á ílíkloa The meat smells

inòsá

inàsá $n$ man (Generic) putsu Inosá

odu uzugbo ta afá á Man is the head of the house

insótsá

Pl:nsotsawo $n$ local thatch house ebexo

intá adv greatly vevie Xe ónú é la óvã inta When he/she saw it he/she was so afraid ìntsé $n$ strength sesẽ Psá obo intsé The man is strong ínú $n$ five at̃ invlá $n$ palm branch edevaya ìnỳ̀ $n$ two eve inyuí $n$ juju edzò ísá $n$ penis ava isàmè $n$ happiness dzidzo isàmè-ìfé $v$ be happy kpo dzidzo ìsàmèyúgò $n$ the experience of happiness dzidzokpokpo 
isàngò $n$ green edible leaf ama si wo dana quna

ishikpé fé itibí $n$ finger for wearing ring asibide si wodea asige do Tota:

itsibi

isíkpé

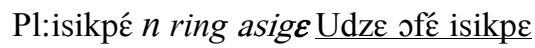
The woman puts on a ring

isíníbá $n$ wasp vava

ísò $n$ faeces emi Kodzo olokpi isó

Kodzo is easing himself

isóbó $n$ calf sobo

isúsó $n$ thatch ebè

ità $n$ three et̃̃

ité $n$ escape si $d z o$

ité $n$ front $\eta g o$ Dze ite Look in front

ití $n$ soil eké Tota: itsi

ìtìbí

Pl:ìtìbí $n$ finger asibide Tota: itsìbí itìbiànú

itìbiànúwo $n$ finger tip asibidenu

Tota: itsìbiànú

itítè $v$ stand erect $d z \mathbf{0}$

itsè $n$ cheek atse, alogo

ìtsé Postp beside exa

itsíbà $n$ vegetable amagbe,

detsifonuwo

itsítsìgo $n$ changes, innovations

totrowo

itutolì

$\mathrm{Pl}$ :itutolìwo $n$ sore, wound in the toenail afofetsu

ivà
$\mathrm{Pl}$ :ivàwo $n$ thing $n u$

ivà det different things vòvòvòwo

ivàdaivà $n$ scale nudánú

ivàdzèwò

Pl:ivàdzèwòwò $n$ onlooker nukpola

ìvafégò $n$ clothes nudodo

ivàflégo $n$ insect nudzodzui

ivàfó $n$ slice (yam, cassava,potato)

nuko

ivàfúivà $n$ soap, locally made

ameyibodzale

ivàgbálí $n$ sin, bad deeds nuṽ

ivàgbálí $n$ whitlow nuvo

ivàgblàwò

Pl:ivàgblàwòwo $n$ teacher nufialá

Ivàgblàwo odu onie xe otogbla iva

Teacher is a person who teaches ogblawò

ivàgòegbè $n$ grinding stone nutukpe

Dgo tonka ivagıegbe tsú He/She

grinds pepper on a grinding stone

ivàkpè $n$ knowledge nunya

Agbigloms olé wá ko ivakpe inya Ananse would be the only one who will have knowledge.

ivàkpegò $n$ food nuqudu Ina momí

ivakpego mí bofi We do not throw

edible food away

ivàméivà

Pl:ivaméivawo $n$ needle abi Ivameíva iwóm The needle pricked me.

ivàmèwò $n$ seamstress nutola

ivàntsienù $n$ these places, areas

nutowo me Akpana édo gu Egypt 
kpe Sudan ivantsienu The Logbas migrated from Egypt and Sudan areas ivànù $n$ bush egbeme

\section{ivànùvò}

Pl:ivànùvo $n$ hunter adelã Ivanukpiwoé sbá agú The hunter killed antelope Tota: əvanuvò, ivanukpiwo ivànyágò

$\mathrm{Pl}$ :ivànyágòwo $n$ possession nunoamesí

ivànyìnù $n$ experience nutefekpokpo ivàyònyì oyòtsì

$\mathrm{Pl}$ :ivayonyi oystsiwo $n$ pen; thing for writing nuplotsí Ivànònyì oyòtsì ofifi The pencil/pen is broken ivatagò

Pl:ivatagòwo $n$ picture nonometata, nutata Pmó ivatago idú ime? Whose picture is this?

ivàtàgò

Pl:ivàtàgòwo $n$ gift nunana ivàtúglí ivà

Pl:ivàtúglíivàwo $n$ belt, waist tying cord. alidziblanú Maglé iva kpe ivàtúglí ivà I have tied my waist with waist tying cord Tota: ivatsugli iva ivàtúnáivà

$\mathrm{Pl}$ :ivàtúnáivà $n$ pressing iron ayon ivàvévé $n$ important thing nu vevie ivàviágò $n$ nursery tefe si wovia nukuwo do ivàviálívà

$\mathrm{Pl}$ :ivàviàlivàwo $n$ thing for fun; pet fefenu ivàvùmàgo $n$ boil nutete ivazásó

Pl:ivazásówo $n$ cooking pot nuqaze Ebítsie obli ivazásó The child broke the cooking pot ivàzàtó

Pl:ivàzàtó $n$ wooden laddle etsi ivàzòtsá $n$ store fiase ivàzòwò $n$ trader asitsala ivèbí

Pl:ivebiwo n seed nuku ivì $n$ dirt edi ivìná pron something nane ivó $n$ foam futukpo ivó $n$ kind of green leaves ademe ivógò $n$ fear vovo ívù $n$ intestines dokavi ivúmá v swell (intr.) of boil ete Ivì $n$ Ewe language Evegbe iwàn $n$ toilet afodzi iwánùwò $n$ dwarf aziza iwò $n$ bee wax anyījo iwondu $n$ honey anyitsí íwòtsò $n$ sting of bees nusi anyi tso tea ame íwó $n$ cold vuvo iyánù $n$ atmosphere yame iyć 3SG. Independent eya iyó $n$ dance ge iyó $n$ body puti iyódògò $n$ help kpekpeqeyu iyógbè $n$ sadness (nu) blanui Amú iló á iqu iyógbe My case is a sad case 
iyógù ofá $n$ bath house tsilekpó

iyógùasó $n$ pot buried in the bath-

house for bathing kolò

iyógùmè

Pl:iyógùmèwo $n$ bathhouse tsilefe

Iyógume idre inta The bathhouse is very dirty

iyókú ivà $n$ other things nu bubuwo

iyókúinà $n$ kinsman fometo

iyókuínó $n$ skin putigbalẽ

iyónágo $v$ reply donyayu iyóyú $n$ peace putifafa Anukpa afє

iyóyú atsí Chiefs made peace among them

iyókplè Pro that is eyatae Onu

udziku iyokple moózón He/She was angry that is why he did not go

iyólólì $n$ roots eke

iyú

Pl:iyúwo $n$ thorn eju Iyú iwəe ak-

petsi uboén Thorn pierced his foot in the farm

ivì $n$ Ewe language Evegbe

K - k

kà v put da nane $d i$

kà $v$ set trap tre mò

kà $v$ instal do (fia)

kà ányí $v$ identify de dzesi

kà eví v dry sia nu Ma ká koko eví

I dried cocoa

kàdù iyé tsú $v$ be certain ka de edzi

káké $v$ take part from ka nane le eju

kámè $n$ place where something is

placed tefe si nane nona

kàmpé n scissors saksi

kániófònyì

Pl:kaniofônyìwo $n$ chimney tsimini

kanyi $v$ realise dzesi

kànyí $n$ light akadi

kányì v oversmoked nusi fiã

kàsàní

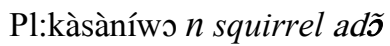

kàwúyoányí $n$ self realisation

amedokuikpokpodzesi kè $v$ open $v u$

ké v jump dzo kpo

kèkè $v$ spread keke

kèlékèlé $n$ first gbãto

kétéké $n$ train keteke

kinké

kinkéwo $n$ bicycle gasó

kisa $v$ be long legbe

kísáyì adj long (of stick) legbe ㅁgbá

kisayi moové ubome yo A long road does not pass by a town

klá v paste kla Jklá pepa na aglie

yó He pasted paper on the wall

klà $v$ hide bè Jklá fe oyó á nu He

hid in the tree

klántsì

Pl:klàntsìwo $n$ rubbish heap

aqukpodzi

klànù $v$ hide, stay secretly no anyi

kpo, bè

klé $v$ split fé 
klé $v$ shine kle

klé $v$ light klẽ

klóá $v$ insult dzù ame

klòyì adj small (person) sueto

Ebitwó kloyi ko atsidu We are only small children

klwá $v$ stink veve

ko adj only kò Agu ntsaa dzaa ko ye ndó The antelope's horn only came out

kòkò àkpǒ $n$ cocoa sack koko kotoku

kòkòafótsí $n$ empty cocoa pod kokogui fuflu

kòkòakpòfégò $n$ putting cocoa beans in a sack kokodedekotoku kokobídá $n$ instrument for plucking cocoa kokogbetsi alo kokogbegá kòkòdàmè $n$ cocoa buying centre kokodafe

kòkòevíkágò $n$ drying of cocoa koko siasia

kókólágò $n$ preparation of a local porridge kókófófó

koy adv real kon

\section{kòtòkú}

Pl:kòtòkúwo $n$ sack kotoku

\section{kotomble}

Pl:kotomble $n$ cocoyam leaf

kotomble Tota: kotombre

kótsóe adj bare fuflu

k̀̀ $v$ wring (clothes) fia (awu)

kذ̀ $v$ be hang le enu kodiátsya $n$ banana akodu Kodiatsia

ibe aloyayie? How many bananas do you want?

kodiátsya fotsí

Pl:kodiátsya fotsíwo $n$ banana peel akodutsro

kófé

Pl:kóféwo $n$ village kəfe

kólí ókó v cough kpé ekpe

kóm $v$ pray do gbeda

kòyklı̀ adj old, something used for a long time nusi tsi, do хохо Mami ifiami konklo fonyi kokoe I used old cutlass to break the cocoa for the beans

kòykó

Pl:kəokówo $n$ drinking glass kołko Jnó akpeteshi konkó inyó He/She drank two glasses of akpeteshi kəsidá $n$ week kwasida kótsú $n$ hospital kodzi kowlá

Pl:kowláwo $n$ necklace kogá kpágò $n$ torn vúvú kpákpá

Pl:kpákpáwo $n$ duck kpakpaxe kpákpátsá adj flat gbadzaa kpálí $v$ collect, cuttings on a farm lo hlo le agbleme kpálí $v$ flow (of a river) síOdzú moókpali milé ukpó A river does not flow climbing a hill kpáne adv now fifilaa 
kpánintá $a d v$ now fifia Tota:

kpáintá

kpántráìtsì $n$ wire used as a trap for animals gale ade si wotrea mo na lãwo.

kpányígbè $n$ sheen akpaligbe

kpàtà $a d v$ suddenly kpata

kpè $v$ know nya Inashina okpe

onkpe Everybody knows something kpè $v$ peel yam, remove outer cover kpa ete okpé idzoo $\mathrm{He} / \mathrm{She}$ peels the yam

kpè $v$ tap (palm tree) kpa ede

kpè óyó $v$ carve kpa ati

kpehelé $n$ green edible leaf ama si wodana quna

kpètèshì $n$ strong local gin akpeteshi

kpetse $v$ throw up and down da (nane) de dzi woava anyi

kpe conj and kple

kpè ivà v eat qu nu Yoo ba té atsí kpe iva Yes, come that we eat

kpé lé v bite ka kple aqu

kpi $v$ go yi

kpí v go (completive) dè

kpiagù adj tall koko

kpíní v become lean zu sue

kpintá $a d v$ really vãvãtoa

kpítá $v$ stumble kli afo

kpítsí $v$ remove something, harvest

eg. pepper de nane da

kpíwán $v$ defecate de afodzi kplà $v$ reduce canopy of a tree $k \mathrm{o}$ ati

ju

kplò $v$ fry to

kplògò $n$ fried totse

kplòtúafutà

Pl:kplòtúmfutá $n$ tablecloth kplodzivo kpòetí $v$ lie down mlo anyi

kpófú $v$ bark wó

kpòkù

Pl:kpòkùwo $n$ knee eklo

kpókúamátsí $n$ fine, in the form of a fowl. koklo si wo nana abe fedodo na ame ene

kpóntì adj short (of stick) kpui

kpóó adv quietly kpoo

kpóyì adj all katã

kpò $v$ lie mlo anyi de tefe aqde

kpò ínyuí $v$ sleep $d o$ al̃

kpómé $n$ place where something is

placed tefe si nane nona

kpómí $v$ remove leaves from a tree

flo ati

kráná adv quiet klenee

kù $v$ die kú

kufetù

Pl:kufetùwo $n$ envelope agbalẽ

kotoku

kúkò v go round tsa godoo Álana

kuko tson They are walking round for a long time

kúkúdzádí $n$ kitchen dzodofí

kúmá $v$ catch something thrown lé nane si woda 
kùndà $v$ be drunk ku aha

kúnkúmà $n$ elbow abokugluinu

kùsèkùsèkùsè $n$ peace, tranquility kùtó

Pl:kùtówo $n$ hat (cap) kuku

kútsí $v$ collect lo Tota: kuti

kusekusekuse used in libation prayer

when asking for peace

L - 1

là $v$ beat (person) fo ame Jgblawo $\mathrm{e}$

olà ebitsi $\hat{\varepsilon}$ The teacher beat the child

là $v$ remove de nane $d a$

lá v make, prepare sth. wo, de (mo)

lá clause final marker lá

là (afuta) $v$ take off (clothes) de avo

là (ndu) $v$ swim fu tsi

là (úkú) v beat (drum) fo vu Mbálá

úkú tę I shall beat drum for him

labídonyui $n$ outdooring viheheqego

le $v$ be.located le

lè $v$ germinate mie

lè $v$ climb lia Olé oyóa He/She

climbed the tree

légbá $n$ idol légba

lèntá $v$ fall from a high position dze

anyi

lè v buy fle Málè abolo ta amu bi I

shall buy abolo for my child Tota: n⿺̀

lí $v$ hold le nu de asi Tota:ri

lí adv again gà

lì̀ $v$ be hard sesẽ

lìlì $v$ grate lìlì

-ló v PRES. PROG. ASP suffix le -m

ló $v$ bitter vé

lò imunyi $v$ weave, plait hair fo da

lò (afuta) $v$ weave (cloth) lõ avo Oló

afúta enzi He/She weaves cloth well

loglo $n$ sideburns tomefu

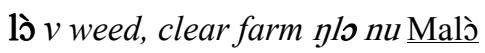

obućnu I weed the farm

$\mathrm{M}-\mathrm{m}$

ma Pro Ist. Pers.Subj. me

màkàni $n$ cocoyam makani

Màmblìwó $n$ Wednesday Kuqda

mángò $n$ another bubu

màngòví $n$ small kitchen stool

dzodofi zikpuivi

mangò

Pl:mangว̀wo $n$ mango mango

mànkànìodò $n$ cocoyam leaves

kotomble; mankani ngba

máwoe $n$ dough amó

mbówàsà $n$ person who has insatia-

ble desire for sweets vemevivito

mè $a d v$ here afisia

mèkoè $n$ this place afisia

mèngbá

Pl:mèngbáwo $n$ bowl agba 


\section{mèngbàkpákpátsá}

$\mathrm{Pl}$ :mèngbàkpákpátsáwo $n$ tray traye

$\mathrm{m} \varepsilon$ det this sia

mé v sew to nu Pmé afútakpagoe $\mathrm{He}$ sews the torn cloth

mé v swallow mi

mé adv what nuka, aleke

mé mé adv to show intensity of sth.

te gbe de nusi wo gblo dzi

mènù $a d v$ where afika Menu alozó

Where are you going?

mgbíní $n$ okro fetri

mì v use, take zá, tso Pmí ikpe iva

inys á nu He chooses one among the two things

mìkpè v choose tiã

mìkú $v$ annoy do dziku

míní v lick qudó

miomis adv cold miomis

mlà $v$ bring tso nu ve mlá $v$ crowded especially in a farm

mimi vevieto le agbleme

mlámìná $n$ eight enyi

mlámlámlá adv kabakaba

mlànkpámá v escape si, dzó

mmo adv there afima

mmuá $n$ flour ewo

mo adv not me...o

mókoé $a d v$ there afima

mó det that má

mó v laugh ko nu Dmó inaa He/She laughs at the person

mókplè $a d v$ why nukatá

mú Pro 1st Pers. Sg. Obj. -m

mú $v$ be dark tsyo

mùmú $v$ complete (e)de, le blibó

múní onkpá $v$ tie rope bla eka

múnímúní adv talking undertone

nufofo de gbeme

$\mathrm{N}-\mathrm{n}$

nà $v$ walk zo (azolĩ) Asangbla ona

blewuu. Awa ana loo Tortoise walks slowly. You are wellcome

ná prep on da nane de

naá question word ma hã

nàgó $v$ different to vovo

nántróblíkpó $n$ anthill in the form of

an umbrella babakó si le abe xexi

ene.

nányí v remember do $\eta k u$ nane $d z i$ nàngò adj big, great, large gã, lolo Dyo nango oye utsaa yó A big tree is at the side of the building ndà $n$ liquor ahà Psaa odzi ndà The man is drunk

ndágùálé

Pl:ndágualewo $n$ claybowl for storing drinks ahakugba

ndágùásó

$\mathrm{Pl}$ :ndágùasó $n$ pot for storing drinks ahakuze

ndàzámè $n$ distillery ahadafe

nqú $n$ water etsi Nqú ntsi asoa nu

Water is in the pot

ndúbiagò $n$ boiling water etsi fiefie

nqúdzá $n$ hot water tsidzodzoe 
ndúdzáodzá $n$ very hot water tsi

dzodzoe heliheli

nqúgò $n$ thirst tsikowuame Nqúgo

nqu nyam I am thirsty

ndúkpálígo $n$ river, stream etosisi

\section{nqúnó ivà}

$\mathrm{Pl}$ :ndunó ivaws $n$ cup, instrument for use in drinking water tsinonu, kopu

Dmi nqúno iva na memgba tsú He put the cup in the bowl

nđúnógò $n$ drinking water etsinono

nqúyúgò $n$ cold water tsifafe

nentswí

Pl:nentswíwo $n$ cow enyi Aba nentwí ekpe vuvo á tsú The killed a cow in the new year Tota: nenkpi

né v get, buy xo

nénù $v$ believe $x \supset d z i$ se Onenu té

Yesu odu onukpa ikpá He believes that Jesus is truly a king

ńfú $n$ palm oil dzomi

nkràwòsá $n$ ginger agumetaku

nò v drink nò Mbánò nqú I shall

drink water

nò $v$ fall (rain) $d z a$ (tsi)

nò (umùshî) v smoke no ’nno umushí

He/She smokes

nta $n$ own puto

ntá $n$ hand asi Atsifó ntá xe atsibí

kpe iva We wash hand when we want to eat

ntámà $n$ back of palm asimegbe

ntátsí $n$ palm (of hand) asifome ntó v pour, liquid. drop on ko de nu

$\eta u$

ntó $n$ ashes afí

ntrónđú $n$ breastmilk enotsi

ntsùrí $n$ ladder eli

ntúbó $n$ front of palm asifome

nù $v$ hear se (nya)

nú Pro 2nd Pers. Plu. Obj. wó

númà $v$ fall down dze anyi

númá $v$ put cloth on ta avo

númá $v$ suck breast no eno

nyà $v$ live no

nyá $v$ to own tó, nu le esi own

nyá $v$ stay (completive) nò

nyàngbò $n$ rainfall tsidzadza

Nyagbo óno uname It rained yesterday

nyàngbò ivù $n$ cloud alilîkpo

Nyagbo ivu iĺe agu There is cloud in the sky

nyàngboìbè $n$ rainy season tsidzayi

Atsibo nyagboibe We are in the rainy season

nyàngbònògò $n$ rainfall tsidzadza

nyì $v$ be that nye má

nyí $v$ bear fruit tse $k u$

nyibi $n$ native child afevi

nyíndé

Pl:nyíndéwo $n$ date palm ayidé

nyínklé

Pl:nyínkléwo $n$ avocado evo

-n(u) neg not -o 


\section{$\eta-\eta$}

yámá v yawn há

ngbíní $n$ okra fetri ngbini ntsi futsue nu Okro is in the soup

jgbò $n$ rashes, lumps on the skin ekó

¡kpè n one qeka

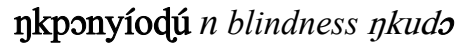

நònyì $v$ write plo nu (de agbalẽ me)

Matanyinu ivaa yonyi He could not

write Tota: yoni

Đónyí $v$ take lion share xo tefe gãato

le numama me
Đótsìgò $n$ era yeyiyi si nane wona jú $v$ see kpo Manú udzié I saw the girl

Đùnyá $v$ sprinkle, broadcast a seed wutsi nu dzi Akpe enúnyá koko é fé uboénu Some broadcast the cocoa in the farm jùyókányí $n$ self realization amedokuikpokpodzesi

\section{$\mathrm{O}-\mathrm{O}$}

$\mathrm{O} \operatorname{det}$ No Ao

ó- Pro 3SG SUBJ é-

obotsú $n$ dew ahu Inosa moovó

ubotsú A man does not fear dew

obúmbà

Pl:obúmbàwo $n$ wing aválã

ódó

Pl:ódówo $n$ feather fu

ódró

Pl:ódrówo $n$ elephant atiglinyi Abá

odró nango okpe They killed a big elephant

odró odj̀ $n$ elephant trunk atiglinyido odùdò

Pl:odùdòwo $n$ butterfly akpakpaluvi

Odzògbènyi $n$ Northerner

Dzogbedzito

ódzú
Pl:odzúwo $n$ river eto Oló ori é odzu é nu Crocodile caught him in the river

Òdzùfî $n$ River in Logba tosisi aqe le Logba

odzúlégò $n$ rainbow anyievs

ódzúnùinó

Pl:ódzúnùinówo $n$ fish akpa

ódzútsúkló

Pl:ódzútsúklówo $n$ boat todzivú

odzúvlèntsí $n$ stream tosisi

odú $n$ sickness dolele

ofá $n$ fence kpototo

ofífie

Pl:ofífiéwo $n$ oil ami

óflù $n$ crazy person amenuwo

ofôntsì $n$ tin ganugui

ófónyì

Pl:mfónyì $n$ gourd ego 
ofû $n$ pain, suffering fù, vevesese

ófú $n$ nose poti

ófú

Pl:ófúwo $n$ guest amedzro Ófú é ósa idze The guest left today

ofúflú $n$ red porridge dzękple

ofûfò $n$ wind eya

ofûfônù $n$ atmosphere yame

ofuí

$\mathrm{Pl}: a f u i ́ n$ thigh atagba

ofuienùkú $n$ thigh bone atafu

ofúntsù $n$ red ant found in the

ground anyidi dzĩ si no anyigba me

ofúntsù $n$ visitor amedzro

ofûnú $n$ navel gbógbónú

ofúnúmúnyí $n$ hair in the nostril

notsimefú

ofútó n enemy futó

ogbómí

Pl:ogbómíwo $n$ monkey kese

ogbótó

$\mathrm{Pl}$ :igbótó $n$ unripe fruit atsikutsetse

gbogbo

oglòyí n knee cap klokpakpe

ògluí

Pl:ògluíwo $n$ mouse afi, alegeli

Oglui oké vutsie nu The mouse rushed out of the hole

Ogódómé $n$ Logba name for Avatime Alesi Logbatowo woyoa

Avatimetowoe

Ogódóményì $n$ Avatime citizen

Avatimeto ogrídí

Pl:ogrídíwo $n$ story putinya eglí

Onukpatsi $\varepsilon$ odá ogridi wa tsú The

old man told us a story

ohàfi

Pl:ihàfî $n$ mattock hoe kodzi si wo-

hona atiglie

ohoyébí $n$ cowry hotsui

okó $n$ crop (cock) ato si le veme na

koklo

okpá $n$ type of fibre (local) ekà

okpenutsigò $n$ half afã

okpùkpè $a d v$ alone deka ko Tota:

okùkpè

okú $n$ place tefe

okú áfá $n$ land of the dead tsiefe

ókúe

Pl:ókúewo $n$ residence nofe

okúmì

Pl:okúmìwo $n$ garden egg agbitsa

okúnàfó

Pl:okúnàfóws $n$ buttocks mefi Tota:

kunafo

okúnkpè $n$ one part (of it), some-

where akpa deka, afiade

okúnù $n$ anus mefime Tota: okuna

okúnyié $n$ that place afima

okúshíokú $n$ everywhere afisiafi

okùtèxoé $n$ funeral grounds kutefe

òló

Pl:òlówo $n$ crocodile elo

olómí $n$ testis voku

olùbù 
Pl:ilùbù $n$ small pot for tapping palm

wine ahakpazi

ombué wutsítsí $n$ lemon donutsi

onflí $n$ black ants anyidi yibo

onflú $n$ red porridge dzenkple

onjie

Pl:nzie $n$ owl adzexe Tota: ojinjie

\section{onkpá}

Pl:ajkpá $n$ rope eka

\section{ónúkpá}

Pl:anúkpá $n$ king, chief amega, fia

\section{onúkpá nángò}

Pl:anúkpă nángò $n$ paramount chief

Logba fiaga

onukpánangò $n$ paramount chief

fiaga

ónyuí $n$ juju edzo

ónyùí $n$ outside gota, xexe Vuinta:

odzogbe mainly used in the Vuinta

dialect

onfú

Pl:onfuwo $n$ worm eno

ōúyé $n$ small insects making nests

in the house ahasusue

opépré $n$ spices pepre

ópété $n$ vulture akaga

otoénù $n$ public assembly ground

ablome

otónù

Pl:otonúwo $n$ guinea fowl atsaxe

Tota: stón’́

otsá $n$ farm-bag agble kotoku

otsíntsí
Pl: otsíntsíwo $n$ spectacle gankui

otsíntsǐ $n$ spectacles gankui

otswe Postp side, fringes eto

otswé

Pl:ntsoe $n$ ear eto Kofi otswe odá

Kofi Kofi's ear is big

otsófi

Pl:otsófiwo $n$ python eṽ

ótsú $n$ forehead ngonu

òtsúntsó n Xylopia aethiopica etsyo

otsùrò

$\mathrm{Pl}$ :atsùrò $n$ brother-in-law enyo

\section{otsyweishíkpé}

Pl:otsyweishíkpé $n$ ear ring toge

otú

Pl:otú $n$ forehead ngonu Tota: otsú

otú

Pl:itú $n$ gun etu

otú kpágò $n$ baldness of the forehead

etakpakpa de ngonu

ótúlí

Pl:ótúlíwo $n$ mosquito emu

ovánánié pron something nane

ovínvlè $n$ green mamba egbedzrolo

ovyò $n$ black berries atitoe

ovyò $n$ litter, refuse gbequdo

ovókpó $n$ insect that causes blind-

ness nudzodzoe si atenu ana ame fe

nku agbã

ovù $n$ market asi

òvù $n$ breath gbògbò

ovuénù 
Pl:ovuéwonu $n$ market asime $\underline{\mathrm{Amu}}$ ma omi ikpe zo ovuenu My mother took some to the market

ovuí $n$ mother's brother, uncle nyrui

Ma kpi amu ovwí wa I went to my uncle's place

ovúmvlè $n$ plant with leaves that causes the body to itch edza; egbe si fia yuti na ame

ovúnù $n$ market asime Igbedi é ilé

ovunu The cassava is in market owò $n$ bee anyí Owo olé vuti ع́ nu

Bee is in the hole

òwòsà

Pl:nwòsàwo $n$ beehive anyitó

oyúbítsí

Pl:oyúbìtsiwo $n$ thief fiafi

oyúyúdógò $n$ stealing fififi

oziáwàsà $n$ poor man ehiató

ozònyì $n$ Akan (person) Ebluto

ozúmè $a d v$ tomorrow etso

\begin{tabular}{|c|c|}
\hline j̀bà $n$ mud ebà & ofáfegò $n$ fence kpotsto \\
\hline obéndà $n$ palmwine deha Tota: & ofánù $n$ house, bathhouse tsilekpome \\
\hline abenda & ofőkétsí $n$ armpit axatome \\
\hline obénqù $n$ palmnut-soup ede detsi & ofŏtsí $n$ door votru \\
\hline Pblòwoe $n$ Creator Mia wola & j́gà \\
\hline obذ̀mغ̀ n settlement, division kponu & Pl:ágà $n$ wife, spouse sronyonu, srõ \\
\hline odà $n$ lowest part of valley abume, & ógàngò $n$ last, the rest momloe \\
\hline balime & ogànyì $n$ palm frond edevaya \\
\hline odó $n$ place in a cocoa farm tefe le & ogàyò n plantain abladzo abladzo \\
\hline koko gble me & ogbá \\
\hline odóntí $n$ waist ali odontsi oló fie & Pl:igbá $n$ road mo \\
\hline Waist is paining him Tota: ədóntsí & ogbá gblà itìbí $n$ forefinger \\
\hline odzá $n$ fire edzo & nyagblosi \\
\hline odzátsúme & ogbádzèmódzè $a d v$ suddenly enu- \\
\hline Pl:idzátsúme $n$ kitchen dzodofi & make \\
\hline Ivakpego iye odzatsume Food is in & ogbánàgò \\
\hline the kitchen & Pl:igbánàgòwo $n$ journey mozozo \\
\hline $\begin{array}{l}\text { òdzògbè } n \text { outside xexe, gota mainly } \\
\text { used in the Tota dialect }\end{array}$ & Dgblólòwò $n$ Nigerian Nigeriato \\
\hline odábíblì $n$ gun etu & ogbذ̀ \\
\hline गेdगेmè & $\mathrm{Pl}$ ligbò $n$ town $d u$ \\
\hline Pl:ìdòmè $n$ bud ati domi & ogó n hunger dowuame \\
\hline
\end{tabular}


ógó $n$ grinding stone ete

ohà

Pl:ihà $n$ pig eha

ohá

Pl:ihá $n$ congregation, group hame, eha

ohlòyí n lust dzodzro

ohlòyí $n$ throat veme

okà $n$ swelling in the groin zoyeku

okà $n$ hen-comb koklo fe ato

óká $n$ palm door mat afotutunu

okànúgbágbá $n$ fowl koklo

okébí $n$ ataku

j̀klà

Pl:ìklà $n$ mat aba

j̀k̀̀ $n$ custom eko

oksánú $n$ lap, around the chest

akonu, akome

okoátú $n$ chest akotá Tota: okəátsu

Okpàyà $n$ God Mawu Atsi dzú ugbe

ta Okpaya We prayed to God

okpàyàbí n Jesus Yesu Dkpayabí

anyíntsé Jesus thank you

okpàyàdzìgo $n$ prayer, calling God

gbedododa

okpàyàdzìme $n$ chaper, a place

where prayer is performed tsotsixo,

tefe si wo doa gbe da le

ókpáyà1́ló $n$ word of God Mawunya

Okpayaíĺ́klontsí n Bible Biblia

Okpayasùmùmè $n$ Chapel; a place

where God is worshipped Tsotsixo

okpè n one deka okpeshiòkpè $n$ any, everyone desiade okpìe $n$ indef. something not known ade

okplè conj because, reason elabe okpò $n$ fist eko ukpo

ว̀kpónyí

Pl:mkpónyí $n$ eye $\eta k u ́$

okúanú $n$ space in front tefe si le $\eta g o$

Dmáwúbí $n$ Jesus, son of God

Mawuvi, Yesu

ว̀mbué

Pl:àmbwé $n$ orange atotonuti ombué

ole syóá nu Orange is in the tree

ondzí adj sweet vivi Pmbué obò

ondzi The orange is sweet

ondà

Pl:andà (wo) $n$ friend, companion

novi

óndá

Pl:andá (wo) $n$ friend novi, eveliá

onfié

Pl:infié $n$ pomade, oil ami, amisisi

ongó

Pl:ingó $n$ unriped fruit, uncooked

food, raw numumu, numabimabi

óntá pron his own etó

onyá $n$ charm edzo si wowona de

ame $d z i$

ónyá $n$ round and yellowish fruit

when ripe akuks

onzye

Pl:inzye $n$ owl adzexe

ongò adj not dry múmu 
ongó adj green gbemu

ongó n immature, unripe, premature,

impure blood matsimatsi, evugbegble

\section{ojkpá}

Pl:inkpá $n$ rope eka Pnkpáa oko эyəa

yo The rope is hanging on the tree

ołkpè $n$ something nane

ołkpèshiókpè $n$ nothing naneke $o$

opánshiá $n$ immature yam etematsitsi

opé $n$ instrument for plucking cocoa

kokogbegá

osá

$\mathrm{Pl}$ : asa $n$ man putsu

ósá $n$ sperm putsunú

osálókpótó $n$ smallish person

amevíme

osámínángò

Pl:asámínángò $n$ leopard ekp̃̃

osánsà

Pl:nsansã n hawk avako

ósó

$\mathrm{Pl}$ :isó $n$ horse eso

otá $n$ boundary pole (tree) lifotsi

ótá $n$ war avà

otagùgò $n$ making war avawows

otว

Pl:ntó $n$ cheek alogo

otsoeyoidá

$\mathrm{Pl}$ :ntsoeyoidàws $n$ ear ring toge

Udzie of ع́ stsoeyoidá The woman wears an ear ring otsòdìbó $n$ material added to gunpowder for firing kabisi otsẃદgo $n$ sponge dish adzalẽgui

otswensã $n$ sponge akutsa Ati mí

stswesã gu yó We use sponge to wash our body

otsyòdìbó support what is being said da asi de nane $d z i$

otswé

Pl:itswe $n$ soap adzale

ovà $n$ behaviour (good) respect

nonome

ovanùvò

Pl:ovanùvòwo $n$ hunter adelã Tota:

ivanùvò

ovávà $n$ local soap ameyibodzalẽ

óviábé adv how much? ho nenie?

Tota: óhuiab́́

ว́vว́wò

Pl:óvówòwo $n$ coward vovonoto

ว́wó

$\mathrm{Pl}$ :iwó $n$ mortar eto $\underline{\text { Ma ywe iva ówo }}$

á nu I pound in the mortar

owòbí

$\mathrm{Pl}$ :iwòbí $n$ pestle tatsi

oxà $n$ trap exà, emò

วyว́

$\mathrm{Pl}:$ ayó $n$ tree ati

ว̀ỳे

Pl:ìỳ̀ $n$ grave yodo

эyó mkpàlé

Pl:iyómkpàlé $n$ beam in a building

xogbati

oyóafotí $n$ bark of a tree ati fe akpá

Tota: əý́afotsi 
эyว́alá

Pl:oyónláwo $n$ branch atiló

oyódzínù

Pl:iyódzìnù $n$ trunk ati fe lobolobo

me

गyว̀kló

Pl:iỳ̀kló $n$ hole in a tree atito Ozinzie otsi syóklo é nu The owl is in the hole in the tree

oyókpéwò $n$ carpenter kabita, atikpala Jyókpéwo é ólómi utrome utsa zugbo The carpenter is working on top of the house oyólólì

Pl:iyòlòlì $n$ cassava agbeli Ma glui oyòlolì idze I uproot cassava today

\section{oyómăntí}

Pl:iyómanntí $n$ bark of a tree atikpa oyótì

Pl:iysti $n$ stick, cane ati Jla ebítsi é kpe oyóti He/She caned the children with a stick

\section{oyว́tsìgbó}

Pl:iyótsìgbó $n$ stump atikpó

òziá $n$ poverty ehia

\begin{tabular}{|c|c|}
\hline pàmprò & pépépé adv exactly pepepe \\
\hline Pl:pampro $n$ bamboo pamplo & pété(ع) Pro completely, all katã \\
\hline pépí $n$ harmattan pépi & pró $v$ wet fotsi \\
\hline péyà & $\mathrm{p}(\mathrm{i})$ rénté $n$ plate agba \\
\hline
\end{tabular}

Pl:peya $n$ pear peya

\section{$\mathrm{R}-\mathrm{r}$}

rí v hold, catch lé de asi, lé ame

rí imó $v$ be involved in a case or

rí ányíná $v$ watch closely le $\eta k u$ de problem kpo nya

nu pu Tota: li anyina

$S-S$

sà v leave, go dzo

sá nqú v fetch water ku tsi

sà zie $v$ lock door tu vo

sàgò $n$ migration $d z o d z o$

sáké $n$ hook for catching fish efù

sákúnábé $n$ insects that destroy cocoa pod nu dzodzoe si gblẽa koko sándzé $n$ brownish growth on cassava that is peeled and kept overnight nu yibs ade si wona de agbeli pu ne woklee dadi enuke de edzi. dze asitsu

sànú

$\mathrm{Pl}$ :sànúwo $n$ seive sranu sàykú $n$ organ sapku sàprádá $n$ onion sabala satifini $n$ bird with bushy tail adúblekese 
sé $v$ cease, stopped se, ewu nu

sefofo

$\mathrm{Pl}$ :sefofows $n$ flower sefofo

sègè $n$ part akpa

shí $v$ cover a container to be airtight

tre nane nu

shíatò $v$ be near te de eju

shíbí $v$ cut tso, lä

shíd ع́ v leave someone at the time

that one is needed de megbe le ame

пu

sìmpoá $n$ deadly boil in the neck,

inside nose fofui si wua ame

skeli $n$ scale nudanu

sókódú $n$ chewing stick atiququ

sòlèmètsá
Pl:sólèmètsáwo $n$ chapel tsotsixo

Solimenyì $n$ Christian Kristoto

sótí $v$ force into ge de eme

srà $v$ sieve srà

sú v pierce $\eta$ o

suá $v$ bore hole in a palm tree de do de edeti me

sùkùgú $n$ school fees sukufe

sùkùkpoétsú $n$ school compound

sukukpodzi

sùsú $v$ urinate do aqudo

súsú $v$ think bù nane puti Masusu té mikisa kuraa atsibiblo iý́ utrome I think that it will not be long we will work on it

$\mathrm{T}-\mathrm{t}$

ta $v$ give na

tá $v$ shoot, throw da tú da (nane)

tá $v$ draw ta nu de agbalẽ me

tá $v$ let na

tá v sting (bee, ant, scorpion) te ame

tà áwá $n$ Greetings (morning) ndi na wò

ta (i)va $v$ swear ta $n u$

tàdzè kò $a d v$ immediately enumake

tányì $v$ can atemu

tàpòlì

Pl:tapoliws $n$ wooden instrument for

grinding in a bowl tapoli

tásà $n$ claw of a crab or scorpion

aqugbo tású

Pl:etású $n$ paternal aunt eté

tátá $v$ inform kla (ame)

tàté $a d v$ as a result eyata

tèdzè $v$ learn srõ nu

tédzi

Pl:tédziwo $n$ donkey tedzi

teè $a d v$ straight tee

téé $a d v$ may be dewohi

téfé $v$ search $d z i ́$

tèlé $v$ make effort wo putete

téní v escape si dzo Tota: tenyi

téní ìnà $v$ respect bu ame, si ame

Tota: tenyi ina

teńtré $v$ lie flat dzene 
Tete Kwashi $n$ Tetteh Quashie, the first variery of cocoa brought to Ghana. Tete Koshi, koko si xoa fe adre hafi tsena. The name of the man who brought cocoa to Ghana. The name is used to refer to this variety

te $v$ say bé

té COMPL that bé

tìmátì $n$ tomato tomato

tínítìnì $n$ instrument for blowing air into fire ayitsi Tota: tsintsin

tò adv never megawo nane $o$

tǒ ábé v fell palm tree mù edeti

tò wú ágù not to be worried mega tsi dzio

tókpótókpó $n$ type of mushroom that is short evlo si le kpuie

tòlé $v$ send do ame

tòngò $n$ thick (of liquid) kpẽkẽe

tòtòkpà $n$ formerly etsã

tò $v$ put a pot under a felled palm tree for wine to drip into it. da ahazi de edeti si womu te ne aha na tsyo de eme

tó $v$ fix on le de nane $\eta u$

tǒlé v push tutu tó

tònká gò ègbè $n$ grinding stone

(pepper) atadi tukpe

tòntá v push tutu

tòyká $n$ pepper atadi

trò v refuse gbé

tró v carry (load) tso (agba)

tsà $v$ be tired dedi fe ameyutete tsà $v$ lodge with someone dze amedzro

tsè $v$ be ready for harvest atikutsetse si tsi ne woagbe

tsè $v$ be old tsi

tséngò $n$ old tsitsito

tsénkle adj thin tsralee

tsétsénklé adj very thin tsralee

tsí $v$ sit no anyi

tsí $v$ stay in, sit no eme

tsì ìvà $v$ divide, share out ma $n u$

tsìbì $v$ small (quantity) sue

tsìdzóndzó v squat no klotsinu

tsídí $v$ be in line le fli me

tsié tí $v$ sit down no anyi

tsímí $v$ crack (palm kernel) zi (nefi)

tsítsì $v$ overturn tro gbo

tsitsié n how something is done alesi wo wo nanee

tsíyí $n$ maize ebli

tsó $v$ cut lã

tsoé $v$ dry fú

tsògá $v$ cross tsoga

tsonyui $v$ start dze gome

tsoénqú $v$ be good and dry esp. friut or vegetable futsi

tsómí $v$ lick bowl in the course of eating dudo agbame ne nu dum

tsòn adv for a long time vuu

tsú odzá v set fire dó dzo

tsuatsòlí $v$ spit de tá

tsùdj̀ $v$ sieve tsra 
tsúnó $v$ tree that is no more yielding

ati si tse vo

tsyé v select tsiá

tsyoéyì v be dry fú

Tsyókpózíwò $n$ Hausa man

Awusato

tsyõ ̃̃ adv long legbee

-tu $v$ PAST PROG.ASP. suffix no $-m$

tú v untie tú

tú Pro 1st Pers. Plu. Obj. mi

Tota:tsu

tú $v$ move to another place vì tué v miss target da dadagbo Tota:

tsúc

tuli

Pl:tulíwo $n$ mosquito emu

tùmgèdzè $n$ hunchback ekpó

tùmpá

Pl:tùmpáwo $n$ bottle atukpa

tùmpánúzìvà

Pl:tùmpánúzìvàwo $n$ bottle -top tuk-

panutuvi

tútúmántú

Pl:tutumantuwo $n$ aligator evé

tútútú adv exactly tututu

$\mathrm{U}-\mathrm{u}$

-u DET the (1)a

úbólótsónyuí

ubá $n$ sth. you have not paid for

afúnú

Pl:úbòlótsonyuiwo $n$ tractor, farm

machine agbledem̃

ubì

ùbóǹ

Pl:ebì $n$ wound abì

ùbí

Pl:ebitó $n$ child qevi

ùbídzé

Pl:ebiédzé $n$ daughter vinyonuvi

ubínyítágò

Pl:ebínyítágò $n$ naming ceremony

nkonanadevi

ubíosá

Pl:ebíasá $n$ son vinutsuvi

ubìrívà $n$ plaster abilegu

ubò

Pl:ebò $n$ farm agble

ubógbà $n$ farm path agblemó

ubókágò $n$ farming agbledede
Pl:èboǹ $n$ farm (in) agbleme

ubónùivà $n$ farm produce agblemen-

uku

ubónùkpíákpívà $n$ sandals for farm-

ing agbledefokpa

ubónùkpíwò

Pl:ebónùkpíwò $n$ farmer agbledela

ubónùtsá

$\mathrm{Pl}$ :ebonùtsǎ $n$ hut agblexo

ubotsù $n$ dew ahu, dzadza

ubómè $n$ town, hidden place for

consultation dume, dahu

udáìvà $n$ opener nuvunu 
udántsí $n$ morning ydime Udántsí

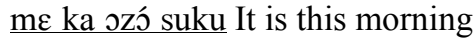
he/she went to school udzédívà $n$ dowry sroqenú udzédruí $n$ tomatoes tomatos udzédrúì $n$ light skinned woman nyonu si biã

udzémílókpótó $n$ cocoyam mankani udzémítébí

Pl:edzémítébí $n$ young lady detugbi udzé

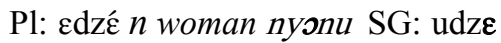
PLU: $\varepsilon d z \varepsilon$

udzì

Pl:edzì $n$ heart $d z i ̀$

udzí $n$ rag used for carrying load tsihé

údzì $n$ broom exa, abaya

udzinyáwò $n$ brave kalẽto

udzìtsú $n$ chest akota

udzitsùimúnyí $n$ chest-hair akotafu

udzúamá $n$ toilet, Tota dialect afodzi

udzùbí

$\mathrm{Pl}$ :udzubiwo $n$ pot for storing potable water tsinoze

udíme $n$ inheritance domenyinu udóbè $n$ afternoon yetro

údú $n$ ten ewo

ufiàlì $n$ sweat fifia

ufidàmè $n$ meeting place Uonu, afisi wow takpekpe le ufió $n$ family fome ufŏtò $n$ marshy terrain tefe si wo tsi le finyafinya

ugà $n$ hundred alafa deka

ùgbè $n$ voice, language gbe,

gbegbogblo

úgbè $n$ father-in-law etó

úgbèdzè $n$ mother-in-law 10̃xo Ugbédzúgo $n$ libation prayer tsifodeanyi

ùgbèdzúmè $n$ church spiritual healing centre doyofe

ùgbèwágò $n$ language speakers

gbegblolawo

ugo $n$ difference vovototo

úgù $n$ husband sroputsu

úgú $n$ debt (for something) fe (ga si le ame $\eta u)$

ugùfâ

Pl:ugufâwo $n$ towel nutsitutunu

(towel)

úgúgà $n$ salary, wage fetu

ugùnè

$\mathrm{Pl}$ :egùnè $n$ sister (either younger or older) novinyonu

ugùsà

Pl:egusá $n$ brother noviwo

ùgúwàsà $n$ married woman srõtó

uhé

Pl:uhéwo $n$ knife hé

ukíntà $n$ elephant grass aqagbe

ukintayì $n$ small grinding stone for grinding medicine herbs atiketukpe ukló 
P1:uklówo $n$ lorry evu

\section{uklòntsí}

Pl:uklontsíwo $n$ book agbalẽ

úkluí

Pl:úkluíwo $n$ cooking stick akpledati

ukpálívǒ $n$ small unburnt sticks in

the farm ati wuwlui siwo mebi o le

dzototo gbě vo.

ukpló

pl:ukplówo $n$ table ekplo

ùkpó

Pl:èkpó $n$ mountain eto

ukpókù

Pl:ekpókù $n$ knee eklò

ukpótsú $n$ mountain top tó tame

ùkú

Pl:èkú $n$ drum evu (si wo fo na)

úkú

Pl:ekú $n$ bone efu

ukúnángo

Pl:ekúnángo $n$ talking drums agblovú

úkúnkú

Pl:ékúnkú $n$ elbow abokugluinu

úlémé $n$ position a person holdls in a society dofe si ame ade le le habobs me.

úló $n$ hernia; oversized testis evo

úloégbé $n$ grinding stone nunyrekpe

ulólì

Pl:elólì $n$ root ati fe eke

úmá

Pl:émáwo $n$ mother dada

úmágùnè
Pl:émágùnèwo $n$ maternal aunt dadia

ùmè $a d v$ here afisia

uméntà $n$ salt edze

ùmó $a d v$ there afima

umókoé adv there afima

úmúshí $n$ smoke dzudzo

úmútí

Pl:émútí $n$ barn avá Tota: umutsi

unámbì $n$ grandchild mamayóví

unámè $n$ yesterday etso Unáme ka

óbá It is yesterday he came

unánsà

Pl:enansà $n$ chief togbi, fia

unutsigò $n$ half afã

unyì $n$ fruit kutsetse

unyí

Pl:enyi $n$ day nkeke

ùnyì $n$ boundary lifó

únyí

Pl:enyí n name $\eta k$ o

urímè

Pl:urímè $n$ handle alo

ùsà

Pl:èsà $n$ nest ato

ùsá

Pl:usá $n$ group, clan sã

usòntà $n$ pit latrine afodzi

úsú $n$ urine aqùdó

usúásó

Pl:usúásó n chamber-pot aqudozi

usùmùnyì

Pl:usùmùwò $n$ worshipper subola

usúsò $n$ old urine aqudo tsitsi 
usùsòfôlí $n$ bladder aqudogui

utí

Pl:etíwo $n$ father fofo Tota: utsi

utísà

Pl:etisà $n$ paternal uncle todia Tota:

utsísà

ùtròmè $n$ work $d$ o

utromèmìgò $n$ work dòwówó

utsá

Pl:atsá $n$ house xome

utsa olo dú the roof is leaking afi le bedzame an expression used to state that there is someone around who hears what is being said and will pass it on to someone who is not supposed to hear it.

utsádòwò

Pl:etsádowo $n$ mason xotula

utsíntsí $n$ middle dome

utsíntsiénù $n$ environment nutowome

útsònyuí

Pl:útsònyuí n machine emó

utú

Pl:etú $n$ anthill babako

utúdímè $n$ government dziququ

uvá $n$ side axadzi

Úvà $n$ Friday Fida

uváfó $n$ part akpa aqe

uvátú $n$ side axadzí Tota: uvátsú

uví

Pl:eví $n$ tail asike

uvlómiébí $n$ type of seed used as

spice in cooking. ayiku

uvú $n$ belly fodo úwá

Pl:ewá $n$ forest ave

uwádzó

Pl:ewádzó $n$ centipede demeh̃

iwadzò

uwádzówádzó

Pl:ewádzówádzó $n$ centipede ahlihá iwodzò

Uwlátè $n$ Monday Dzoda

Uwló $n$ Sunday Kwasida

Uwó $n$ Tuesday Blada

ùzí $n$ noise ylidodo

úzí

Pl:ezí n door (way) votru monu

uzídáidebi $n$ key safui

uzídáivà $n$ key safui

uzó

Pl:ezó $n$ big pot for storing water zo uzùgbó $n$ head ta

uzúgbófía $n$ headache taquame

uzúgbófídàgo $n$ meeting takpekpe

uzúgbófó

Pl:ezúgbófó $n$ skull ametakoli

uzúgbógbàivà

Pl:uzúgbógbàivàwo n scissors sakisì, apasú

uzúgbógbàwò $n$ barber takola

uzúgbóglívà $n$ head scarf takú

uzugbóimúnyí $n$ hair on the head

tádá

uzúgbókpágò $n$ bald head etakpãkpã

uzúgbómà $n$ back of the head

vudome 
uzúgbóntsí $n$ top of the head

\section{dzodome}

uzúgbóvúmágò $n$ disease condition

which makes the person who suffers from it to have a swollen head dolele si nana ame fe ta tena

uzúngbá $n$ life agbenono
$\mathrm{V}-\mathrm{V}$

và $v$ borrow dó $n u$

váfó $n$ side axadzi

vè $v$ pass va $y i$

vèf'́ $v$ enter ge de eme

vévé adj important vevie

viá $v$ nurse a seed viá

viálìvà $v$ play games fe fefe, di ako

víní $v$ weave thread, knit 1̃, gbì ka

víví $v$ showing off amedokui dodo de

$d z i$

vlá $v$ bury di

vlí $v$ winnow, removing chaff from

maize and beans gbj̀ ebli alo ayi be-

na atsa nado le eme.

vlò v peel cassava kpa agbeli óvlo

igbedi é He/She peels the cassava

vlòvlòvlò $a d v$ growing fast tsi ka-

bakaba

vlù $v$ uproot ho

vó $v$ fear võ vónyí v ugly vló, nusi menya kpo o

vù $v$ blow (with mouth) do fufu de nu

me

vù $v$ castrate tá

vù asó v mould (pot) me ze

vui $a d v$ never, stop mega wo nane o

vuí $v$ stop doing something dzudzo

nane wow

vulí $n$ tobacco atama

vúmá $v$ swell te

vuǹkpá $n$ red pad worn by women

nyonuwo fe godui dziĩ

vuóvù $v$ breathe gbo vu ovu

vùshì $n$ vagina kolo

vùshìtsúimúnyí $n$ female pubic hair eqotafú

vutí

Pl:vutíwo $n$ hole edo Tota: vutsi

vùvò adj new yeye

vúvó adj spoil gbegblẽ

$W-W$

wà v say, speak, tell someone some-

thing gblo Atowá Ikpáná? Do you

speak Logba language?

wá $n$ place gbó

wá $v$ break open vu nane

wàsà $n$ owner puto wéseé adj coarse flatsa (can be reduplicated)

wlà $v$ to waste something gble nane to mazámazá me

wlí $v$ many, plenty sugbo 
wlíwlí adv small parts suesue, wliWli

wlué $v$ deceive ble ame

-wò $n$ belong to -to

wò(bî) $v$ give birth to a child $d z i$ vi

wo $v$ be stuck le de enu

-wò Plural suffix wó

wó v prick tó (ame)

wò zúgbó $v$ head to, take ones mat-

ter to tso ame fe nya yi tefe ade.

wófé v pierce $\eta$

wokpokuetsì $v$ kneel dze klo wokpò $v$ knock somebody with fist fo ame kple kó

wontétsí $n$ menstruation asidoanyi

wù $v$ remain tsí anyí

wú Pro 2nd Pers. Sg. Obj. wò

wutsítsí adj small sue

wútsíwútsí adj tiny, small grains of

gari, rice wuziwuzi

wúwò v heat mè

wúwò ásó v heat, roast inside pot

after use for some time yiyi ze me

$X-x$

xenyì conj but gake

xlèxé conj before hafi xòxòe adv already xохо

xòxú v gather fofú

\section{$Y-y$}

yà $v$ erect a pole in the farm for yam

tu ati de ete $\eta u$.

yáyá $n$ nakedness amama

yáyí v look for something di

yé $v$ stand le tsitre

yéyé $v$ wait to dzo ame

yé $v$ remove de nane da

yé conj and eye

yì $v$ be weedy to gbe

yí $v$ remove tsá do go

yì v be full yó

yídé $v$ wait for a person to na ame

yó Postp side (skin) puti

yóvúdzè
Pl:yóvuwòedze $n$ white woman yevunyonu

yòvúne

$\mathrm{Pl}$ :yovunewo $n$ coconut ene

yòvúnyì $n$ whiteman yevu

yú $v$ be cold fa Atsú wá iyú Our place here is cool. There is peace here

yùánú $v$ taste do nu kpo

yúdó v steal fi

yuédí $v$ weep, cry fa avi

yué v pound (in a mortar) tó nu le to me Jyue fufui kpe igbedie $\mathrm{He} / \mathrm{She}$ pounded fufu with cassava yuíyó' v dance du ye Udze á oyo iyó The woman danced 


\section{$Z-Z$}

zá $v$ row, paddle, drive ku todzivu

zá $v$ cook da nu Mazíva odzatsume I cooked in the kitchen

zá ndá $v$ distill qa aha

zàlá v dream ku droe

zándzé $n$ firefly kedzuikedzui

zénklă

Pl:zenklăwo $n$ pot stand zelenu

zì $v$ good nyui

zì v close tu

zí $v$ carry tso

zí v uproot hò

zí iló v make a case against someone

wo nya de ame pu

zí (ìvà ásó nù) v cover (a pot) tu nu eze $n u$

ziá $v$ be necessary hiá

zia $v$ wash a sore klo abi

zìntìmú $n$ darkness viviti zò v sell dzra nu

zó v go yi

zò (ikú) v sing dzi hà Ebitsi olozó

iku The child is singing

zròní $n$ ringworm zolîlí zroni olé

ebitsi zugbo ringworm is in the

child's head

zù $v$ descend di va anyi

zù $v$ grow big (roots) đó

zú $v$ wake f̃

\section{zúgbózúgbóbí}

Pl:zúgbózúgbóbíws $n$ tadpole kokovi zúgbózúgbóbí olé nqu é nu tadpole is in the water

zuikú $v$ sing dzi ha Adzi é ólózó iku The bird is singing zùtsí $v$ sit no anyi zúzò ásò v roast, heat new pot in oven after moulding. me ze 


\section{English-Logba index}

\begin{tabular}{|c|c|c|c|}
\hline & & $\mathbf{a}$ & \\
\hline 'abolo' & Pl:abolo, see: & ant & ateléwo, see: atélé. \\
\hline & abólózágò & antelope & Pl:ngúwo, see: agú. \\
\hline abomination & bùsú. & anthill & Pl:etú, see: utú. \\
\hline advice & adajù. & anthill in the & form of an umbrella \\
\hline after that & ímóámá. & & nántróblíkpó. \\
\hline afternoon & udóbè. & anus & okúnù. \\
\hline again & do; lí. & any, everyon & okpeshiòkpè. \\
\hline $\begin{array}{l}\text { again, also } \\
\text { ago }\end{array}$ & $\begin{array}{l}\text { dó. } \\
\text { dzé. }\end{array}$ & arm & $\begin{array}{l}\text { Pl:ygbàshì, see: } \\
\text { agbàshì. }\end{array}$ \\
\hline ahead & dzà. & armpit & ofőkétsí. \\
\hline Akan (person & ) ozònyì. & arrive, happe & a dzú. \\
\hline aligator & $\begin{array}{l}\text { Pl:tutumantuwo, see: } \\
\text { tútúmántú. }\end{array}$ & $\begin{array}{l}\text { arrow } \\
\text { as a result }\end{array}$ & $\begin{array}{l}\text { igbè. } \\
\text { áný́ménù; tàté. }\end{array}$ \\
\hline 11 & kpóyì. & ashes & ntó. \\
\hline alone & okpùkpè. & ask & bú. \\
\hline already & xòxòe. & ask (request) & bú. \\
\hline also & f'́; ga. & atmosphere & ídí; iyánù; ofûfônù. \\
\hline always & ebíasiá. & Avatime and & Nyagbo name for \\
\hline ancestors & ánánsá. & & Logba Benugba. \\
\hline ancestral stoo & anasábiá. & Avatime citiz & en Ogódóményì. \\
\hline $\begin{array}{l}\text { and } \\
\text { animal }\end{array}$ & $\begin{array}{l}\text { kpe; ý́. } \\
\text { Pl:mbówó, see: abu }\end{array}$ & avocado & $\begin{array}{l}\text { Pl:nyínkléwo, see: } \\
\text { nyínklé. }\end{array}$ \\
\hline $\begin{array}{l}\text { annoy } \\
\text { annoyance } \\
\text { another }\end{array}$ & $\begin{array}{l}\text { mìkú. } \\
\text { dzìkú. } \\
\text { mángò. }\end{array}$ & axe & Pl:nvì, see: àvì. \\
\hline
\end{tabular}

B - b

back ámántí. baldness of the forehead otú kpágò.

back of body amá. back of palm ntámà. ball P1:mkpáfló-ivàwo, back of the head uzúgbómà. back of the neck imómà. backbone amantsikú. bad gbálí.

bag Pl:nkpòyì, see: akpòyì. bald head uzúgbókpágò. see: akpáfló-ivà.

ball, shoes Pl:mkpá iva, see: akpá iva. bamboo pàmprò. banana kodiátsya. banana peel Pl:kodiátsya fotsíwo, see: kodiátsya fotsí. barber uzúgbógbàwò. 


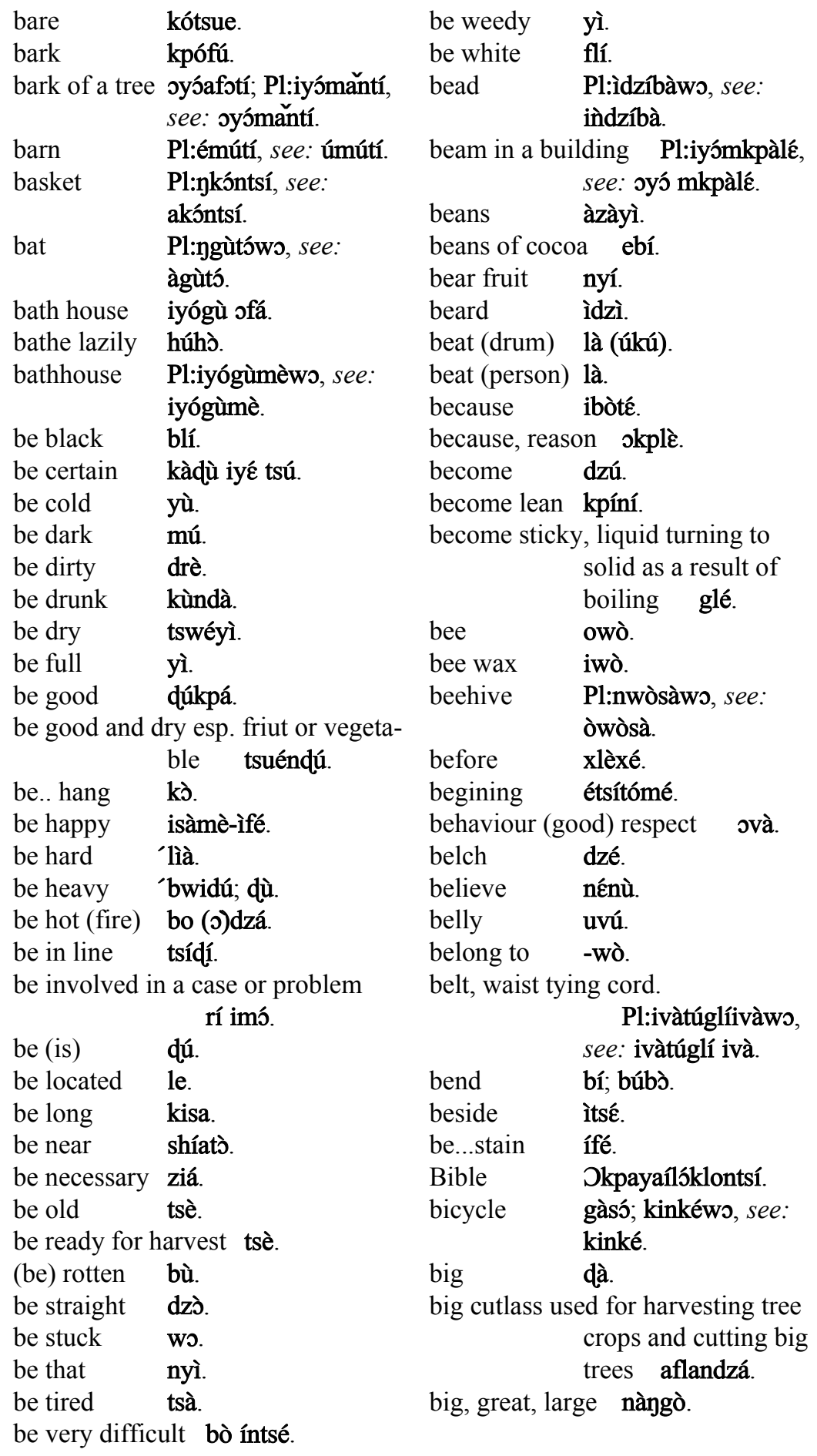


big pot for storing water Pl:ezó, see: boundary ùnyì.

uzó.

boundary pole (tree) stá.

bird Pl:ndzì, see: adzì.

bowl

$\mathrm{Pl}$ :mèngbáwo, see:

bird possessed with evil spirit

Pl:ndzexé, see: adzexé.

bird with bushy tail satifini.

birds' nest Pl:ndzìsà, see: adzìsà.

biscuits

Pl:akpónówo, see: branch

mèngbá.

bowl containing assorted clothes to show the wealth of a clan dzinkle.

bite ‘kṕ́ lé.

bitter ló

brave udzinyáwò.

bitterness, agony Pl:afiánugo, see:

bread gbégbánfó.

break blí; fífi.

break open wá.

black bíblì.

black ants onflí.

black ants; live in coffee trees

breaking cocoa pods to remove

\section{Pl:nkpánkpàyìdàdà}

black berries ikádzà; oviò. see : akpánkpàyìdàdà

black pepper $\mathrm{Pl}$ :afûtsáì, see: afûtsáì.

bladder usùsòfôlí.

blind $\quad$ Pl:nkpónyíblìgo, see: akpónyíblìgo.

blindness ykponyíodú.

blood dzòsú.

blow (of wind) fûfô ̀̀lólá.

blow (with mouth) vù.

boat

Pl:akróws, see: akró;

Pl:ódzútsúklówo, see:

ódzútsúkló.

body

iyó.

boil ivàvùmàgo.

boil, of water biá.

boiling water nqúbiagò.

bone

Pl:ekú, see: úkú.

book

Pl:uklontsíwo, see:

uklòntsí.

beans fónyí.

breast Pl:ntrówo, see: atró;

Pl:ntró, see: átró.

breastmilk ntróndú.

breath òvù.

breathe vuóvù.

bring mlà.

broad, especially of leaves

gbéngeé.

broad green leaves used as wrapper axlàmàkpá.

broken pot $\mathrm{Pl}$ :nsóblìgò, see: ásóblìgò.

broom Pl:fiofiows, see:

fiòfió; údzì.

brother gusà; Pl:egusá, see: ugùsà.

brother (elder) Pl:fowo, see:'fǒ.

brother younger Pl:àmgùsàkloiwo, see: àmgùsàkloi.

brother-in-law Pl:atsùrò, see: otsùrò.

brownish growth on cassava that is

bore hole in a palm tree suá.

borrow và.

bottle

P1:abodiabó, see: peeled and kept overnight sándzé.

$\begin{aligned} & \text { abodiabó; Pl:tùmpáwo, } \\ \text { bottle -top } & \text { Pl:tùmpánú. } \\ & \text { see: tùmpànàwón } \\ & \end{aligned}$

bucket

Pl:bokitiwo, see:

bókìtì.

bud Pl:ìdòmè, see: òdòmè.

build dò.

bury vlá. 


$\begin{array}{llll}\text { bush } & \text { ivànù. } & \text { buttocks } & \text { Pl:okúnàfówo, see: } \\ \text { bush, outside } & \text { Pl:nkèlén, see: èkèléǹ. } & & \text { okúnàfó. } \\ \text { but } & \text { dzué; xenyì. } & \text { buy } & \text { lè. } \\ \text { butterfly } & \text { Pl:odùdòwo, see: } & \text { buyer } & \text { aléwò. } \\ & \text { odùdò. } & & \end{array}$

\section{C - c}

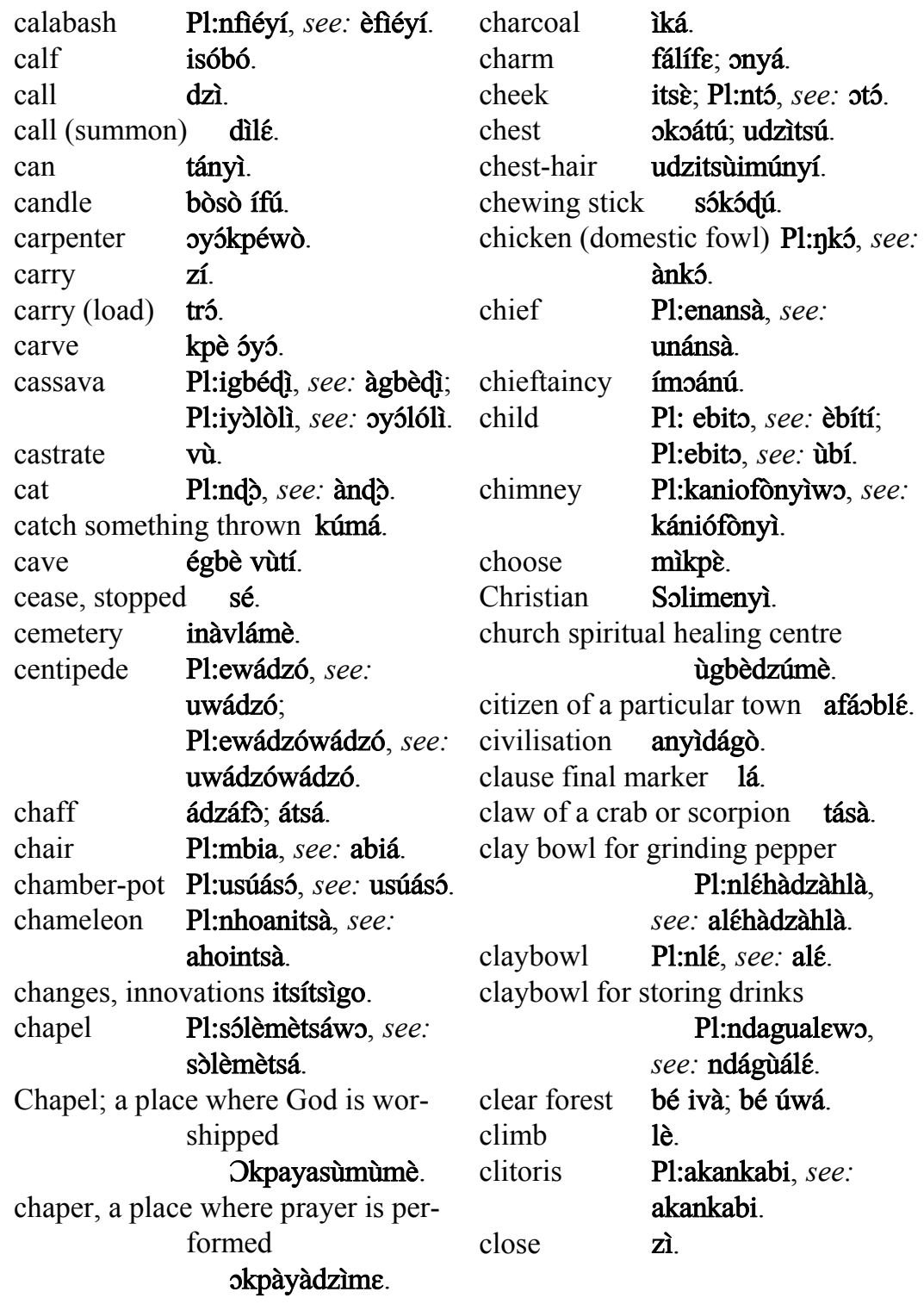




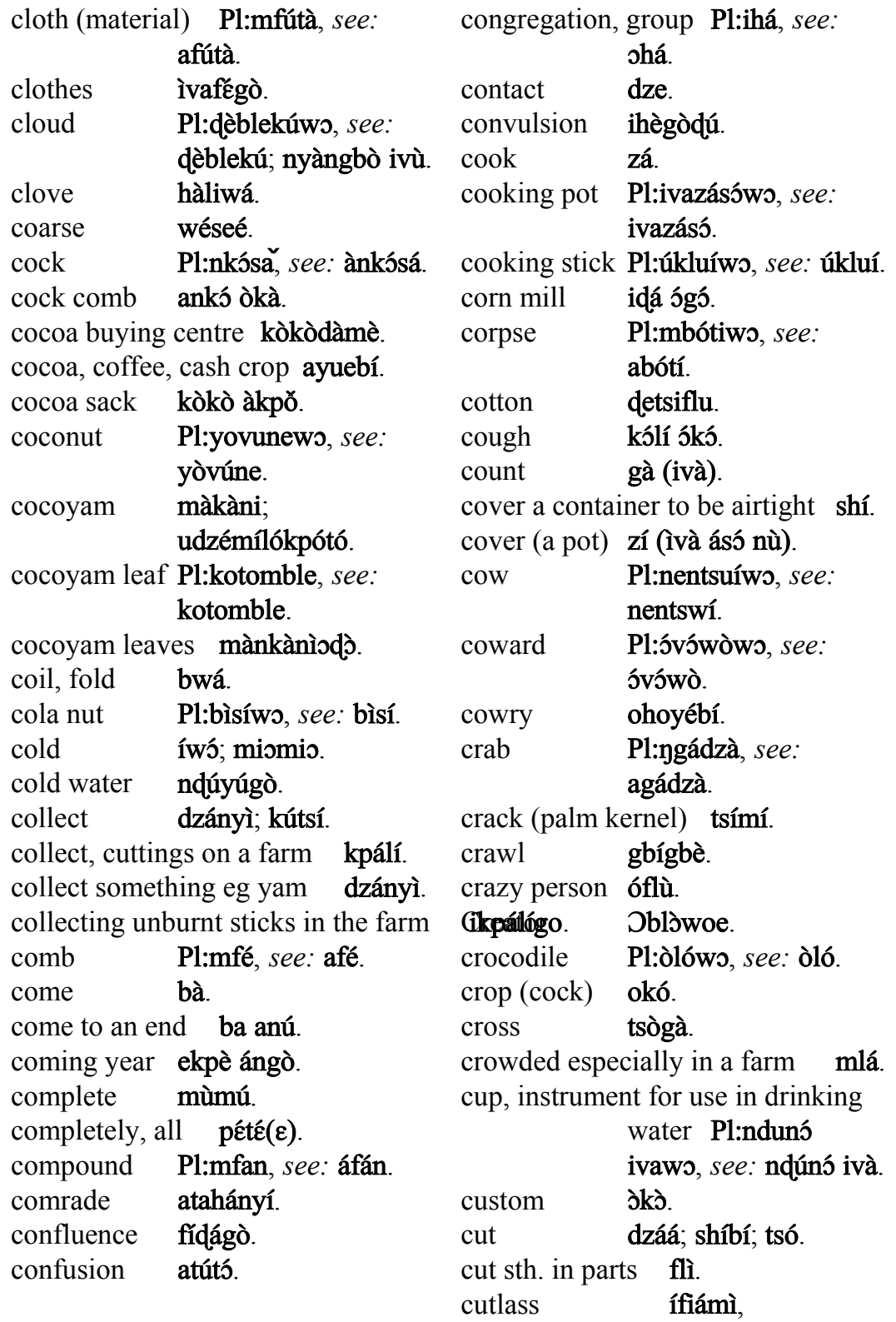

D - d

$\begin{array}{llll}\text { dance } & \text { iyó. } & \text { date palm } & \begin{array}{l}\text { Pl:nyíndéwo, see: } \\ \text { darkness }\end{array} \\ \text { ídí imún zìntìmú. } & & \text { nyíndé }\end{array}$ 


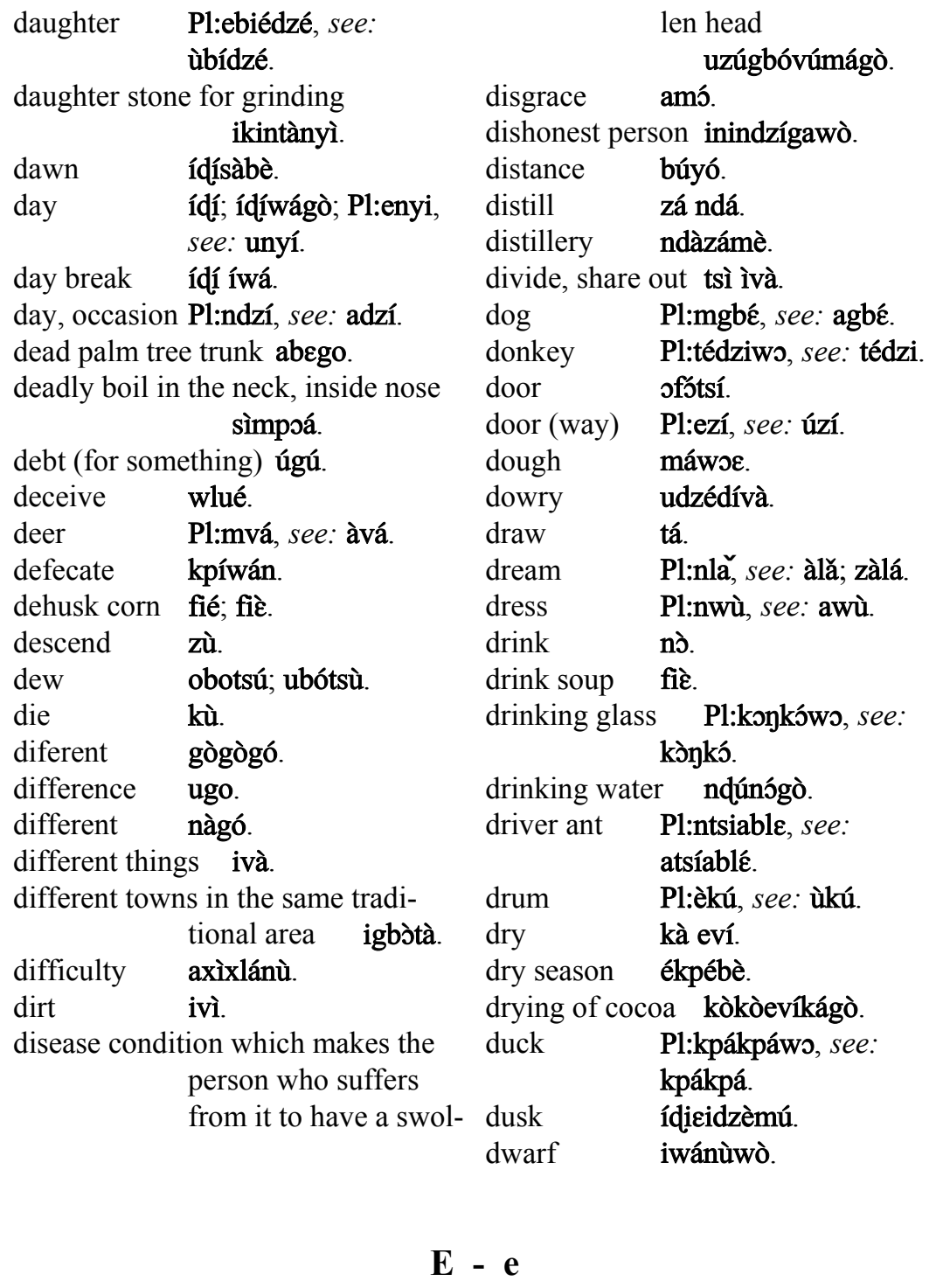

$\begin{array}{llll}\text { ear } & \text { Pl:ntsue, see: otsué. } & \text { earthen bowl for frying gari galik- } \\ \text { ear ring } & \text { Pl:otsueishíkṕ́, see: } & & \text { plòálé. } \\ & \text { otsueishíkpé; } & \text { earthworm } & \text { Pl:ntenyi, see: } \\ & \text { Pl:ntsueyoidàwo, see: } & & \text { antènyì. } \\ & \text { otsueyoidá. } & \text { East } & \text { Evibúmè. } \\ \text { early } & \text { anyilé. } & \text { eat } & \text { kpè ivà. } \\ \text { earth (soil) } & \text { Pl:étíwo, see: étí. } & \text { eat in bits } & \text { fúní. } \\ & & \text { eat; suck } & \text { dí. }\end{array}$




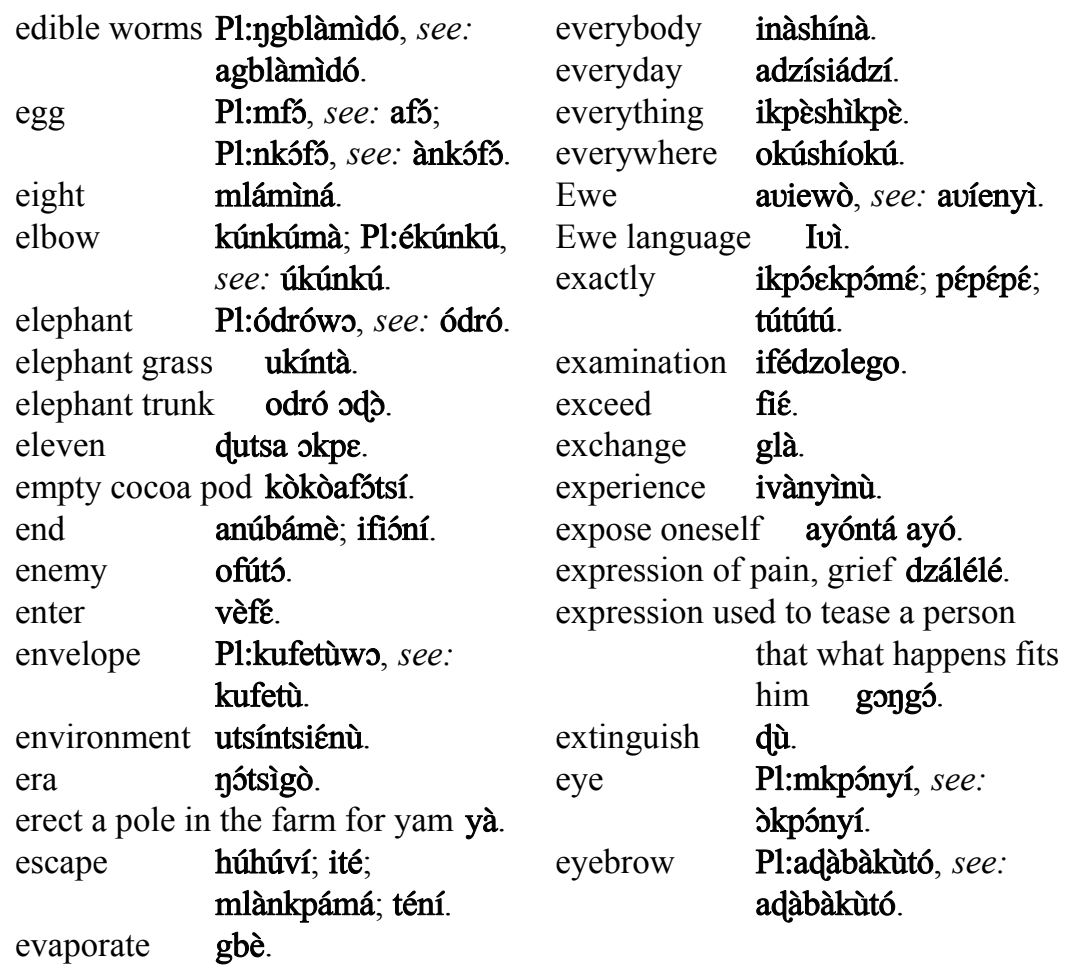

F - f

\begin{tabular}{|c|c|c|c|}
\hline ace & anyinù. & fast & gbángbán. \\
\hline aeces & íbí; ísò. & fat & dà; ífú. \\
\hline all & buétsí; gbó. & father & Pl:etíwo, see: utí. \\
\hline ll down & númà. & father-in-law & úgbè. \\
\hline all from a tre & e lèntá. & fear & bàmá; ivógò; vó. \\
\hline 11 (rain) & nò. & feather & Pl:ódówo, see: ódó. \\
\hline ly & ufió. & fell palm tree & tǒ ábé. \\
\hline S & awóete. & female pubic $\mathrm{h}$ & hair \\
\hline $\mathrm{rm}$ & Pl:ebo, see: ubo. & & vùshìtsúimúnyí. \\
\hline rm bag & Pl:nkpǒ, see: akpǒ. & fence & ofá; ofáfegò. \\
\hline (in) & Pl:èboǹ, see: ùbóǹ. & ferment & bù (koko). \\
\hline path & ubógbà. & fetch water & sá nqú. \\
\hline produce & ubónùivà. & fetish shrine & amònù. \\
\hline bag & otsá. & fever & eví. \\
\hline mer & Pl:ebónùkpíwo, see: & fight & gù; gù ímà. \\
\hline & $\begin{array}{l}\text { ubónùkpíwò. } \\
\text { ubókágò. } \\
\text { ifié. }\end{array}$ & 18 & $\begin{array}{l}\text { to fist, exchange } \\
\text { blows. guokp̀ }\end{array}$ \\
\hline
\end{tabular}




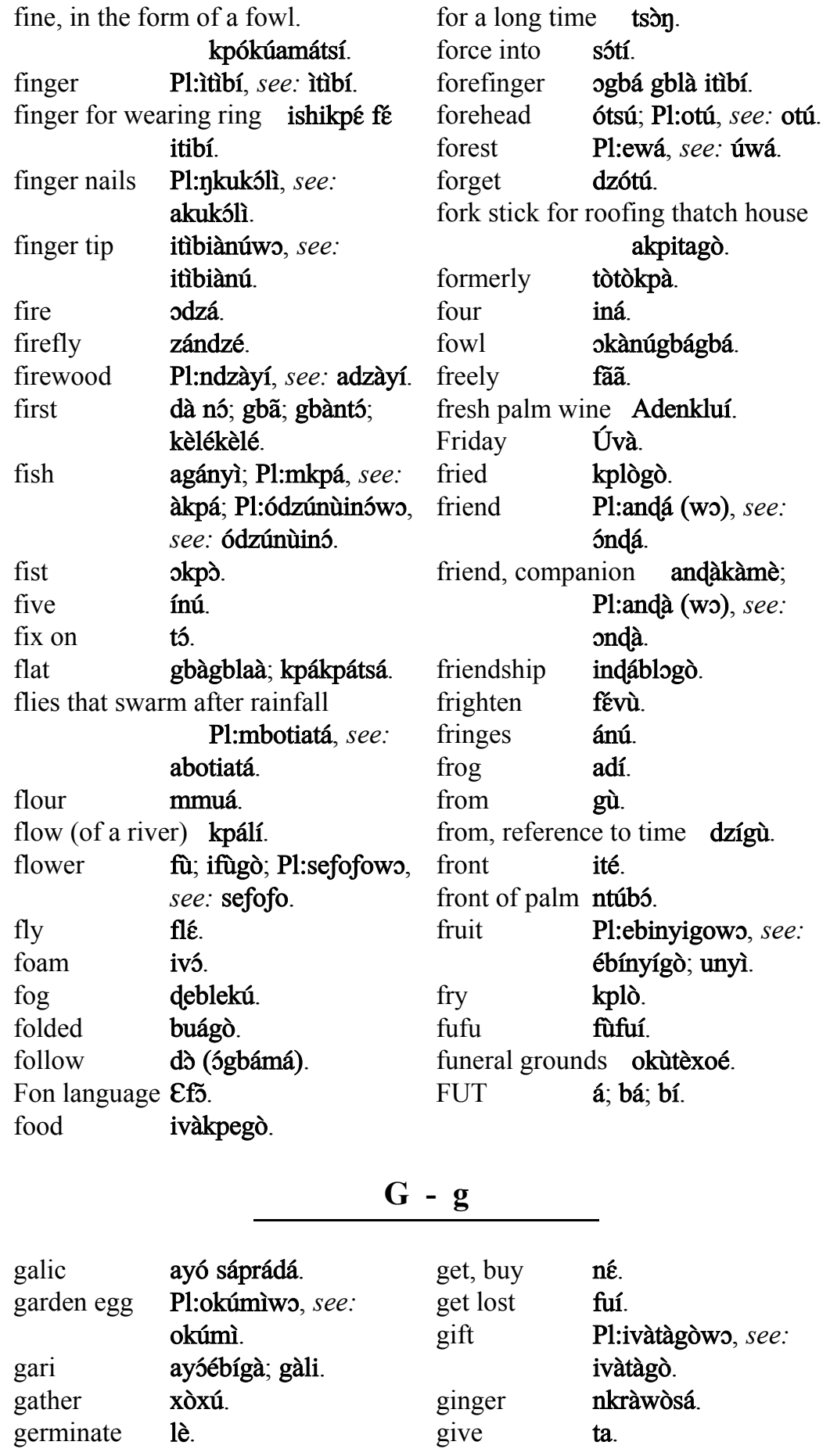


give an account bù.

give birth to a child wò(bî).

give discount dò.

glove

Pl:agbashiawù, see: agbashiawù.

go kpi; zó.

go (completive) kpí.

go round kúkò.

goat

God

goitre

good

gourd

government

grandchild

grass

grasscutter

grasshopper

grate

grater

grave

greatly

greedy person Pl:nnyinkléwò, see: anyikléwò.

green green edible leaf isàngò; kpehelé. green edible leaves fótètè; gbómá. green mamba ovínvlè.

greet fé ánú.

greet (salute) in the morning gànú.

Greetings (morning) tà áwá. grey hair imúnyífügò.

grind gò.

grinding stone ivàgòegbè; ógó; úloégbé.

grinding stone (pepper) tònká gò ègbè.

ground etíkótsoé.

groundnut àví.

group, clan Pl:usá, see: ùsá.

grow big (roots) zù.

growing fast vlòvlı̀vlò.

guest Pl:ófúwo, see: ófú.

guinea fowl P1:otonúwo, see:

otónù.

gum étèkùshì.

gun ídákpà; Pl:itú, see:

otú; odábíblì.

gunpowder idù.

\section{$\mathbf{H}-\mathbf{h}$}

\begin{tabular}{|c|c|c|c|}
\hline \multirow{2}{*}{\multicolumn{2}{|c|}{$\begin{array}{l}\text { hair imúnyí. } \\
\text { hair in the nostril ofúnúmúnyí. } \\
\text { hair on the head uzugbóimúnyí. }\end{array}$}} & head & uzùgbó. \\
\hline & & head scarf & uzúgbóglívà. \\
\hline $\begin{array}{l}\text { hair on the he } \\
\text { hairdresser }\end{array}$ & $\begin{array}{l}\text { ead uzugbóimúnyí. } \\
\text { imúnyíblòwò. }\end{array}$ & head to, take & $\begin{array}{l}\text { ones matter to wò } \\
\text { zúgbó. }\end{array}$ \\
\hline & $\begin{array}{l}\text { afã; okpenutsigò; } \\
\text { unutsigò. }\end{array}$ & $\begin{array}{l}\text { headache } \\
\text { hear }\end{array}$ & $\begin{array}{l}\text { uzúgbófía. } \\
\text { nù. }\end{array}$ \\
\hline & Pl:ntá, see: átá; ntá. & & Pl:edzì, see: udzì. \\
\hline ndkerchief & dúkùbí. & hearth & Pl:ntruí, see: átruí. \\
\hline & erson plays $\mathrm{i}$ & & wúwò. \\
\hline SS & $\begin{array}{l}\text { group. Pl:urímè. } \\
\text { isàmè. }\end{array}$ & heat pot afte & $\begin{array}{l}\text { use for some time } \\
\text { wúwò ásó. }\end{array}$ \\
\hline $\operatorname{ttan}$ & ékpé; pépí. & eel & Pl:mkpadzìdzí, see: \\
\hline & Pl:kùtówっ, see: kùtó. & & ak \\
\hline $\operatorname{man}$ & Tsyókpózíwò. & & Pl:mkpakpò, see: \\
\hline$v^{\prime}$ & Pl:nsansã, see: osánsà & & akpákpò; \\
\hline
\end{tabular}




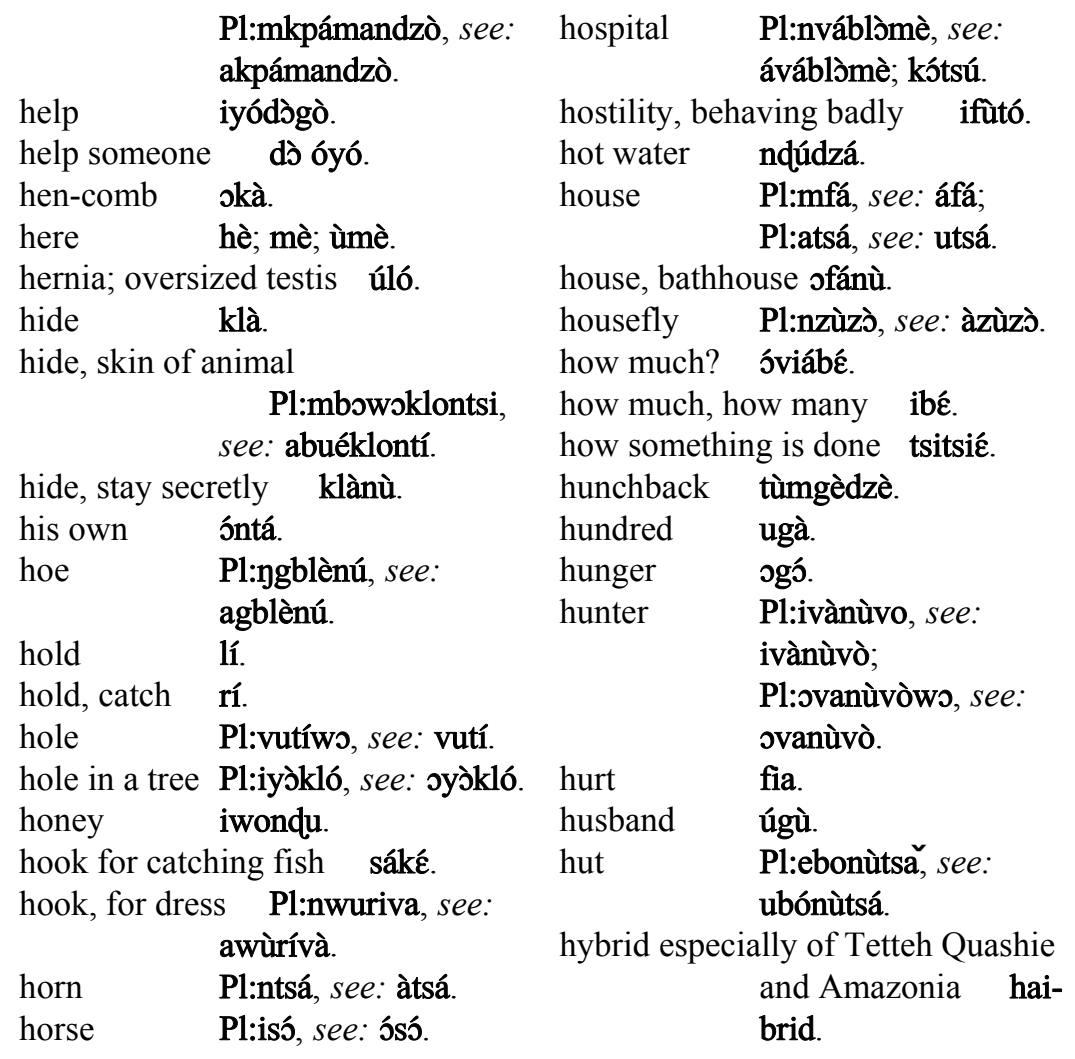

\section{I - i}

$\begin{array}{ll}\text { identify } & \text { kà ányí. } \\ \text { idol } & \text { Pl:mmó, see: amò; } \\ & \text { légbá. }\end{array}$

ill-treat a child gbòmògbòmò.

immature, unripe, premature, impure blood ongó.

immature yam spánshiá.

immediately tàdzè kò.

important vévé.

important thing ivàvévé.

in addition to that dò.

incomplete endengle.

indef. something not known okpié.

indegene dzòlèafé.

indiscipline ihánágò. inform tátá.

inheritance udíme.

insect ivàflégo.

insect that causes blindness ovókpó.

insects that destroy cocoa pod

sákúnábé.

instal kà.

instrument for blowing air into fire

tínítìnì.

instrument for grating cassava ag-

belìlì idá.

instrument for plucking cocoa

Pl:nsósó, see:

asósó; kokobídá; spé. 


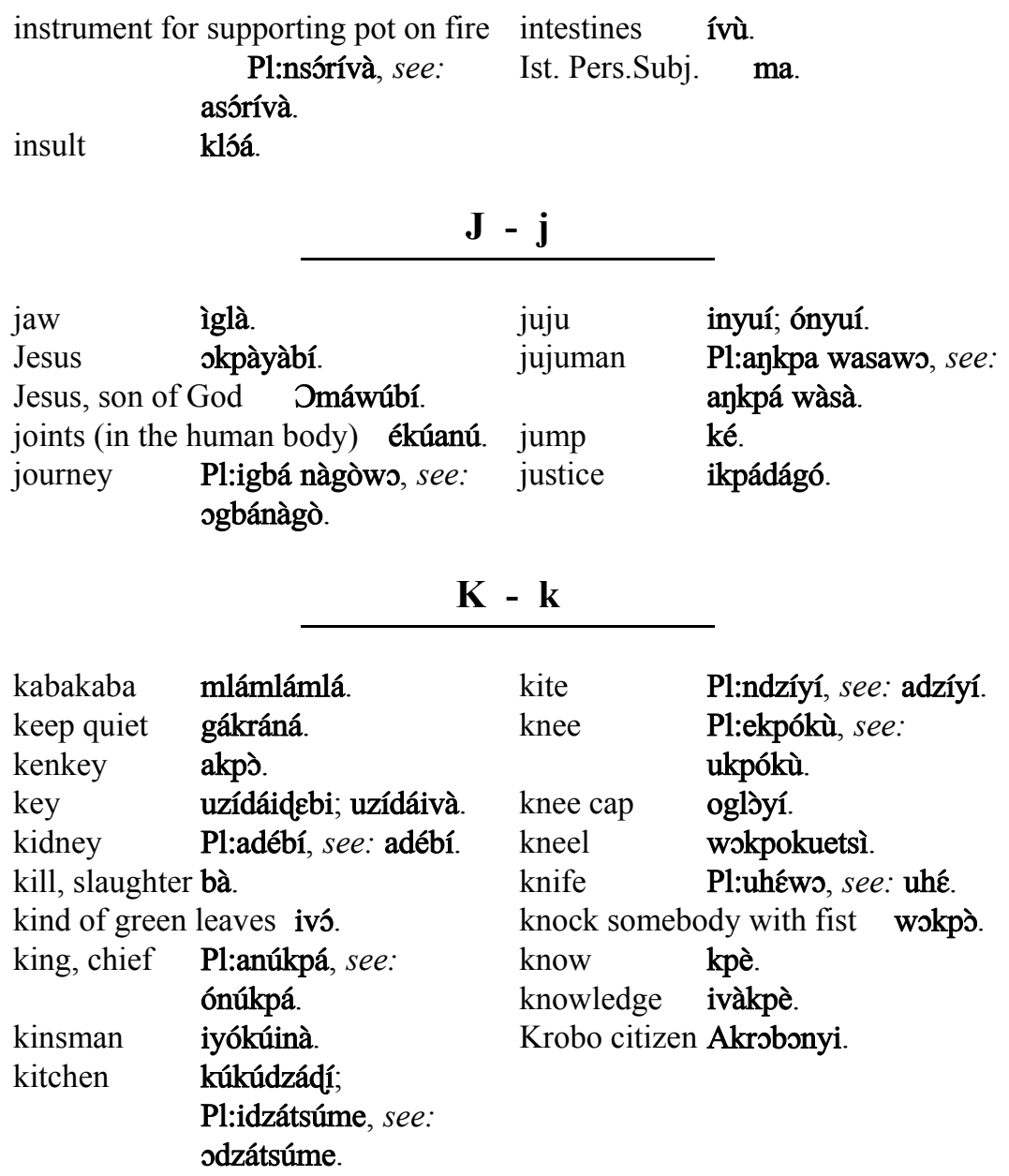




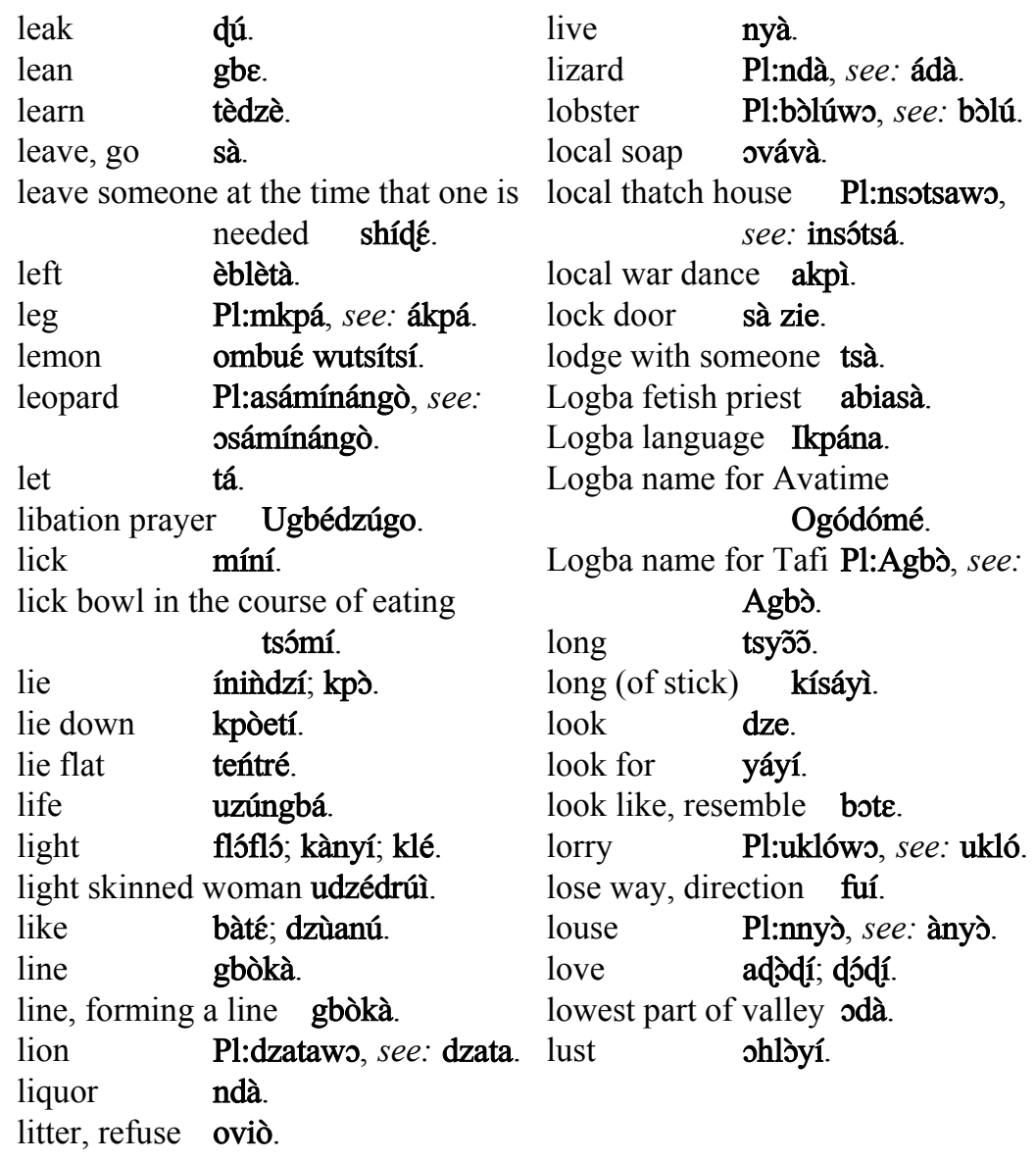

M - m

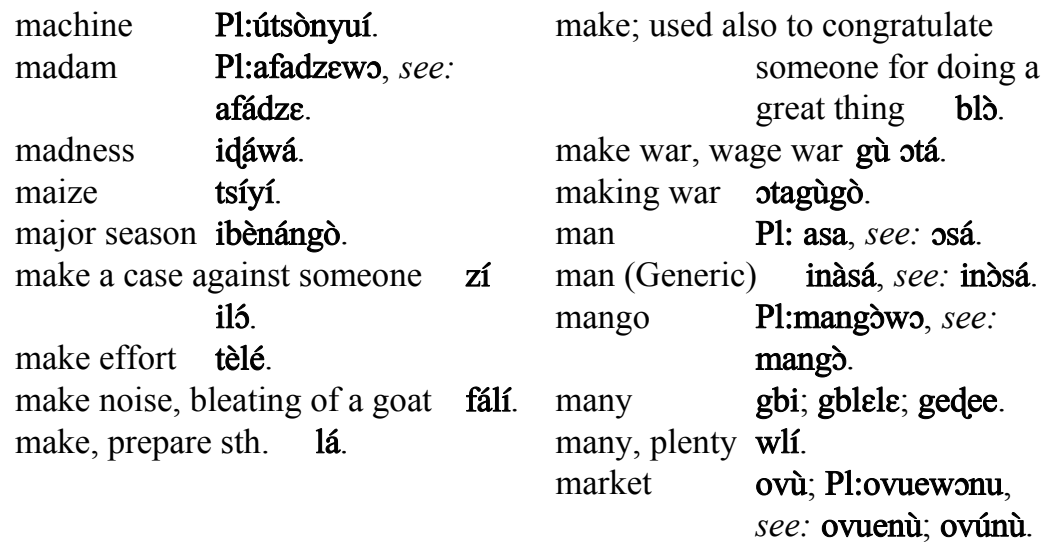




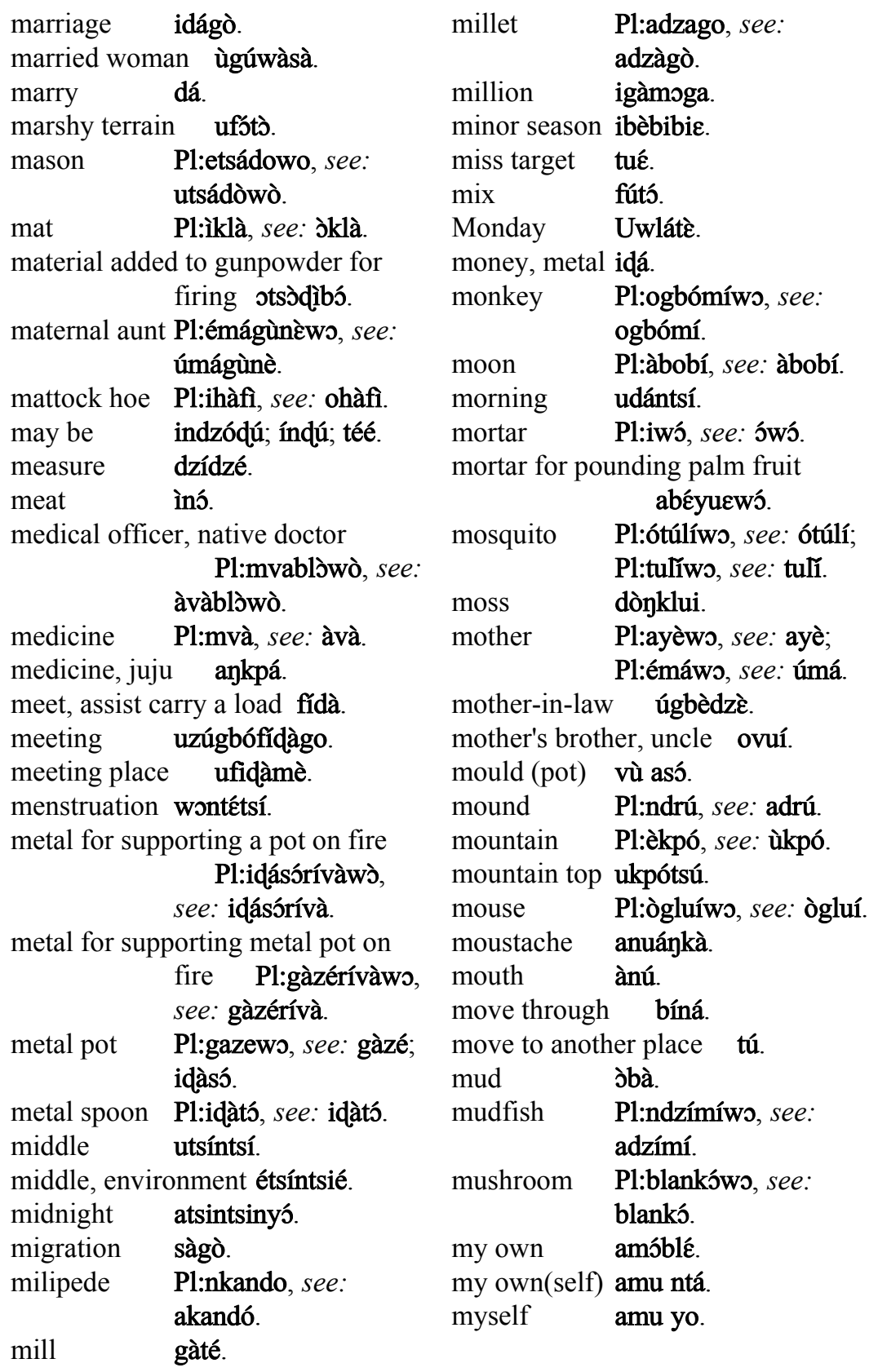




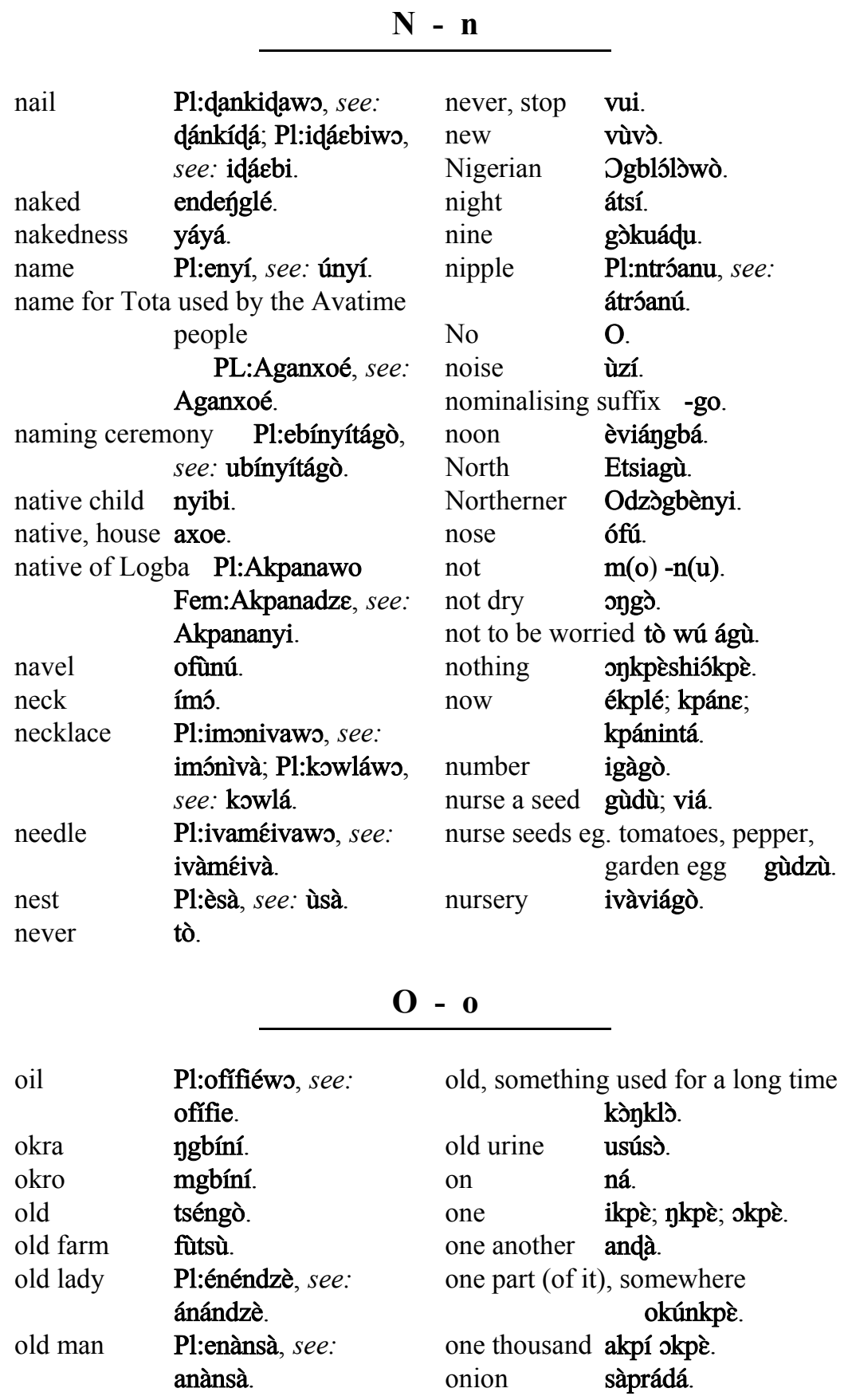




\begin{tabular}{|c|c|c|c|}
\hline onlooker & $\begin{array}{l}\text { Pl:ivàdzèwòwò, see: } \\
\text { ivàdzèwò. }\end{array}$ & $\begin{array}{l}\text { our own } \\
\text { outdooring }\end{array}$ & $\begin{array}{l}\text { atsú oblé; atu ntá. } \\
\text { labídonyui. }\end{array}$ \\
\hline only & dzaa; ko. & outside & ónywí; j̀dzògbè. \\
\hline open & bú; c & noked & kányì. \\
\hline opener & udáì & over & tsítsì. \\
\hline or & alo. & owl & Pl:nzye, see: onjie; \\
\hline orange & 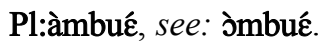 & & Pl:inzie, see: onzie. \\
\hline ordinal suffix & lber -blé. & ow & blé; nta; ny \\
\hline organ & sàn & owner & wàsà. \\
\hline origin, source & gùn & owner of & aurant ba \\
\hline
\end{tabular}$$
\mathbf{P}-\mathbf{p}
$$

\begin{tabular}{|c|c|c|}
\hline pain afiá. & part & sègè; uváfó. \\
\hline pain, suffering ofû. & pass & vè. \\
\hline air of spectacles gànkú. & PAST PROG. & ASP. suffix \\
\hline $\begin{array}{l}\text { lm branch Pl:ngànyì, see: agànyì; } \\
\text { invlá. }\end{array}$ & $\begin{array}{l}\text { past time } \\
\text { paste }\end{array}$ & $\begin{array}{l}\text { ebiábè. } \\
\text { klá. }\end{array}$ \\
\hline palm door mat óká. & paternal aunt & Pl:etású, see: tású. \\
\hline frond ogànyì. & paternal uncle & Pl:etisà, see: utísà. \\
\hline 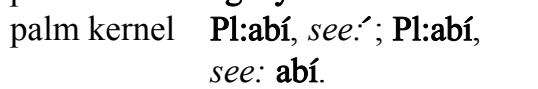 & pawpaw & $\begin{array}{l}\text { P1:bàfúnúbáwo, see: } \\
\text { bàfúnúbá. }\end{array}$ \\
\hline lm kernel oil Pl:abîofie, see: & pay & gà (ugú). \\
\hline $\begin{array}{c}\text { abíofifie. } \\
\text { lm kernel shell Pl:abifo, see: }\end{array}$ & peace & $\begin{array}{l}\text { iyóyú. } \\
\text { ility kìsèkỳsèkỳsè }\end{array}$ \\
\hline $\begin{array}{l}\text { lm kernel shell Pl:abifo, see: } \\
\text { abífó. }\end{array}$ & peace, tranqui & ility kùsèkùsèkùsè. \\
\hline $\begin{array}{l}\text { abito. } \\
\text { mat on which cocoa is dried } \\
\text { blekété. }\end{array}$ & $\begin{array}{l}\text { pear } \\
\text { pebble } \\
\text { peel cassava }\end{array}$ & $\begin{array}{l}\text { Pl:peya, see: peya. } \\
\text { egbètàtsì. } \\
\text { vlò. }\end{array}$ \\
\hline $\begin{array}{ll}\text { palm (of hand) ntátsí. } \\
\text { palm oil nfú. } \\
\text { palm-chaff ibísà. }\end{array}$ & $\begin{array}{l}\text { peel, remove } \\
\text { peel vam, rem }\end{array}$ & $\begin{array}{l}\text { cocoa pod for the } \\
\text { beans fónyí. } \\
\text { hove outer cover kpè. }\end{array}$ \\
\hline palm-husk ibíkpà. & pen; thing for & writing Pl:ivanonyi \\
\hline abéndà; obéndà. & & ivànònyì oyòtsì. \\
\hline $\begin{array}{l}\text { Pl:mgbòté, see: } \\
\text { agbòté. }\end{array}$ & $\begin{array}{l}\text { penis } \\
\text { pepper }\end{array}$ & $\begin{array}{l}\text { ísá. } \\
\text { tònká. }\end{array}$ \\
\hline $\begin{array}{l}\text { paramount chief Pl:anúkpă nángò, } \\
\text { see: onúkpá nángò; } \\
\text { onuknánangò }\end{array}$ & performers of & $\begin{array}{l}\text { puberty rites } \\
\text { abàbléfewò. } \\
\text { Pl-ahá see. ìnà }\end{array}$ \\
\hline $\begin{array}{l}\text { Pl:nkàtàmá, see: } \\
\text { akàtàmá. }\end{array}$ & Person from $Y$ & $\begin{array}{l}\text { Yoruba land } \\
\quad \text { P1:Alatawo, see: }\end{array}$ \\
\hline awówòe. & & Alata. \\
\hline Pl:akówo, see: akó & person, hum & $\mathrm{n}$ being inàdzengò. \\
\hline
\end{tabular}




$\begin{aligned} & \text { person who has insatiable desire for } \\ & \text { sweets mbówàsà. }\end{aligned}$
$\begin{array}{ll}\text { person who works in the company } \\ \text { that buys cocoa and } \\ \text { coffee báyá. }\end{array}$
$\begin{array}{ll}\text { pestle } & \text { Pl:iwòbí, see: owòbí. } \\ \text { picture } & \text { Pl:ivatagòwo, see: } \\ \text { ivatagò. }\end{array}$
$\begin{array}{ll}\text { piece of cracked calabash } \\ \text { pierce } & \text { sú; wófét. } \\ \text { pig } & \text { Pl:ihà, see: shà. } \\ \text { pineapple } & \text { Pl:atandrewo, see: } \\ \text { atándré. }\end{array}$
pipe for smoking tobacco
Pl:angbluewo, see: aygblue.
pit latrine 'usòntà. place okú; wá. place in a cocoa farm odó. place where cases are settled ilówáme.

place where cocoa is weighed gadamè. place where dirges are sung edítàfâ. place where something is placed kámè; kpómé. porridge Pl:mvù, see: avù.

porridge made for babies entsì.

porridge made from local rice amúávú.

position a person hols in a society úlémé.

possession $\quad \mathrm{Pl}$ :ivànyágòwo, see: ivànyágò.

pot Pl:nsó, see: ásó.

pot buried in the bath-house for

pot for storing drinks bathing iyógùasó. Pl:ndágùasó, see: ndágùásó.

pot for storing potable water

Pl:udzubiwo, see: udzùbí.

pot stand Pl:zenklawo, see: zénklǎ.

poultry house ankósálìmè.

pound (in a mortar) yué.

pour dódù; glà; gù.

pour, liquid. drop on ntó.

pour out dóvù.

poverty j̀zyá.

pray dzùgbè; kóm.

prayer, calling God skpàyàdzìgo.

praying mantis gbénıgbé.

pregnant woman améwasà.

preparation of a local porridge

kókólágò.

PRES. PROG. ASP suffix -lo.

present time blànyé.

press bó.

pressing iron $\mathrm{Pl}$ :ivàtúnáivà, see: ivàtúnáivà.

prick wó.

pubic hair $\quad \mathrm{Pl}$ :afúnùimúnyí, see: afúnùimúnyí.

public assembly ground otwénù. puff adder Pl:bewo, see: bé. pull hè.

push tǒlé; tòntá.

put kà. 
put a pot under a felled palm tree for putting cocoa beans in a sack wine to drip into it.

kòkòakpòfégò.
tว̀.
python
Pl:otsófiwo, see:

put cloth on númá. otsófi.

put in $\quad \mathbf{\varepsilon}$.

put on (cloth) gbá (afútà).

\begin{tabular}{llll} 
& & $\mathbf{Q}-\mathbf{q}$ & \\
\cline { 3 - 4 } & & & kráná. \\
quantity & ashiánú. & quiet & kráná. \\
quarrel & ayùnyì. & quietly & kpóo. \\
question word & naá. & &
\end{tabular}

$\mathbf{R}-\mathbf{r}$

\begin{tabular}{|c|c|c|}
\hline rag used for $\mathrm{c}$ & $\begin{array}{l}\text { Pl:mfútàtsi, see: } \\
\text { afútàtsì. } \\
\text { arring load udzí. }\end{array}$ & $\begin{array}{l}\text { remove something, harvest eg. pep- } \\
\begin{array}{ll}\text { per kpítsí. } \\
\text { reply } & \text { iyónágo. }\end{array}\end{array}$ \\
\hline rainbow & odzúlégò. & reserve something \\
\hline season & $\begin{array}{l}\text { nyàngbò; } \\
\text { nyàngbònògò. } \\
\text { nyàngboìbè. }\end{array}$ & $\begin{array}{ll}\text { residence } & \text { Pl:ókuewo, see: ókue. } \\
\text { respect } & \text { 'bù; téní ìnà. } \\
\text { return } & \text { dzú; dzúzó. }\end{array}$ \\
\hline ashes, lumps & on the skin ngbò. & return (away from the speaker) \\
\hline $\begin{array}{l}\text { rat } \\
\text { reach }\end{array}$ & $\begin{array}{l}\text { Pl:nléléwっ, see: àlélé. } \\
\text { fô. }\end{array}$ & $\begin{array}{l}\text { dzúsà. } \\
\text { o speaker dzúbà. }\end{array}$ \\
\hline ach the requ & lired number fló. & ayànà. \\
\hline ealise & $\begin{array}{l}\text { kon. } \\
\text { kanyi. }\end{array}$ & $\begin{array}{l}\text { Pl:ajàyàkúwò, see: } \\
\text { ayànàkú. }\end{array}$ \\
\hline eally & kpintá. & adzòkloyì; ímbí. \\
\hline$d$ & druí; druyi. & rich man \\
\hline ed ant found & in the ground ofúntsù. & idzòwà. \\
\hline ed ants; liv & $\begin{array}{l}\text { in fruit trees. } \\
\text { gbèdzègbèdzè. }\end{array}$ & $\begin{array}{l}\text { Pl:ndrǔ kisai, see: } \\
\text { adrú kisai. }\end{array}$ \\
\hline red clay for re & enovating the hearth & right \\
\hline & & right (side) \\
\hline ed pad worn & by women vuǹkpá. & Pl:isíkpé, see: isíkpé. \\
\hline $\begin{array}{l}\text { ed porridge } \\
\text { educe canop }\end{array}$ & & $\begin{array}{l}\text { ringworm } \\
\text { rise }\end{array}$ \\
\hline refuse & trò & Pl:odzúwo, see: ódzú. \\
\hline remain & wù. & River in Logba Adò; Òdzùfi. \\
\hline $\begin{array}{l}\text { emember } \\
\text { emove }\end{array}$ & $\begin{array}{l}\text { nányí. } \\
\text { là; yé; yí. }\end{array}$ & $\begin{array}{r}\text { river in Logba Tota through Klikpo } \\
\text { and enters the Havor }\end{array}$ \\
\hline & c & $\begin{array}{ll} & \text { river Ányò. } \\
\text { stream ndúkpálígo. }\end{array}$ \\
\hline
\end{tabular}




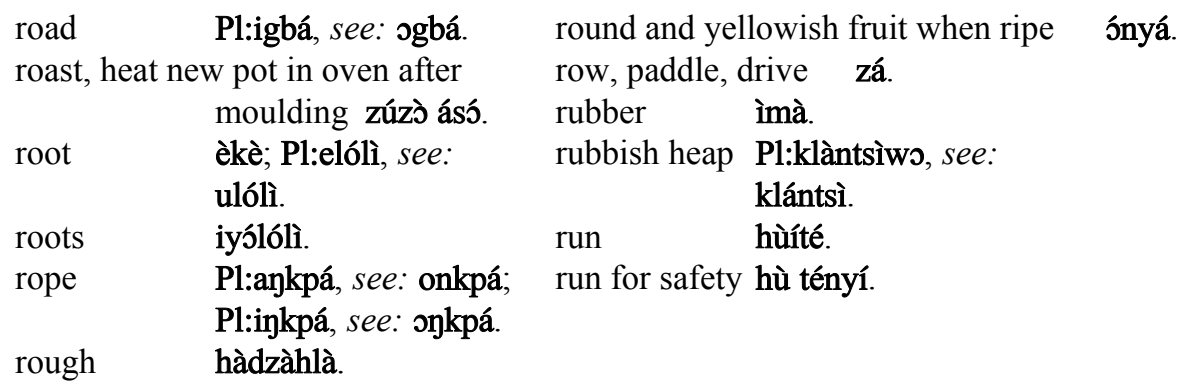

S - s

\begin{tabular}{|c|c|c|c|}
\hline $\begin{array}{l}\text { sadness } \\
\text { salary, wage }\end{array}$ & $\begin{array}{l}\text { Pl:kòtòkúwo, see: } \\
\text { kòtòkú. } \\
\text { iyógbè. } \\
\text { úgúgà. }\end{array}$ & seive & $\begin{array}{l}\text { Pl:nsoć, see: asoć; } \\
\text { Pl:sànúwo, see: sànú; } \\
\text { tsùrò. } \\
\text { tsyé. }\end{array}$ \\
\hline saliva & àtsòlí. & \multirow{2}{*}{\multicolumn{2}{|c|}{$\begin{array}{l}\text { self realisation } \\
\text { self realization }\end{array}$}} \\
\hline salt & uméntà. & & \\
\hline sand & Pl:mfièyì, see: infièỳ̀. & sell & zò. \\
\hline \multicolumn{2}{|c|}{ sandals for farm } & send & tòlé. \\
\hline & ubónùkpíákpívà. & set fire & tsú odzá. \\
\hline sandpit & infièyìgbàr & set trap & kà. \\
\hline Saturday & Áyádzí. & \multicolumn{2}{|c|}{ settlement, division obòmè. } \\
\hline say & té. & seven & glànクkpe. \\
\hline \multirow{2}{*}{\multicolumn{2}{|c|}{$\begin{array}{l}\text { say, speak, tell someone something } \\
\text { wà. }\end{array}$}} & sew & mé. \\
\hline & & shed & àkpàntà. \\
\hline scale & ivàdaivà; skeli. & sheen & kpányígbè. \\
\hline \multicolumn{2}{|c|}{$\begin{array}{ll}\text { scent of something } & \text { ilàlí. } \\
\text { school compound } & \text { sùkùkpoétsú. }\end{array}$} & sheep & $\begin{array}{l}\text { Pl:nfêshìwò, see: } \\
\text { èfêshì. }\end{array}$ \\
\hline school fees & sùkùgú. & she-goat & Pl:mbúdze, see: \\
\hline si & kàmpé; & & abúdze. \\
\hline & $\begin{array}{l}\text { Pl:uzúgbógbàivàwo, } \\
\text { see: uzúgbógbàivà. }\end{array}$ & $\begin{array}{l}\text { shine } \\
\text { shoe }\end{array}$ & $\begin{array}{l}\text { klé. } \\
\text { Pl:mfokpá, see: }\end{array}$ \\
\hline scorpion & $\begin{array}{l}\text { Pl:agánćwo, see: } \\
\text { agáné; Pl:nlá, see: alá. }\end{array}$ & & $\begin{array}{l}\text { afôkpá; Pl:nkpívà, see: } \\
\text { ákpívà. }\end{array}$ \\
\hline scythe & Pl:ntsìnì, see: átsìnì. & shoot & tá. \\
\hline seamstress & ivàmèwò. & short (of stick) & kpóntì. \\
\hline search & téfé. & shoulder & Pl:abúkpa, see: \\
\hline season & ibè. & & abúkpá. \\
\hline see & yú. & shoulder bone & Pl:abukpákú, see: \\
\hline $\begin{array}{l}\text { seed } \\
\text { seed yam }\end{array}$ & $\begin{array}{l}\text { Pl:ivebiwo, see: ivèbí. } \\
\text { idzózúgbó. }\end{array}$ & $\begin{array}{l}\text { shout } \\
\text { showing off } \\
\text { shrink }\end{array}$ & $\begin{array}{l}\text { abukpákú. } \\
\text { fézí. } \\
\text { víví. } \\
\text { dónù. }\end{array}$ \\
\hline
\end{tabular}




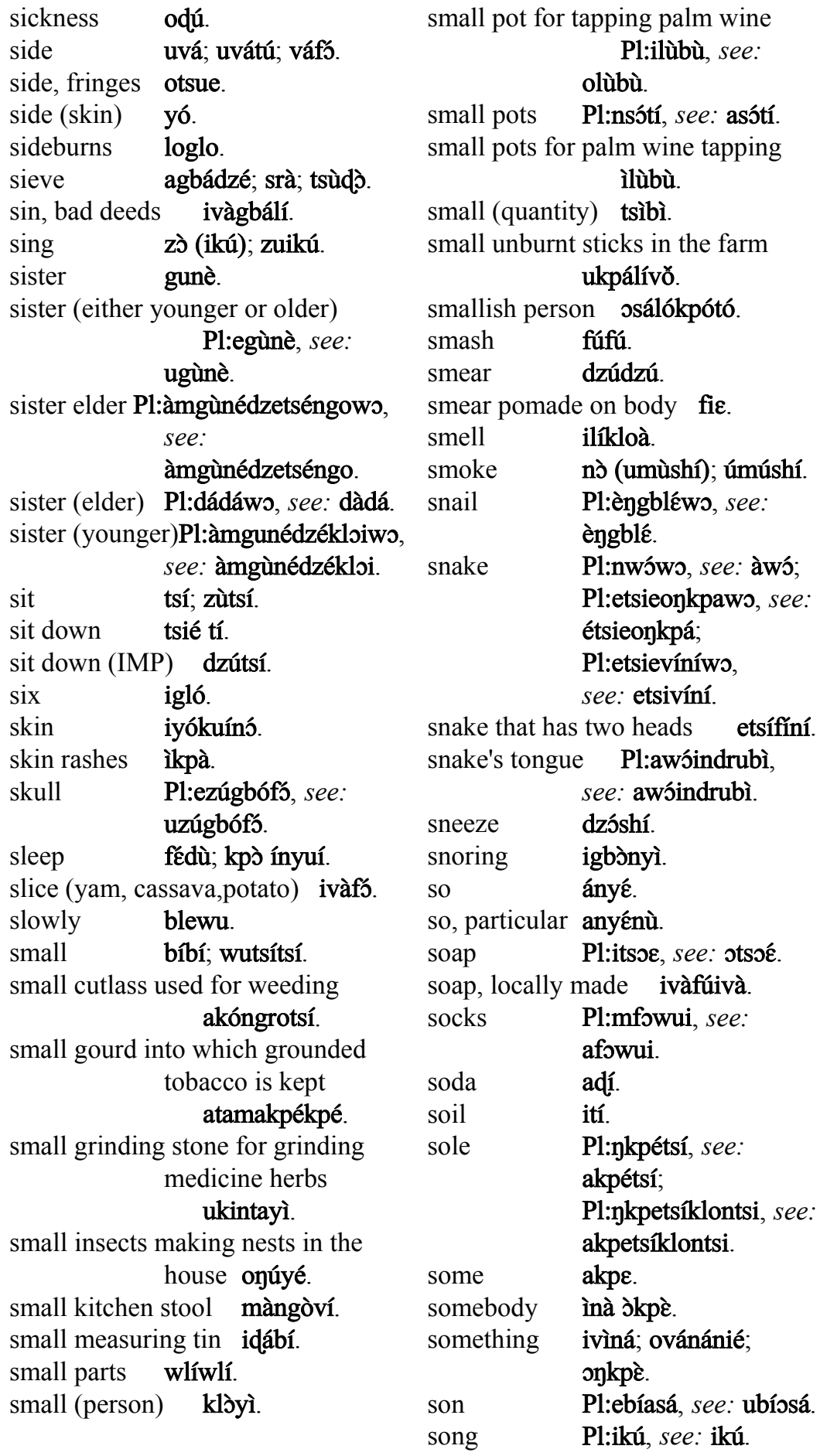


sore, wound in the toenail

Pl:itutolìwo, see: itutolì.

sound dzù

soup fútsú.

South Etsíetsí.

sow (seeds in a hole) dù ivà.

space in front skúanú.

speakers of other dialects

Pl:afiáwo, see:

afiáwo.

spear ígbè.

spectacle $\quad \mathrm{Pl}$ : otsíntsíwo, see: otsíntsí.

spectacles otsíntsǐ.

speech

sperm

spices

spider

spider's web

Pl:alágà, see: alágà.

ósá.

opépré.

Pl:ngbíglomò, see:

agbíglomò.

Pl:ygbìfútà, see:

agbìafútà; $\mathrm{Pl}:$ gbímà, see: agbímà.

spit

split tsuatsòlí.

spoil

klé.

sponge

sponge dish

spread

vúvó.

วtsวensã.

otsózgo.

kèkè.

sprinkle, broadcast a seed yùnyá.

squat

tsìdzóndzó.

squirrel

P1:kàsàníwo, see:

kàsàní.

stand dzí; dzuídé; yé.

stand erect itítè.

star

Pl:àtàwòlìbíwo, see: àtàwólíbí.

start dze; tsonyui.

stay, be in

bò.

stay (completive)

nyá.

stay in, sit tsí.

steal yúdó.

stealing oyúyúdógò.

step over sth. fámvè.

sth. fall and lying down gbógbè.

sth. you have not paid for ubá. stick, cane Pl:iyoti, see: oyótì.

stick for playing talking drum

P1:ykpítágò, see:

$$
\text { akpítágò. }
$$

sticky gonií.

sting (bee, ant, scorpion) tá.

sting of bees íwòtsò.

stink kluá.

stir blù.

stir (palm oil) hòdò.

stomach àmènù.

stomach-ache amenfiá.

stone égbè.

stop doing something vuí.

store ivàzòtsá.

story Pl:ogrídíwo, see:

ogrídí.

straight teè.

strainer Pl:mfié, see: afié.

stream odzúvlèntsí.

strength ìntsé.

strong local gin kpètèshì.

stumble kpítá.

stump Pl:iyótsìgbó, see:

oyótsìgbó.

suck di.

suck breast númá.

suddenly kpàtà; ogbádzèmódzè.

sun èví.

Sunday Uwló.

support what is being said

swallow mé.

otsyòdîbó.

swear dzì ivà; ta (i)va.

sweat ufiàlì.

sweep gbà.

sweet ondzí.

swell vúmá.

swell ( intr.) of boil ivúmá.

swelling in the groin skà.

swim là (ndu). 


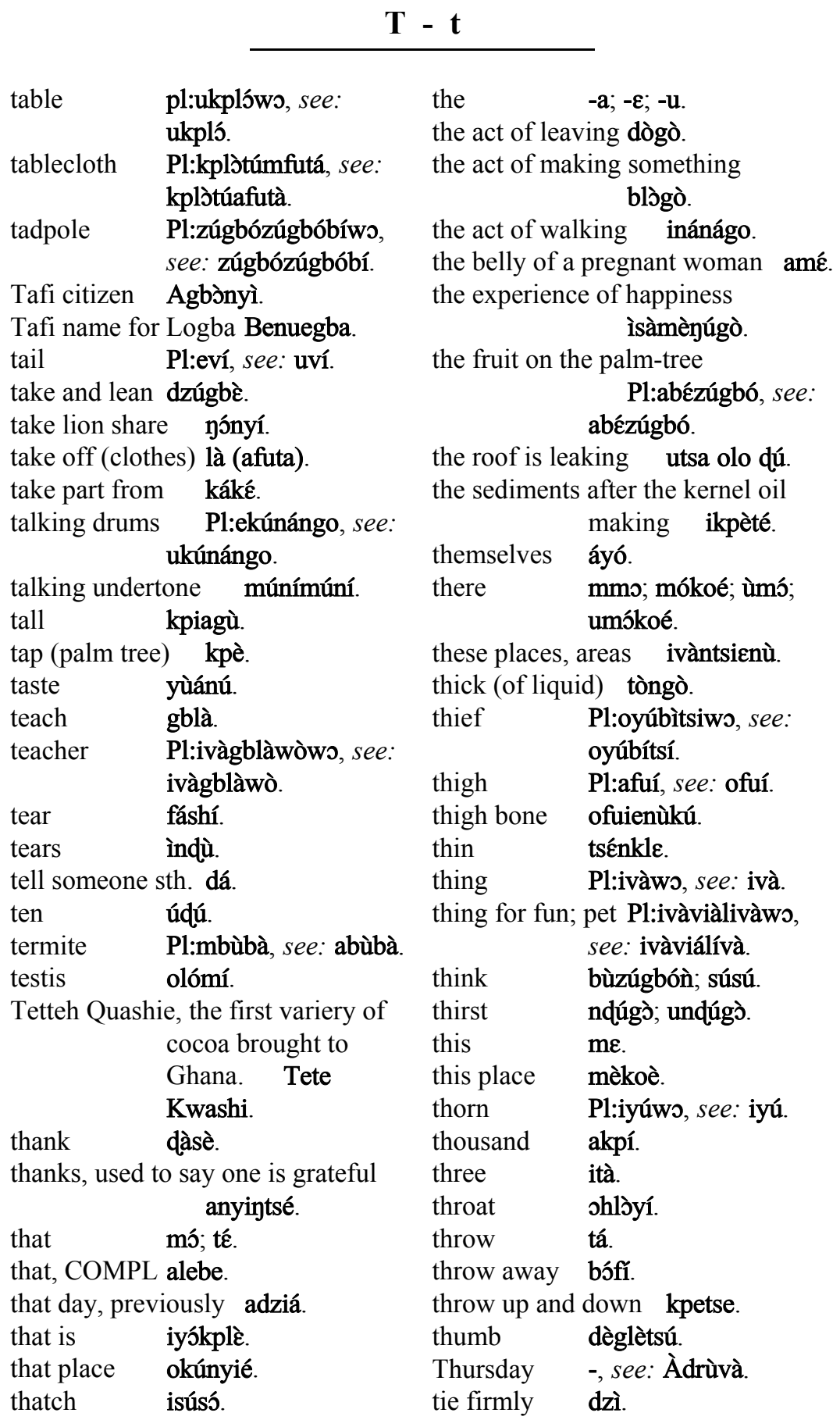




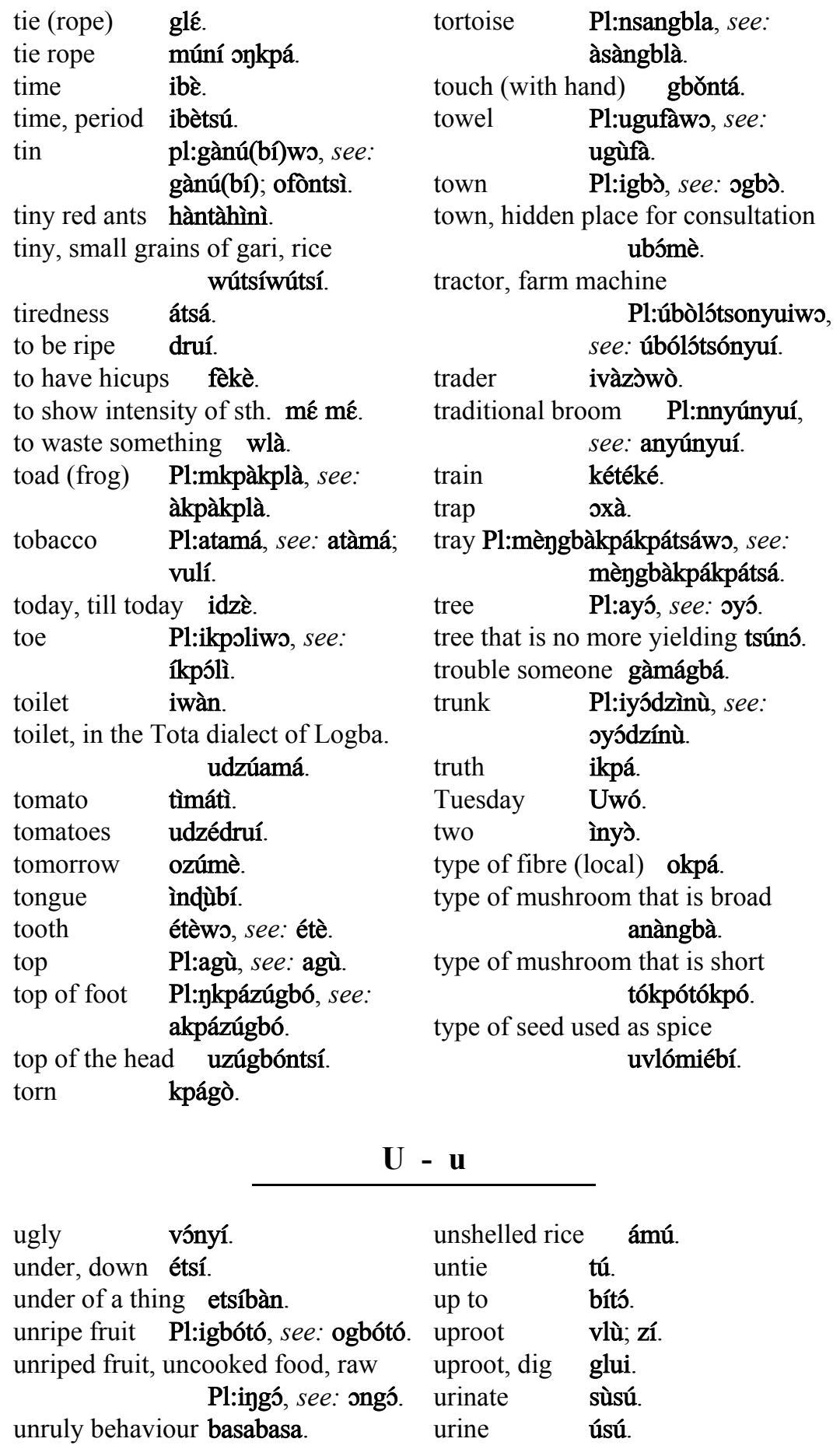


use, take mì.

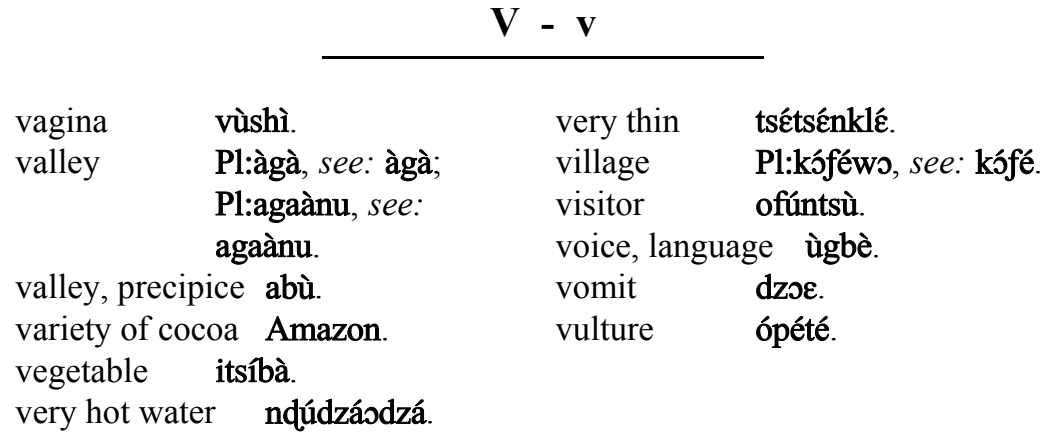

\begin{tabular}{|c|c|c|}
\hline \multicolumn{2}{|c|}{$\mathbf{W}-\mathbf{W}$} & \multirow[b]{2}{*}{ pró. } \\
\hline odóntí. & wet & \\
\hline yéyé. & what & mé. \\
\hline wait for a person yídé. & where & mènù. \\
\hline wake & whistle & fíní fîfîndù. \\
\hline íná; nà. & white & flíyì. \\
\hline wall (of a house) Pl:àglì, see: àglì. & whiteman & yòvúnyì. \\
\hline $\begin{array}{ll}\text { war } & \text { ótá. } \\
\text { wash a sore } & \text { zia. }\end{array}$ & whitewoman & $\begin{array}{l}\text { Pl:yóvuwòedze, see: } \\
\text { vóvúdzè. }\end{array}$ \\
\hline wash (body) gù (iyó). & whitlow & ivàgbálí. \\
\hline wash (thing), clean fô (ivà). & why & mókplè. \\
\hline isíníbá. & wife, spouse & Pl:ágà, see: ógà. \\
\hline watch closely rí ányíná. & wind & ofûfô. \\
\hline water & wind, tie sth $r$ & round bálá. \\
\hline water yam & window & Pl:fésréwo, see: fésré. \\
\hline $\begin{array}{l}\text { watery stool ikpètèivá. } \\
\text { wave (hands) húhú ágbàsì. }\end{array}$ & wing & $\begin{array}{l}\text { Pl:obúmbàwo, see: } \\
\text { obúmbà. }\end{array}$ \\
\hline way, process étsíné. & winnow, remc & oving chaff from maize \\
\hline wear eg. dress fé. & & and beans vlí. \\
\hline wear eg. hat bua. & wire used as a & a trap for animals \\
\hline weave (cloth) lò (afuta). & & kpántráìtsì. \\
\hline $\begin{array}{l}\text { weave, plait hair lò imunyi. } \\
\text { weave thread, knit víní. }\end{array}$ & witch & $\begin{array}{l}\text { Pl:ndzewasa, see: } \\
\text { adzewàsà. }\end{array}$ \\
\hline $\begin{array}{l}\text { Wednesday Màmblìwó. } \\
\text { weed, clear farm lò. }\end{array}$ & woman & $\begin{array}{l}\text { Pl:edzé, see: ìnàdzé; } \\
\text { Pl: cdzé, see: udzé. }\end{array}$ \\
\hline $\begin{array}{ll}\text { week } & \text { kosidá. } \\
\text { weep, cry } & \text { yuédí. } \\
\text { well } & \text { énzí. }\end{array}$ & wooden instru & $\begin{array}{l}\text { ument for grinding in a } \\
\text { bowl Pl:tapoliwo, } \\
\text { see: tàpòlì. }\end{array}$ \\
\hline well-cooked bè. & wooden laddl & e Pl:ivàzàtó, see: \\
\hline Eviègbef'́mè. & & ivàzàtó. \\
\hline
\end{tabular}




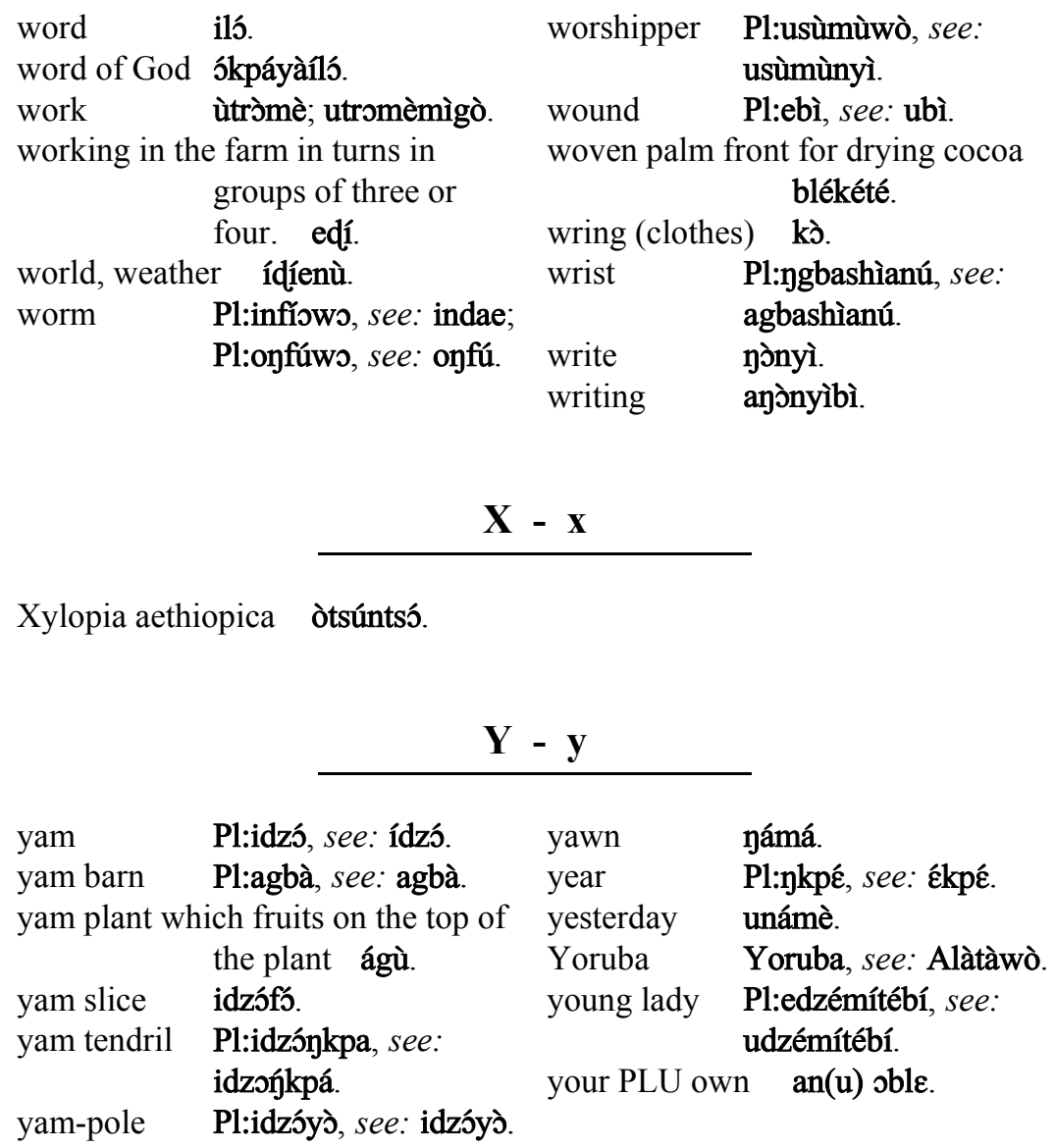




\section{REFERENCES}

Agbedor, Paul. (1994) Verb serialization in Ewe. Nordic Journal of African Studies 3: $21-42$

Aikhenvald, Alexander Y. (2000) Classifiers: a typology of noun categorization devices. Oxford: Oxford University Press.

Ameka, Felix K. (1986) The use and meaning of selected particles in Ewe. MA Thesis, Australian National University, Canberra

Ameka, Felix K. (1991) Ewe: its grammatical constructions and illocutionary devices. $\mathrm{PhD}$ Thesis, Australian National University, Canberra

Ameka, Felix K. (1992) Focus constructions in Ewe and Akan: a comparative perspective In: Proceedings of the Kwa comparative syntax workshop MIT 1992 MIT Working Papers in Linguistics 17 Collins, Chris and Victor Manfredi eds. pp. 1-25 Cambridge MA: MIT Dept. of Linguistics and Philosophy

Ameka, Felix K. (1998) Les particules énonciatives en Ewe [Utterance particles in Ewe]. In: Les langues d'Afrique Subsaharienne. S. Platiel and R. Kabore, eds. pp. 179-204. Faits de Langues 11-12. Paris: Ophrys.

Ameka, Felix K. David Wilkins and Carlien de Witte (1999) Picture Series for Positional Verbs: Eliciting the verbal component in locative descriptions. In 'Manual' for the 1999 field season. David Wilkins. ed. (For the Language and Cognition Group) pp. 48-56 Nijmegen: MPI for Psycholinguistics.

Ameka Felix K. (2005) Multiverb constructions in a West African areal typological perspective. Proceedings of the Trondheim Summer School in Linguistics. Dorothea Beermann \& Lars Hellan eds. Available at

http://edvarda.hf.ntnu.no/ling/tross/TROSS03-toc.html (consulted 22 ${ }^{\text {nd }}$ October, 2007).

Ameka, Felix K. (2006) Ewe serial verb constructions in their grammatical context In: Serial verb constructions. A cross-linguistic typology. Aikhenvald A Y \& RMW Dixon eds. pp. 124-141. Oxford: Oxford University Press.

Ameka, Felix K. (to appear) Information packaging in Kwa: micro-variation and typology. In Studies in Kwa syntax. Enoch Aboh \& James Essegbey eds. Dordrecht: Kluwer Publishers.

Ameka, Felix K. \& James Essegbey (2006) Elements of the grammar of space in Ewe. In: Grammars of space Stephen C. Levinson and David Wilkins eds. pp. $359-$ 398. Cambridge: Cambridge University Press. 
Ameka, Felix K. \& M. E. Kropp Dakubu (in press) Introduction: In: Aspect and Modality in Kwa eds. Felix K. Ameka \& M. E. Kropp Dakubu Amsterdam: John Benjamins

Amenumey, D.E.K. (1986) The Ewe in pre-colonial times. Accra: Sedco Publishing.

Anderson, Stephen (1985) Inflectional morphology In: Language typology and syntactic description Vol.111: Grammatical categories and the lexicon. Timothy Shopen ed. pp. 150-201 Cambridge: Cambridge University Press.

Bearth, Thomas (1999) The contribution of African linguistics towards a general theory of focus: update and critical review Journal of African Languages and Linguistics. 20: 121-156

Bertho, R. P. (1952) Les dialectes du Moyen-Togo. Bulletin de I'IFAN, B, 14:10461107.

Bhat, D.N.S. (1994) The adjectival category - criteria for differentiation and identification. Amsterdam: John Benjamins

Blench, Roger (2001) What have we learnt since Heine? Paper presented at the $32^{\text {nd }}$ Annual Conference on African Linguistics and subsequently revised. Berkeley, $23^{\text {rd }}-25^{\text {th }}$ March 2001.

Blench, Roger (2006) Do the GTM languages constitute a genetic group and if so, what is the evidence? Paper presented at the International Workshop on the Description and Documentation of the GTM Languages. July 24-29, 2006. Bishop Konings Social Centre, Ho Ghana.

Bodomo, Adams (2002) The syntax of serial verbs in Dagaare. In: New directions in Ghanaian linguistics Felix.K Ameka \& E.Kweku Osam eds. pp. 27-53. Accra: Black Mask

Bouquiax, Luc \& Jaqueline M.C Thomas (1992) Studying and describing unwritten languages. Dallas: Summer Institute of Linguistics

Bowerman Melissa \& Eric Pederson (1993) Topological Relations Pictures Series. In: Manual for the space stimuli kit 1.2. Eve Danziger and Deborah Hill eds. pp. 40-50 Nijmegen: Max Planck Institut für Psycholinguistik, Cognitive Anthropology Research Group

Breedveld, J.O. (1995) Form and meaning in Fulfulde: a morphological study of Maasinankoore. Leiden: Research School CNWS

Carlson, Robert (1994) A grammar of Supyire. Berlin and New York: Mouton de Gruyter 
Casali, Rod F. (2003) [ATR] value asymmetries and underlying vowel inventory structure in Niger-Congo and Nilo-Saharan. Linguistic Typology 7.3: 307-382.

Chafe, Wallace (1976) Givenness, contrastiveness, definiteness, subjects and topics In: Subject and topic C.N. Li ed. pp. 25-55. New York: Academic Press.

Clements, G. Nick (2000) Phonology In: African languages. an introduction. Bernd Heine and Derek Nurse eds. pp.123-160. Cambridge: Cambridge University Press.

Comrie Bernard \& Norval Smith (1977) Lingua Descriptive Studies Questionnaire. Lingua 42: 1-72.

Comrie, Bernard \& Sandra A. Thompson, (1985) Lexical nominalisation In: Language typology and syntactic description Vol.111: Grammatical categories and the lexicon. Timothy Shopen ed. pp.349-396 Cambridge: Cambridge University Press.

Comrie Bernd, Edward L. Keenan (1979) Noun phrase accessibility revisited. Language: 55. 3:649 - 664

Croft, William \& Cruse, D. Allan (2004) Cognitive linguistics. Cambridge: Cambridge .University .Press.

Dakubu, M E Kropp (1981) One voice: the linguistic culture of an Accra lineage. Leiden: African Studies Centre

Dakubu, M.E. Kropp \& Kevin C. Ford (1988) The Central Togo languages. In: The languages of Ghana M.E. Kropp Dakubu ed. pp. 119-153 London: Kegan Paul International.

Dakubu, M.E, Kropp (2005) The syntax of focus in Ga and Akan and the significance of related constructions. Paper presented at the International Conference on "Focus in African languages" Humboldt University \& ZAS Berlin October 2005.

Dakubu, M. E. Kropp (2006) Pushing back linguistic time in the Trans-Volta: movement, assimilation and loss. Paper presented at the International Workshop on the Description and Documentation of the GTM Languages. July 24-29, 2006. Bishop Konings Social Centre, Ho Ghana. Available at http: //rogerblench. info/Language $\% 20$ data/NigerCongo/GTML $\%$ 20Website/HoWorkshop2006/Papers/(consulted 21st October, 2007)

Diesel, Holger (1999) Demonstratives: form, function and grammaticalization. Amsterdam: John Benjamins 
Dik, Simon C. (1997) The theory of Functional Grammar Part 1 The structure of the clause. Berlin: Mouton de Gruyter

Dik, Simon C. (1978) Functional Grammar. Amsterdam: North Holland

Dixon, R.M.W. (1997) The rise and fall of languages. Cambridge: Cambridge University Press.

Dixon, R.M.W. (2004) Adjective class in typological perspective In: Adjective classes. A cross-linguistic typology. R.M.W. Dixon and Alexander Y. Aikhenvald eds. pp. 1-45. Oxford: Oxford University Press.

Dixon, R.M.W. (2006) Complement clauses and complementation strategies in typological perspective In: Complementation: A cross-linguistic typology R.M.W. Dixon \& A.Y. Aikhenvald eds. pp.1-48. Oxford: Oxford University Press

Doke, Clement M (1935) Bantu linguistic terminology. New York: Longmans Green \& co.

Dolphyne, Florence A. (1988) The Akan (Twi-Fante) language: its sound systems and tonal structure. Accra: Ghana Universities Press..

Dolphyne, Florence A. (1987) On negating the consecutive verb in Akan. Journal of West African Languages. 19.1: 70-80

Dorvlo, Kofi (2004) A preliminary phonology of Logba. In: Studies in the Languages of the Volta Basin 2 M.E. Kropp Dakubu \& E.Kweku Osam eds. pp. 239-249 Legon: Department of Linguistics, University of Ghana.

Dorvlo, Kofi (2007) Serial verb constructions in Logba. In: Leiden Papers in Linguistics 4.2. Pepijn Hendiks, Felix Rau, Katerǐna Součkova, \& Jenneke van der Wal eds. pp. 1-16. Available at http://www.lucl.nl consulted $11^{\text {th }}$ November 2007 .

Dryer, Mathew S. (2006) Descriptive theories, explanatory theories and basic linguistic theory In: Catching language: the standing challenge of grammar writing Felix K. Ameka, Alan Dench \& Nicholas Evans eds. pp. 207 - 234. Berlin: Mouton de Gruyter

Durie, Mark (1997) Grammatical structures in verb serialization In: Complex predicates. Alex Alsina, Joan Bresnan \& Peter Sells, eds. Stanford: CSLI

Duthie, Alan S. (1996) Introducing Ewe linguistic patterns. Accra: Ghana Universities Press.

Egblewogbe, Eustace Y. (1992) The remnant concept and the distribution of Guan. Afrika und Übersee, 75: .43-57 
Essegbey, James (1999) Inherent complement verbs revisited. Towards understanding argument structure in Ewe PhD Thesis, Leiden University (MPI Dissertation Series)

Essegbey, James (2004) Iconicity and motion verbids In: Studies in the Languages of the Volta Basin 2 M.E. Kropp Dakubu \& E.Kweku Osam eds. pp. 24-35 Legon: Department of Linguistics, University of Ghana.

Essizewa, Komlan (2007) Kabiye-Ewe code-switching: classic code-switching or composite code-switching? A paper presented at a conference on Code-switching and West Africa: Theory and its implications. University of Ghana, Legon November $26-27,2007$.

Evans, Nicholas (to appear) Reciprocal constructions: Towards a structural typology In: Reciprocals and reflexives: cross-linguistic and theoretical explorations. Ekkerhard Konig \& Volker Gast eds. Berlin: Mouton de Gruyter

Greenberg, Joseph H. (1963) History and present status of the Kwa problem. In Actes du second colloque international de linguistique negro-africaine. M. Houis. G. Manessy, and S. Sauvageot, eds. pp. 215-217. Dakar: Université de Dakar and West African Languages Survey.

Greenberg, Joseph H. (1966) The languages of Africa. The Hague: Mouton for Indiana University.

Heine, Bernd (1968) Die Verbreitung und Gliederung der Togorestsprachen. Berlin: Dietrich Reimer

Heine, Bernd (1997) Cognitive foundations of grammar. New York / Oxford: Oxford University Press.

Heine, Bernd, Ulrike Claudi \& Friederike Hunnemeyer (1991) Grammaticalization: A conceptual framework. Chicago/London: The University of Chicago Press

Kemmer, Suzanne (1993) The middle voice. Amsterdam/Philadelphia: John Benjamins

Keenan, Edward L. (1985) Relative clauses. In: Language typology and syntactic description Vol.11: Complex constructions. Timothy Shopen ed. pp. 141-168. Cambridge: Cambridge University Press.

Keenan, Edward L \& Bernard Comrie (1977) NP accesibility and universal grammar Linguistic Inquiry 8:63-100

Ladefoged, Peter (1964) A phonetic study of West African languages. Cambridge: Cambridge University Press. 
Lefebvre, Claire \& Anne-Marie Brousseau (2002) A grammar of Fongbe. Berlin, New York: Mouton de Gruyter

Levinson Stephen C. \& David P. Wilkins eds. (2006) Grammars of space. Cambridge: Cambridge: Cambridge University Press.

Lewis Marshall (1985) Ewe relativization, NP Accessibility and Universal Grammar. Unpublished Essay, Indiana University, Bloomington

Lyons, John L. (1977) Semantics. Cambridge: Cambridge .University .Press.

McKinney, Carol V (2000) Globe-trotting in sandals: a field guide to cultural research, Dallas: SIL International

Noonan, Michael (1985) Complementation In: Language typology and syntactic description Vol.ll: Complex constructions. Timothy Shopen ed. pp. 42-138. Cambridge: Cambridge University Press.

Nugent, Paul (1997) Myths of origin and origins of myth: Politics and the uses of history in Ghana's Volta Region. Berlin: Das arabisch Buch

Nugent, Paul (2005) A regional melting pot. The Ewe and their neighbours in Ghana and Togo. In: The Ewe of Togo and Benin. Benjamin Lawrence ed. pp. 29-43 Accra: Woeli Publishing Services.

Osam, E. Kweku (2004) The Trondheim Lectures. An introduction to the structure of Akan: its verbal and multiverbal systems. Legon: Department of Linguistics, University of Ghana,

Payne, John R. (1985) Negation. In: Language typology and syntactic description Vol. I: Clause structure. Timothy Shopen ed. pp. 197-242 Cambridge: Cambridge University .Press.

Payne Thomas (1997) Describing morphosyntax: a guide for field linguists. Cambridge: Cambridge University Press

Plehn, Rudolf (1899) Beitrage zur Volkunde des Togo-Gebietes Mittheeilungen des Seminars fur Orietalische Sprachen, 1899. 2, part III, pp. 87-124. pp 11-42

Ring, Andrew J. (1981) Ewe as a second language: a sociolinguistic survey of Ghana's Central Volta Region, Legon: Institute of African Studies, University of Ghana.

Ring, Andrew J. (1995) Lelemi tone. Papers from GILLBT's seminar week, January 30-February 3 1995, Tamale, pp. 16-26. Tamale: GILLBT Press. 
Saah, Kofi K. \& Ezekiel Eze (1997) Double objects in Akan and Igbo. In: Object positions in Benue-Kwa. R. M. Dechaine and V. Manfredi eds. pp.139 - 151 The Hague: Holland Academic Graphics.

Sadock, Jarold M. \& Arnold M. Zwicky (1985) Speech act distinctions in syntax. In: Language typology and syntactic description Vol 1. Clause structure. Timothy Shopen ed. pp.155-196. Cambridge: Cambridge University Press

Sapir, Edward (1922) Language. New York: Harcourt and Brace

Schuh, Russell G. (1995) Avatime noun classes and concord. Studies in African Linguistics 24.2:123-149

Sebba, Mark (1987) The syntax of serial verbs: an investigation into Sranan and other languages. Amsterdam: John Benjamins.

Schaefer, Ronald P. (2001) Ideophonic adverbs and manner gaps in Emai. In: Ideophones Erhard F. K. Voeltz \& Christa Kilian-Hatz eds. pp. 339-355 Amsterdam / Philadelphia: John Benjamins

Siewierska, Anna (2004) Person. Cambridge: Cambridge University Press

Stassen, Leonard (1985) Comparison and Universal Grammar. Oxford: Basil Blackwell

Stewart, John M. (1963) Some restrictions on objects in Twi. Journal of African Languages 2: $145-149$

Stewart, John M. (1970) Tongue root position in the Volta-Comoe languages and its significance for the reconstruction of the original Bantu sounds. African Language Studies 11: 340-350

Stewart, John. M (1989) Kwa. In: The Niger-Congo languages. J. Bendor-Samuel, ed. pp. 217-246. Lanham: University Press of America

Struck, R. (1912) Einige Sudan -Wortstamme. Zeitschrift fur Kolonialsprachen 2:233 253, 309-323

Talmy Leonard (1983) How language structures space. In: Spatial orientation: Theory research and application. Herbert Pick \& Linda Acredolo eds. pp. 225-320. New York: Plenum Press

van der Hulst, Harry \& Norval Smith (1986) 'Reduced vowel harmony systems in Togo Remnant languages.' Paper presented at the $17^{\text {th }}$ annual meeting of the Dutch Linguistics Society, $25^{\text {th }}$ January 1986. Amsterdam.

Van Valin, Robert D. Jnr. \& La Polla, Randy J. (1997) Syntax: structure, meaning and function. Cambridge: Cambridge University Press. 
Welmers, William. E. (1973) African language structures. Berkeley: University of California Press

Westermann, Diedrich. (1903) Die Logbasprache in Togo. Zeitschrift fur Afrikanische und Ozeanische Sprachen, 7: 23-39.

Westermann Diedrich. (1930) A study of the Ewe language. Oxford: Oxford University Press

Westermann, Diedrich \& Margaret Bryan (1952) Languages of West Africa. Handbook of African Languages 2 London: Oxford University Press for International African Institute

Williamson, Kay \& Roger M. Blench (2000) Niger-Congo In: African languages: an introduction. Bernd Heine \& Derek Nurse eds. pp. 11- 42. Cambridge: Cambridge University Press. 


\section{Summary}

A grammar of Logba (Ikpana) provides a description of Logba, one of the fourteen Ghana-Togo-Mountain (GTM) languages spoken by approximately 7,500 speakers on the South-Eastern frontiers of the Ghana-Togo border. This book is made up of fourteen chapters and it is the outcome of a research based on two periods of a total of fifteen months of fieldwork in the Logba speaking communities.

Chapter one introduces the people, geographical location, the classification of the language and some of its characteristic features. Chapter two describes the phonological system of the language showing clearly that Logba has three syllable types which are all open syllables. These are: peak only, which can be a vowel or a nasal, simple onset and peak, and an onset made up of two consonants plus peak. Logba is a tone language with two basic tones: These are High and Low with falling and rising tones generated phonetically. Tone is realized on vowels and syllabic nasals. Logba has twenty-two consonants and seven vowel phonemes. There are no phonemically nasalized vowels in the language. An Advanced Tongue Root (ATR) vowel harmony system where the stem determines the [ATR] value of the affixes is found in Logba.

In chapter three the noun class system is presented showing Logba to have three interconnected systems: prefix classes, singular plural pairings and agreement systems. This reveals a combination of external verb agreement and noun phrase internal agreement resulting in nine different agreement classes: five singular and four plural classes. Two of the 'plural' agreement classes also contain nouns that have no number distinction. There are mass nouns with a noun prefix $\mathrm{i}$ - in class VIII and liquid nouns with a nasal prefix in class II. The types and the structure of NP are discussed in chapter four. One striking feature displayed in the NP is that it is only the numerals one to six that function in the Quantifier slot and the Determiners that are marked for agreement with the noun head. There is no agreement relation, however, between the adjective and the noun head. Logba has an adjective class comprising a non derived term gbali 'bad' and several terms derived from other categories and they are only used attributively. The discussion in chapter five is centred on the two adposition classes in the language: Logba has five prepositions and nine postpositions out of which five have grammaticalised from body part terms.

Chapter six is about basic clause structure and some specific verbal and non verbal constructions. Logba is an SVO language. The subject is cross referenced on the verb with a form which agrees with the subject in class. The subject marker is followed by tense aspect and mood (TAM) markers and then the verb stem. In three place constructions with a single verbal element, the Recipient precedes the Theme.

The five chapters that follow are centered on verbal constructions with different degrees of complexity. Chapter seven discusses verbs and verbal modifiers. The structure of the verb, and the inherent semantic features used to classify the verbs are also 
discussed. The verbs are classified according to the number of core arguments they require. One place verbs require one core argument. Two place verbs require two arguments and the largest number of verbs belongs to this group. There are however few three place verbs. Some verbs can belong to more than one of the three groups depending on a change of semantic function of the subject. The next chapter provides a brief background on the notion of sentence functions and goes on to discuss declarative, imperative and interrogative sentences. Prosodic pitch raising of final syllable is used to signal polar questions while special tags and question words are employed in the formation of other types of questions. mó 'which' mé 'what/how' and bé 'how much/how many' are the three question words identified in Logba.

Clauses that are embedded in other structures or are adjoined to other clauses in complex sentences are discussed in chapter nine. The first part is centered on relative clauses and it is followed by a section on complement clauses and various types of adverbial clauses. The position of a non-core constituent that is relativised is filled by an invariant marker in the relative clause. This marker displays the same assimilatory phonological pattern as the definiteness morpheme. Chapter ten discusses Serial Verb Constructions (SVCs). In an SVC in Logba the subject is marked on the initial verb and the subsequent verbs are not marked. The VPs share the same TAM expressed with the initial verb and negation is expressed with the initial verb using a bipartite morpheme. Reported speech, reflexive construction and reciprocal constructions are discussed in chapter eleven.

Chapter twelve presents topic and focus in Logba. First, topic constructions are discussed indicating that there is no special marker to signal the topicality of a constituent but rather a topicalised constituent occurs at the starting point of the sentence. This is followed with a description of focus constructions. Two strategies are described which vary according to dialects for term focus. In one, the term-focus marker $\mathrm{ka}$ is used and is placed immediately after the constituent that is focused. The other strategy is used mainly in the Tota dialect. The prominent NP is fronted and is recapitulated by the independent pronoun followed by the rest of the clause (without any dedicated focus marker). The verb is focused by placing the bare form of the copy of the verb immediately before the verb.

The last two chapters relate to constructions that are sometimes considered marginal to grammar but which are crucial for communication. Chapter thirteen is a discussion of three kinds of words: Ideophones, interjections and particles. The final chapter presents routine expressions used for social interaction. This includes greetings, expressions used to show appreciation to someone at work, invitations to someone for dinner and expressions of welcome, disclaimers and expressions of farewell. These expressions are cultural codes and are given a particular interpretation depending on how and where it is performed. An attempt is made to explain the circumstances in which these expressions are used and their underlying meanings. 
The book ends with representative texts collected from native speakers resident in the Logba towns. These include stories, proverbs, riddles, procedural and socio-cultural organizational texts. In addition, there is a Logba-English-Ewe wordlist and EnglishLogba index. 



\section{Samenvatting}

A grammar of Logba (Ikpana) geeft een beschrijving van het Logba. Het Logba wordt gesproken door zo'n 7,500 bewoners van het gebied in het Zuidoosten palend aan de grens tussen Ghana en Togo en is één van de veertien Ghana-Togo-Mountain (GTM) talen. Dit proefschrift, bestaande uit veertien hoofdstukken, is het resultaat van vijftien maanden veldonderzoek in Logba sprekende gemeenschappen.

In hoofdstuk één introduceert de auteur de Logba gemeenschappen, hun geografische locatie, de classificatie van de Logba taal en enkele kenmerken ervan. In het tweede hoofdstuk wordt het fonologische systeem van de taal besproken. Dit systeem toont duidelijk aan dat het Logba onderscheid maakt tussen de volgende drie typen open lettergrepen: (1) lettergreep met alleen een piek, dit kan een klinker of een nasaal zijn, (2) lettergreep met enkelvoudige onset en een piek, en (3) lettergreep met complexe onset en een piek. Logba is een toontaal. De basistonen zijn hoog en laag met dalende en stijgende tonen als fonetische allotonen. Toon is gerealiseerd op lettergrepen en syllabische nasalen. Logba heeft tweeëntwintig medeklinkers en zeven klinkers. De taal kent geen fonemisch onderscheiden nasalen. Wel kent het Logba een Advanced Tongue Root (ATR) klinker harmonie systeem waarbij de stam de ATR waarde van de voor- en achtervoegsels bepaalt.

In hoofdstuk drie wordt ingegaan op het Logba naamwoordklassensysteem. Dit bestaat uit drie samenhangende systemen: één op basis van naamwoord voorvoegsels, één op basis van enkelvoud-meervoud paren en één op basis van concordantie. De externe concordantie met het subject in werkwoorden en de concord binnen de nominale constituent resulteren in negen verschillende klassen: vijf enkelvoud- en vier meervoudklassen. Twee van de meervoudklassen bevatten ook zelfstandig naamwoorden die geen getalonderscheid kennen (mass nouns): Klasse VIII die bestaat uit zelfstandig naamwoorden met voorvoegsel i- en klasse II die bestaat uit zelfstandig naamwoorden voor vloeistoffen met een nasaal voorvoegsel. In hoofdstuk vier behandelt de auteur de verschillend soorten nominale constituenten en de structuur van de NP. Een opvallend kenmerk van de NP is dat enkel de telwoorden één tot en met zes concordantie vertonen. De deteminers ook vertonen concordantie met het hoofd van de nominale constituent. Er is echter geen concordantie tussen het bijvoeglijk naamwoord en het hoofd van de nominale constituent. Logba kent een klasse van bijvoeglijk naamwoorden bestaande uit de niet-afgeleide term gbali 'slecht' en verschillende termen die zijn afgeleid van andere categorieën; bijvoeglijk naamwoorden worden louter attributief gebruikt. In hoofdstuk vijf staan de voorzetsels centraal. Het Logba kent vijf voorzetsels en negen postposities, waarvan er vijf gegrammaticaliseerd zijn van woorden die verwijzen naar lichaamsdelen.

In hoofdstuk zes wordt ingegaan op de basis zinsstructuur en enkele specifieke verbale en niet-verbale constructies. Logba is en SVO taal. Het onderwerp wordt 
gecodeerd op het werkwoord door middel van concordantie met de klasse van het onderwerp. Het subjectvoorvoegsel wordt gevolgd door tense-aspect-mood (TAM) morfemen en de stam van het werkwoord. In zinnen met drie argumenten gaat de recipiënt vooraf aan het thema.

In de vijf volgende hoofdstukken ligt de nadruk op verbale constructies met verschillende graden van complexiteit. In hoofdstuk zeven worden werkwoorden en hun modificeerders besproken. Ook wordt ingegaan op de structuur van het werkwoord en de inherente semantische kenmerken die gebruikt worden voor de classificatie van werkwoorden. De werkwoorden worden geclassificeerd volgens het aantal kernargumenten dat deze werkwoorden vereisen. De intransitieve werkwoorden hebben slechts één kernargument. Het grootste aantal werkwoorden bestaat echter uit werkwoorden met twee argumenten. Daarnaast zijn er een aantal werkwoorden met drie argumenten. Sommige werkwoorden kunnen tot verschillende van deze drie groepen behoren als gevolg van een verandering van de semantische functie van het subject.

In hoofdstuk acht wordt kort ingegaan op de functies van zinnen en worden bewerende, imperatieve en vraag zinnen behandeld. Een stijgende toon op de zinsfinale lettergreep maakt de zin tot een ja/nee vraag; andere vraagzinnen vereisen vraagwoorden. In het Logba zijn de volgende drie vraagwoorden vastgesteld: mó 'welke', mé 'wat/hoe' en bé 'hoeveel'.

In hoofdstuk negen bespreekt de auteur zinnen die zijn ingebed in andere zinnen of underszins met andere zinnen complexe zinnen vormen. Het eerste deel gaat over bijzinnen en wordt gevolgd door een sectie over complementzinnen en verschillende typen bijwoordelijke zinnen. In de bijzin is er een onveranderlijk element op de plaats van het hoofd bijzin mits het geen kernargument is. Dit element vertoont dezelfde fonologische patronen van assimilatie als het definietheidsmorfeem.

Hoofdstuk tien behandelt seriële werkwoord constructies (SVCs). In een seriële werkwoord constructie in Logba wordt het subject alleen op het eerste werkwoord aangeduid en niet op de daarop volgende werkwoorden. De VPs delen dezelfde TAM die worden uitgedrukt op het eerste werkwoord en ook de negatie wordt uitgedrukt op het eerste werkwoord met gebruik van een tweeledig morfeem. In hoofdstuk elf behandelt de auteur de indirecte rede, en de wederkerige en wederkerende constructies.

In hoofdstuk twaalf worden topic en focus in het Logba gepresenteerd. Eerst behandelen we topic constructies. Topics staan aan het begin van de zin en hebben geen specifieke topic-aanduider. Daarna volgen de focusconstructies. Twee strategieën worden beschreven voor constituentfocus die variëren per dialect. In één van de twee strategieën, wordt de constituentfocusaanduider ka direct na de constituent geplaatst waarop de nadruk ligt. De andere strategie is hoofdzakelijk gebruikt in het Tota dialect. De prominente NP wordt aan het begin van de zin geplaatst gevolgd door het ernaar verwijzende onafhankelijke voornaamwoord en weer gevolgd door de rest van de zin 
(zonder enige specifiek aanduiding focus markeerder). Het werkwoord wordt benadrukt door de kopie van het (naakte) werkwoord onmiddellijk voor het werkwoord te plaatsen.

De laatste twee hoofdstukken gaan over constructies, die in een grammatica soms als marginaal worden beschouwd, maar die cruciaal zijn voor de communicatie. In hoofdstuk dertien worden drie typen woorden besproken: ideofonen, tussenwerpsels en partikels. In het laatste hoofdstuk presenteren we standaarduitdrukkingen gebruikt worden voor sociale interactie. Deze omvatten groeten, uitdrukkingen die gebruikt worden om waardering te tonen voor iemand op het werk, uitnodigingen voor een maaltijd, uitdrukkingen die dienen om iemand welkom te heten, en uitdrukkingen voor het nemen van afscheid. Deze uitdrukkingen kunnen worden opgevat als culturele codes. De interpretatie is afhankelijk van hoe en waar zij worden uitgesproken. De juiste omstandigheden voor correct gebruik van deze uitdrukking worden behandeld.

Het proefschrift eindigt met een representatieve verzameling van teksten van moedertaalsprekers die woonachtig zijn in Logba gebied. Deze omvatten verhalen, spreekwoorden, raadsels, procedurele en sociaal-culturele teksten. Tenslotte zijn in dit proefschrift ook een Logba-Engels-Ewe woordenlijst en een Engels-Logba index opgenomen. 



\section{Curriculum vitae}

Kofi Dorvlo was born in Keta in the Volta Region of Ghana on $10^{\text {th }}$ April 1953. From 1974 to 1976, he trained as a teacher after secondary school and taught briefly in basic schools in the Volta Region. He continued his education at the then Advanced Teacher Training College, Winneba from 1981 to 1984 where he obtained a Diploma in English and Education. After teaching in Bishop Herman Secondary School, Kpando, and Ho Polytechnic from 1984 to 1992 , he entered the University of Ghana where he studied for and was awarded a Bachelor of Arts degree in English and Linguistics in 1996. After teaching for two years at OLA Girls' Secondary School, Ho, he embarked on a Masters in Linguistics course in 1998. In 2000, he received a Master of Philosophy degree in Linguistics (University of Ghana, Legon) and was subsequently appointed Research Fellow at the Language Centre of the same university. From May 2003 to October 2007 he was a PhD scholar in the Department of African Languages and Cultures and the Leiden University Centre for Linguistics (LUCL) researching and documenting the language and culture of Logba funded under the Endangered Languages Programme of the Netherlands Organisation for Scientific Research (NWO). 
